STUDIES IN NEW ZEALAND OLIGOCENE

AND MIOCENE PLANT MACROFOSSILS*

$$
\text { by }
$$

ALINE MARY HOLDEN

Submitted for the degree of Doctor of Philosophy in Geology at the Victoria University of Wellington

August 1983

*Throughout the following account the term

'megafossil' has been substituted for

'macrofossil' in line with preferred Australian usage . 
Frontispiece. Reconstruction of New Zealand mid-Tertiary

lowland swamp forest of the type which contributed extensively to Southland an Central Otago Lignites.

Key:

1. Kauri (Agathis ?australis)

2. Kahikatea (Dacrycarpus ?dacrydioides) mature trees

3. Kahikatea, young trees

4. Rimu (Dacrydium ?cupressinum)

5. Mixed broadleafed trees including Nothofagus spp, Lauraceae

6. Flax (Phormium sp.)

7. Raupo (Typha $\mathrm{sp}$ ) and Cyperaceae

Pollen and megafossil evidence indicates that Huon Pine (Dacrydium ?franklinii) may also have been important in these communities. Local variations in microtopography were probably important in governing species distribution within the forest swamp, with kauri and beech growing on somewhat better-drained ground. 


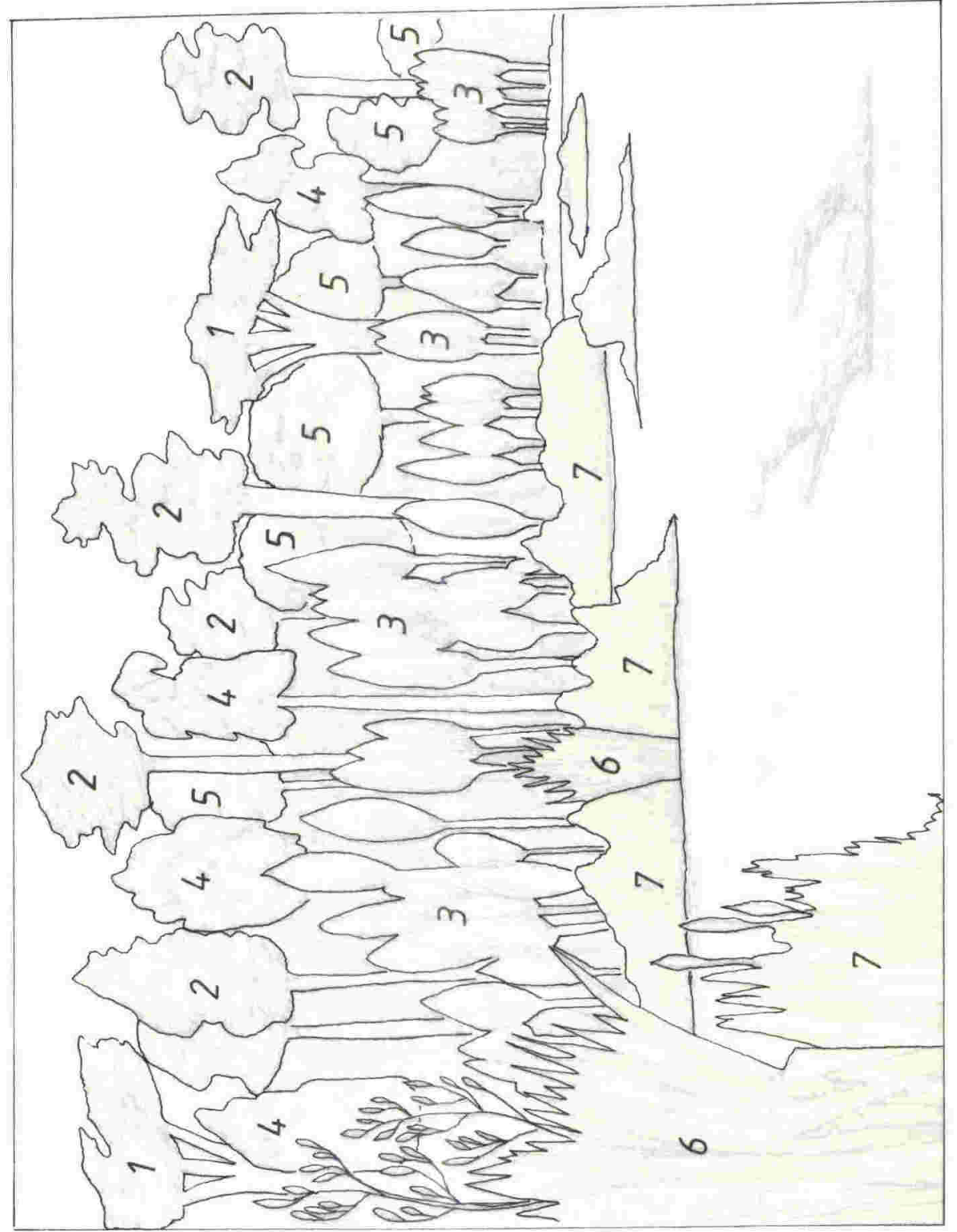


TABLE OF CONTENTS

Table of contents . . . . . . . . . . iv

List of tables ............... vii

List of figures . . . . . . . . . . vii

List of plates ............ . . xiv

Abstract 1

Chapter 1. Introduction 3

Chapter 2. Materials and Methods

Materials $\quad 17$

$\begin{array}{ll}\text { Methods } & 17\end{array}$

$\begin{array}{ll}\text { Photography } & 17\end{array}$

Drawings 18

Preparation techniques $\quad 18$

Scanning electron microscopy 20

Living material $\quad 20$

Thin sections $\quad 20$

Chapter 3. The Oligocene-Miocene Floras 21

of Southland

Geology $\quad 22$

Landslip Hill section $\quad 25$

Mataura Valley $\quad 28$

Age $\quad 30$

Flora $\quad 31$

Paleoenvironment $\quad 35$

Silica cementation $\quad 39$

Chapter 4. The Miocene floras of Central 45 Otago

Geology $\quad 45$

Nevis Valley $\quad 52$

Bannockburn, Cromwell \& St. Bathans 54

Coal Creek Flat 59

Floras 61

Nevis Oil shale 61

Bannockburn, Cromwe11 \& St. Bathans 64

Coal Creek Flat, Roxburgh 66

Age $\quad 68$

Paleoenvironment $\quad 69$

Chapter 5. The Miocene floras of the Buller- 74 Inangahua region

Geology $\quad 74$

Age 83

Flora $\quad 83$

Paleoenvironment $\quad 87$

Paleoclimate $\quad 94$ 
(Table of Contents ctd.).

Chapter 6. Note on the Miocene floras of the 98 Dunedin area

Age

102

Flora

102

Paleoenvironment

Chapter 7. Note on the Miocene flora of Great Barrier 108 Island

Age

Flora

111

Paleoenvironment

Chapter 8. Systematics 115

Spermatopsida - Gymnospermae $\quad 116$

Coniferalales 116

Podocarpaceae 117

Cupressaceae 129

Araucariaceae 130

Spermatopsida - Angiospermae 135

Dicotyledones 136

Fagaceae 136

$\begin{array}{ll}\text { Casuarinaceae } & 148\end{array}$

Other described taxa 154

Filicopsida - Filicales 154

Osmundaceae 154

Gleicheniaceae $\quad 155$

Cyatheaceae 155

Dennstaedtiaceae $\quad 156$

Davalliaceae $\quad 157$

$\begin{array}{ll}\text { Blechnaceae } & 157\end{array}$

Spermatopsida, Angiospermae, Dicotylelones 159

Monimiaceae 159

Lauraceae 160

Cunoniaceae 163

Euphorbiaceae 164

$\begin{array}{ll}\text { Myrtaceae } & 165\end{array}$

Dicotyledones incertae sedis $\quad 170$

Monocotyledones - Liliales 177

$\begin{array}{ll}\text { Smilacaceae } & 177\end{array}$

$\begin{array}{ll}\text { Chapter 9. General discussion } & 179\end{array}$

$\begin{array}{ll}\text { References } & 203\end{array}$

$\begin{array}{ll}\text { Acknowledgements } & 234\end{array}$

Appendix A. Pollen and spores from Blue Lake 235

St. Bathans (H41) and Harliwick's Lignite Pit, Roxburgh (G43) Central Otago New Zealand - D.T. Pockna11, Palynology section, N.Z. Geological Survey 
(Table of Contents ctd.).

Appendix B. Fossil Diatomaceae from some Neogene fresh water sediments - Margaret

A. Harper, Department of Geology, Victoria University of Wellington

Appendix C. Catalogue of undescribed species 246

$\begin{array}{ll}\text { Figures } & 274\end{array}$

$\begin{array}{ll}\text { Plates } & 348\end{array}$

ERRATUM: The photographic plates (Plates 1-12) in this volume have been bound in reversed order. 
List of tables

Table 1.1 Fossil collections examined

Table 3.1 Plant megafossil taxa identified from Gore Lignite Measures

Table 4.1 Plant megafossil taxa identified from the Nevis Oil Shale

Table 4.2 Plant megafossil taxa identified

from Manuherikia Group sediments at Bannockburn and St. Bathans

Table 4.3 Plant megafossil taxa identified

from Manuherikia Group sediments at

Coal Creek Flat, Roxburgh

Table 5.1 Plant megafossil taxa identified

from the Longford and Frog Flat Formations

Table 5.2 Fossil spores and pollen from Coal

Creek, Inangahua Junction

Table 6.1 Plant megafossil taxa identified from the

Kaikorai Leaf Beds (Dunedin Volcanic Complex)

Table 7.1 Identified plant mega- and microfossils from Great Barrier Island

Table 9.1 Distribution and affinites of identified New Zealand Oligocene-Miocene plant megafossils

Table 9.2 Prominent families and genera of living and fossil communities in the southwest Pacific

Appendix A, table 1. Pollen and spore percentages for samples G43/f2A and B and H4l/f28

Appendix B table 1. Sample V2850, Bannockburn 240 table 2. Sample V2849, Nevis 242 table 3. Sample B411 Great Barrier Island 243 table 4. Sample V2855 St. Bathans 244 table 5. Sample V2847 Fraser's Gully, Kaikorai, 245 Dunedin Summary of results

\section{List of Figures}

Text Figure 2.1. Comparison of white light and infra red photography

Text Figure 3.1. Map of Gore district showing major outcrops of Gore Lignite Measures and cover beds 
(List of figures ctd.).

Text Figure 3.2. Stratigraphic column for section at Landslip Hill

Text Figure 3.3. Landslip Valley looking east. Southern

sector of slip scarp and margin of debris train

Text Figure 3.4. Landslip Hill, southern end of summit

plateau looking east, showing outcropping boulders of plant-bearing quartzite

Text Figure 3.5. Landslip Hill, large boulder of plant-

- bearing quartzite on summit plateau showing mould of tree trunk

Text Figure 3.6. Generalised stratigraphic column for Mataura Valley

Text Figure 3.7. Landslip Hill, block of plant-bearing quartzite showing silicified conifer branchlet (Dacrydium sp. aff. cupressinum) and leaves

Text Figure 3.8. Landslip Hill, block of plant-bearing quartzite showing silicified cone of Gymnostoma stellata and leaves

Text Figure 3.9. ?Proteaceae, silicified epidermis showing 40 trichomes

Text Figure 3.10. Nothofagus sp., silicified lower epidermis and underlying tissues showing stomata and veinlets

Text Figure 3.11. Silicone rubber cast, epidermis of Dacrydium sp. aff. cupressinum, showing stomatal bands

Text Figure 3.12. Thin section photomicrograph of quartzite 40 showing interlocked overgrowths with compromise crystal boundaries between quartz grains, and spherulitic cement (dark area, right centre) crossed nicols, x 110

Text Figure 3.13. Scanning electron micrograph of fractured 40 surface of quartzite showing overgrowths on quartz grains and spherulitic cement

Text Figure 3.14. Enlargement of Fig 13, right centre 40

Text Figure 4.1. Map of part of Range and Basin Province 48 of Central Otago, showing main outcrops of Central Otago Lignite Measures (Manuherikia Group) and cover beds (after Wood 1962 and Mutch 1963)

Text Figure 4.2. Dip slope of Rough Range as seen looking south from Idaburn opencast showing stripped and tilted surface of fossil peneplain with numerous schist tors 
(List of figures ctd.).

Text Figure 4.3. Area of old peneplain surface at summit

of Carrick Range, showing large schist tors

Text Figure 4.4. Steeply dipping Manuherikia Group sediments at mouth of Bannockburn Creek adjacent to fault

Text Figure 4.5. General view of Lower Nevis basin from Duffer's Saddle looking southwest. Tertiary rocks of the Nevis Formation show up as prominent 1ight-coloured outcrops in high terraces along lower slopes of spurs

Text Figure 4.6. Generalised stratigraphic column for Nevis Valley

Text Figure 4.7. Nevis Oil Shale: exposure in Ministry of Works pozzolan quarry, Shale Ridge, showing thinly-bedded, fissile shale breaking into angular slabs

Text Figure 4.8. Shale Ridge, Nevis Valley looking west, showing areas of bare ground mantled with loose shale slabs

Text Figure 4.9. Bannockburn: mouth of Bannockburn Creek showing steeply-dipping Manuherikia Group sediments forming prominent bluffs. The exposure shown in Fig 4.4 is in the bluff at the right of the photograph

Text Figure 4.10. St. Bathans: northern side of old gold workings showing light-coloured quartzose Manuherikia Group overlying dark Torlesse Group basement. The contact here is clearly not faulted

Text Figure 4.11. St. Bathans: general view of Blue Lake and old gold workings, looking west, showing highly quartzose Tertiary sediments with thin lignite overlying Torlesse Group basement

Text Figure 4.12. St. Bathans: reddened, baked sediment ("porcellanite") at eastern end of workings

Text Figure 4.13. St. Bathans: western end of old gold workings, 60 cross-bedded white quartz sands and gravels of Manuherikia Group and fossiliferous clay bed

Text Figure 5.1. Map of Murchison area showing distribution of 75 Longford Formation and correlatives

Text Figure 5.2. Hillside just south of Longford Junction showing 77 characteristic topography developed in Longford Formation rocks: resistant sandstones and conglomerates left as strike ridges following erosion of interbedded siltstones and shales

Text Figure 5.3. Longford formation rocks exposed in bluffs at mouth of Nuggety Creek. Parts of two upward-fining sedimentary cycles are visible. Rapid erosion of a fissile carbonaceous shale is causing undercutting of the overlying massive muddy sandstone 
(List of figures ctd.)

Text Figure 5.4. Closeup view of outcrop in Fig 5.3 showing uppermost unit (carbonaceous shale) of one sedimentary cycle and basal units of overlying cycle

Text Figure 5.5. Frog Flat Formation: several pinnae of a palm frond in a fallen block at Frog Flat Junction

Text Figure 5.6. Fossil leaves from the Longford and Frog

Flat Formations showing plastic deformation: the venation pattern was originally symmetrical

Text Figure 5.7. Paleoenvironmental reconstruction for the Longford Formation

Text Figure 6.1. Map of Dunedin area showing distribution of Tertiary leaf beds

Text Figure 7.1. Map of Great Barrier Island showing distribution of Beeson's Island Volcanics

Text Figure 8.1. Dacrydium sp. aff. cupressinum; silicone rubber cast of abaxial leaf surface showing stomatal bands

Text Figure 8.2. Silicified leaf showing internal structure

Text Figure 8.3, 8.4. Dacrydium franklinoides; silicone rubber cast

Text Figure 8.5. Microstrobos sp.; branchlet showing thickened 122 leaf margins.

Text Figure 8.6. Microcachrys imbricatus; silicone rubber cast of branchlet showing fragmentary ciliate wing on margin

Text Figure 8.7. Libocedrus bidwillii; abaxial surface of

leaf showing stomatal bands

Text Figure 8.8. Diselma archeri; leaf apex

Text Figure 8.9. Microcachrys tetragona; leaf margin

Text Figure 8.10. Microcachrys imbricata; silicone rubber cast of branchlet showing leaf margin with remains of ciliate wing

Text Figure 8.11. Libocedrus compressa; silicone rubber cast 126 of internal surface of lower epidermis showing stomata

Text Figure 8.12. Agathis sp. aff. australis; internal surface of silicified lower epidermis showing stomata in roughly parallel rows 
Text Figure 8.13. Nothofagus southlandica; silicified lower epidermis and mesophyll showing trichome base and stomata

Text Figure 8.14. N. bidentatus silicified upper epidermis

Text Figure 8.15. Silicified lower epidermis showing stomata

Text Figure 8.16. Gymnostoma sp.: silicone rubber cast of

branchlet fragment, two internodes with leaf sheaths, free part of leaf blade missing

Text Figure 8.17. Casuarina avenacea; silicone rubber cast of base of cone, stomatal groove arrowed

Text Figure 8.18. Dicotyledones incertae sedis species E; silicified lower epidermis

Text Figure 9.1. Possible paleogeography of New Zealand for Upper Oligocene (Duntroonian Stage) and Upper Miocene (Tonga porutuan Stage) assuming all transcurrent movement on the Alpine Fault was pre-Tertiary

Text Figure 9.2A. Possible paleogeography of New Zealand for Oligocene (Whaingaroan and Duntroonian Stages) assuming major transcurrent movements on the Alpine Fault are post Miocene

Text Figure 9.2B. Possible paleogeography of New Zealand for Upper Miocene (Tongaporutuan Stage) assuming major transcurrent movements on the Alpine Fault are post-Miocene

\section{Figures to accompany Systematics (Chapter 8)}

Fig. 1. Podocarpus obtusifolius 0liver, Dacrycarpus sp. aff. dacrydioides (A. Rich.) de Laub. and Dacrydium sp. aff. cupressinum Lamb

Fig. 2. Dacrydium franklinoides sp. nov., Microcachrys imbricata sp. nov., Phyllocladus strictus sp. nov. Phyllocladus sp., Libocedrus compressa sp. nov., Libocedrus sp., Araucaria sp. Agathis sp. aff. australis Salisb., Agathis sp. and Araucaria sp.

Fig. 3. Nothofagus southlandica sp. nov. and Nothofagus novae278 zealandiae (Oliver) Holden

Fig. 4. Nothofagus bidentatus Holden and Nothofagus pinnata (Oliver) Holden comb. nov.

Fig. 5. Nothofagus oblonga Holden and Nothofagus oliveri Holden

Fig. 6. Nothofagus australis (0liver) Holden comb. nov. and Nothofagus kaikoraiensis (Oliver) Holden comb. nov. 
Fig. 7. Gymnostoma stellata Campbell and Holden sp. nov.,

Gymnostoma crassa sp. nov. Casuarina avencaea Campbell and

Holden sp. nov. and Casuarina sp.

Fig. 8. Leptopteris hymenophylloides (A. Rich) Presl. and Gleichenia southlandica sp. nov.

Fig. 9. Alsophila sp. aff. tricolor (Col.) Tryon and

Davallia tasmanii H.C. Field

Fig. 10. Blechnum maruiense sp. nov. Blechnum proceroides (Oliver) Holden comb. nov.

Fig. 11. Laurelia cuneata 0liver, Cryptocarya longfordiensis Holden and Litsea dawsoniana Holden

Fig. 12. Litsea dawsoniana Holden, Ceratopetalum kaikoraiense

Oliver, Cryptocarya sp. and Mallotus sp.

Fig. 13. Metrosideros diffusoides sp. nov., Metrosideros

laeta 01 iver, Xanthostemon sp. and Eucalyptus roxburghiensis sp. nov.

Fig. 14. Dictyledones incertae sedis Species A and Species B 300

Fig. 15. Dicotyledones incertae sedis Species C, Species D 301

and Species E

Fig. 16. Dicotyledones incertae sedis Species F, Ripogonum latipetiolatum (Oliver) Holden comb. nov. and Ripogonum sp.

Figures to accompany catalogue of undescribed species

Fig. 17. ?Trichomanes sp., Phymatosorus sp. aff. diversifolium (Willd.) Pic. Ser., Dicksonia sp. aff lanata Col., Hypolepis sp. aff. tenuifolium (Forst. f.) Bernh. var, pellucida (Col.) Hook., Pteridium aquilinum (L.) Kuhn. var esculentum (Forst.f.) Kuhn., ?Antrophyum sp. and FFF009.

Fig. 18. Blechnum sp., Blechnum sp. aff. discolor (Forst. f.) keys., BIV003, FFF010, NFM003, GLM016, ?Agathis sp. ?Pseudowintera sp. and OLMO11.

Fig. 19. FFF011, Hedycarya sp., GLM018, OLM012, GLM019 and ?Cryptocarya sp.

Fig. 20. Beilschmiedia tarairoides Pens., Cryptocarya murchisoniensis Holden, GLMO20, Cinnamomüm miocenicum Holden, ?Ascarina sp. and ?Macropiper sp.

Fig. 21. Cryptocarya tutakiae Holden ?Melicytus sp. and Calpidia zealandica Oliver 
(List of Figures to accompany catalogue of undescribed species ctd.)

Fig. 22. Calpidia zealandica Oliver, ?Stenocarpus sp.

?Banksia sp., Kermadecia merytifolia Holden and ?Beauprea sp.

Fig. 23. Knightia oblonga Oliver, GLM022, OLM015, GLM023,

Longfordia banksiaefolia Holden, GLM024, GLM025 and

Banksiaephyllum sp.

Fig. 24. OLMO16, OLM017, OLM018, OLM019 and FFF013

Fig. 25. Metrosideros sp., FFF014; Metrosideros sp.,

NFM004; GLM027 and OLM020

Fig. 26. NFM004; NFM005; OLM021; FFF015; ?Leptospermum sp;

Lophomyrtus sp. and NFM006

Fig. 27. OLM022; ?Garcinia sp.; Elaeodendron rigidum Ett.; LDF028; OLM024; FFF017 and OLM025

Fig. 28. NFM007; Ixerba semidentata 01iver; LDF029; NFM008; OLM026; OLM027; OLM028; and BIV005

Fig. 29. OLM029; NFM009; ?Streblus sp. ?Paratrophis sp.; BIV006; OLM031; ?Cupaniopsis sp.; LDF031; NFMO10 and ?Alectryon sp.

FIG. 30. LDF033; Nothopanax distans Oliver;

FFF020; ?Parafatsia Blackburn; Kaikoraia gracilis 0liver; ?Planchonella sp. and LDF035

Fig. 31. ?Myrsine sp.; FFF022; Geniostoma oblonga Oliver;

?Geniostoma sp.; LDF036; Apocynophyllum affine Ett.;

Coprosma praerepens Oliver and Coprosma pliocenica Oliver

Fig. 32. Coprosma pliocenica 01iver; Coprosma sp.; Senecio

pliocenica Oliver; cf Avicennia sp.; ?Dysoxylum sp. OLM033 OLM034 and GLM032

Fig. 33. Loranthophyllum dubium Unger; OLM035 and GLM032

Fig. 34. OLM036; LDF037; LDF038; LDF039; OLM037 and FFF025

Fig. 35. KLB023; LDF040; FFF025; GLM033; Typha robusta O1iver and NFM012

Fig. 36. GLM034; GLM035; GLM036 and GLM037

Fig. 37. GLM038; FFF026; LDF041; Rhopalostylis sp. and 
Frontispiece Reconstruction of New Zealand Mid-Tertiary lowland iil swamp forest of the type which contributed extensively to Southland and Central Otago lignites

Plate 1.

Fig. 1. Dacrydium sp. aff. cupressinum, branchlet fragment

Fig. 2. Phyllocladus strictus sp. nov. Holotype, xl

Fig. 3. ?Araucaria sp. (seed), Holotype $\mathrm{x} 2$

Fig. 4. Agathis or Araucaria sp., (pollen cone) Holotype, x3

\section{Plate 2.}

Fig. 1. Nothofagus southlandica sp. nov. Holotype x2

Fig. 2. ?Araucaria sp. (leaf) x2

Fig. 3. Nothofagus novae-zealandiae (Oliver) Holden x1.25

Fig. 4. Nothofagus bidentatus Holden Holotype $\times 1.75$

Plate 3.

Fig. 1. Nothofagus oliveri Holden $x 2$

Fig. 2. Nothofagus oblonga Holden Holotype x1.75

Fig. 3. Nothofagus australis (Oliver) HoIden comb. nov. x1

Fig. 4. Nothofagus bidentatus Holden xl

Plate 4. Gymnostoma stellata Campbell and Holden, female cones

Fig. 1. Holotype, mature cone, $x 3$

Fig. 2. Silicone rubber cast from Holotype x2

Fig. 3. Immature cone $x 7$

Fig. 4. Mature cone $x 3$

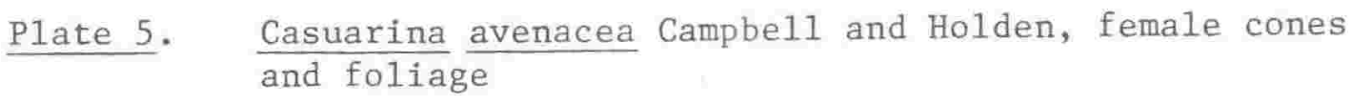

Fig. 1. Cluster of mature cones, xl

Fig 2. Mature cone, x2

Fig. 3. Foliage, $x 1$

Fig. 4. Foliage, $x 1$ 
(List of Plates ctd.).

Plate 6.

Fig. 1. Gymnostoma crassa sp. nov. holotype, mature female cone, silicone rubber cast $\times 3$

Fig. 2. Gleichenia southlandica sp. nov. Holotype x0.75

Fig. 3. Blechnum proceroides (Oliver) comb. nov. xl.

Fig. 4. Cryptocarya longfordiensis Holden Holotype x2

Plate 7.

Fig. 1. Litsea dawsoniana Holden, Holotype $\times 1.75$

Fig. 2. Metrosideros laeta Oliver x3

Fig. 3. ?Eucalyptus roxburghiensis sp. nov. Holotype x1.25

Plate 8.

Fig. 1. Hymenophyllum mio-zealandicum $\times 5$

Fig. 2. Laurelia cuneata Oliver $\times 2$

Fig. 3. GLM018, ?Monimiaceae x6

Fig. 4. LDF021, ?Ascarina sp. $\mathrm{x} 4$

P1ate 9.

Fig. 1. GLM035, fruit, external and internal mould $\times 4$

Fig. 2. GLM036, fruit $\times 4$

Fig. 3. GLM037, fruit $\mathrm{x} 4$

Fig. 4. GLM038, ?Elaeocarpaceae, fruit x3

Fig. 5. GLM037, fruit $\times 5$

Platé 10.

Fig. 1. GLM040, fruit or seed, natural mould, x2

Fig. 2. GLM040, fruit or seed, silicone rubber cast, surface view $\times 1.5$

Fig. 3. GLM040, fruit or seed, silicone rubber cast, side view $\mathrm{xl} .5$

Fig. 4. GLM041, ?fruit, natural mould x3 
(List of Plates ctd.).

Plate 11.

Fig. 1. GLMO42 x3

Fig. 2. GLMO43 $\times 4$

Fig. 3. GLMO44 ?fruit, natural mould $\times 3$

Fig. 4. GLM041 silicone rubber cast $\times 1.75$

Fig. 5. GLM044, ?fruit, silicone rubber cast xl.75

Plate 12.

Fig. 1. GLM046, ?fruit $\times 4$

Fig. 2. GLM047, ?fruit $\times 3.75$

Fig. 3. GLM047, ?fruit $\times 2.75$

Figs. 4 \& 5. OLM039, rootstocks, Gramineae or Cyperaceae, xl 


\section{ABSTRACT}

Assemblages of fossil leaves ranging in age from Upper Oligocene to Upper Miocene or Lower Pliocene have been examined from localities in Southland, Central Otago, the Dunedin area, the Buller region and Great Barrier Island. Nearly 200 form taxa have been recognised so far; of these 52 are figured and described and the remainder are included in an illustrated catalogue. Conifer $\stackrel{S}{\mathrm{e}}$, Casuarinaceae and Nothofagus spp. are discussed in detail.

Thirteen new species are named and described: Gleichenia southlandica, Hypolepis maruiensis, Blechnum maruiense, Dacrydium (Lagarostrobos) franklinoides, Microcachrys imbricata, Phyllocladus strictus, Libocedrus compressa, Nothofagus southlandica, Gymnostoma stellata, Gymnostoma crassa, Casuarina avenacea, Metrosideros diffusoides and ? Eucalyptus roxburghiensis. Six new species are described but not named as more detailed study is still proceeding. A further ten new form taxa are identified to genus level only.

The fossil flora from the Kaikorai Valley, Dunedin, originally described by Oliver (1936) is revised and Blechnum proceroides, Nothofagus pinnata, N. australis, N. kaikoraiensis and Ripogonum latipetiolatum are new names arising from this revision.

The fossil assemblages from Southland and Central Otago are derived from heath, swamp and forest communities developed on an early to mid Tertiary peneplain. In contrast the fossil floras of the Buller region reflect predominantly forest vegetation developed on young soils of a prograding coastal floodplain backed by rapidly rising fault block ranges, while the fossil floras of Dunedin and Great Barrier Island reflect vegetation periodically affected by volcanic activity. Late 0ligocene and Miocene climates throughout New Zealand appear to have been humid and at least as warm as Auckland today, although conditions on the east coast of the South Island may have been cooler and drier than on the west.

The sediment containing the Landslip Hill fossil flora is interpreted as a silcrete and resembles similar deposits in Australia. The uncompressed state of the fossils and the preservation of turgid cell structures indicates early silica cementation in a surface or near-surface environment, probably as a result of direct precipitation of silica from ground water. 
The present-day New Zealand flora appears to be derived in part from the late Cretaceous flora of coastal eastern Gondwanaland. Other southwest Pacific floras may share a similar origin, and may also have contributed to the New Zealand flora following fragmentation of the continental margin.

The distribution of New Zealand Tertiary plants, as far as it is known, is consistent with the inferred paleogeography. 
A number of Oligocene and Miocene megafossil floras from New Zealand are described. They are the Oligocene (Duntroonian to Waitakian Stages) floras of the Gore Lignite Measures, particularly that from Landslip Hill; the early to mid Miocene (Pareora to Southland Series) floras of Central Otago, and the Middle and Upper Miocene floras of the BullerInangahua region (Southland Series) and of Dunedin and Great Barrier Island (Waiauan to Kapitean Stages). Details of the fossil localities are given in Table 1.1 .

Oligocene and Miocene fossil floras of New Zealand are important because they record the vegetation that existed both before the increase in relief caused by the Kaikoura orogeny and before the drastic climatic decline leading to the Pleistocene glaciations. Thus they represent the ancestral matrix from which the present flora developed. Much information is already available from the palynological studies of the past 40 years, but palynology has limitations stemming principally from over-representation of wind pollinated species, poor representation of species with fragile pollen and the impossibility of resolving taxa with conservative pollen types. Plant megafossil studies are complementary to palynology, as palynology gives an indication of regional vegetation while megafossils tend to reflect more local variationsh In spite of the difficulties of working with megafossils, they can provide information in those areas where the pollen record is deficient.

As far as possible I have tried to describe the floras within the context of their environments, rather than to treat them simply as exercises in systematics. I have not attempted palynological investigations of any of the localities but have used published and unpublished palynological records, where they are available, as a check on the megafossil determinations. The results outlined below present a new view of New Zealand Tertiary vegetation, but a great deal more work is required on Tertiary plant megafossils and pollen before a complete picture is obtained.

Compared with some other branches of paleobiology, paleobotany has received relatively little attention in New Zealand. Most work on fossil plants has concentrated on palynology because of its importance to 


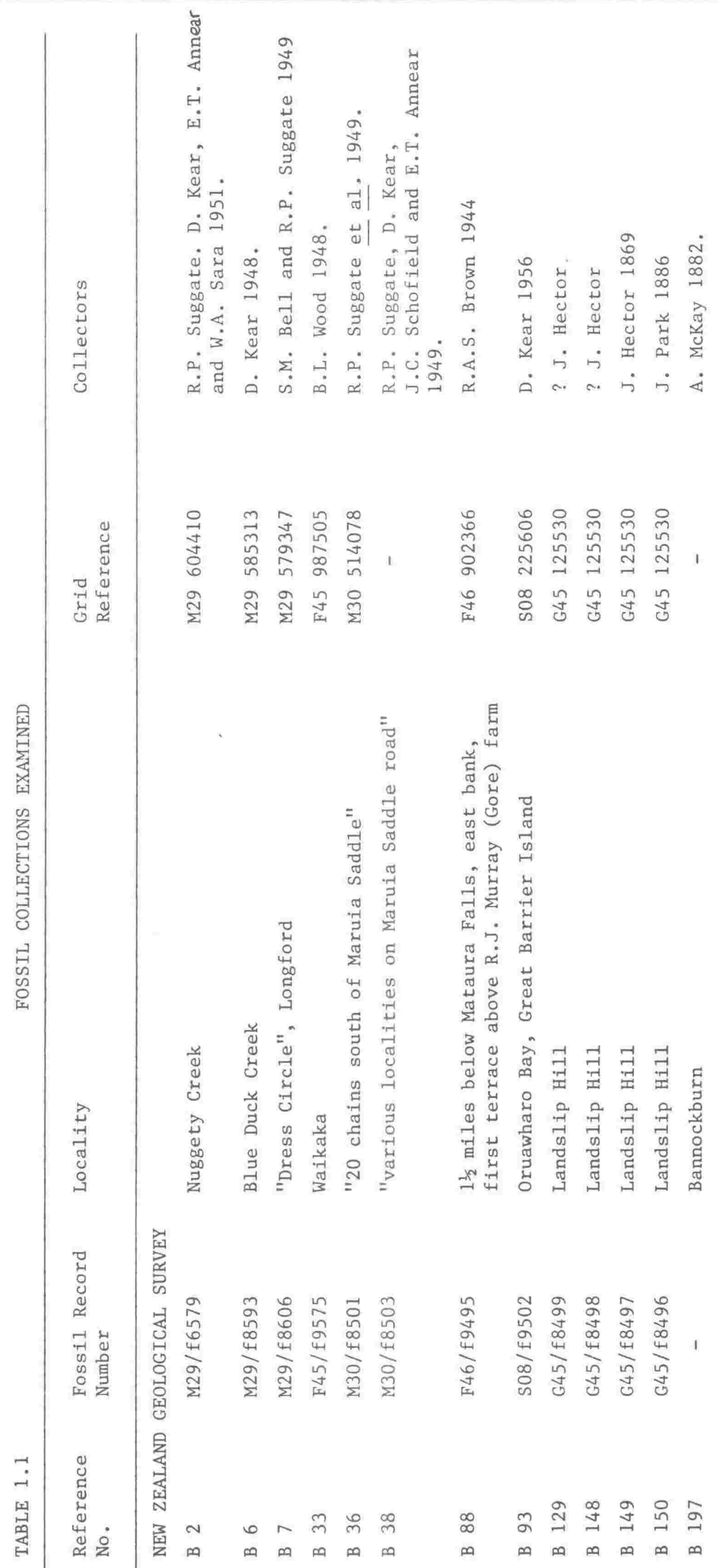




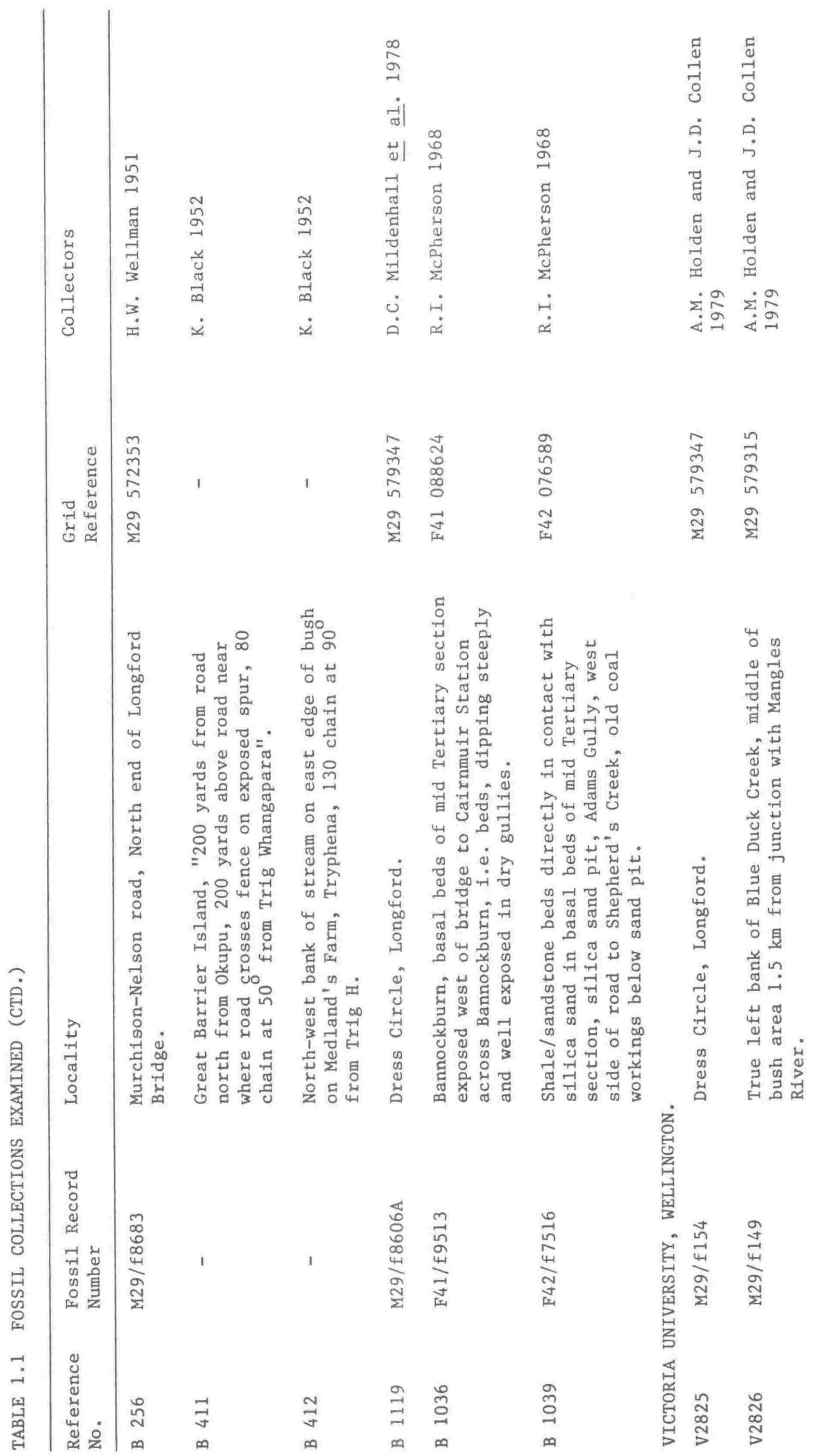




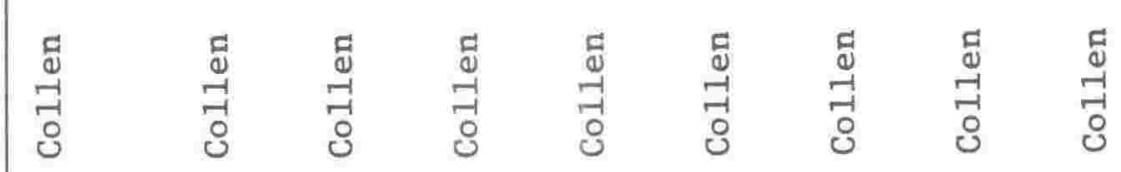

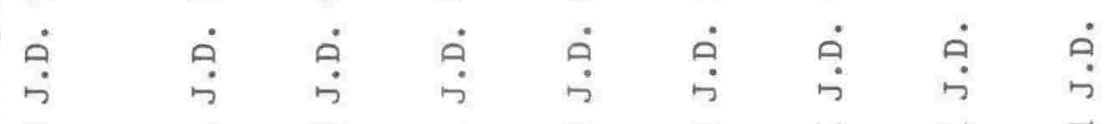

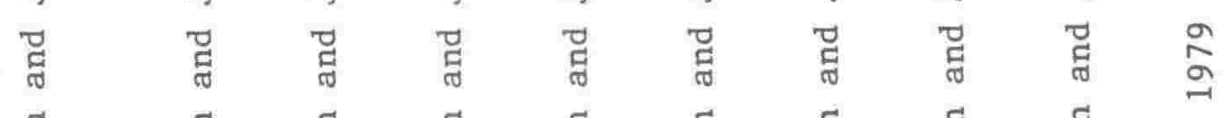

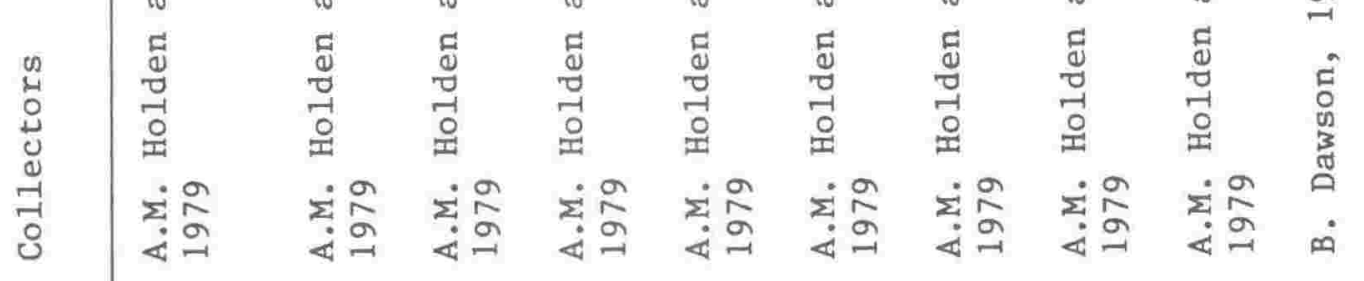

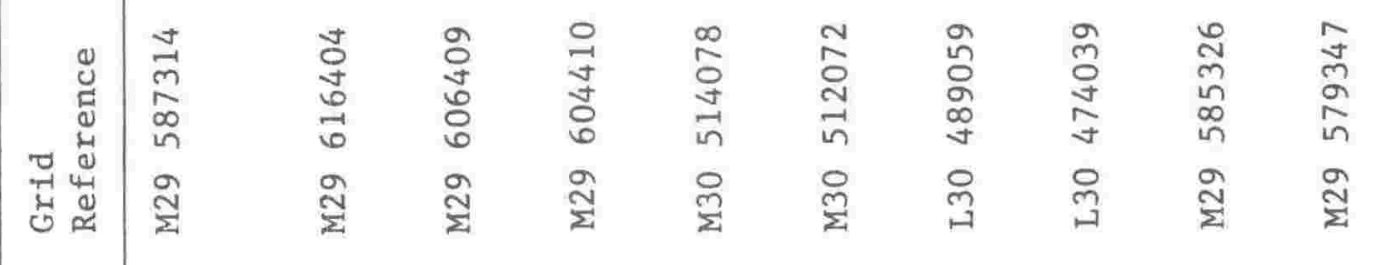

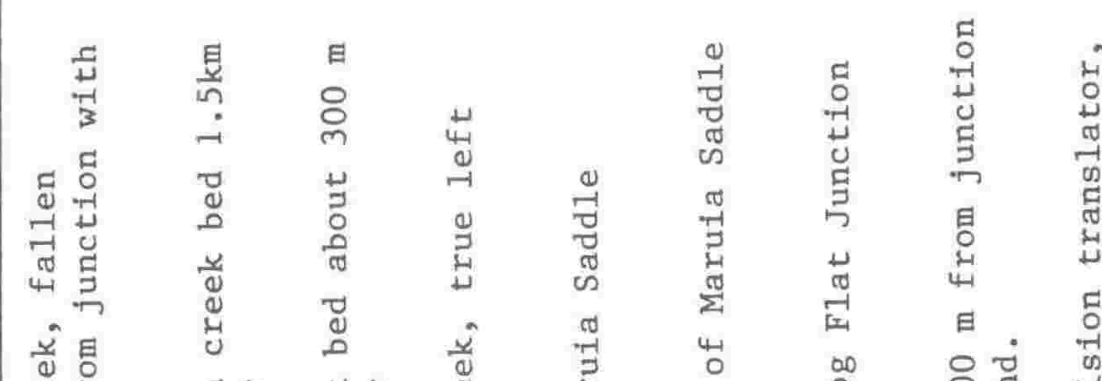

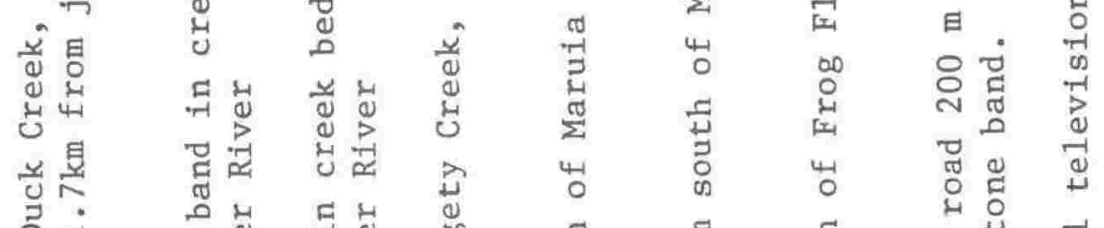

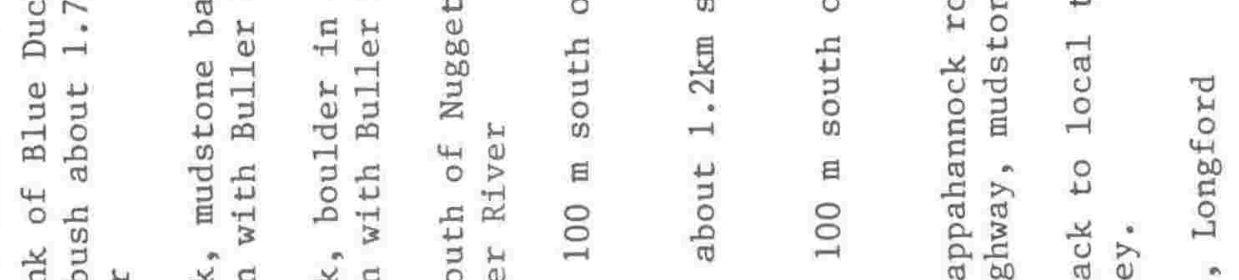

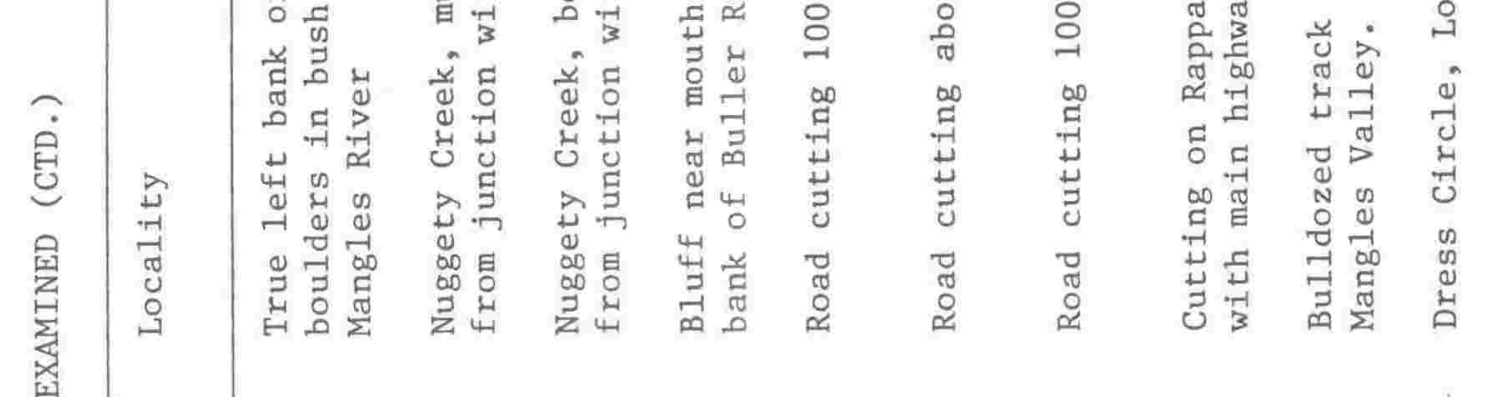




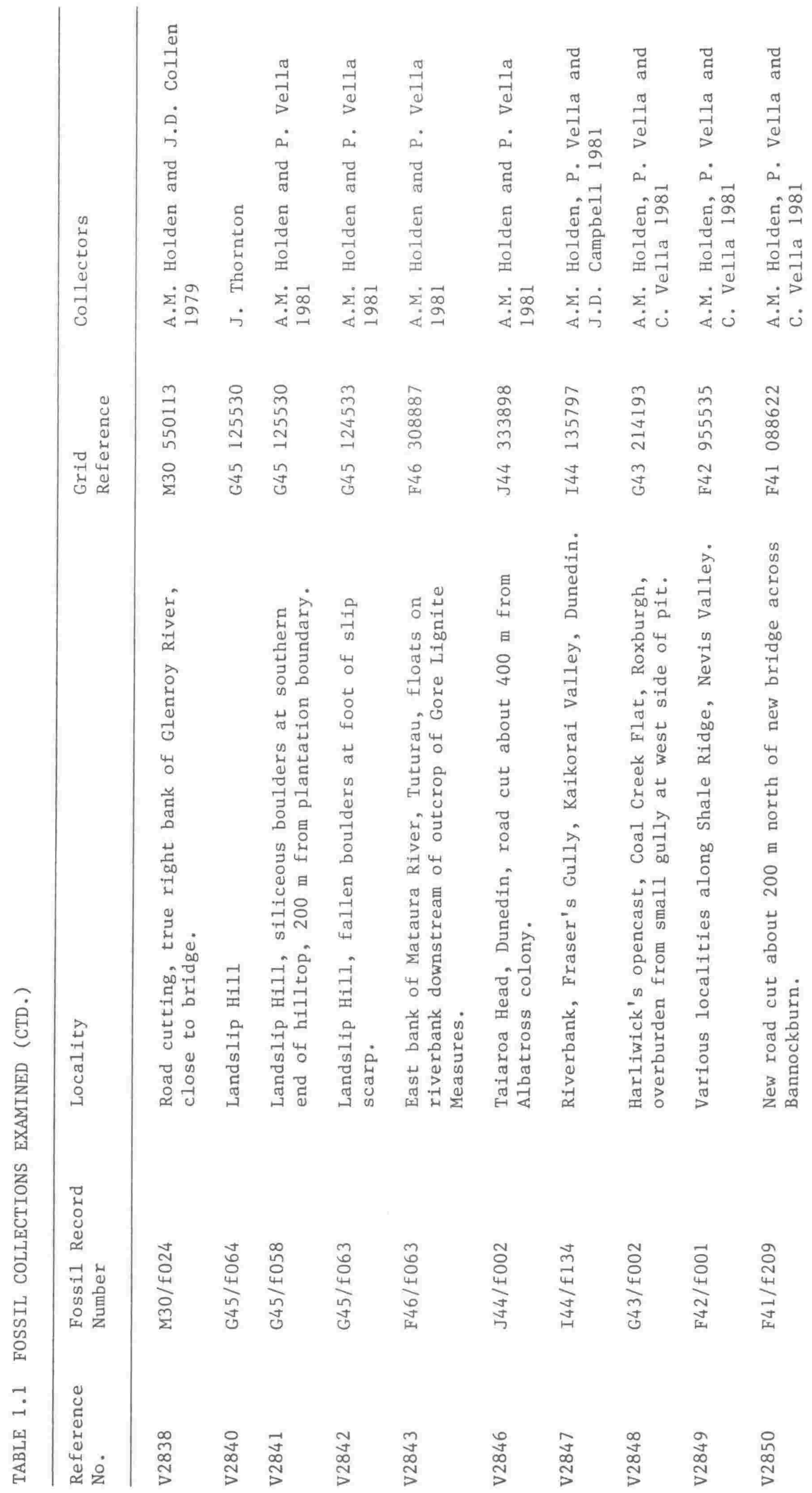




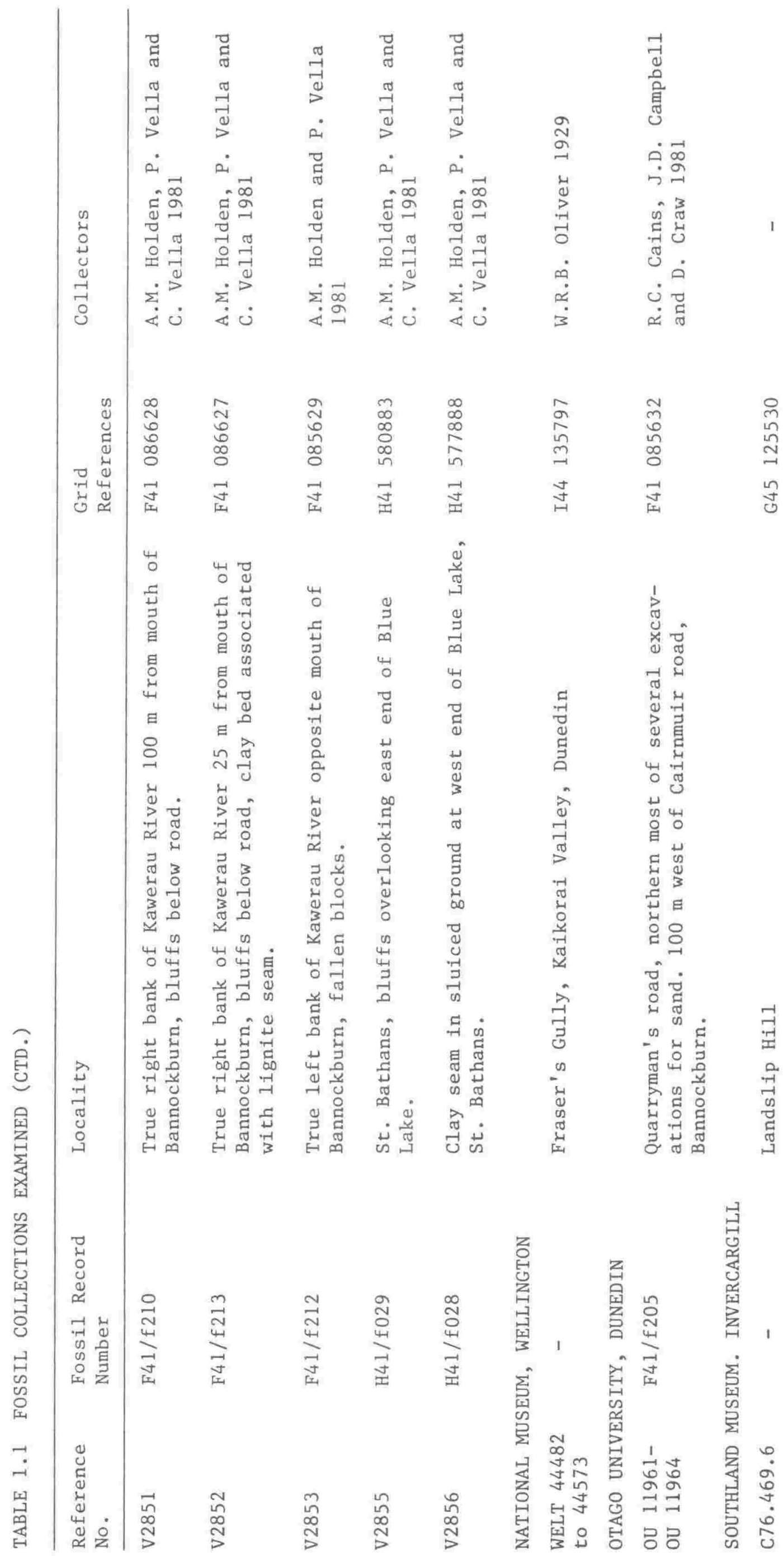


stratigraphy and paleoclimatology. Thus in New Zealand palynology and paleobotany have become more or less synonymous. New Zealand plant megafossils of all ages have received little attention, although recent work by Retallack (1979; 1981) has improved knowledge of New Zealand Triassic floras.

A number of publications in the latter half of the nineteenth century and in the first few years of this century dealt with the systematics of specimens from a number of localities of differing ages. Two of them, by Unger (1864) and Ettingshausen (1887), have formed the basis of most subsequent work on New Zealand Cretaceous and Tertiary plant megafossils. Lists of fossil plant names drawn up by Hector for a projected major work must be regarded as nomina nuda (Mildenhall 1970a). Tertiary material, the most relevant to the origins of the present flora, was largely neglected until Oliver (1928; 1936) and Penseler (1930) described fossil leaves from the Waipaoa Series of poverty Bay (Late Pliocene to Pleistocene), Kaikorai Valley, Dunedin (Upper Miocene) and Pukemiro Colliery, Waikato (Eocene). Evans (1931; 1937) investigated fossil wood from the Central otago lignites and reported evidence of Nothofagus, Agathis, Podocarpus, Dacrydium and Phyllocladus, but published few descriptions. Berry (1926) described Cocos and proteaceous fruits from Mangonui, North Auckland (Miocene), and McQueen (1953; 1954b). investigated Pliocene and Pleistocene megafossil floras from Rangitikei, Hawke's Bay and Poverty Bay. McQueen re-examined some of Oliver's material from Poverty Bay and made some revisions as well as describing new species of similar age from other localities.

The scanty literature on the Tertiary megafossils contrasts with the large amount of published information on New zealand plant microfossils, mostly by W.F. Harris, R.A. Couper and D.C. Mildenhall. The picture of Tertiary vegetation that has emerged is not in accord with that from early megafossil studies. As early as 1938, Kräusel (quoted in Evans, 1938) called for a re-evaluation of New zealand fossil plants as he doubted the accuracy of many of the identifications made by Ettingshausen and others, particularly those of north temperate affinities. Mouton (1966) suggested that such misidentifications were due to an unconscious bias on the part of the investigators which caused them to assign fossils to the taxa with which they were most familiar. Early assignments of New Zealand 
molluscs were similarly biased.

Long before plant microfossils were studied there was a difference of opinion concerning the plant megafossils. Hector (1879) saw little evidence to suggest that Tertiary floras were substantially different from those of the present, while Ettingshausen (1887) felt that only part of the Tertiary flora was ancestral to the present flora whilst the other part had become extinct without descendants.

One reason for the neglect of plant megafossils is the doubt of many botanists that they can be accurately identified. This problem applies to plant fossils of all ages but becomes critical in Upper Cretaceous and Tertiary assemblages, which are dominated by angiosperm leaves, because leaf characters are little used in angiosperm taxonomy and they tend therefore to be little studied. Accurate identification of fossil leaves with living genera and families is not, however, a prerequisite for usefulness in stratigraphic correlation, a fact that has tended to be overlooked in the face of criticism from botanists interested in phylogeny.

Seward (1898) discussed a number of potential sources of error in identifying plant fossils. The difficulties were also outlined by Mouton (1966), and include variability, parallelism of form, loss of characters in the process of fossilisation and the difficulty of distinguishing between simple leaves and the isolated leaflets of compound leaves. Mildenhall (1973) conducted an experiment involving the identification of plaster moulds of recent leaves, and found that even to experienced botanists leaf characters are sufficiently unfamiliar to cause misidentification in the absence of such information as colour, texture and general form of the plant. Some taxa caused more difficulty than others, highly distinctive leaf forms being more readily identified than more generalised leaf forms. A further factor, that of tectonic distortion, has been encountered in the present study.

Parallelism as illustrated by the following examples can lead to confusion between unrelated taxa. Leaves of species of Eugenia and Metrosideros (Myrtaceae) are closely paralleled by certain species of Ficus (Moraceae) such as F. benjamina, and leaves of Coriaria arborea 
(Coriariaceae), a dicotyledon, bear a striking resemblance to small leaves of Ripogonum scandens (Smilacaceae), a monocotyledon (pers. obs.). Cronquist (1968) mentiong that leaves of Gnetum gnemon (Gnetaceae), a gymnosperm, have sometimes been mis-identified as coffea arabica (Rubiaceae), an angiosperm.

Further serious problems result from loss of characters in the process of fossilisation. Relatively few fossil leaves are complete, leaf apices are often damaged, and frequently even where the leaf base is preserved much or all of the petiole is missing. Compound leaves usually break up into constituent leaflets, and stipules are seldom preserved. The quality of fossil impressions varies considerably. Anatomical details, particularly of leaves, are only observable in exceptional circumstances, for example in petrifactions or in mumified remains. Details of fine venation are not always present and sometimes only the main veins may be visible in the fossil. In addition, chemical or tectonic factors may destroy normally resistant cuticles. This is a common problem in New Zealand fossil leaves.

Asymmetry, one of Mouton's criteria for distinguishing isolated leaflets of compound leaves from simple leaves, is not completely reliable. A number of plants, including Myrsine asymmetrica and species of Euclayptus (Myrtaceae) and Mallotus (Euphorbiaceae) have asymmetrical simple leaves. Further, tectonic distortion of fossils may cause normally symmetrical leaves to appear asymmetrical.

However Mouton (1966) described how the problem of accurate identification of fossil leaves can be approached systematically and called for more detailed analysis of leaf characters of living plants as an aid to the identification of fossils. New methods such as scanning electron microscopy of latex and silicone rubber casts of fossil plants (Chaloner and Gay 1973; Watson and Alvin 1976) may give valuable information on epidermal characters where cuticle is not preserved, epifluorescence microscopy offers a method of examining fossil and living cuticles and other remains without involved preparation (Friedrich and Schaarschmidt 1977; Schaarschmidt 1981), and computer analysis of the architectural characters of living and fossil leaves may also prove helpful (Hill 1980 ).

Further difficulties occur in the environmental and climatic interpretation 
of fossil plant assemblages (Lange 1982). Hill 1981 concluded that long distance dispersal of plant remains would probably affect any interpretation based on foliar physiognomy, particularly if species from more than one vegetation type were included in the assemblage. Hill also pointed out that it is often difficult to determine the extent to which a fossil assemblage has been affected by long distance transport. However the distance that leaves can be transported is probably on average much less than the distance that pollen can be transported, and yet the paleoecology of fossil pollen is a vigorous and growing subdiscipline.

Black (1929), discussing plant beds from the Yorkshire Jurassic, distinguished drifted plant material from in situ plant material by several means. Drifted material was characterised by abundance of species, paucity of fragile forms and of entire leaves and fronds, alignment of fossils mainly parallel to bedding planes and marked difference between assemblages only a short distance apart stratigraphically. In situ material contained more comminuted debris, fewer species, more whole fronds and delicate forms and stems and roots at angles to the bedding planes. Since many of the plant fossils examined in the present study appear to be drifted, material could have come from some distance and may reflect not only the vegetation of the immediate vicinity, but also that of the hinterland. Few studies have been undertaken in New Zealand to show to what extent drifted debris reflects the vegetation of the immediate surroundings. McQueen (1969) investigated lake and swamp sediments at Lake Pounui in the eastern foothills of the Rimutaka range (Wellington Province). He found that only a small proportion of the available material is likely to be fossilised, and of this, species with coriaceous or very fibrous leaves are likely to be over-represented. Further, lakes fed by slow flowing streams, where swamps may act as filters, contain leaves and fruits from the immediately adjacent vegetation in their sediments, while areas of deposition fed by freely flowing streams may contain a considerable proportion of allochthonous material. It is likely therefore that leaf beds associated with lacustrine sediments and coal seams may more accurately represent the vegetation of the immediate surroundings than leaf fossils in fluvial sediments.

More recently Drake and Burrows (1980) found a good qualitative and quantitative representation of the surrounding forest, excepting ground layer plants and epiphytes, in samples of litter from the bottom of Lady 
Lake, Westland. Swamp monocotyledons and aquatics were also poorly represented, probably because of poor preservation and the overabundance of leaf and twig litter. Seeds were uncommon. Well preserved litter was concentrated near the lake shore, the authors inferred that most litter entered the lake by stream and wind transport and direct fall.

The present writer made a brief qualitative examination of drifted plant debris deposited on the flats about the mouth of the Aorere River at Collingwood, northwest Nelson. Leaves and recognisable fragments of a large number of species were observed, together with much comminuted debris. The species identified were Beilschmiedia tawa, Coriaria arborea, Weinmannia racemosa, Coprosma robusta, Laurelia novae-zealandiae, Nothofagus fusca, N. solandri var solandri, N. menziesii, Myrsine sp. and Olearia sp. As the living vegetation at the mouth of the Aorere River is largely salt swamp dominated by Juncus maritimus var. australiensis Buch. and introduced pasture grasses, most of the leaves must have been transported a considerable distance. In particular Nothofagus menziesii does not grow in the lowlands but is found in the ranges $10-15 \mathrm{~km}$ from the Aorere River mouth. Recognisable podocarp remains were rare, and most seen were still green. Contrary to expectation, podocarp branchlets may be broken up rapidly and are not readily preserved. Podocarps, and possibly other conifers as well, may be under-represented in drifted fossil assemblages. Recognisable monocotyledonous material was rare. The bulk of the dicotyledonous leaves were coriaceous and included abundant Nothofagus leaves. In New Caledonia, where degradation of forest litter is rapid the writer has noticed that the litter in beech stands contains a higher proportion of whole leaves than that in the surrounding forest. This is particularly true for stands of $\mathrm{N}$. aequilateralis, where the soil surface may be covered by a more or less complete carpet of whole leaves (pers.obs.). Furthermore, in a study of nine beech forest lakes in Westland, New Zealand, Paerl et al. (1979) concluded that most of the organic material present in the most heavily stained of the lakes was derived from the surrounding beech forests and that much of this material was at least partially resistant to degradation, again suggesting that Nothofagus leaves may be preferentially preserved and over-represented in fossil floras.

In paleoenvironmental reconstructions it is usual and often necessary 
to assume that fossil species had similar ecological requirements to their living relatives. Hughes (1976) pointed out that this assumption may not always be valid, citing the case of the Upper Cretaceous conifer which produced classopollis pollen. This plant appears to have been a member of the mangrove community, a habitat occupied by no living conifer. Townrow (1965b) suggested that both Athrotaxis and Microcachrys, conifers at present confined to cool, humid areas of Tasmania, preferred lowland habitats in Tertiary times.

Various physiognomic parameters have been used as indicators of paleoclimate. In general, tropical and subtropical forests are marked by evergreen trees with leaves in the mesophyll size range (lamina area 20.25 to $182.35 \mathrm{~cm}^{2}$, Dilcher 1974). Webb (1959) recognised a notophyll (small mesophyll), lamina area 20,25 to $45.0 \mathrm{~cm}^{2}$ ) size category which characterised Australian subtropical forests.

The proportion of entire-margined leaves in a fossil flora has been extensively used in the past as an index of paleoclimate. This is based on the conclusions of Bailey and Sinnott $(1915 ; 1916)$ who found from an analysis of regional floras a relationship between a high percentage of species with entire leaf margins and a high mean annual temperature. There were a number of notable exceptions, among them the flora of New Zealand with a high percentage of species with entire leaf margins but a relatively low mean annual temperature.

Wolfe and Hopkins (1967) and Wolfe (1971) used Bailey and Sinnot's conclusions to deduce large climatic fluctuations during the Tertiary on the Pacific coast of North America. Axelrod and Bailey (1969), while accepting that climatic fluctuations had taken place, disputed that the variations were of the magnitude claimed by Wolfe and Hopkins. Dolph (1979) failed to find any significant correlation between the percentage of species with entire leaves and mean annual temperature in the vegetation of Costa Rica. He concluded that while the relationship proposed by Bailey and Sinnot may hold for large regional floras, most fossil floras are the result of purely local depositional processes, or at least contain an over-representation of lakeside and streamside plants. It seems therefore that leaf margin characters are a dubious index of paleotemperature. 
Recently Romero (1980) has suggested a relationship between climate and compound toothing of the leaf margins of different species of Nothofagus in South America, suggesting that compound teeth are characteristic of an oceanic climate. This hypothesis is as yet untested.

The living flora of New Zealand is unique in several ways. The proportion of woody evergreens is high compared with northern hemisphere temperate forests, and a number of lowland forest species show growth habits characteristic of tropical and subtropical vegetation; for example buttressed trunks (Laurelia, Nothofagus fusca, N. truncata), strangler habit (Metrosideris robusta), cauliflory and ramiflory (Dysoxylum, Melicytus), 'tank epiphytes' (Astelia, Collospermum), woody lianes (Parsonsia, Metrosideros spp.) and shrubby epiphytes (Griselinia). Lowland podocarp-broadleaf forests are structurally complex.

Cockayne (1928) identified seven distinct elements in the modern New Zealand flora and named them Endemic, Cosmopolitan, Australian, Subantarctic, Lord Howe and Norfolk Island, Paleotropic and Paleozealandic. In view of the present isolation of the New Zealand botanical region, the presence of plants with close relatives in such distant areas as Southeast Asia and southern South America has posed a problem to phytogeographers. The recently developed plate tectonic hypothesis has provided an economical solution to some of the problems, although there is still considerable debate as to the relative importances of long distance dispersal and in situ evolution.

\section{considered in terms of geologic time}

The vegetation of a given area $/$ is not static but is undergoing constant change and development. Its composition at any time is a function of ancestry, existing and preceding environments, and geographic connections, both past and present. The high degree of endemism in the New Zealand flora, estimated to be from 80\% (Cockayne 1928) to 85: (Millener 1960; Moore 1979), indicates long isolation. The fact that many of the endemic species are restricted to small areas and belong to large genera such as Coprosma, (Rubiaceae), Hebe (Scrophulariaceae) and Olearia (Compositae) in which interspecific hybridisation and polymorphy are common, suggests that these groups have undergone 
recent and rapid diversification (Raven 1973). The small number of genera involved may indicate a reduction in the flora prior to diversification. Some support for this is provided by the low diversity of lowland species, with about 100 genera and 130 species (an average of 1.3 species per genus) compared to a world average of about 12.5 species per genus (Millener 1960). The most positive data for resolving the question of the age and origin of various elements of the modern flora are in the fossil record. Mildenhall (1980) has summarised the evidence from pollen, but the history of some families, for example Lauraceae, cannot be determined by this means (D.C. Mildenhall, pers. comm.).

Many paleobotanical authors treating Cretaceous and Tertiary fossils for example Axelrod, Chaney and Macginitie have assigned fossils to Recent genera. This practice has drawn considerable criticism, particularly from Hughes $(1963,1976,1978)$. In general, the older the fossils the more dubious such identifications become, and Hughes (1963) proposed that the code of Botanical Nomenclature be modified to incorporate a time factor in the definition of genera as applied to fossils. That suggestion has not been adopted (vide Stafleu, 1978).

The normal procedure has been followed in this account, with the reservation that the genera and species described must be qualitatively different from living taxa in that they are based on isolated organs rather than on complete plants. 
Materials

In February 1979 the writer with Dr. J.D. Collen collected plant fossils from eleven sites in the Murchison-Maruia area. Material from a further 15 sites in Otago and Southland was collected by the writer and Professor P. Vella in January 1981. A small collection from Longford was donated by Mr. Brett Dawson and another from Landslip Hill by Mrs. Jocelyn Thornton. Additional material was loaned by the Southland Museum and a large amount by the N.Z. Geological Survey, Lower Hutt. A list of the collections examined is given in Table 1.1.

Most of the material studied was dicotyledonous leaf fossils, with fewer gymnosperms and ferns, and rare monocotyledons. Fruits and seeds were uncommon except at Landslip Hill. Matrices varied from poorly consolidated sandstones and clays through indurated sandstones and siltstones to strongly cemented quartzite, and modes of preservation varied from impressions and carbonised compressions to mummified leaves with well preserved cuticle and structurally preserved silicified material. This variability necessitated a number of different study methods.

The fossils were compared with specimens of New Zealand and exotic plants collected by the writer, and with material in herbaria at the Botany Department, Victoria University, the National Museum, Wellington, and at O.R.S.T.O.M., Noumea, New Caledonia.

\section{Methods}

Each fossil was catalogued and fully described. Direct, oblique and reflected illumination were used singly and in combination to show up surface features. Well preserved specimens of each leaf or fruit type were selected for illustration by photography and drawing.

\section{Photography}

Photographs were taken on Ilford FP4 or Ilford Pan F film developed in Microphen, using a $35 \mathrm{~mm}$ single lens reflex camera with extension tubes, or a plate camera, and were printed using medium to hard (3-4) grade paper. It was found that photographs rarely gave completely satisfactory illustrations of fossil leaves. In the case of carbonised compressions 
a $2 \mathrm{X}$ yellow filter gave some, and a $4 \mathrm{X}$ red filter gave substantial, improvement in contrast. An experiment was conducted using infra red film. The same fossils were photographed using FP4 film and a 4X red filter and Kodak infra red black and white film with a $1 \frac{1}{2} \mathrm{X}$ blue filter. The infra red film was processed for 5 mins in Microphen. A comparison of the results is shown in Fig 2.1. The photographs taken with infrared film show a small improvement in contrast, but this is largely off-set by the coarse grain structure. The experiment might repay repeating with different fossil material, but results obtained so far indicate that only marginal improvements in clarity can be expected. The film is difficult to handle owing to its sensitivity to heat and light. As cameras must be loaded and unloaded in darkness and film must be stored under refrigeration and processed as soon as possible after exposure the technique is unsuitable for use in the field without special equipment.

\section{Drawings}

Drawings were prepared using a modification of a method described by Dilcher (1974). Acetate film was taped over the selected fossil and the leaf outline and venation pattern traced onto the film with a sharp needle. A dissecting microscope was used to assist recording of fine detail. The drawing was then rubbed with a soft pencil (grade 6B) to fill the scratches, taped on to thin white paper, placed on a light table and traced. Owing to the irregular surface of many of the fossiliferous blocks it was necessary to cut small pieces of acetate to fit, thus making the photographic method of reproduction recommended by Dilcher difficult. While the method is capable of producing fairly detailed drawings the act of scratching the acetate tends to obscure the finer details and produces confusing shadows. Very small specimens and details of fine venation were drawn using a camera lucida fitted to a Leitz dissecting microscope or a drawing attachment on a wild binocular microscope.

\section{Preparation techniques}

Fossil leaves from St. Bathans (H41/f028) and Kaikorai (I44/f134) which had adhering cuticle were lifted on collection using transparent adhesive tape and placed in envelopes, indexed and filed. The fossil cuticles were prepared by the method described by Christophel and Blackburn (1978), stained with Saffranine 0 , and mounted in phenol glycerine jelly. 

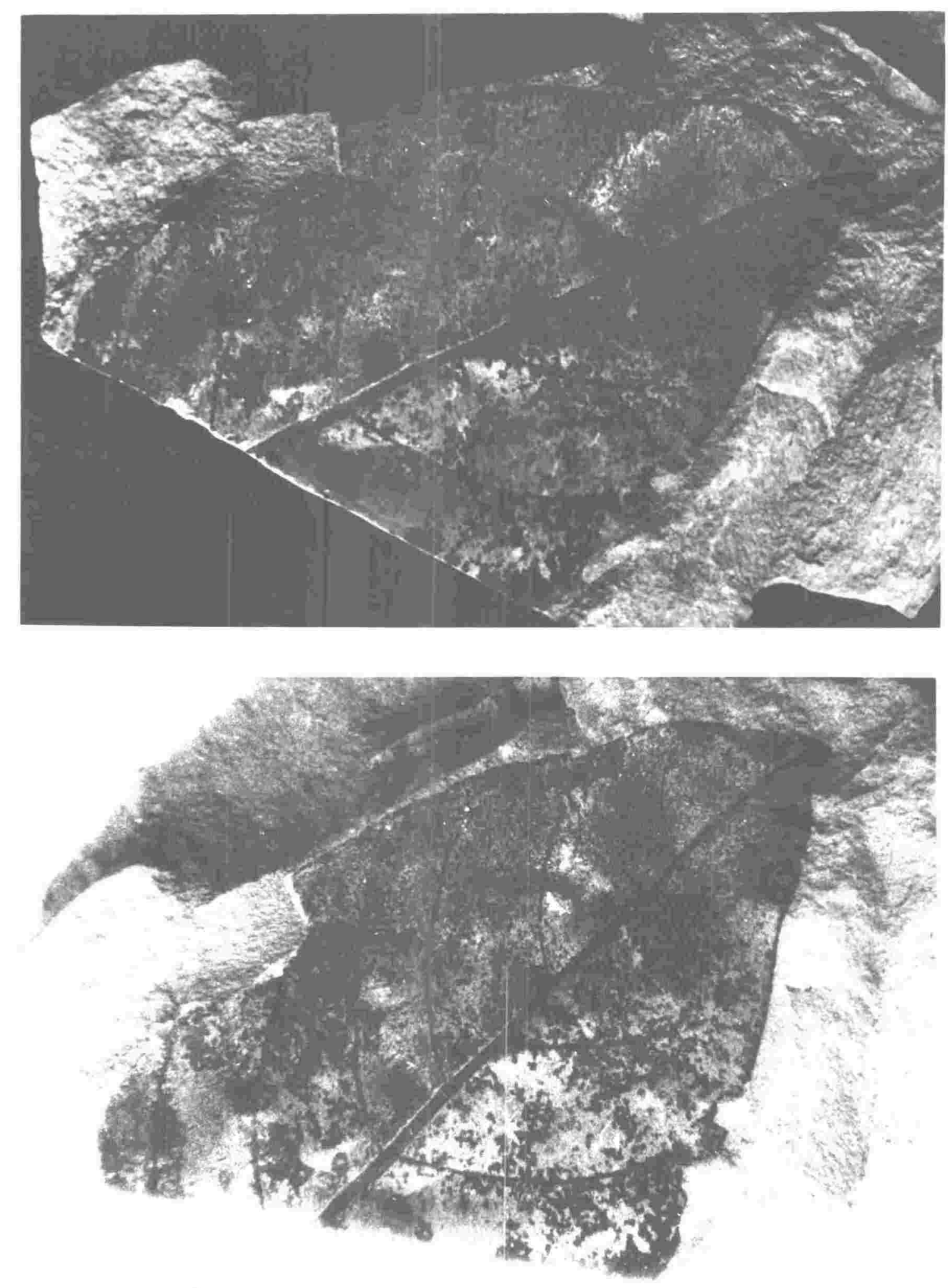

FlG, 2,1: Comparison of white light and infrared photography.

TOP, Fossil leaf photographed using FP4 film and $2 X$ red filter.

BOTTOM, The same leaf photographed using infra-red film and 1,5X blue filter (see text). 
described by Chaloner and Gay (1973) using casting latex supplied by Para Rubber Company. While this material was easy to use, took a good impression, and could be readily removed from the mould, the casts showed appreciable shrinkage after a few days and were unsuitable for accurate measurement. Silicone rubber casts were prepared as described by Watson and Alvin (1976) and Kelly and McLachlan (1980) Using Silastic 3120 RTV (Dow-Corning), with Teepol as release agent. The greater viscosity of the uncured rubber, and a tendency to brittleness when cured, makes application to, and removal from, complex moulds somewhat difficult, but the material shows less shrinkage than latex, giving measurements closer to the true dimensions of the original. The use of a release agent is essential.

\section{Scanning Electron Microscopy}

Silicified sediment and plant material from Landslip Hill, and silicone rubber casts of natural moulds from Landslip Hill and impressions from other localities were examined using the scanning electron microscope. All materials for scanning electron microscopy were mounted on stubs, coated with gold-palladium and examined in a Phillips 500 Scanning Electron Microscope at an accelerating voltage of $30 \mathrm{kv}$.

\section{Living material}

For comparison purposes leaf skeletons and cleared leaves were prepared as described by Dilcher (1974). Leaf skeletons were pressed after bleaching and mounted on black card. Cleared leaves and parts of cleared leaves were mounted in canada balsam between glass slides. Skeletons can be obtained readily from leaves such as those of Melicytus and Nothofagus but the process is not as successful with leaves with less fibrous venation, and skeletons could not be prepared from fleshy or leathery leaves such as those of Araliaceae. It was usually necessary to dry slides of cleared leaves mounted in canada balsam under weights.

\section{Thin sections}

Thin sections of sandstones from the Longford and Frog Flat Formations and silicified sediment and wood from Landslip Hill were prepared and examined by standard procedures. 
The plant megafossils described here are from the Upper Oligocene to basal Miocene rocks of the Gore Lignite Measures (Wood 1956). These underlie most of the lowland around Gore and in the Mataura Valley (Wood 1956, 1966). The principal fossil plant locality is at Landslip Hill $10 \mathrm{~km}$ east of Gore. Fossil wood is abundant in most lignite pits, but fossil leaves have been found in few of them and are rare. None were found by the writer in thorough searches of the Mataura Paper Mills pit and the now abandoned and flooded pit at Asher's Siding east of Invercargill, and only a few poorly-preserved impressions in fallen blocks of overburden at Goodwin's opencast, Waimumu.

Tertiary deposits are limited almost entirely to the lowlands where they unconformably overlie strongly folded and deeply weathered Permian to Jurassic basement (Wood 1956). The most elevated outcrop is at Landslip Hill (335 m). At a number of places, for example west of Waimumu and to the north and west of Chatton and Waikaia (Wood 1966). Tertiary deposits are faulted against the pre-Cretaceous rocks which form the major upland areas. Except in the north of the Gore Subdivision and in the Waikaia district and the vicinity of Landslip Hill, the Landon strata are covered by Pliocene and Quaternary gravels.

The region was warped and faulted in the late Tertiary (Wood 1956, 1966). Two structural trends have caused alignment of topographic features: a northeast trend related to Tertiary tectonic movements, and a more obscure northwest trend caused by renewed activity on Mesozoic structures formed during the Rangitata Orogeny. Faulting and lateral variation of the sediments made correlation of the lignite seams difficult before the recent coal exploration programme. (Isaac 1981a, 1981b).

Although Hector had collected plant fossils from Landslip Hill as early as 1862 (Ettingshausen 1887), the first published reference was by Montgomery (1883) in a letter to the editor of the N.Z. Journal of Science in which he described the occurrence of fossil plants in quartzite exposed in a large landslip about 5 miles from Pukerau railway station. Ettingshausen (1887) described five species of fossil plant collected from Landslip Hill naming them as Sequoia novae-zeelandiae, also known from Shag Point, Otago (Haumurian), Dryophyllum dubium, Apocynophyllum elegans, A. affine and Elaeodendron rigidum. Oliver (1950) assigned Apocynophyllum 
elegans to Pittosporum and recorded the presence of Carpodetus, Pomaderris, Araucaria, Dacrydium and a leaf "... resembling the extinct fern Linguifolium". Oliver also considered plant fossils from Ohat to be of 0ligocene age but they are now known to be of Cretaceous to Eocene age (Bowen 1964). Bell (in Wood, 1956) identified a single leaf from a lignite pit near Gore as Geniostoma and Evans (1937) identified a number of woods from lignite from the area. Until now there has been no further work on plant megafossils from the Gore Lignite Measures.

Couper (1953b; 1960a) and later D.C. Mildenhall and D.T. Pocknall (unpublished work; Pockna11,1982a,b) have examined a large number of samples from the Gore Lignite Measures for pollen.

\section{GEOLOGY}

The Gore Lignite Measures (Wood 1956; Couper 1959) are Landon (Oligocene to Lower Miocene) fresh-water beds outcropping extensively in the Gore district and the Mataura Valley (Map Fig 3.1). They are thickest and most extensive in the west where they interbed with the Chatton Marine Formation, and are thin and discontinuous in the east (Wood 1956). On the western side of the Pomahaka Valley the lignite measures are interbedded with the Pomahaka Estuarine Bed which passes laterally into a bed of quartzose greensand on the eastern side of the valley. In the Waikaia district Healy (1936) recognised two units of lignite measures, an upper Waikaia "Series" and a lower Welshman's "Series" separated by the Chatton Marine Formation.

Lindqvist (1983) referred to the complete lignite-bearing sequence in the Gore Area as the Gore Formation, locally interbedded with the Chatton Marine Formation and included the Pomahaka Estuarine Bed and interbedded lignite seams within the Gore Formation as Pomahaka Member. The lignite measures contain carbonaceous sandstones and siltstones, mudstones, quartz sandstones, quartzites, white kaolin clays, lignite seams and rare quartz gravels (Wood 1956, Couper 1959). In some places lignite seams have been on fire in the past, forming "porcellanites" (reddened baked sediments) which are particularly common along Okapua Creek north of Chatton, (Wood 1956, 1966). Lignite has been mined at many localities, mainly in small private opencast workings. Oil shale was formerly mined from one pit about a mile north of Freshford as fuel for gold dredges (Morgan 1914), but the pit has now collapsed and shale is no longer exposed (Healy and Willett 1937). 


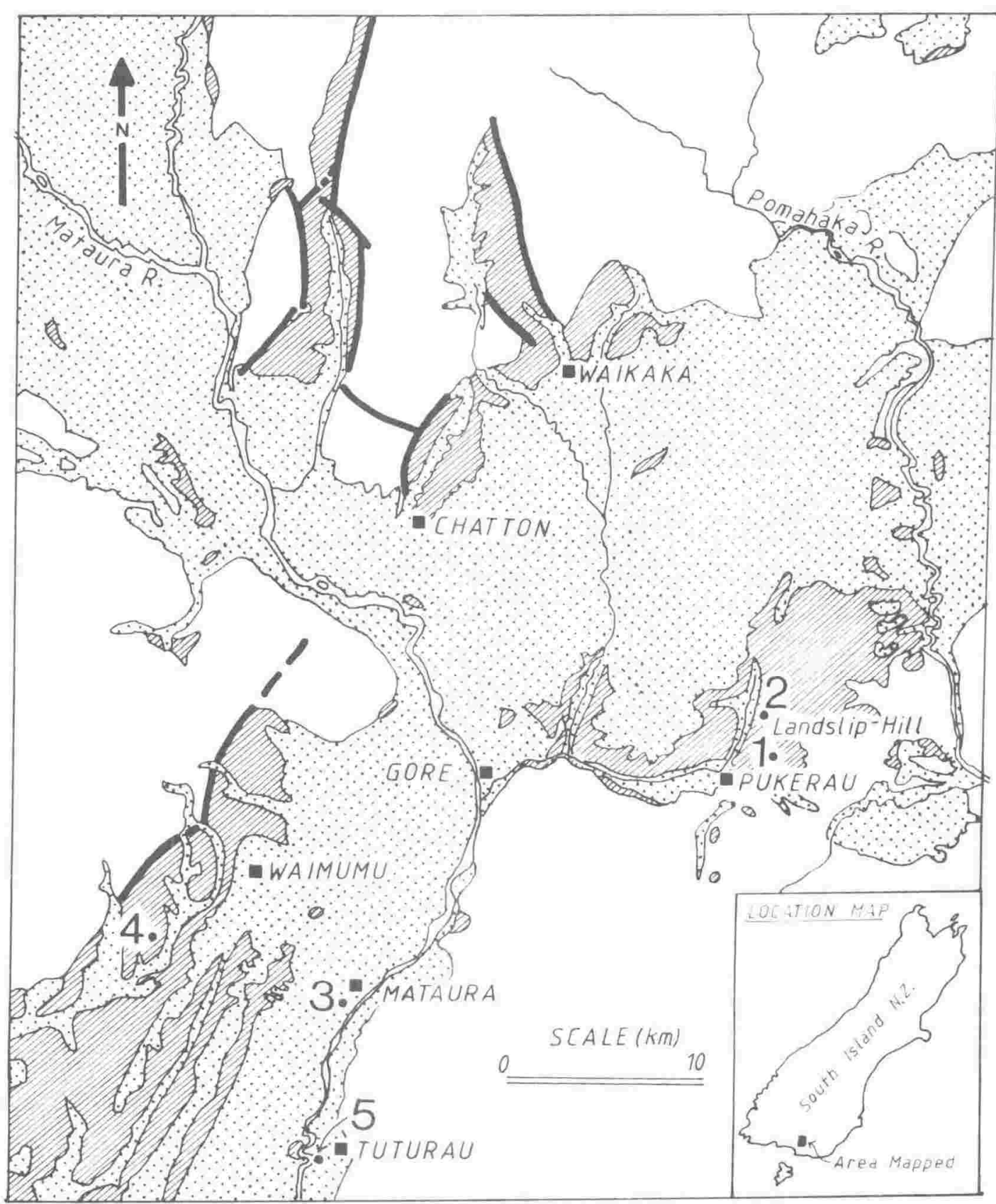

ED. Gore Lignite Measures

$\because$ Undifferentiated Pliocene and Quaternary gravels FlG, 3.1 Map of Gore district showing major outcrops of Gore Lignite Measures and cover beds [after Wood 1966]

Fossil sample sites:

1. Landslip Hill summit.

2. Landslip Hill, slip face.

3. Mataura Paper Mills opencast.

4. Goodwin opencast. Waimumu.

5. Riverbank section. Tuturau. 

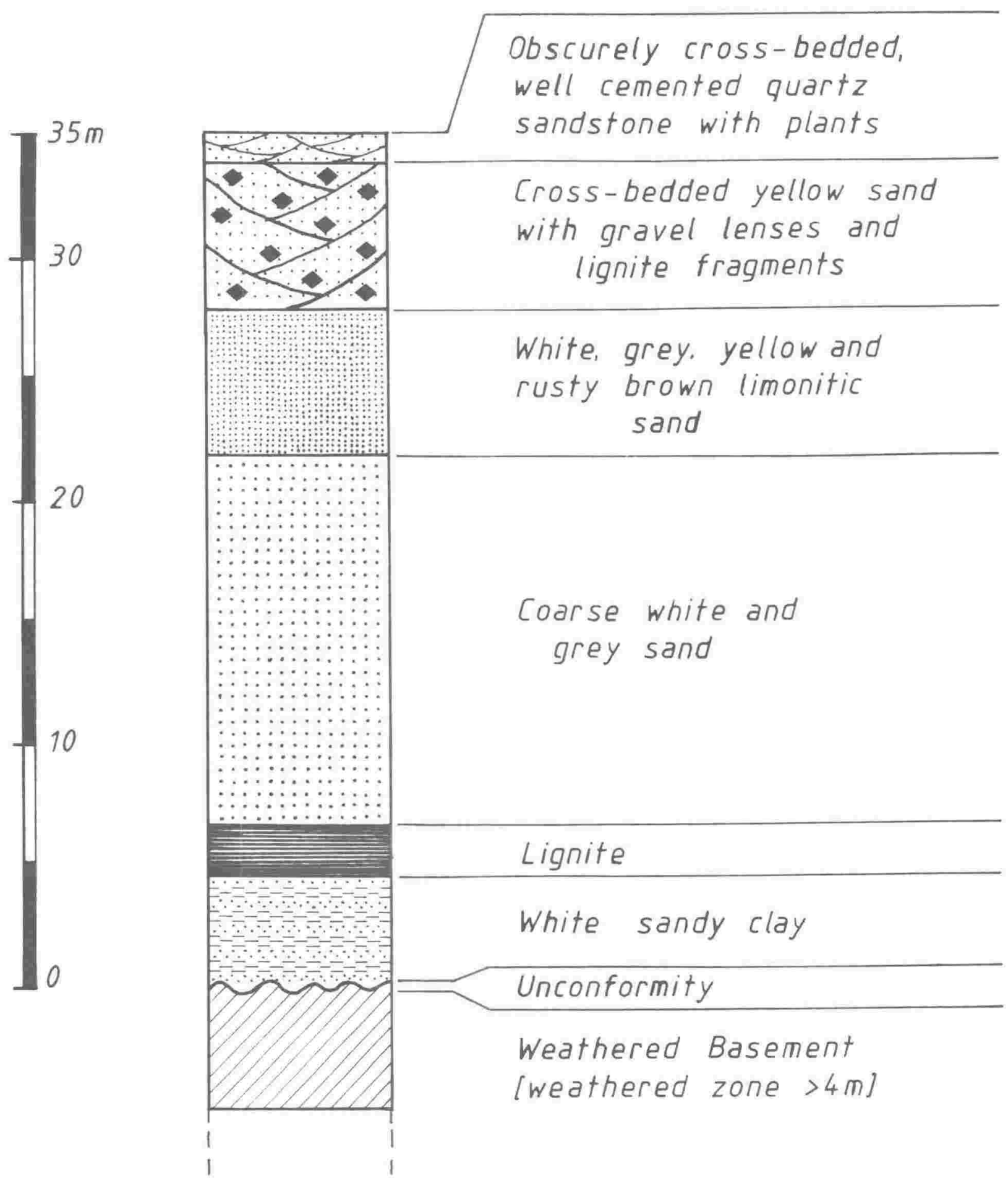

Fig. 3.2 Stratigraphic column for section at Landslip Hill [data from Wood 1956] 


\section{$\underline{\text { Landslip Hill section }}$}

Landon beds dipping gently at an angle of about $10^{\circ}$ are exposed at Landslip Hill, near Pukerau east of Gore (Map, Fig 3.1). In situ beds were obscured by slumping at the time of the writer's visit and a stratigraphic column (Fig 3.2) has been compiled from data given in Wood (1956). The Tertiary sequence unconformably overlies deeply weathered basement. The lowest unit is described as a white sandy clay, and is overlain by a lignite seam about $2 \mathrm{~m}$ thick. Above the lignite are several thick beds of sand, all poorly consolidated. The quartzite itself forms a relatively thin capping bed 1 to $1.5 \mathrm{~m}$ thick.

About seven kilometers to the north of Landslip Hill, sections exposed in a series of slump blocks along the north face of Cemetery Hill, Waikoikoi Valley, show Pomahaka Beds overlying Permian basement and in turn overlain by $60 \mathrm{~m}$ of quartzose fluvial deltaic sands, conglomerates and silty clays of the Gore Lignite Measures, an unknown thickness of Chatton Marine Formation and a further 50-100 m of Gore Lignite Measures including Landslip Hill Quartzite. The Pomahaka Beds in this area contain both marine and freshwater facies (Lindqvist and Pocknall, 1983).

Several large landslips have occurred on the west side of the hill. The most recent has formed a semicircular scar more than $1 \mathrm{~km} 1$ ong and $30 \mathrm{~m}$ high (Fig 3.3). A train of hummocky debris extends for $2 \mathrm{~km}$ into Landslip Valley, with frequent large boulders of quartzite. Several small tarns and numerous boggy hollows have formed on the surface of the slip debris. The distribution of organic remains in the slip scar is not uniform, with large branches being commoner at the northern and southern ends than in the centre.

Numerous large boulders of quartzite litter the top and western flanks of the hill. Many specimens were collected from the southern end of the summit plateau close to the boundary of Pukerau Plantation (Fig 3.4). Boulders here contain abundant plant material including moulds of substantial tree trunks (Fig 3.5). The material is extremely hard and fossils could only be collected with the aid of a sledge hammer. The rock splinters with a roughly conchoidal fracture and no preferred direction of cleavage. 


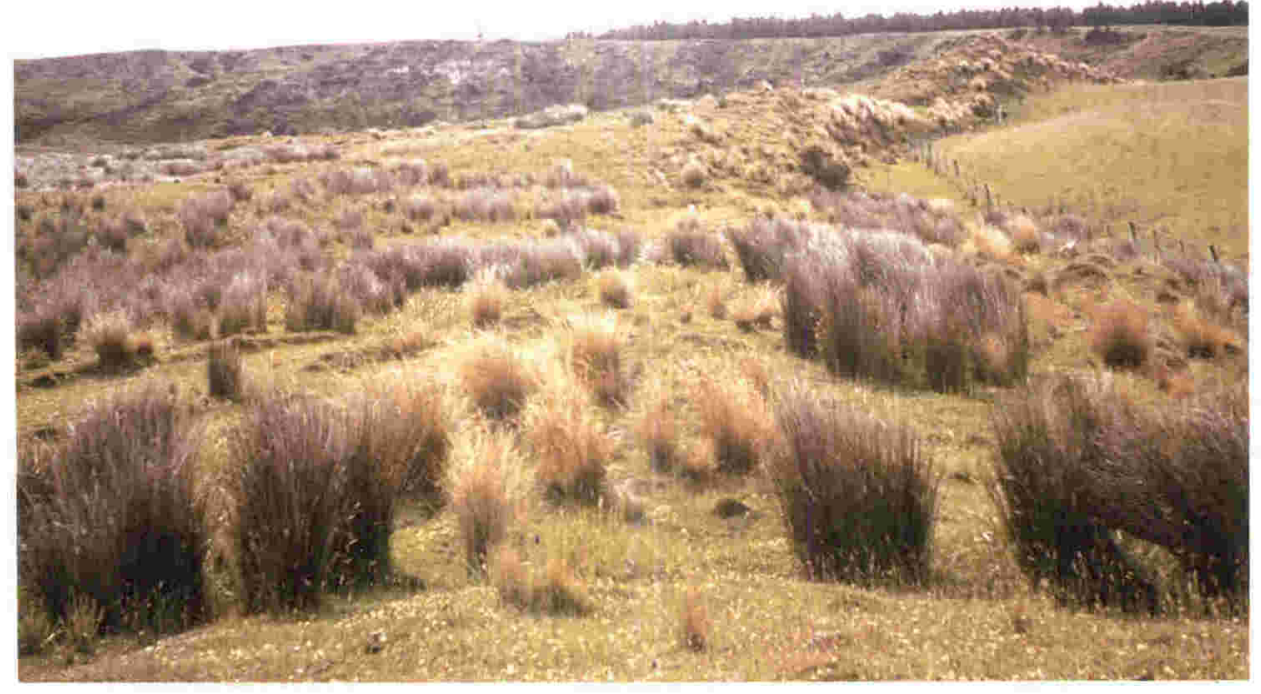

FlG, 3 . 3 Landslip valley looking east: southern sector
of slip scarp and margin of debris train.

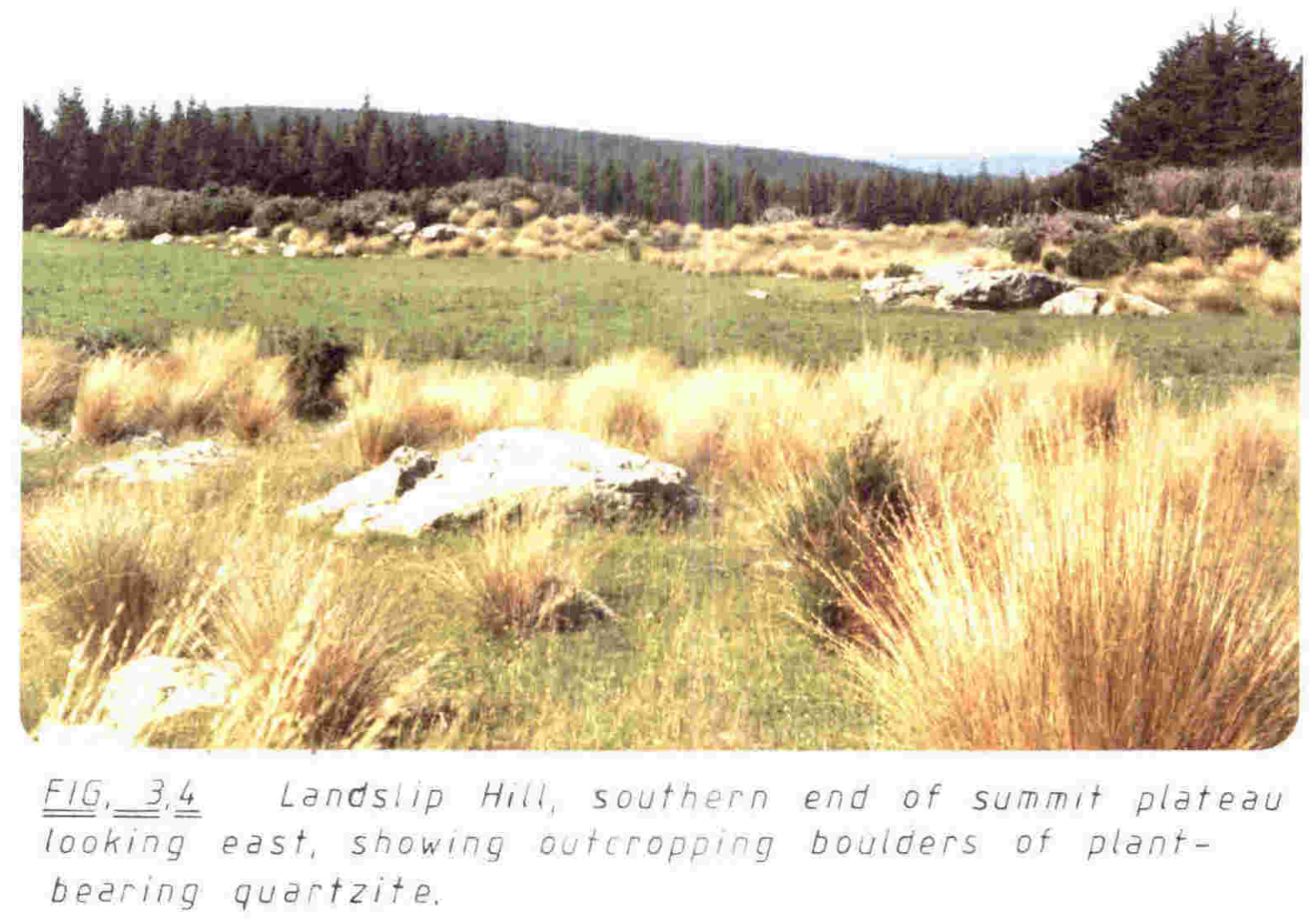




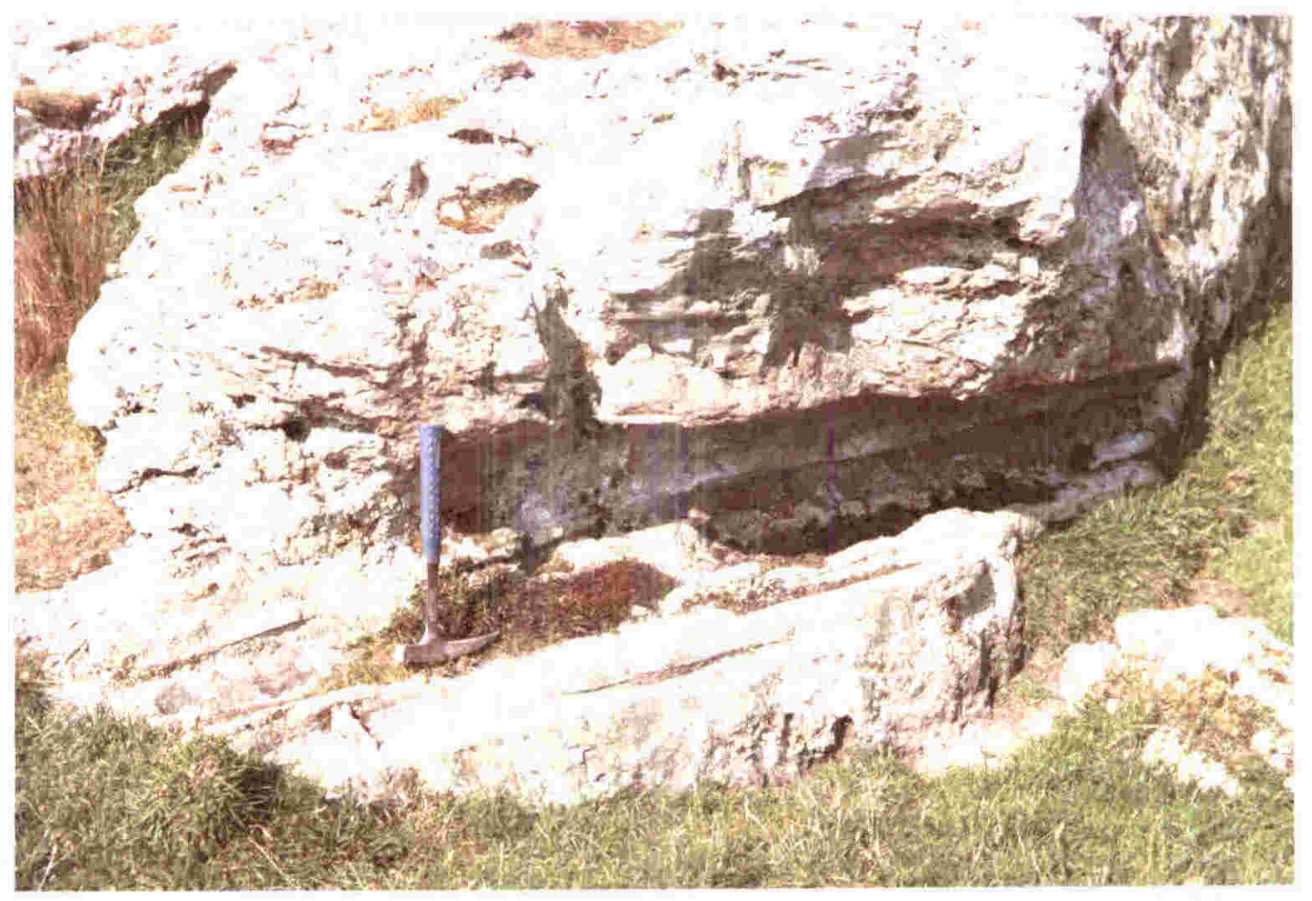

$\underline{\underline{F l G}}, 3,5$ Landslip Hill, large boulder of plant-bearing quartzite on summit plateau showing mould of tree trunk [hammer for scale]. 
Similar cemented quartz sands occur elsewhere in northern Southland and in Central Otago, and some of them contain plant fossils (G. Mason, pers. comm.).

\section{Mataura Valley}

Elsewhere in the region the lignite measures are less sandy than at Landslip Hill. A generalised stratigraphic column for the Mataura Valley (Fig 3.6) was compiled from data in Willett (1948). Detailed stratigraphic columns for Hedgehope Stream (Mataura Valley) are given by Lindqvist and Pocknall (1983). Leaf fossils were collected from detached blocks on the river bank downstream of an outcrop in the east bank of the Mataura River near Tuturau. Only the lowest beds of the sequence here could be examined as much of the section is inaccessible except by boat. The lowest bed visible was a lignite at river level, overlain by 2-3 m of carbonaceous mudstone then an intensely burrowed muddy sandstone 1.5 to $2 \mathrm{~m}$ thick and about $1 \mathrm{~m}$ of cross-bedded sand and silt truncated by an erosion surface and overlain by alluvium. The sequence dips gently northwards at an angle of about $10^{\circ}$. Beds above the cross-bedded sand could not be reached, but further carbonaceous beds were visible. Other outcrops exposed in terraces along the Mataura River have also yielded leaf fossils, along with pollen, brachiopods and fragments of marine molluscs in poorly sorted carbonaceous muddy sand (Couper 1959).

A seam of lignite about $4 \mathrm{~m}$ thick is being worked at the Mataura Paper Mills pit just south of Mataura township. The lignite is very woody, particularly towards the base of the seam. Silicified tree trunks are common and cause some problems in the mining and processing of the lignite. Above the main seam is about $1 \mathrm{~m}$ of carbonaceous silt and a further $1 \mathrm{~m}$ of lignite. The overburden is little more than $2 \mathrm{~m}$ thick. Resin is abundant but a thorough search failed to discover any leaf fossils.

At the Goodwin coal pit at Waimumu the pit profile is similar to that at Mataura, but at the southern end of the pit there is a siltstone lens 2-3 $\mathrm{m}$ thick in the main seam. A number of poorly preserved leaf fossils were found in fallen blocks of the siltstone. Recognisable leaf remains in blocks of lignite from pits in the Waimumu region are stored in the Southland Museum, but no leaves were seen on the writer's visit and miners at the pit said that such fossils were rare. The lignite is woody with 


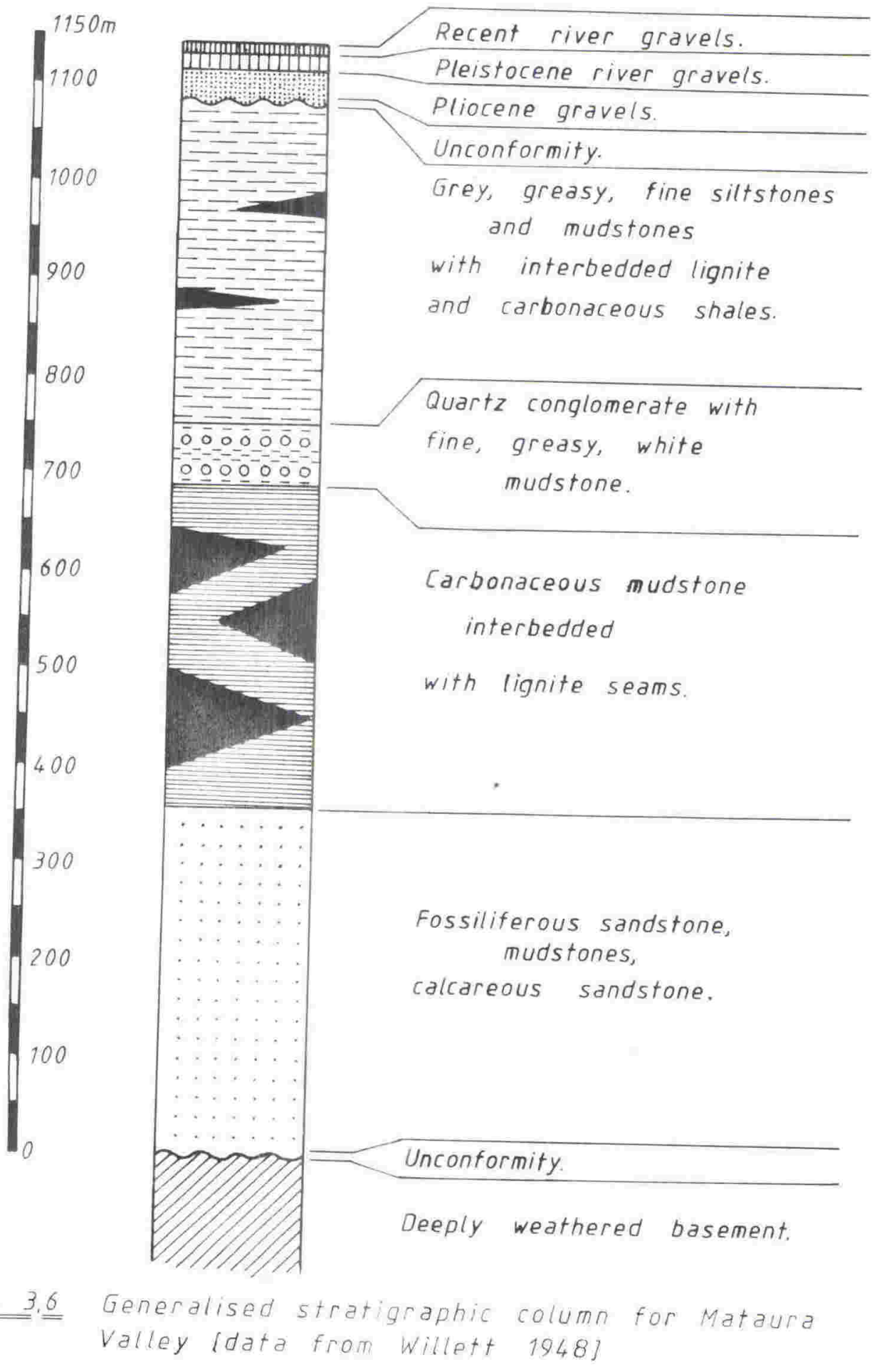


a few silicified tree trunks.

The only site visited on the Southland plains was the abandoned pit at Asher's Siding east of Invercargill. The pit could not be examined in detail as the workings are flooded. However, lignite showing above the water level was woody and the fibrous nature of some trunks suggests that they were tree ferns.

Suggate (1959) gave rank numbers of between 0.2 and 4.6 to lignites associated with the Oligocene strata, indicating depths of burial of less than 1525 metres and generally between 100 to 600 metres. Sulphur contents are low, between 0.1 and 1.0 per cent (Willett 1948; Suggate 1959).

$\underline{\text { AGE }}$

Marine formations interbedded with the Gore Lignite Measures have been reliably dated on melluscan and foraminiferal evidence (Marwick 1929; Hornibrook, pp 84-85 in Wood 1956). Estuarine and marine beds have also yielded good pollen floras (Wood 1956; Couper 1960). The Chatton Marine Formation and the Pomahaka Estuarine Bed in the north of the area are of Duntroonian age, (Oligocene) and lignite measures beneath them are considered to be also Duntroonian, although some in the Pomahaka Valley may be as old as Kaiatan or Bortonian (Eocene). Lignite measures overlying the marine and estuarine formations are Waitakian (Couper 1960a).

Further south, estuarine beds exposed along the Mataura river near Brydone area have ylelded Waitakian faunas and pollens (Hornibrook, p 457 in Fleming 1959; Couper 1960a). The overlying lignite measures are probably Waitakian but may range upward into the Pareora Series. Some lignite measures in the Waimumu area are mapped as Southland Series by Wood (1966) and marine beds underlying lignite near Asher's Siding are of Altonian (Lower Southland Series) age (Isaac 1981a; 1981b).

The stratigraphic relationships of the Lands ${ }_{k}^{k}$ ip Hill Quartzite are uncertain. Landslip Hill appears not to have been submerged by the Oligocene transgression so the relationship of the quartzite to the Chatton Marine Formation and the Pomahaka Estuarine bed is unknown. The time interval represented by the underlying sands cannot be accurately estimated, but a Duntroonian to Waitakian (mid to upper Landon) age seems likely. 
The megafossil assemblage from Landslip Hill comprises at least 40 distinct forms (table 3.1), including leaves, twigs, fruits, and seeds. The collection may not be exhaustive as the hardness of the rock makes collecting difficult. The fossils are generally uncompressed and may take the form of natural moulds ( Fig 3.5) or silicified leaves, fruits and stems (Figs 3.7, 3.8). No organic material remains but in some cases siliceous solutions have penetrated the tissues and preserved fine details of surface and internal structures of leaves and some stems (Figs 3.9,3.11). These have been studied with the scanning electron microscope both by direct examination of silicified tissue and by examination of silicone rubber casts.

Only a few species have been collected from the Mataura estuarine beds. The fossils are mainly impressions and carbonised compressions without cuticle, but seeds, conifer fragments and well-preserved fragments of disseminated cuticle have been obtained by bulk maceration of some of the sediments. Pollen assemblages from the region are variable, some containing few taxa and others 100 or more (D.C. Mildenhall, pers. comm.).

In contrast to other fossil plant assemblages examined conifer remains are abundant and varied. This may be due to rapid burial of the plant debris (see below). Kauri (Agathis ?australis) was a common constituent of forest communities and may have been dominant, at least locally. Leaves of at least one species of Agathis are present at Landslip Hill, and Evans (1937) identified Agathis wood from the lignite at Mataura. Chemical analysis of resins from lignites in the region showed the presence of agathic acid, known to occur in $\underline{A}$. australis and the related Malayan species A. alba (Evans 1937; Brandt 1939). Agathis was not the only araucarian present, as leaves of at least one species of Araucaria, of the broad leafed section Colymbea now confined to South America, are quite common at Landslip Hill.

At least one species of Libocedrus (Cupressaceae) was also present. The fossils somewhat resemble the living New Zealand $\underline{L}$. plumosa and certain living New Caledonian species (de Laubenfels 1972). Most living species of Libocedrus are dimorphic, juvenile leaves often being slightly larger and of different shape to adults, and the variation observed in the fossils may represent juvenile and adult foliage. 
TABLE 3.1. PLANT MEGAFOSSIL TAXA IDENTIFIED FROM GORE LIGNITE MEASURES .

PTERIDOPHYTA

ANGIOSPERMAE

Gleichenia southlandica sp. nov. ?Pseudowintera sp.

GYMNOSPERMAE

Ceratopetalum kaikoraiense Oliver Nothofagus southlandica sp. nov.

Podocarpus sp. aff. totara G. Benn.ex Dacrydium sp. aff. cupressinum Lamb.

D. franklinoides sp. nov.

N. novae-zealandiae (Oliver) Holden

Gymnostoma stellata sp. nov.

Microcachrys imbricata sp. nov.

G. crassa sp. nov.

Phyllocladus sp.

Proteaceae (5 taxa)

Libocedrus compressa sp. nov.

Banksiaephyllum

Libocedrus sp.

Elaeodendron rigidum Ett.

Agathis sp. aff. australis Salisbury

Agathis sp.

?Myrsine sp.

Araucaria sp.

Apocynophyllum affine Ett.

Typha robusta Oliver

Apocynophyllum elegans Ett.

An additional 25 unnamed taxa have also been recognised. 


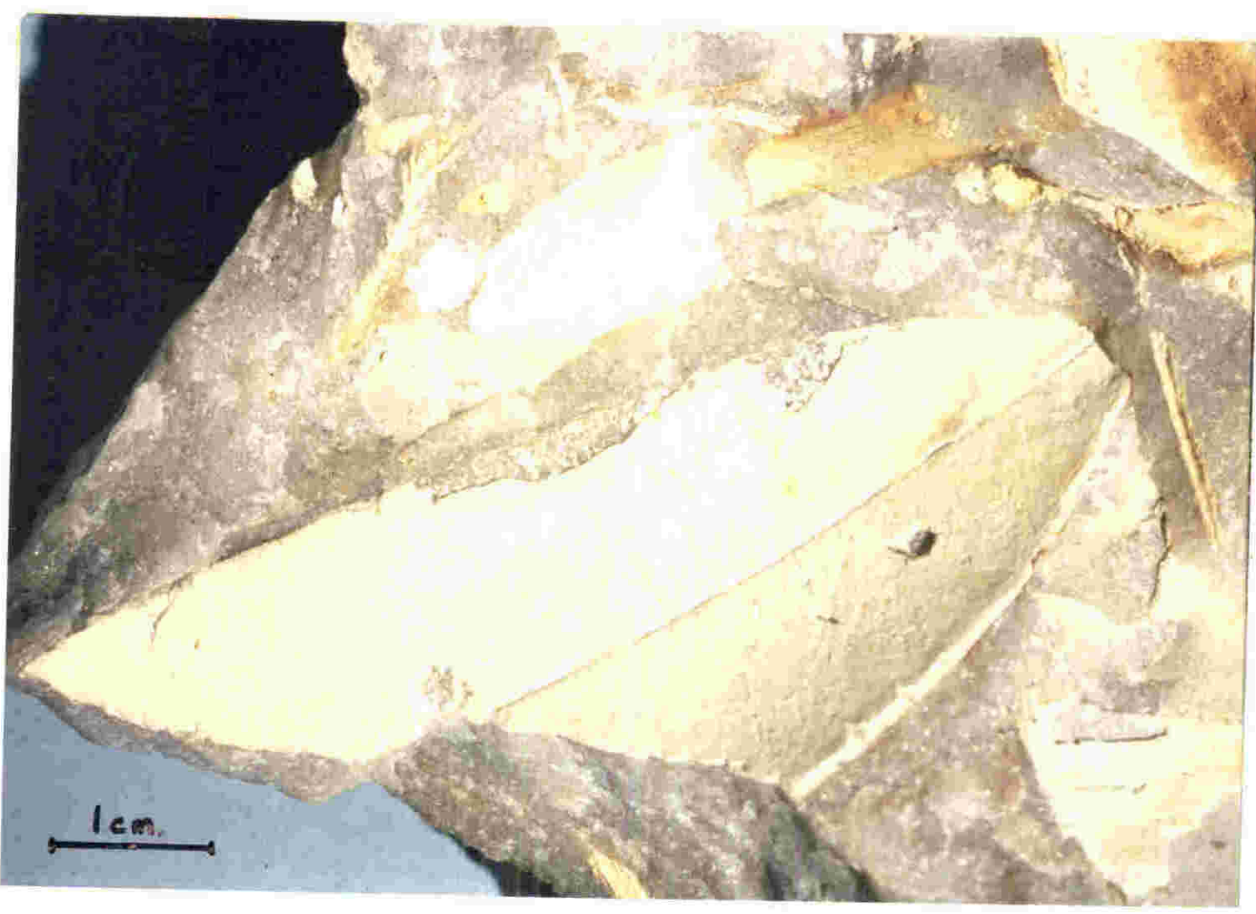

FlG, 3.7 Landslip Hill, block of plant-bearing quartzite cupressinum] and leaves.

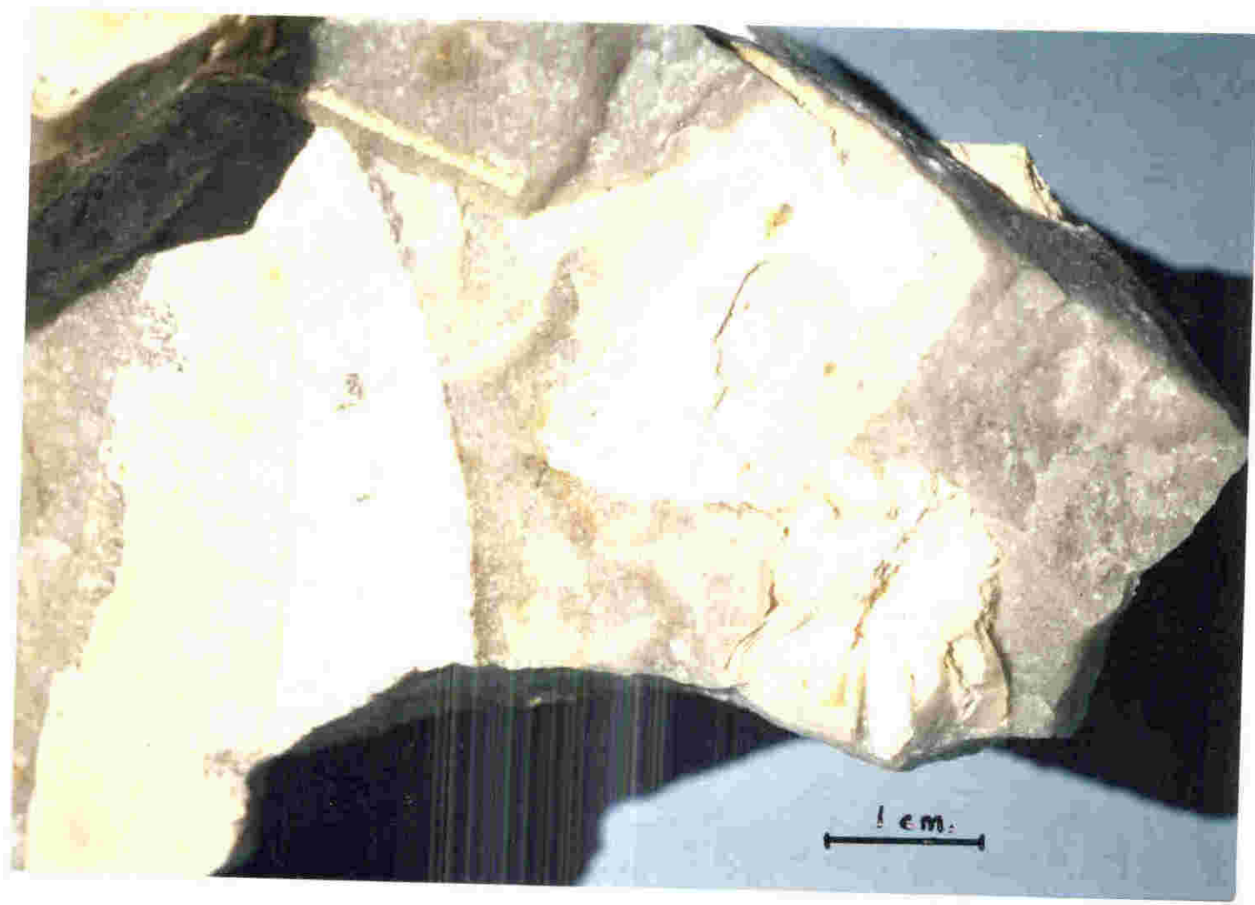
FlG. 3. Landslip Hill, block of plant-bearing quartzite
showing silicified cone of Gymnostoma stellata and leaves. 
Podocarpaceae are represented by a number of genera. Pollen assemblages suggest the presence of Phyllocladus, Dacrydium cupressinum, Dacrydium 'franklinii' group, Dacrydium biforme/bidwillii group, Dacrycarpus dacrydioides, Microcachrys and Microstrobos (Couper 1960a; Pocknall 1982a, 1982b). Phyllocladus megafossils occur at Tuturau where they are quite common, and at Landslip Hill. Foliage similar to that of Dacrydium cupressinum is quite common at Landslip Hill. Microcachrys,

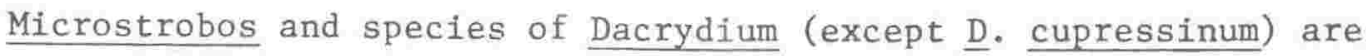
not easy to identify from vegetative material as all have small, closely imbricated scale leaves. Those of Microcachrys are opposite and decussate, the others spirally arranged. Foliage of their kind is common. Microcachrys megafossils have been recognised and appear to be abundant. It is probable that the fossil identified by Ettingshausen as Sequoia novae-zealandiae is a species of Dacrydium related to $\underline{\text { D. franklinii. }}$

Cones of at least two, and possibly three, species of Casuarinaceae are common at Landslip Hill (Campbell and Holden 1984). The morphology of the cones and twigs indicates that the fossils belong to the genus Gymnostoma (L.A.S. Johnson, pers, comm.). These fossils are discussed more fully in Chapter 8.

Two species of beech occur at Landslip Hill. Neither resembles living New Zealand species. One appears to be a small form close to Nothofagus novae-zealandiae (Oliver) Holden, the other somewhat resembles the living South American N. procera. The latter occurs with Phyllocladus in drifted blocks at Tuturau, and also in the Nevis Oil Shale (Chapter 4). Both species are discussed in detail in Chapter 8.

Pollen assemblages indicate the presence of a number of Proteaceae (Couper 1960a; Pocknall 1982a,b.). A number of species of leaves of probable proteaceous affinity occur at Landslip Hill, including forms reminiscent of Banksia integrifolia. A small fragment of a leaf resembling a number of Tertiary Australian species assigned to Banksiaephyllum by Ettingshausen (1888) and the New Zealand fossil Dryandra comptoniaefolia (Ettingshausen 1887) was also found.

The commonest fossil leaves at Landslip Hill are those described by Ettingshausen (1887) as Dryophyllum dubium and Apocynophyllum affine. Dryophyllum dubium resembles the New Zealand fossil species Ceratopetalum $\underline{\text { kaikoraiense }}$ and the living Australian species $\underline{C}$. apetalum, and may well 
belong to this genus, some of Ettingshausen's leaves may however be a species of Nothofagus. The affinities of Apocynophyllum affine are uncertain but could be with Apocynaceae. Another common form is a large, lanceolate leaf with close set, branching secondary veins and an irregular p. 174, Figs 3.7 and $3.8(p .33)$, Fig. 15 no. 8 , no. 11 (p.302). marginal vein $\lambda$ Leaf morphology suggests affinities with Myrtaceae, Myrsinaceae or Sapotaceae $A$ Pollen of all three families occur in the Gore Lignite Measures and associated sediments (Pocknall 1982a, b.).

Also common are leaves resembling those of Dracophyllum and Leucopogon (Epacridaceae) and a leaf which Oliver (1950) referred to as 'a fern resembling Linguifolium'. In an unpublished manuscript held at N.Z. Geological Survey, Lower Hutt, he gave this fossil the name Glossoidea divergens and commented on its superficial resemblance to Cordyline terminalis. The leaves differ from those of Cordyline in a number of respects including the presence of minute marginal teeth in some specimens and its affinities are obscure.

The only Pterophyta so far found are fragments of fronds of Gleichenia. The pinnule form suggests a relationship with the living New Zealand species G. dicarpa (G. circinata) and $\underline{G}$. microphylla but differs from both, and the fossil is probably closer to the Mesozoic G. gleichenoides from Australia and India (Gould 1974). Pollen assemblages suggest the presence of a number of other ferns including Paesia and Phymatosorus, but no leaf fossils referable to these genera were found.

A number of different species of fruits and seeds have been found. They are probably all of plants not now found in New Zealand. The taxonomic affinities of most are obscure.

\section{PALEOENVIRONMENT}

During the late Eocene most of Southland was a slowly subsiding land surface on which extensive coal measure sequences were laid down. Remnants of the coal measures outcrop in the Ohai region (Beaumont Coal Measures), at Orepuki and Hedgehope, and in the Pomahaka valley (Wood 1966). A large lake or barred lagoon, fringed with swamps, existed for a time in the Orepuki region giving rise to thin oil shales (Willett and Wellman 1940). Throughout the South Island sediments of this age are highly quartzose and commonly overlie deeply weathered basement, thought to be the result of 
widespread peneplanation that followed the Rangitata Orogeny (Gage 1980).

Widespread marine transgression during the oligocene reached a maximum during the time represented by the Duntroonian Stage when the Chatton Marine Formation and the Pomahaka Estuarine Bed were laid down. The marine beds are thickest in the west, that is in the upper Waiau valley and along Hump Ridge. They accumulated in a small trough which began to form in the late Eocene and persisted through Oligocene and Miocene times (Wood 1966). Sediments vary from deep water mudstones and limestones to glauconitic sandstones, estuarine beds and deltaic and fluviatile deposits and have been interpreted as indicating deep water along the present Waiau Valley adjacent to a shallow shelf sea covering much of the central part of Southland with nearshore and terrestrial environments in the east. The exact position of the coast at the time of maximum transgression is uncertain.

While there is no direct evidence that any of the beds underlying the quartzite at Landslip Hill are marine, both the Pomahaka Estuarine Bed and the Chatton Marine Formation are interbedded with Gore Lignite Measures underlying Landslip Hill Quartzite at Cemetery Hill (Lindqvist and Pocknall 1983), and the overall sequence suggests that the area was subject to a number of minor marine transgressions during Duntroonian time.

Coal measure deposition took place in large coastal swamps and a lake or barred lagoon similar to that suggested at Orepuki (Willett and Wellman 1940) but of uncertain extent must have existed for a time in the vicinity of Freshford. Sedimentation cycles recording brackish inundations of peat swamps followed by estuarine and shallow marine deposition, and finally infilling of the bay and re-establishment of peat swamps have been described from Pomahaka beds in Waikoikoi Valley by Lindqvist (1983). The coastal swamps migrated southwards with the shoreline after the sea began to recede and the lignite measures overlying the marine beds are thought to represent a prograding delta (Isaac 1981a, b.). This is supported by the facts that the lignite measures young to the south and that the thick lignite seams occur in the lower part of the freshwater sequence.

Oligocene vegetational patterns in Southland were complex, and both pollen and megafossil assemblages contain elements from a number of distinct communities. Among those represented are lowland forest, possibly a Tertiary analogue of the Agathis/Nothofagus truncata/Metrosideros forest found in isolated areas of Northland (Sexton 1941) and on Little Barrier 
Island; swamp forest with Dacrycarpus, Dacrydium and Laurelia; 1imited areas of broadleafed forest, probably on levees where nutrient status may have been higher; fresh water swamp with Typha; and some areas of raised bog with Sphagnum. Couper (1953a; 1960a), reported pollen of Juncaceae and Restoniaceae. Most species of these two families are plants of wet ground and some species are characteristic of salt marsh. Pocknall (1982a, b.) suggested that the plant communities indicated by pollen assemblages represented stages in a hydroseral succession from forested raised swamp to open water supporting very little vegetation and Sluiter and Pocknall (1983) suggested close similarities existed between vegetation and successions in the Oligocene swamps of Southland and those which gave rise to the Latrobe Valley coals of Victoria.

The long period of peneplanation during the early Tertiary probably led to widespread impoverishment of the soils except for limited areas of rejuvenation along the rivers. This is reflected in the deeply leached basement and in pollen and megafossil assemblages. A marked heathland and acid bog assemblage is present, indicated by the presence of Sphagnum, Gleichenia, Paesia and Dracophyllum. Some of the Proteaceae, Sapotaceae and Myrsinaceae may also have been members of this community, as may Gymnostoma. Most of the forest species so far recognised were trees whose modern analogues form mor humus and are tolerant of low nutrient status, for example Agathis, Nothofagus and Cunoniaceae. Broadleafed trees demanding a high level of soil nutrients appear to have been scarce.

The extensive kauri forest may possibly have caused some of the soil improverishment. Under humid conditions acid litter, only slowly decayed by soil organisms, accumulates to considerable depth on the floor of kauri forests. Humic acids from the litter promote intense leaching of underlying soil while at the same time the slow rate of decay does not return to the soil the nutrients extracted by the trees (Taylor 1947; Ecroyd 1982). The surface layer of humus is susceptible to erosion, particularly if the forest cover is damaged, and where podzolisation is extreme the nutrient status of the underlying soil may be too poor to permit regeneration of forest (Taylor 1947; Esler and Rumbal1 1975). Extensive burning and felling of kauri forest in Northland and Coromandel in both pre-European and post-European times has led to the formation of large tracts of infertile soils, 'gumlands', supporting a scrub vegetation of Leptospermum scoparium with Epacridaceae (including Dracophy1lum), Pomaderris spp., 
sedges, ferns (particularly Pteridium and Gleichenia) and Lycopodium spp. Some areas of gumland around Kaikohe have been invaded by introduced species of Hakea (Proteaceae) (Esler and Rumball 1975), as are podzolised pakihi soils in north west Nelson (author's observation). Kauri forest is one of the few New Zealand forest types which is sensitive to fire damage as virgin stands (Ecroyd 1982). Storm damage and fires caused by lightning strike may have been important factors causing deforestation of peneplained soils during the early and mid Tertiary.

Two poorly preserved GLM 031, p. 265, Fig 32 no. 4 (p 336) closely resemble closely resemble leaves of the New Zealand mangrove Avicennia marina var. resinifera. Avicennia pollen is not known 1n New Zealand below the Quaternary, a record from the Miocene (Couper 1953) being incorrect (Mildenhall 1980). The earliest record of Avicennia pollen elsewhere in the world is Miocene (Muller 1981) and, if confirmed, the Mataura leaves would be the earliest known occurrence of Avicennia. Environmental conditions in Oligocene Southland would have been suitable for the growth of mangroves, and the cool to warm temperate climate indicated by pollen assemblages (Pocknall 1982b) and ocean paleo-temperatures (Hornibrook 1971) would have been marginally favourable. Large-scale root structures likened to mangrove roots have been observed in the west high wall of Newvale Opencast (Lindqvist and Pocknall 1983).

Many of the Southland lignite seams are not underlain by seat earths (Isaac 1981b). The absence of a seat earth has been taken as indicating that the plant material which formed the overlying coal was drifted (Speight 1931). It is however difficult to envisage an environment in which large volumes of coarse organic debris such as tree trunks and large branches could be transported into a depositional basin without the accompaniment of a considerable quantity of mineral matter. While dirt bands and silt lenses do occur in the seams, the bulk of the lignite is without visible clastic material and the average ash content is generally between 3.5 and $5.0 \%$ (Suggate 1959). Moore (1968b) concluded that there was no sequential relationship between seat earths and coal seams, and that seat earths will only be present beneath a seam if local conditions favoured its formation or preservation. It seems likely that the Southland lignites were formed from an in situ peat swamp which was at time forested. Forest peats of some depth are not uncommon in New Zealand today and considerable areas 
occur in the west coast of the North Island north of Wellington (Harris 1968).

Agathis and Nothofagus do not normally grow in New Zealand swamps today but both are rather shallow rooted and could perhaps survive where the permanent water table is relatively high. McQueen (1976) observed Nothofagus antarctica growing on deep peat in southern Chile. The presence of Nothofagus wood and abundant kauri wood and resin reported by Evans (1937) could be due to flooding of forests containing these trees which would then be replaced by species more tolerant of waterlogged conditions. Cranwell (1949) reported abundant kauri logs at the base of the Waikato peats at some localities. More work is needed on the soils underlying peat swamps in New Zealand if the significance of the presence or absence of seat earths is to be assessed, and a detafled study of variations in flora from the bottom to the top of the lignite seams is needed to clarify details of vegetational succession. Some work of this sort has been undertaken in Australia (Luly et al., 1980; Blackburn 1981) which may be relevant to New Zealand. Pocknall (1982) carried out a palynological examination of a lignite seam in a drillhole near Kapuka, Southland, and showed some vegetational changes through the profile, but the study was limited.

\section{Silica Cementation}

Silica cemented horizons occur at a number of localities. Similar silica cemented horizons occur in Central Otago, and stone tools manufactured from such rocks have been found at a number of South Island archaeological sites (Simmons and Wright 1967; Anderson 1981). Throughout the Gore Lignite Measures coal ranks are generally very low (Suggate 1959) indicating that burial has been very shallow, and the quartzite is cemented by cryptocrystalline quartz, an early diagenetic effect occurring at shallow depth of burial (Dapples 1967; 1979a; 1979b).

Thin sections show the rock to be well-sorted, medium to coarse sandstone composed almost entirely of detrital quartz. Grains are sub-rounded to well wounded. Polycrystalline grains are rare. The cement is spherulitic microcrystalline silica with some suggestion of growth banding. Scanning electron micrographs of the quartzite show syntaxial overgrowths on the quartz grains and also a number of small euhedral quartz crystals among the spherulites. Some compromise boundaries are evident where overgrowths are developed, and some grains show minor, probably late, etching. (Fig 3.12, Figs 3.13, 3.14). 

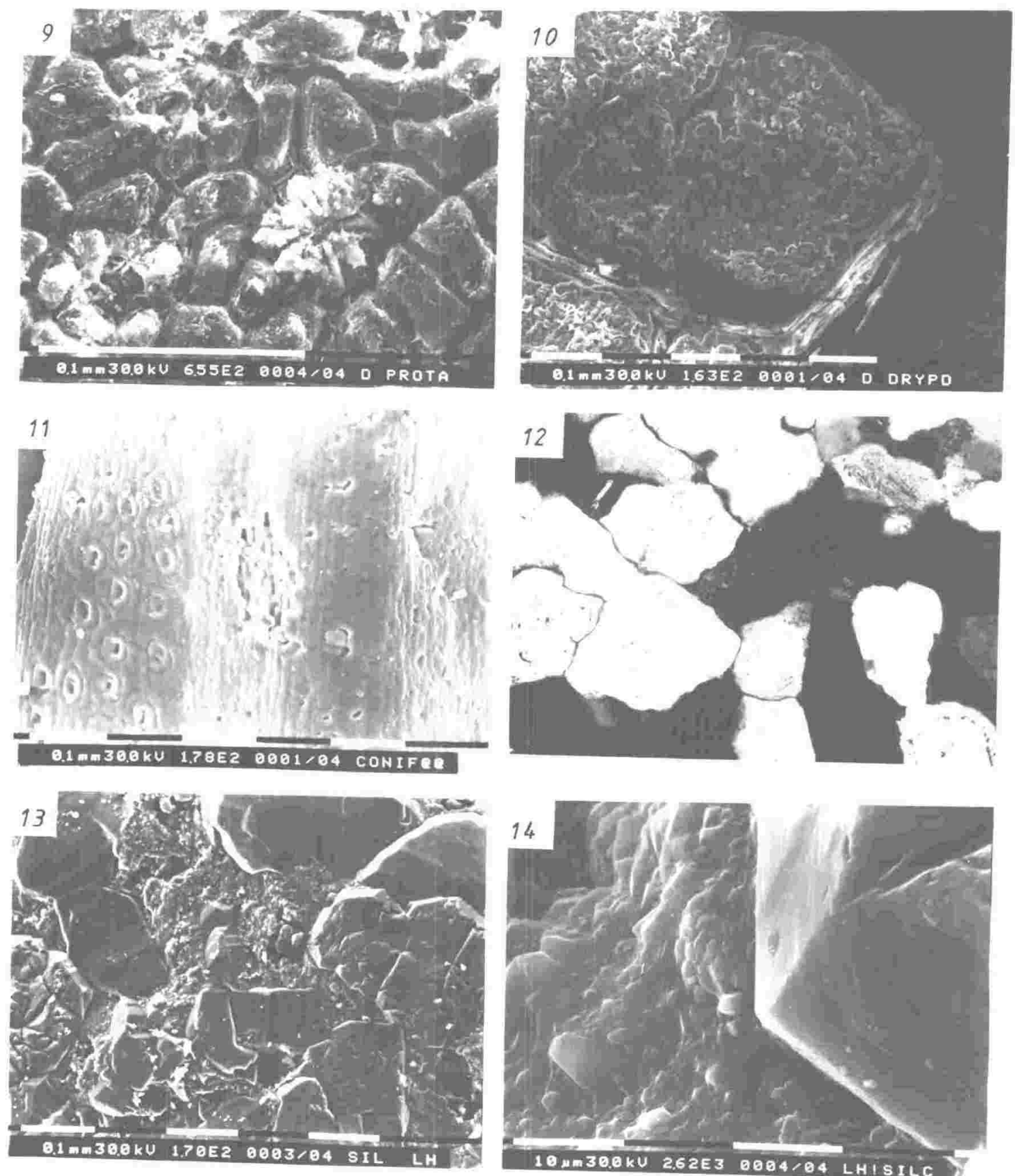

FIG. 3.9: ? Proteaceae, silicified epidermis showing trichomes.

FlG, 3. 10: Nothofagus sp., silicified lower epidermis and underlying tissues showing stomates and veinlets.

FIG, 3.11: Silicone rubber cast, epidermis of Dacrydium sp. aff. cupressinum showing stomatal bands.

FlG, 3.12: Thin section photomicrograph of quartzite showing interlocked overgrowths with compromise crystal boundaries between quartz grains, and spherulitic cement [dark area, right centre], crossed nicols, $x 110$.

FIG, 3.13: Scanning electron micrograph of fractured surface of quartzite showing overgrowths on quartz grains and spherulitic cement.

FlG, 3.14: Enlargement of Fig. 13, right centre. 
Much of the secondary silica replacing wood is friable, but some stems are sufficiently well impregnated to be sectioned without embedding, and occasionally show recognisable cell structure. Scanning electron micrographs of silicified leaf tissues show remarkable preservation of details. Fig 3.9 shows epidermal cells and trichomes of a species of Proteaceae and Fig 3.10 lower epidermis and underlying mesophyll of Nothofagus sp. Fig 3.11 shows a silicone rubber cast of epidermis of Dacrydium sp. aff cupressinum. Silica has formed a steinkern within the cells and has also been deposited in the intercellular spaces. The cell walls themselves were not silicified and have disappeared. Silica deposited on the surface of leaves and stems has preserved details of epidermal structures which are reproducible in silicone rubber casts.

The excellent state of preservation of many of the Landslip Hill fossils including uncompressed araucarian pollen cones and other structures suggests that the earliest stages of silicification were synchronous, or nearly synchronous, with deposition. Ambrose and Flint (1981) suggested similar early silicification took place in South Australian silcrete floras. The Landslip Hill deposit also appears to be analogous with one from Woomera, South Australia, studied by Lange (1978) and described as "... a slumped waterborne sand containing plant litter, some fresh, some eroded by transport...". Lange concluded that the rapid development of a contact film of silica by a mechanism as yet unknown was critical to the formation of the fossils. He appears to have examined only the surface of the silicified material. The preservation of details of subsurface tissues in leaves from Landslip Hill suggests that the infiltrating siliceous solutions deposited silica both in the intercellular apaces and inside the cells but apparently not in the cell walls, implying that the cause of precipitation may be some surface property of the cell wall materials.

The structure and mode of cementation of the Landslip Hill quartzite is similar to that of some Australian silcretes, particularly the "subbasaltic" silcretes described by Watts (1978). The term 'silcrete' was first proposed by Lamplaugh (1902) for sporadic concretionary masses in loose material indurated by a siliceous cement, and has since been applied to a variety of rocks occuring mainly in arid and semiarid areas of Australia and southern Africa.

The first phase of fossilisation at Landslip Hill was burial of the plant 
material in wet, coarse grained river sediment. The preservation of details as small as turgid epidermal cells and guard cells indicates that the deposition of silica began almost immediately. Most of the silica precipitated in this early phase was amorphous, in the form of spherulites. This protected the organic matter from compression by filling pore spaces and so imparting considerable mechanical strength to the quartz sediment/wood mixture. Starting contemporaneously cell contents were replaced by fine amorphous silica. Bacterial action may have been retarded by low pH. Replacement was complete before there had been any appreciable decomposition.

Following the initial phase which the complete lack of compression in the fossils indicates took place close to the ground surface, further quartz precipitation occurred as syntaxial overgrowths on detrital grains at the expense of the spherulites (Figs 3.12,3.13). There also appears to have been some recrystallisation of the spherulites, indicated by the presence of the small euhedral quartz crystals (Fig 3.14). A late phase of quartz etching, probably requiring a pH of about 9 (Siever 1972), took place, but this was minor.

The environmental significance of silcretes is uncertain. There are two problems in their formation that need to be explained; firstly, the origin of the siliceous solutions, and secondly the mechanism of early silica precipitation. Surface silicification is supposed to take place mainly in two environments, either in localities where hydrothermal activity or leachates from volcanic ash beds give rise to ground waters saturated with silica or in regions where high concentrations of salt such as $\mathrm{NaCl}, \mathrm{Na}_{2} \mathrm{SO}_{4}, \mathrm{Fe}_{2} \mathrm{O}_{3}$, or $\mathrm{MgO}$, or large amounts of cellulose or other carbohydrates cause silica to be precipitated from silica-charged ground waters (Dapples 1967; 1979a; 1979b; Smale 1973). Grant and Aitchison (1970) specifically exclude from their definition of silcrete all siliceous material formed as a result of hydrothermal activity, confining the term to rocks cemented by silica produced by normal surficial physico-chemical processes.

In Australia there appears to be a relationship between laterites and silcretes and it is suggested that much of the silica originated from desilicification of soil minerals during intense chemical weathering in relatively humid areas. The silica is presumed to have been transported in groundwaters to more arid areas, sometimes over considerable distances, 
and there precipitated as silcrete in lower lying regions with poor drainage (Stephens 1964; 1971), although this has been disputed by Bruckner (1966). The relationship between silcrete and laterite is supported by the observation that silcrete may, in places, pass laterally into ferruginous laterite poor in silica (Langford-Smith and Dury 1965).

Woolnough (1927a; 1927b) related the development of concretionary horizons at or near ground surface, "duricrusts", to stages of extreme peneplanation when sluggish drainage caused the less soluble products of chemical weathering, mainly colloidal silica, alumina and iron exides, to be retained more or less in situ. Retallack (1977) suggested that opaline phytoliths were the source of the cryptocrystalline quartz cement in Triassic gannisters (originally the eluvial $A_{2}$ horizons or paleosols) from the Upper Narrabeen Group of the Sydney Basin, but it is difficult to see how this source could provide the volume of siliceous cement evident in the Landslip Hill Quartzite.

Silcretes in Australia and southern Africa occur mainly in arid and semarid regions (Stephens 1964; 1971; Hutton et al. 1972; Smale 1973) and it is usually assumed that such climates, with the concomitant fluctuations in water table, are necessary for their formation. Silcretes do not appear to be actively forming in these regions today. In Australia some local areas of silcrete seem to have formed under more humid conditions along recent or ancient watercourses (Stephens 1971). Some of these have been related to the eruption of overlying basalts but trace element analyses of the silcrete (Taylor and Smith 1975) indicate that the basalt has contributed nothing to their formation. Silcretes are reported from a number of areas outside Australia and southern Africa including the Eocene Reading Beds of southern England (Kerr 1955), which do not appear to have been deposited in an arid or semi-arid environment, and from the Neogene Ogallala Formation of Kansas, first appearing in the Valentine Member, thought to have been deposited under more or less humid conditions (Frye and Leonard 1957; Swineford and Franks 1959).

Watts (1977) suggested that reducing conditions and a low subsoil pH under a wet climatic regime were important in the early phases of silcrete formation over much of inland Australia and that subsequent climatic change to aridity favoured their further development and preservation. Williamson (1959) suggested that some small occurrences of silcrete in Western Australia, 
seemingly cemented aeolian sands, may have been formed as a result of the evaporation of intermittent lakes, Ambrose and Flint (1981) have recognised silicified strandlines associated with stillstand stages of a Miocene lake in South Australia which slowly evaporated under conditions of increasing aridity. McGowran (1978) equated laterite formation with periods of warm, humid climate and silcrete formation with climatic deterioration resulting in cooler, drier climate.

There is no evidence for widespread volcanic or hydrothermal activity in Southland during the Oligocene and early Miocene, and none for an arid climate. Although average leaf sizes in the Landslip Hill assemblages are small, in the microphyll size range comparable to the present New Zealand flora, and many of the leaf species have toothed margins, pollen assemblages (Pocknall $1982 a, 1982 b$ ) coupled with the inferred widespread development of swamps $A$ suggest a warm, humid climate. The small average leaf size may be due to local environmental conditions, for example poor soils, or to depositional sorting favouring the preservation of the smaller sun leaves over larger shade leaves (Spicer 1980). A seasonal rainfall pattern might have resulted in considerable fluctuations in water table without radically affecting the type of vegetation, causing silica released to groundwaters by intense chemical weathering to be precipitated in low lying areas in the manner proposed by Woolnough (1927a, b). There is some evidence that silica cementation may take place even under constantly humid conditions. Evans (1965) demonstrated rapid partial cementing of a pure quartz sand allowed to settle in daylight in an M/5 solution of sodium-ATP and a similar result was obtained by suspending pure quartz sand in a $1 \%$ solution of sodium alginate. In both cases the sediment/biochemical mixture remained moist throughout. Evans further observed that cemented clusters of quartz grains are frequently found in peatland and woodland soils. 
The plant megafossil assemblages studied have come from Miocene fresh water sediments of the Manuherikia Group in the Cromwell region and Manuherikia Valley (Wood, 1962; Mutch, 1963) and from the Wedderburn Formation (correlated with the upper part of the Manuherikia Group) of eastern Centra1 Otago (Williamson, 1939). Collections examined were from the Nevis Valley, the Bannockburn area, St. Bathans, Idaburn and Coal Creek Flat, Roxburgh.

The megafossil assemblages of Central Otago fall into three distinct groups; firstly that of the Nevis Oil Shale, secondly a Central Otago assemblage to be found with local variants at several localities in the Bannockburn and Cromwell area and at St. Bathans, and finally the small assemblage from the overburden of Harliwick's Opencast at Coal Creek Flat, Roxburgh.

Although a number of collections of Tertiary plant fossils have been made from Central Otago, including those by Sir James Hector in 1864 and Alexander McKay in 1888, the fossils have been little studied. Ettingshausen (1887) described three species from Dunstan; Lomariopsis dunstanensis, Aspidium tertiario-zealandicum (also found at Shag Point) and Senforthia zeelandica. Oliver (1950) in his review of the New Zealand fossil flora, gives the age of the Dunstan fossils as Eocene but does not refer to them by name. In an unpublished manuscript held at the N.Z. Geological Survey library, Lower Hutt, he refers Lomariopsis dunstanensis to Blechnum, Aspidium tertiario-zealandicum to Cyclosorus and Seaforthia zeelandíca to Rhopalostylis. Park $(1906 ; 1908)$ and Williams (1974) mention fossil leaves at a number of localities in the Manuherikia Group and Evans (1937) identified a number of fossil woods from lignite at Roxburgh.

\section{GEOLOGY}

The Tertiary sequence in Central Otago includes both fresh water and marine sediments and reflects the gradual transgression of the sea across New Zealand in Oligocene times. In the Cromell and Manuherikia basins the Tertiary sediments appear to be entirely fresh water facies (Wood, 1962), but to the east in the Maniototo basin there are two separate fresh water 
sequences, an older Hogburn "series" and a younger Wedderburn "series" separated by a marine interval, the Naseby Greensand (Williamson, 1939). West of Queenstown, Tertiary sediments younger than Arnold series are exclusively marine (Wood, 1962). Although a number of localities to the east of Idaburn were examined, no plant fossils were found and attention has therefore been confined to the wholly fresh water Manuherikia Group (including the St. Bathans Beds) in the Cromwell and Manuherikia basins and in the Nevis and Clutha Valleys.

The area studied lies in the range and basin province of Central Otago (Fig 4.1). The relatively soft Tertiary and early Pleistocene rocks, veneered by late Pleistocene gravels, unconformably overlie deeply weathered basement, generally late Paleozoic to Mesozoic schist but at St. Bathans and other localities along the northern boundary of the region Mesozoic "greywackes" of the Torlesse Supergroup (Wood, 1962; Mutch, 1963). The Manuherikia Group contains quartz gravels and sands, silts, white kaolin clays, carbonaceous beds and lignite seams, some of considerable thickness (Park, 1906; 1908; Wood, 1962; Williams, 1974). Oil shale is known from a number of localities including Dairy Creek near Clyde (Park, 1906), Cambrians in the upper Manuherikia Valley, and Idaburn (Willett, 1943b). The largest deposit is in the Nevis Valley (Henderson, 1923; Willett, 1943a; Williams, 1974). The shales at Idaburn and Cambrians are the richest in New Zealand yielding on average 55.6 gallons of crude oil per ton with a sulphur content of $0.25 \%$ (Willett, 1943b), but the deposits are too small to be economic.

The quartz gravels, known as "granite wash" by the miners, are commonly auriferous, as are the overlying Pliocene ("Maori Bottom") and Pleistocene gravels (Park 1906; 1908). These gravels have been worked, mainly by hydraulic sluicing, at many places in Central otago. Numerous small lignite mines were opened at the same time to provide fuel both for gold dredges operating in the rivers and for domestic use (Park, $1906 ; 1908)$. Thick seams were worked at Bannockburn, Dairy Creek, Naseby and Hyde, but the only mines still operating are those at Idaburn and at Coal Creek Flat near Roxburgh.

Beds of cemented quartz conglomerate and quartz sand are known $\underline{\text { in }}$ situ at a number of localities, for example at Chatto Creek, where a bed $1.5 \mathrm{~m}$ thick was reported, and at German Hill (Park, 1906). Williams (1974) reports another such bed at the base of the lignite measures 
Fig 4.1. Map of part of Range and Basin Province of Central Otago showing main outcrops of Central Otago Lignite Measures (Manuherikia Group) and cover beds (after Wood 1962 and Mutch 1963).

Fossil sample sites:

1. Bluffs at mouth of Bannockburn Creek (V2851, V2852).

2. New road cut, 200m north of new road bridge (V2850).

3. Kawerau River bluffs.

4. Shale Ridge, Nevis Valley.

5. Clay seam, west end of Blue Lake, St. Bathans.

6. Bluffs at east end of Blue Lake, St. Bathans.

7. Idaburn opencast.

8. Harliwick's opencast, Coal Creek Flat. 

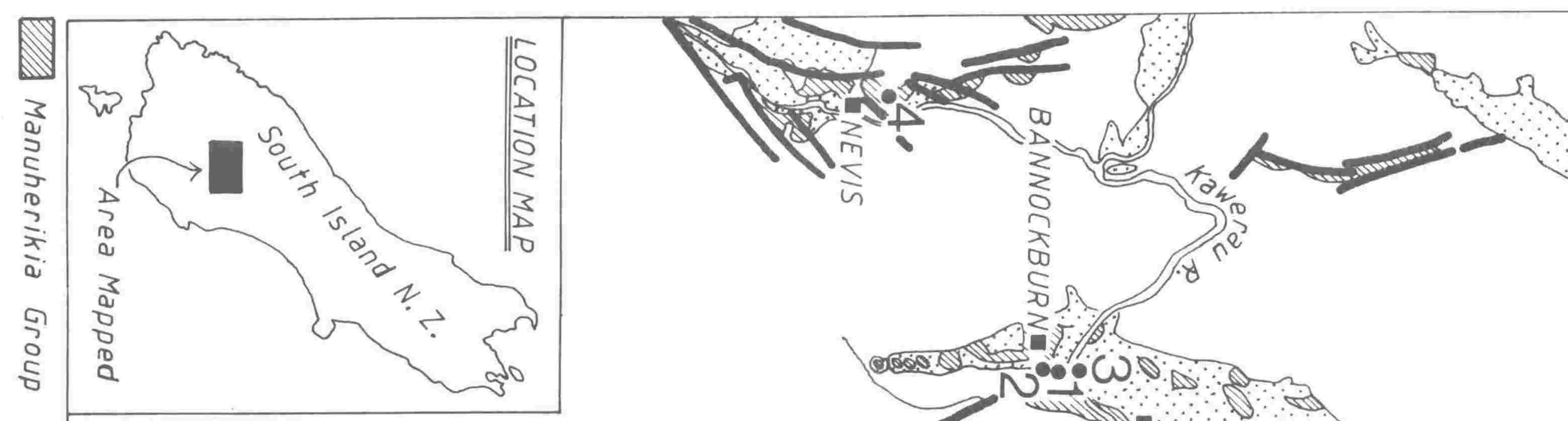

$\leftrightarrow$

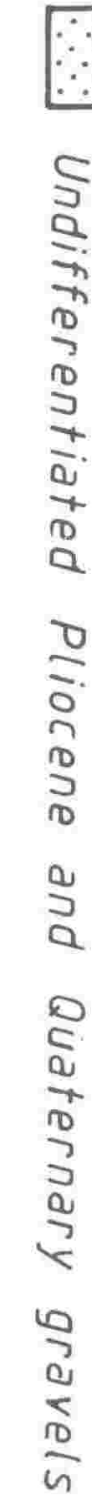

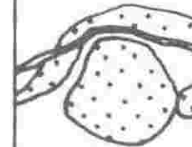

o

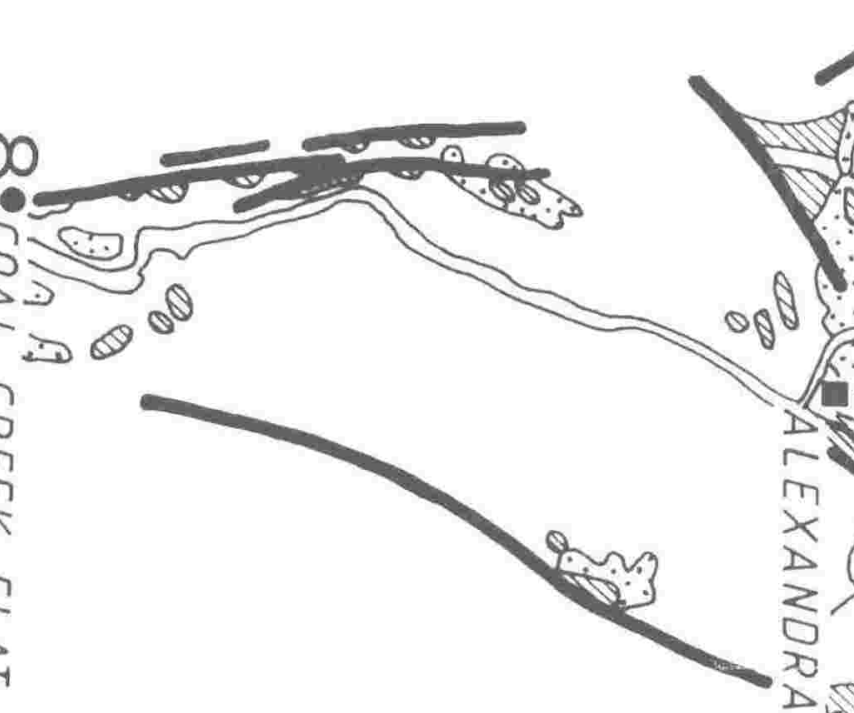

a. 0 o $\frac{1}{\pi}$

8 (

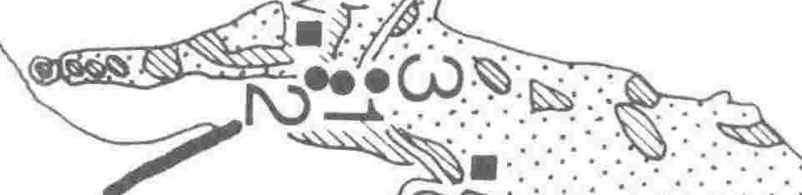

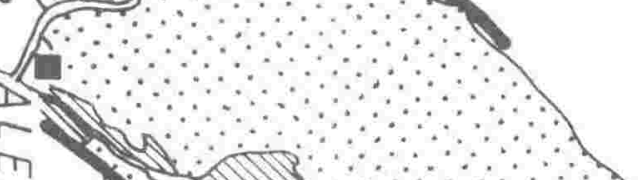

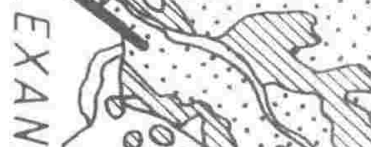

z) 80.

2

$D$

$0_{0}^{2} \int_{-2} \quad 1$
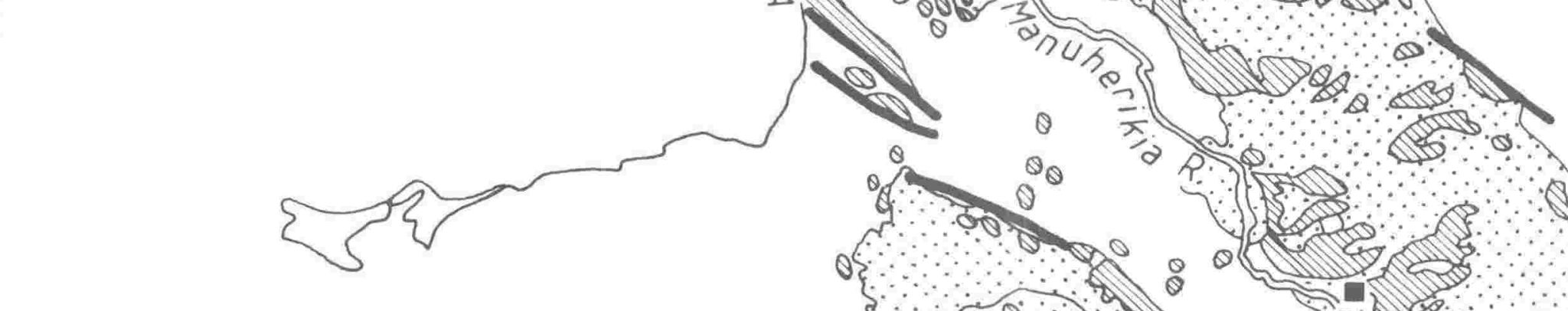

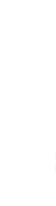
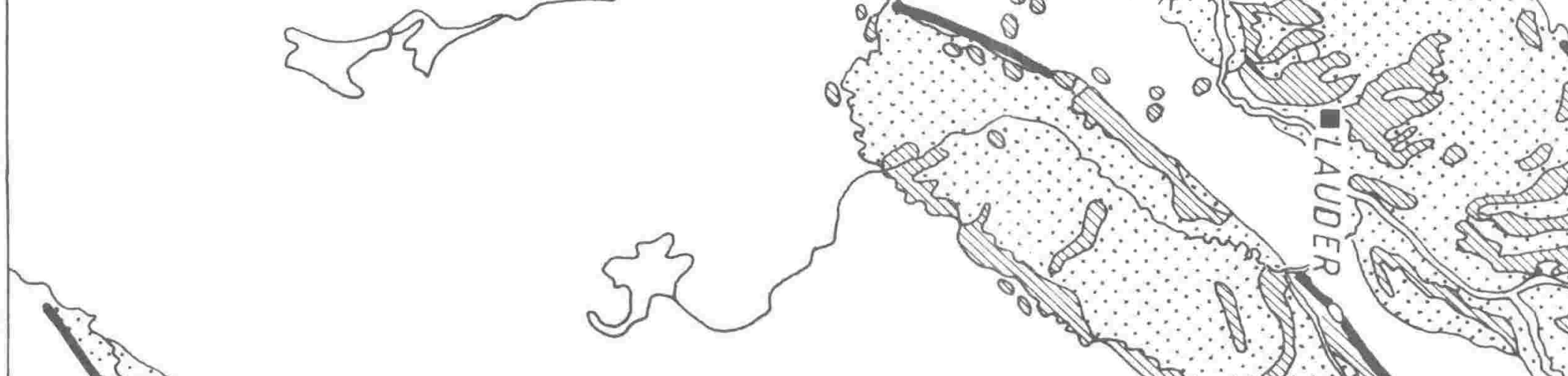

1

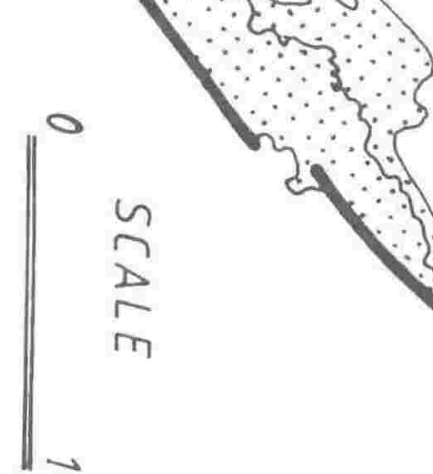

후
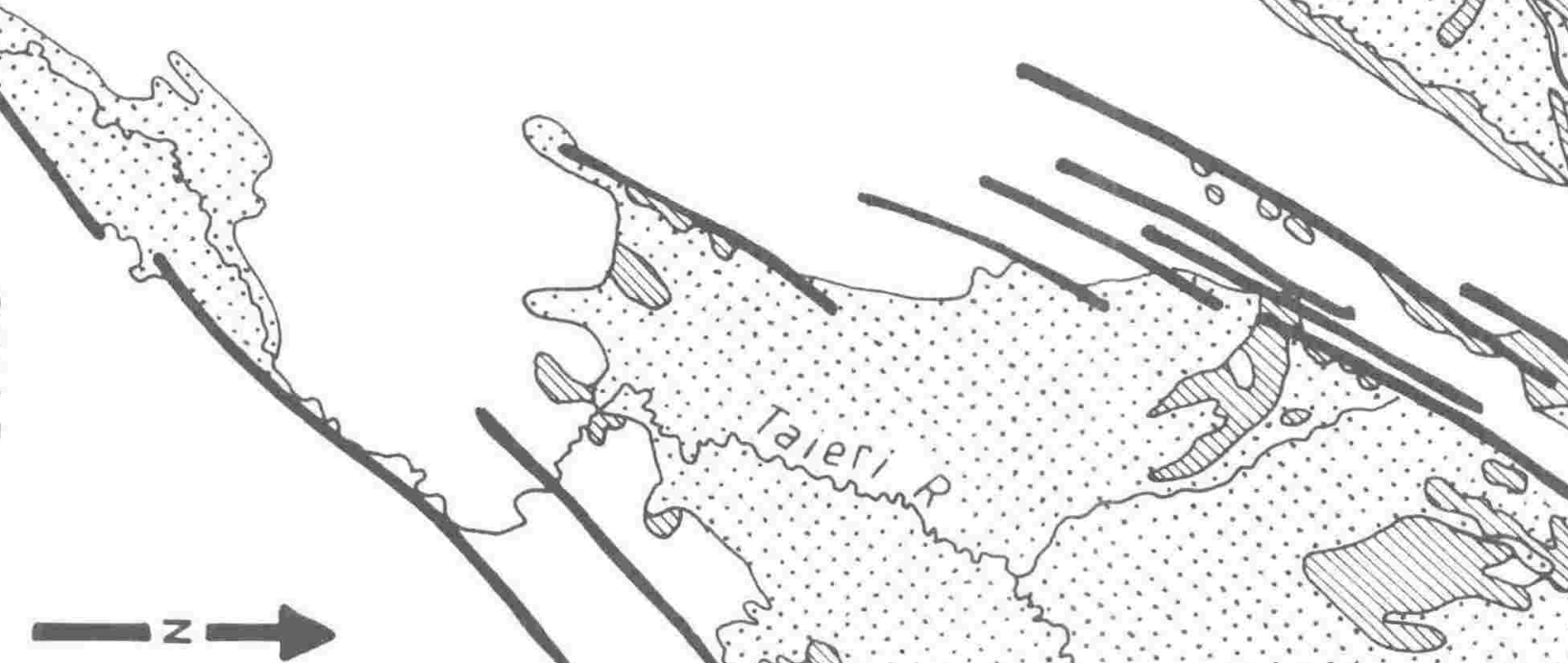

in

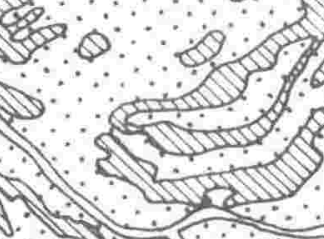

.

248

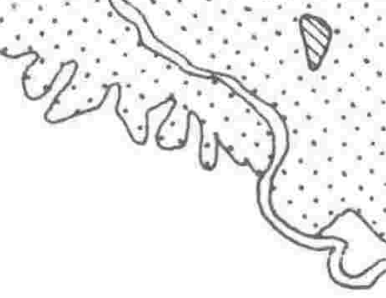




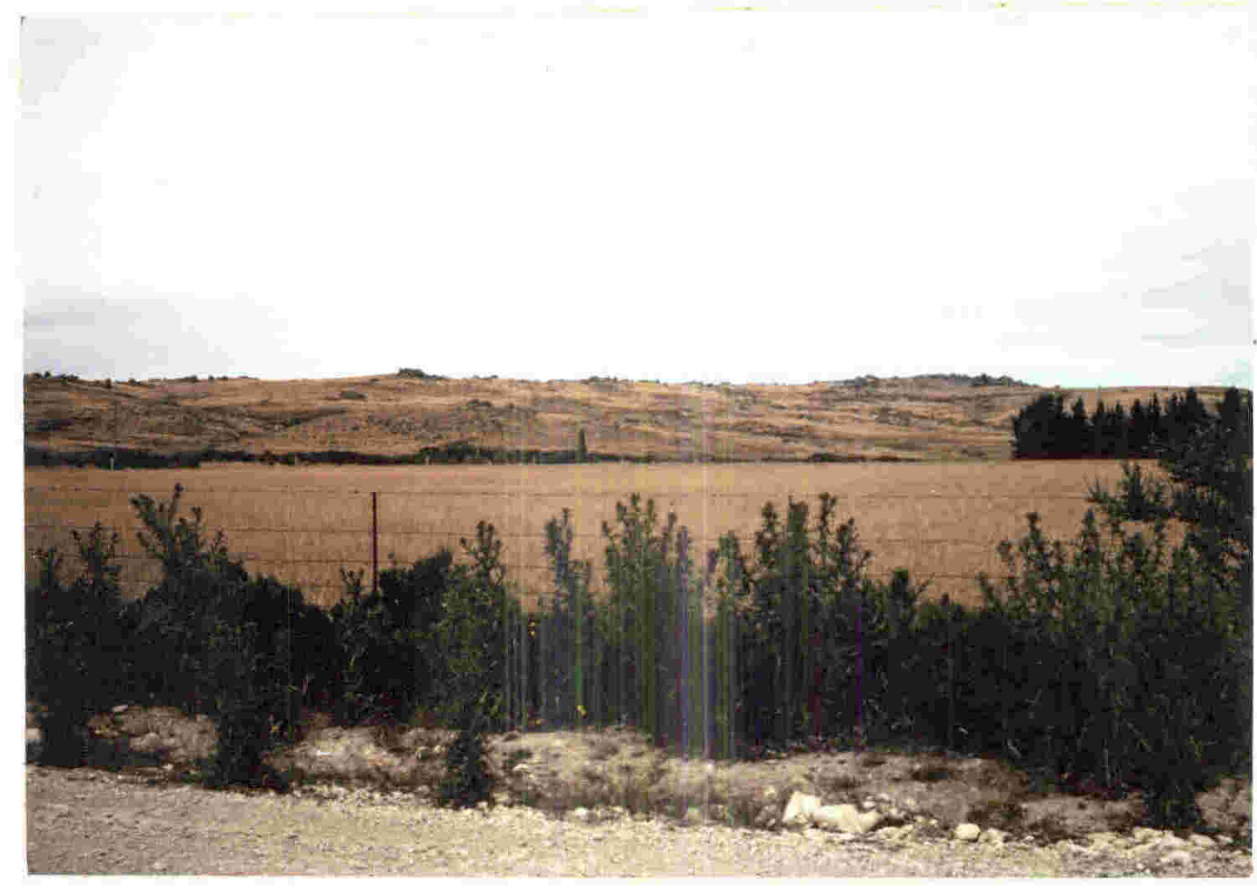

Flg. 4.2 Dip slope of Rough Range as seen looking south from ldaburn opencast, showing stripped and tilted surface of fossil peneplain with numerous schist tors.

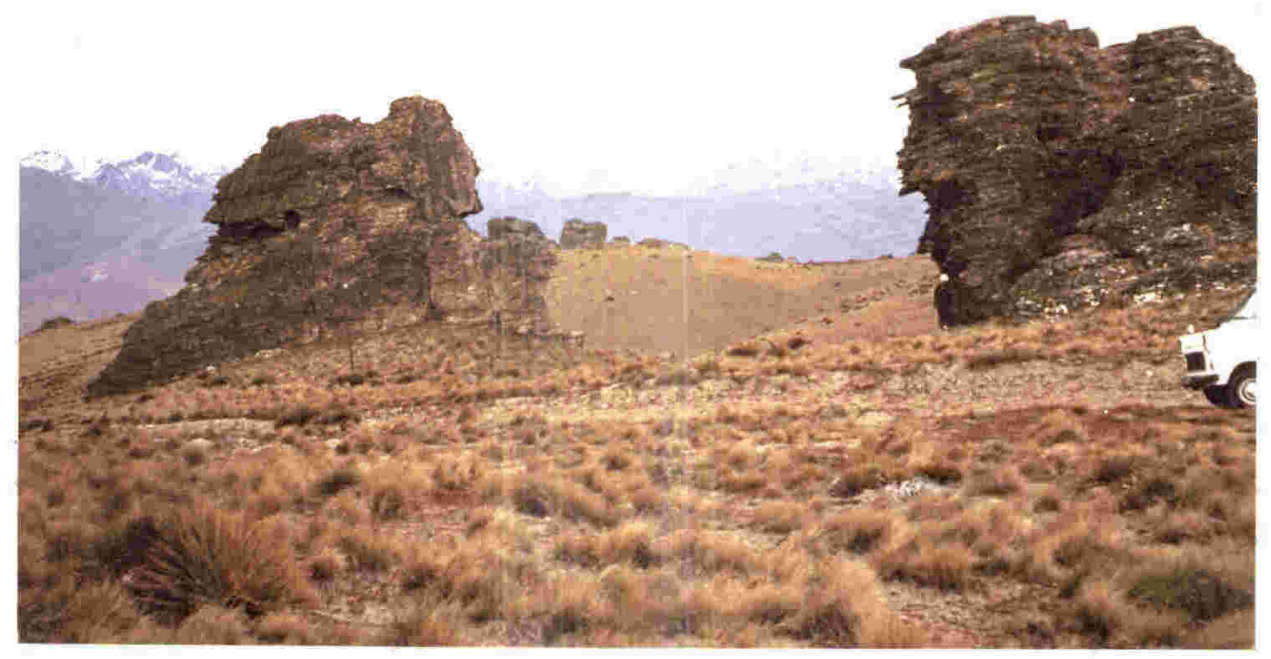

$\underline{\underline{F l G}} \underline{4}, 3$ Area of old peneplain surface at summit of Carrick Range showing large schist tors. 
underlying the Nevis Oil Shale. Residual boulders, known to the miners as "chinamen" or "sarsen stones" are common throughout the region. Most are white or grey in colour and cemented by silica, but in a few places, for example near Galloway in the Manuherikia Valley, boulders partly cemented with iron oxides have been reported (Park, 1906). Red staining associated with the weathered basement has been noted at a number of localities including Chatto Creek (Norris, Carter and Turnbul1, 1978) and Nevis (Williams, 1974).

Basal Manuherikia Group sediments near Lauder contain stromatolites which generally occur as residuals scattered on the schist surface (Norris, Carter and Turnbu11, 1978). They are known in situ at one locality, but this has not been seen by the writer and the nature of the containing sediments is not known.

A number of large north east trending faults have given rise to a series of plateau-like mountain ranges alternating with broad valleys which give the range and basin province its name. To the north and south the province is bounded by mountainous regions where the main structural trends run north-west to south-east (Park, 1908; Cotton, 1917a; Williamson, 1933). The ranges are marked by even crests which may be gently undulating with few well-defined peaks but many schist tors, some of large size (Figs 4.2 and 4.3). They are without descending spurs or foothills. The faults are generally upthrown on the western side and in profile the ranges are assymmetrical, with a steep south-east facing scarp and a gentle north-west facing dip slope, the surface of which is dissected by many gullies and also bears many tors (Fig 4.2).

Tertiary and younger sediments lie mainly in the intermontane basins, with only a few isolated outliers left on the stripped schist surface of the ranges to show that cover was once more extensive. The basins occupy fault angle depressions and the main outcrops of Tertiary sediments are around the margins where the contact between basement and covering strata is exposed. Most of the larger sluicing claims were in such areas. Along the faults the Tertiary beds have been much deformed and may dip at high angles (Park, 1906; 1908) (Fig 4.4). Some of the overlying gravels may be similarly affected but they are not usually so severely deformed. 


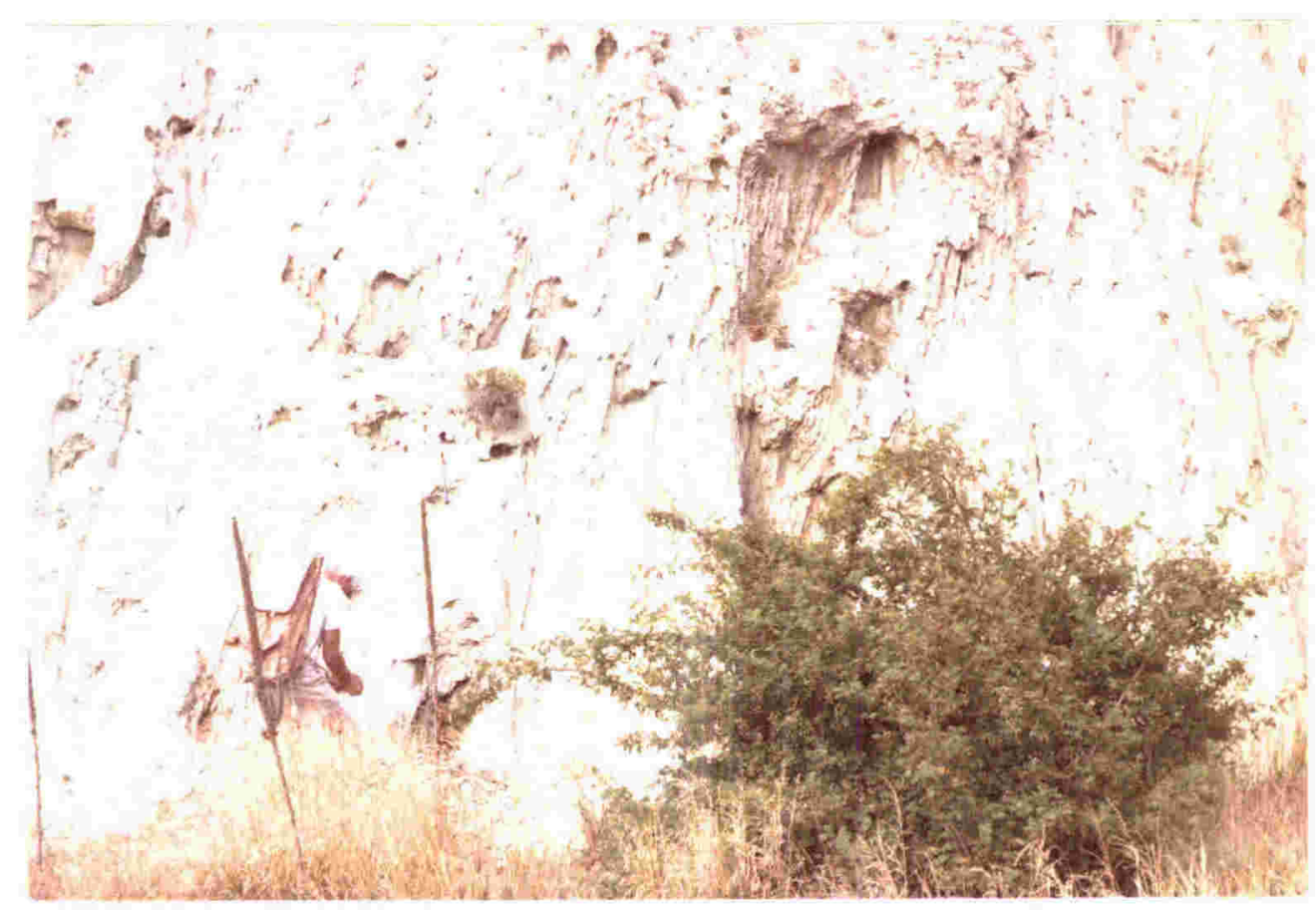

$\underline{\underline{F l G}}$ 4. 4 Steeply dipping Manuherikia Group sediments at the mouth of Bannockburn Ereek adjacent to fault

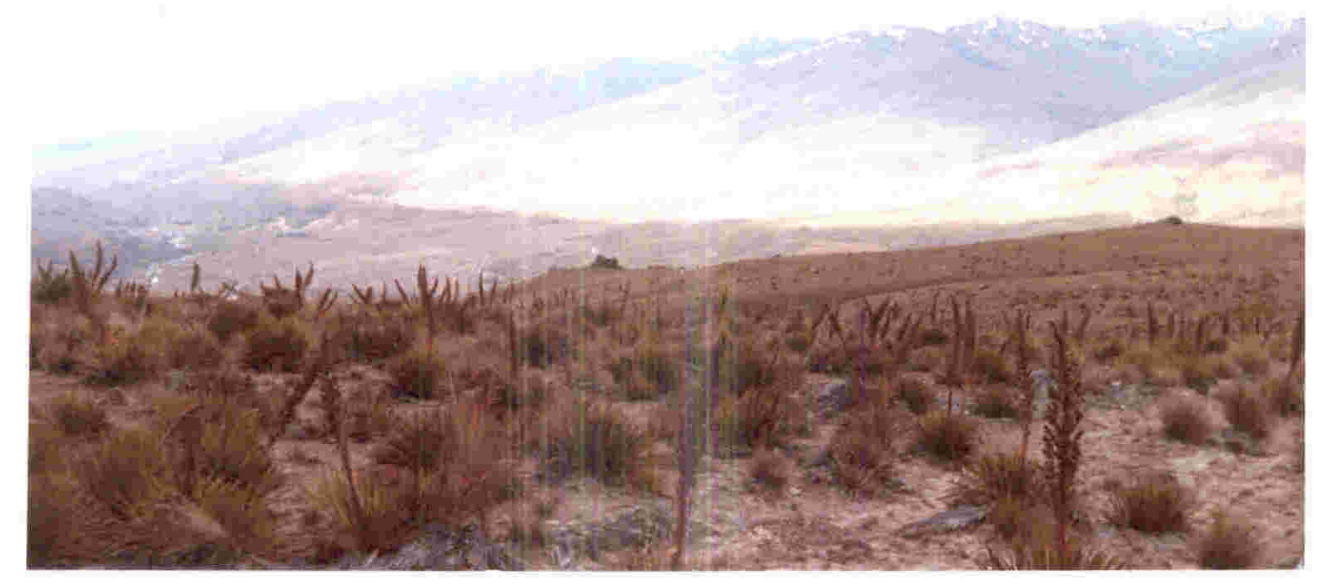

FlG. 4.5 General view of ower Nevis basin from Duffers Saddle looking south west. Tertiary racks of the Nevis Formation show up as prominent light-coloured outcrops in high terraces along lower slopes of spurs. 
Nevis Valley Fig 4.1

The Nevis River, a tributary of the Kawerau, drains a valley approximately $48 \mathrm{~m}$ long in a NE-trending fault angle depression between the Hector Mountains and the Remarkables to the west and the Garvie Mountains and the Carrick Range to the east. The valley opens into two basins in which Tertiary and younger sediments are preserved connected by a gorge cut in basement. The river drains the Lower Nevis basin through a deep, youthful gorge ca. $13 \mathrm{~km}$ long and joins the Kawerau at Nevis Bluff (Henderson, 1923). Access to the valley is by a road over the Carrick Range or by four-wheel drive tracks northwards over Doolan's Saddle to Gibbston in the Kawerau Gorge or southwards from the Upper Nevis basin to Garston. Although the area is isolated it once supported a considerable population although there is now no trace of the settlement (McGill, 1980). Alluvial gold and lignite were mined in the Lower and Upper Nevis basins and quartz reefs were worked at the summit of the Carrick Range. The Ministry of Works and Development has recently investigated the oil shale deposit as a source of pozzolan for the Clutha Power Scheme (Douglas et al., 1978).

The Tertiary rocks are generally exposed in high terraces along both sides of the Lower Nevis basin (Fig 4.5). The Upper Nevis basin was not visited in the course of this study. Generally the Tertiary strata in the Nevis valley have been included in the Manuherikia Group (Douglas et al., 1978). Earlier authors did not differentiate them (Henderson, 1923; Willett, 1943a; Wood, 1962) but Williams (1974) recognised a Nevis Formation with three members in conformable upward succession; a basal coal measure member, an oil shale member and the Dell Sandstone member (Fig 4.6). Douglas et al. (1978) gave the names Nevis Lignite and Nevis Shale to the lower two units. Henderson (1923) erroneously stated that the lignite measures overlie the shale having based his conclusion on an overthrust section.

The Nevis Lignite Measures contain quartz sandstone, siltstone, clay, quartz gravel and two thick lignite seams, the upper one being $10-15 \mathrm{~m}$ thick in places and persistent (Williams, 1974; Willett, 1943). The base of the Tertiary sequence is a red, gritty clay derived from severely weathered schist and containing an horizon of strongly cemented quartzite 


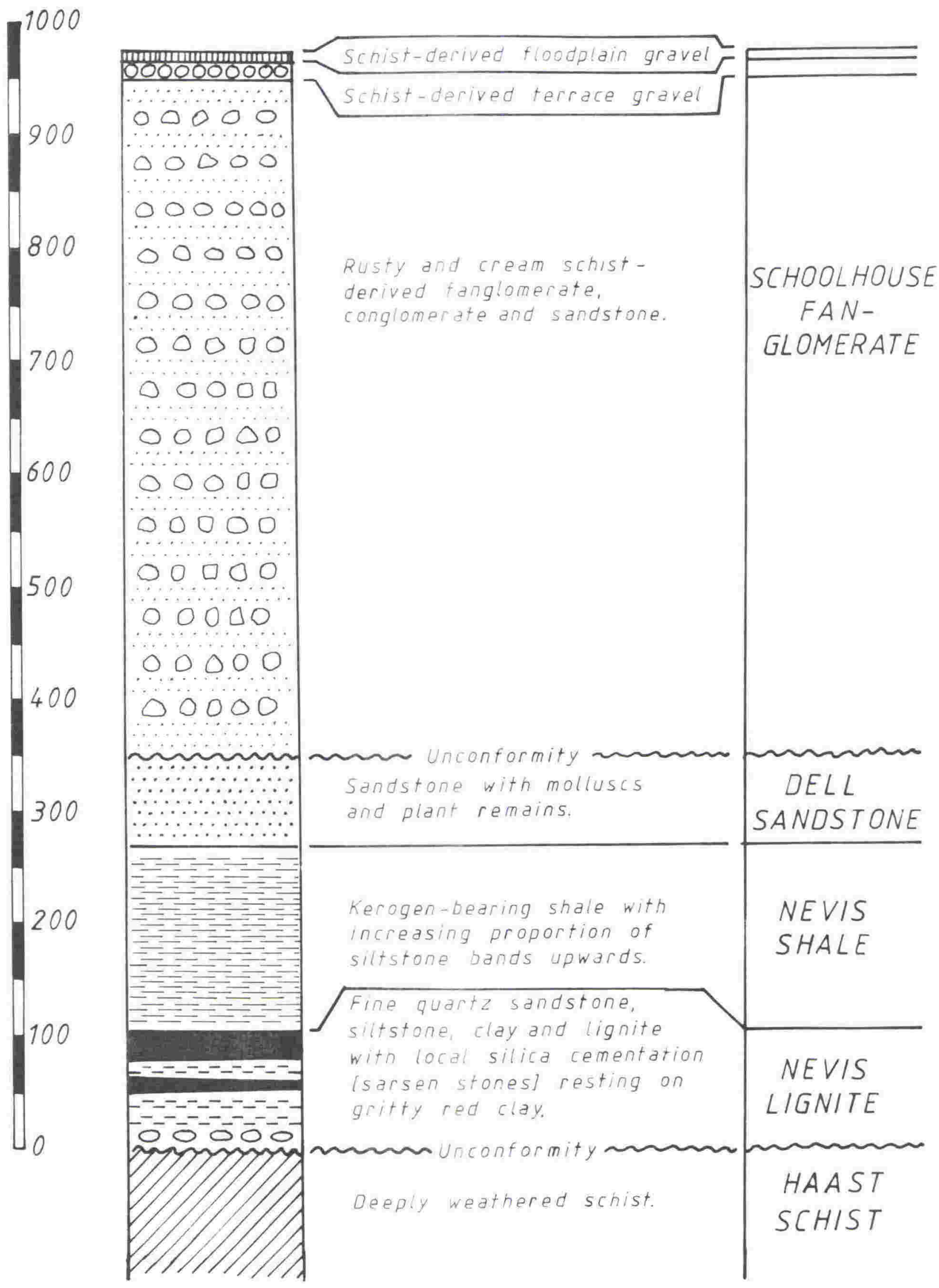

FlG. 4. 6 Generalised stratigraphic column for Nevis Valley lafter Williams 1974 and Douglas et al. 1978] 
boulders. At most places the oil shale rests directly on the upper lignite seam. The shale is tough and dark brownish-grey to almost black when fresh, bleaching to pale grey, or cream on weathering. Cut or broken surfaces show a varve-like structure with alternating very thin light and dark laminae. Leaf remains are common and frequently show plastic deformation similar to that observed in leaf fossils from the Longford Formation. Moulds of disarticulated fish bones are frequent and a few decalcified Hyridella shells were found. The bedding is frequently contorted (Fig 4.7). Being very fissile, the shale readily breaks up into angular slabs in weathered exposures. Along Shale Ridge and at many other localities extensive areas devoid of vegetation are mantled with shale slabs (Fig 4.8).

The shale is richer in hydrocarbons at the base, becoming progressively leaner upward, and is interbedded with micaceous sand and silt towards the top. It contains abundant vivianite, and crystals of anapaite $\left(\mathrm{Ca}_{2} \mathrm{Fe}\left(\mathrm{PO}_{4}\right)_{2} \cdot 4_{2} \mathrm{O}\right)$ have been found in drill cores (Williams, 1974). It passes unconformably into the Dell Sandstone Member, formerly included in the oil shale (Henderson, 1923; Willett, 1943). This is a cream, brown or grey micaceous muddy sandstone containing some fresh water mussel shells and abundant leaf impressions and plant debris but no coal or coalified logs. The upper surface of this member is eroded and overlain unconformably by the coarse, angular, schistose gravels and interbedded sands of the Schoolhouse Fanglomerate (Williams, 1974). The writer collected fossil leaves from only the oil shale along Shale Ridge.

Bannockburn, Cromwe11 and St. Bathans Fig 4.1

On the eastern side of the Carrick Range, Tertiary strata outcrop along the valleys of the Bannockburn and its tributary, Shepherd's Creek. The deposits continue on the north side of the Kawerau River and underlie much of the Cromwell Basin. A narrow schist ridge, upon which the Bannockburn bridge is built, intersects the cover beds to the south of the Kawerau but schist is not traceable in the north bank of the river (Wood, 1962). The area has been extensively sluiced for gold and lignite was mined from a $6 \mathrm{~m}$ seam in Shepherd's Creek and from a poorer grade seam in the Bannockburn (Park, 1908). The original Bannockburn township was sited on the flats at the mouth of 


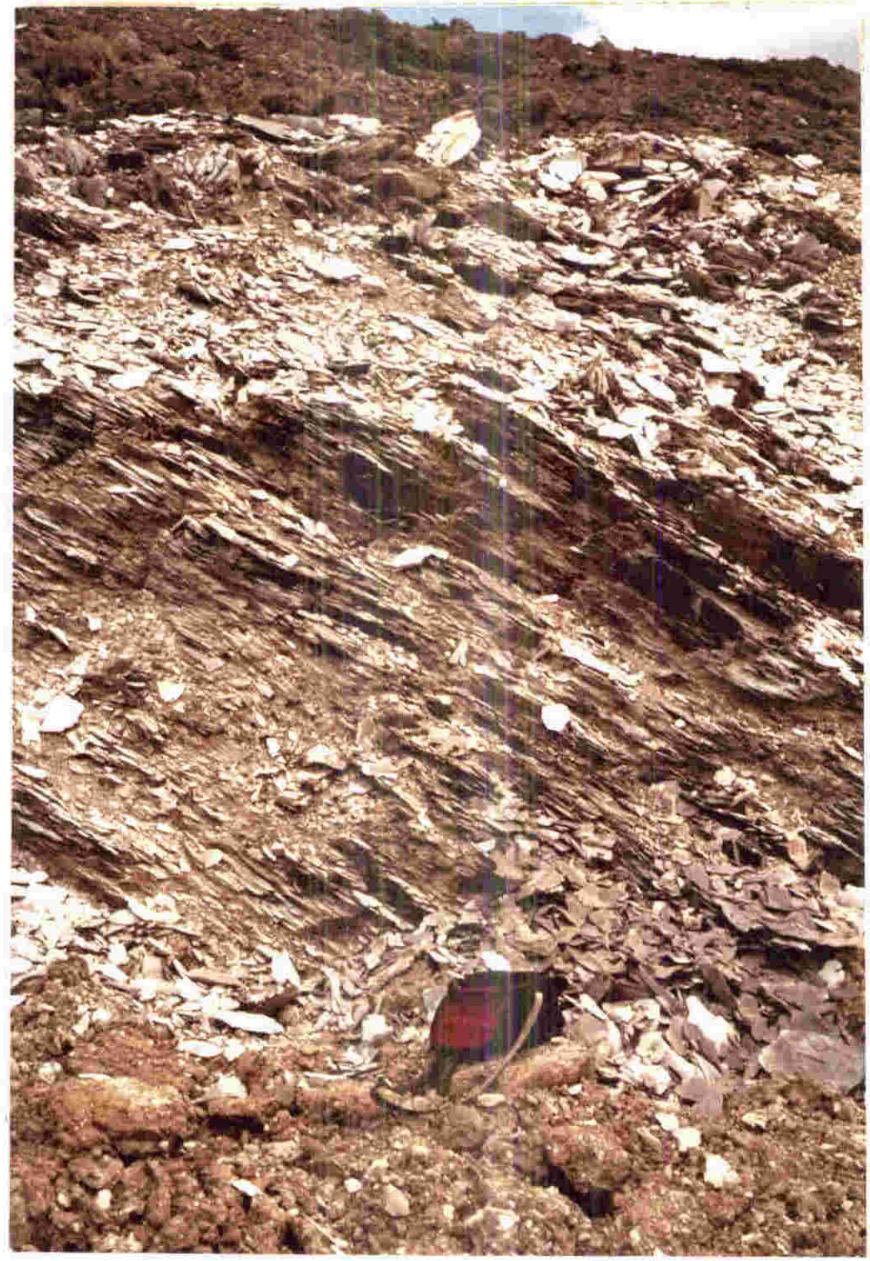

FIG, 4. 7 Nevis Oil Shale; exposure in Ministry of Works pozzolan quarry, Shale Ridge, showing thinly-bedded, fissile shale breaking into angular slabs.

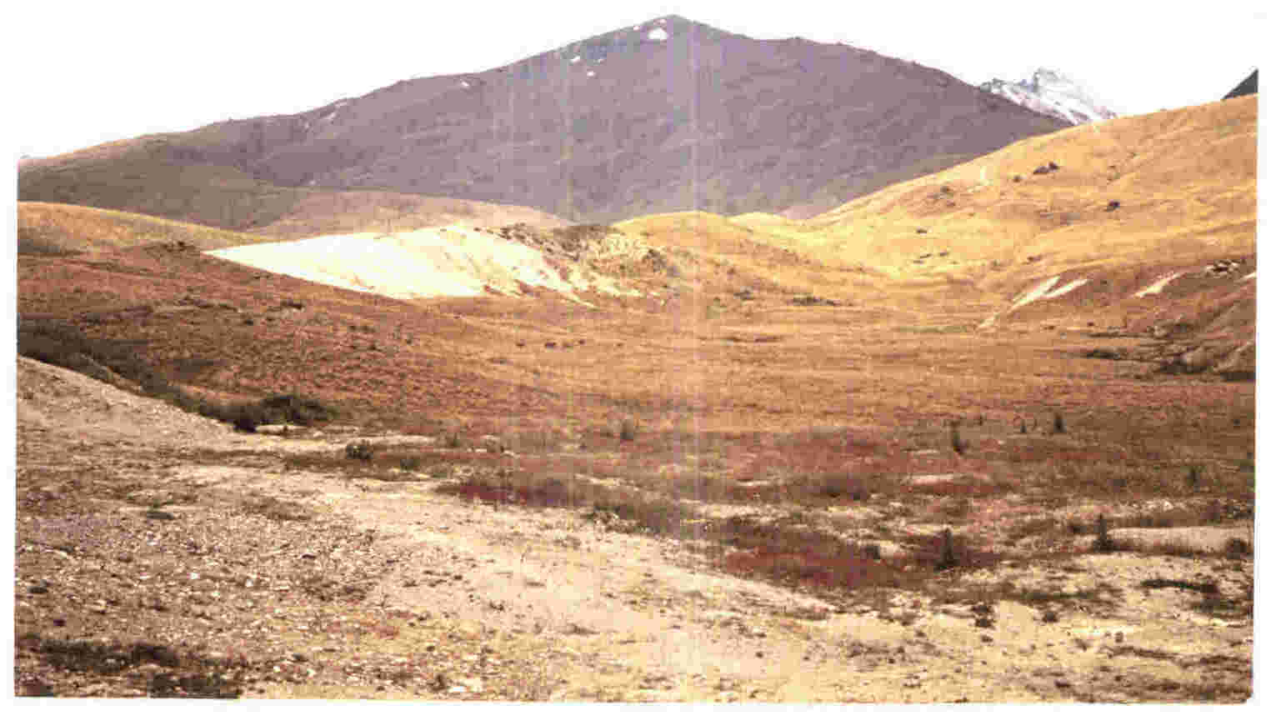

FlG. 4.8 Shale Ridge, Nevis valley looking west, showing

areas of bare ground llight-coloured mantled with loose

shale slabs. 
the Bannockburn but was later moved to its present site (McGil1, 1980). Plant fossils were collected from a number of sites along the Bannockburn, where Manuherikia Group sediments form bluffs along the west bank (Fig 4.9). The sequence here was described by Park (1908) from an unmeasured section exposed in the floor of alluvial claims but now obscured. Beds exposed in the bluffs include micaceous muddy sandstones, fissile carbonaceous shales resembling the Nevis Oil Shale, white quartz sand, white kaolinitic clays and thin, dirty lignite seams. Plant fossils occur sporadically throughout, particularly in the carbonaceous shale and kaolinitic clay. Some beds in the area contain crystals of gypsum, some of large size (J. Thornton, pers. comm.), and small gypsum crystals were found associated with organic remains. Along Bannockburn Creek the beds are faulted against the schist ridge, and close to the fault, at the junction with the Kawerau River, the beds are more or less vertical (Fig 4.4). Schist scree and colluvium obscure details of the section.

Manuherikia Group sediments also outcrop in the cliffed northern bank of the Kawerau between Bannockburn Bridge and Cromwell. A number of sections along this reach were described by Park (1908) and Douglas et al. (1978). A few leaf impressions were obtained from fallen blocks near the bridge but the cliffs are now largely overgrown and exposures are poor.

In the upper Manuherikia basin about $300 \mathrm{~m}$ of Tertiary sediments comprise quartz conglomerate, quartz sand, plastic white clay, oil shale, lignite and greenish gypsum-bearing clay with fresh water fossils (Harrington and Couper, 1959). The main outcrops are in old gold workings at St Bathans and nearby Vinegar Hill and Cambrians. Willett (1943b) reported that the oil shale deposit at Cambrians was a bed less than $2 \mathrm{~m}$ thick underlying a $6 \mathrm{~m}$ lignite seam and containing numerous fragments of yellow-brown resin and a few quartz pebbles.

A thick Tertiary sequence unconformably overlying Torlesse Supergroup argillites is exposed in the old gold workings at St Bathans. Sluicing operations have stripped the cover beds to basement in places showing that the contact along the northern side of the workings is not faulted (Fig 4.10) although Mutch (1963) mapped a number of faults close by. A small lake now occupies the mine floor (Fig 4.11). The beds exposed are 


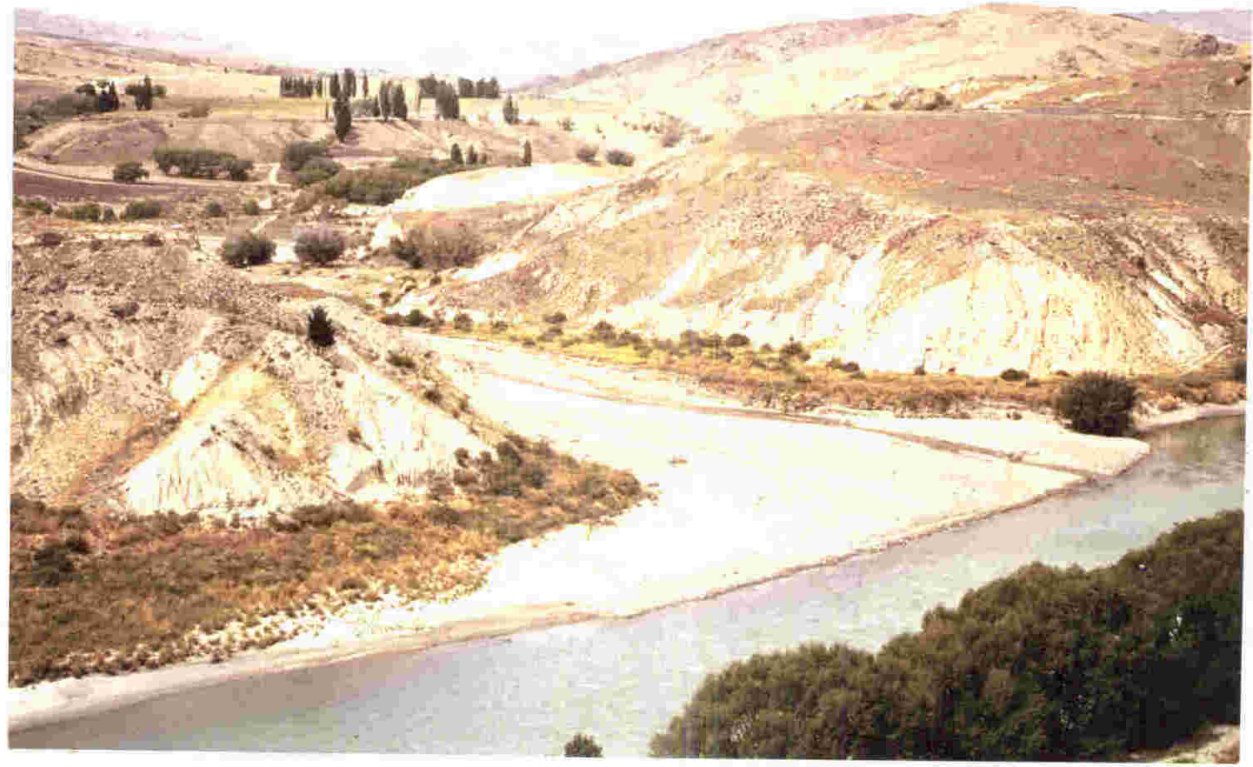

FlG 4 , $\underline{\underline{9}}$ Bannockburn; mouth of Bannockburn Creek showing steeply-dipping Manuherikia Group sediments forming prominent bluffs. The exposure shown in Fig. 4.4 is in the bluff at the right of the photograph.

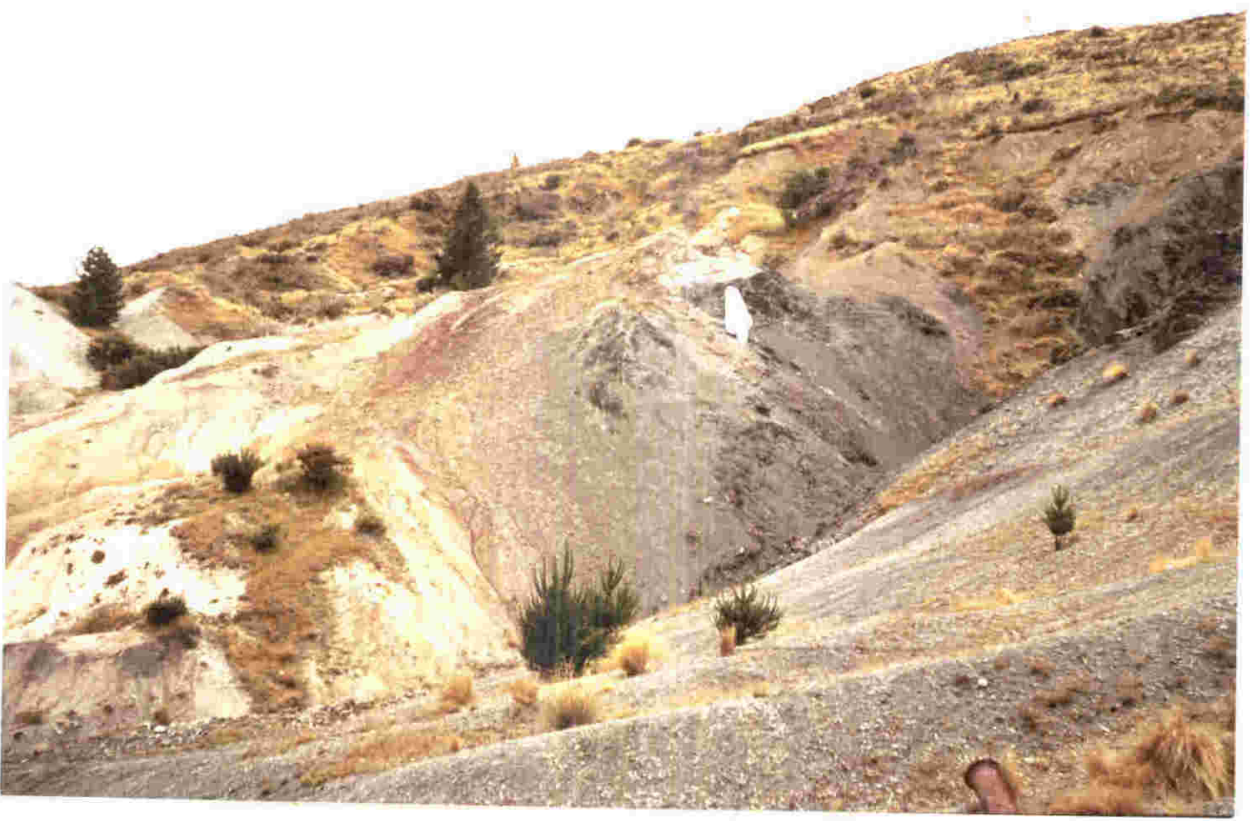

FlG, 4.10 St Bathans; northern side of old gold workings overlying light-coloured, quartzose Manuherikia Group

clearly Group basement. The contact [arrowed] is here clearly not faulted. 


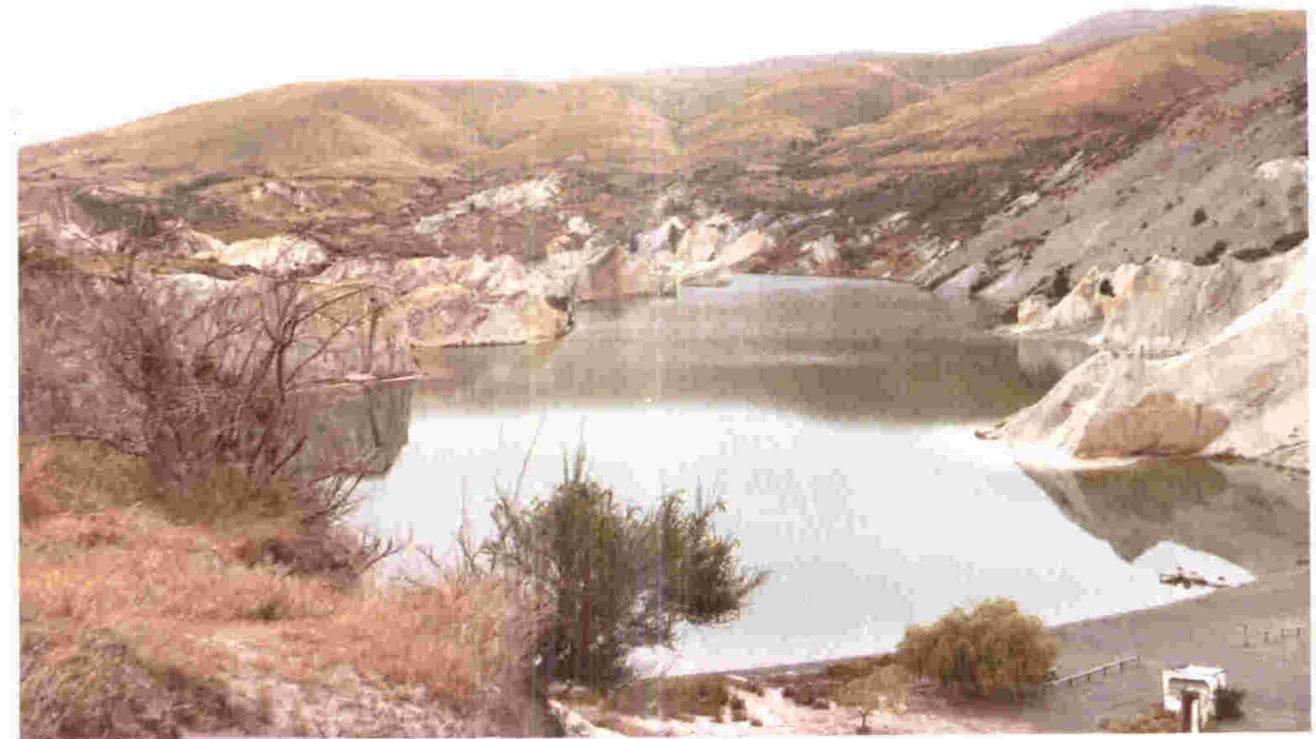

FlG, 4.11 St Bathans; general view of Blue Lake and old gold workings, looking west, showing highly quartzose Tertiary sediments with thin lignite overlying Torlesse Group basement.

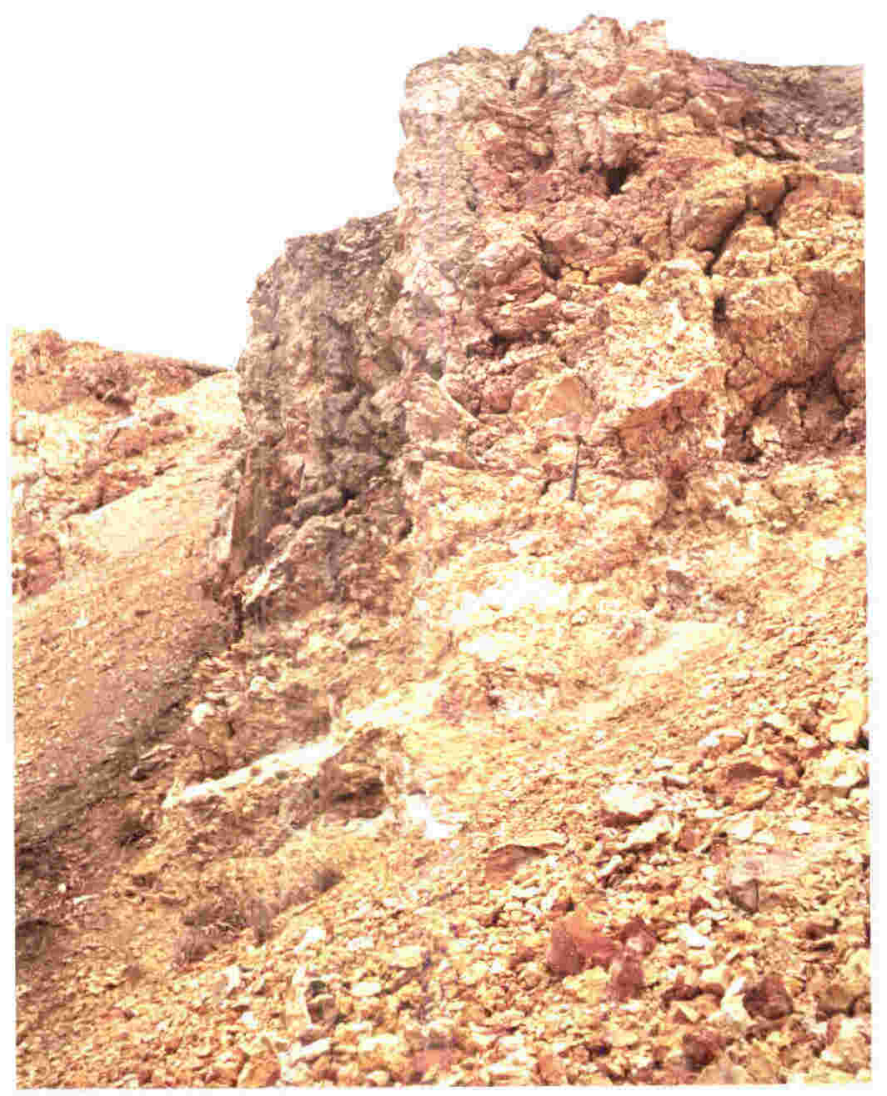

$\frac{\text { FlG }}{\text { at }}, \frac{4}{\text { eastern }}$

St Bathans; reddened, baked sediment

["porcellanite"] end of workings [hammer for scale]. 
predominantly white quartz gravels, grits and sands, generally poorly consolidated, with interbedded white and purplish-brown clays and thin seams of dirty lignite. Mutch mapped a small area of Landon marine beds at the western end of the workings, but no evidence of this was found during the author's visit and Mutch may have mapped the occurrence on the basis of unconfirmed reports of very thin marine beds in water races and sluicing claims mentioned by Harrington (1955) and Harrington and Couper (1959). Morgan (1920) reported a green fossiliferous clay with fresh water mussels and fish remains which may have been mistaken for marine beds by miners.

Although several lignitic beds are exposed in the workings all are of poor quality. A small area of red and yellow baked sediments ("porcellanite") (Fig 4.12) is present at the eastern end of the pit and may indicate the former presence of a thicker lignite lens which has burnt away. The lowest seam, about $5 \mathrm{~m}$ above the base of the southern wall of the pit is composed almost entirely of poorly preserved leaf remains mixed with a fine muddy sand. Additional poorly preserved plant fossils were collected from a peaty horizon composed of alternating laminae of of lignitic clay and carbonaceous sand near the top of the section. Many good leaf impressions were collected from the western end of the workings in the area mapped by Mutch (1963) as containing marine beds. These fossils were in a $1 \mathrm{~m}$ bed of purplish-brown silty clay (Fig 4.13) stratigraphically above the quartz gravel overlying the uppermost lignite exposed in the pit. The silty clay grades down into a pale greenishgrey plastic clay at the base. Many of the fossils have well preserved cuticle and some leaves are more mummified than carbonised. X-ray diffraction analysis of crystal aggregates that are abundant in the bed showed the presence of quartz, gypsum and an unidentified minor component, probably clay minerals.

\section{Coal Creek Flat Fig 4.1}

At Coal Creek Flat near to the Roxburgh Dam and about $6 \mathrm{~km}$ north of the town is an infaulted outlier of Tertiary strata on the west bank of the Clutha River (Wood, 1966). This is the southernmost of a series of such outliers (Wood, 1962). It is approximately $3 \mathrm{~km}$ by $0.5 \mathrm{~km}$ and spans the lower ends of Coal Creek and Washpool Creek. Lignite has been mined from the flat since the early days of gold mining at 


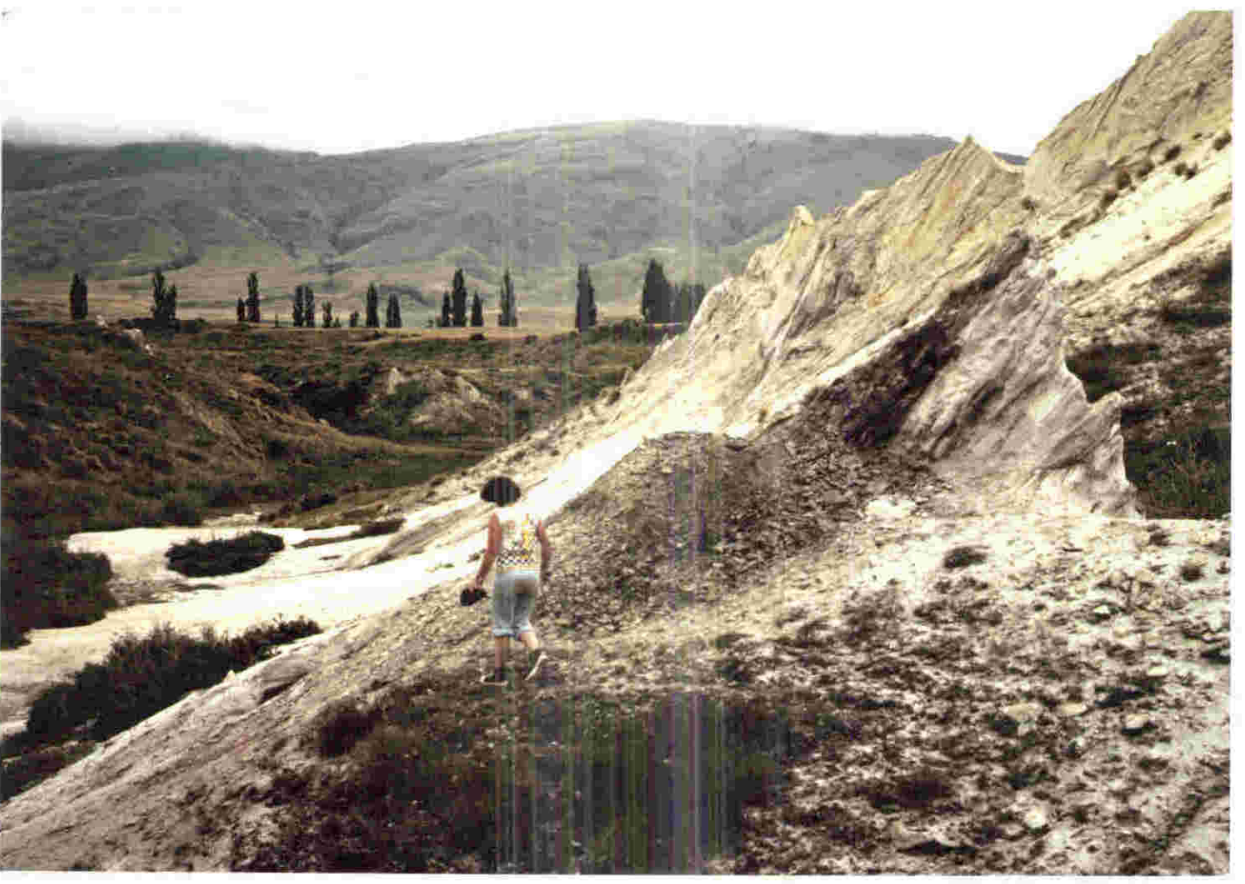

FlG.4.13 St Bathans; western end of old gold workings cross-bedded white quartz sands and gravels of Manuherikia Group and fossiliferous clay bed [dark area, right centre]. 
first to provide fuel for the gold dredges, and Speight (1931) described the two opencast mines still operating.

Thick coal is exposed in the workings in the lower part of Washpool Creek, overlying sandstone with schist and quartz pebbles and a bed of white clay. The lower $5 \mathrm{~m}$ of the lignite is resinous with two partings of carbonaceous shale. The upper part, estimated by Speight to be approximately $30 \mathrm{~m}$ thick, shows little resin but contains several shaly partings and lenses of white clay and passes up into carbonaceous shales and finally muddy sands, which are ferruginous in parts. The lignite is in places canneloid and has tree trunks throughout, somewhat compressed and lying parallel to the bedding (Speight, 1931).

The only pit currently being worked is Harliwick's Pit at the lower end of Coal Creek, where at least $5 \mathrm{~m}$ of lignite is exposed. This site has been worked more or less continuously and the remains of two old drives can still be seen in the west wall. The floor of the pit is highly irregular and of whitish clay containing abundant plant fragments. The lignite contains resin horizons and numerous compressed stems and branches. In the wall of one of the old drives small lenses of pale blue-grey plastic clay grading up into silt, sand and carbonaceous shale were observed. The overburden is a pale blue-grey lacustrine siltstone containing leaf impressions and well-preserved fossil Hyridella.

\section{FLORAS}

Nevis Oil Shale

About twenty species (Table 4.1) have been recognised from the Nevis Oil Shale, mainly dicotyledonous leaves, but with a few twigs and fruits, conifer and fern remains. The assemblage is quite distinct from any other so far found in Central otago. It appears to have some species in common with the Oligocene-Miocene floras of Southland, but a number of the species present are not so far known from anywhere else.

Among the most abundant fossils are leaves of species of Fagaceae and Cunoniaceae, often associated in montane forests in New Zealand today. Nothofagus southlandica is known as well from Landslip Hill and Tuturau in Southland but has not so far been recorded anywhere else. N. novae- 
TABLE 4.1. PLANT MEGAFOSSIL TAXA IDENTIFIED FROM THE NEVIS OIL SHALE.

PTERIDOPHYTA

Cyatheaceae

GYMNOSPERMAE

Dacrycarpus sp. aff. dacrydioides ? Podocarpaceae

ANGIOSPERMAE

Litsea dawsoniana Holden Nothofagus southlandica sp. nov.

N. bidentatus Holden

N. australis (Oliver) comb. nov.
?Beauprea

Myrtaceae (2)

Ceratopetalum kaikoraiense Oliver Cunoniaceae

? Papilionaceae or Caesalpinaceae (2)

?Sapindaceae

Kaikoraia gracilis Oliver ?Araliaceae

Apocynophyllum affine $\varepsilon t t$.

?Zingiberaceae

4 additional unnamed taxa have also been recognised. 
zealandiae is a common and widely distributed Tertiary species. The Cunoniaceae are represented by Dryophyllum dubium Ett., also found at Landslip Hill and by other fossil leaves, probably a species of Cunonia or Weinmannia. Another link with the Landslip Hill flora is a single leaf Apocynophyllum affine Ett.

Of particular interest are a number of fossils suggesting the presence of genera no longer represented in New Zealand. One is a large, probably Myrtaceous, leaf with a marked marginal vein. It resembles fossils from Longford tentatively assigned to Xanthostemon but is larger. A number of smaller leaves, possibly of the same species, are closer to the Longford fossils in size. A single fragment from the base of a large, probably monocotyledonous leaf is similar to the leaves of Hedychium (Zingiberaceae) and Canna (Cannaceae). Neither genus is native to New Zealand today, but both have become naturalised in warmer parts of the country (Healy and Edgar, 1980). Canna is a genus of plants from the West Indies and Central and South America, and its present distribution suggests that it is unlikely to have existed in New Zealand during the Tertiary Period. The present range of Hedychium is from Madagascar through India to South-east Asia and Malaysia. One species (ㅂ. is probably native to Queensland and Northern New South Wales (Hodgson \& Paine 1971). The fossil resembles the Cretaceous Pakawaua speciosa (Ett.) Mildenha11 (?Musaceae) from Pakawau (Mildenha11, 1972a) but is smaller.

Two fragments of leguminous seed pods possibly represent two distinct species. They do not resemble fruits of any living New Zealand species, but are similar to those of many exotic genera including Derris (Papilionaceae) and various Caesalpinaceae.

Pollen analyses of samples from all three members of the Nevis Formation by D.C. McIntyre (Williams 1974) indicate that important elements of the vegetation were Nothofagus ('brassii' and 'fusca' groups), Casuarina, Araucariaceae, Podocarpaceae and Myrtaceae. While a number of leaves of Nothofagus species were found, remains of Casuarina and conifers are scarce. This discrepancy may be due to over-representation of wind pollinated species in offshore pollen assemblages. Myrtaceae are generally insect pollinated but their pollen grains are usually small and probably easily carried by wind. A few apical fragments of 
Casuarina branchlets, a few leaves resembling those of Podocarpus totara and a small branchlet similar to juvenile Dacrycarpus dacrydioides have been found.

McIntyre reported that the most abundant organic remains in the pollen preparation from the Dell Sandstone were specimens of the green alga Pediastrum cf. botryanum which has since been reported from other sites in Central Otago. Overseas abundant fossil Pediastrum have been recorded from the Eocene Green River $0 i l$ Shale of North America (Bradley 1929) and from the early Tertiary of Australia (Cookson 1953). Douglas et al. (1978) reported fossil Diatomaceae and other siliceous remains, possibly sponge spicules, from the Nevis oil Shale. A sample of the shale was submitted to Dr. M.A. Harper who identified a number of species of Diatomaceae (Appendix B) and provided information regarding their ecological requirements.

Bannockburn, Cromwell and St. Bathans (Table 4.2)

Assemblages from these localities are distinct from those of the Nevis Shale and are sufficiently alike to be treated together. In both the Bannockburn/Cromwell area and at St. Bathans the commonest fossils are large leaf impressions resembling Pittosporum eugenioides. It is not certain whether this is a species of Pittosporum or a member of some other family. Members of Araliaceae and Euphorbiaceae may show a similar venation pattern. Leaves from St. Bathans have yielded wellpreserved cuticle which may enable eventual identification. Also common at St. Bathans are impressions of a fairly large leaf resembling Weinmannia or Cunonia (Cunoniaceae). This fossil species is also present, but less commonly, at Bannockburn.

Also present at both St. Bathans and Bannockburn are leaves of probable Lauraceous affinity and leaves resembling Geniostoma (Loganiaceae). One probable Lauraceous species is common to both St. Bathans and Nevis.

Casuarina cones and foliage were found at Bannockburn but not at St. Bathans. They are not conspecific with cones and foliage from Landslip Hill and are possibly the remains of a species of cryptostome Casuarina. 
TABLE 4.2. PLANT MEGAFOSSIL TAXA IDENTIFIED FROM MANUHERIKIA GROUP SEDIMENTS AT BANNOCKBURN AND ST. BATHANS

PTERIDOPHYTA

$$
\text { (Col.) Tryon }
$$

*Alsophila sp. aff. tricolor * Eucalyptites roxburghiensis sp. nov. *Blechnum sp. + ? Stenocarpus

Cunoniaceae

ANGIOSPERMAE

+ Cunoniaceae

+Litsea dawsoniana Holden

* Papilionaceae or Caesalpinaceae

+Cryptocarya sp.

?Cryptocarya sp. ?Geniostoma $\mathrm{sp}$.

*Calpidia zealandica Oliver + ? Streblus sp.

*Nothofagus novae-zealandiae (Oliver) *? Araliaceae ${ }^{*} \mathrm{~N}$. australis (Oliver) comb. nov. Holden* Ripogonum sp.

*Casuarina avenacea Camphell e Hoddent Phormium sp. * Metrosideros pliocenica Oliver
*Bannockburn only
+ St. Bathans only

An additional 24 unnamed taxa have been collected from Bannockburn and 7 from St. Bathans. 
No Nothofagus leaves were found at St. Bathans, but two or three species occur at Bannockburn including the widespread Tertiary species N. novae-zealandiae and another species with leaves resembling those of living $\underline{N}$. truncata. There are several Myrtaceae including leaf fragments reminiscent of species of Metrosideros, Xanthostemon and Eucalyptus. Two species of ferns were found at Bannockburn, one probably a species of Cyathea and the other a species of Blechnum with distant pinnae.

Many leaves cannot be assigned to modern New Zealand genera. From St. Bathans there is a proteaceous leaf resembling Stenocarpus, possibly one of Ettingshausen's "oaks", and from Bannockburn leaves resembling those of present-day Piper, Caesalpinia, Canavallia, Capparis and Drimys species. A large leguminous seed pod not resembling any living New Zealand species was also found. The assemblage does not appear to have any parallel in New Zealand today.

A few fragments of swamp plants are preserved at Bannockburn, including sections of Phormium leaves. In situ stocks, probably of lake margin sedges, were found in a clay bed associated with a thin seam of dirty lignite in the bluffs at the mouth of Bannockburn Creek.

A sample of matrix from the St. Bathans leaf bed was submitted to Dr. D.T. Pocknall of N.Z. Geological Survey for Palynological examination (Appendix A). There is little correspondence between the megafossil assemblage from this bed, outlined above, and the pollen assemblage, which is dominated by 'brassii' beech (Nothofagidites cranwellae $62 \%$ ) with smaller percentages of 'fusca' beech (N. lachlanae $5 \%$ ), Myrtaceae (7\%), Elaeocarpaceae (5\%) and Casuarinaceae (Haloragacidites harrisii $4 \%$ ).

Samples of Lacustrine shale from Bannockburn and lignitic sand from a horizon stratigraphically underlying the leaf bed at St. Bathans were examined for Diatomaceae by Dr. M.A. Harper (Appendix B).

\section{Coal Creek Flat, Roxburgh (Table 4.3)}

An examination of compressed stems and resin from the lignite by Evans (1931; 1934; 1936; 1937) indicated forest vegetation with Agathis, Podocarpus, Phyllocadus and Nothofagus cf. fusca. Samples of resin were 
Table 4.3. Plant Megafossil taxa identified from Manuherikia Group sediments at Coal Creek Flat, Roxburgh.

\section{GYMNOSPERMAE}

?Podocarpus sp. (wood, Evans 1936). Phyllocladus sp. (wood, Evans 1937), Agathis sp. aff. australis (wood and resin, Evans 1934).

\section{ANGIOSPERMAE}

Nothofagus sp. (wood, Evans 1931).

Eucalyptites roxburghiensis sp. nov.

?Rhopalostylis sp.

An additional six unnamed taxa have also been recognised. 
analysed by Hosking (1929) and Brandt (1939) and found to contain agathic acid, produced in large quantities by Agathis australis and the related Malaysian species $\underline{A}$. alba. The overburden assemblage differs markedly from that of the lignite. Only a few species are present, and the most abundant fossils are impressions of lanceolate to falcate glandular leaves with a venation pattern resembling that of some species of Eucalyptus. Eucalyptus type pollen is known from Miocene sediments in Central Otago (Mildenha11, 1980) and constitutes ca. 50\% of some Pliocene assemblages (D.C. Mildenhall, pers. comn.).

Other leaves include some poorly preserved impressions similar to a common leaf type from Landslip Hill but larger. The precise affinities of this species are as yet unknown. Other impressions possibly represent species of Compositae. Fragments of palm fronds and seeds similar to those of Rhopalostylis were also found.

Two samples of overburden material were submitted to Dr. D.T. Pocknall for palynological examination (Appendix A). As at St. Bathans there is little correspondence between pollen and megafossil assemblage. The pollen spectrum is dominated by Casuarinaceae (Haloragactdites harrisii, 26 and 32\%), "brassii" beech (Nothofagidites cranwellae, 22 and 29\%), and Myrtaceae (many forms, not distinguished, 16 and 10\%), with significant proportions of "fusca" beech (Nothofagidites lachlanae, 8 and $8 \%$ ), "menziesii" beech (‥ asperus, 3 and 4\%), Macaranga/Mallotus (Tricolporopollenites endobalteus, 5 and $4 \%$ ) and Haloragaceae (Haloragacidites haloragoides, 4 and $2 \%$ ). Of these only Myrtaceae (?Eucalyptus) are represented in quantity in the megafossil assemblage.

AGE

Age relations in the Central Otago freshwater sequences are somewhat complex, dating is difficult and it is not always possible to correlate strata from one exposure to the next. Marine beds interbedded with the fresh water sequences in the Maniototo Depression have yielded Whaingaroan foraminifera and Duntroonian to Waitakian molluscan fossils (Williamson 1939). These beds represent a temporary marine incursion into parts of Central Otago at the transgression maximum.

Fossil pollen assemblages from the lower part of the Wedderburn Formation immediately overlying the marine beds are comparable to floras 
from the post-Duntroonian 1ignites of the Mataura Valley. Most pollen samples examined have been from the upper part of the Wedderburn Formation and are somewhat younger (Couper and Harrington, 1959). The formation is generally mapped as Pareora to Southland in age (Wood 1962; Mutch 1963).

A sample of lignite from the Nevis Valley examined by D.J. McIntyre yielded fossil pollen indicating an age not older than Duntroonian and not younger than Altonian, but no closer determination was possible (Williams 1974). Plant megafossils from the overlying oil shale suggest that it is of similar age to the Landslip Hill Quartzite and the post-Duntroonian lignites of the Mataura Valley.

Wood (1960) considered the beds at Coal Creek Flat to be Landon to Pareora in age. Couper (1953a) gives the age of the lignite from this pit as Landon, but later changed this to Pareora after examining further samples (Couper 1960a). The high proportion of Eucalyptus-like leaves in the overburden could indicate that this is younger than the lignite, possibly Pliocene, but pollen assemblages from the same beds, while lacking in critical age-specific taxa, are similar to those obtained from Manuherikia Group sediments elsewhere in Central Otago and an age as young as Pliocene is unlikely (D.T. Pocknall, pers. comm. Appendix A).

\section{PALEOENVIRONMENT}

Intense leaching of the basement and the generally quartzose nature of the sediments suggests that the Central Otago fresh water beds were laid down on a land of low relief under peneplain conditions and with major topographic trends different to those of the present day. The sea advanced over the eastern part of the region during the Oligocene and then retreated again during the Miocene. There is no evidence of marine incursions west and south of Naseby (Isaac 1981c) and the known distribution of marine beds suggests that at maximum transgression the coastline ran just west of a line through Naseby and Swinburn. Harrington (1955) suggested a line from St. Bathans to Swinburn on the basis of the unconfirmed reports of Naseby Greensand at St. Bathans. Douglas (1980) interpreted the Manuherikia Group sequence in the St. Bathans-Idaburn area as a large fluvio-deltaic complex but made no mention of marine beds at St. Bathans. 
Douglas et al. (1978) interpreted Manuherikia Group sediments in the Bannockburn-Cromwell area as a fluvio-lacustrine sequence with extensive areas of swamp. Thin beds of lignite and rootlet bearing clays alternating with carbonaceous lake sediments, some approaching oil shale and containing Hyridella, leaf impressions and fish bones, indicate that lake margins fluctuated and were swampy at places. Fossil Diatomaceae from the lacustrine facies indicate a lake approximately $10 \mathrm{~m}$ deep with shallow, gently sloping margins and probably warm, eutrophic, somewhat alkaline water. The presence of rare specimens of diatom species commonly found in brackish or coastal waters may be related to water of high conductivity rather than close proximity to the sea. The dominance of the heavily silicified planktonic diatom Melosira granulata indicates that the lake waters may have been fairly turbulent as a result of wind stirring up surface waters (Dr. M.A. Harper, pers. comm., Appendix B).

The sequence in the Nevis Valley indicates two periods of peat accumulation. The peat-forming vegetation appears to have originally advanced across deeply leached soils which had been subjected to at least one period of silcrete formation. The upper lignite is succeeded, apparently conformably, by the Nevis 0il Shale although there is no report of the upper part of the seam being canneloid, as might be expected if the sequence is conformable. Peat formation probably ceased as a result of flooding of the swamp. The flooding may have been due to a rise in water table, or subsidence of the basin, or both.

The fineness of the terrigenoclastic material forming the basal shales indicates deposition relatively far from shore (Douglas et al. 1978). Diatoms from the oil shale (Table 2 , Appendix B) indicate a deep lake, about $100 \mathrm{~m}$ deep and possibly with steep sides, although sediment from the centre of a lake with shallow, weedy margins might contain only a very few epiphytic species if the lake were large enough. The lake water at this stage appears to have been alkaline and probably eutrophic. Williams (1974) suggested that variable sodium contents in the oil shale ash indicated slight ground water salinity, but this is not evident from the lake diatoms.

The proportion of terrigenous sediment increases toward the top of the 
shale as reflected by lower oil yields and increasing numbers of interbedded siltstone bands. The oil shale passes conformably and progressively upwards into coarser sandstones, siltstones and gravels of the Dell Sandstone, indicating an increasing influx of terrigenous material, presumably resulting from a change in tectonic regime. Douglas et al. (1978) interpret the sequence as accretionary fans or wedges of terrigenoclastic sediment which prograded into a region of accumulating organic lake mud, indicating commencement of uplift around the lake margins. The abundant Pediastrum cf. botryanum in pollen preparations from the Dell Sandstone may indicate that the lake at this stage was mildly eutrophic, but conditions favouring the formation of Pediastrum blooms are uncertain. The only recorded instance of such a bloom in a present day New Zealand lake was in Lake Wairarapa (Wellington Province) in the summer of 1959 (Flint 1975). This is a large, shallow, eutrophic lake then surrounded by considerable areas of wetland. Strong winds causing considerable waves with consequent mixing of top and bottom waters are frequent. The lake may also receive appreciable quantities of wind-borne salt from the sea during periods of southerly gales. The Nevis lake appears however to have been deep, and probably was thermally stratified with a stagnant hypolimnion at least during the period of oil shale deposition.

Plant megafossil assemblages throughout Central Otago are enigmatic because so few of the leaves can be assigned to extant New Zealand taxa. Until more leaves can be identified it is not possible to say how closely pollen and megafossil assemblages relate to one another, although present evidence indicates that the assemblages from facies other than lignite do not correspond closely. Pocknall (Appendix A) interprets pollen floras from Roxburgh and St. Bathans as indicating full forest growing under moist, humid warm temperate conditions, with local areas of wetland inhabited by Haloragis (Haloragicidites haloragoides) Sparganium and Restoniaceae. However similar pollen assemblages could be given by more open vegetational formations with patches of forest, as occur in the serpentinite massifs of New Caledonia (Jaffre, 1980). The discrepancy between the abundance of Nothofagus pollen and the scarcity of Nothofagus leaves indicates that Nothofagus stands were probably scattered. It seems unlikely that the beech forests contributing to the pollen rain were restricted to adjacent 
uplands as Nothofagus wood is reported from lignite at Roxburgh (Evans 1937).

The presence of Casuarina (Cryptostomae?), ?Eucalyptus and leguminous trees suggest that conditions may have been drier at times. McIntyre (in Williams 1974) considered a period of Casuarina dominance in pollen spectra from the Nevis $0 i 1$ Shale as indicating a period of somewhat drier climate. The abundance of gypsum in many Central Otago Tertiary sediments, particularly at Bannockburn and evidence of some ground water salinity from the Nevis Oil Shale (Williams 1974) may also indicate a dry climate. The area need not have been any more arid than Central Otago today, where rainfall averages between 350 and $550 \mathrm{~mm}$ per annum and estimated evapotranspiration exceeds combined rainfall and available soil moisture in most months of the year (N.Z. Meteorological Service 1973). Areas of saline soils with localised inland occurrences of salt marsh plants such as Salicornia and Atriplex exist in the southern part of the Maniototo Basin (Raeside et al. 1966) and small, temporary salt lakes are reported from Sutton, near Middlemarch and from Patearoa Station south of Ranfurley in the southern Maniototo Basin (Bayley 1967).

The significance of the stromatolites occurring near Lauder is not clear. Sectioned examples show that they have been formed around cores, of ten quartz pebbles. The stromatolites show pitted surfaces and contorted laminae, suggesting that they are of fresh water origin (Fritsch and Pantin 1946; Freytet and Plaziat 1965; Golubic 1973; Monty 1976). The conditions under which fresh water stromatolites form are not fully understood. They may form in waters supersaturated in calcium carbonate (Eggleston and Deane 1976) but there is evidence to suggest that the lime content of the water is not critical to their formation (Fritsch and Pantin 1946; Golubic 1973). In the Everglades of southern Florida calcitic freshwater and brackish water algal muds alternating with and sometimes passing laterally into freshwater peats are forming in a subtropical climate where warm humid summers are followed by mild dry winters and the rainfall pattern is showery, giving a succession of short wet and dry periods (Monty and Hardie 1976). The assymetrical disposition of the laminae about the core suggests that the stromatolites formed in a low-energy littoral-1acustrine environment, or in the bed of a 
disturbed or overturned (Logan et al. 1964; Freytet and Plaziat 1965).

In summary the Central Otago region appears in mid-Miocene times to have been a low-lying peneplain covered with a complex of sluggish rivers, lakes and extensive peat swamps, affected towards the end of the period by tectonic movements which eventually gave rise to the basin and range topography evident today. Haematite staining of the deeply rotted schist surface (Norris, Carter and Turnbull 1978) may represent remnants of lateritic paleosols. The presence in many places of silica-cemented quartz sands indicates that there was also at least one phase of silcrete formation. The possible significance of silcretes was discussed in Chapter 3.

Pediastrum is relatively abundant in pollen preparations from a number of localities besides Nevis (N.Z.G.S. unpublished records) and may indicate that most of the lakes in the region were eutrophic. Bayley and Williams (1973) suggest that eutrophic lakes would be a feature of peneplained regions, and that an inverse relationship exists between lacustrine productivity and erosion. This may explain why most New Zealand oil shales are associated with quartzose coal measures. Spores of Sphagnum sp. are also common in some pollen preparations (N.Z.G.S. unpublished records) indicating areas of oligotrophic bog. Highmoor peats may be produced in areas where groundwaters are rich in nutrients when peat accumulates above the level of percolating groundwaters (Tansley 1949). It is probable that the vegetation which formed the Central Otago lignites represents a hydroseral succession from eutrophic lake to eutrophic swamp - swamp forest - raised bog, but this can only be determined by detailed botanical profiling of the lignite seams. 
Miocene plant fossils occur in rocks of the Longford Formation outcropping around Murchison and in correlatives of the Longford Formation in the Upper Maruia Valley and the Inangahua Valley. Dr. R.P. Suggate (pers. comm.) reports a few poorly preserved leaves in the Upper Mangles Formation. Although extensive collections have been made from the Longford Formation there has been scarcely any detailed study of the fossils. Couper (1953) published descriptions of a number of palynomorphs from correlatives of the Longford Formation at Coal Creek, Inangahua Valley. No leaves were found at the site although they do occur elsewhere in the Inangahua region (H.W. Wellman, pers. comm.).

\section{GEOLOGY}

The Longford Formation is a thick sequence of freshwater sediments. The type section was defined as Nuggety Creek for two miles to the junction with the Buller River, and thence upriver to the synclinal axis (Fyfe 1968). Nuggety Creek runs approximately normal to the strike of the formation and most exposures are in the creek bed. The uppermost beds are exposed in prominent bluffs overlooking the Buller River

The formation name is taken from Longford Junction between Nuggety Creek and Murchison, where the sediments are well exposed and easily accessible. The 1 : 250,000 geological map (Bowen 1964) shows the formation extending from the headwaters of coal creek about $1 \mathrm{~km}$ west of Owen River in the north southwards to the Upper Maruia Valley (Fig 5.1). Cutten (1979) remapped the sequence south of the Matakitaki River as the Rappahannock Group.

The formation is preserved in the axis of a tightly folded syncline approximately $70 \mathrm{~km}$ long and $10 \mathrm{~km}$ wide. The type section is some 3200 metres thick but the top is nowhere known. Dips along both flanks of the syncline reach $80^{\circ}$ and lessen towards the axis. No major faults interrupt the sequence. Longford rocks are generally well-exposed in the river valleys. In the north, the Buller River flows along the synclinal axis, but at Longford, where it is joined by the Mangles River it turns to cross the strike of the Longford beds before the 


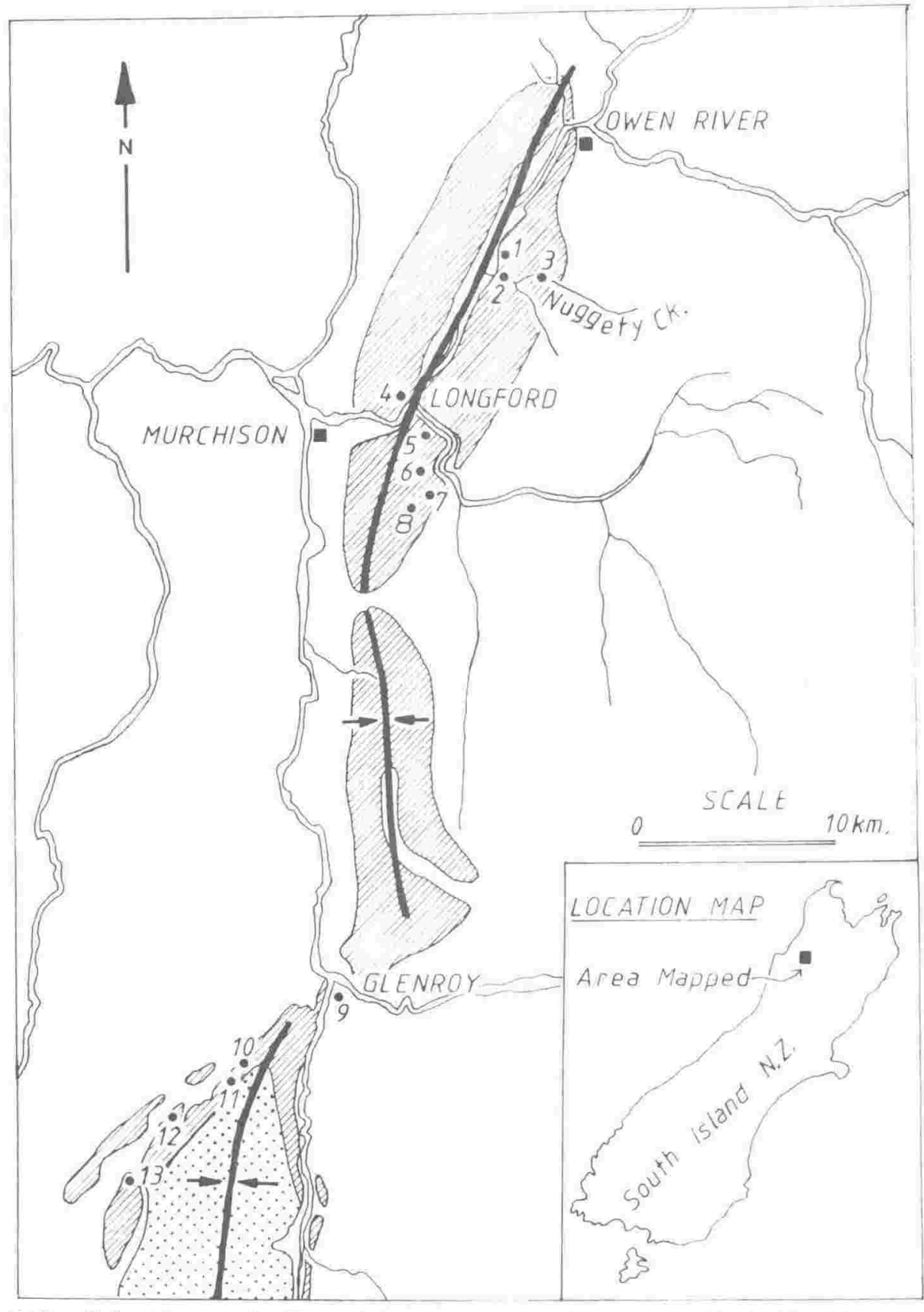

FlG, 5. 1 Map of Murchison area showing distribution of Longford Formation and correlatives lafter Bowen 1964]

VIIIA Longford and Frog Flat Formations.

$\therefore$ Spargo and Devil's Knob formations.

Fossil sample sites:

1. Nuggety Creek, mouth.

4. North end of old road bridge, Longford.

5, Dress Circle, Longford.

6. Mangles Valley television translator track.

$7 \& 8$, Blue Duck Creek. 9. Glenroy.

$10 \& 11$. Maruia Saddle road.

12. Road cutting. Frog Flat Junction [Burnbrael.

13. Road cutting, Rappahannock Valley. 
confluence of the Matakitaki River at Murchison. South of Longford the synclinal axis follows the crest of a range of hills running parallel with the Matakitaki Valley as far as Six Mile Creek. Further south the distribution of the Longford beds is less certain and probably is not as shown by Bowen (R.P. Suggate, pers. comm.). South of Horse Terrace correlatives of the Longford Formation underlie the hills between the Maruia saddle road and the valley of the Glenroy River, and extend southward into the upper Maruia valley where they unconformably overlie Paleozoic rocks of the Haupiri Group.

The formation contains conglomerates, grits, banded sandstones, siltstones, shales and coal seams. Coals are commoner in the basal part of the sequence (Henderson 1929). Although Henderson stated that conglomerates also are commoner in the lower part of the sequence, observations made during the present study indicate that they are fairly evenly distributed throughout. Consolidated conglomerate bands in the Longford Formation form prominent strike ridges some of which can be traced for several kilometres across country on aerial photographs, and which form a striking and characteristic topography (Fig 5.2). In creek beds differential erosion has left conglomerates and sandstones forming shallows and rapids while deeper pools overlie the softer siltstones and shales.

Longford beds conformably overlie marine massive sandstones of the Upper Mangles Formation. A sandstone horizon with an estuarine assemblage of Chione sp., turritellids and other mollusca forms an easily recognisable base to the Longford Formation in several sections (R.P. Suggate, pers. comm.), but has not been found in the type section in Nuggety Creek, where the base of the formation is taken as the first conglomerate band (Fyfe 1968).

Well defined fining-upward sedimentary cycles are characteristic of the Longford Formation. They are well displayed in the bluffs overlooking the Buller River at the mouth of Nuggety Creek (Figs 5.3, 5.4). Fig 5.3 shows at least two units, each containing a thick bed of muddy sandstone at the base fining upwards to a light grey mudstone with many leaf impressions. Above the mudstone in one of the units is a dark, carbonaceous shale capped by a thick layer of fossil leaves, mainly beech. The carbonaceous shale weathers very readily. The above description 


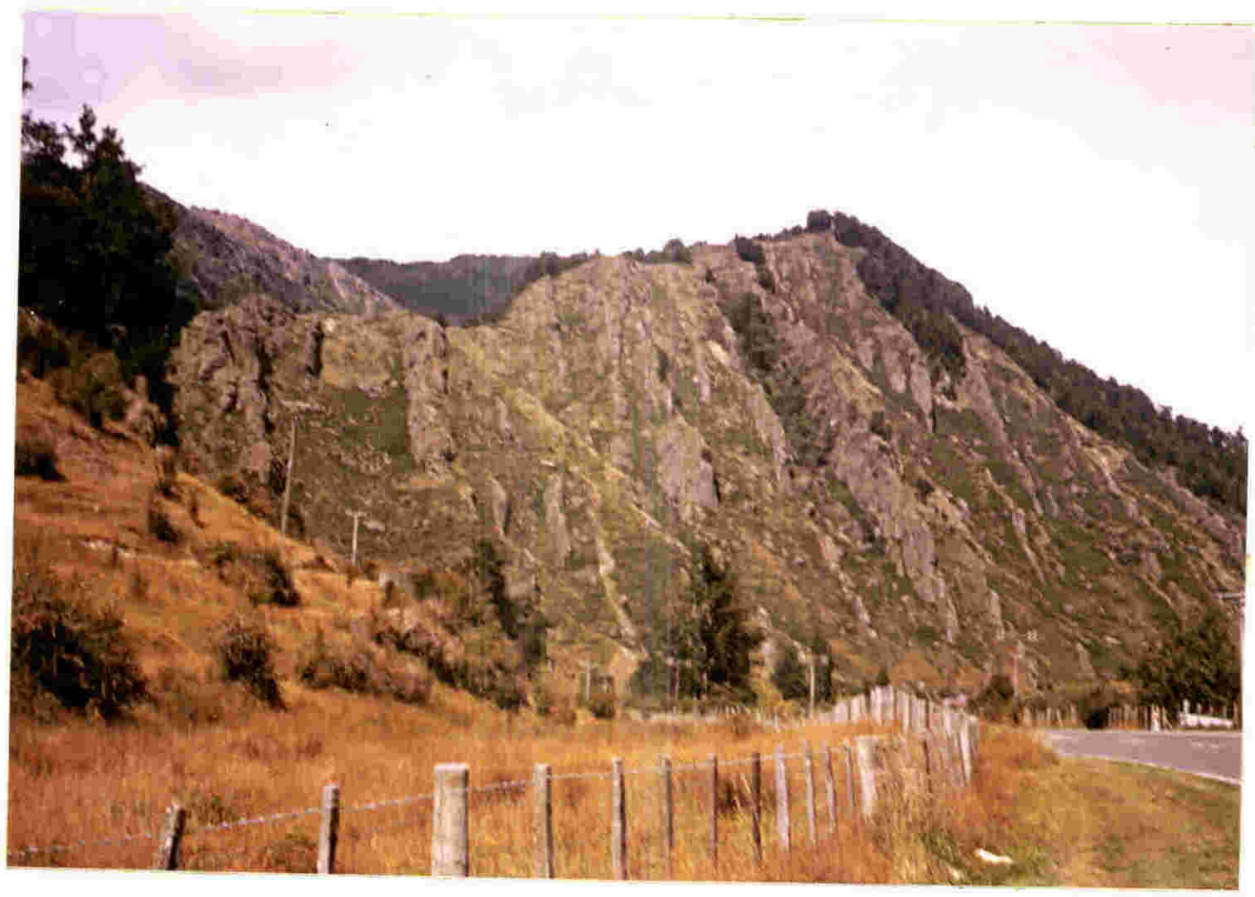

FIG, 5,2 Hillside just south of Longford Junction showing characteristic topography developed in Longford Formation rocks: resistant sandstones and conglomerates left as strike ridges following erosion of interbedded siltstones and shales.

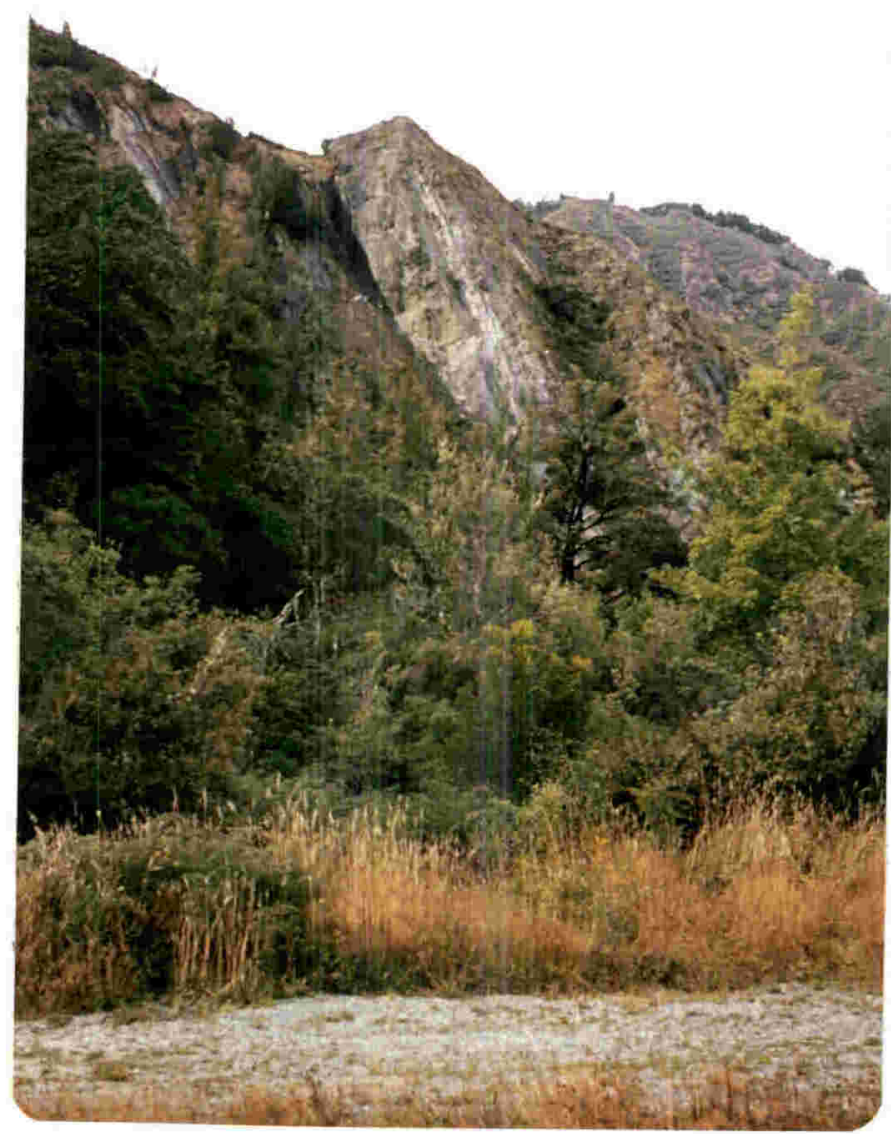

$\underline{\underline{F l}} \underline{\underline{5}} \underline{\underline{3}}$ Longford Formation rocks exposed in bluffs at mouth of Nuggety Creek. Parts of two upward-fining sedimentary cycles are visible. Rapid erosion of a fissile carbonaceous shale is causing undercutting of the overlying massive muddy sandstone. 


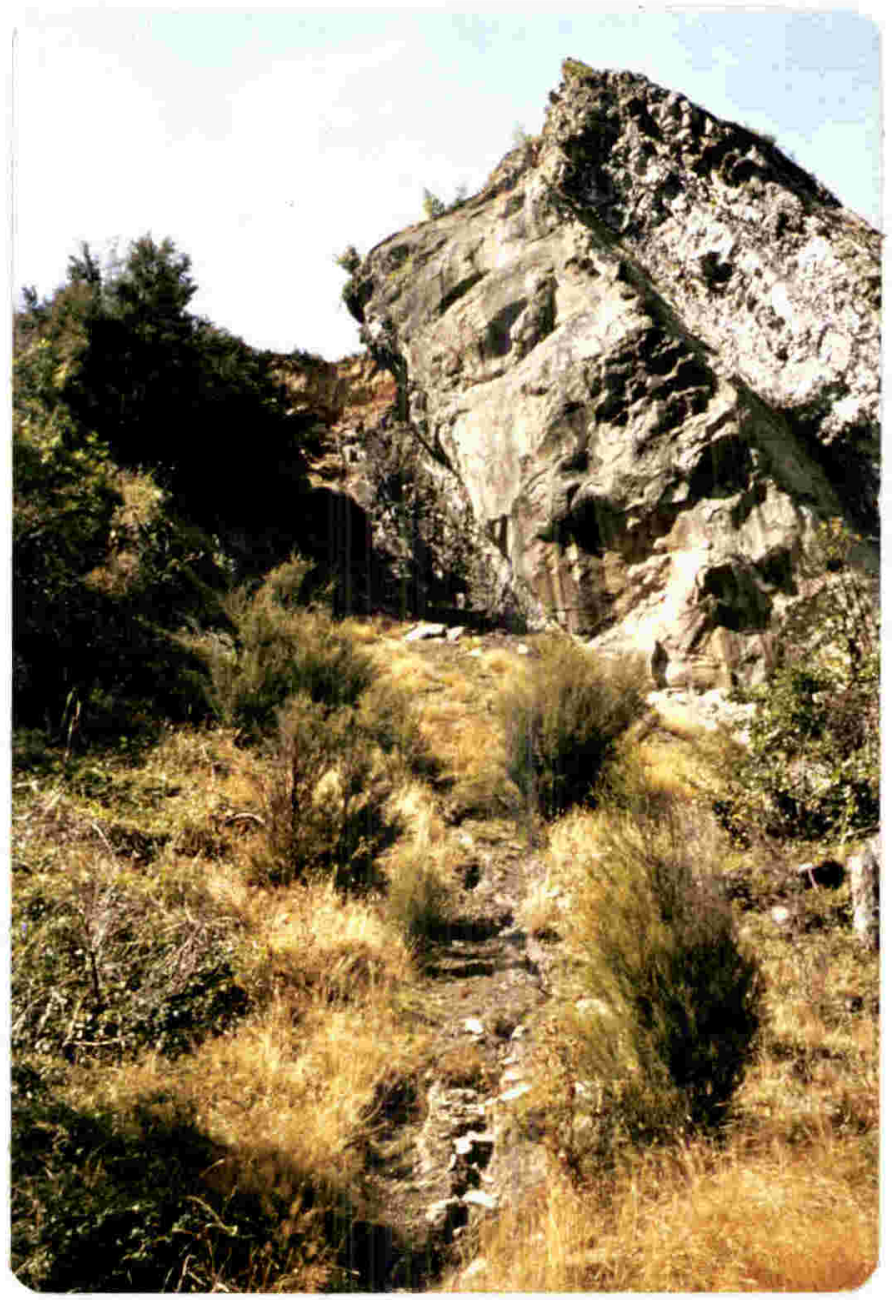

FlG, 5.4 Close up view of outcrop in Fig. 5.3 showing uppermost unit [carbonaceous shale] of one sedimentary cycle and basal units of the overlying cycle. 
applies to the exposure as seen on the writer's visit in 1979. By 1982, when the writer again visited the site the fossil leaf horizon had largely been eroded away from the base of the overlying sandstone.

An exposure at Longford at a similar height above the base of the formation shows thick beds of conglomerate interbedded with coarse grit, sandstone and mudstone. The grit occurs as small lenses, and there is some cross-bedding and scouring in the sandstones. The mudstones are generally thinly laminated, and boudinage and fine internal folding indicate deformation of the sediments. The pebbles in the conglomerate show slight imbrication and there are some large pieces of wood. The plant fossils, mainly leaves, are generally in mudstones, although a few occur in sandstones. The leaves lie along the bedding planes and many have been deformed by bedding plane slip. Formerly two large tree trunks, approximately in growth position with roots present, were visible (J.D. Collen, pers. comm.) but these have now disappeared.

In a basal section at Blue Duck Creek, Mangles Valley (Fig 5.1) the dominant rock type is a medium to coarse, thinly laminated sandstone deeply weathered to a yellowish colour. Chione sp., turritellids and other molluscs consistent with an estuarine environment are found near the contact with the Upper Mangles Formation, together with sparse leaf fossils and comminuted plant debris. The calcite of the shells has dissolved, leaving external and internal moulds. Just above the base of the formation a coal seam about $30 \mathrm{~cm}$ thick outcrops in the stream bed and is overlain and underlain by light grey mudstones containing numerous leaf fossils. In collections from this locality at N.Z. Geological Survey many of the fossils are severely deformed, and some of the slabs show well-developed slickensides. A bulldozed track in the Mangles Valley to the television translator (Fig 5.1) exposes a deeply weathered medium sandstone containing abundant leaf fossils and plant fragments.

A number of localities in the Rappahannock Group were examined (Fig 5.1). Attention was confined to the lowest member, the Frog Flat Formation (Cutten 1979). An exposure in a road cutting at the eastern end of the Glenroy River bridge shows coarse sandstone and grit grading into fine siltstone with carbonaceous bands and thin coal. The outcrop is 
somewhat shattered and at one point the exposure is traversed by a small fault. Thin, well defined laminae are present. Unweathered material is dark grey in colour and very micaceous; weathering gives a yellow to reddish colour. The fossils are severely oxidised and with one or two exceptions, impressions are poor, with little detail preserved and with somewhat polished surfaces. Whole leaves and large fragments are more common than at Blue Duck Creek or the translator road.

A small exposure just south of the Maruia Saddle road summit contains thinly laminated fine sandstone grading to fine mudstone with isolated leaves, mainly grasslike forms, and with a narrow coaly band in the mudstone. Low bluffs further south along the road are of massive conglomerate and thinly laminated siltstone with abundant leaf remains. All exposures are deeply weathered and yellowish in colour. Many of the leaf fragments have adhering cuticle, but microscopic examination shows that little structural detail has been preserved.

The Frog Flat Formation is again exposed in a road cutting at Burnbrae just south of the road junction (Fig 5.1), where massive sandstone alternates with siltstones, mudstones and carbonaceous bands. The overall colour is light to medium grey. The sediments are very shattered and somewhat weathered. Several pinnae of a palm frond were found (Fig 5.5), but could not be collected intact. Rocks exposed further south beside the Rappahammock Valley road about 100 metres from the main highway are similarly shattered. Two conglomerate bands outcrop there, with fine mudstone, siltstone, sandstone and lenses of grit between them. The fire, light grey siltstones and mudstones show numerous trails and other marks, possibly rain splashes, on the bedding planes. Leaf fossils occur in the finer sediments and are concentrated in bands. Large pieces of wood occur in the conglomerates.

Samples of sandstone from Glenroy, Blue Duck Creek and the television translator road were examined by Dr. J.D. Collen. The sample from Glenroy is a fine muddy sandstone with abundant clay matrix and much organic matter, mostly appearing as elongated particles. The bulk of the sand fraction is quartz grains, subrounded to subangular in shape, some showing undulose extinction. No authigenic overgrowths were seen and only a few polycrystalline grains. No feldspars were found and only uncommon biotite. 


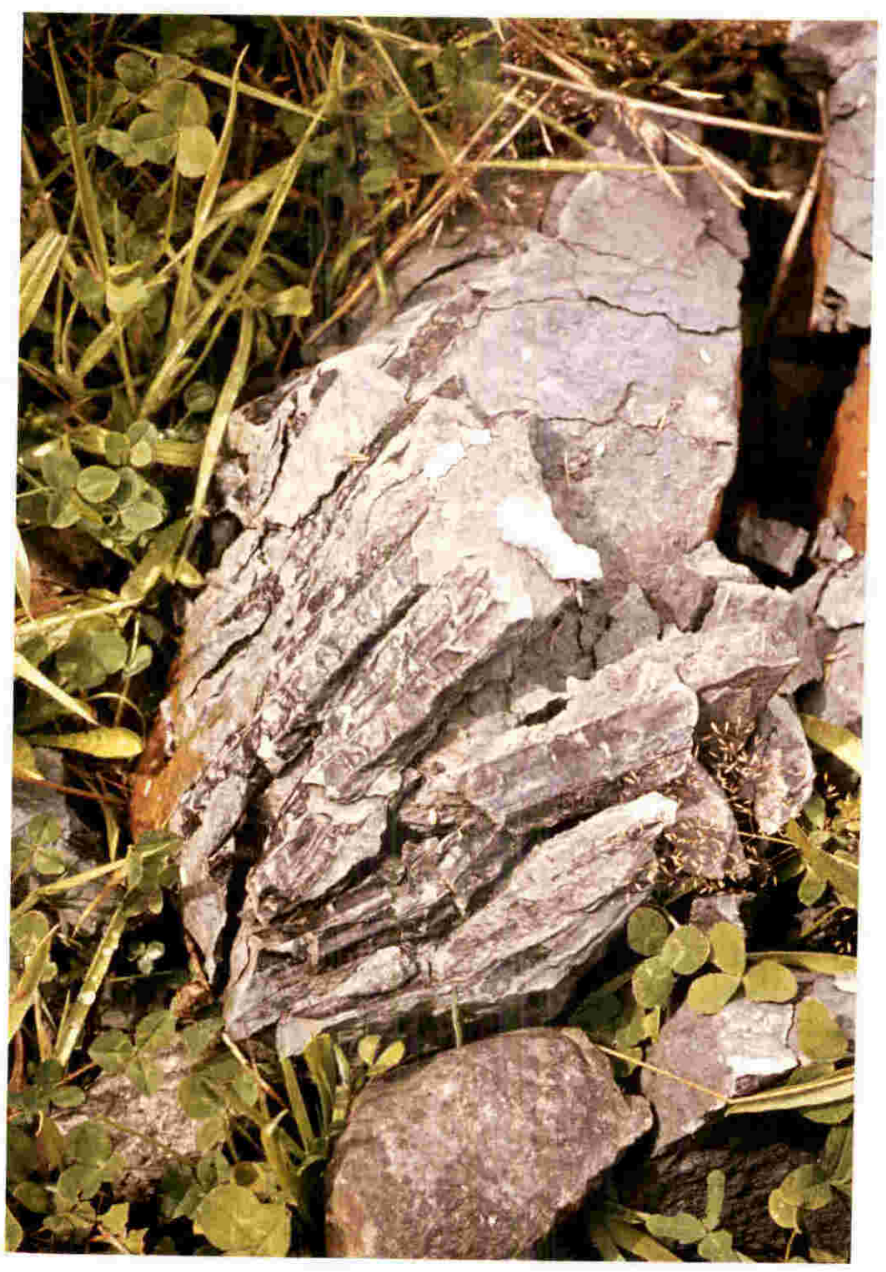

\begin{tabular}{l} 
FlG, 5,5 Frog Flat Formation: several pinnae of a \\
\hline palm frond in a fallen block at Frog flat Junction.
\end{tabular} 
The sample from Blue Duck Creek is a medium sandstone, partly ironstained, with some clay matrix, iron minerals and calcite cement. The sand fraction is again mainly of quartz grains of subrounded to angular shape with no overgrowths and few polycrystalline grains. Feldspars are uncommon and mainly oligoclase. No microcline was seen. Grains of augite, white mica, chlorite and hornblende are also present. The material from the television translator track is similar in composition, an ironstained fine muddy sandstone with abundant organic matter and lacking in calcite.

Although seemingly well-consolidated, the mudstones and shales are readily disaggregated by soaking in water for periods of half an hour or more. The carbonaceous shale from Nuggety Creek tends to break up into small flakes when moistened, and weathers rapidly.

Coal and impure coaly bands are present at a number of localities. Mining has been carried out in the Murchison area, but the coal seams are generally impersistent and dip at steep angles. Seams up to 3 metres thick have been reported (Fyfe 1968) but in most cases lens out in a short distance. The thick seam worked at the seymour mine, coal Creek had a prominent stone band in the middle. Mr. Morrie Win of Porirua who worked at this mine as a young man has informed me that the seam dipped at a steep angle and the workings extended under the Buller River, making them liable to flooding. Coals, particularly near Murchison, are badly crushed.

Coal in the Longford Formation is generally of bituminous to subbituminous rank. In the north, around Murchison and at Coal Creek, the coals are generally low-swelling high volatile bituminous coals. Suggate (1959) gives analyses of seam samples from the Seymour Mine in Coal creek and from mines near Murchison. Volatiles amounted to $39.7 \%$ and $38.8 \%$ respectively, with ash at $11.2 \%$ and $4.9 \%$ and sulphur at $0.8 \%$ giving rank numbers of 10.6 for Seymour Mine and 11.3 for Murchison. The high ash content at seymour is probably related to the presence of the stone band in the midale of the seam. In the upper Matakataki Valley further south thin seams of bituminous coal were worked for forge fuel. Coals in the Upper Maruia Valley are only thin and of bituminous to sub-bituminous rank (Fyfe 1968). 
AGE

Fyfe (1968) suggested a possible Taranakian age for the major part of the Longford Formation, based on a Waiauan (Southland Series, Mid Miocene) age inferred from sparse foraminiferal faunas from the underlying Upper Mangles Formation. Cutten (1979) reported ages in the Rappahannock Group ranging from possibly Taranakian for the basal Frog Flat Formation to Wanganuian (Nukumaruan Stage) for the uppermost Devil's Knob Formation. The latter age was based on a lithological correlation with the old Man Gravels of the Reefton area and has recently been confirmed by palynology (D.C. Mildenhall, pers. comm.).

Bowen (1968) considered a Waiauan (Southland Series, late Middle Miocene) age possible for the lower part of the Longford Formation in the Murchison area. Recent remapping of the region has resulted in a reassessment of the age of the formation and evidence now indicates that it is not older than Clifdenian, and the highest beds preserved are probably still within the Southland series (R.P. Suggate, pers. comm.). A close similarity of the floras of the Longford Formation and the Frog Flat Formation suggests that the two are of a similar age. Probable correlatives of the Longford Formation in the Inangahua Valley overlie Southland marine beds at Coal Creek (Couper 1960).

\section{FLORA}

The Longford flora is very rich. So far over 80 different forms have been distinguished (Table 5.1), including ferns, conifers, and angiosperms. Some fossil bryophytes and lichens may also be present. Most of the fossils are leaf impressions, generally without cuticle, and most identifications have been based on detailed comparison of venation pattern. A number of seeds and a very few flowers have also been found.

The most abundant fossils are leaf impressions of four species of Nothofagus (Holden 1982a). The species are quite different from present-day New Zealand beeches. The leaves generally exceed $10 \mathrm{~cm}$ in length and are similar to those of modern New Caledonian species. Tertiary pollen assemblages are dominated by Nothofagus of the 'brassii' type now only found in New Caledonia and New Guinea. The only pollen of any sort so far isolated from the Longford Formation is of this group, 
TABLE 5.1. PLANT MEGAFOSSIL TAXA IDENTIFIED FROM THE LONGFORD AND FROG FLAT FORMATIONS.

PTERIDOPHYTA

Litsea dawsoniana Holden

Leptopteris hymenophylloides (A. Rich) Pros(Beilschmiedia tarairoides Penseler Hymenophyllum sp. aff. sanguinolentum (forst. Swarts Cinnamomam miocenicum Holden

? Trichomanes sp.

? Ascarina

Dicksonia sp. aff. lanata Col.

?Macropiper

Alsophila sp. aff.tricolor (Col.) Tryon ?Melicytus

Phymatosorus sp. aff. diversifolium Calpidia zealandica Oliver

Hypolepis maruiense sp. nov.

Davallia tasmanii H.C. Field

Nothofagus novae-zealandiae (Oliver) Holden

?Antrophyum

Blechnum proceroides (Oliver) comb.nov.

B. maruiense sp. nov.

N. bidentatus Holden

N. oblonga Holden

N. oliveri Holden

Blechnum sp. aff. discolor (Forst.f.) Keys Kermadecia merytifolia Holden

?Beauprea.

GYMNOSPERMAE

Knightia oblonga Oliver

?Podocarpaceae

Agathis sp. aff. australis Salisbury

?Araucaria sp.

Longfordia banksiaefolia Holden

Mallotus sp.

Metrosideros diffusoides sp. nov.

M. pliocenica Oliver

ANGIOSPERMAE

?Pseudowintera sp.

M. laeta Oliver.

?Winteraceae

Hedycarya sp.

Laurelia cuneata Oliver

Metrosideros sp.

?Xanthostemon sp.

Lophomyrtus sp.

Cryptocarya longfordiensis Holden

Ceratopetalum kaikoraiense Oliver

C. tutakiae Holden

C. murchisoniensis Holden

Loranthaceae

c. bulleriana Holden

?Parafatsia

?Araliaceae

Geniostoma oblonga Oliver

?Paratrophis sp.

?Alectryon sp.

?Coprosma sp.

?Dysoxylum sp.

?Cupaniopsis sp.

Kaikoraia gracilis Oliver

Loranthophyllum dubium Unger

Palmae

?Planchonella sp.

Typha robusta Oliver

?Myrsinaceae

24 additional unnamed taxa have also been recognised from the Longford and Frog Flat Formations. 
the bulk being of Nothofagidites matauraensis Couper (D.C. Mildenhall, pers. comm.). N. matauraensis dominates the pollen assemblage from Coal Creek, Inangahua (Couper 1953a). Venation pattern cannot be considered a reliable guide to pollen type, as a venation pattern similar to that of the fossils is found not only in the 'brassii' group but also in Nothofagus moorei (F. Muell) Krasser (menziesii group) and $\underline{N}$. allesandrii Espinosa (fusca group).

Next to the beeches, the most characteristic plants of the Longford flora were various species of Lauraceae (Holden 1982b). Beilschmiedia tarairoides Pens. appears to be a Tertiary relative of the presentday B. taraire (A.Cunnd Kirk of the northern kauri forests. It has been recorded from the upper Eocene in the Waikato coal field (Penseler 1930). Of the other genera represented in the Longford flora, only Litsea is still found in New Zealand. The Longford species Litsea dawsoniana however refsembles more closely the living Australian rain forest species $\underline{L}$. leefiana (F. Muell) Merr. than the native $\underline{L}$. calicaris (A. Cunna) Kirk. L. calicaris is known as a fossil from the Castlecliffian (Pleistocene) Waipaoa Series of Poverty Bay (Oliver 1928). The genera Cryptocarya and Cinnamomum, although no longer represented in New Zealand are found more or less world-wide in tropical and sub-tropical regions. It is interesting to note that one species from Longford

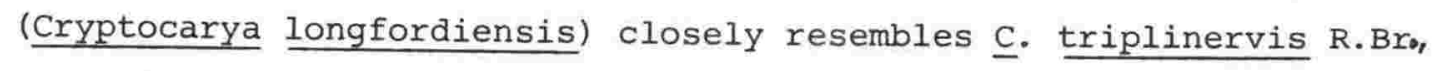
a species living in both Australia and Lord Howe Island. The close resemblance in venation pattern between some species of Cryptocarya and Cinnamomum suggests that at least some of the New Zealand fossils assigned to the latter genus are perhaps species of Cryptocarya.

Pollen grains of the Lauraceae are rarely found in Tertiary sediments as they are fragile and not readily preserved (D.C. Mildenhall, pers. comm.). Macphail (1980) has suggested that in the case of Beilschmiedia the poor record may be due to very low pollen production rather than poor preservation. Beilschmiedia pollen reported from the Miocene (Couper 1953a) was probably misidentified.

Other significant elements were various Myrtaceae. Metrosideros pliocenica Oliver and $\underline{M}$. diffusoides $\mathrm{sp}$. nov. resemble the living New Zealand species $\underline{M}$. diffusa (Forst. f.) Oliver, $\underline{\text { M. }}$ colensoi Hook. f. and $\underline{M}$. Carminea Oliver, all members of the subgenus Mearnsia (Dawson 1976), and were probably lianes. M. longfordiensis resembles the living

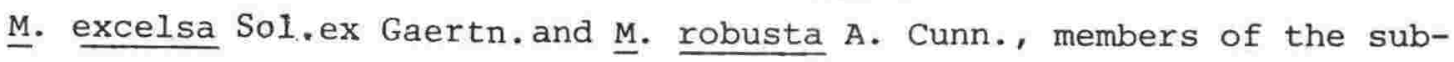


genus Metrosideros, which are mainly forest trees (Dawson 1976).

Large myrtaceous leaves from the vicinity of Longford resemble those of a number of species of Xanthostemon and Tristaniopsis, in particular X. vieillardii (Brongn. et Gris.) Niedenzu. Neither genus is represented in New Zealand today but both are found in Australia and New Caledonia.

Owing to similarities in leaf form between various genera of Myrtaceae and the resemblance of leaf morphology between Myrtaceae and species of Ficus (Moraceae) it has not been possible to place some leaves of Myrtaceous or Moraceous type with any degree of confidence on present evidence, but two distinctive leaf forms may be species of Ficus. Pollen grains of the Myrtaceae are difficult to differentiate below family level although scanning electron microscopy is making this easier. Those of the Moraceae are of a conservative type not readily distinguished from those of a number of other families (D.C. Mildenhall, pers. comm.). The history of the two families in New Zealand as inferred from pollen occurrences is therefore bound to be incomplete.

A number of families, notably Proteaceae, Winteraceae, Euphorbiaceae and Sapotaceae appear on pollen evidence to have been better represented in the Tertiary than at present (Mildenhall 1980). That is confirmed by the presence in the Longford flora of Knightia, ?Kermadecia, Longfordia (Proteaceae) (Holden 1982b), Pseudowintera, ?Drimys (Winteraceae), Planchonella and the extinct Kaikoraia gracilis Oliver (Sapotaceae) and Mallotus (Euphorbiaceae).

Ferns appear to have been relatively abundant and diverse. The commonest, or most frequently preserved, is Blechnum proceroides (Oliver), a form related to the Blechnum capense (B. procerum) complex. Steep, shady banks are a typical habitat for living New zealand ferns belonging to this complex.

The presence of Davallia tasmanii H.C. Field in the Longford flora is notable as this species is now confined to the Three Kings Islands, and evidently lived further south in the past although fossil spores are not known below the Quaternary (Mildenhall 1980). Another notable form is a fern resembling Antrophyum (Vittariaceae), a small tropical family. 
Species of Antrophyum are found in Australia, New Caledonia (Brownlie 1969) and Polynesia (Brownlie 1977) so it is not improbable that the genus was present in New Zealand during the Tertiary although spores of the family have not been found (D.C.Mildenhall, pers. comm.).

Palms seem to have been abundant, and more than one species may have been present. Some of the impressions resemble Ettingshausen's (1887) Seaforthia novaezeelandiae from the Miocene of Central otago. Conifer remains are rare, and this group may well be under-represented as discussed before (see Introduction). The sparse remains so far recognised indicate the presence of Agathis, ?Araucaria, ?Dacrydium and Podocarpus. Casuarina remains are also scarce. Only a single fruit and a few fragments of poorly preserved twigs and bark have so far been found. The heavy forest may have offered few habitats for these light demanding trees.

No pollen floras are available from the Longford Formation or the Frog Flat Formation. The tectonic history of the sediments precludes good preservation (D.C. Mildenhall, pers. comm.), but Couper (1953a) reported a number of species from beds of similar age in the Inangahua Valley (Table 5.2). The pollen assemblage contains many fewer species than the Longford macroflora, but includes Rhopalostylis, Phormium, Triorites harrissii (Casuarinaceae), Leptospermum, Metrosideros, Nothofagus (several species) Elytranthe, Dacrydium, Podocarpus, Blechnum and Hymenophyllum.

PALEOENVIRONMENT

The Murchison Basin is one of a series of sedimentary 'basins', probably fault angle depressions, which formed on the west coast of the South Island at various times between the late Cretaceous and early Pleistocene (Gage 1949; 1980). The Tertiary sequence in the Murchison area begins with basal quartzose coal measures and shallow marine sediments of the Maruia Formation (Arnold series, Eocene) followed by mudstones and limestones of the Matiri Formation (Landon Series, oligocene). These are in turn overlain unconformably by marine turbidites of the Lower Mangles Formation of Altonian age (Lillie 1980). The turbidites pass up into massive marine sands of the Upper Mangles Formation and finally into estuarine and fluviatile beds of the Longford Formation of Southland age. The relationship between sequences at Murchison and in the Maruia Valley is unclear. Cutten suggested (1979) that the 
TABLE 5.2. FOSSIL SPORES AND POLLEN FROM COAL CREEK, INANGAHUA JUNCTION. (DATA FROM COUPER 1953a, 1960a).

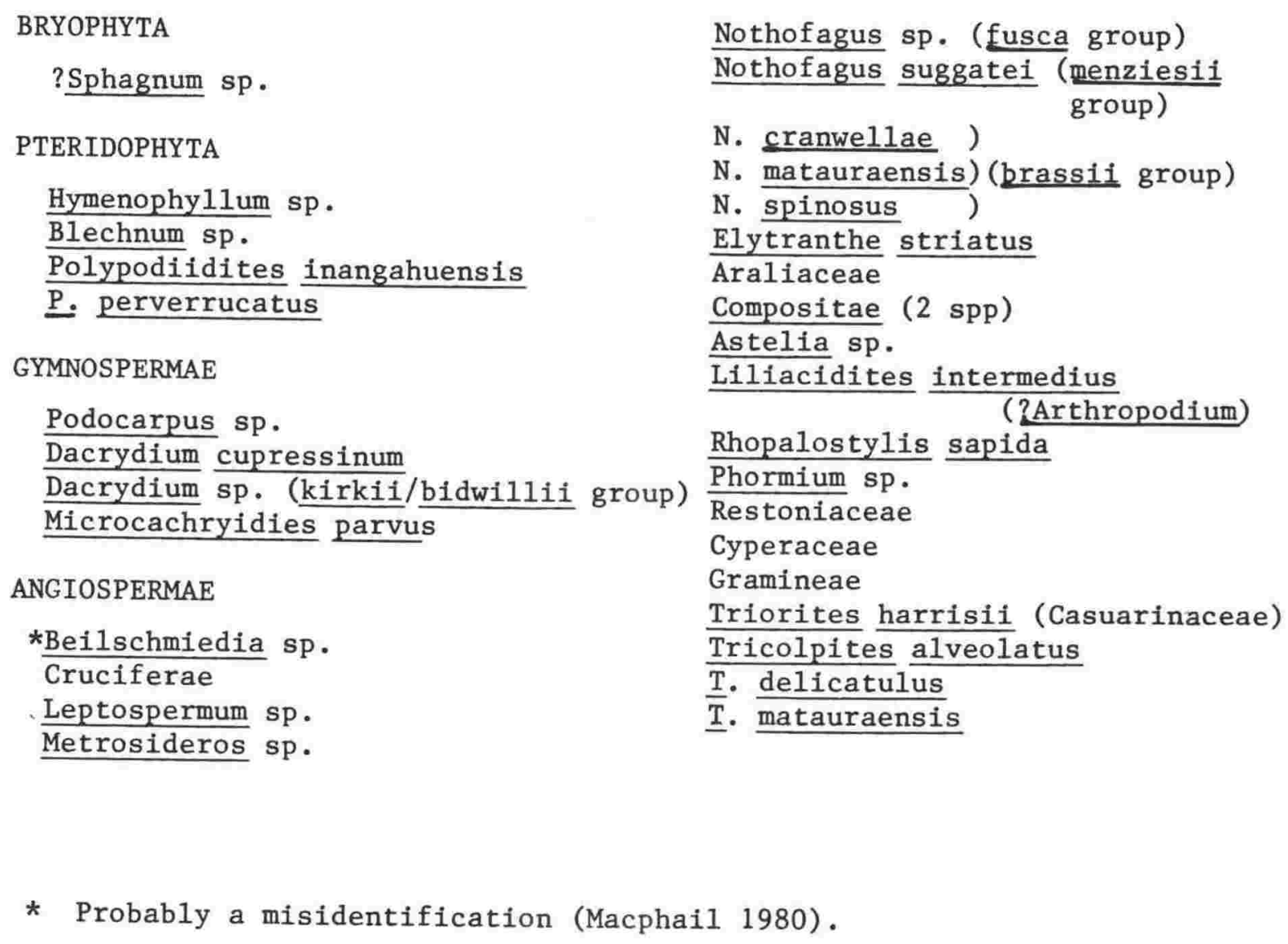

* Probably a misidentification (Macphail 1980). 
Murchison and Maruia sedimentary basins were entirely separate, but that deposition of the Longford and Frog Flat formations was in part contemporaneous.

The known thickness of later Miocene sediments in the Murchison Basin is over $6500 \mathrm{~m}$, about half being in the Longford Formation. As the top of the Longford Formation is not known the total original thickness of Miocene sediments is unknown. The coal analyses published by Suggate (1959) give an estimated depth of burial of about 3500 metres $(10,600 \mathrm{ft}$ ) for the main seam at the seymour mine, Owen River (about $300 \mathrm{~m}$ above the base of the formation). That estimate is consistent with the $3200 \mathrm{~m}$ of Longford Formation preserved in the type section at Nuggety Creek. Slightly higher rank coal in a mine near Murchison indicates a still greater depth of burial. Low sulphur levels in the coals are thought to indicate that there was no subsequent marine transgression (Wellman 1952; Suggate 1959).

Rapid subsidence during the middle and late Miocene was accompanied by an abundant supply of sediment which kept the basin filled to above sea level. The abundant supply, together with the predominance of coarse conglomerates, suggests nearby rising land of substantial relief. Fleming (1962) proposed a range of mountains in the area of the present St Arnaud and Richmond ranges supplying material to both the Longford Formation in the West and Miocene conglomerates in Marlborough to the east, but Cutten (1979) suggested that the source of much of the Longford and Frog Flat conglomerates lay in the Caples Terrane of Otago, now displaced some $420 \mathrm{~km}$ to the south by transcurrent movement on the Alpine Fault. Boudinage observed at Longford may indicate downslope movement of unconsolidated sediments caused by seismic disturbances and many of the fossils have undergone some plastic deformation (Fig 5.6).

A widespread shellbed at the base of the formation contains abundant fossils of the bivalve chione sp. which by analogy with the living C. stutchburyi Gray indicates an estuarine or sheltered shore environment where wave action and tidal scour are sufficient to prevent excessive accumulations of mud (Moreton and Miller 1968). The presence of Longford or equivalent beds directly overlying Paleozoic granites and gneisses in the Maruia Saddle area suggests the possibility of 

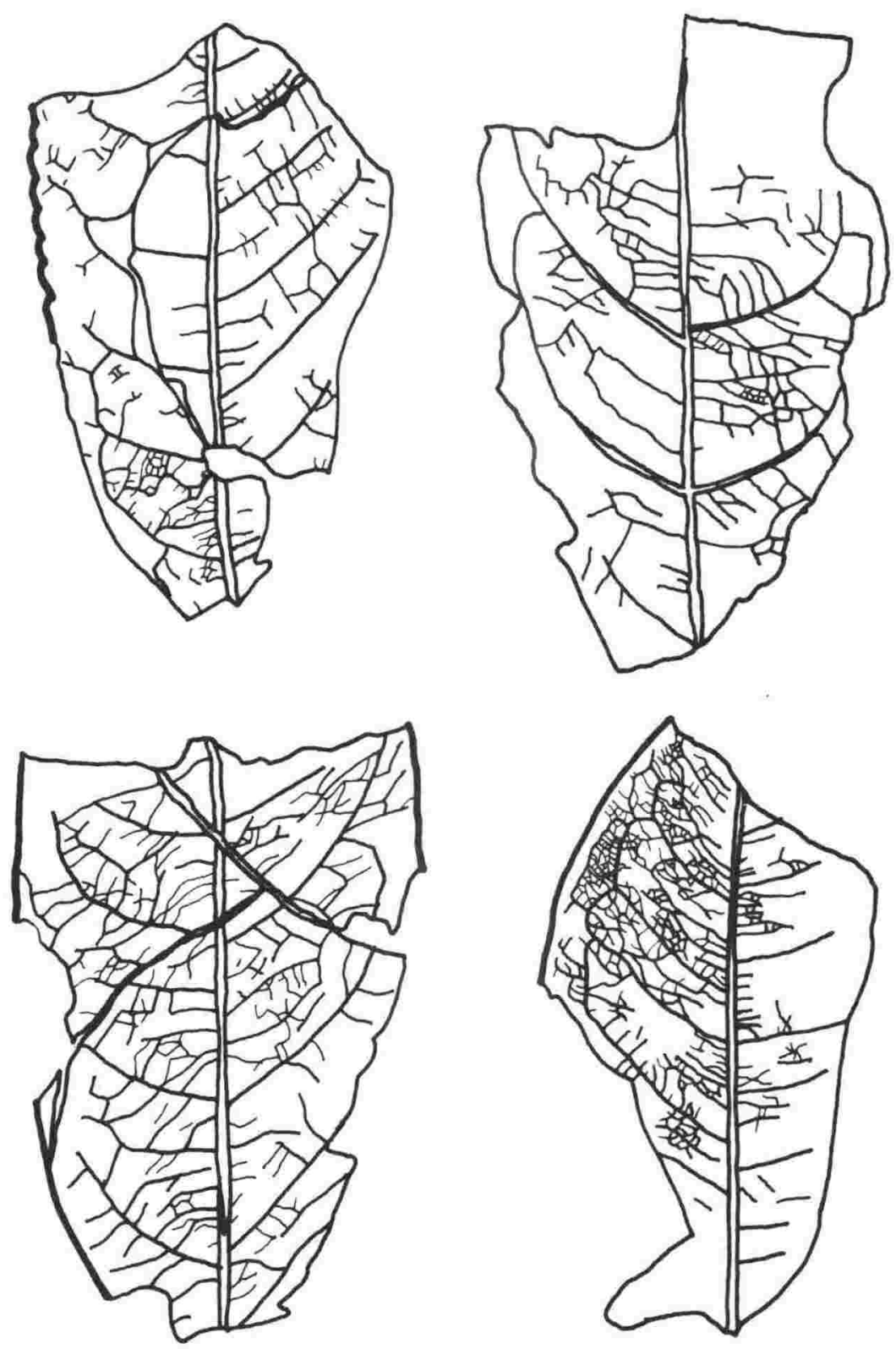

Fig. 5, 6 Fossil leaves from the Longford and Frog flat formations showing plastic deformation: the venation pattern was originally symmetrical. 
emergent land in the area between Mt. Mantell and the Victoria Range, while the occurrence of Miocene fresh water beds similar to the Longford Formation in the Inangahua Valley (Bowen 1964) support the concept of a complex system of embayments topographically similar to the present Manukau and Kaipara harbours, although perhaps the Gulf of Thailand would be a better analogy, during mid and late Tertiary times (Fleming, 1962).

The fluviatile beds were deposited by cyclic sedimentary processes (Figs 5.2, 5.3) with regular deposition of thick bands of conglomerate alternating with sandstones, siltstones and shales, often rich in organic matter. The cycles are predominantly asymmetrical and appear to be similar to the "fining upward cyclothems" (Allen 1970) in the Devonian 01d Red Sandstone of the British Isles. The generalised cycle at Longford is:

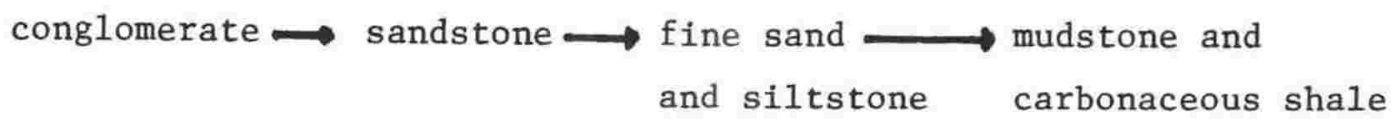

The conglomerate and carbonaceous shale are sometimes absent. Such upward fining sequences have been held to result from the sedimentary processes associated with the sinuous, migrating channels of meandering rivers (Visher 1965, 1972; Collinson 1978; Selley 1978). However the coarseness and abundance of the conglomerate suggests a fairly fastflowing bedload river with a moderately steep gradient. Such rivers normally produce braided channels. Miall (1977) drew attention to the fact that certain types of braided stream produce fining upward cycles which could be confused with meandering river sequences. The facies assemblages seen in many Longford Formation and Rappahannock Group sections are consistent with Miall's "Donjek type" of braided river deposit, dominated by sand or gravel and distinguished by fining upward cycles caused by lateral point bar accretion and vertical channel aggradation.

The cyclicity of this type of deposit is thought to reflect deposition at four different topographic levels (Miall 1977) ranging from permanent channels and bars only exposed during low water stages to densely vegetated dry islands subject only to overbank deposition during times of flood. Many present-day New Zealand rivers, particularly in the South Island, have reaches showing these characteristics. 
Fossiliferous blocks of laminated micaceous siltstone collected from localities along the Maruia Saddle road may represent a deposit conforming to Miall's "Bijou Creek type" of braided river sediment, thought to result from flash floods and ephermeral streams. The presence of flowers, fragments of delicate ferns such as Leptopteris and lichens which are not usually preserved in fossil assemblages also suggests rapid deposition under flood conditions. Massive muddy sandstone overlying carbonaceous shale at Nuggety creek may also be a result of flood. It appears to have been deposited in a backswamp area, probably as a result of breaching of a levee (Duff et al. 1967). There is little evidence of scouring here. The shale with its capping of leaves appears to have been deposited in a lake or pool, in quiet or even stagnant conditions. Carpets of partly decayed leaves can be very resistant to disturbance, as can fine clays, and consequently the effects of scour may be less pronounced than where sediments are coarser.

Floodplain deposits occur throughout the geological column. One example that has been comprehensively studied is the Devonian old Red Sandstone of the Welsh borderland, which has been compared to the modern floodplain of the Colorado River (Allen 1962; 1963). The grey colour of the unweathered Longford beds, coupled with the absence of mudcracks and similar structures, indicates deposition in a humid environment, with a high water-table close to, or even above, the depositional surface maintaining reducing conditions (Collinson 1978).

Humid climate floodplain deposits are associated with the Permian Gondwana coal measures in Africa, India, Australia and Antarctica (Duff et al. 1967) and point bar and overbank sediments have also been recognised in the Kapuni Formation (Upper Eocene) of New Zealand (Hill and Collen 1978). Sedimentary cycles from the New South wales coal measures (Duff 1967) and the Beacon Group of Antarctica (Barrett 1965) are generally comparable with those from Murchison, except that there is more conglomerate in the Longford Formation. This is due to the relatively short distance between the Murchison basin and the source of its sediments.

Vertical aggradation and lateral accretion in braided and meandering streams are not the only possible causes of the observed sedimentary cycles. Westoll (1968) lists a number of other possible causes including episodic or continuous crustal deformation, eustatic changes in sea level, climatic change, compaction and sub-compaction of sediments and isostatic 
adjustments in land levels. Of these the most likely to be encountered in Tertiary rocks are subsidence due to compaction of sediments and crustal deformation, although it has recently been suggested that substantial eustatic changes in sea level have taken place throughout Phanerozoic time (Vail et al. 1977; Loutit and Kennett 1981). It is known that regional subsidence was taking place at the time of deposition and it is likely that this was in part episodic, associated with intermittent movements on the Alpine and associated faults. If this were the case, sinking in the depositional basin could result in the formation of extensive coastal and lowland swamps, while rejuvenation caused by uplift in the source area could cause intermittent influxes of coarse sediment. Precise information regarding the processes taking place requires a detailed sedimentological investigation beyond the scope of the present study.

The modern Buller River runs for long stretches of its course through gorges cutting across the axes of the present-day ranges. This indicates the river was in existence before uplift of the ranges, i.e. it is antecedent (Cotton 1941). The Maruia and Matakitaki rivers also have antecedent reaches and the Longford and Frog Flat Formations may represent the confluent floodplains of forerunners of the present Buller, Matakitaki and Maruia Rivers. In general form these rivers probably resembled many of the larger present day west coast rivers, for example the Little Wanganui and Whataroa rivers, with broad, braided channels containing numerous partially and heavily vegetated islands and barred mouths favouring the development of coastal lagoons and swamps.

The Longford, Frog Flat and Spargo conglomerates are composed mainly of clasts of Paleozoic and Mesozoic greywackes and volcanics (Fyfe 1968; Cutten 1979), containing some granite clasts and at a few places some of Tertiary sandstone and mudstone. Schist pebbles are not found except in the Devil's Knob Formation (Nukumaruan) of the Rappahannock Group. Cutten (1979) argued that most of the transcurrent movement on the Alpine Fault took place after the conglomerates were laid down, tectonic movements during the Miocene being predominantly vertical. The Tertiary mudstone and sandstone pebbles at a few scattered localities indicates local uplift and erosion of parts of the depositional basin.

The flora is composed predominantly of forest trees. Allowing for the over- 
representation of woody plants in fossil assemblages (McGinitie 1953), this indicates a predominantly forest cover. Many of the leaves belong to genera characteristic of humid or rainforest environments, for example Cryptocarya, Ceratopetalum and Nothofagus. By anology with living relatives some may have been coastal trees (Metrosideros sp., Heimerliodendron) and some lianes (Metrosideros diffusoides, M. pliocenica). The presence of some species of Nothofaqus in abundance in lacustrine beds showing evidence of quiet water deposition, as at Nuggety Creek, indicates that at least these species grew on the floodplain itself, rather than on nearby hills. In New Caledonia, "brassii" type beeches tend to grow in more or less pure stands rather than as scattered trees in the forest as a whole, although $\underline{N}$. codonandra may be found as isolated trees in disturbed areas. While most of the beech stands in New Caledonia are montane, small stands, often of young trees of approximately the same age, may be found at lower levels along stream banks e.g. N. aequilateralis. The leaves of $\underline{N}$. aequilateralis are similar to those of $\underline{N}$. oblonga, a rather common beech of the Longford Formation.

The flora includes Laurelia, a genus characteristic of lowland swamp forest in New Zealand and Chile, although trees may occur in drier situations. Cockayne (1928) reported instances of Nothofagus species growing in semi-swamp forest in south westland. The presence of Typha and Cordyline in the Longford Formation indicates open swamp communities at some places, as does the presence of phormium pollen in Miocene strata in the Inangahua Valley (Couper 1953a).

Most of the workable coal in the Longford Formation is in the form of lenticular seams in the lowest 300 to $600 \mathrm{~m}$. Higher in the sequence there are only carbonaceous shales and thin coaly beds. The most extensive coal swamps may have been coastal, possibly occupying lowlying areas and lagoons behind a beach ridge. On the west coast of the South Island today the vegetation of such areas varies from kahikatea (Dacrycarpus dacrydioides) and silver pine (Dacrydium colensoi) forest in south westland to Phormium tenax with fringing stands of Rhopalostylis sapida near Karamea (author's observation). Casuarina, which is generally not tolerant of shade, probably found suitable niches along riverbanks and beach ridges, and at forest margins.

The conifers may well have formed an emergent stratum. Agathis australis, 
Dacrydium cupressinum and many Araucaria species are tall trees. Acaucaria is a frequent emergent in New Caledonian montane forests and Dacrydium cupressinum is one of the commonest emergent trees in New Zealand mixed lowland forest. The main canopy was probably composed of Nothofagus spp. Lauraceae, Ceratopetalum and other large trees. A schematic paleoenvironmental reconstruction is given in Fig 5.7.

\section{PALEOCLIMATE}

The Longford beeches are all large leafed and comparable to the present day species of New Caledonia and New Guinea, where they grow in tropical montane forests with a relatively frost-free climate and nearly constant humidity (van Steenis 1971a; 1976). Most of the trees in the Longford flora are now confined to more northerly latitudes and include a number no longer represented anywhere in New Zealand. Beilschmiedia taraire and Agathis are confined to forests north of $38^{\circ}$ while Heimerliodendron and Planchonella are even more restricted, occurring in northern coastal localities only. Davallia tasmanii is confined to the Three Kings Islands. Plants such as Laurelia, Hedycarya and Rhopalostylis, are still found in the South Island but are largely restricted to the mild, wet regions of the West Coast. Casuarina, Cryptocarya, etc. are no longer represented in our flora but are common in the warmer parts of Australia, in New Guinea and New Caledonia, and in other tropical and sub-tropical countries. Consideration of these points indicates a climate that was as warm as or warmer than the lowlands between latitudes $30^{\circ} \mathrm{S}$ and $35^{\circ} \mathrm{S}$ today. Many of the plants found are characteristic of rainforest environments, indicating that the climate of the west coast of New Zealand during the Miocene was at least as wet as today. The presence of Hymenophyllum ?Trichomanes and Leptopteris hymenophylloides is confirming evidence of high humidity.

The existence of warm, wet conditions is also supported by the relatively large average size of the leaves, and the rather high incidence of acuminate apices and the high proportion of leaves with entire margins are characteristic of sub-tropical and tropical vegetation. The warm temperature inferred from the Longford flora is in fair agreement with estimates from other sources (Devereux 1968; McQueen et al 1968; Beu and Maxwell 1968; Kennett 1978). 
FIG. 5.7: Paloomriromental reeonstruction for the Lengford Formation.

Pellen and megafeseil assomblages give goed ovidenee for at leat four vegetational formations:

1. Rainferest en better drained stes composed ef Araucarlaceae, Pedecarpaceat, Lauraceae, Nethofarue spp.. a diverse assemblage of broad-leafed trees and shrubs, and forne.

2. Swamp forest on poorly drained sitos, with Daerrearpue; Dacrydium spp.. Laure11a, palms and rerns.

3. Open fresh water swamps with palms, Phoralue, Cordrline, Irphe and Cyperaceae, dopending on lovel of the water table.

4. River bank and forest margin communities with palms, Casuarinacoae, Mallotue, Cordyline and Blechnum precero1dee. 


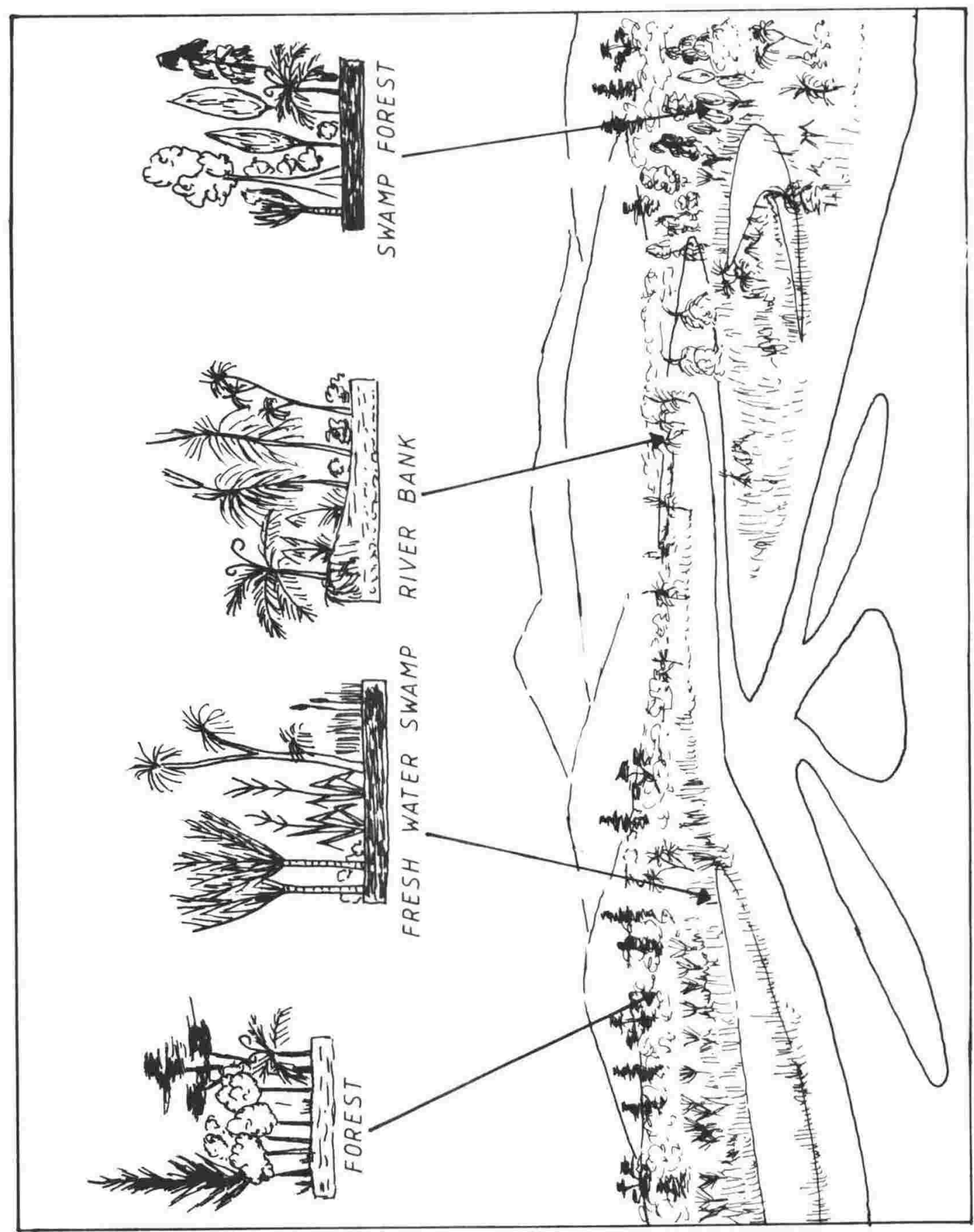


NOTE ON THE MIOCENE FLORAS OF THE DUNEDIN AREA

This study of the Dunedin fossil flora is a revision of the Upper Miocene plant fossils from Fraser's Gully, Kaikorai Valley, described by Oliver (1936) supplemented by two small collections made by the writer from Fraser's Gully and Taiaroa Head (Map: Fig 6.1). Both fossil localities are associated with the "older floodplain deposits" of Benson (1935).

Plant fossils were first collected in Kaikorai Valley by Marshall (1901) from a bank on the north side of Fraser's Creek. Marshall distinguished several species, which he thought to be of Oligocene age and which he identified as oak, elm, beech or birch, Magnolia, Metrosideros and Piper. The collection was later sent to Mr. H. Deane in Australia and has since been lost, together with Deane's manuscript containing the descriptions (Oliver 1936).

Dr. W.R.B. Oliver, the then director of the National Museum, Wellington, recollected the same locality in 1929 and later published descriptions of 25 species (Oliver 1936). The exact locality from which oliver and Marshall collected their fossils is not known, and although Fraser's Gully is regularly visited by parties of students from Otago University, material as well preserved as that in the National Museum has never been found again (J.D. Campbell, pers. comm.).

Leaf beds associated with the "older floodplain deposits" are known from elsewhere in the Dunedin area. Oliver (1936), examined leaf impressions from oil shale in the upper Leith Valley but found them to be indeterminable. Leaf fossils of the same age are also recorded from carbonaceous shales outcropping near Waitati (McKellar 1966). Park (1903) described leaf beds at Waikouaiti, north of Dunedin and stated that fossils included poorly preserved leaves of beech, oak, elm, myrtle and ferns. The sediments containing these fossils suggest that the leaf bed was formed at some time during the second eruptive phase (McKellar 1966). A further series of leaf beds in Benson's "younger floodplain conglomerate" outcrop at Pine Hill and under the Union Street Bridge (Coombs et al. 1960b). Oliver (1936) examined fossils submitted to him from Pine Hill but could recognise only "a large-leafed Coprosma close 


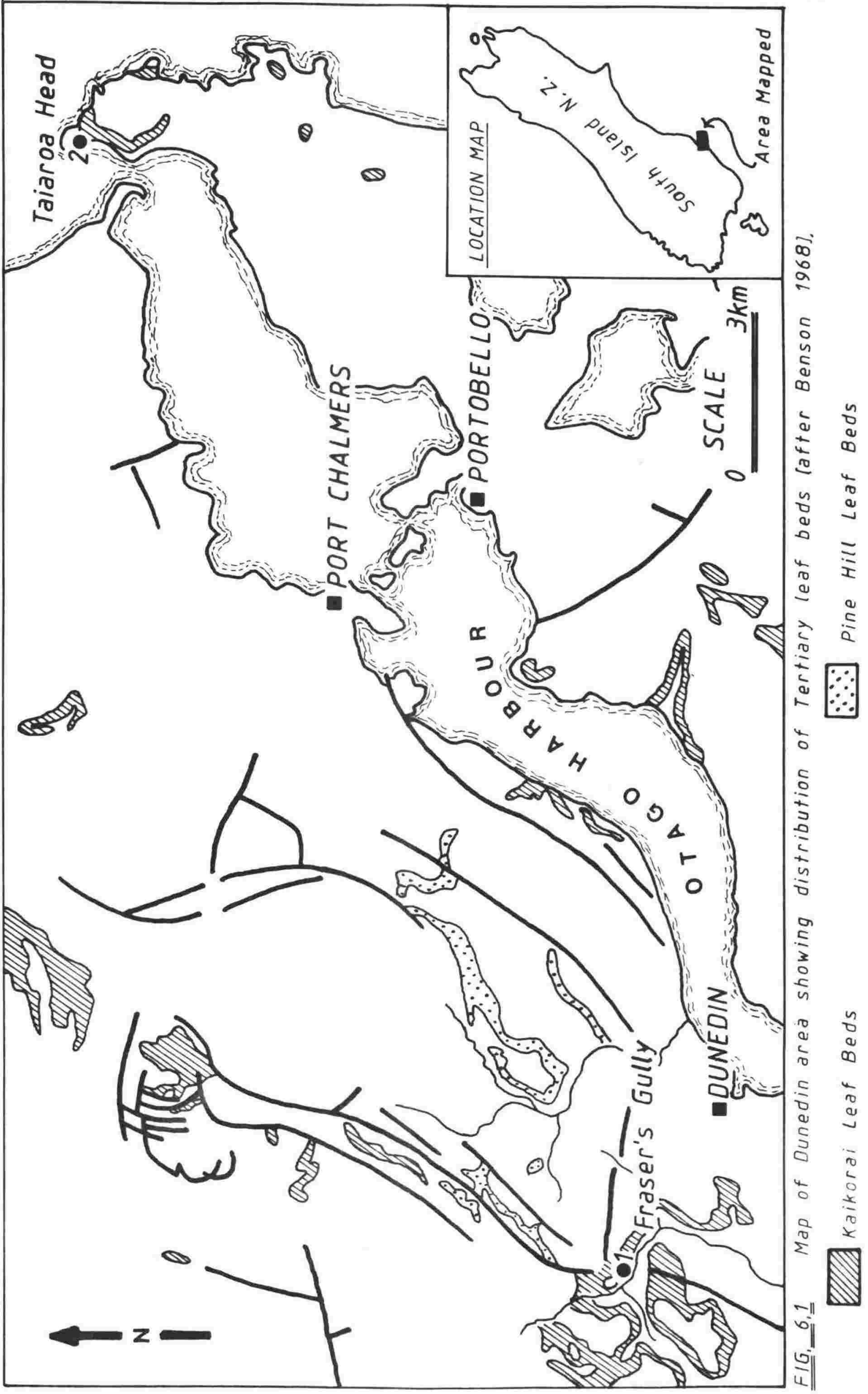


to c. vulcanica Oliver of the Upper Pliocene...". Well-preserved leaf fossils also occur in diatomite at Foulden Hills near Middlemarch in the Taieri Valley north west of Dunedin (J.D. Campbell, pers. comm.).

The geology of the Dunedin area is complex. A long period of volcanic activity, mainly in late Miocene to early Pliocene times, formed a suite of rocks termed the Dunedin Volcanic Complex by Benson (1959). The activity was divisible into three major eruptive phases, with evidence of a fourth, initial, phase. (Benson 1959; Coombs 1965). Basement rocks in the area are schists similar to those underlying most of Central Otago. on these were deposited breccias (Henly Breccia) and quartzose conglomerates and coal measures of the Tuatau Formation. Marine transgression over the late Cretaceous - early Tertiary peneplain resulted in the deposition of a thick sequence of limestone, marine sandstones and mudstones which underlie the Dunedin Volcanic Complex (Coombs 1965; McKellar 1966). At some localities the volcanics are clearly unconformable on the Tertiary marine formations which are truncated by an erosion surface of low relief (Park 1903; Marshall 1906; McKellar 1966).

Volcanic activity began with an initial phase of trachytic eruptions centred on Middle Harbour in the Portobello-Port Chalmers area (Benson 1959; Coombs 1965). Initial phase trachytic and basaltic tuffs are interbedded with fossiliferous marine sandstones and limestones of the Waipuna Bay Formation of Waiauan age at Waipuna Bay, Dowling Bay and Blanket Bay on the northern shores of Otago Harbour (Coombs et al. 1960a). The eruptions of this phase were on a small scale compared with those of later phases. Initial phase flows and fragmentals are overlain, apparently conformably in places, by material of the first major eruptive phase. Eruptions of this phase were again centred in the portobello area and were mainly basaltic at first and became phonolitic later. The phase concluded with a series of explosive eruptions from vents along a line south east from Port Chalmers (Benson 1942; 1959; Coombs 1965). Fragmentals from these vents, together with carbonaceous sediments and impure diatomites form the Kaikorai Leaf Beds (Benson 1959b).

The second eruptive phase also began with basaltic effusions from the Portobello centre and resulted in the most varied and voluminous deposits of the complex. A number of subsidiary vents also appear to have been active and the phase closed with an explosive episode which emplaced a 
second bouldery conglomerate with associated leaf beds (Pine Hill Leaf Beds). By the end of the phase flows had reached points up to $30 \mathrm{~km}$ north and west of the main eruptive centre (Coombs 1965). Volcanic activity in the Dunedin area concluded with a third major eruptive phase from vents in the region of Mount Cargill, west-northwest of the old portobello centre. During and following the emplacement of the third phase basalts and phonolites considerable tectonic deformation of the region took place (Benson 1959).

Outcrops of Kaikorai Leaf beds in Fraser's Gully are few and rather poor. Most are in the bed and banks of the creek. The fossils are contained in lenses of fine, whitish, water-lain tuff and are concentrated in carbonaceous bands separated by unfossiliferous laminae up to $3 \mathrm{~cm}$ thick. Marshall (1906) reported some 30 to 35 metres of conglomerate conformably overlying the leaf-bearing beds in Fraser's Gully. Benson (1959b) stated that the Kaikorai leaf beds and associated conglomerates were lensoid and varied from 3 to about 70 metres in thickness. Skeletons of fossil fish identified as Galaxias (Oliver 1936) were found with the leaves.

The material becomes friable as it dries and the fossils tend to curl away from the matrix. A number of mummified Blechnum fronds showing some details of cellular structure were present in material collected by the writer, and some fossils had cuticle showing recognisable structure. The cuticle was difficult to prepare because it tended to break up into roughly quadrangular fragments on exposure. The fossils collected by Oliver in 1929 are brownish films and impressions, some showing fine detail.

At Taiaroa Head a small outcrop of Kaikorai Leaf Beds is exposed in a road cutting some 300 metres south of the parking area at the road end. About $1.5 \mathrm{~m}$ of interbedded water-laid tuff and diatomaceous silt overlie a fine pebble conglomerate and are overlain by a coarser, angular conglomerate. The beds dip south-east at an angle of about $10-15^{\circ}$. They are thinly laminated and intersected by two series of vertical joints at about right angles to each other. The outcrop is deeply weathered and mid yellow to yellow-brown in colour. Most of the leaves are rather poorly preserved but some show details of fine venation. All organic material has disappeared. 
Marshall (1901) considered the plant fossils associated with the Kaikorai Leaf Beds to be of oligocene age, although it is not clear upon what grounds. Benson $(1935 ; 1942)$ invoked a late Tertiary peneplain to account for the facts that the volcanic complex is unconformable on the early and mid-Tertiary marine beds and that the contact is clearly an erosion surface. To allow sufficient time for the development of the peneplain Benson proposed a Pliocene age for the commencement of volcanic activity. Oliver (1936) accepted Benson's date but considered the plant megafossils to indicate an age "... at least as old as the lower Pliocene....". Couper (1953a; 1953b) examined pollen assemblages from a number of localities in the Dunedin area including Waitati and Fraser's Gully and tentatively placed the Kaikorai Leaf Beds in the upper Taranaki (Kapitean) or lower Wanganui Series but later (Couper and McQueen 1954) listed both the Kaikorai and Waitati floras as Taranaki Series.

These late Miocene to Pliocene ages now appear to be too young. The Waipuna Bay Formation which includes interbedded tuffs of the initial eruptive phase has been dated as waiauan on foraminiferal evidence (Coombs et al. 1960a); an initial phase aegirine-augite-fayalite trachyte gave a potassium-argon date of $15.0 \mathrm{my} \pm 3 \%$ and a third phase basic phonolite was similarly dated as $11.1 \pm 2 \%$. A further series of potassium-argon dates (McDougall and Coombs 1973) gave ages varying from $13.1 \mathrm{my} \pm 0.1$ for an initial phase trachyte to $10.1 \mathrm{my} \pm 0.2$ for a third phase phonolite. Second phase rocks gave dates varying from 11.3 to 12.1 my. These dates are roughly in accord with a probable waiauan age assigned by Dr. W.F. Harris (Coombs et al. 1960b) to a pollen assemblage from carbonaceous beds outcropping under the Union street bridge and tentatively mapped by Benson as post second major eruptive phase.

Recent palynological examinations of carbonaceous sediments associated with the Dunedin Volcanic Complex indicate ages younger than those obtained by potassium-argon dating (D.C. Mildenhall, pers. comm.). The reasons for this discrepancy are uncertain.

FLORA (Table 6.1)

A number of Oliver's identifications need to be revised. Pollen evidence 
TABLE 6.1. PLANT MEGAFOSSIL TAXA IDENTIFIED FROM THE RAIKORAI LEAF BEDS (DUNEDIN VOLCANIC COMPLEX).

PTERIDOPHYTA Nothofagus pinnata (Oliver) comb. nov ?Trichomanes sp. aff. reniforme Forst $\{\underline{N}$. australis (Oliver) comb. nov. Hypolepis sp. aff. tenuifolia (Forstf) N. kaikoraiensis Oliver var pellucida (col.) Hook. Bernh. Metrosideros pliocenica Oliver Blechnum proceroides (Oliver) comb. nov. Blechnum sp. aff. patłersonii (R. B r ) M. Laeta Oliver GYMNOSPERMAE

Podocarpus obtusifolius Oliver

ANGIOSPERMAE

Laurelia cuneata Oliver Calpidia zealandica Oliver Knightia oblonga Oliver Ceratopetalum kaikoraiense Oliver Metrosideros sp. Mett.

Ixerba semidentata Oliver Nothopanax distans Oliver Kaikoraia gracilis Oliver Geniostoma oblonga Oliver Coprosma praerepens Oliver c. pliocenica Oliver Senecio pliocenicum Oliver Nothofagus novae-zealandiae (Oliver) Typha robusta Oliver One additional unnamed taxon has also been recognized. 
indicates that the genus Fagus appears never to have been present in the southern hemisphere except as a result of human introduction (Mildenhall 1980). All fagaceous fossil leaves formerly assigned to Fagus are probably species of Nothofagus. Oliver's fossil genus Parafagus which he considered to be allied to quercus (Oliver 1936) cannot be maintained (Holden 1982a) and leaves described as Parafagus spp. are here included in Nothofagus as are the fossil leaves described as Ulmophyton pliocenicum by Oliver (See Systematics, Chapter 8 ).

In keeping with current taxonomic thinking, Lomaria proceroides is transferred to Blechnum and Calpidia zealandica to Heimerliodendron. Ixerba semidentata, Coprosma praerepens, c. pliocenica, senecio pliocenicum and Nothopanax distans require further investigation before their status can be assessed.

Oliver described the basal part of a leaf with a long stout petiole and acrodromous venation as Coriaria latipetiolata. Coriaria species generally have subsessile leaves. No living species so far seen by the writer has the broad long petiole as seen in the fossil. The venation of Coriaria resembles closely that of Ripogonum (Smilacaceae) which does have a long petiole. The fossil is therefore transferred to Ripogonum. Fragmentary cuticle has been obtained from material collected by the writer, but has yet to be compared with cuticles of living Coriariaceae and Smilacaceae. However the form of the stomatal complex is similar to that illustrated by Macmillan (1972) for Ripogonum. Leaves of this species appear to have been quite common, as several impressions were found by the writer.

Of the fossils collected by the writer from Fraser's Gully, one was a species of Blechnum with broad fronds similar to those of $\underline{B}$. patfersonii. The matrix was however so friable that the fossil could not be collected whole. There were also two further impressions of uncertain affinity, one suggesting a frond of Trichomanes reniforme and the other leaves of some species of Smilax or auriculate leaf bases of some Compositae, for example Sonchus spp and some herbaceous Senecio species. Matrix from the fossils was examined for diatomaceae by Dr. M.A. Harper, whose report is included in Appendix B.

The fossil assemblage from Taiaroa Head is even poorer in species and 
is dominated by beeches; 90 - 95\% of all leaf fossils collected from this locality were species of Nothofagus. The leaf margins are often poorly preserved, and consequently it is difficult to assign them to species, but Nothofagus kaikoraiense appears to have been particularly common, while $\mathrm{N}$. australis and $\mathrm{N}$. novae-zealandiae were present but less abundant. Only a few other species were found, including several leaves of Laurelia cuneata, one small leaf resembling Ixerba semidentata, fragments of fern pinnae similar to the living New Zealand species Hypolepis pellucida and a myrtaceous leaf, probably a species of Metrosideros.

\section{$\underline{\text { Paleoenvironment }}$}

The Waipuna Bay Formation of Waiauan age, interbedded with initial eruptive phase tuffs, is a shallow marine sequence containing fossiliferous sandstones and limestones. Palagonitic tuffs and basaltic flows containing pillow-like forms occur in early first phase eruptives at Maori Pa Point. Eruptions appear therefore to have begun from one or more offshore vents resulting in the formation of a small volcanic archipelago (Coombs et al. 1960b) which by the end of the first major phase was joined to the mainland. The Kaikorai Leaf Beds and their associated conglomerates were deposited in a shallow synclinal valley or valleys towards the end, or in a period of quiescence immediately following, the first phase (Benson 1959b). There is little evidence for the extensive Tertiary peneplain proposed by Benson (1935). The erosion surface truncating the early to mid Tertiary marine sediments in the Dunedin area appears to be the result of rather local tectonic activity prior to and contemporaneous with the outbreak of volcanic activity (Wood 1968).

The Dunedin floras are probably nearly contemporaneous with parts of the Longford Formation, but are poorer in species. A number of species (Nothofagus novae-zealandiae, N. bidentatus, Laurelia cuneata, Metrosideros pliocenica, Kaikoraia gracilis, Knightia oblonga, Ceratopetalum kaikoraiense and Blechnum proceroides) are common to both floras. A few species (Nothofagus bidentatus, N. australis and Ceratopetalum kaikoraiensis) are common to the Dunedin area and the probably younger flora of Great Barrier Island. 
Extensive beech forest indicates a rather humid climate, and associated species (Heimerliodendron, Kaikoraia, Knightia, Ceratopetalum) indicate that average temperatures were probably warmer than those experienced in the Dunedin area today. The beech forest probably grew close to sea level and on the lower slopes of the volcanic edifice, and the presence of Laurelia at both Fraser's Gully and Taiaroa Head indicates that the forest may have been locally swampy, while Typha suggests open water and non-forested eutrophic swamps. Diatom assemblages identified by Dr. Harper indicate neutral to acid, probably eutrophic, water which was very shallow and weedy. Dr. Harper further indicates that the diatom assemblage published by oliver (1936), from a different lens, probably lived in more alkaline waters.

The discrepancy between potassium-argon dates on the volcanics and dates inferred from pollen assemblages in interbedded sediments may be related to the fact that the vegetation was apparently depauperate. The possibility of local climatic effects resulting from an east coast cold current are discussed later (Chapter 9). Forest destruction due to volcanic activity may also have had a significant effect on the vegetation. Nicholls (1963) concluded that effects of ash showers from the 1886 Tarawera eruption on high forest had been small in the long term, except where airfall deposits were deep or had been hot enough to kill vegetation outright, although in the short term there might have been considerable destruction of ground layer and understory plants. Observations of damage to vascular plants caused by ash fall from the eruption of Mt. St. Helens (Mack 1981) show that forest trees are relatively little affected by ashfall but that overloading caused extensive destruction and damage to ground herbs. Flowering and fruiting were also inhibited.

Even in areas affected by ashfall heavy enough to cause severe damage to standing forest, vegetation may recover fairly rapidly where erosion strips the ash cover to expose the original soil. This may occur either by epicormic regeneration or by germination of dormant seeds. Such regeneration was observed on Volcan Barcena (Islas de Revillagigedo, Mexico) (Brattstrom 1963) and following the Tarawera eruption (Nicholls 1963).

Beech does not appear to have been an important pioneer in volcanically devasted areas in New Zealand in Holocene times, perhaps because the 
poor seed dispersal capacity (Preest 1963) makes its advance slow. This is not so in South America (McQueen 1977), where a number of species are important early colonisers of volcanic soils. This may be due to the ability of many South American beeches, particularly deciduous species, to regenerate epicormically or from root suckers following damage (McQueen 1976; 1977). Regeneration from root suckers has also been observed in evergreen 'brassii' type beeches in New Guinea (Paijmans 1976). Regeneration in modern New Zealand beeches is by seed, but this may not have been the sole method in the past. 
Three small collections now held at N.Z. Geological Survey, Lower Hutt, form the basis of this account. These were made by $\mathrm{K}$. Black (2 localities) in 1952 and D. Kear in 1956 (Table 1.1). Some of this material was mentioned by Couper and McQueen (1953) but the localities were wrongly recorded. A sample of carbonaceous sediment containing fossil leaves from Medland's stream was examined for microflora by Couper (1953b).

The original discoverer of the best-known plant localities, those in Medland's Stream, is unknown, but in 1931 a Mr. A.G. Sanderson presented a collection to the Auckland Institute and Museum. This collection was later sent to Dr. W.R.B. Oliver of the National Museum, Wellington, for identification and subsequently returned to Auckland. The descriptions were never published, but Hayter (1954) included oliver's report to the director of the Auckland Museum in an appendix to his thesis, and the list of species was published by Couper (1953b). The Auckland collections have not been examined by the writer.

Fossil leaves occur at a number of localities (Map fig. 7.1) in lenses of lignitic lacustrine sediments interbedded with flows and fragmentals of the Beeson's Island Volcanics. The fossil localities were not visited by the writer and stratigraphic and topographical details have been taken from accounts by a number of authors, especially Hayter (1954).

Geologically, Great Barrier Island is a part of the Coromandel Peninsula and became isolated when the postglacial rise in sea level drowned the area that is now Colville Channel (Fleming 1979). The island is a dissected mountain approximately $35 \mathrm{~km}$ long and $20 \mathrm{~km}$ wide. Along the sheltered west coast drowned valleys form many inlets with fringing volcanic bedrock islands and reefs (Bartrum 1921). The east coast, exposed to the Pacific ocean swell, has a more regular outline and in places sandy beaches are backed by dunes and extensive areas of swamp (Mason 1951).

Basement rocks, outcropping only in the north and east of the island are indurated and contorted argillites, greywackes and conglomerates of Jurassic age. Over most of the island the Mesozoic basement is 


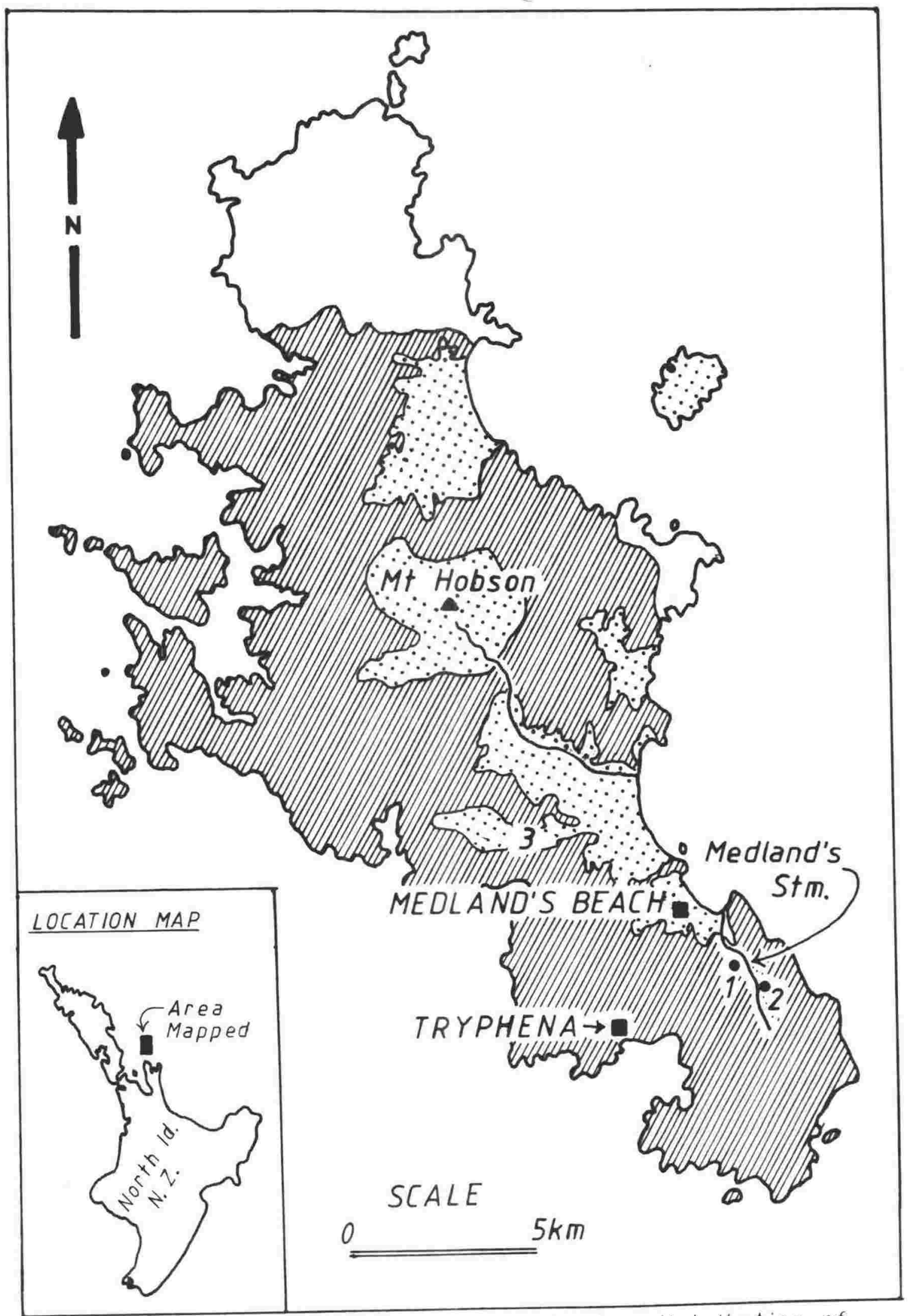

FIG. 7.1 Map of Great Barrier Island showing distribution of Beeson's island Volcanics [after Thompson 1960].

Beeson's Island

$\because \because$ Younger rhyolites

Volcanics landesites] $\quad[\because$ and sediments

Fossil localities: 1 \& 2 Medland's Stream.

3 Road north from okupu [B411]. 
unconformably overlain by a sequence of Upper Miocene to Pleistocene volcanics. Most are andesitic pyroclastics, lavas and minor intrusives mapped as Beeson's Island Volcanics (Upper Miocene to Pliocene). Rhyolitic lavas and breccias of the Whitianga Group (Pliocene to Pleistocene) unconformably overlie the andesitic sequence. At Te Ahamata (Whitecliffs) late phase hydrothermal activity resulted in mineralisation and sinter deposits (Thompson 1960; Ramsay 1971). The only remaining active volcanicity is represented by hot chloride springs near Kaitoke Swamp (Wilson and Moore 1973). A swarm of minor earthquakes affected the island in 1953 (Gage 1980).

The name Beeson's Island Volcanics was introduced by Hector (1870), and was used by McKay (1897) and Fraser and Adams (1907) for slightly altered and seemingly young andesitic rocks of the Coromandel peninsula. The type locality is Beeson's Island in Coromandel Harbour (Kear 1959). Skinner $(1962 ; 1967)$ has shown that the supposedly older and younger andesites are in fact coeval and inseparable. The remapping of northern Coromandel (Skinner 1976) has resulted in the division of the Miocene/ Pliocene andesitic rocks into a number of formations including a redefined Beeson's Island Formation. The volcanic stratigraphy of Great Barrier Island is in need of a corresponding revision.

The best-known fossil locality is in the bed of Medland's Stream approximately $1.5 \mathrm{~km}$ from its mouth (Thompson 1960). To quote Hayter (1954): "....the exposure, some 30 feet across by 10 feet high, consists of tuffaceous, carbonaceous, fissile sandstone dipping east-northeast at $30^{\circ}$. These beds appear to be lensoid, possibly representing a former fresh water pool in which volcanic ash was deposited burying the leaves which had collected in the pool. This deposit yielded a good macroflora but a poor microflora.

A further outcrop 5 feet high by 40 feet wide of lithologically identical material was discovered in a western tributary of the main stream some two miles north of the latter (c. 60 chains at $189^{\circ}$ from Trig G). Small lenses an inch or two thick of black to brown comminuted debris with some bright black coally material in thin bands occur in the lower part of the outcrop. Plant macrofossils are poorly preserved but a good microflora was collected... the beds dip north at $15^{\circ}$, the dip varying to a little east of 
north.... The bedded andesitic fragmentals in which these fossiliferous beds occur dip almost uniformly at $25^{\circ}$ to $30^{\circ} \ldots$.."

The fossiliferous siltstones are light yellow-brown to light grey and well consolidated with occasional coarse quartz grains and moderately abundant diatom frustules. The same siltstones contain compressed and decalcified impressions of the freshwater mussel Hyridella sp. (Hayward 1973a).

AGE

On stratigraphic grounds Morgan (1924) considered the andesitic volcanics of the Coromandel Peninsula and Great Barrier Island to be of Miocene age. The pollen assemblage from the carbonaceous lens in the tributary of Medland's Stream, N31/504, indicated an age not younger than mid-Pliocene and not older than Taranakian (Upper Miocene), with a Taranaki age favoured (Couper 1953b).

\section{FLORA}

The macrofossil assemblage is small and mainly leaves, but one cluster of flowers or fruits was examined and Oliver's report on the Auckland collection mentioned an unidentified flower (Hayter 1954). Identified collections from the site all showed a marked uniformity of taxonomic composition. Table 7.1 gives the Great Barrier fossils identified in this study, Oliver's list of the plants in the Auckland Museum collection, and Couper's pollen list.

Ceratopetalum (Cunoniaceae) and Casuarinaceae (represented by the palynomorph Haloragacidites trioratus Couper) are now extinct in New Zealand and Nothofagus is no longer found on Great Barrier Island (Kirk 1869). Otherwise, with the exception of a few forms of uncertain affinity, the fossil flora resembles the present flora of the island.

The Nothofagus species resemble those of the Dunedin area and this is supported by the similarities in fossil beech pollens of Great Barrier Island and Dunedin (Couper 1953b). The leaves are unlike modern New Zealand Nothofagus. The impression B411/9 cannot be definitely identified but the general form suggests a cluster of flowers or fruits of Loranthaceous affinity, resembling fruits of Loranthus sp. or flowers of Elytranthe sp. 
Loranthaceae are semi-parasitic shrubs and some species show a fairly high degree of host specificity. The living New Zealand species of Loranthus is found on a wide range of hosts. The principal host of Elytranthe in New Zealand is Nothofagus (Allan 1961), although E. adamsii, a rare species confined to Great Barrier Island and the Colville Peninsula, is found mainly on Coprosma, Melicope and Myrsine.

of the conifers, Agathis still forms a forest on Great Barrier Island. now confined mainly to the mesozoic basement rocks in the north and east (Kirk 1869; Mason 1951). The Phyllocladus fossils do not resemble closely any of the living New Zealand species, but one of these, P. glaucus Carr. occurs to at least $600 \mathrm{~m}$ on Mount Hobson in Great Barrier (Moore 1973). Libocedrus plumosus, represented amongst the fossils (01iver in Couper 1953b) is still represented on Great Barrier in forests above about $200 \mathrm{~m}$ (Mason 1951). The podocarp remains are similar to leaves of Podocarpus totara or to juvenile leaves of Dacrydium biforme or D. kirkii. D. biforme is absent from Great Barrier Island today (Kirk 1869; Moore 1973), but the island is the type locality for D. kirkii, a relatively rare species known from scattered localities in the Auckland province (Poole and Adams 1980).

A sample of the matrix from the Great Barrier fossils was examined for diatoms by Dr. Margaret Harper of Victoria University (Appendix B, Table 3). All the species identified are common in fresh water today, rather less than $40 \%$ being planktonic, the remainder being benthic forms.

\section{PALEOENVIRONMENT}

The leaves and other plant remains occur in water-laid andesitic tuffs. The presence of numerous Hyridella sp. (Hayward 1973a) indicates that these sediments were deposited in a freshwater lake or pond rather than in a river. The diatoms indicate standing freshwater of shallow to moderate depth: deeper water would be expected to have more than $40 \%$ planktonic forms. The presence of Pinnularia indicates only slight flow while abundant Melosira may indicate disturbance of the water surface by wind. Relatively high numbers of Cymbella suggest the presence of fairly abundant aquatic macrophytes. The waters were neutral to alkaline rather than acid, with a fairly high level of dissolved silica. The level of dissolved silica is probably attributable to the presence of tephras, which favour the growth of diatoms (Harper 1981). 
McQueen (1969) presented evidence that subfossil leaves in the beds of lakes and pools where there is little through flow reflect fairly accurately the immediately surrounding vegetation. Allochthonous material is relatively rare. The bulk of the Great Barrier assemblage suggests lowland forest although Phyllocladus spp. and Libocedrus plumosa are found to quite high levels (ca. 300 - 600 metres) on Great Barrier today. With the exception of Nothofagus and other extinct forms the forest appears to have been of much the same type as that on the island today and it is probable that the climate was also somewhat similar. In addition to the forest there is evidence of a more open scrubland community with Pteridium and Leptospermum. The small size of the Lophomyrtus leaves suggests that they too came from an open situation. Muehlenbeckia is characteristic of scrub and forest margin and can become invasive where forest is disturbed. The presence of pollen of Typha and Cyperaceae indicates the presence of swampy ground.

There are a number of possible explanations for the small number of species in the assemblage. Firstly, it may reflect a reduction in floral diversity due to a late Miocene cold episode. It is not clear however whether the very cold sea temperatures inferred from foraminifera (Kennett 1967) had a comparable effect on land floras (McQueen et al. 1968). Although some changes are seen in Late Miocene (Kapitean) palynofloras and a few characteristic Tertiary pollens disappeared at that time extensive extinctions did not take place until mid pliocene to early Pleistocene times (Mildınhall 1980).

Secondly, the assemblage may have been derived from the vegetation of a very small area and may not reflect a genuinely depauperate flora. Thirdly, the flora may have been genuinely depauperate due to local environmental factors other than climate. The plant fossils are from lignitic lenses interbedded with andesitic fragmentals (Hayter 1954). The lake had been in existence sufficiently long for an appreciable fauna and flora to have developed as indicated by the relative abundance of Cymbella, a benthic diatom generally epiphytic on water weeds (M.A. Harper, pers. comm.) and numerous Hyridella shells (Hayward 1973a). It may have formed during a temporary cessation of volcanic activity. The possible effects of volcanic activity on vegetation are discussed in more detail in connection with the Dunedin flora. Geological investigations on Great Barrier Island indicate that pyroclastic flows, lava flows (Hayter 1954; Thompson 1960) and lahars (Hayward 1973b) may all have been important factors in forest disturbance. 
Approximately 200 taxa have so far been recognised from the Mid-Tertiary localities studied. Of these, three groups of plants have been selected for special study; Nothofagus, Casuarinaceae and Gymnospermae. All three are important elements of Southern Hemisphere Tertiary floras and are of considerable biogeographic interest. Of the remaining fossils, only those which are particularly common or well-preserved are described. The rest are included in an illustrated catalogue (Appendix C). In some cases it has been possible to give a tentative identification, but names in the catalogue should be regarded as provisional and subject to alteration should more data become available. In many cases no identification has been possible owing to shortage of living material for comparision, or to poor preservation.

Most of the identifications of the leaf fossils are based on venation patterns only. Epidermal characters have so far only been observed in silicified leaves from Landslip Hill, and in reasonably well preserved cuticles from St. Bathans and Kaikorai. So far only a few of the fossil fruits have been identified.

The six-digit grid references given refer to the cited sheets of the New Zealand 1:50,000 topographic map series (NZMS 260). Al1 New Zealand fossil record file numbers are prefixed by the 1:50,000 sheet number. Plant megafossils held at N.Z. Geological Survey, Lower Hutt, have catalogue numbers prefixed by $B$. Those held at Victoria University of Wellington have numbers prefixed by $V$, and specimens held in the type room have a type room catalogue number prefixed by VH. Material held in the herbarium of the National Museum, Wellington, has a catalogue number prefixed by the code WELT, material held at Southland Museum by C. Each fossil taxon has been designated by a catalogue number comprising a 3 letter stratigraphic code and a three digit reference number.

The taxononic treatment follows that of Allan (1961) and Moore and Edgar (1970) unless otherwise stated. 


\section{SPERMATOPSIDA - GYMNOSPERMAE}

Gymnosperms have a long fossil record in New Zealand, first appearing in the Permian (miembers of the Glossopteris Flors; McQueen 1954a; Mildenhall 1970b). Mesozoic megafossil floras indicate the presence of Pteridospermales, Pentoxylales, Ginkgoales, Cycadeoidales, Cycadales and Coniferales. The only non-coniferous gymnosperm to persist beyond the end of the Mesozoic however appears to be Ephedra (Gnetaceae), the pollen of which disappears from the fossil record at the end of the Pliocene (Mildenhall 1980).

\section{CONIFERALES}

The southern conifers belong to four distinct families, the Taxaceae (Austrotaxus) often being placed in a separate order (Taxales) (Sporne 1965). Two of the families, Taxodiaceae and Cupressaceae, have many more species in the northern hemisphere than in the southern although there are approximately the same number of cupressaceous genera in each hemisphere. Araucariaceae and Podocarpaceae are now predominantly austral in distribution. Araucariaceae have a substantial fossil history in both hemispheres but Podocarpaceae appear to be of southern origin and the few representatives north of the equator are held to be relatively recent immigrants (Sporne 1965). However Dilcher (1969) identified Eocene fossil conifer branchlets from eastern North America formerly described as Taxodium, Taxites or Sequoia as Podocarpus on the basis of cuticular anatomy.

Conifers dominated the New Zealand vegetation during the Jurassic and early Cretaceous (Fleming 1979). Florin (1940) recognised Athrotaxis (Taxodiaceae) from Shag Point (Haumurian). This record probably corresponds to Ettingshausen's Sequoia novae-zealandiae. The genus is now confined to Tasmania. Megafossils and fossil pollen indicate that some New Zealand conifers (Agathis australis, Dacrydium cupressinum and Dacrycarpus dacrydioides) may be virtually unchanged since late Cretaceous or early

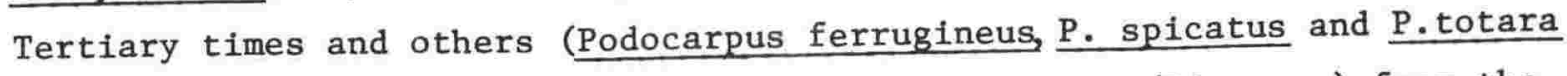
since not later than mid Tertiary. A record of Pinus (Pinaceae) from the New Zealand Cretaceous (Ettingshausen 1887) is erroneous and there is no reason to suppose that this exclusively northern hemisphere family was ever present in the south until introduced by man. 
Male strobili terminal or axillary, sporophylls bisporangiate, female strobili of uniovulate sporophylls cone-like or reduced to a swollen, fleshy receptacle with a single terminal ovule. Trees or shrubs with persistent leaves, lanceolate to linear, spreading or awl-like or scalelike and imbricate; or rudimentary and replaced by phylloclades. Phyllotaxy generally spiral (opposite and decussate in Microcachrys). Pollen grains bi- to trisaccate, or air sacs more or less absent.

The family is generally regarded as comprising seven genera with about 150 species (Allan 1961; Sporne 1965). Five (Phy1locladus, Saxegothaea, Microcachrys, Microstrobos and Acmopyle) contain few species, Microcachrys and Saxagothaea being monotypic and confined to Tasmania and Chile respectively. The remaining two genera, Podocarpus and Dacrydium, each contain many species. Podocarpus has been divided into eight sections (Buchholtz and Gray 1948). Quinn (1970) concluded that while the smaller genera of Podocarpaceae are natural, Podecarpus and Dacrydium are artificial assemblages and that each of the eight sections of Podocarpus should be elevated to generic rank while Dacrydium should be split into at least five genera. De Laubenfels (1972), in his revision of gymnosperms for the Flore de 1a Nouvelle Calédonie et Depéndances divides Podocarpus into a number of genera, suggesting that podocarpus ferrugineus and P.spicatus be included with the New Caledonian species $\underline{P}$. ferruginoides and other closely related species in Prumnopitys Philander. De Laubenfels also places Dacrydium taxoides Brongn. et Gris in the new genus Falcatifolium. Quinn (1982) has recently revised the genus Dacrydium and has split it into four genera in addition to Falcatifolium.

Of all the families of living conifers, Podocarpaceae show perhaps the greatest morphological and ecological diversity, ranging from tall trees to prostrate sub-lianoid shrubs and occupying habitats which vary from closed forest to subalpine scrub and bog. New Caledonian species include one of the few conifers to grow in shallow water around lake margins (Descussocarpus minor (Carriere) de Laub,) and the only known parasitic gymnosperm, Parasitaxus ustus (Veil1.) de Laub. (Carlquist 1965; de Laubenfels 1972). While the aquatic or semi-aquatic and parasitic habits are rare in living conifers, they many not have been so in the past. 
Podocarpacene appear to have been present in New Zealand since at least late Jurassic times (Fleming 1979) and Podocarp-like foliage is known from rocks as old as Triassic. Fossil pollen show that Podocarpaceae had a wide distribution in Gondwanaland during the Mesozoic (Couper 1960b).

\section{Podocarpus L'Héritier}

Type species: Podocarpus elongatus (Aiton) L'Héritier.

Plants dioecious, rarly monoecious, seeds axillary or terminal, nut-like or drupe-like, solitary. Leaves lanceolate to linear, spreading, at least in juveniles.

GLM001 Podocarpus sp. aff. totara G. Benn. ex D. Don. Fig 1.2,1.3,1.5,1.6. Branching conifer fragment, branchlet diverging at c. $60^{\circ}$; leaves spirally arranged, sessile, spreading 8-10 $\mathrm{mm}$ long and possibly 1-2 mm broad, linear-lanceolate. Midrib central, rather obscure, veins parallel; leaf margin somewhat revolute.

The exact size and shape of the leaves is difficult to determine due to their being embedded in resistant matrix. The branchlet form suggests podocarpaceous foliage similar to that of Podocarpus totara or juvenile foliage of certain species of Dacrydium, for example D. biforme (Ifook.) Pilger. Fossil pollen similar to Podocarpus totara and Dacrydium biforme occurs in the Gore Lignite Measures (N.Z.G.S. unpublished data).

Hypotype: V2841.36 and V2849.36A (counterparts), Gore Lignite Measures, Duntroonian to Waitakian stages, Upper 01igocene to Lower Miocene; G45/ f058, Lands1ip Hill, siliceous boulders at southern end of hilltop, $200 \mathrm{~m}$ from plantation boundary G45 125530, A.M. Holden and P. Vella, 1981. Victoria University, Wellington.

Dimensions: Branch fragment $53 \mathrm{~mm}$ long, leaves about $6 \mathrm{~mm}$ long and $1.5 \mathrm{~mm}$ broad.

Stratigraphic range: 01igocene to Recent.

KLB001 Podocarpus obtusifolius 0liver.

Fig 1.1

Podocarpus obtusifolius 0liver 1936, p 289, fig 2

Section of branchlet $25 \mathrm{~mm}$ long; leaves alternate or spirally arranged, possibly twisted to lie in the same plane; bark longitudinally wrinkled; leaves 10-12 mm long by 2-2.5 mm broad, more or less oblong, straight or somewhat falcate, spreading; apices obtuse, bases assymetrical, cuneate, angle with petiole wider on proximal side. Main vein single, obscure; 
leaf marked with parallel striations.

The character of the leaf base recalls that seen in Podocarpus spicatus or P. ferrugineus. The leaf apices appear to be damaged, and may originally have been mucronate as in $P$. spicatus, the leaves are however larger than those of $\underline{P}$. spicatus.

Holotype: WELT 44542 (Mid Miocene), Kaikorai Leaf Beds; Waiauan Sta겅 Fraser's Gully, Kaikorai Valley, Dunedin, I44 135797, W.R.B. Oliver 1929. National Museum, Wellington.

Dimensions: Branch fragment $27 \mathrm{~mm}$ long, leaves $11 \mathrm{~mm}$ long and $2.25 \mathrm{~mm}$ broad. Stratigraphic range: Mid Miocene

Dacrycarpus de Laubenfels

Type species: Dacrycarpus imbricatus (B1ume) de Laubenfels. Juvenile leaves dimorphic, those of ultimate branchlets complanate, falcate, dorsi-ventrally flattened, those of second order branchlets small, imbricate, scale-1ike; adult leaves usually linear, more or less scale-like, spirally arranged. Pollen cones small, terminal; ovulate cones terminal, ovules 1.

The genus contains nine living species distributed from Southeast Asia to New Zealand but not present in Australia (de Laubenfels 1972). Megafossils assignable to Dacrycarpus are known from Tertiary rocks in Chile (Florin 1963) and from a number of Tertiary localities in Australia (Cookson and Pike 1953). Allan (1961) includes the New Zealand species in Podocarpus.

NFMO01 Dacrycarpus sp. aff dacrydioides (A. Rich.) de Laubenfels. Fig 1.4 Tip of a conifer branchlet $18 \mathrm{~mm}$ long by $10 \mathrm{~mm}$ broad, leaves apparently spirally arranged but bent to lie in one plane; proximal leaves linear, acute to acicular, up to $3 \mathrm{~mm}$ long; distal leaves dorsi-ventrally flattened, falcate, 4-8 $\mathrm{mm}$ long by $0.5-0.7 \mathrm{~mm}$ broad, apices obtuse or apiculate, bases asymmetrical, produced into a decurrent wing, sessile; midrib simple, more or less prominent.

The size, form and arrangement of the leaves suggest juvenile foliage of Dacrycarpus dacrydioides. Similar foliage is seen in the living New Caledonian species D. vieillardii (Parl.) de Laubenfels (de Laubenfels 1972). There is also a strong resemblance to Podocarpus praecupressinum Ett., a fossil species that appears to have been widespread in Australia during the early Tertiary (Cookson and Pike 1953). 
Dacrycarpus dacrydioides is a tall tree of forests, particularly swamp forests, in high rainfall areas throughout New Zealand (Poole and Adams 1980). It is not usually found on bog soils. Fossil pollen of Dacrycarpus is known from Upper Eocene onwards in New Zealand (Mildenhall 1980). Pollen attributed to $\underline{D}$. dacrydioides has been recorded from early Miocene strata in a drillhole at Kapuka, Southland (Pocknall 1982a) and from a number of Oligocene to Miocene localities in Southland and Central Otago (N.Z. Geological Survey unpublished reports).

Hypotype: V2849.67 Nevis Formation, Oil Shale Member, Pareora Series Lower Miocene; F42/f001, Nevis Valley, F42 955535, A.M. Holden, P. Vella and C. Vella January 1981, Victoria University, Wellington.

Dimensions: Branchlet fragment $18 \mathrm{~mm}$ long, leaves 4-8 mm 1ong and 0.5$0.7 \mathrm{~mm}$ broad.

Stratigraphic range: Upper Eocene to Recent.

Dacrydium Sol. ex Forst. f.

Type species: Dacrydium cupressinum Lamb.

Male strobili terminal, rarely axillary, subtended by basal scales, sporophylls imbricate, bisporangiate, female branchlets terminal or subterminal, ovules solitary, fruit ovoid, nutlike, arillate. Leaves dimorphic, those of juveniles dorsiventrally flattened, or acicular; adult leaves smaller, acicular or scale-like and imbricate.

Trees or shrubs of lowland to subalpine forest and scrub. Lowland occurrences in the tropics are generally confined to leached sandy podzols (Florin 1963). Palynologists recognise at least three distinct groups of Dacrydium species in New Zealand fossil assemblages typified by Dacrydium cupressinum, D. bidwillii and D. franklinii. Of these both the $\underline{D}$. cupressinum group and the D. bidwillii group are living in New Zealand today. Dacrydium franklinii is at present confined to Tasmania but the corresponding palynomorph (Phyllocladites mawsonii) was formerly widely distributed (Couper 1960b) and was present in New Zealand from late Cretaceous to Miocene (Mildenhall 1980). Quinn (1982) has recently revised the genus Dacrydium and has split it into four genera, Dacrydium sensu stricto typified by $\underline{D}$. cupressinum and including all New Caledonian and Southeast Asian species, Lepidothammus with two species, one in New Zealand and one in Chile, Lagarostrobos with two species, one in New Zealand and one in Tasmania, and Halocarpus endemic to New Zealand. 
GLM002 Dacrydium sp.aff. cupressinum Lamb.

Figs $1.7,1.8,1.9,1.10$, 1.11, Plate 1.1

Numerous branchlet fragments, 3-5 mm diameter. Leaves spirally arranged, spaced 1-2 mm apart, imbricate, leaf blades keeled, acute to subacute, linear subulate, subfalcate spreading to more or less appressed, rhomboidal to triangular in cross section. Stomata probably on both abaxial and adaxial surfaces, those on the abaxial surface sunken, arranged in two bands on either side of the keel, each band containing ca. 4 rows of stomata (Fig 8.1), hypodermis well-developed (Fig 8.2).

The fossils closely resemble branchlets of the living New Zealand species Dacrydium cupressinum. This species is not closely related to other New Zealand members of the genus, its nearest relatives being D. araucarioides Brongn. et Gris., D. balansae Brongn. et Gris., and D. Iycopodioides Brongn. et Gris. of New Caledonia, D. novo-guineense Gibbs of New Guinea, D. gibbsiae Stopf. of Borneo, D. beccarii Parl. of Malaya and the widespread D. elatum Wallich. of Malaya, Borneo, the Philippines and Fiji (Franklin 1968).

Dacrydium cupressinum is a tall tree of lowland and montane forest in the higher rainfall areas of New Zealand (Allan 1961; Poole and Adams 1980). It grows on all but the very driest and wettest soils and tends to promote rapid podzolisation on free-draining soils (Franklin 1968). The related D. elatum is a characteristic tree of lowland tropical podzols in Sumatra and Borneo (Florin 1963). Pollen of D. cupressinum is known from Upper Cretaceous onwards (Mildenha11 1980), and is common at many localities in Southland and Central Otago (Couper 1953a; 1960a). It appears to have been abundant in the vegetation which contributed to the lignite seam in drillhole 1191 at Kapuka in South1and (Pocknall 1982a).

Hypotype: V2841.53, Gore Lignite Measures, Duntroonian to Waitakian Stages (Upper Oligocene to Lower Miocene); G45/f058, Landslip Hill, siliceous boulders on hilltop at southern end of hill $200 \mathrm{~m}$ from plantation boundary, G45 125530, A.M. Holden and P. Vella, 1981; Victoria University, Wellington.

Dimensions: Branchlet fragment $15 \mathrm{~mm}$ long, leaves to $3 \mathrm{~mm}$ 1ong. Illustrated specimens: B148.21 and 1026, Landslip Hill, G45/f 8498, collected by J. Hector; V2841.3, V2841.11A from the same locality as hypotype, 

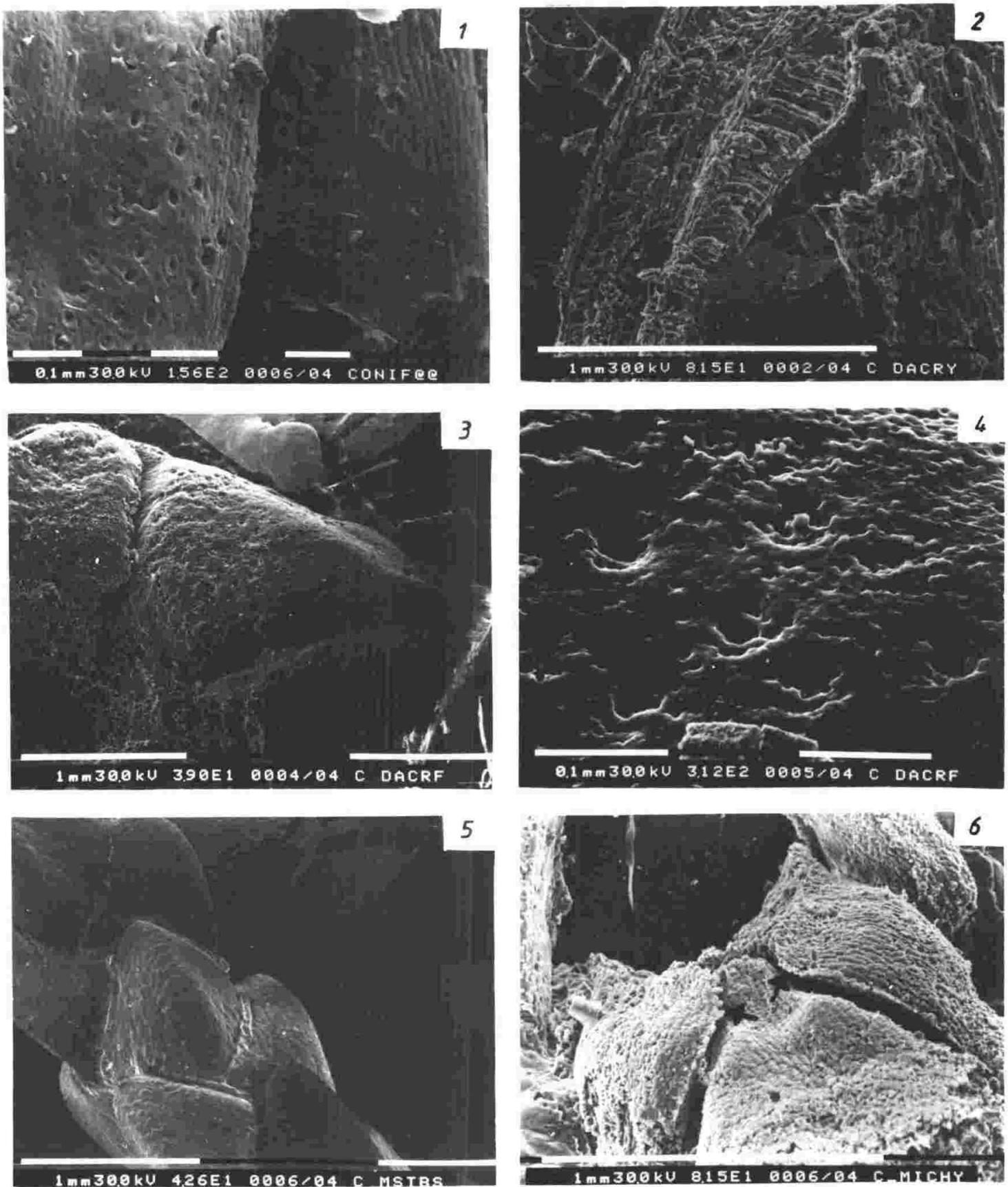

FlG, g. 1: Dacrydium sp. aff. cupressinum; silicone rubber cast of abaxial leaf surface showing stomatal bands.

FIG. 8. 2: silicified leaf showing internal structure.

$\underline{\underline{F I G S}}, \underline{\underline{8}}, \underline{\underline{3}}, \underline{\underline{8}}, \underline{\underline{4}}: \underline{\mathrm{D}}$ franklinoides; silicone rubber cast of

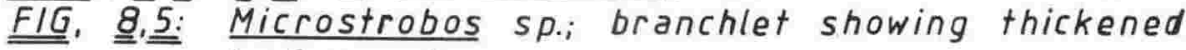
leaf margins.

E1G. 으, $\underline{\underline{6}}$ : Microcachrys imbricatus; silicone rubber cast of branchlet showing fragmentary ciliate wing on margin (arrowed). 
Other material examined: B33.1, B33.8; F45/f9575, Waikaka F45 986435, B. Wood 1948; B149.6, G45/f8497, Landslip Hill, G45 125530, J. Hector, 1869 ; B150.1, B150.8, B150.11, B150.14, B150.15, Landslip Hill, G45/f8496, J. Park, 1886; V2840.2, V2840.6, G45/f064, Landslip Hill, G45 125530, J. Thornton; V2841.8, V2841.11, V2841.13, V2841.23, V2841.36, V2841.63, V2841.74, V2841.87, V2841.88, G45/f058, Lands1ip Hil1, G45 125530, A.M. Holden and P. Vella, 1981. Stratigraphic range: Upper Cretaceous to Recent.

CLM 003 Dacrydium franklinoides sp.nov. Figs $2.1,2.2,2.3$

Sequoia novae-zeelandiae pro parte Ettingshausen 1891, p. 254, P1ate XXIV $5-7,7 a$.

Athrotaxis novae-zeelandiae (Ett.) 0liver 1950, p 6.

Branchlets terete, $1.5-3 \mathrm{~mm}$ diameter, leaves spirally arranged, frequently appearing to be in 4 - 5 ranks, small, scale-like, imbricate, appressed; laminae concave, somewhat keeled, broadly triangular, apex subacute to obtuse; stomata probably on both surfaces of the leaf, those on abaxial surface sunken, scattered, not arranged in distinct bands (Fig 8.3, Fig 8.4).

Ettingshausen (1887) described Sequoia novae-zeelandiae on the basis of cones and foliage from Haumurian strata at Shag Point, eastern Otago, and included in this species branchlet fragments from Landslip Hill. Florin (1940; 1063) placed the Shag Point material in Athrotaxis (Taxodiaceae), probably on the basis of Ettingshausen's descriptions and illustrations, as he does not appear to have examined the fossils. It is unlikely that the Shag Point and Landslip Hill fossils are conspecific.

A number of conifers have spirally arranged, imbricate, concave scale leaves, including Dacrydium spp., Microstrobos and Athrotaxis sp. Microstrobos has distinctly thickened leaf margins and stomata on the adaxial surface only, (Fig 8.5). In Athrotaxis and New Zealand species of Dacrydium the stomata on the abaxial surface are in two distinct bands on either side of the keel. In respect of the distribution of stomata the fossils most closely resemble Dacrydium franklinii, a species endemic to Tasmania. Fossil pollen similar to that of D. franklinii (Phyllocladites mawsonii) was widespread in the southern hemisphere during the Tertiary (Couper 1960b) indicating that the present range 
is relictual. Quinn (1982) groups D. franklinii with the New Zealand species $D$. colensoi Hook. in the new genus Lagarostrobos on the basis of cone morphology in spite of differences in pollen morphology and flavone chemistry.

Dacrydium franklinii is a fairly tall tree of cool temperate rain forests in Tasmania. It is locally frequent on river banks, swampy flats and lake shores to about 800 metres (Curtis 1957).

Holotype: V2841.22, Duntroonian to Waitakian Stages (Upper Oligocene to Lower Miocene), G45/f058, Landslip Hill, siliceous boulders on hilltop at southern end of the hill $200 \mathrm{~m}$ from plantation boundary G45 125530, A.M. Holden and P. Vella, 1981, Victoria University, Wellington. Dimensions of holotype: Branchlet fragment $31 \mathrm{~mm}$ long and $1.7 \mathrm{~mm}$ diameter.

Illustrated specimens: B148.13, locality G45/f8498, Lands1ip Hill, G45 125530, J. Hector.

Other material examined: V2841.11, V2841.29A, V2841.48, all from the same locality as the holotype; V2842.3, V2842.4, V2842.11A, G45/f063, Landslip Hill, fallen boulders at foot of slip face, G45 124533, A.M. Holden and P. Vella, 1981.

Stratigraphic range: Late Cretaceous to Miocene.

Microcachrys Hook $\mathrm{f}$.

Type species: Microcachrys tetragona (Hook.) Hook. f. Branchlets generally 4 angled, leaves scale-like, imbricate, opposite and decussate.

A genus of one living species endemic to Tasmania. Fossil pollen of Microcachrys occur in New Zealand from Oligocene to Pliocene (Mildenhall 1980. The genus had a wide distribution in the southern hemisphere during Tertiary times (Couper 1960b). Megafossils attributable to Microcachrys have not so far been reported elsewhere.

GLM004 Microcachrys imbricata sp. nov.

Figs $2.4,2.5,2.6,2.7$ Branchlets terete to quadrangular, 1-2 mm in diameter, branching in more than one plane; leaves imbricate, appressed, scale-like, opposite and decussate. Laminae broadly triangular, concave, not or only obscurely keeled, acute to subacute. Leaf margin narrowly winged and probably ciliate (Fig 8.6). Epidermal cells in distinct rows, rectangular, longitudinally elongate. Stomata on abaxial surface occasional or absent. 
Opposite and decussate scale leaves are characteristic of many members of the Cupressaceae including the living Austral species Libocedrus bidwillii Hook. f. (New Zealand) and Diselma archeri Hook. f. (Tasmania). They are also found in the podocarpaceous genus Microcachrys. Libocedrus bidwillii has strongly keeled amphistomatic leaves, the stomata on the abaxial surface being arranged in two narrow bands (Fig 8.7). Diselma archeri lacks stomata on the abaxial surface of the leaf. It also has entire leaf margins and the leaf apex is minutely roughened (Fig 8.8). The leaf margins of Microcachrys tetragona are ciliate and the leaf apices are more or less smooth (Fig 8.9). Silicone rubber casts taken from. the fossils show traces of a ciliate wing along the leaf margin (Fig 8.6,8.10) and there is little sign of the roughening of the leaf apex seen in Diselma.

Fossil pollen of Microcachrys is relatively abundant in Southland 01igocene-Miocene assemblages (Mildenha11 1980) but was apparently absent from the vegetation which formed the lignite in the drillhole at Kapuka (Pocknall 1982a).

The living species, Microcachrys tetragona, is a prostrate shrub of subalpine habitats, particularly exposed ridges and wet moors, on the mountains of the central plateau and in the south and south west of Tasmania (Curtis 1956). Wardle (1968) used Microcachrys pollen as an indicator of the continued existence during the Tertiary of wet peneplained uplands with infertile soils. However, Townrow (1965b) suggested that Microcachrys, together with another Tasmanian subalpine conifer genus Athrotaxis, had undergone a change in ecology and in the early Tertiary grew on peneplained lowlands with a warm, moist climate.

Holotype V2841.63, Gore Lignite Measures, Duntroonian to Waitakian, Upper Oligocene to Lower Miocene, G45/f058, Landslip Hill, siliceous boulders on hilltop at southern end of hill, $200 \mathrm{~m}$ from plantation boundary. G45 125530, A.M. Holden and P. Ve1la, 1981. Victoria University, Wellington.

Dimensions: Branchlet fragment $8.5 \mathrm{~mm}$ long and $1.2 \mathrm{~mm}$ diameter. Illustrated specimen: V2841.2 V2841.17 from the same locality; V2842.10 F45/f063 Landslip Hill, fallen boulders at foot of slip scarp F45 124533, A.M. Holden and P. Vella 1981 . 

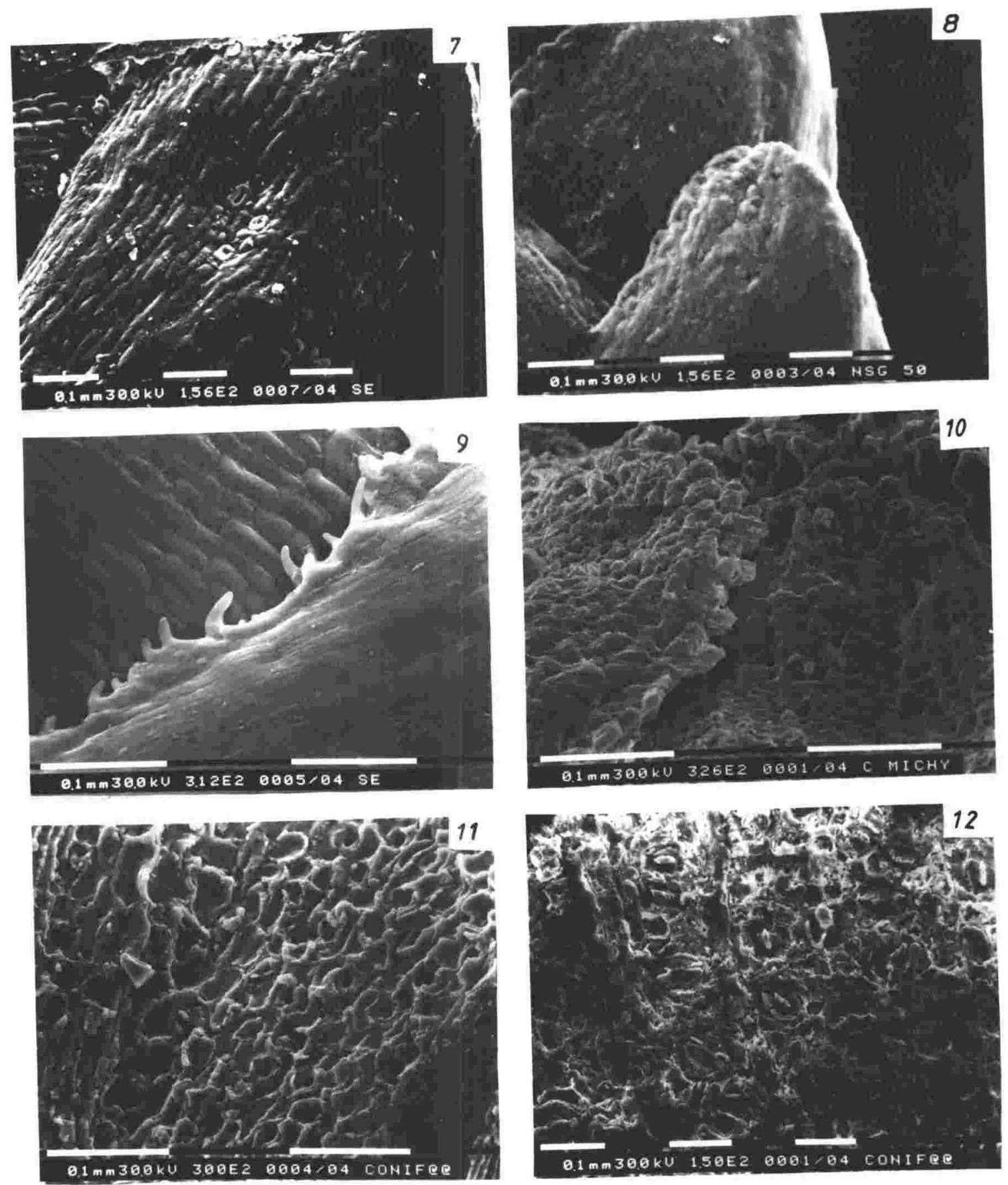

FIG, 8,7: Libocedrus bidwillii; abaxial surface of leaf showing stomatal bands.

FIG. 8, $\underline{\underline{8}}$ : Diselma archeri; leaf apex.

FIG. 으. Microcachrys tetragona; leaf margin.

FIG,,$\underline{\underline{8}}$ : 1 M imbricata; silicone rubber cast of branchlet showing leaf margin with remains of ciliate wing.

FlG, 8.11: Libocedrus compressa; silicone rubber cast of internal surface of lower epidermis showing stomata.

ElG, 을. 12: Agathis sp. aff. australis; internal surface of silicified lower epidermis showing stomata in roughly parallel rows. 
Other material examined: V2841.7, V2841.17, V2841.29A, V2841.36, V2841.37, V2841.41, V2841.44, V2841.48A, V2841.51, V2841.55, V2841.70, V2841.78A, V2841.80, V2841.80A, V2841.86A, V2841.87, V2841.87A, V2841.89, from the type locality; V2842.2, G45/f063 Landslip Hill, fallen boulders at the foot of slip face, G45 124533, A.M. Holden and P. Ve11a 1981; V2840.1, G45/f063, Landslip Hill, collected by J. Thorntou; B148.3, B148.15, Landslip Hill, G45/f8498, G45 125530, J. Hector 1869; B150.5, B150.7, B150.10, B150.11, B150.14, B150.15, G45/f8496 Landslip Hil1, G45 125530 , J. Park 1886.

Phyllocladus L.C. et A. Rich.

Type species: Phyllocladus aspleniffolius (Labil.) J.D. Hooker.

Branchlets often whorled, leaves spirally arranged, more or less caducous, branchlets concrescent into flattened leaf-like phylloclades, male strobili stalked, fascicled; female strobili sessile on margins of modified phylloclades or solitary, in the axils of arrested branchlets; fruit nut-like, arillate.

A genus of about 6 species of trees and shrubs in New Zealand, Tasmania, New Guinea, Borneo and the Philippines. Fossil pollen of Phyllocladus first appears in the New Zealand fossil record in the late Eocene (Mildenhall 1980) and in Australia at about the same time (Cookson and Pike 1954). Phyllocladus pollen has been reported from the lower Tertiary of Seymour Island, western Antarctica (Cranwell 1959). Megafossils are

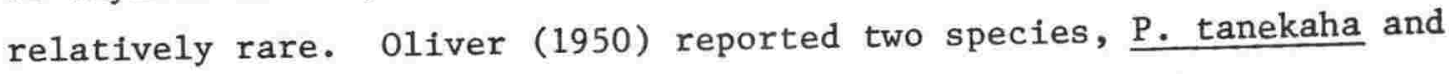
P. toatoa from Eocene strata at Wangapeka, Nelson, but the names are not validly published, being without the diagnoses and illustrations required by the Code of Botanical Nomenclature. Couper (1953b) reported the occurrence of Phyllocladus megafossils at Great Barrier Island. Three fossil species have been described from the Australian Tertiary (Cookson and Pike 1954). of these, P. simplex Deane from the Ottway Basin, Victoria, has been discounted as the fossils are indeterminable, and $\underline{P}$. asplenoides Ettingshausen (1888) from Vegetable Creek, New South Wales, was regarded as somewhat doubtful. Only $\mathrm{P}$. morwellensis Deane from Yallourn was considered sufficiently well preserved to constitute a reliable record. Fossil wood tentatively assigned to Phyllocladus has been reported from the Tertiary of South America (Couper 1960b) but the identification is open to question. 
BIV001 Phyllocladus strictus sp. nov

Fig 2.8 Plate 1.2 Phylloclades 28-51 mm long by 12-16 mm wide, ovate to obovate, somewhat narrow, irregularly lobed; lobes truncate and sometimes reduced to large, blunt teeth; base cuneate; venation pinnate to flabellate, midrib, where present, somewhat obscure, sinuous; veins dichotomously branched at narrow angles, anastomoses rare or absent.

The fossils are apparently phylloclades of a species of Phyllocladus but, lacking cuticle, cannot be positively identified. They do not closely resemble any living New Zealand species, being generally narrower and differing in the shape of the lobes. They do somewhat resemble the Australian Tertiary species Phyllocladus asplenoides Ett. from Vegetable Creek, New South Wales (Ettingshausen 1888).

Holotype: B411.1, Beeson's Island Volcanics, Taranaki to Wanganui Series, Great Barrier Island, "200 yards from road north from Okupu, 200 yards above road, near where road crosses fence on exposed spur, 80 chain at $50^{\circ}$ from Trig Whangapara," K. Black 1952. N.Z. Geological Survey, Lower Hutt.

Dimensions: $51 \mathrm{~mm}$ long and $17 \mathrm{~mm}$ broad. Stratigraphic range: Upper Miocene to Pliocene.

GLM005 ?Phyllocladus sp.

Figs $2.9,2.10$

Several incomplete fragments $15-25 \mathrm{~mm}$ long and 10-20 mm broad, probably rather broadly rhomboidal, base cuneate, margins in some cases showing a number of obscure to more or less prominent lobes with truncate apices. Venation pinnate to flabellate, some impressions showing a rather obscure, sinuous midrib, veins straight to recurved, branching dichotomously at narrow angles, $10-20^{\circ}$, little evidence of anastomoses.

The fossils are rather poorly preserved in a friable medium, and are mostly impressions or carbonised compressions without cuticle. The displayed characters are consistent with a species of Phyllocladus. The phylloclades are broader than those from Great Barrier Island but display a similar pattern of lobing. They do not closely resemble those of any living New Zealand species. There are a number of similarities with P. asplenoides Ett. from the Tertiary of New South Wales. Illustrated specimens: V2843.10, V2843.18, Gore Lignite Measures, Duntroonian to Waitakian Stages (Upper 01igocene to Lower Miocene), 
F46/f063, Tuturau, floats in riverbed downstream from outcrop of Gore Lignite Measures, F46 308887, A.M. Holden and P. Ve11a, 1981. Other material examined: V2843.3, V2843.5, V2843.6, V2843.7, V2843.10 from the same locality.

\section{CUPRESSACEAE}

\section{Libocedrus Endlicher}

Type species: Libocedrus plumosa (D. Don) Sargent

Trees or shrubs with opposite scale-like leaves in four rows; cones of 4-6 woody scales in opposite pairs.

A number of genera have at times been included in Libocedrus, including Calocedrus Kurz, Pilgerodendron Florin, Austrocedrus Floria \& Boutelje and Papuacedrus Li (Dallimore and Jackson 1966), but Allan (1961) regarded Libocedrus as including the New Zealand and New Caledonian species only. The fossil record of Libocedrus is poor. The pollen is rather fragile and is difficult to distinguish from that of other genera of Cupressaceae (D.C. Mildenhall, pers. comm.). Megafossils assigned to the living New Zealand species L. plumosa have been reported from Great Barrier Island (Couper 1953b; Florin 1963).

The two living New Zealand species have different ecological requirements. L. plumosa is a tree of lowland to montane forest north of a line from north west Nelson and Taranaki to Hawke's Bay. L. bidwillii Hook. f. is a tree of montane to subalpine forest extending south to Foveaux Strait. The New Caledonian species are mainly montane, generally of humid regions or regions with moist soils, although $\underline{L}$. yateensis cuillaumin may be found in drier situations and at lower altitudes (de Laubenfels 1972).

GLM006 Libocedrus compressa sp. nov.

Fig 2.11, 2,12 P1ate 2.2

Branchlets heterophyllous, flattened; leaves in four ranks, lateral leaves falcate, acute to subacute, connate, sheathing, decurrent, 3-6 mm long by 1.5-3 mm broad, dorsal and ventral leaves smaller, 1-2 mm long by 1-2 mm broad, more or less trianglar, appressed, somewhat keeled. Stomata in 2 bands, on both surfaces of the leaves, but more numerous on ventral surface, sunken (Fig 8.11).

The branchlets somewhat resemble those of the living New Zealand species L. plumosa but are larger. The leaves lack the furrows seen in L. plumosa, 
and the lateral, dorsal and ventral leaves are more noticeably different in size. The fossils are perhaps closer to the living New Caledonian species, particularly L. austro-caledonica Brongn. \& Gris. Comparisan with illustrations (de Laubenfels, 1972) suggests that the fossil lacks the recurved margin to be seen in S. austrocaledonica

Holotype V2841.44, Gore Lignite Measures, Duntroonian to Waitakian Stages (Upper 01igocene to Lower Miocene), G45/f058, Landslip Hill, siliceous boulders exposed on hilltop at southern end of hill $200 \mathrm{~m}$ from plantation boundary. G45 125530, A.M. Holden and P. Ve1la, January 1981.

Victoria University, Wellington.

Dimensions: Branchlet fragment $18 \mathrm{~mm}$ long and $4 \mathrm{~mm}$ broad.

Illustrated specimen: V2841.87 from the type locality.

Other material examined: V2841.7, V2841.15, V2841.35, V2841.42, V2841.42A, V2841.46, V2841.46A, V2841.53, V2841.69, V2841.79, al1 from the type

locality.

Stratigraphic range: Upper Oligocene - Lower Miocene.

CLM007 Libocedrus sp.

Fig 2.14

Branchlet fragment $19 \mathrm{~mm}$ long and $12 \mathrm{~mm}$ broad, flattened, heterophy1lous; lateral leaves spreading, falcate, acute, connate, 5-7 mm 1ong by ca. $2 \mathrm{~mm}$ broad; dorsal and ventral leaves smaller, ovate to triangular, appressed, $2-2.5 \mathrm{~mm}$ long and $1-1.5 \mathrm{~mm}$ broad.

The features displayed by the fossil are consistent with a species of Libocedrus, but the leaves are larger than those of any living species. The general form suggests that it may be juvenile foliage. Material examined: V2841.64A, Gore Lignite Measures, Duntroonian to Waitakian stages (Upper Oligocene to Lower Miocene), G45/f058, Landslip Hill, boulders exposed on hilltop at southern end of hill, G45 125530 , A.M. Holden and P. Vella, 1981.

\section{ARAUCAR IACEAE}

Large trees, buds scaly, leaves spirally arranged, broad and flat or narrow and quill-like; male flowers in elongate, cylindrical cones, sporophylls spirally arranged, bearing 5-15 pollen sacs; female cones globose or subglobose, cone scales broad, spirally arranged, deciduous when mature.

Araucariaceae is an ancient family, the earliest known members being Triassic (Sporne 1965) although an alliance with the Paleozoic Lebachiaceae has been claimed (Seward 1919). Living members are confined to the 
southern hemisphere, but fossils are known from both hemispheres. (Florin 1963). In New Zealand the earliest known araucarian fossils are Araucarites sp., megafossils from the mid-Triassic plant beds at Mount Potts, Canterbury, and sparse pollen (Araucariacites sp.) from Triassic strata in south Auckland (Fleming 1979). There are two living genera, Araucaria and Agathis. Only Agathis is indigenous to New Zealand today.

\section{Araucaria}

Type species: Araucaria araucana (Molina) Koch Trees, often with whorled branches; leaves sessile, clasping the stem, imbricate, scale-like, awl-shaped and triangular, or quadrangular in cross section, or dorsiventrally flattened, broad, with the apex produced into a pungent point; seeds united with the cone scales.

Florin (1963) recognised four sections in the genus Araucaria: Bunya with one species (A. bidwillii Hook.) in coastal Queensland; Columbea with two species in Central South America; Intermedia with three species in New Guinea and Eutacta, the largest section, with representatives in eastern Australia, Norfolk Island, New Caledonia and adjacent islands and New Guinea. Section Eutacta is centred in New Caledonia, where there are 13 species (de Laubenfels 1972).

The oldest fossils attributed to Araucaria are from the late Triassic of India. Araucaria appears to have been widely distributed through all parts of Pangea during the mid Mesozoic, but Araucariaceae disappeared from the Laurasian part of the supercontinent during the Late Cretaceous. There is only one recorded fossil occurrence in Africa, in the early Cretaceous (Florin 1963). Ettingshausen (1887) described two Cretaceous species which he assigned to Araucaria, A. haastii from Shag Point and Malvern Hills and A. danai, also from Shag Point. A further specimen of A. danai has recently been collected from Coverham, south eastern Marlborough (author's identification). It is unlikely that A. danai is in fact a species of Araucaria. Its affinities are uncertain. Oliver (1950) used the names A. carinaria ( $A$ A. haastii) and A. buchanani ( $=$ A. danai) for the Shag Point fossils. These names were originally given by Hector, but are invalid. Oliver also refers to Araucaria fossils from Landslip Hill but did not figure or describe them.

Detached leaves, broad, ovate, bases clasping, apices in all cases missing. 
Veins parallel, numerous, occasionally anastomosing. Stomata on one surface only, numerous, arranged in rough1y parallel rows, sunken with thickened rims.

The leaves appear to be those of a species of Araucaria sect. Coly ymbea, now found only in South America. They may be conspecific with A. haastii Ett. from Shag Point and Malvern Hills, but Ettingshausen's description implies that the leaves of A. haastii were somewhat keeled, a character not shown by the Landslip Hill fossils. The keel may have been an artefact of preservation, as leaves of A. haastii collected by the writer from Shag Point are not keeled. Araucaria nathorstii Dusén from Tertiary strata at Punta Arenas, Chile and Rio Negro, Argentina is similar to A. haastii (Berry 1928).

Illustrated specimens: B150.9, B150 unnumbered, Gore Lignite Measures, Duntroonian to Waitakian Stages, G45/f8496, Landslip Hill, G45 125530 , J. Park 1886, V2841.1, G45/f058, Landslip Hill, siliceous boulders exposed on hilltop at southern end of hill $200 \mathrm{~m}$ from plantation boundary, G45 125530, A.M. Holden and P. Vella, 1981.

Other material examined: V2841.6, V2841.92, V2841.92A, G45/f058, Lands1ip Hill, G45 125530. A.M. Holden and P. Vella 1981.

Stratigraphic range: Upper Oligocene to Lower Miocene.

Agathis Salisbury

Type species: Agathis dammara (Lambert) L.C. Richard

Trees, leaves broad and flattened, without pungent points, usually with short, flat stalks, or if sessile not clasping the stem; seeds not united with cone scales.

Agathis first became evident as a distinct genus in the Upper Cretaceous (Ecroyd 1982). There are about 15 species distributed from the Philippines to Polynesia, Australia and New Zealand. The New Zealand species is endemic (A1lan 1961). The present range of the genus appears to be only a little smaller than in the past, fossil species being known outside the present range only from the South Island of New Zealand and from south eastern Australia (Florin 1963). 
A number of species have been described from New Zealand Late Cretaceous sediments (Ettingshausen 1887; Oliver 1950). Pollen attributed to Agathis is known from the Cretaceous onwards (Mildenhall 1980) but is generally scarce, probably as a result of poor preservation and under-representation (Pocknall 1982a).

LDF001 Agathis sp. aff. australis Salisbury Fig 2.19,2.20,2.22,2.24 Leaves lanceolate to oblong, 2-ca $10 \mathrm{~cm}$ long and 5-12 mm broad, thick, apices acute to rounded, bases narrowed, sessile or sub-sessile, not clasping the stem, veins numerous, paralle1, obscure; stomata on one surface only, arranged in roughly parallel lines (Fig 8.12) sunken, in pits with thickened margins.

The leaves agree essentially with those of the living New Zealand species A. australis, the leaves of which are rather variable, those of juveniles being larger than adult leaves, and lanceolate in shape as opposed to oblong. Agathis australis has a cuticular micromorphology which is distinct from that of any other living species of Agathis and forms an isolated group (Ecroyd 1982). Cookson and Duigan (1951) described A. yallournensis from the Latrobe Valley, Victoria, which is thought to be close to A. australis (Ecroyd 1982).

Hypotype: V2829.3, V2829.24 (counterparts) Longford Formation, Waiauan to Tongaporutuan Stages, Mid to Upper Miocene, M29/f152, Nuggety Creek, boulder in creek bed $300 \mathrm{~m}$ from junction with Buller River, M29 606409, A.M. Holden and J.D. Collen 1979, Victoria University.

Dimensions: $47 \mathrm{~mm}$ long and $15 \mathrm{~mm}$ broad.

Illustrated specimens: V2841.74, Gore Lignite Measures, Duntroonian to Waitakian Stages, Upper 01igocene to Lower Miocene, G45/f058, Landslip Hill, siliceous boulders on southern end of hilltop, $200 \mathrm{~m}$ from plantation boundary, G45 125530, A.M. Holden and P. Vella 1981; B150.17, G45/f8496, Landslip Hill, G45 125530, J. Park 1886. Other material examined: V2841.45, V2841.71, G45/f058, Landslip Hil1, G45 125530, A.M. Holden and P. Vella 1981. Stratigraphic range: Upper Oligocene to Recent. 
GLM009 Agathis sp.

Fig 2.21

Leaves about $79 \mathrm{~mm}$ long and $20-25 \mathrm{~mm}$ broad, lanceolate to lanceolatefalcate, apex ?acute, base cuneate, leaves sessile or sübsessile; veins numerous, parallel, equal; stomata numerous, on one surface only, arranged in roughly parallel lines sunken, in pits with thickened margins.

The characters displayed by the fossil leaves are consistent with a species of Agathis. The leaves are longer and broader than those of the indigenous A. australis.

Illustrated specimen: V2841.51, Gore Lignite Measures, Duntroonian to Waitakian Stage, Upper 01igocene to Lower Miocene, G45/f058, Landslip Hill, siliceous boulders on southern end of hilltop, $200 \mathrm{~m}$ from plantation boundary, G45 125530, A.M. Holden and P. Vella, 1981.

Other material examined: V2841.6, from the same locality; V2840.3. Gore Lignite Measures, G45/f064, Landslip Hil1, G45 125530, J. Thornton. Stratigraphic range: Upper 01igocene to Lower Miocene.

\section{ARAUCARIACEAE INCERTAE SEDIS}

GLMO10 Agathis or Araucaria sp. A.

Plate 1.4

Pollen cone fragment, $28 \mathrm{~mm}$ long and $10 \mathrm{~mm}$ diameter, cylindrical, apex possibly rounded, central $2.5-3 \mathrm{~mm}$ diameter; cone scales rhomboidal in surface view, ca. $1.5 \mathrm{~mm}$ broad and $0.7 \mathrm{~mm}$ deep, spirally arranged, diverging at right angles from axis, each scale ca. $2.5 \mathrm{~mm}$ long; pollen sacs several, elongate, on underside of sporophyll.

The fossil is clearly an araucariacean pollen cone but it is not clear whether it is of a species of Araucaria or Agathis. The cone is longer and broader than those of Agathis australis, the dimensions being closer to those of Araucaria heterophylla (Salisb.) Franco.

Ref. specimen: V2841.85 and 85A (counterparts), Gore Lignite Measures, Duntroonian to Waitakian Stages (Upper Oligocene to Lower Miocene), G45/f058, Landslip Hill, siliceous boulders on hilltop at southern end of hill 200 m from plantation boundary G45 125530, A.M. Holden and P. Vella, January 1981, Victoria University. Stratigraphic range: Upper Oligocene to Lower Miocene. 
GLM011 Araucaria or Agathis Sp. B

Figs $2.17,2.18$

Pollen cone fragments to $24 \mathrm{~mm}$ long and $7-8 \mathrm{~mm}$ in diameter, cylindrical, central axis ca. $1.7 \mathrm{~mm}$ diameter. Sporophylls rhomboidal in surface view, $1 \mathrm{~mm}$ broad and $0.5 \mathrm{~mm}$ deep in surface view, spirally arranged, diverging from axis at right angles, $2.5 \mathrm{~mm}$ long, pollen sacs several, elongate, on lower surface of sporophyll.

The fossils are smaller than, and probably not conspecific with, sp. A. The dimensions are similar to those of male cone of Agathis australis.

Ref. Specimen: V2841.78A and 78B (counterparts), Gore Lignite Measures, Duntroonian to Waitakian Stages (Upper Oligocene to Lower Miocene), G45/f058, Landslip Hill, siliceous boulders on hilltop at southern end of hill $200 \mathrm{~m}$ from plantation boundary G45 125530, A.M. Holden and P. Vella, 1981. Victoria University. Stratigraphic range: Upper Oligocene to Lower Miocene.

\section{LDF002 ?Araucaria sp. \\ P1ate $1.3 \quad$ Fig 2.23}

Seed $24 \mathrm{~mm}$ long by $14 \mathrm{~mm}$ wide, base ca. $6 \mathrm{~mm}$ wide, obovate to more or less triangular, somewhat asymmetrical; strongly flattened, ca. $6 \mathrm{~mm}$ thick; a single strong keel approximately central on each surface, becoming obscure towards thickened, roughened apex; apex rounded, seemingly damaged, base probably incomplete; surface, particularly towards base marked by parallel striations; a coally layer ca. $0.5 \mathrm{~mm}$ thick and shining in appearance is present between the fossil and the matrix.

Illustrated specimen: B2.58, Longford Formation, Waiauan to Tongaporutuan Stages, (Mid-Upper Miocene), M29/f6579, Nuggety Creek, M29 604410, R.P. Suggate, D. Kear, E.T. Annear and W. Sara 1951. Stratigraphic range: Mid-Upper Miocene.

\section{SPERMATOPSIDA: ANGIOSPERMAE}

The first undoubted angiosperms appeared towards the end of the Lower Cretaceous, in the Albian, and thereafter diversified rapidly, attaining more or less world-wide distribution by the end of the Cretaceous (Brenner 1976). There are a number of reports of pre-Cretaceous angiosperms, 
but the status of these plants is as yet unclear (Hughes 1976). In New Zealand, the first angiosperm pollen is from Albian strata in the Clarence valley and East Wellington (F1eming 1979).

\section{DICOTYLEDONES}

Dicotyledonous leaves tend to dominate most plant megafossil assemblages from Late Cretaceous onwards. However it is possible that some early angiosperm-like leaves may in fact belong to extinct gymnosperms, as leaves of living Gnetum gnemon closely resemble those of some dicotyledonous angiosperms. Of the two living sub-classes of angiosperms, the dicotyledons are by far the most abundant and diverse.

\section{FAGALES - FAGACEAE}

Trees or shrubs, leaves simple, alternate, stipulate; male flowers in spikes, female flowers solitary, involucrate, fruit and nut enclosed in a cupule.

The family is an ancient one and is, like the Casuarinaceae, difficult to place in any phylogenetic scheme (Poole, 1949; Hutchinson 1967). Fagaceous fossils are known from Cretaceous rocks in all continents (Darrah 1939) except perhaps Africa. The family is best developed in the northern hemisphere, only three genera, Lithocarpus, Castanopsis and Nothofagus occurring south of the equator (Hutchinson 1967). Of these, only Nothofagus appears to be definitely Austral. Early workers (Unger 1864; Ettingshausen 1887; 0liver 1936) identified a number of New Zealand fossil leaves as species of Fagus and Quercus, both genera confined to the northern hemisphere before human introduction. Pollen belonging to these genera has not been found in New Zealand (Mildenhal1 1980) and the identifications are probably incorrect.

Nothofagus Blume

Type species: Nothofagus betuloides (Mirb.) Oerst.

Leaves alternate, simple, toothed or entire; stipules caducous; fruit a woody, winged nut in a scaly cupule.

Living members of the genus are trees or shrubs of temperate or tropical montane regions and are strictly austral in distribution. Nothofagus and the northern genus Fagus comprise the subfamily Fagoidae (Poole 1949). Van Steenis (1971a) proposed that the two genera diverged from a common ancestor 
in south east Asia and spread respectively to the southern and northern hemispheres, but current plate tectonic models (Smith and Hallam 1970) make this unlikely, and while Nothofagus pollen appears in the pollen record in the Upper Cretaceous, Fagus pollen first appears in the 01igocene (Muller 1981).

Infrageneric taxa are recognisable in Nothofagus. Van Steenis (1976) recognises two sections on morphological grounds, Section Nothofagus the members of which are deciduous and best developed in South America, and Section Calusparassus which contains the evergreen species. Both sections are further subdivided, Nothofagus into two subsections, Antarcticae (8 species in South America and Tasmania (N. gunnii (Hook. f.) Oerst.)) and Pumilae ( 1 species in South America), and Calusparassus into 3 subsections, Quadripartitae (8 species in South America, New Zealand, eastern Australia and Tasmania), Tripartitae (one species with two subspecies in New Zealand and Bipartitae, (about 18 species in New Guinea and New Caledonia). The New Caledonian species were formerly placed in Trisyngyne Baillon and assigned to the Euphorbiaceae.

Palynologists recognise a different set of infrageneric categories based on three distinct types of pollen morphology. Pollen of 'brassii' type is uniform throughout, and peculiar to, section Bipartitae. The other two pollen types ('fusca' type and 'menziesii' type) do not relate to any particular infrageneric taxon in van Steenis' scheme. (Cookson and Pike 1955; van Steenis 1971b; 1976).

In New Zealand 'brassii' type pollen fossils first appear in the late Cretaceous (Arawhanan to Teratan) Paparoa Beds (Couper 1960a; Mildenha11 1980) while 'fusca' type first appears in the Haumurian (Maastrichtian) and 'menziesii' type in the Paleocene (Muller 1981). Leaves assigned to Fagaceae are known from Late Cretaceous onwards (Fleming 1979).

There are sporadic reports of Nothofagus pollen in the northern hemisphere but these may well be due to wind blown pollen and should not be taken as indicating Nothofagus forests (van Steenis 1971a). Bandulska (1924) assigned the leaf fossil Dictylophyllum stopesae from the Eocene Bournemouth Beds of Southern England to Nothofagus on the basis of cuticular anatomy, but the record is unconfirmed. 
Leaves simple, microphyll to mesophy11, sometimes dimorphic with a distinct juvenile form; generally ovate, eliptic or oblong, margin toothed or entire; teeth simple or compound, frequently glandular; leaf base cuneate, obtuse, rounded or truncate, only rarely cordate (N. glauca), sometimes asymmetric but not usually strongly so; venation craspedodromous or semi-craspedodromous, secondaries generally regularly spaced, parallel to subparallel, straight or somewhat curved; tertiary veins diverging at right angles, orthogonal-reticulate or percurrent; highest vein order $5 \mathrm{th}$, higher order venation generally orthogonal; laminar glands and/or trichomes present in some species. 
Oliver (1936) recognised several species of fagaceous leaves from Kaikorai, Dunedin, and assigned them to the extant genera Fagus and Nothofagus and to a genus of extinct plants, Parafagus which he thought to be allied to Quercus. This division cannot be maintained as all the characters used by 0liver to distinguish the three genera are to be found in living Nothofagus species (van Steenis 197la; Holden 1982a). The leaves from Kaikorai described by Oliver as Ulmophyton pliocenicum also do not differ significantly from Nothofagus.

GLMO12 Nothofagus southlandica sp. nov.

Figs $3.1,3.2,3.3,3.4,3.5$

Plate 2.1

Leaves ovate to lanceolate, 30-60 mm long and 15-25 mm broad, apex obtuse to acute, base cuneate, somewhat oblique, margin serrate, teeth acute, straight-sided, two per secondary vein; venation pinnate, craspedodromous, simple; midrib weak to moderate, straight, becoming more or less sinuous above; secondaries straight, parallel, diverging at narrow to moderate angles, more or less regularly spaced 4-8 mm apart; tertiaries diverging at right angles, percurrent, straight or forked; higher order venation orthogonal, highest vein order $5^{\circ}$. Upper epidermis in non venous area more or less isodiametric, those over veins elongate; anticlinal walls straight; lower epidermal cells more or less isodiametric in non-venous areas, anticlinal cell walls straight; stomata on lower epidermis only (Fig 8.13) randomly orientated, in areolar areas, cyclocytic; trichomes present on lower epidermis, sparse, occurring singly, trichome basal cells radial, in several rows.

The gross morphology is consistent with a species of Nothofagus, but not with any living New Zealand species. The leaf shape, particularly the somewhat oblique leaf base, and gross venation resembles more closely some South American species, for example N. öbliqua (Mirb.) Oerst. and N. alpina (Popp \& End1.) Krasser, but the pattern of marginal teeth is not the same.

The structure of the lower epidermis (Fig 8.13) bears a striking resemblance to Bandulska's (1924) illustration of the living South American species N. betuloides confirming that the leaf is a species of Nothofagus. Due to the somewhat abraded nature of the silicifed surface of the Landslip Hill fossils (the only locality at which epidermal structures were preserved) 
it was not possible to accurately estimate stomatal or trichome frequency.

Holotype: V2841.13 and 13A (counterparts), Gore Lignite Measures Duntroonian to Waitakian Stages (Upper 01igocene to Lower Miocene), G45/f058, Landslip Hill, siliceous boulders exposed on hilltop at southern end of hill, G45 125530, A.M. Holden and P. Ve1la, 1981. Victoria University, Wellington.

Dimensions: Leaf $53 \mathrm{~mm}$ long and $21 \mathrm{~mm}$ broad.

Illustrated specimens: B149.6, G45/f8497, Landslip Hill, G45 125530, J. Hector, 1869; B150.5, G45/f8496, Landslip Hil1, G45 125530, J. Park, 1886: V2849.59A V2849.93, Nevis Formation, Oil Shale Member, Pareora Series, Lower Miocene, F42/f001, various localities along Shale Ridge, Nevis Valley, F42 955535 , A.M. Holden, P. Vella and C. Vella, 1981.

Other material examined: B149.6, G45/f8497, Landslip Hill G45 125530, J. Hector, 1869; B150.18, G45/f8496, Landslip Hil1, G45 125530, J. Park, 1886; V2841.16, V2841.39, V2841.91, G45/f058, Landslip Hil1 G45 125530 , A.M. Holden and P. Vella, 1981; V2843.10, V2843.11, V2843.13, V2843.14, V2843.15, V2843.16, Gore Lignite Measures, F46/f063, Tuturau F46 308887 , A.M. Holden and P. Vella, 1981.

KLB002 Nothofagus novae-zealandiae (Oliver) Holden Figs 3.6,3.7, 3.8,3.9

$$
\text { Plate 2.3; } \quad 3.10,3.11,3.12
$$

Nothofagus novae-zealandiae (Oliver) Holden 1982, 71, figs 2.1,2.2,2.5 Fagus novae-zealandiae Oliver 1936; 289, fig 4

Fagus maorica 01iver 1936:290, fig 5

Mesophy11, 30-115 mm 1ong, 14-15 mm broad; oblong to elliptic, somewhat narrow, apex acuminate to attenuate; base cuneate; margin serrate teeth fairly large, acute, straight-sided or with upper side concave, simple, mostly one per secondary vein, sinus rounded, spacing more or less uniform around complete margin; laminar glands present; petiole short, moderately stout; venation craspedodromous, simple; midrib weak to moderate, straight, secondaries at least 13 pairs, alternate, uniformly spaced ca. 4-7 mm apart, angle of divergence more or less uniform, narrow to moderate, $45-50^{\circ}$, straight to slightly curved, weak near apex otherwise moderate, tertiaries weak, percurrent, at right angles to secondaries; highest order venation 5 th; higher orders of venation orthogonal, areoles small, perfect, orientated. Upper epidermis (Fig 8.14) cells isodiametric, 

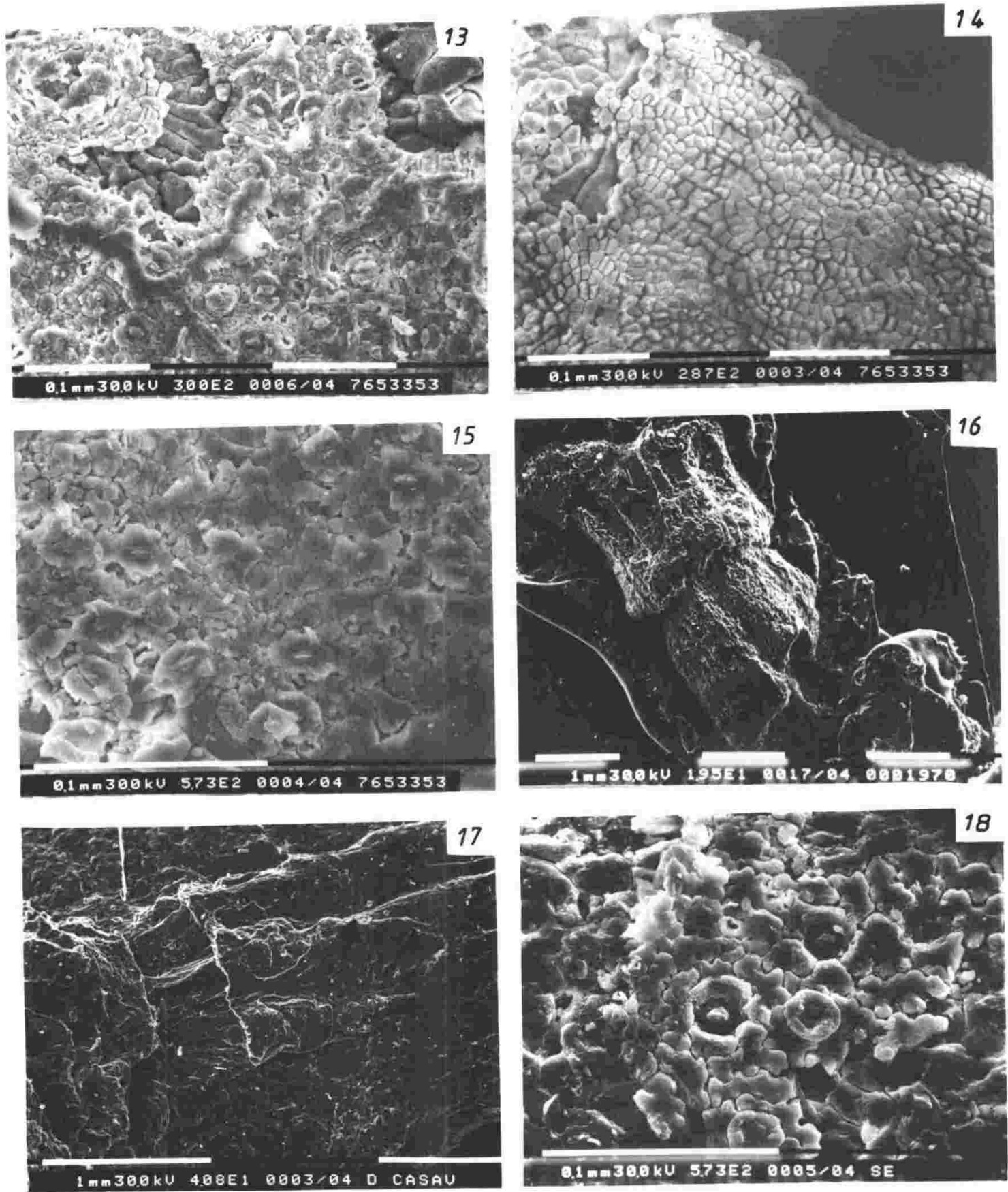

FIG, 8,13: Nothofagus southlandica; silicified lower epidermis I and mesophyll showing trichome base and stomata. FIG, 은 $\underline{\underline{N}}$ bidentatus; silicified upper epidermis.

FIG. 8. 15: silicified lower epidermis showing stomata.

FIG, 8, 16: Gymnostoma sp., silicone rubber cast of branchlet fragment, two internodes with leaf sheaths, free part of leaf blade missing.

FlG. 8.17: Casuarina avenacea; silicone rubber cast of base of cone, stomatal groove arrowed.

FIG, 을 Dicotyledones incertae sedis species $E_{;}$silicified lower epidermis. 
to more or less elongate, quadrangular to hexagonal, anticlinal walls straight, cells over veins elongate; lower epidermis (Fig 8.15) - cells ?isodiametric, anticlinal walls somewhat undulate; stomata on lower epidermis only, in areolar areas, ?cyclocytic, details somewhat obscure.

In addition to the Longford and Kaikorai localities given by Holden (1982a) leaves of this species have also been found at Landslip Hill (Southland) and Tuturau (Southland) and Bannockburn (Central Otago). The Landslip Hill fossils are smaller on average than those from the remaining localities, but otherwise do not differ significantly. This may reflect local edaphic or climatic conditions or it could represent the difference between sun leaves and shade leaves or adult and juvenile foliage. Such size differences do occur in modern Nothofagus notably in N. moorei ('menziesii' group) and N. baumanii and N. codonandra ('brassii' group). Depositional sorting can result in over-representation of the smaller sun leaves in sites distant from the source (Spicer 1980). Fossils from Great Barrier Island tentatively assigned to $\mathrm{N}$. novae-zealandiae by Thompson (1960) are better placed in N. bidentatus Holden (see below).

Holotype: WELT 44482, Kaikorai Leaf Beds Waiauan Stage (Mid Miocene), Fraser's Gully, Kaikorai Valley, I44 135797, W.R.B. Oliver 1929; National Museum, Wellington.

Dimensions: Leaf $71 \mathrm{~mm}$ long and $34 \mathrm{~mm}$ broad.

Illustrated specimens: V2841.21, V2841.38, Gore Lignite Measures, Duntroonian to Waitakian Stages, G45/f058, Landslip Hill, siliceous boulders at southern end of hilltop, $200 \mathrm{~m}$ from plantation boundary, G45 125530, A.M. Holden and P. Vella 1981; VH 93, Longford Formation, Waiauan to Tongaporutuan Stages, Mid to Upper Miocene, M29/f154, Dress Circle, Longford, M29 579347, A.M. Holden and J.D. Collen 1979; V2830.1, M29/f153, bluffs at mouth of Nuggety Creek, true left bank of Buller River, M29 604410 . A.M. Holden and J.D. Collen, 1979; B2.26, M29/6579, Nuggety Creek, M29 604410, R.P. Suggate, D. Kear, E.T. Annear and W.A. Sara 1951; B7.64, M29/f8606, Dress Circle, Longford, M29 579347, S.M. Bell and R.P. Suggate 1949.

Other material examined: WELT 44483, WELT 44484, WELT 44486, WELT 44487, WELT 44488, WELT 44492, WELT 44494, from the type 1ocality; V2840.1, Gore Lignite Measures, G45/f064, Landslip Hill, G45 125530, J. Thornton; V2841.4, V2841.6, V2841.68, V2841.75, G45/f058, Landslip Hill, G45 125530, A.M. Holden and P. Vella 1981; B129.1, G45/f8499, Landslip Hill, G45 125530, J. Hector; В38.3, В38.4, В38.37, В38.56, В38.93, В38.97, В38.98, В38.99, В38.100, 
B38.102, Frog Flat Formation, Waiauan to Tongaporutuan Stages, Mid to Upper Miocene, M30/f8303, Maruia Saddle road, R.P. Suggate, D. Kear, J.C. Schofield and E.T. Annear 1949; V2843.2, Gore Lignite Measures, F46/f063, Tuturau, F46 308887, A.M. Holden and P. Vella 1981; V2850.10, Central Otago Lignite Measures, Manuherikia Group, Pareora to Southland Series, Lower to Mid Miocene, F41/f209, Bannockburn, F41 088624, A.M. Holden, P. Vella and C. Vella 1981; V2851.6, Manuherikia Group, F41/f210, Bannockburn, F41 086628, A.M. Holden, P. Vella and C. Vella 1981. Stratigraphic range: Upper Oligocene to Upper Miocene.

LDF003 Nothofagus bidentatus Holden

Nothofagus bidentatus Holden 1982: 72, figs 2.3,2.4,2.6,2.8,2.9,4.2, 4.3 Nothofagus novae-zealandiae Thompson 1960

Mesophy11, 50-150 mm long and 20-55 mm broad, symmetrical, oblong to lanceolate, somewhat narrow, apex acuminate to attenuate; base cuneate; margin serrate, more or less undulate, teeth acute to obtuse, straightsided, simple, generally two per secondary vein, sinus rounded, spacing uniform around entire margin; laminar glands present; petiole short, stout; venation craspedodromous, simple or semicraspedodromous, often mixed in the same leaf; midrib weak to moderate, straight; secondaries alternate, more or less uniformly spaced, 4-9 mm apart, diverging at moderate angles, straight or somewhat curved, joining superjacent at more or less right angles branch running to second tooth; tertiaries orthogonal reticulate or percurrent forked, crossing at right angles between secondaries, oblique to midrib, predominantly alternate; highest order venation orthogonal, areoles well-developed, oriented, small.

Fossils assigned to this species are known from Longford (Holden 1982a), Kaikorai, Nevis and Great Barrier Island. The Great Barrier fossils, although tentatively assigned to Nothofagus novae-zealandiae by Thompson (1960) are included in this species because of the two teeth per secondary vein and the frequently semicraspedodromous venation.

Holotype: B2.54, Longford Formation, Waiauan to Tongaporutuan Stages (Mid to Upper Miocene) M29/f6579, Nuggety Creek, M29 604410, R.P. Suggate, D. Kear, E.T. Annear and W. Sara, 1951; N.Z. Geological Survey. Dimensions: $83 \mathrm{~mm}$ long and $39 \mathrm{~mm}$ broad. 
Illustrated specimens: VH96, Longford Formation, M29/f154, Dress Circle, Longford, M29 579347, A.M. Holden and J.D. Collen, 1979; B7.14, M29/f8606, Dress Circle Longford, M29 579347, S.M. Bel1 and R.P. Suggate, 1949; B411.4, B411.7, Beeson's Island Volcanics, Taranaki to Wanganui Series, Upper Miocene to Lower Pliacene, Great Barrier Island, 200 yards from road north from Okupu, 200 yards above road near where road crosses fence on exposed spur, 80 chain at $50^{\circ}$ from Trig Whangapara, K. B1ack, 1952; V2849.32, V2849.66, V2849.82, Nevis Formation, Oil Shale Member, Pareora Series, Lower Miocene, F42/f001, Shale Ridge, Nevis Valley, F42 955535, A.M. Holden, P. Vella and C. Vella, 1981.

Other material examined: B2.19, B2.20, B2.23, B2.37, B2.45, M29/f6579, Nuggety Creek, M29 604410, R.P. Suggate, D. Kear, E.T. Annear and W. Sara, 1951; B7.12, B7.13, B7.15, B7.20, B7.25, B7.31, B7.42, B7.52, B7.54, B7.55, B7.59, B7.63, M29/f8606, Dress Circle, Longford, M29 579347, S.M. Be11 and R.P. Suggate, 1949; B38.1, B38.46, B38.93, B38.102, B38.106, Frog Flat Formation, Waiauan to Tongaporutuan Stages, M30/f8503, various localities on the Maruia Saddle road, R.P. Suggate, D. Kear, J.C. Schofield and E.T. Annear, 1949; B411.10, Great Barrier Island, K. Black 1952.

Stratigraphic range: Lower Miocene to Lower Pliocene.

KLB003 Nothofagus pinnata (O1iver) comb. nov. Figs 4.9,4.10,4.11. Parafagus pinnata Oliver 1936; 293, fig 9

Parafagus otakouia 01iver 1936; 292, fig 8

Parafagus angustifolia 01iver 1936; 293, fig 10.

Microphy11 to small mesophy11, leaves ca. 55-80 mm long and 18-32 mm broad, ovate to lanceolate; apices all damaged but probably acute to acuminate; base obtuse to subrounded; margin serrate, teeth simple, acute, straight sided, rather large, spacing and size somewhat uneven, sinus subangular to rounded: oetiole_short. moderately stout; venation pinnate, craspedodromous, simple; midrib moderate, straight, secondaries diverging at moderate angles, $50-60^{\circ}$, angle more or less constant or decreasing distally, curved, branched; tertiaries diverging at acute angles from lower, and obtuse angles from upper side of secondaries, percurrent, forked, convex or retroflexed, oblique to midrib; highest order venation $5^{\circ}$; higher order venation random, areoles polygonal, rather small. 
The leaves are similar to those of Nothofagus bidentatus but differ in respect of the obtuse or rounded leaf base and the coarser, less regular teeth. Oliver originally described three closely similar species of Parafagus (see synonymy) but the differences between them are insignificant. The species is known so far only from the type locality. It may perhaps represent a juvenile leaf form.

Holotype: WELT 44519, Kaikorai Leaf Beds, ?Waiauan Stage (Mid to Upper Miocene), Fraser's Gully, Kaikorai Valley, I44 135797, W.R.B. Oliver, 1929; National Museum, Wellington.

Dimensions: $56 \mathrm{~mm}$ Long and $30 \mathrm{~mm}$ broad; petiole $4 \mathrm{~mm}$.

Illustrated specimens: WELT 44484, WELT 44532, from the type locality. Other material examined: WELT 44520, WELT 44521, WELT 44522, WELT 44523, WELT 44524, WELT 44525, WELT 44526, WELT 44529, WELT 44531, WELT 44533, WELT 44534, WELT 44535, WELT 44536, WELT 44537, WELT 44539, WELT 44540, WELT 44541, all from the type locality.

Stratigraphic range: Mid Miocene.

LDF004 Nothofagus oblonga Holden Figs $5.1,5.2,5.3,5.4$. Plate 3.2 Nothofagus oblonga Holden 1982: 72, figs 3.3,3.6,3.7,4.1

Microphy11 to smal1 mesophy11, 60-100 mm long by 20-30 mm broad; oblong to eliptic, narrow; apex obtuse; base cuneate; margin entire, revolute; petiole not preserved; venation pinnate, semicraspedodromous; midrib stout, straight; secondaries alternate, regularly spaced, 7-9 mm apart, diverging at moderate to wide angles, curved; tertiaries orthogonal reticulate to percurrent forked, crossing at right angles, oblique to midrib. Higher order venation orthogonal, highest order venation $5^{\circ}$; areoles small, well-formed, quadrangular, oriented.

The leaf resembles in margin and in shape the New Caledonian species

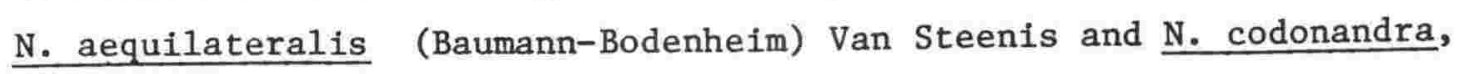
(Baillon) Van Steenis, particularly the former.

Holotype: B7 56, Longford Formation, Waiauan to Tongaporutuan Stages (Mid to Upper Miocene ), M29/f8606, Dress Circle, Longford, M29 579347, S.M. Bell and R.P. Suggate 1949. N.Z. Geological Survey, Lower Hutt. Dimensions: $61 \mathrm{~mm}$ long and $21 \mathrm{~mm}$ broad.

Illustrated specimens: B38.14, Frog Flat Formation, Waiauan to Tongaporutuan Stages, M30/f8503, various localities on the Maruia Saddle road, R.P. Suggate, D. Kear, J.C. Schofield and E.T. Annear 1949; B7.15, 
B7.28, from the type locality.

Other material examined: B7.6, B7.34, B7.64 from the type 1ocality; B38.6, B38.41, B38.89, B38.90, B38.91, M30.f8503, various localities on the Maruia Saddle road, R.P. Suggate, D. Kear, J.C. Schofield and E.T. Annear, 1949 .

Stratigraphic range: Mid-Upper Miocene

LDF005 Nothofagus oliveri Holden Figs 5.5,5.6,5.7,5.8. Plate 3.1 Nothofagus oliveri Holden 1982: 72, figs 3.1,3.2,3.5

Mesophy11, 100-170 mm 1ong by ca. $60 \mathrm{~mm}$ broad, more or less narrow oblong; apex obtuse to acute; base probably cuneate; margin serrate, often strongly recurved and teeth obscure; teeth obtuse, simple, 2-3 per secondary vein, more or less evenly spaced around entire margin; sinus rounded; laminar glands present; venation pinnate, craspedodromous or semi-craspedodromous, midrib moderate, straight; secondaries alternate, regularly spaced 7-11 mm apart diverging at moderate to wide angles, $50-65^{\circ}$, more or less uniformly curved, joining superjacent at right angles, branch to second tooth; tertiaries orthogonal reticulate to percurrent forked, oblique to midrib, crossing at right angles between secondaries, predominantly alternate, close set; higher order venation orthogonal, rather thick, highest order venation 5th; areoles rather small, well developed, oriented, quadrangular.

The fossil leaves have the characteristics of Nothofagus. The strongly recurved margins of some specimens suggests the presence of both adult and juvenile leaves. While distinct juvenile leaf forms are not a marked feature of Recent New Zealand species, they are found in N. moorei (F. Muel1.) Krasser from Australia, which the fossil species resembles, although it is much larger, and in various New Caledonian species. In the case of $\mathrm{N}$. baumanniae (Baumann-Bodenheim) Van Steenis the margins of juvenile leaves are regularly and strongly toothed, while adults have recurved, more or less entire margins. Although fairly common, this species is less abundant than $\mathrm{N}$. bidentatus.

Holotype: B2 49, Longford Formation, Waiauan to Tongaporatuan Stages (Mid to Upper Miocene), M29/f6579, Nuggety Creek, M29 604410, R.P. Suggate, D. Kear, E.T. Annear and W.A. Sara; N.Z. Geologica1 Survey.

Dimensions: $111 \mathrm{~mm}$ long and $50 \mathrm{~mm}$ broad.

Illustrated specimens: B2.23, B2.59, from the type locality. VH 99 , M29/f154, Dress Circle, Longford, M29 579347, A.M. Holden and J.D. Collen, 1979. 
Other material examined: B7.69, M29/f8606, Dress Circle, Longford, M29 579347, S.M. Be11 and R.P. Suggate, 1949; V2825.24, V2825.29, M29/f154, Dress Circle, Longford M29 579347, A.M. Holden and J.D. Collen 1979; B38.48, B38.67, B38.105, Frog Flat Formation, Waiauan to Tongaporutuan Stages, M30/f8303, Maruia Saddle road, R.P. Suggate, D. Kear, J.C. Schofield and E.T. Annear, 1949; B256.10 Longford Formation, M29/f8683, Murchison-Nelson road, north end of Longford Bridge, M29 572353, H.W. We11man 1951.

Stratigraphic range: Mid-Upper Miocene.

KLB00 4 Nothofagus australis (01iver) comb. nov. Figs $6.1,6.2,6.3,6.4,6.5$ Plate $3.3: \quad 6.6,6.7,6.8,6.11$

Fagus australis 01iver 1936: 291, fig 6.

Fagus maorica pro parte 01iver 1936: 290, fig 5a.

Leaf ovate to broadly ovate, 45-70 $\mathrm{mm}$ long and 25-55 mm broad, apex acuminate-attenuate; base obtuse to subrounded, somewhat oblique, margin serrate, teeth acute, straight sided, one per secondary vein, simple or with one accessory denticle, especially towards leaf base, sinus rounded, spacing somewhat irregular; petiole slender; venation craspedodromous, simple; midrib moderate, straight or flexuous; secondary veins alternate distally, opposite or subopposite near base, diverging at moderate angles, generally straight, basal few pairs somewhat recurved, subparalle1; tertiaries percurrent, forked, crossing at right angles between secondaries, opposite or opposite and alternate; 4 th order venation orthogonal, 5 th random; areoles medium to sma11, oriented, pentagonal to polygonal.

Fossils agreeing with $\underline{N}$. australis are known from Kaikorai and Taiaroa Head (Dunedin), Nevis and Bannockburn (Central Otago) and Great Barrier Is land.

Holotype: WELT 44498, Kaikorai Leaf Beds, ?Waiauan Stage (Mid to Upper Miocene), Fraser's Gully, Kaikorai Valley, I44 135797, W.R.B. Oliver 1929; National Museum, Wellington.

Dimensions: $50 \mathrm{~mm}$ long and $32 \mathrm{~mm}$ broad.

Illustrated specimens: WELT 44487, from the type locality; B411.2, Beeson's Island Volcanics, Taranaki to Wanganui Series, Upper Miocene to P1iocene, Great Barrier Island, 200 yards from road north from Okupu, 200 yards above road near where road crosses fence on exposed spur, 80 chain at $50^{\circ}$ from Trig Whangapara, K. Black 1952; V2850.29, V2850.40, Central Otago Lignite Measures, Manuherikia Group, Pareora to Southland series, Lower to Mid Miocene, F41/f209, new road cut $200 \mathrm{~m}$ north of new 
bridge across Bannockburn, F41 088622, A.M. Holden, P. Vella and C. Ve11a 1981; V2851.16, Manuherikia Group, F41/f210, true right bank of Kawerau River, $100 \mathrm{~m}$ from mouth of Bannockburn, bluffs below road, F41 086628, A.M. Holden, P. Ve1la and C. Vella 1981; V2849.20, Nevis Formation, Oil Shale Member, Pareora Series, Lower Miocene, F42/f001, various localities along Shale Ridge, Nevis Valley, F42 955535, A.M. Holden, P. Vella and C. Vella 1981; V2846.46, Kaikorai Leaf Beds, J44/f002, Taiaroa Head, J44 333898, A.M. Ho1den and P. Vella 1981. Other material examined: WELT 44485, WELT 44491, WELT 44496, WELT 44497, WELT 44501, WELT 44502, WELT 44503, NELT 44505, WELT 44506, WELT 44507, WELT 44508, from the type locality. V2846.1, V2846.6, V2846.8, V2846.17, V2846.38, V2846.42, V2846.44, V2846.46, J44/f002 Taiaroa Head. J.44 333898, collected by A.M. Holden and P. Vella 1981.

Stratigraphic range: ?Lower Miocene to Lower Pliocene.

KLB005 Nothofagus kaikoraiensis 01iver. Figs $6.9,6.10,6.12,6.13,6.14$ Nothofagus kaikoraiensis 01iver 1936: 291, fig 7 Ulmophyton pliocenicum 01iver 1936: 294, fig 11.

Leaves microphyl1 to small mesophy11, 40-70 mm long and 20-40 mm broad; ovate to broadly ovate, apex acuminate-attenuate; base obtuse, somewhat oblique, margin serrate, teeth compound, one per secondary vein, each with several accessory denticles; denticles acute, straight-sided, sinus acute to sub-rounded; venation craspedodromous, simple; midrib moderate, straight or more or less flexuose, particularly distally; secondaries alternate, straight or somewhat curved, some branched, lowermost pair recurved and bearing several strong branches on the basal side; tertiary veins diverging at acute to right angles, percurrent, forked or convex, oblique to midrib; higher order venation orthogonal, areoles somewhat irregular, small.

Fossils of this species are known so far only from Kaikorai and Taiaroa Head, Dunedin. The characters displayed by $\mathrm{N}$. kaikoraiensis 0liver overlap with those of Ulmophyton pliocenicum 0liver and the two are here treated as conspecific. The latter was distinguished on the basis of the strong branches from the basal side of the lowest pair of secondaries. This is occasionally seen in leaves of some species of Nothofagus, particularly some South American species. Oliver suggested an affinity with Ulmus (U1maceae) for U1mophyton, but pollen of U1mus is not known from New Zealand sediments older than Recent (Mildenhall 1980). 
Holotype: WELT 44509, Kaikorai Leaf Beds, Waiauan Stage (Mid-Miocene) Fraser's Gully, Kaikorai Valley, I44 135797, W.R.B. Oliver, 1929;

National Museum, Wellington.

Dimensions: $55 \mathrm{~mm}$ long and $30 \mathrm{~mm}$ broad.

Illustrated specimens: WELT 44545, WELT 44545A, from the type locality; V2846.25, V2846.28, Kaikorai Leaf Beds, J44/f002, Taiaroa Head, Dunedin, J44 333898, A.M. Holden and P. Vella, 1981.

Other material examined: WELT 44500, WELT 44510, WELT 44511, WELT 44513, WELT 44514, WELT 44515, WELT 44517, WELT 44518, from the type locality; $\mathrm{V} 2846.3, \mathrm{~V} 2846.10, \mathrm{~V} 2846.11, \mathrm{~V} 2846.14, \mathrm{~V} 2846.15, \mathrm{~V} 2846.18, \mathrm{~V} 2846.19$, $\mathrm{V} 2846.20, \mathrm{~V} 2846.21, \mathrm{~V} 2846.23, \mathrm{~V} 2846.24, \mathrm{~V} 2846.27, \mathrm{~V} 2846.29, \mathrm{~V} 2846.30$, V2846.37, V2846.39, V2846.40, V2846.46, V2846.49, locality J44/f002, Taiaroa Head, Dunedin, J44 333898, collected by A.M. Holden and P. Ve1la 1981.

Stratigraphic range: Mid to Upper Miocene.

\section{CASUARINACEAE}

Trees, photosynthetic organs the smaller branchlets; leaves in whorls, reduced to toothed sheaths fused with the stem over most of their length; male inflorescences catkin-like, simple or branched; female flowers in compact heads, maturing to woody cones.

Casuarinaceae is a small, isolated family of xeromorphic trees, mainly austral. It has been treated as monogeneric and divided informally into two divisions, Gymnostomae and Cryptostomae (Poisson 1874). The characters of the two divisions were reviewed by Flores (1977). Johnson (1980) elevated the division Gymnostomae to generic rank, and recognition of several genera within the Cryptostomae is under consideration (L.A.S. Johnson, pers. comm.).

Pollen grains of casuarinacean affinity (Haloragacidites trioratus Couper 1953 syn. Triorites harrissii Couper 1953) have been reported from sediments varying in age from Teurian (Paleocene) to Waitotaran (Late P1iocene) (Mildenhall and Harris 1971) and are often abundant. Sporadic pollen grains of Casuarinaceae in Quaternary and Recent sediments are considered to have been blown across the Tasman Sea from Australia (Mildenhall 1976; 1980; Close et al. 1978). The earliest reported occurrence of fossil casuarinacean pollen is from the Lower Paleocene 
of New Zealand (Muller 1981). Ettingshausen (1887) described vegetative fragments from Upper Cretaceous strata at Pakawau and Grey River (Casuarinites cretaceus) and Shag Point (Casuarina deleta). The material has since been lost (D.C. Mildenhall, pers. comm.) and as Ettingshausen's illustrations are unconvincing, and the rocks concerned are older than the earliest recorded occurrence of Casuarinacean pollen, the status of these taxa is in doubt.

Gymnostoma L.A.S. Johnson

Branchlets 4-angled, sometimes obscurely so, generally glabrous; leaves fused into sheaths, in whorls of 4 , stomata in bands along leaf edges with 0-1 subsidiary cells between rows of guard cells, epidermal cells hexagonal; male inflorescences branched, female flowers in compact heads, generally in whorls of 4; cone valves (bracteoles) strongly exserted.

Type species: Gymnostoma nodiflora (Thunb.) L.A.S. Johnson

The species now included in Gymnostoma were regarded by Barlow (1959) as the most primitive Casuarnaceas. They are now more or less confined to the tropics. Megafossil studies show that it was formerly more widespread. A11 early Tertiary casuarinacean megafossils so far discovered in Australia are species of Gymnostoma, Eryptostomae not appearing until the Miocene (Christophel 1980). The genus is represented in Australia today by a single species confined to Northern Queensland (L.A.S. Johnson, pers comm.). The only casuarinacean megafossil so far known from South America, from the Miocene of Patagonia (Frenguelli 1943), although originally compared to Cryptostomae is now thought to be a species of Gymnostoma (Christophe1 1980).

It was formerly thought, in view of the present distribution of Gymnostoma, that the Casuarinaceae originated in the Old World Tropics: Eocene Gymnostoma species (e.g. that from Anglesea, Victoria) grew at a time when Australia was at high latitudes adjacent to Antarctica, although this does not mean that Eocene climates in Australia were particularly cold. Marine microfossil assemblages indicate that temperatures at the time were rather warm even at high latitudes (Kennett 1978). Warm water foraminifera (Hornibrook 1971) and the presence of a limited assemblage of reef corals in Northland (Squires 1962a; 1962b; Hayward 1977) indicate that New Zealand 
late 01igocene and early and mid Miocene climates were warmer than today, but probably subtropical at best. The evidence from plant megafossils suggests that the Casuarinaceae had an early existence in the temperate regions of the fragmenting continents of Gondwanaland and from there spread into the tropics.

The history of Gymnostoma parallels that of the 'brassii' beeches (Nothofagus). In both, a wide geographical range during the Tertiary has been reduced, presumably by climatic changes, and living representatives are now confined to the tropics.

GLM013 Gymnostoma stellata Campbel1 and Holden Figs 7.1,7.2,7.3. Plate 4 Gymnostoma stellata Campbell and Holden (in prep.) figs 2, 3, 4, 5, 6.

Female inflorescences compact, immature cone ca. $6 \mathrm{~mm}$ diameter and $6 \mathrm{~mm}$ long, florets in whorls of 4 , each floret subtended by an ovate to triangular, acuminate bract $3 \mathrm{~mm}$ long and $3.5 \mathrm{~mm}$ broad, tips of bracts spreading; bracteoles of immature cone 2, lateral, inconspicuous. Mature cones ca. $20 \mathrm{~mm}$ long by $15 \mathrm{~mm}$ diameter, short, cylindrical; bracts inconspicuous, bracteoles enlarged into two triangular, strongly exserted valves enclosing fruits; 5-6 whorls of valves per cone, uppermost and lowermost whorls sterile, line of dehiscence colinear in alternate whorls.

A number of fragments of rather stout, obscurely 4-angled branchlets with shallow, open intercostal furrows (Fig 8.16) and leaves in whorls of four are associated with the cones but organic connection cannot be demonstrated in the available material.

The characteristics of the fossils are consistent with Gymnostoma and the cones resemble those of G. papuanum (S. Moore) L.A.S. Johnson. They also resemble casuarinacean fossils from Anglesea, Victoria (Christophel 1980).

Holotype: V2840.4, Gore Lignite Measures, Duntroonian-Waitakian Stages (Upper 01igocene to Lower Miocene), G45/f064, Landslip Hill, G45 125530 , J. Thornton; Victoria University, Wellington. Dimensions: Part of cone $16 \mathrm{~mm}$ long and $18 \mathrm{~mm}$ diameter.

Illustrated specimens: V2841.63, G45/f058, Landslip Hill, siliceous boulders on southern end of hilltop, $200 \mathrm{~m}$ from plantation boundary, F45 125530 , A.M. Holden and P. Vella 1981. 
Other material examined: V2840.3, G45/f064. from the type locality, J. Thornton; V2841.1, V2841.6, V2841.8, V2841.8A, V2841.37, V2841.91, G45/f058, Landslip Hill, G45 125530 A.M. Holden and P. Vella 1981; V2842.1A, V2842.3, V2842.4, V2842.5, V2842.10, V2842.10A, V2842.13, G45/f063, Landslip Hill, fallen boulders at foot of slip face, G45 12.4533, A.M. Holden and P. Vella, 1981.

Stratigraphic range: Upper Oligocene to Lower Miocene.

GLM014 Gymnostoma crassa sp. nov.

Figs $7.4,7.5$ Plate 6.1

Mature female cones ca. $20 \mathrm{~mm}$ long and $15 \mathrm{~mm}$ diameter, cylindrical; bracteoles in whorls of 4, large, triangular, strongly exserted; bracts oblong-acuminate, sessile, furrowed, swollen so that the bracteoles are partially immersed; ca. 6 whorls of bracteoles per cone, uppermost and lowermost whorls abortive, line of dehiscence colinear in alternate whorls.

The cones are consistent with Gymnostoma. They are distinguished from G. stellata from the same locality by the swollen bracts and partially immersed valves.

Holotype: B148.1026, Gore Lignite Measures, Duntroonian to Waitakian Stages (Upper 0ligocene to Lower Miocene), G45/f8498, Landslip Hill, G45 125530 , ?J. Hector; N.Z. Geological Survey, Lower Hutt, duplicate cast held at Victoria University.

Dimensions: Diameter $12 \mathrm{~mm}$.

I1lustrated specimen: V2840.8, G45/f064, Landslip Hill, F45 125530, J. Thornton.

Other material examined: B148.3, G45/f8498, from the type locality, collected by ?J. Hector.

\section{Casuarina}

Trees or shrubs, branchlets terete, occasionally 4-angled, generally pubescent but hairs sometimes confined to intercostal grooves; leaves fused into sheaths in whorls of 4 or usually more; stomata in bands along edges of leaves, enclosed in deep intercostal grooves, epidermal cells rectangular; mature cones cylindrical or globose, florets in whorls, usually of more than four florets per whorl; valves not or only moderately exserted; fruit samaroid. 
OLM001 Casuarina avenacea Campbe11 and Holden

Figs 7.6,7.7,7.8. Plate 5 Casuarina avenacea Campbel1 and Holden (in prep.) figs 7, 8, 9, 10, 11, 12, 13, 14.

Assimilatory branchlets slender, apparently grooved (fig 8.17); leaves in whorls of 4, free portions triangular; cones in clusters on large branchlets, small, cylindrical, 12-16 mm long and 5-6 mm diameter; bracts obscure, bracteoles rounded, only moderately exserted, probably 4-5 valves per whorl; cones of 5-6 whorls, line of dehiscence colinear in alternate whorls. Owing to the extreme compression of the fossils the number of valves per whorl cannot be fixed beyond doubt.

The cones do not resemble those of Gymnostoma stellata or G. crassa from Landslip Hill, nor do they closely resemble the Australian Eocene fossils described by Christophel (1980). The number of valves and the degree of exsertion is closer to cones from the Yallourn brown coals of Victoria described by Pike (1953). The presence of four leaves per sheath in the vegetative material does not necessarily imply a placing within Gymnostoma as a number of Cryptostomae have four leaves to a whorl, including $\mathrm{C}$. torulosa Ait. and C. descaisneana F. Muell..

Holotype: OU11961, Central Otago Lignite Measures, Manuherikia Group, Pareora to Southland Series, Lower to Mid Miocene, Locality F41/f205, quarryman's road, northermost of several excavations for sand, $100 \mathrm{~m}$ W of Cairnmuir Road, Bannockburn, Central Otago, F41 085623, R.C. Cains, J.D. Campbel1 and D. Craw 1981; Otago University.

Illustrated specimens: V2850.43, Central Otago Lignite Measures, Manuherikia Group, Pareora to Southland Series, Lower to Mid Miocene, F41/f209, new road cut $200 \mathrm{~m}$ north of new bridge across Bannockburn, F41 088622, A.M. Holden, P. Vella and C. Vella 1981; V2851.8, V2851.14A Manuherikia Group, F41/f210, true right bank of Kawerau River $100 \mathrm{~m}$ from mouth of Bannockburn, bluffs below road, F41 086628, A.M. Holden, P. Vella and C. Vella 1981.

Other material examined: V2850.7,.7A, F41/f209, Bannockburn, F42 088622 , A.M. Holden, P. Ve1la and C. Vella, 1981; V2851.10,F41/f210, Bannockburn F41 086628, A.M. Holden, P. Vella and C. Vella 1981.

Stratigraphic range: Lower - Mid Miocene. 
FFF001 Casuarina sp.

Winged fruit $7 \mathrm{~mm}$ long by $2 \mathrm{~mm}$ broad, achene ovoid, ca. $1.5 \mathrm{~mm}$ diameter; wing obovate, apparently hyaline, with a strong central midrib, apex damaged.

The fossil is consistent with a single fruit of a species of Casuarinaceae. Possible vegetative material has also been found but the fossils are too poorly preserved to be determinable.

Holotype: B38.27, Frog Flat Formation, Waiauan to Tongaporutuan Stages, Mid to Upper Miocene, M30/f8303, various localities on the Maruia Saddle road, R.P. Suggate, D. Kear, J.C. Schofield and E.T. Annear, 1949; N.Z. Geological Survey.

Dimensions: $7 \mathrm{~mm}$ long by $2 \mathrm{~mm}$ wide.

Stratigraphic range: Mid to Upper Miocene.

OTHER DESCRIBED TAXA

FILICOPSIDA - FILICALES

OSMUNDACEAE

FFF002 Leptopteris hymenophylloides (A. Rich) Presl. Figs 8.1,8.2,8.3,8.4 Frond at least 2-pinnate, pinnae probably oblong or linear, ca. 2-2.5 cm wide; pinnules diverging at moderate to wide angles from slender rachis, oblong, ca. 10-15 mm long by 4-6 mm broad, apex acute to attenuate, base broad, attached by entire width, pinnatifid, segments acute, more or less triangular, rather narrow; nerves free, simple or forked, one passing to apex of each segment.

The fragments appear to be conspecific with the living New Zealand species Leptopteris hymenophylloides.

Hypotype: B38.98, Frog Flat Formation, Waiauan to Tongaporatuan Stages Mid to Upper Miocene; M30/f8503, "various localities on the Maruia Saddle road", R.P. Suggate, D. Kear, J.C. Schofield and E.T. Annear, 1949;

N.Z. Geological Survey.

Dimensions: $35 \mathrm{~mm}$ long by $26 \mathrm{~mm}$ broad. 
Illustrated specimen: $\quad B 38.42$ from the same locality

Stratigraphic range: Mid Miocene to Recent.

Other material examined: В38.12, В38.16, В38.38, В38.46, В38.93, B38.96 from the same locality.

GLEI CHENIACEAE

GLM015 Gleichenia southlandica sp. nov. Fig 8.5, 8.6, Plate 6.2 Portions of fern frond, pinnae large, at least 70-120 mm long by 40-80 mm broad, probably oblong; axis stout, rounded, smooth, 2-3 mm diameter, secondary pinnae linear, at least $45 \mathrm{~mm}$ long, 4-5 mm broad, opposite to alternate, diverging at right angles from rachis, spaced $2-4.5 \mathrm{~mm}$ apart; axis of secondary pinnae stout, rounded; pinnules short, oblong to semi-orbicular, cucullate, apex rounded, base broad, pinnule attached by entire width of base, bases contiguous but not confluent, midrib of pinnule stout, impressed, veinlets not preserved.

The fossil is a species of subgenus Glelchenia, and differs from the living New Zealand representatives in that the pinnules are not oblong-triangular as in $\underline{G}$. microphylla, and are larger, not as strongly cucullate and not reflexed as is common in G. circinata (G. dicarpa). It is more like the Mesozoic species G. gleichenoides of Autralia and India (Gould 1974).

Holotype: C76.469.6, Gore Lignite Measures, Duntroonian to Waitakian stages, Upper Oligocene to Lower Miocene; Landslip Hill, Pukerau, collector unknown: Southland Museum.

Dimensions of Holotype; $127 \mathrm{~mm}$ long and $93 \mathrm{~mm}$ broad. Stratigraphic range: Upper Oligocene to Lower Miocene.

CYATHEACEAE

FFF003 Alsophila sp. af. tricolor (Co1.) Tryon F1g 9.1, 9.2, $9.3,9.4$.

Fragments of pinnately compound fronds; pinnae oblong or lanceolate; secondary rachis straight or curved; pinnules set at wide angles to rachis, $8-25 \mathrm{~mm}$ long by $3-6 \mathrm{~mm}$ broad, oblong, apices acute, bases more or less confluent, margins obscurely toothed or entire, often both at different parts of the same frond; venation of pinnule pinnate, central vein strong, veinlets occasionally simple, usually forked once or twice, 
free, somewhat recurved.

The fragments resemble in form and venation pinnae of the living New Zealand tree fern Alsophila tricolor, the pinnules in which vary in form depending on their position in the leaf. A similar venation pattern is found in Pteridium aquilinum (L) Kuhn, but the fossil fragments resemble neither the living New Zealand nor the living New Caledonian forms.

Hypotype: B412, Beeson's Island Volcanics, Taranaki to Wanganui Series, Upper Miocene to Pliocene, Great Barrier Island, NW bank of stream in E. edge of bush on Medland's Farm, Tryphena, 130 chain at $90^{\circ}$ from Trig A., K. Black 1952. N.Z. Geological Survey. Dimensions of Hypotype: $88 \mathrm{~mm}$ long and $105 \mathrm{~mm}$ wide.

Illustrated specimens: B36.13. Frog Flat Formation, Waiauan to Tongaporutuan Stages, Mid to Upper Miocene; M30/f8501, "20 chains south of Maruia Saddle", M30 514078, R.P. Suggate et al. 1949; V2852.9A, Central Otago Lignite Measures, Manuherikia Group, Pareora to Southland Series, (Lower to Mid Miocene), F41/f213, mouth of Bannockburn Stream, clay bed associated with lignite seams, bluffs below road. F41 086627, A.M. Holden and P. Vella 1981.

Other material examined: V2852.5, V2852.6, V2852.7, V2852.8, Manuherikia Group, F41/f213, Bannockburn, F42 086627. A.M. Holden and P. Vella 1981; B197.3, B197.11, B197.45, B197.56, Bannockburn, A. McKay 1882.

Stratigraphic range: Lower Miocene to Recent.

\section{DENNSTAEDTIACEAE}

FFF004 Hypolepis maruiensis sp. nov. Figs 10.5,10.7

Numerous fragments of isolated pinnae. Frond pinnately compound, at least bipinnate, pinnae straight, spreading, oblong or lanceolate, attenuate, at least $50 \mathrm{~mm}$ long by $20 \mathrm{~mm}$ broad. Pinnules ca. 8-12 mm long, subacute, bases approximate, becoming confluent towards apex of pinna, margin crenate; venation of pinnule pinnate, veinlets forked once, both branches to a single lobe, free.

The frond form and venation pattern corresponds to that of various living New Zealand species of Hypolepis, particularly forms of $\underline{H}$. tenuifolia (Forst. f.) Bernh, from which it differs in the absence of accessory denticles. 
Holotype: B36.18, Frog Flat Formation, Waiauan to Tongaporutan Stages, Mid to Upper Miocene; M30/f8501, "20 chains south of Maruia Saddle", M30 514078, R.P. Suggate et al., 1949. N.Z. Geological Survey.

Dimensions: $55 \mathrm{~mm}$ long and $48 \mathrm{~mm}$ broad.

Other material examined: B36.7, В36.8, В36.10, В36.11, В36.14, В36.16, B36.19, from the same locality.

Stratigraphic range: Mid - Upper Miocene.

\section{DAVALLIACEAE}

\section{FFF005 Davallia tasmanii H.C. Field}

Fig $9.5,9.6,9.7$

Several fragments of fern pinnae. Laminae probably 3 - pinnate, pinnae lanceolate, at least $30 \mathrm{~mm}$ long by $12 \mathrm{~mm}$ wide, axis somewhat sinuous, winged; pinnules pinnatisect, ca. $10 \mathrm{~mm}$ long by $4 \mathrm{~mm}$ wide, more or less oblong, truncate, midrib stout, sinuous; segments oblong, obtuse to truncate, to $5 \mathrm{~mm}$ long, 1 nerve per segment; sori submarginal, terminal on veinlets, cup-shaped, c. $2 \mathrm{~mm}$ long by $1.5 \mathrm{~mm}$ wide, striate.

The fossils are apparently conspecific with the living New Zealand species Davallia tasmanii (P.J. Brownsey, pers. comm.).

Hypotype: B38.34, Frog Flat Formation, Waiauan to Tongaporutan Stages, Mid to Upper Miocene; M30/f8503, "various localities on the Maruia Saddle road". R.P. Suggate, D. Kear, J.C. Schofield and E.T. Annear, 1949.

N.Z. Geological Survey.

Dimensions: $32 \mathrm{~mm}$ long and $13 \mathrm{~mm}$ broad.

Illustrated specimen: B38.32 from the same locality.

Other material examined: В38.22, В38.27, В38.30, В38.31, В38.32, В38.33, from the same locality.

Stratigraphic range: Mid Miocene to Recent.

\section{BLECHNACEAE}

KLB006 Blechnum proceroides (Oliver) comb. nov. Figs 10.2,10.3,10.4,10.6 Plate 6.3

Lomaria proceroides 0liver 1928, p 289, fig 24

Lomaria proceroides 01iver 1936, p 288, fig 1

Frond pinnate; rachis stout, $3.2 \mathrm{~mm}$ diameter, grooved, the surface marked with fine longitudinal striations; pinnae distant, linear to lorate, at least $55 \mathrm{~mm}$ long and probably much longer, 15-22 mm broad, spreading; base obtuse, 
oblique, with marked costa, apex somewhat variable, rounded, obtuse or attenuate, margin undulate, toothed, finely and bluntly serrate with uniformly spaced, straight-sided teeth, re-entrant angle ca. $90^{\circ}$, sinus angular; venation pinnate, midrib of pinna stout, grooved, curved to straight, veinlets diverging at moderate to wide angles, $50^{\circ}-70^{\circ}$, parallel, uniformly spaced, 8-11 per cm at margin, simple or once forked, each nerve to sinus; intercostal areas striate.

The fossils correspond to specimens described as Lomaria proceroides by Oliver $(1928$; 1936) recorded from Ormond (Pleistocene) and Kaikorai (Mid to Upper Miocene). Lomaria is now regarded as a synonym for Blechnum. (see Allan, 1961)

Holotype: B195.11, Waipaoa Series, Castlecliffian (Lower Pleistocene) Ormond, PovertyBay, collected by W.R.B. Oliver. N.Z. Geological Survey. Illustrated specimens: B2.14, B2.41, Longford Formation, Waiauan to Tongaporutuan Stages, Mid to Upper Miocene, M29/f6579, Nuggety Creek, M29 604410, R.P. Suggate, D. Kear, E.T. Annear and W.A. Sara 1951, B38.17, Frog Flat Formation, Waiauan to Tongaporutuan Stages, M30/f8503, various localities on Maruia Saddle road, R.P. Suggate, D. Kear, J.C. Schofield and E.T. Annear 1949; WELT P4954, Kaikorai Leaf Beds, Waiauan Stage, Mid Miocene, Fraser's Gully, Kaikorai Valley, Dunedin, I44 135797, W.R.B. Oliver 1929.

other material examined: B2.5, B2.8, B2.9, B2.13, B2.14, B2.15, B2.16, B2.17, B2.30, B2.46, M29/f6579, Nuggety Creek, M29 604410, R.P. Suggate, D. Kear, E.T. Annear and W.A. Sara 1951; B7.4, M29/f8606, Dress Circle Longford, S.M. Be1l and R.P. Suggate 1949; B38.17, B38.75, B38.103, B38.110, Frog Flat Formation, Mid to Upper Miocene, M30/f8503, "various localities on the Maruia Saddle road", R.P. Suggate, D. Kear, J.C. Schofield and E.T. Annear, 1949; V2834.11, V2834.12, V2834.17, V2834.18, V2834.19, V2834.21, V2834.24, V2834.34, V2834.37; L30/f031, Rappahannock, L30 474037, A.M. Holden and J.D. Collen 1979.

Stratigraphic range: Mid Miocene to Pleistocene.

LDF006 B1echnum maruiense sp. nov.

Fig 10.1

Frond 1- pinnate, at least $8 \mathrm{~cm}$ broad; rachis stout, ca $1.8-2.0 \mathrm{~mm}$ diameter. smooth, rounded, winged; pinnae arising at moderate to wide angles, midribs straight, somewhat stout, ca. $0.5 \mathrm{~mm}$ wide; pinnae linear-oblong, 12-16 mm wide and at least $5 \mathrm{~cm}$ long, alternate, bases broad, somewhat auriculate, approximate or confluent, attached by entire base; margin undulate, obscurely toothed; nerves diverging at moderate to wide angles, parallel, simple or once forked at varying levels, 13-16 per $\mathrm{cm}$ at margin. 
Holotype: B256.3 and .6 (two parts of a single impression), Longford Formation, Waiauan to Tongaporutuan Stages, Mid to Upper Miocene; M29/f8683, "Murchison-Ne1son road, north end of Longford Bridge". M29 572353, H.W. Wellman, 1951, N.Z. Geologica1 Survey.

Dimensions: $80 \mathrm{~mm}$ long and $85 \mathrm{~mm}$ broad.

Other material examined: B256.12 from the same locality.

Stratigraphic range: Mid to Upper Miocene.

SPERMOTOPSIDA, ANGIOSPERMAE, DICOTYLEDONES

MONIMIACEAE

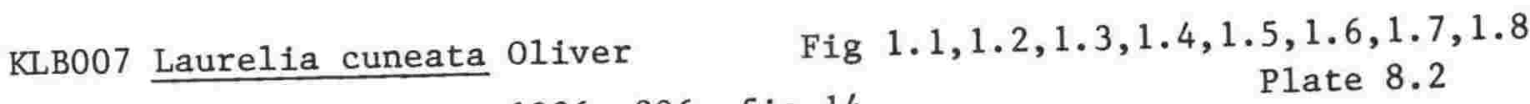

Laurelia cuneata 01iver 1936, 296, fig 14

Leaves 20-89 mm long by 15-45 mm broad, elliptical to obovate, sometimes somewhat asymmetrical; apex bluntly acuminate with a short drip-tip, base cuneate, margin crenate to crenate-serrate, teeth simple, obtuse to rounded, somewhat coarse, regularly spaced around greater part of margin except cuneate base, sinus more or less angular; petiole stout, rather long; venation pinnate, semi-craspedodromous or reticulodromous; midrib stout, straight; secondary veins rather weak, diverging at moderate angles, $50^{\circ}$ to $60^{\circ}$, somewhat narrower at base than apex, branched, irregularly spaced, with frequent compound inter-secondaries, loop forming branches joining superjacent secondary at acute angles, forming angular loops somewhat distant from margin and enclosed by tertiary and higher order arches; tertiary veins diverging at variable angles from secondaries, randomly reticulate, thick compared with secondaries; higher order venation poorly differentiated from tertiary, areoles large, imperfect, random.

Holotype: WELT 44550, Kaikorai Leaf Beds, Waiauan Stage, Mid Miocene, Fraser's Gully, Kaikorai Valley, I44 135797, W.R.B. Oliver, National Museum, Wellington.

Dimensions: $55 \mathrm{~mm}$ long and $33 \mathrm{~mm}$ broad (leaf blade), petiole $12 \mathrm{~mm}$. Illustrated specimens: V2846.36, Kaikorai Leaf Beds, J44/f002 Taiaroa Head, J44 333898, A.M. Holden and P. Vella, 1981; B7.38, B7.44, B7.46, Longford Formation, Waiauan to Tongaporutuan Stages, Mid-Upper Miocene, M29/f8606, Dress Circle, Longford, M29 579347, S.M. Bell and R.P. Suggate. 1949; B38.16, B38.97, Frog F1at Formation, Waiauan to Tongaporutuan Stages, M30/f8503, various localities in Maruia Saddle road, R.P. Suggate, D. Kear, 
J.C. Schofield and E.T. Annear 1949.

Material examined: WELT 44547 from type locality; V2847.9, Kaikorai Leaf Beds, I44/f134, Fraser's Gully, Kaikorai Valley, Dunedin, I44 135797, A.M. Holden, P. Ve1la and J.D. Campbe11, 1981; B7.18, B7.25, B7.45, B7.47, B7.69, B7.70, B7.71, M29/f8606, Dress Circle Longford. M29 579347, S.M. Bell and R.P. Suggate, 1949, V2825.15, M29/f154, Dress Circle, Longford, M29 579347, A.M. Holden and J.D. Co1len, 1979. Stratigraphic range: Mid-Upper Miocene.

\section{LAURACEAE}

LDF007? Cryptocarya longfordiensis Holden Figs 11.9,11.10,11.11,11.12 Plate 6.4

?Cryptocarya longfordiensis Holden 1982, 83-4, figs 1.8,1.9,1.10 Microphyl1, $40 \times 22 \mathrm{~mm}$, elliptic to ovate, apex missing but probably obtuse to more or less rounded, margin entire; petiole normal, fairly stout, at least $10 \mathrm{~mm}$ long; venation acrodromous suprabasal perfect; primary nerves 3 , weak to moderate, laterals extending about two thirds to three quarters of the way up the leaf, secondaries from laterals on outer side only, angle of divergence wide to right angles, $65^{\circ}$ to $90^{\circ}$, moderately thick, curved, joining superjacent at acute angle to form prominent loops; intersecondaries compound, strong veins passing between primaries convex, some forked; tertiaries percurrent, straight or sinuous, crossing more or less at right angles between secondaries, alternate, thick, higher order venation obscure, weak.

This type of venation is found in Cinnamomum and Cryptocarya and some genera of Lauraceae. The fossil bears a strong resemblance to Cryptocarya triplinervis, R. Brown of north Queensland and Lord Howe Island, the main difference being the more or less rounded base of the Longford fossils as opposed to the cuneate base of the living species.

Holotype: B7.70, Longford Formation, Waiauan to Tongaporutuan Stages (Mid to Upper Miocene). M29/f8606, Dress Circle, Longford, M29 579347. S.M. Bell and R.P. Suggate, 1949. N.Z. Geological Survey.

Dimensions: $46 \mathrm{~mm}$ long and $22 \mathrm{~mm}$ broad.

Illustrated specimens: B2.54, Longford Formation, M29/f6579, Nuggety Creek, M29 604410, R.P. Suggate, D. Kear, E.T. Annear and W. Sara, 1951, B7. 75 . 
M29/f8606, Dress Circle, Longford, M29 579347: S.M. Be11 and R.P. Suggate 1949, B256.20 and 24 (2 parts of same impression), M24/f8683, Murchison Nelson road, north end of Longford Bridge, M29 572353, H.W. We1lman 1951. Other material examined: B7.36 and B7.75, M29/f8606, Dress Circle, Longford, M29 579347, S.M. Be11 and R.P. Suggate, 1949; B36.2, B36.3, Frog Flat Formation, Waiauan to Tongaporutuan Stages, M30/f8501, Maruia Saddle Road, south side of summit, M30 512072, R.P. Suggate et al., 1949.

Stratigraphic range: Mid to Upper Miocene.

LDF008? Litsea dawsoniana Holden Figs 11.13,11.14,12.1,12.2 Plate 7, no.l. ?Litsea dawsoniana Holden 1982, 85, figs 1,2

Large microphy11 to mesophy11, 60-120 mm long and 30-60 mm broad, symmetrical, elliptic; apex obtuse to emarginate, sometimes splitting along midrib; base obtuse to rounded margin entire, plane or recurved; petiole stout; venation pinnate, brochiodromous, loops close to margin; midrib weak to moderate, straight, secondaries opposite to alternate, at least seven pairs, spacing rather distant below, becoming closer above, angle or divergence narrow to moderate, $45^{\circ}$ to $60^{\circ}$, more or less uniform, rather thick, somewhat curved, sometimes branched, joining superjacent at acute angles, enclosed by secondary arches; intersecondaries compound; tertiaries percurrent, forked, retroflexed, or convex, diverging at acute angles from lower side and obtuse angles grom upper side of secondaries, oblique to midrib, often approaching horizontal towards margin, predominantly alternate, thick, 2-5 mm apart; higher order venation not well differentiated, random to orthogonal, rather weak, areoles well-developed, more or less orientated, small, pentagonal, possibly with unbranched veinlets.

The venation pattern described is found in a number of genera of Lauraceae, particularly Litsea, Cryptocarya and Endiandra, which are all common in rainforests in Australia, New Caledonia and Polynesia. The Longford fossils resemble closely Litsea leefiana (F. Muell.) Merr., from Queensland.

Holotype: V2836 (VH105), Longford Formation, Waiauan to Tongaporutuan Stages, Mid to Upper Miocene, M29/f156, Dress Circle, Longford, M29 579347 , B. Dawson, 1979; Victoria University, Wellington.

Dimensions: $80 \mathrm{~mm}$ long and $40 \mathrm{~mm}$ broad. 
I1lustrated specimens: B2.39, Longford Formation, M29/f6579, Nuggety

Creek, M29 604410, R.P. Suggate, D. Kear, E.T. Annear and W.A. Sara 1951; V2849.13, Nevis Formation, Oil Shale Member, Pareora Series, Lower Miocene, F42/f001, various localities along Shale Ridge, Nevis Valley, F42 955535 , A.M. Holden, P. Vella and C. Vella 1981; V2856.83, St. Bathans Beds, Manuherikia Group, Pareora to Southland Series, Lower to Mid Miocene, H4l/f028, clay seam in sluiced ground, west end of Blue Lake, St Bathans Central Otago, H41 577888, A.M. Holden, P. Vella and C. Vella, 1981. Stratigraphic range: Lower to Upper Miocene.

OLM002 ?Cryptocarya sp.

Fig 12.6

Part 1eaf, microphy11; $29 \mathrm{~mm}$ 1ong and $12 \mathrm{~mm}$ broad, total width of leaf probably ca. $24 \mathrm{~mm}$; suborbicular; apex rounded, emarginate; base more or less rounded; margin entire; leaf texture probably coriaceous; venation acrodromous, ?basal, imperfect; primary veins 3, straight to more or less curved, moderate to weak, the first secondaries from central primary arising ca. $2 / 3$ of the way up leaf, secondaries from lateral primaries from outer side only; all secondaries diverging at narrow to moderate angles, the angle increasing distally; tertiaries diverging at acute to right angles, percurrent, convex, straight or forked, predominantly opposite. Upper epidermis of thick-walled isodiametric cells 10.75-18.4 im diameter, anticlinal walls straight; 1ower epidermal cells in non-venous areas isodiametric to rectangular, $13.8-21.5 \mu$ long ( $a v=18.75 \mu$ ) and $11.5-15.3 \mu$ wide (av=13.5 $\mu$ ), more or less random, cells over veins rectangular, end walls square to oblique; anticlinal cell walls straight to subrounded; stomata randomly orientated, material too fragmentary for accurate estimation of stomatal index; guard cells $13.8-18.4 \mu$ 1ong ( $a v=16.6 \mu$ ) and $4.6-7.7 \mu$ broad ( $a v=5.84 \mu)$; subsidiary cells $13.8-24.5 \mu$ long ( $a v=19.2 \mu$ ) and $7.7-15.7 \mu$ broad ( $a v=11.7 \mu)$, ?brachyparacytic; guard cells more or less level with surface, inner stomatal ledge conspicuous, plain; poles of guard cells generally marked by overlapping subsidiary cells; trichomes sparse, material too fragmentary for accurate estimation of trichome frequency, arranged singly; basal cells radial, trichome base thickened.

Holotype: V2856.59 and .59A (counterparts), St. Bathans Beds, Manuherikia Group, Pareora to Southland Series, Lower to Mid Miocene, H41/f028, clay seam in sluiced ground, west end of Blue Lake, St. Bathans. Central Otago, H41 577888, A.M. Holden, P. Vella and C. Vella, 1981; Victoria University, Wellington. 
Dimensions: $29 \mathrm{~mm}$ long and $12 \mathrm{~mm}$ broad.

Other material examined: V2856.85 from the type locality.

Stratigraphic range: Pareora to Southland Series; Lower to Mid Miocene.

\section{CUNONIACEAE}

KLB008 Ceratopetalum kaikoraiense 01iver

Figs $12.3,12.4,12.5,12.7,12.8$,

$$
12.9,12.10,12.11
$$

Ceratopetalum kaikoraiense Oliver 1936; 297, fig 16

Dryophyllum dubium pro parté Ettingshausen 1887: 268, P1.XXVI, 19, 19a,

$$
\text { P1.XXVII, } 6 .
$$

Microphy $11,30-70 \mathrm{~mm}$ long and 9-22 mm broad; 1anceolate; apex attenuate to acuminate-attenuate; base obtuse to cuneate, sometimes somewhat asymetrical; margin serrate, teeth simple, acute, straight sided or acuminate, sinus rounded, 1-3 teeth per secondary vein, regularly spaced around complete margin; petioles missing in all specimens; venation pinnate, craspedodromous, simple or semicraspedodromous, midrib moderate to stout, straight; secondaries diverging at moderate to wide angles, $50-70^{\circ}$, usually somewhat curved, branched, intersecondaries composite, loop forming branches joining superjacent at acute angles; tertiaries diverging at right angles or at acute angles from the lower and obtuse angles from the upper side of secondary, reticulate, or percurrent forked: higher order venation not well-differentiated from tertiary, more or less orthogonal; areoles imperfect, veinlets once or twice branched.

The fossils resemble leaves of the living Australian species Ceratopetalum apetalum D. Don, a tall tree of subtropical rainforest in eastern Australia, which often forms pure stands (Francis, 1970). The venation pattern of $\underline{C}$. apetalum is somewhat variable. Some forms could be confused with species of Nothofagus, but there are usually one or more composite intersecondaries between the secondaries which are not found in Nothofagus. Some of the leaves from Landslip Hill described as Dryophyllum dubium by Ettingshausen are comparable to the holotype of Ceratopetalum kaikoraiense, others appear to be species of Nothofagus.

Holotype: WELT 44551, Kaikorai Leaf Beds, ?Waiauan Stage, (Mid Miocene), Fraser's Gully, Kaikorai Valley, I44 135797, W.R.B. Oliver, 1929; Nationa1 Museum, Wellington. 
Dimensions: $33 \mathrm{~mm}$ long and $19 \mathrm{~mm}$ broad.

Illustrated specimens: V2849.15, V2849.16, V2849.17, Nevis Formation, 0i1 Shale Member, Pareora Series, Lower Miocene, F42/f001, various localities along Shale Ridge, Nevis Valley, F42 955535, A.M. Holden, P. Vella and C. Vella, 1981; B411.1, Beeson's Island Volcanics, Taranaki to Wanganui Series (Upper Miocene to P1iocene), 200 yards from road north from Okupu, 200 yards above road near where road crosses fence on exposed spur, 80 chain at $50^{\circ}$ from Trig Whangapara, K.Black 1952. V2841.7,V2841.37 Gore Lignite Measures, Duntroonian to Waitakian Stages (Upper Oligocene to Lower Miocene), G45/f058, Landslip Hill, siliceous boulders on southern end of hilltop $200 \mathrm{~m}$ from plantation boundary, G45 125530, A.M. Holden and P. Ve1la, 1981; V2838.1, Frog Flat Formation M30/f028, roadside cutting, true right bank of Glenroy River close to bridge M30 550113, A.M. Holden and J.D. Collen, 1979.

Other material examined: V2841.4, V2841.4A, V2841.5, V2841.6, V2841.7, V2841.13, V2841.14, V2841.22, V2841.37, V2841.39, V2841.69, V2841.72, V2841.82, V2841.86, V2841.86A, V2841.89, G45/f058, Lands1ip Hi11, G45 125530, A.M. Holden and P. Ve1la, 1981; B148.3, B148.10, B148.12, B148.1027, G45/f8498, Landslip Hill, G45 125530, ?J. Hector; B149.6, G45/f8497, Landslip Hill, G45 125530, J. Hector, 1869; B150.1, B150.2, B150.6, B150.16, G45/f8496, Lands1ip Hill, G45 125530, J. Park, 1886; V2849.54, F42/f001, Nevis Valley, F42 955535, A.M. Holden, P. Vella and C. Vella, 1981; B2.22, Longford Formation, Waiauan to Tongaporutuan Stages (Mid to Upper Miocene), M29/f6579, Nuggety Creek, M29 604410, R.P. Suggate, D. Kear, E.T. Annear and W.A. Sara, 1951; B6.1, B6.6, B6.7, B6.9, B6.10, B6.13, B6.14, B6.15, M29/f8593, Blue Duck Creek, M29 585313, D. Kear 1948; B256.4, M29/f8683, Longford, M29 572353, H.W. Wellman 1951; B38.10, B38.18, M30/f8503, Maruia Saddle road, R.P. Suggate, D. Kear, J.C. Schofield and E.T. Annear, 1949; V2838.1, V2838.1A, V2838.7, V2838.8, V2838.10, V2838.10A, M30/f024, true right bank of Glenroy River, road cut close to bridge, M30 550113, A.M. Holden and J.D. Collen 1979; WELT 44552 from the type locality. Stratigraphic range: Upper Oligocene to Lower Pliocene.

EUPHORBIACEAE

LDF009?Mallotus sp. Fig 12.12,12.13,12.14.

Mesophy11; leaves 30-90 $\mathrm{mm}$ long and $20-50 \mathrm{~mm}$ broad; broadly ovate, broadest ca. 1/4 way up leaf, frequently somewhat asymmetrical; apex attenuate to 
to acuminate-attenuate; base rounded to subcordate; margin entire; venation eucamptodromous to brochiodromous; midrib rather weak, straight; secondaries opposite, or opposite below becoming alternate distally, 10-20 mm apart, closer together at base, diverging at narrow to moderate angles, curved, lowest pair generally and others occasionally branched, loop-forming branches joining superjacent at acute to right angles forming loops enclosed by secondary and higher order arches; intersecondaries rare, composite; tertiaries crossing at right angles or diverging at acute angles from lower and obtuse angles from upper, side of secondaries, percurrent, forked, oblique to midrib or more or less horizontal in some leaves, alternate, somewhat distant; highest order venation $6^{\circ}$, higher order venation suborthogonal to subrandom, areoles perfect, oriented, sma11, quadrangular to polygonal; marginal venation probably looped.

The asymmetrical form of the leaf suggests isolated leaflets, and in general form and venation the fossils resemble leaflets of some species of Leguminosae sensu lato for example Phasaeolus. Asymmetrical simple leaves occur in some species of Mallotus (Euphorbiaceae), for example M. philippinensis Muell and M. japonicus Muell. The fossils closely resemble leaves of both of these species. Fossil euphorbiaceous pollen of Mallotus/Macaranga type (Tricolporopollenites endobalteus McIntyre) are often abundant in New Zealand Oligocene and Miocene sediments particularly in the South Island (Mildenhall 1980).

Holotype: B256/1, Longford Formation, Waiauan to Tongaporutuan Stages (Mid to Upper Miocene), M29/f8683, Murchison-Nelson road, north end of Longford Bridge, M29 572353, H.W. Wellman 1951; N.Z. Geological Survey. Dimensions: $65 \mathrm{~mm}$ 1ong and $40 \mathrm{~mm}$ broad.

Illustrated specimens: B256.5 from the type locality; B36.2, Frog Flat Formation, Waiauan to Tongaporutuan Stages, Mid-Upper Miocene, M30/f501, Maruia Saddle, south side of summit, M30 514078, R.P. Suggate et al. 1949. Other material examined: B256.3, B256.10, B256.11, B256.16, B256.27, a11 from the type locality.

Stratigraphic range: Waiauan to Tongaporutuan, Mid to Upper Miocene.

MYRTACEAE

LDF010 Metrosideros diffusoides sp. nov. Figs $13.1,13.2$

Leaves 10-15 $\mathrm{mm}$ 1ong and 8-10 mm broad, ovate, apex obtuse to rounded, 
base rounded to subcordate, margin entire, glands not obvious; petiole not preserved but the shape of the base suggests that this was short or the leaves subsessile; venation pinnate, camptodromous; midrib moderate, straight; secondaries numerous, crowded, branched, uniting near margin to form a more or less prominent marginal vein which diverges from the midrib ca. 3-4 mm above leaf base, lowest pair of secondaries uniting with it at obtuse angles; intersecondaries frequent, compound; tertiaries diverging at variable angles, randomly reticulate, areolation imperfect or lacking.

In shape, size and venation the fossil leaves correspond to those of the living $\underline{M}$. diffusa (Forst. f.) 0liver. It would also appear to be related to $\underline{M}$. colensoi Hook. f., from which it differs in the rounded leaf apex. Both $\underline{M}$. diffusa and $\underline{M}$. colensol are slender, woody lianes of coastal and lowland forests, $\underline{M}$. colensoi being the more restricted, not being found further south than latitude ca. $42^{\circ}$. In view of the close similarity between the leaves of the two living species and the fossil it seems possible that they were of similar habit. The two living species are endemic.

Holotype: B7.9 and B7.68 (counterparts), Longford Formation, Waiauan to Tongaporutuan Stages Mid to Upper Miocene, M29/f8606, Dress Circle, Longford, M29 579347, S.M. Bell and R.P. Suggate, 1949. N.Z. Geological Survey.

Dimensions: $18 \mathrm{~mm}$ long by $9 \mathrm{~mm}$ broad.

Illustrated specimen: V2827.6, Longford Formation, M29/f150 B1ue Duck Creek, M29 587314, A.M. Holden and J.D. Collen 1979.

Other material examined: B7.19, B7.22, both from the type locality. Stratigraphic range: Mid to Upper Miocene.

KLB009 Metrosideros pliocenica 01iver Figs $13.3,13.4,13.5,13.8$
Metrosideros pliocenica Oliver 1936: 299, fig 19

Leaves $20-25 \mathrm{~mm}$ long and 7-12 mm broad, ovate; apex obtuse to acute, base cuneate, margin entire, somewhat recurved; petiole apparently very short, rather stout; venation pinnate, camptodromous; midrib moderate, straight; marginal vein diverging at moderate angles from midrib about $4 \mathrm{~mm}$ above base, lowest pair of secondaries joining marginal vein at 
obtuse angles; intersecondaries frequent, composite; tertiaries diverging at variable angles, randomly reticulate; areoles imperfect.

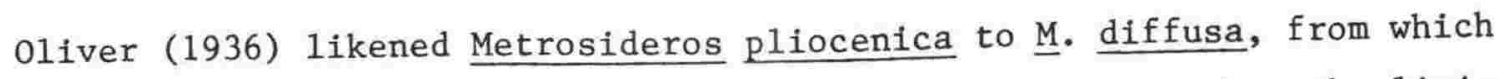
it differs in having a cuneate leaf base. It also approaches the living M. carminea 0liver in form. It is clearly distinct from the fossil species M. diffusoides described above.

Holotype: WELT 44554, Kaikorai Leaf Beds, Waiauan Stage (Mid Miocene), Fraser's Gully, Kaikorai Valley, Dunedin, I44 135797, W.R.B. Oliver 1929. National Museum, Wellington.

Dimensions: $19 \mathrm{~mm}$ long and $19 \mathrm{~mm}$ broad.

Illustrated specimens: B36.3, Frog Flat Formation, Waiauan to Tongaporutuan Stages M30/f8301, Maruia saddle, south side of summit, M30 514078 , R.P. Suggate et al. 1949; B38.4, Frog Flat Formation, M30/f8303, various localities on Maruia Saddle road, R.P. Suggate, D. Kear, J.C. Schofield and E.T. Annear, 1949; B1036.18, Central Otago Lignite Measures, Manuherikia Group, Pareora to Southland Series, Lower to mid Miocene, M41/f9513, Bannockburn, F41 088624, R.I. McPherson 1968.

Stratigraphic range: Lower to Upper Miocene.

KLB010 Metrosideros laeta 01iver Figs 13.6,13.7,13.11 Plate 7.2 Metrosideros laeta 01iver 1936; 299, fig 18

Lamina 20-70 mm long and 10-30 mm wide, microphyl1; entire, eliptic to ovate, apex acuminate-attenuate; base obtuse to cuneate; laminar glands evident in some specimens; petiole missing; venation camptodromous; midrib straight, moderate; secondaries diverging at moderate to wide angles, varying somewhat irregularly, straight to more or less sinuous, sometimes branched, uniting to form a marginal vein arising close to the base and passing round entire leaf; intersecondaries composite; tertiaries diverging at variable angles, randomly reticulate, areolation poor or lacking.

The leaves are similar to those of the Recent species Metrosideros

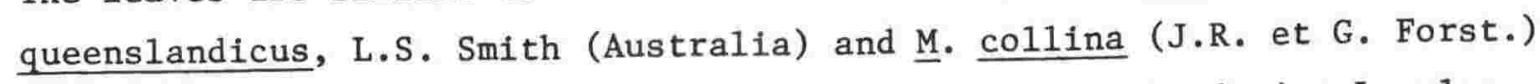
A. Gray, (New Caledonia). Leaves of the living Ficus benjamina L. also show a similar shape and venation pattern, and its leaf lamina bears numerous warts or glands which could be confused with the oil glands of Myrtaceae. 
Holotype: WELT 44555, Kaikorai Leaf Beds, ?Waiauan Stage, Mid Miocene, Fraser's Gully, Kaikorai Valley, Dunedin, I44 135797, W.R.B. Oliver 1929; Nationa1 Museum, Wellington.

Dimensions: $41 \mathrm{~mm}$ long and $25 \mathrm{~mm}$ broad.

Illustrated specimens: B38.112, Frog Flat Formation, Waiauan to Tongaporutuan Stages, M30/f8303, various localities on Maruia Saddle road, R.P. Suggate, D. Kear, J.C. Schofield and E.T. Annear 1949; V2835.15, Longford Formation, Waiauan to Tongaporutuan, M29/f155, track to Mangles Valley television translator, M29 585236, A.M. Holden and J.D. Collen 1979 .

Other material examined: B7.53, Longford Formation, M29/f8606, Dress Circle, Longford M29 579347, S.M. Bell and R.P. Suggate, 1949, V2838.7, Frog Flat Formation, M30/f024, roadside cutting on true right bank of Glenroy River close to bridge, M30 550113, A.M. Holden and J.D. Collen 1979.

Stratigraphic range: Mid to Upper Miocene.

LDF011? Xanthostemon sp.

Figs $13.11,13.12$

Leaves 50-150 $\mathrm{mm}$ 1ong and 20-50 $\mathrm{mm}$ broad, mesophy1.1; narrow obovate, apex rounded, base cuneate; margin entire; lamina with numerous glands; petiole not preserved; venation camptodromous; midrib stout, 1.0 to $1.5 \mathrm{~mm}$ broad mid leaf, generally straight; secondaries weak, closely spaced, diverging at wide to more or less right angles, or at moderate angles and strongly reflexed, angle of divergence widest at base, course of secondaries straight to sinuous, sometimes branched, uniting to form a marginal vein 1-2 mm from margin with enclosing outer arches; tertiaries diverging at variable angles, randomly reticulate or percurrent forked and at a more or less constant angle to the midrib; higher vein orders poorly preserved and apparently poorly differentiated into vein orders, random.

The leaves resemble those of a number of genera of Myrtaceae, in particular those of Xanthostemon and Tristaniopsis, both of which have species with narrow, obovate leaves. In size, shape and venation the leaves are comparable to those of the living New Caledonian species Xanthostemon veillardii (Brongn. et Gris) Niedenzu. Both Xanthostemon and Tristaniopsis are genera characteristic of open scrubland in New Caledonia although some species are found in forests (J.W. Dawson, pers. comm.; G. McPherson, pers. comm.). In Australia these genera are more 
characteristic of forest situations (Francis 1970).

Holotype: B256.12, Longford Formation, Waiauan to Tongaporutuan Stages (Mid to Upper Miocene) M29/f8683, Murchison-Nelson road, north end of Longford Bridge, M29 572353, H.W. Wellman 1951; N.Z. Geological Survey. Dimensions: $88 \mathrm{~mm}$ long and $45 \mathrm{~mm}$ broad.

Illustrated specimen: B256.3 from the type locality.

Other Material examined: V2825.12, M29/f154, Dress Circle, Longford, M29 579347, A.M. Holden and J.D. Collen 1979; V2835.16, M29/f155, Mangles Valley television translator track, M29 585376, A.M. Holden and J.D. Collen 1979.

Stratigraphic range: Lower to Mid Miocene.

OLM003 Eucalyptites roxburghiensis sp. nov. Figs $13.10,13.13,13.14,13.15$ Plate 7.3

Sma11 mesophy11, leaves 50-100 $\mathrm{mm}$ 1ong and 15-35 mm broad, lanceolate, asymmetrical at least at base, often more or less falcate, apex acute to attenuate, base obtuse to cuneate, oblique; margin entire; lamina bearing numerous glands; petioles long, rather stout; venation pinnate, camptodromous; midrib moderate, straight or curved; secondaries weak, diverging at moderate angles, generally not parallel, straight, curved or branched, uniting near margin to form a more or less conspicuous marginal vein 1-2 $\mathrm{mm}$ from the margin; intersecondaries numerous, composite; tertiaries diverging at somewhat variable angles, randomly reticulate, higher order venation poorly preserved and poorly differentiated into vein orders, random. areolation imperfect or lacking.

The fossil leaves appear to have been isobilateral. In shape, venation and form of petiole they are closely comparable to leaves of many living species of Eucalyptus. The genus is not found native in New Zealand today, but a number of species are extensively planted and some have become naturalised. Pollen grains attributed to Eucalyptus are known from Miocene to early Pleistocene sediments in New Zealand (Mildenhall 1980) and may be locally abundant, constituting up to fifty per cent of all pollen found in some Pliocene localities in Central Otago (D.C. Mildenha11, pers. comm.).

Holotype: V2848.15, Central Otago Lignite Measures, Manuherikia Group, Pareora to Southland Series (Lower to Mid Miocene), G43/f002, Harliwick's opencast, Coal Creek Flat, Roxburgh, overburden from small gully at west side of pit, G43 214193, A.M. Holden, P. Vella and C. Vella 1981; Victoria 
University, Wellington.

Dimensions: $74 \mathrm{~mm}$ long and $24 \mathrm{~mm}$ broad.

Illustrated specimens: V2848.43 from the type locality; V2850.30 and V2850.30A (counterparts), F41/f209, Bannockburn, F41 088622, A.M. Holden, P. Vella and C. Vella 1981 .

Other material examined: V2848.6, V2848.6A, V2848.7, V2848.13, V2848.14, $\mathrm{V} 2848,16, \mathrm{~V} 2848.25, \mathrm{~V} 2848.26$, V2848.27, V2848.27A, V2848.28, V2848.32, $\mathrm{V} 2848.34, \mathrm{~V} 2848.35, \mathrm{~V} 2848.36, \mathrm{~V} 2848.37, \mathrm{~V} 2848.38, \mathrm{~V} 2848.39, \mathrm{~V} 2848.40$, from the type locality; B1036.37, B1036.49, F41/f9513, Bannockburn, F41 088624 , collected by R.I. McPherson 1968.

Stratigraphic range: Lower to Mid Miocene.

\section{DICOTYLEDONES INCERTAE SEDIS}

OLM004 Species A

Figs $14.1,14.2,14.3,14.4,14.5$

Mesophyl1, 50-110 mm 1ong by 40-90 mm broad; broadly elliptic to obovate. sometimes somewhat asymmetrical, apex rounded to more or less emarginate, base obtuse to cuneate; margin entire; venation pinnate, eucamptodromous to brochiodromous; midrib moderate, straight, longitudinally ribbed and possibly tomentose; secondaries diverging at moderate to wide angles, subopposite to alternate, curved, sometimes branched, loop forming branches joining superjacent at acute to right angles, loops enclosed by secondary and higher order arches; intersecondaries rare, composite; tertiaries diverging at acute to right angles, percurrent, forked, oblique to midrib, becoming horizontal towards margin, opposite or opposite and alternate; highest order of venation 7 th?; higher vein orders random; areoles imperfect, irregular with twice-branched included veinlets. Upper epidermis: cells $23-31 \mu$ long (av $=27.15 \mu$ ) and $16.9-24.6 \mu$ broad $(\mathrm{av}=19.5 \mathrm{u})$, isodiametric to more or less rectangular, thick-walled, random; anticlinal walls with U-shaped undulations ornamented by thickened ridges. Lower epidermis: cells in areolar areas $21.5-31 \mu$ (av $=25.8 \mu)$ long and $16.9-23.2 \mu(\mathrm{av}=19.8 \mu)$ wide, more or less isodiametric, hexagonal to random, anticlinal walls straight; cells over veins elongate, $27.6-58.3 \mu(\mathrm{av}=43.8 \mu)$ long and $10.75-18.8 \mu(\mathrm{av}=$ 15.04u) wide, end walls square to oblique, anticlinal walls straight: stomatal index $2.85 / 100 \mu \mathrm{m}^{2}$; guard cells $16.9-27.6 \mu(\mathrm{av}=21.5 \mu)$ long and $6.2-12.6 \mu(\mathrm{av}=8.6 \mu)$ wide, subsidiary cells absent or poorly differentiated; stomata on lower epidermis only; 
stomatal complex polycytic, anomocytic; stomata somewhat sunken, stomatal ledges conspicuous, plain, poles of guard cells marked by overlapping subsidiary cells: trichome index $1.88 / 100 \mu \mathrm{m}^{2}$; trichomes sparse to absent on upper epidermis, fairly frequent on lower, particularly on veins and veinlets; occurring singly, basal cells radial, trichome base thickened.

The form and venation of the leaves is similar to that of the living New Zealand species Beilschmiedia taraire (A. Cunn) Kirk. The epidermal characters are consistent with those of Lauraceae.

Ref. Specimen: V2856.38, V2856.38A (counterparts), Centra1 Otago Lignite Measures, St. Bathans Beds, Pareora to Southland Series, Lower to Mid Miocene, H41/f028, clay seam in sluiced ground, west end of Blue Lake, St. Bathans, Central Otago, H41 577888, A.M. Holden, P. Vella and C. Vella, 1981; Victoria University, Wellington.

Dimensions: $72 \mathrm{~mm}$ long and $52 \mathrm{~mm}$ broad.

Illustrated specimens: V2850.25, V2850.25A (counterparts) Central Otago Lignites, Manuherikia Group, Pareora to Southland Series, Lower to Mid Miocene, F41/f209, new road cut $200 \mathrm{~m}$ north of new bridge across Bannockburn Stream, F41 088622, A.M. Holden, P. Vella and C. Vella, 1981; B1036.38, B1036.47, Manuherikia Group, Pareora to Southland Series, F41/f9513, Bannockburn, basal beds of mid-Tertiary section exposed west of bridge to Cairnmuir Station, F41 088624, R.I. McPherson, 1968.

Other material examined: B1036.36, B1036.37, F41/9513, Bannockburn, F41 088624, collected by R.I. McPherson 1968; B193.51, Bannockburn, A. McKay 1882; V2850.41, V2850.41A, F41/f209, Bannockburn, grid ref F41 088622 ,

A.M. Holden, P. Vella and C. Vella 1981; B38.1, B38.97, Frog Flat Formation, Waiauan to Tongaporutuan Stages, Mid to Upper Miocene, M30/f8503, various localities on Maruia Saddle road, R.P. Suggate, D. Kear, J.C. Schofield and E.T. Annear, 1949 .

Stratigraphic range: Lower to Upper Miocene.

OLM005 Species B

Fig 14.6

Mesophy11, estimated length at least $120 \mathrm{~mm}$, width $31 \mathrm{~mm}$, narrow elliptic or oblong, apex and base missing but base probably cuneate; margin entire; venation pinnate, camptocromous, eucamptodromous or brochiodromous; midrib moderate, straight; secondaries diverging at moderate angles, strong, rather irregularly spaced, curved; intersecondaries composite; tertiaries diverging at right angles or at acute angles from the lower side and acute 
angles from the upper side of secondaries, percurrent, forked or sinuous, predominantly opposite; highest order venation 5 th or 6 th, higher orders of venation suborthogonal, thick; areoles small, random. Upper epidermis fragmentary; cells in non-venous areas more or less isodiametric 13.8$18.4 \mu$ diameter $(\mathrm{av}=16.27 \mu)$, thick-walled, pentagonal to hexagonal, anticlinal walls rounded: lower epidermis, cells in non-venous areas more or less isodiametric, $16.9-26.1 \mu$ long (av $=18.73 \mu)$ and $15.3-21.5 \mu$ wide $(\mathrm{av}=17.8 \mu)$, hexagonal, anticlinal walls straight to rounded: stomata on lower epidermis only, material too fragmentary for an accurate estimate of stomatal or trichome frequency, randomly orientated, brachyparacytic, subsidiary cells $15.3-27.6 \mu$ long (av $=22.1 \mu$ ), and $9.25-16.9 \mu$ wide $(\mathrm{av}=13.35 \mu)$, guard cells sunken, $12.3-21.5 \mu$ long $(\mathrm{av}=18.25 \mu)$ and $4.6-9.2 \mu$ wide $(\mathrm{av}=5.84 \mu)$, poles of guard cells marked by overlapping subsidiary cells: trichomes on lower surface only, occurring singly, chiefly over veins and veinlets, basal cells radial, base somewhat thickened.

The fossil may belong to Lauraceae, possibly a species of Litsea or Cryptocarya. Similar venation is also found in some species of Macaranga (Euphorbiaceae).

Ref. Specimen: V2856.19, Central Otago Lignite Measures, St. Bathans Beds, Pareora to Southland Series, Lower to Mid Miocene, H41/f028, clay seam in sluiced ground, west end of Blue Lake, St. Bathans, Central Otago, H41 577888, A.M. Holden, P. Vella and C. Vella 1981; Victoria University, Wellington.

Dimensions: $99 \mathrm{~mm}$ long and $32 \mathrm{~mm}$ wide.

Stratigraphic range: Pareora to Southland Series.

OLM006 Species C

Fig $15.1,15.2,15.3$

Microphy 11, 30 to $70 \mathrm{~mm}$ long and 18 to $25 \mathrm{~mm}$ broad, narrow elliptic to lanceolate, apex acute to obtuse, base cuneate, margin entire; venation pinnate, brochiodromous; midrib moderate to stout, straight; secondaries diverging at moderate to wide angles, curved abruptly near margin and joining superjacent at acute angles; intersecondaries composite; tertiaries and higher vein orders poorly differentiated, ramified or random reticulate, some showing admedial development; areolation imperfect

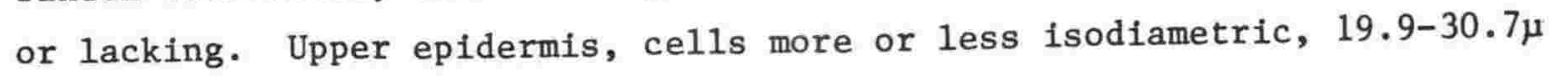


long $(\mathrm{av}=23.92 \mu$ ) and $16.9-21.5 \mu$ wide $(\mathrm{av}=19.48 \mu)$, pentagonal to hexagonal, anticlinal walls straight: 1ower epidermis, cells in nonvenous areas more or less isodiametric, $24.5-29.2 \mu$ long (av $=26.7 \mu$ ) and $16.9-24.5 \mu$ wide $(\mathrm{av}=21.32 \mu)$, pentagonal to hexagonal, anticlinal walls straight to rounded: stomata on lower surface only, randomly orientated, brachyparacytic to amphiparacytic, stomatal index $1.72 / 100 \mu^{2}$; subsidiary cells $19.5-30.7 \mu$ long $(\mathrm{av}=23.5 \mu)$ and $7.6-13.6 \mu$

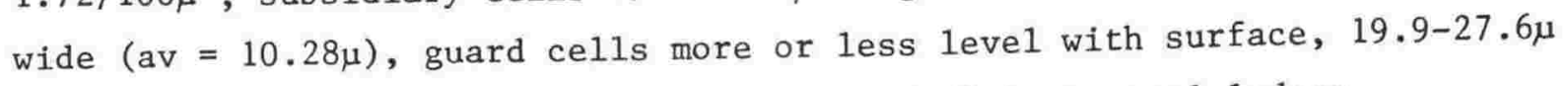
long $(\mathrm{av}=22.9 \mu)$ and $4.6-6.15 \mu$ wide $(\mathrm{av}=5.38 \mu)$, stomatal 1edges conspicuous, ?ornamented, poles of guard cells often marked by overlapping subsidiary cells: trichomes absent from both surfaces.

Ref. specimen: V2856.51, Central Otago Lignite Measures, St. Bathans Beds, Pareora to Southland Series, Lower to Mid Miocene, H41/f028, clay bed in sluiced ground, west end of Blue Lake, St. Bathans, Central Otago, H41 577888, A.M. Holden, P. Vella and C. Vella 1981: Victoria University, Wellington.

Dimensions: $54 \mathrm{~mm}$ long and $23 \mathrm{~mm}$ broad.

Illustrated specimens: V2856.27 from the type locality; B38.77, Frog Flat Formation, Waiauan to Tongaporutuan Stages, Mid to Upper Miocene, M30/f8503, various localities on Maruia Saddle road, R.P. Suggate, D. Kear, J.C. Schofield and E.T. Annear, 1949. Other material examined: B38.27, M30/f503, various localities on Maruia Saddle road, collected by R.P. Suggate, D. Kear, J.C. Schofield and E.T. Annear, 1949; V2849.55 Nevis Formation, 011 Shale Member, Pareora Series, Lower Miocene, F42/f001, Shale Ridge, Nevis Valley, F42 955535 , A.M. Holden, P. Vella and C. Vella, 1981.

Stratigraphic range: Lower - Upper Miocene.

OLM007 Species D

Figs $15.4,15.5,15.6,15.7,15.9,15.10$

Mesophy11, leaves 60-150 mm long and 20-45 mm broad, narrow elliptic to lanceolate; apex attenuate; base cuneate, sometimes somewhat asymmetrical; margin entire; petiole stout; venation pinnate, eucamptodromous to brochiodromous; midrib stout, straight; secondaries weak, numerous, irregularly spaced, subopposite to alternate, diverging at moderate to wide angles, angle varying somewhat irregularly but generally narrowest mid leaf, course straight, curved or branched, 
joining superjacent at acute to right angles, loops enclosed by secondary, tertiary and higher order arches; intersecondaries numerous, simple and composite; tertiaries diverging at variable angles, reticulate, somewhat random, areoles possibly incomplete, random, irregular with branched included veinlets.

Leaves of this type are one of the commonest fossils at the several Bannockburn localities and at St. Bathans. The venation somewhat resembles that of Pittosporum eugenioides, but the leaf shape is different. Similar venation patterns are also found in Elingamita (Myrsinaceae) and in species of Sapotaceae, Euphorbiaceae and Araliaceae. The Central Otago fossils resemble the fossil species Nothopanax reticulatus from Pleistocene rocks in Poverty Bay (Oliver 1928).

Ref. specimen: B197.4, B197.5 (counterparts), Central Otago Lignite Measures, Manuherikia Group, Pareora to Southland Series, Lower to Mid Miocene, Bannockburn, A. McKay 1882; N.Z. Geological Survey.

Dimensions: $97 \mathrm{~mm}$ long and $36 \mathrm{~mm}$ wide.

Illustrated specimens: V2850.19, Manuherikia Group, Pareora to Southland Series, F41/f209, Bannockburn, new road cut $200 \mathrm{~m}$ north of new road bridge over Bannockburn Creek, F41 088622, A.M. Holden, P. Vella and C. Vella 1981; V2853.3, Manuherikia Group, Pareora to Southland Series, F41/f212, fallen blocks, true left bank of Kawerau River opposite mouth of Bannockburn Creek, F41 085629, A.M. Holden, P. Vella and C. Vella 1981; V2856.1, V2856.32, V2856.45, St. Bathans Beds, Pareora to Southland Series, H41/f028, clay seam in sluiced ground, west end of Blue Lake, St. Bathans, Central Otago, H41 577888, A.M. Holden, P. Vella and C. Vella, 1981.

Other Material examined: B197.54 from the type locality; B1036.21, B1036.27, B1036.29, B1036.35, B1036,39, B1036.46, B1036.47, F41/f9513, Bannockburn, F41 088624, R.I. McPherson 1968; V2850.2, V2850.3, V2850.6, V2850.15, V2850.23, F41/f209, Bannockburn, F41 088622, A.M. Holden, P. Vella and C. Vella, 1981; V2851.14, F41/f210, Bannockburn, true right bank of Kawerau River $100 \mathrm{~m}$ from mouth of Bannockburn Creek, bluffs below road, F41 086628, A.M. Holden, P. Vella and C. Vella 1981; V2856.20, V2856.23, V2856.43, V2856.46, V2856.67, V2856.74, V2856.75, V2856.76, V2856.83, H41/f028, St. Bathans, H41 577888, A.M. Holden, P. Ve1la and C. Ve11a, 1981 . Stratigraphic range: Lower to Mid Miocene. 


\section{GLM016 Species E}

Figs $15.8,15.11$

Mesophy11, leaves 80-180 mm long and 25-45 mm broad, lanceolate; apex attenuate, base more or less rounded; margin entire; venation pinnate, camptodromous; midrib moderate, straight; secondaries numerous, weak, diverging at variable angles, often strongly reflexed, sinuous, curved, straight or branched, uniting to form marginal vein 2-3 mm from margin; intersecondaries simple to composite. Tertiaries poorly differentiated from higher vein orders, angle of divergence variable, randomly reticulate; lower epidermis with somewhat elongate cells in areolar areas, anticlinal walls sinuous, stomatal complex ?anomocytic (fig 8.18 ).

The pattern of venation suggests possible affinities with Myrtaceae, Moraceae, Apocynaceae, Myrsinaceae or: Sapotaceae.

Ref. specimen: V2841.27 and 27A (counterparts), Gore Lignite Measures, Duntroonian to Waitakian Stages, Upper Oligocene to Lower Miocene, G45/f058, Landslip Hill, Pukerau near Gore, Southland, siliceous boulders at south end of hilltop, $200 \mathrm{~m}$ from plantation boundary, G45 125530, A.M. Holden, and P. Vella 1981; Victoria University, Wellington.

Dimensions: $98 \mathrm{~mm}$ 1ong and $25 \mathrm{~mm}$ wide.

Illustrated specimen: V2841.87A, from the type locality. Other material examined: V2841.7, V2841.8, V2841.23, V2841.24, V2841.26, V2841.28, V2841.42, V2841.64, V2841.72, V2841.79, V2841.87, from the type locality; V2842.5, V2842.11, V2842.13, G45/f063, fallen boulders at foot of slip scarp, G45 124533, A.M. Holden and P. Vella, 1981.

Stratigraphic range: Upper Oligocene to Lower Miocene. 
Microphyl1 to small mesophy11, 40-90 mm 1ong and 20-45 $\mathrm{mm}$ broad, elliptic to ovate or obovate; apex ?acute; base obtuse to cuneate, margin crenate-serrate, teeth prominent, obtuse with convex sides, or rounded, somewhat irregularly spaced, sinus angular; lamina gland-dotted; venation craspedodromous, simple or semicraspedodromous, sometimes mixed in the same leaf; midrib moderate to stout, straight; secondaries diverging at moderate angles, more or less regularly spaced, frequently branched and branches often uniting to form rough, angular loops; tertiaries diverging at acute angles from the lower side of the secondaries and obtuse angles from the upper, percurrent, forked, retroflexed or convex, usually more or less horizontal except close to the midrib; highest order of venation 6 th or $7 \mathrm{th}$, higher vein orders random, areoles small, polygonal, imperfect, with ?twice branched included veinlets.

Leaves of this form are among the commonest fossils at St. Bathans. A few leaves have also been found at Bannockburn. The characters displayed suggest an affinity with Cunoniaceae, for example Weinmannia, but the fossil leaves are larger than those of either of the living New Zealand species.

Ref specimen: V2856.20, Central Otago Lignite Measures, St. Bathans Beds, Pareora to Southland Series, Lower to Mid Miocene, H41/f028, clay seam in sluiced ground, west end of Blue Lake, St. Bathans, Central Otago, H41 577888, A.M. Holden, P. Vella and C. Vella 1981; Victoria University, Wellington.

Dimensions: $73 \mathrm{~mm}$ long and $39 \mathrm{~mm}$ broad.

I1lustrated specimens: V2856.3, V2856.77, from the type locality; B1036.38, B1036.47, Manuherikia Group, Pareora to Southland Series, F41/f9513, basal beds of mid Tertiary section exposed west of bridge to Cairnmuir Station over Bannockburn, F41 088624, R.I. McPherson, 1968. Other material examined: B1036.79, F41/f9513, Bannockburn, F41 088624, collected by R.I. McPherson, 1968; V2856.2, V2856.6, V2856.8, V2856.9, V2856.16, V2856.22, V2856.23, V2856.26, V2856.29, V2856.32, V2856.33, V2856.37, V2856.42, V2856.47, V2856.48, V2856.54, V2856.67, V2856.68, $\mathrm{V} 2856.69, \mathrm{~V} 2856.70$, V2856.71, V2856.80, V2856.82, from the type locality. Stratigraphic range: Lower to Mid Miocene. 


\section{SMILACACEAE}

KLB011 Ripogonum latipetiolatum (Oliver) comb. nov. Figs 16.6,16.7,16.8 Coriaria latipetiolata 01iver 1936: 298, fig 17

Leaves 40-100 mm long and 15 to $50 \mathrm{~mm}$ broad, ovate, apex missing in all fossils, base obtuse; margin entire; petiole rather long, broad; venation acrodromous, basal, ?perfect; midrib moderate, about $1 \mathrm{~mm}$ broad midleaf, straight; laterals weaker, curved; secondaries diverging at moderate to wide angles, those from outer side of laterals abruptly curved near margin and joining superjacent at obtuse angles to form marginal vein enclosed by a series of tertiary arches; tertiaries ramified, transverse, diverging at various angles, higher order venation poorly differentiated, random; areolation ?lacking.

Fragmentary cuticle was obtained from some fossils, but a complete cuticular description was not possible. Cells in areolar areas roughly rectangular, thick-walled, random, end walls square or oblique, anticlinal walls undulate, undulations "U" shaped; stomatal complex lacking subsidiary cells, sunken. The material was too fragmentary for stomatal frequency to be assessed.

0liver's identification was based on a single fossil, which he assigned to Coriaria on venation characters. A number of other fossils were collected by the writer, and it was from these that cuticular preparations were made. Venation patterns in Coriaria and Ripogonum are closely similar. All living species of Coriaria so far examined by the writer have subsessile leaves, whereas leaves of Ripogonum have long broad petioles. The large, rectangular epidermal cells with undulate cell walls are consistent with Ripogonum. Species of Coriaria so far examined
have straight anticlinal walls to the epidermal cells, with prominent pitting.

The living New Zealand species, R. scandens, J.R. et F. Forst, is a liane of podocarp dominated, or hardwood forests of lowland and montane zones in both islands. It is often common in semi-swamp forests, and may be an indicator of alluvial and colluvial substrata (Macmillan 1972). 
Holotype: WELT 44553, Kaikorai Leaf Beds, ?Waiauan Stage, Mid Miocene, Fraser's Gully, Kaikorai Valley, I44 135797, W.R.B. Oliver, 1929;

National Museum, Wellington.

Dimensions: $67 \mathrm{~mm}$ long and $45 \mathrm{~mm}$ broad.

I1lustrated specimens: V2847.12, V2847.17, Kaikorai Leaf Beds,

?Waiauan Stage, I44/f134, Fraser's Gully, Kaikorai Valley, I44 135797 ,

A.M. Holden, P. Ve1la and J.D. Campbe11, 1981.

Other Material examined: V2847.3, 5, 8, 16, from the type locality;

V2846.2, Kaikorai Leaf Beds, J44/f002, Taiaroa Head, Dunedin, J44 333898 , A.M. Holden and P. Vella 1981.

Stratigraphic range: Mid to Upper Miocene.

OLM007 Ripogonum SP.

Fig 16.9

Mesophy11, leaves 60-140 mm 1ong and 25-70 mm broad; ovate, sometimes asymmetrical, apex acute to obtuse, base more or less rounded, margin entire; venation acrodromous, suprabasal; midrib moderate, straight or curved; laterals 4-6, progressively weaker towards margin; midrib and laterals joined by oblique, more or less parallel veins; tertiaries randomly reticulate or ramified, diverging generally at acute angles, higher order venation poorly differentiated into vein orders, random; marginal venation looped.

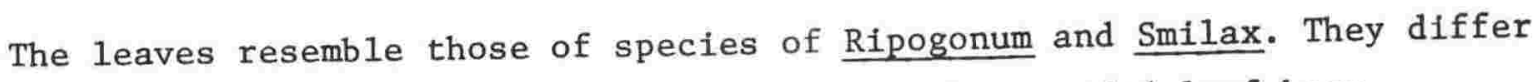
from the fossil Ripogonum latipetiolatum in the rounded leaf base.

Pef. specimen: B1036.35, Central Otago Lignite Measures, Manuherikia Group, Pareora to Southland Series, Lower to Mid Miocene, F41/f9513, basal beds of mid-Tertiary section exposed west of bridge to Cairnmuir Station across Bannockburn, F41 088624, R.I. McPherson, 1968; N.Z. Geological Survey. Dimensions: $134 \mathrm{~mm}$ long and $60 \mathrm{~mm}$ broad. Other material examined: B1036.3, B1036.24, B1036.25, B1036.26, B1036.37, $\mathrm{B} 1036.47$, $\mathrm{B}: 036.50$, from the type locality. Stratigraphic range: Lower to Mid Miocene. 
The present islands of New Zealand are the largest emergent parts of a mostly submerged block of continental crust. During Paleozoic and early Mesozoic times the block formed part of the foreland and the marginal geosyncline of the Gondwana supercontinent (Fleming 1979). The geosyncline may have extended across Antarctica to South America (Andean Geosyncline) but this is disputed (Katz 1973). Reconstructions based on sea-floor spreading data (Griffiths 1971; Griffiths and Varne 1972; Carter and Norris 1976; Smith and Briden 1977; Crook and Belbin 1978) place New Zealand between southeastern Australia and Marie Byrd Land (West Antarctica) and geological similarities are consistent with this interpretation (Cooper 1975; 1976). Close similarities in 1ithology and faunas between geosynclinal deposits in New Zealand and New Caledonia suggest a close relationship and the later geological histories of both show remarkable similarities (Avias 1953; Lillie and Brothers 1970).

From considerations of Gondwana reconstructions it is clear that the New Zealand botanical region should not be considered as a series of isolated oceanic islands, but as the emergent parts of a microcontinent, the average elevation of which is considerably below sea level. So defined, the region would include New Caledonia and Lord Howe and Norfolk Islands, and possibly Fiji as well. Early Tertiary dispersal of plants along such an extended system and in situ evolution could account for the diverse elements (Cockayne 1928) of the present flora. The key to New Zealand biogeography lies in the extent to which the New Zealand microcontinent was emergent during the period following the formation of the Tasman ocean basin. Seismic profiling indicates that the Lord Howe Rise has probably been under fairly deep water since at least Eocene times (Willcox et a1. 1980) but data are sparse. So far there has been little investigation of the Norfolk Ridge.

New Zealand Paleozoic and earlier Mesozoic floras as far as they are known are similar to, if not identical with, those of Antarctica and eastern Australia (Mildenhal1 1970b,1980; Retallack 1977a, 1979, 1981) and are typical Gondwana assemblages. The similarity between the New Zealand and Australian floras persisted until late Cretaceous times (Mildenha11 1980), but subsequent1y diverged. It is now generally accepted that at least 
part of the Tertiary flora of New Zealand is derived from the late Cretaceous flora of eastern Gondwana (Fleming 1979), but it is uncertain how large this Gondwana element is and how and when the remaining plants arrived.

Fossil pollen (Mildenhall 1980) and plant megafossils (this account; Ettingshausen 1887; Oliver 1928, 1936, 1950; Penseler 1930) support Ettingshausen's contention that only part of the New Zealand Tertiary flora has been ancestral to the present, the other part having become extinct without living local descendants. The substance of Ettingshausen's work, however, was based on the hypothesis that there existed a worldwide Tertiary flora which was fragmented by the events of the Pleistocene and subsequently gave rise to the present floral provinces by extinction and evolution (Marshall 1901). Even a superficial survey of world fossil floras is sufficient to show that floristic provinciality has been a feature of world vegetation periodically since Permian times (Gould 1982).

Although a world-wide uniform Tertiary flora can no longer be seriously entertained, the abundance of Nothofagus pollen in the Tertiary record of Australia, New Zealand, South America and Antarctica has led some authors to suggest the existence of a Tertiary southern hemisphere 'Nothofagus flora' of which most of the species grew in beech/conifer dominated rainforests (Gill 1975). Megafossil assemblages do not fully support this concept. In Australia, although Nothofagus pollen is common in most mid-Miocene and older Tertiary sediments (Martin 1978), fossil Nothofagus leaves are absent from many Tertiary localities (D.C. Christophe1, pers. comm.). The present study indicates that a similar situation may have existed in parts of New Zealand. Fossiliferous sediments at St. Bathans and Roxburgh both yielded assemblages with abundant Nothofagus pollen (D.T. Pocknal1, report appendix A), but no Nothofagus leaves or fruits, and at Bannockburn and Nevis only occasional Nothofagus leaves were found.

The discrepancy may well be due to the ease with which Nothofagus pollen is transported by wind. Work by McKellar (1973) and Myers (1973) has shown that Nothofagus 'fusca' type pollen can constitute a substantial proportion of the modern pollen rain at considerable distances (up to $60 \mathrm{~km}$ ) from the nearest source, but that Nothofagus 'menziesii' type 
pollen is not so readily transported (McKellar 1973) and may be underrepresented in fossil pollen assemblages. Mildenhall (1976) reported Nothofagus 'fusca' type pollen as one of the commonest exotic pollens in Pleistocene peat samples from the Chatham Islands, about $650 \mathrm{~km}$ from the nearest present-day stands of beech on the New Zealand mainland. Isolated grains have been found in Quaternary peat on Tristan da Cunha, over $4000 \mathrm{~km}$ from the nearest source in South America (Hafsten 1960). Available data indicate that Nothofagus 'brassii' type pollen is also transported long distances (D.C. Mildenhall, pers. comm.). The possibility of Nothofagus being over-represented in megafossil assemblages was discussed earlier (see Introduction). If as seems probable, Nothofagus (at least 'brassii' and 'fusca' types) are also over-represented in fossil pollen assemblages, the fossil record may present a distorted picture of the status of the Southern beeches in Tertiary vegetation, and while undeniably the vegetation of some areas may have been dominated by Nothofagus, a uniformly Nothofagus-dominant flora as such probably did not exist.

Nothofagus forest as seen in present-day New Zealand does not exist in New Caledonia (Dawson 1963; pers. obs.), the closest approach being ridge crest stands of $\mathrm{N}$. aequilateralis (identified as $\underline{\mathrm{N}}$. balansae by Dawson) south of the Col de Rousettes (Dawson 1966), and N. baumannii on Mont Mou (pers. obs.). More often, trees occur in the rainforest, frequently as distinct groves (Dawson 1963; pers. obs.) although in the case of $\mathrm{N}$. discoidea in the upper Thy Valley there is considerable admixture of other rainforest trees (pers. obs.).

Most New Zealand pre-Pliocene Nothofagus leaves are large and similar in morphology to modern New Caledonian beeches, the exceptions being N. southlandica, N. australis and N. kaikoraiensis, all of which show similarities in morphology to modern South American species. While it is tempting to equate the former group with 'brassii' pollen type and the latter with 'fusca' or 'menziesii' pollen types, it is not safe to do so as leaf morphology does not appear to be invariably related to pollen morphology. Two living species, the South American N. allessandrii and the Australian N. moorei have a morphology similar to many New Zealand fossil beech leaves and to living New Caledonian species, but have 'fusca' and 'menziesii' type pollen respectively. 
Gymnosperms, a prominent element of lowland and montane to subalpine forests in New Zealand today appear on pollen evidence to have been important in Tertiary forests as well, but again, the megafossil evidence does not fully support this view. While conifer remains are abundant in the Landslip Hill silcrete flora they are uncommon elsewhere, perhaps as a result of under-representation as discussed earlier (see Introduction).

Pocknall (1978) analysed the pollen content of moss cushions from south Westland and found that conifer pollen tended to be frequent close to the site of growth but rare elsewhere. Podocarpaceous pollen probably can, however, be carried long distances as Mildenhall (1976) reported that pollen of Podocarpaceae formed a significant proportion of the exotic pollen in Chatham Island peats. Araucariaceae may also be underrepresented in fossil pollen assemblages, as percentages of araucariacean pollen are low in Southland and Central Otago lignites and associated sediments (D.T. Pocknall, pers. comm.) compared with the abundant megafossil remains (wood, resin, leaves, pollen cones etc.).

Another important element in the New Zealand Tertiary vegetation, as indicated by fossil pollen, are the Casuarinaceae. Ettingshausen (1887) illustrated vegetative fragments from Upper Cretaceous strata at Pakawau and Grey River (Casuarinites cretaceus) and Shag Point (Casuarina deleta), but the material has since been lost and Ettingshausen's illustrations are unconvincing. Casuarinaceae (represented by the palynomorph Haloragacidites trioratus syn. Triorites harrisii Couper (Mildenhall and Hlarris 1971)) are not known from rocks older than Teurian (Lower Paleocene) (Mildenhall 1980) and poorly preserved megafossils of Equisetum (Equisetaceae) or Ephedra (Gnetaceae) could be mistaken for Casuarina: Fossil spores similar to those of Equisetum are known from the Jurassic Ohika Beds (Couper 1953a) and Equisetacean megafossils are known from a number of mesozoic localities (0liver 1950). Ephedra pollen is known from the Late Cretaceous to P1iocene (Mildenhall 1980).

Because Casuarina pollen is known to be blown across the Tasman Sea from Australia (Moar 1969; Mildenhal1 1976; Close et al. 1978), botanists have been unimpressed by palynologist's claims that Casuarinaceae lived in New Zealand in Tertiary times, but definite casuarinacean megafossils are now reported in New Zealand Tertiary sediments (Campbe11 and Holden 1981). 
probably

The megafossils/represent both gymnostome and cryptostome Casuarinaceae, whereas the fossil pollen cannot be distinguished below family level.

A number of families represented in New Zealand today by only one or two species appear on pollen and megafossil evidence to have been better represented in the Tertiary, particularly Proteaceae, Euphorbiaceae and Sapotaceae (Mildenhall 1980; this account). Notable extinctions have also taken place in Myrtaceae (Xanthostemon/Tristaniopsis; ?Eucalyptus) and Leguminosae sensu 1ato (Acacia). Conversely, to date, there is little evidence in the mid-Tertiary fossil record of some plant groups prominent in the present-day vegetation, for example, Hebe and small leaved Coprosma species.

Like other major groups of vascular plants, ferns have been affected by extinctions and a notable example is a fossil from Maruia Saddle resembling a species of Antrophyum, a genus belonging to the small tropical family Vittariaceae. Oliver (1928) reported a fossil species of Platycerium from Castlecliffian sediments at Ormond, Poverty Bay. Species of Platycerium can be successfully grown out of doors in milder parts of New Zealand today (author's observation).

The reasons for the extinction of certain plants are not always obvious, given the ecological requirements of their living relatives (eg. Microcachrys, Dacrydium franklinoides or the performance of introduced relatives in New Zealand today, either in cultivation (Proteaceae, Myrtaceae - Eucalyptus and Syzygium, Casuarinaceae, Araucaria, Platycerium etc.) or as naturalised plants (Mimosaceae - Acacia, Myrtaceae Eucalyptus, Proteaceae - Hakea etc.). Equally puzzling is the survival of a number of thermophilic plants of mainly tropical affinity (Dysoxylum, Avicennia) while others (Bombax, Cocos) became extinct.

Several authors have classified the New Zealand flora into biotic elements from their geographic affinities (Cockayne 1928; Fleming 1962; 1979; van Balgooy 1971). Identified elements of the New Zealand mid-Tertiary megafloras studied reflect the same pattern of geographical relationships. These are summarised in Table 9.1. Voluminous literature on southern hemisphere biogeography has been reviewed from a New Zealand viewpoint by Craw (1978). Two schools of thought can be recognised - a "dispersalist" school and a "vicariance" school, the former exemplified by Darlington 

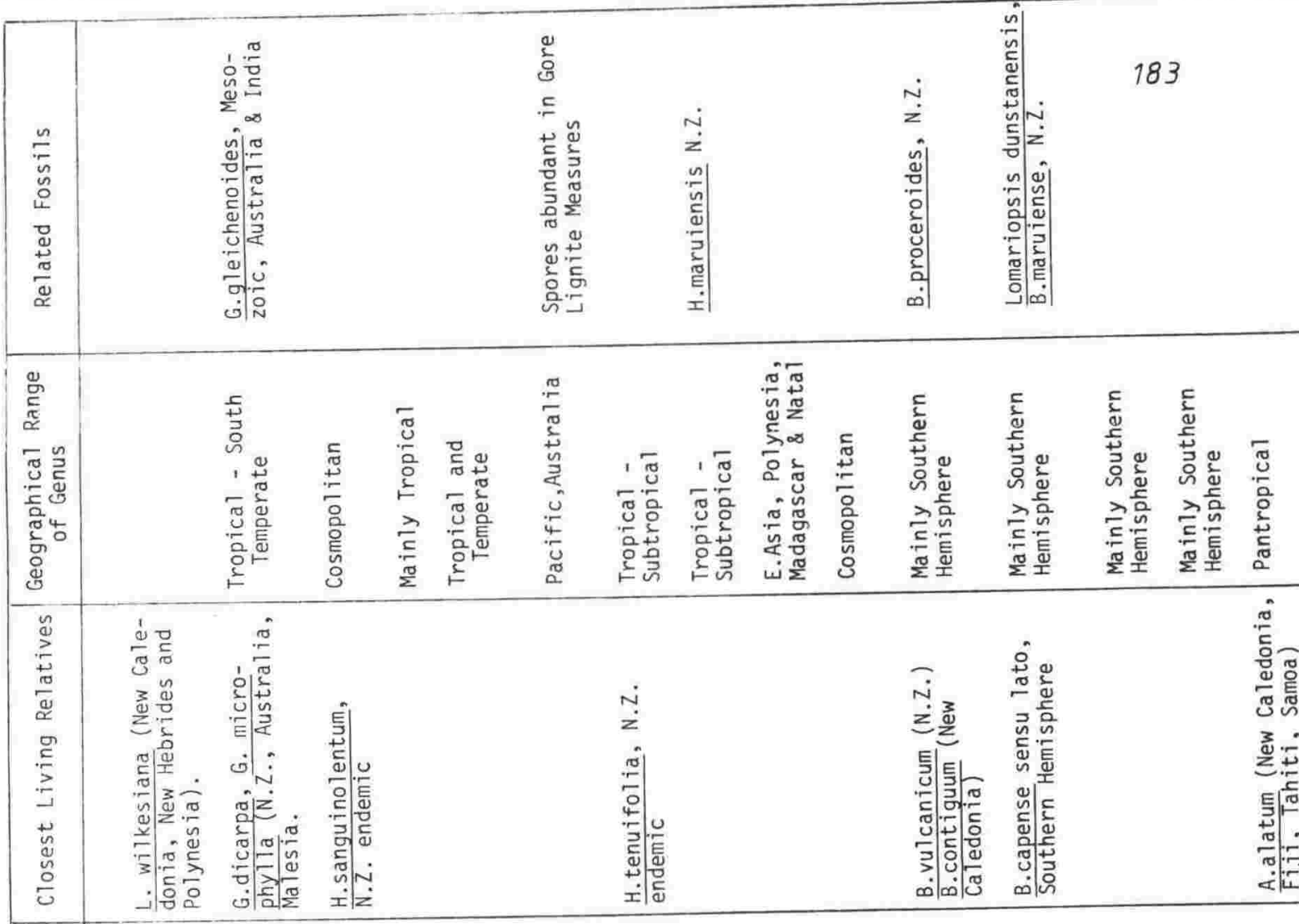

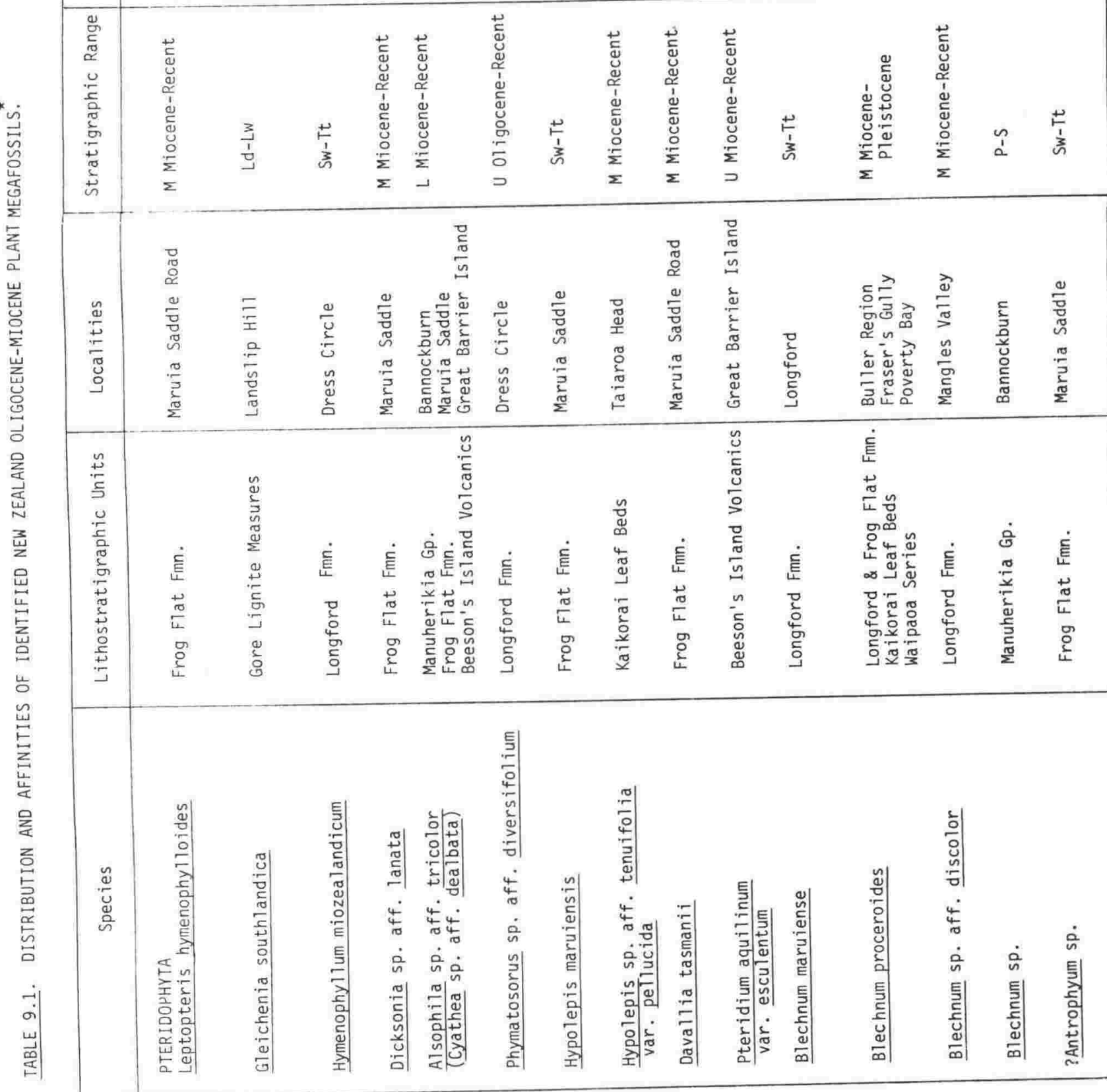




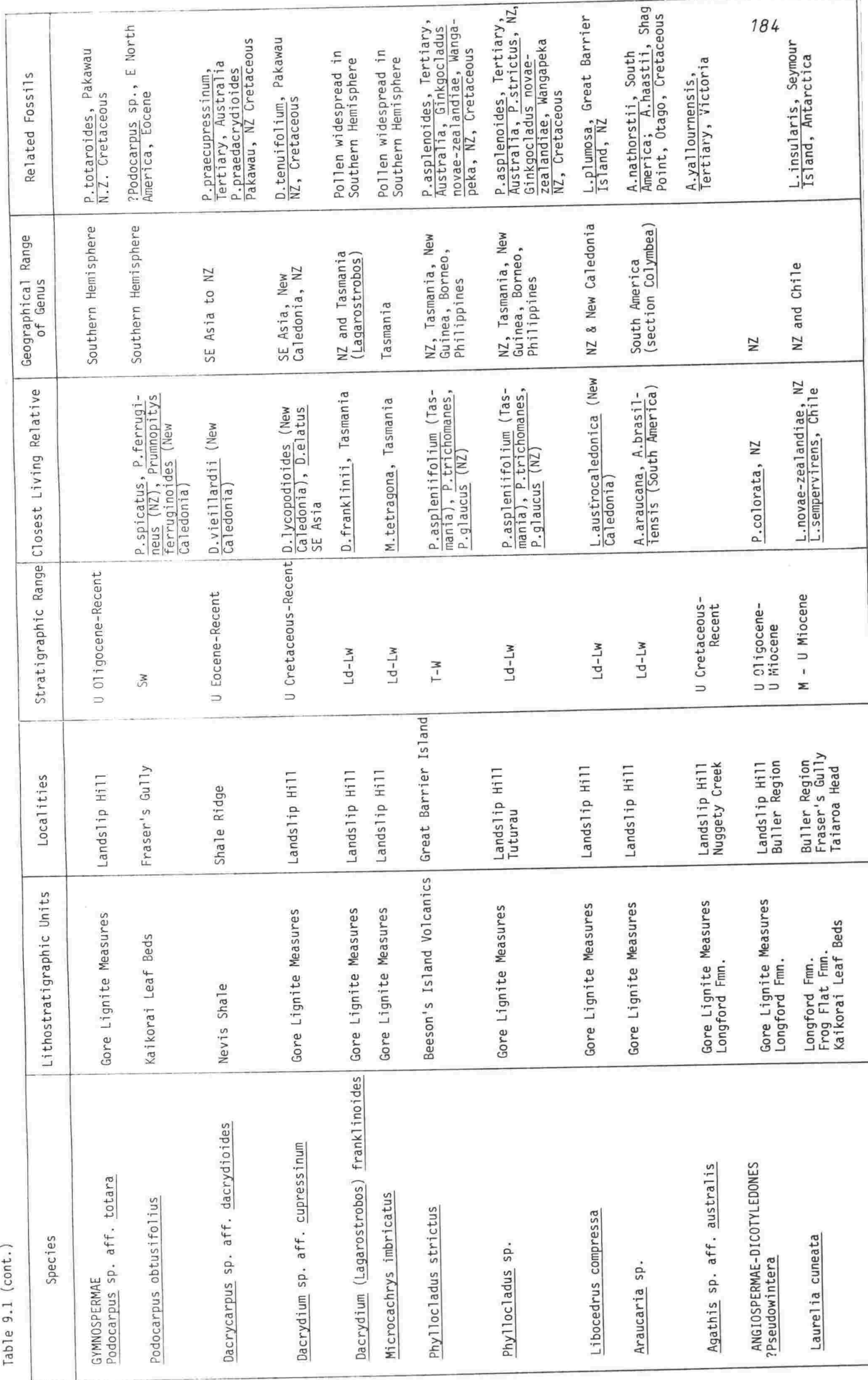




\begin{tabular}{|c|c|c|c|c|c|c|c|c|c|c|c|c|c|c|c|}
\hline 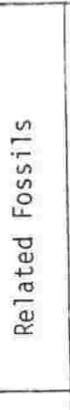 & & 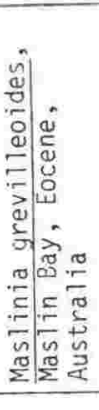 & 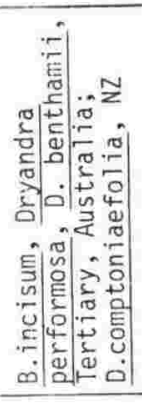 & 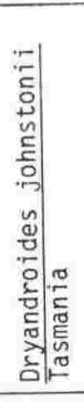 & 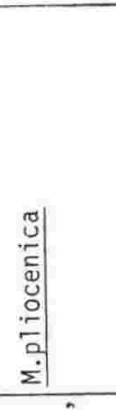 & 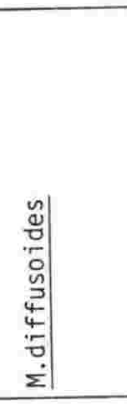 & & $\begin{array}{l}0 \\
0 \\
0 \\
\vdots \\
\vdots \\
\Sigma\end{array}$ & & 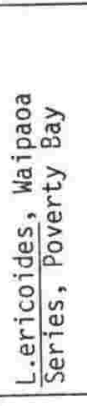 & & & 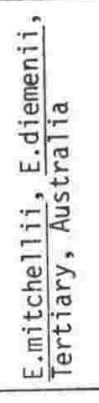 & 186 & \\
\hline 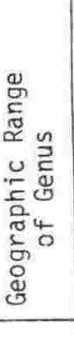 & & 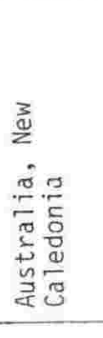 & & 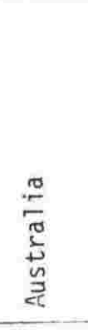 & 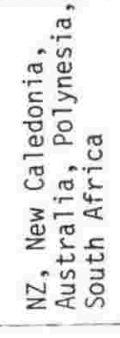 & 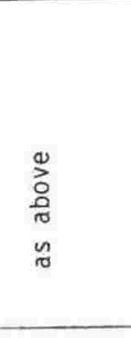 & $\begin{array}{l}\stackrel{0}{0} \\
\text { o. } \\
\tilde{\pi} \\
\tilde{\sigma}\end{array}$ & $\begin{array}{l}0 \\
\text { Dे } \\
0 \\
\tilde{0} \\
0 \\
0\end{array}$ & 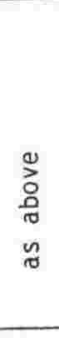 & 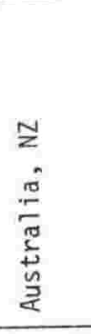 & 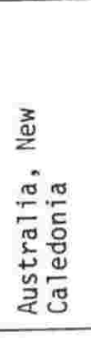 & $\tilde{z}$ & 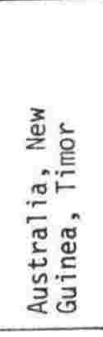 & & 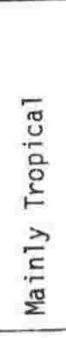 \\
\hline 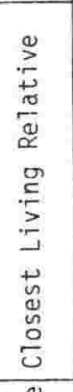 & 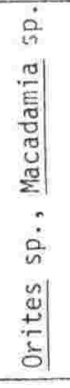 & 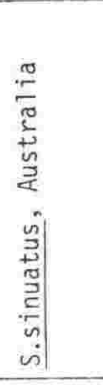 & 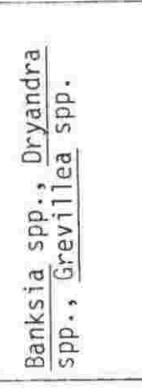 & & 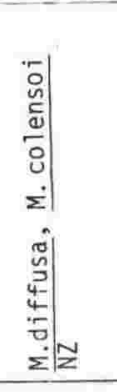 & 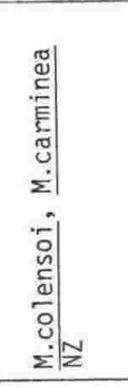 & 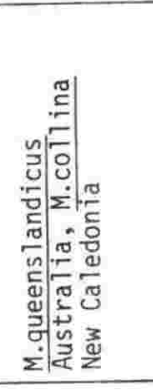 & 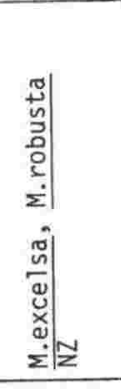 & 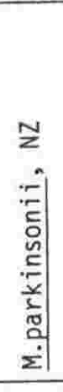 & 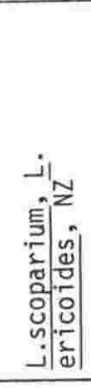 & 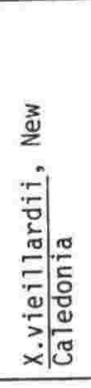 & 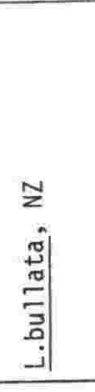 & & 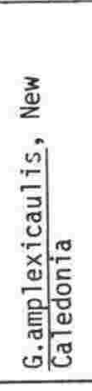 & 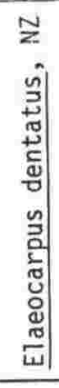 \\
\hline 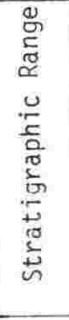 & 蒿 & $\hat{a}$ & $\begin{array}{l}3 \\
1 \\
0 \\
0\end{array}$ & 章 & $\begin{array}{l}\stackrel{\overrightarrow{5}}{\frac{1}{3}} \\
\vec{n}\end{array}$ & 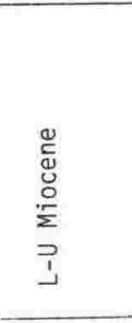 & 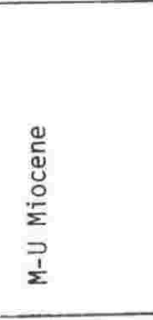 & 芦 & z & 3 & 䓂 & 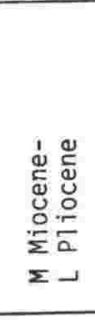 & $\hat{d}$ & $\stackrel{n}{a}$ & $\frac{3}{1}$ \\
\hline 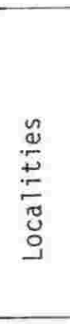 & 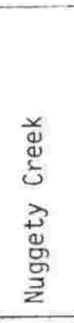 & 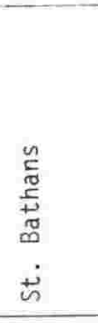 & 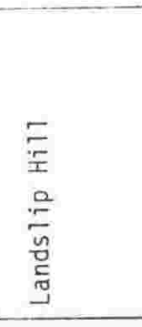 & 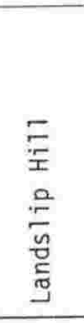 & 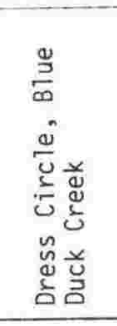 & 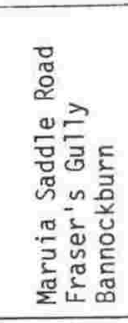 & 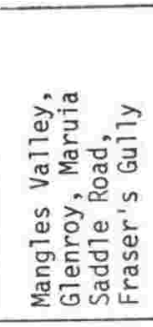 & 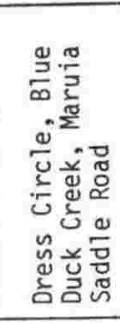 & 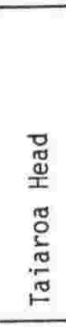 & 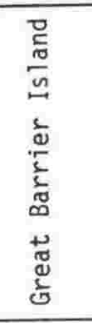 & 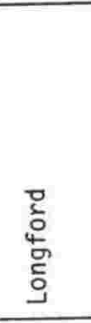 & 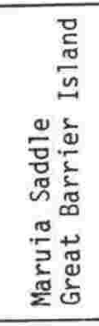 & 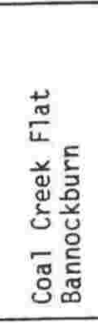 & 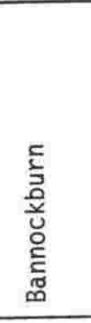 & 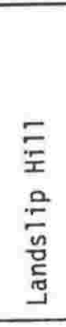 \\
\hline 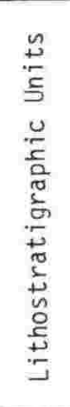 & 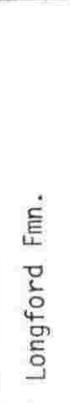 & 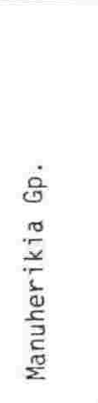 & 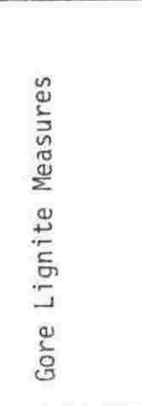 & 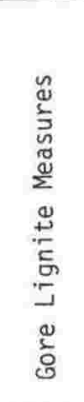 & 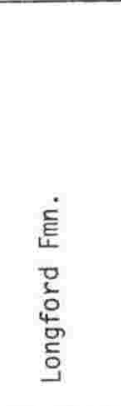 & 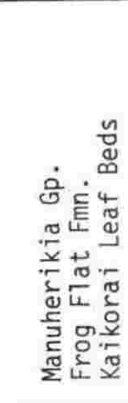 & 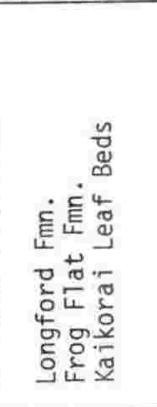 & 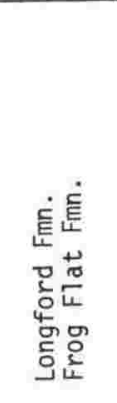 & 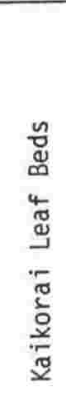 & 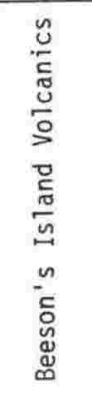 & 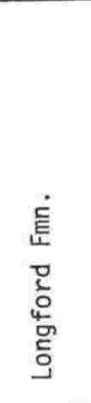 & 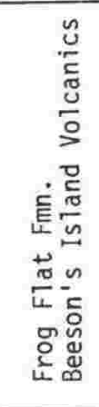 & $\begin{array}{l}\dot{0} \\
0 \\
\frac{\pi}{2} \\
\frac{\pi}{2} \\
\frac{0}{5} \\
\frac{\tilde{E}}{2} \\
\frac{\pi}{2}\end{array}$ & 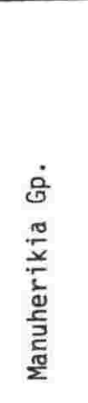 & 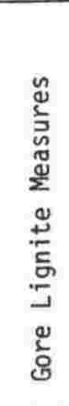 \\
\hline $\begin{array}{l}\frac{\tilde{u}}{\bar{u}} \\
\stackrel{\tilde{N}}{0}\end{array}$ & 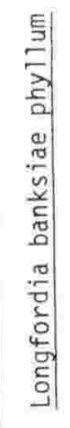 & 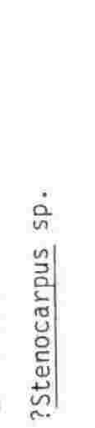 & 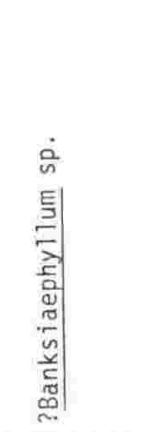 & 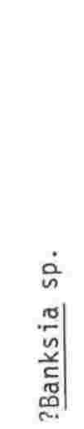 & 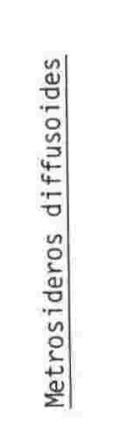 & 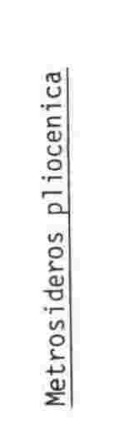 & 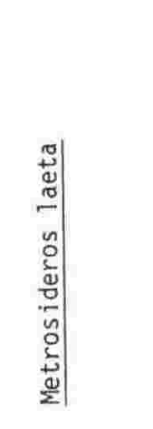 & 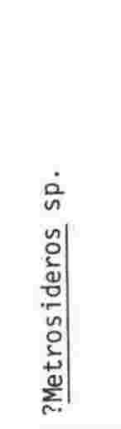 & 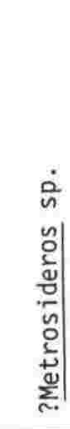 & 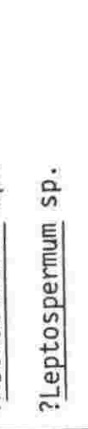 & 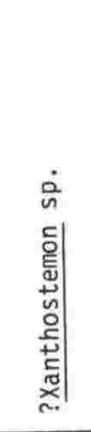 & 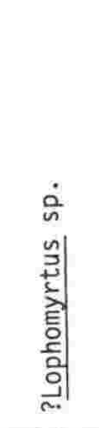 & 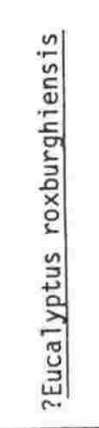 & 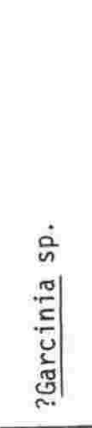 & 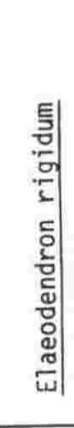 \\
\hline
\end{tabular}




\begin{tabular}{|c|c|c|c|c|c|c|c|c|c|c|c|}
\hline 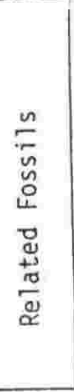 & 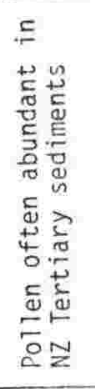 & 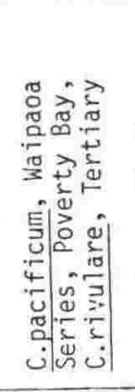 & 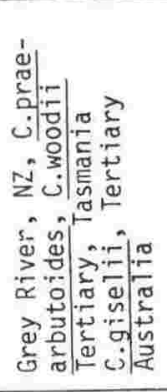 & & 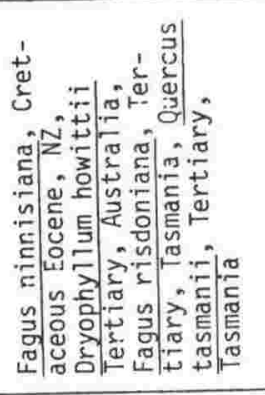 & 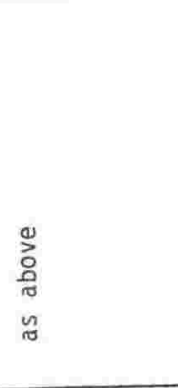 & 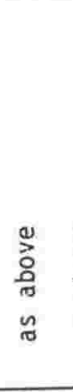 & 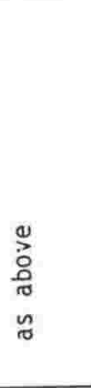 & & 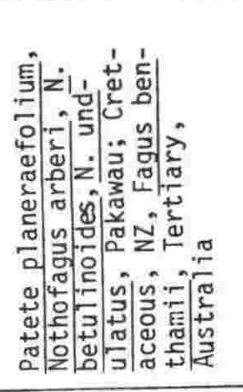 & 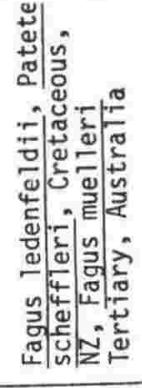 \\
\hline 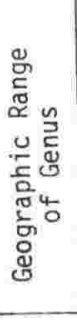 & 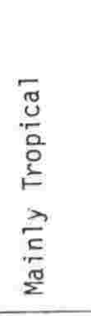 & 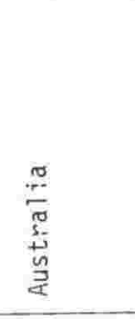 & & 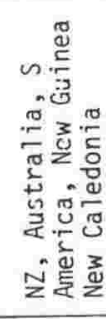 & 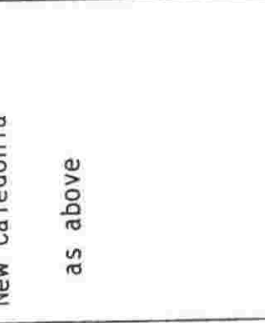 & 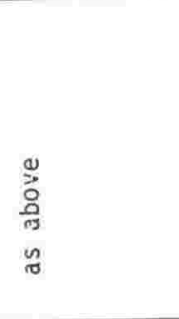 & 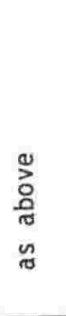 & $\begin{array}{l}0 \\
\text { Dे } \\
\text { Dे } \\
\text { n }\end{array}$ & 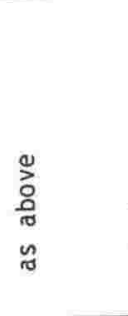 & 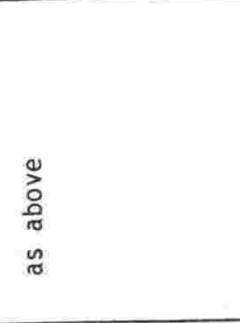 & 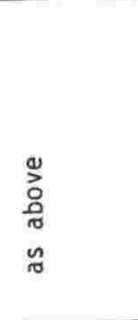 \\
\hline 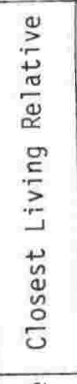 & 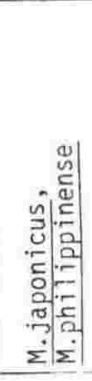 & 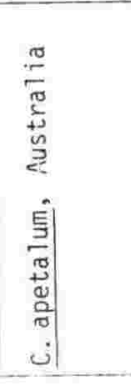 & & 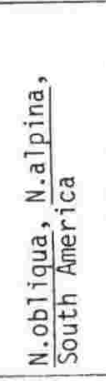 & 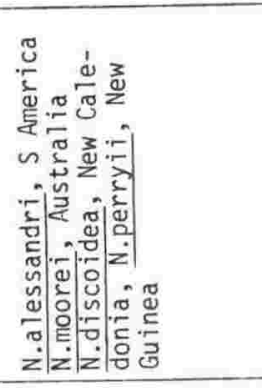 & $\begin{array}{l}0 \\
0 \\
0 \\
\pi \\
\pi\end{array}$ & $\begin{array}{l}0 \\
\text { Dे } \\
\text { D. } \\
\text { in } \\
10\end{array}$ & 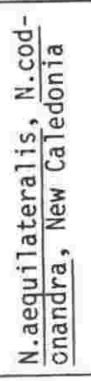 & 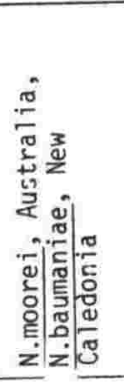 & & \\
\hline 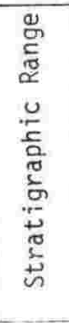 & \begin{tabular}{l}
$\stackrel{5}{F}$ \\
\multirow{3}{*}{}
\end{tabular} & 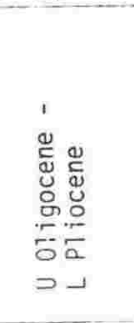 & & 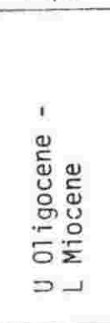 & 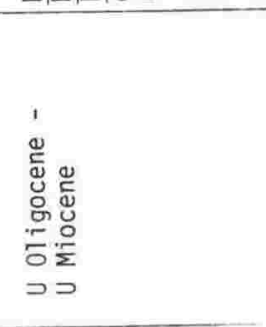 & 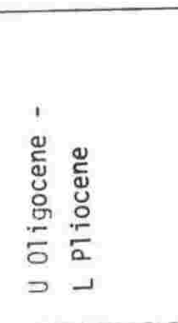 & z & 营 & 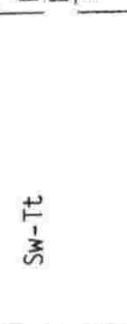 & 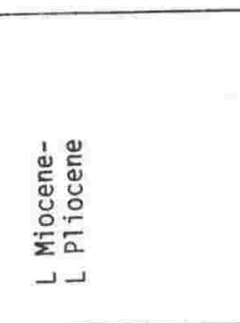 & 3 \\
\hline 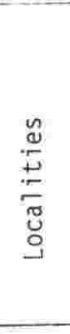 & 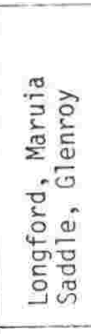 & 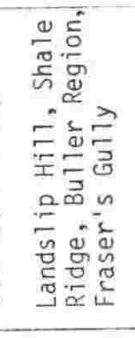 & 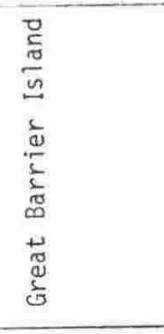 & 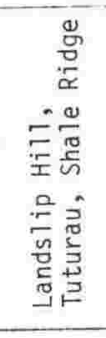 & 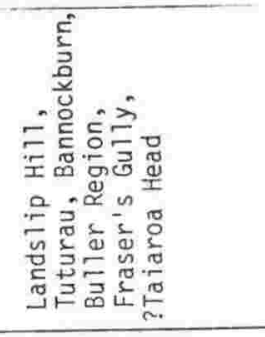 & 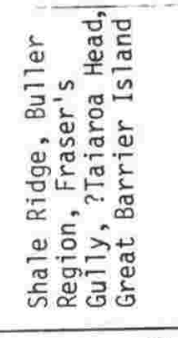 & 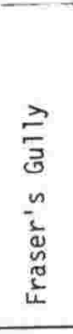 & 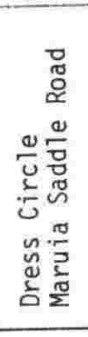 & 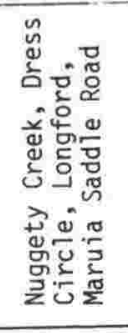 & 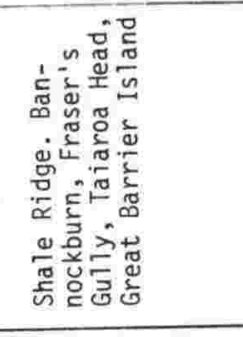 & 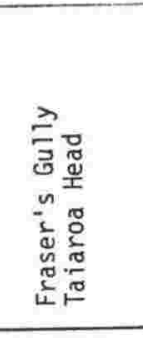 \\
\hline 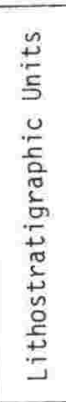 & 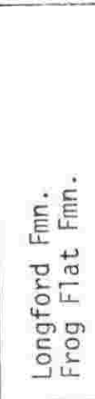 & 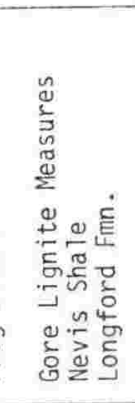 & 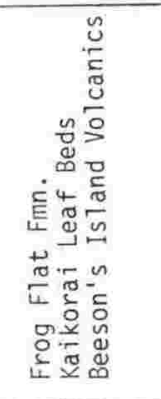 & 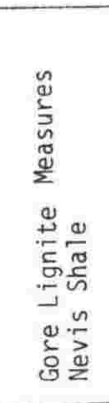 & 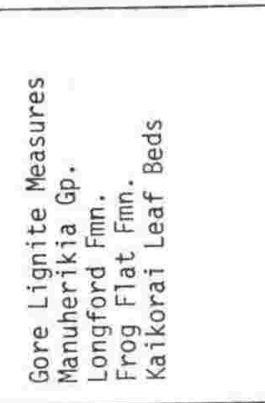 & 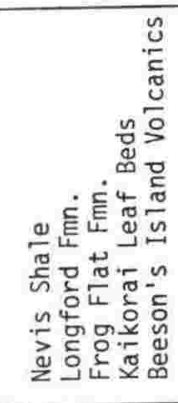 & 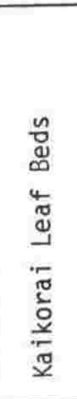 & 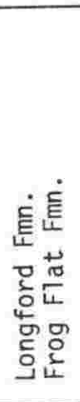 & 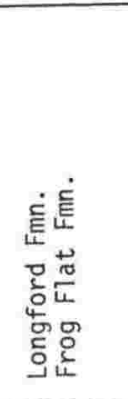 & 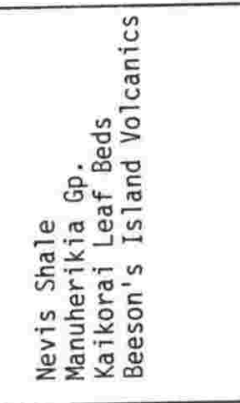 & 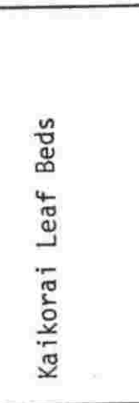 \\
\hline 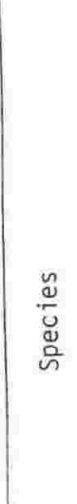 & $\begin{array}{l}\dot{0} \\
\dot{n} \\
\frac{3}{3} \\
0 \\
\frac{\pi}{0} \\
\frac{\pi}{2}\end{array}$ & 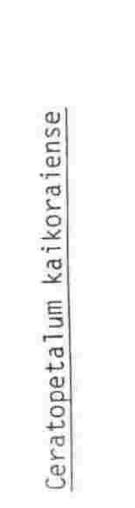 & 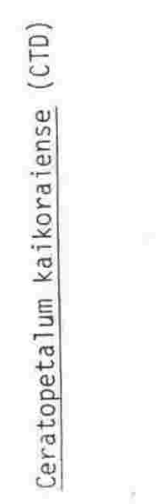 & 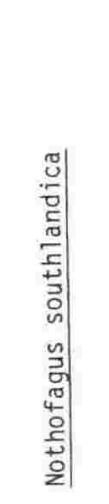 & 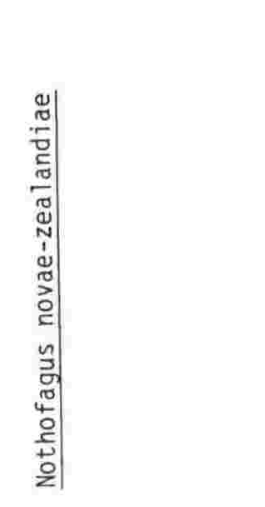 & 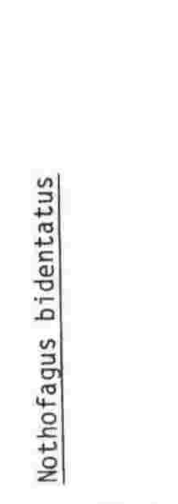 & 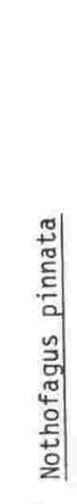 & 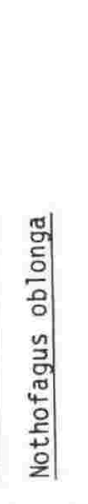 & 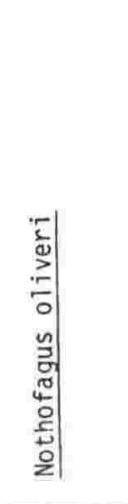 & 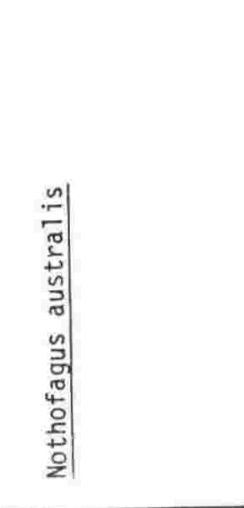 & 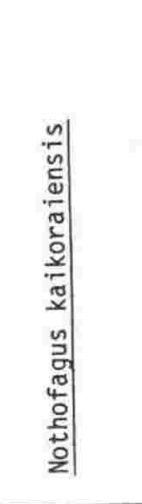 \\
\hline
\end{tabular}




\begin{tabular}{|c|c|c|c|c|c|c|c|c|c|c|c|c|c|}
\hline 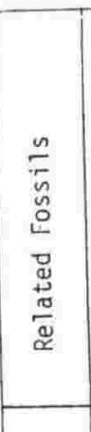 & 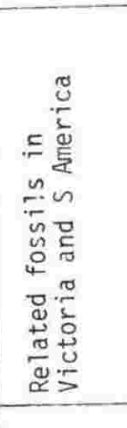 & 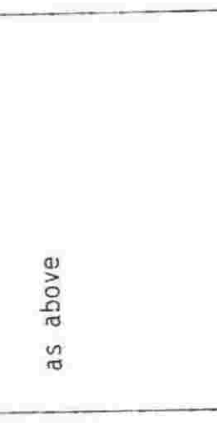 & & & & 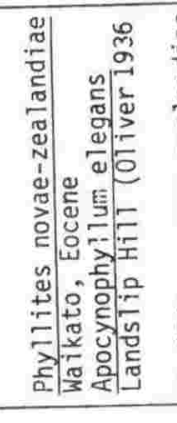 & 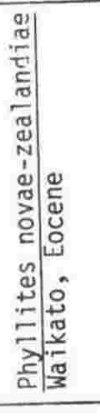 & & 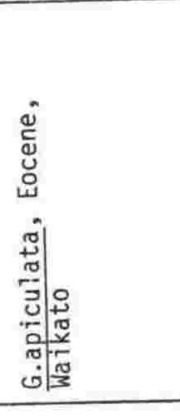 & 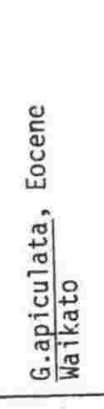 & & 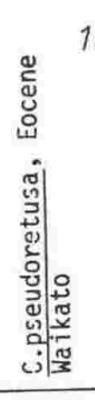 & 188 \\
\hline 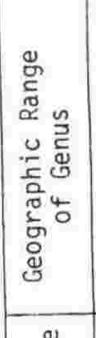 & 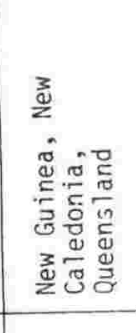 & 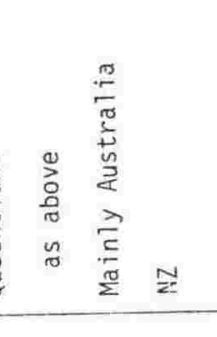 & 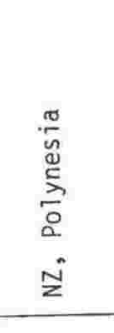 & 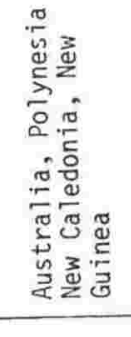 & 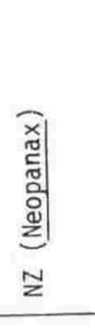 & & 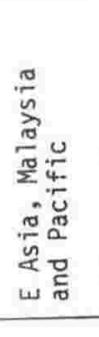 & 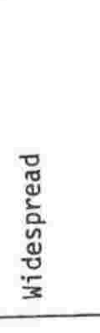 & 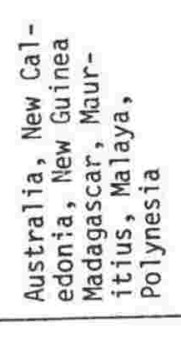 & 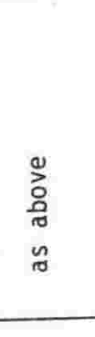 & 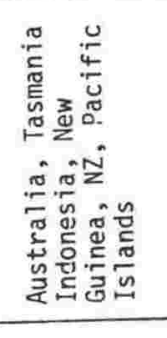 & 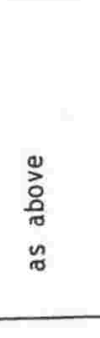 & 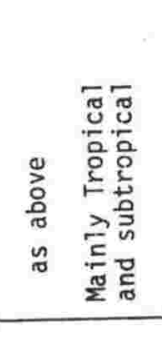 \\
\hline 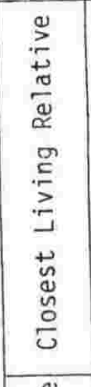 & 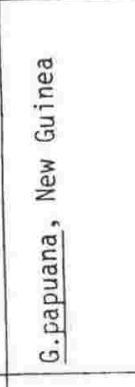 & 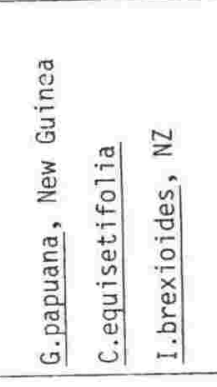 & 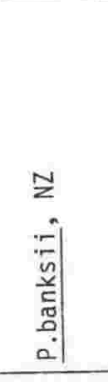 & 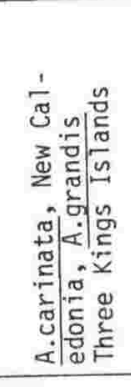 & 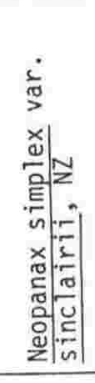 & & 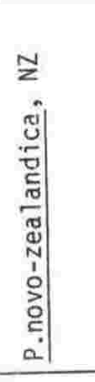 & 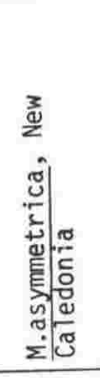 & 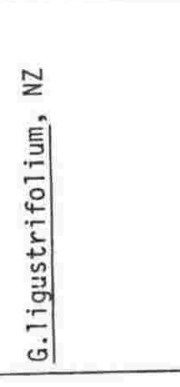 & & 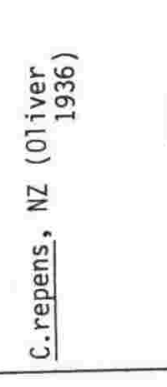 & 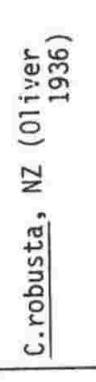 & 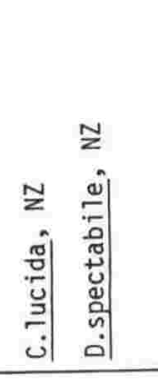 \\
\hline 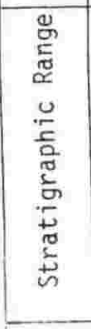 & 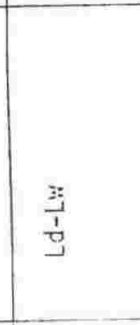 & 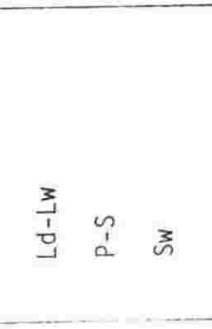 & 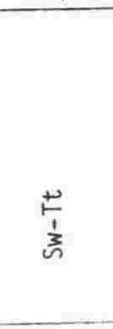 & 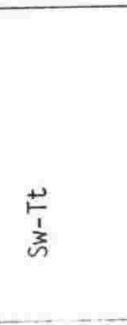 & ? & 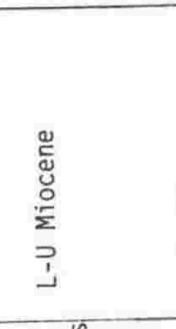 & 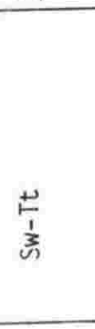 & 矛 & 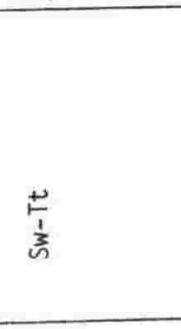 & $\tilde{a}$ & 夯 & s & 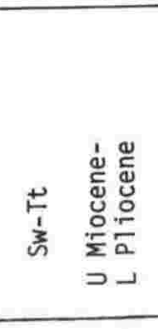 \\
\hline 兽 & 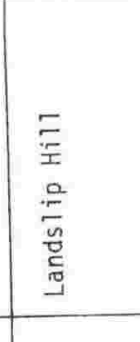 & 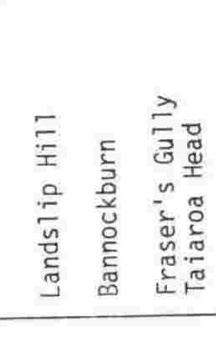 & 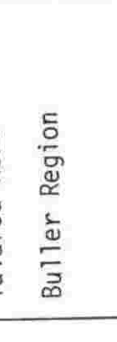 & 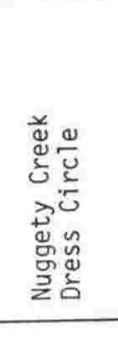 & 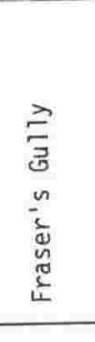 & 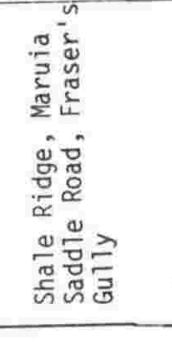 & 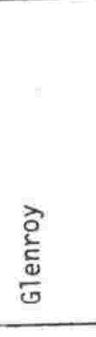 & 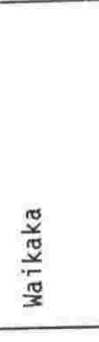 & 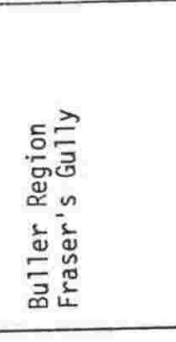 & 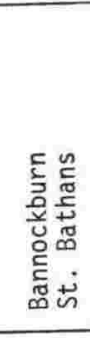 & 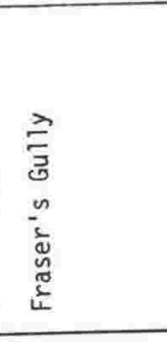 & 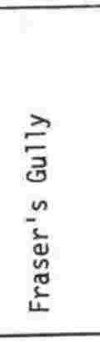 & 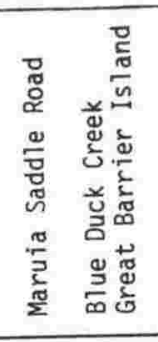 \\
\hline 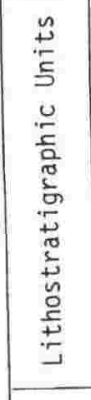 & 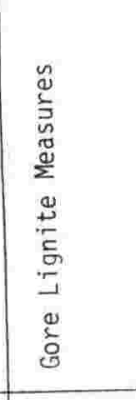 & 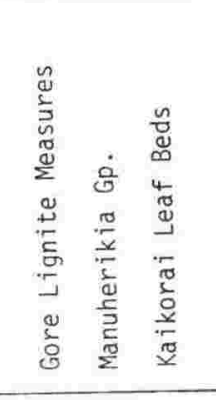 & 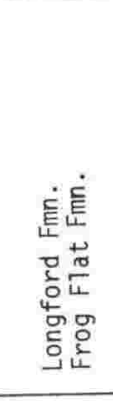 & 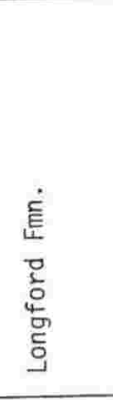 & 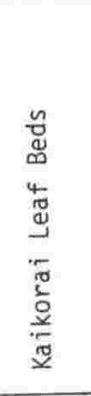 & 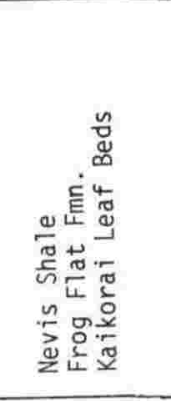 & 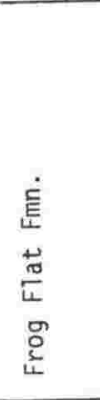 & 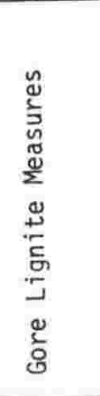 & 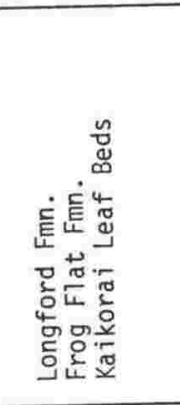 & 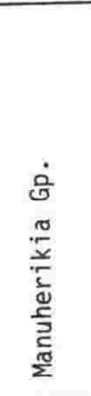 & 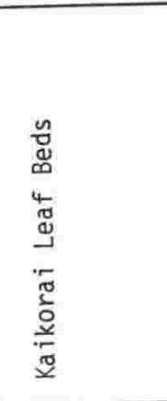 & 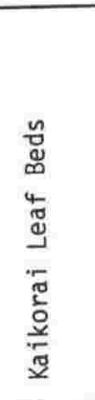 & 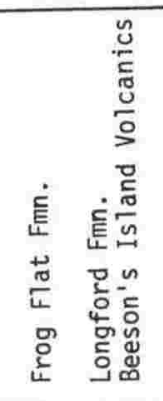 \\
\hline 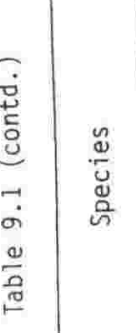 & 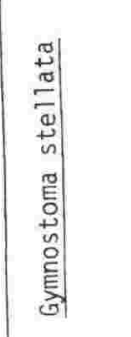 & 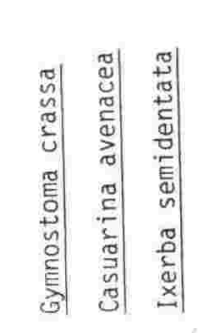 & 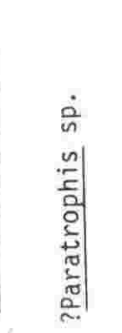 & 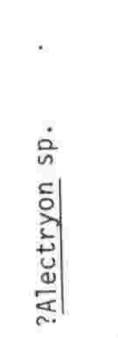 & 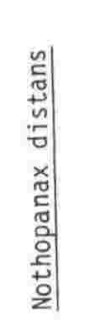 & 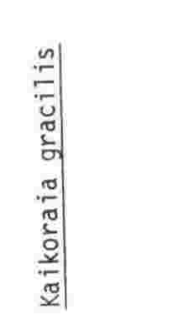 & $\begin{array}{l}\frac{1}{0} \\
\frac{0}{a} \\
\frac{0}{0} \\
\frac{0}{0} \\
\frac{0}{0} \\
\frac{0}{c}\end{array}$ & 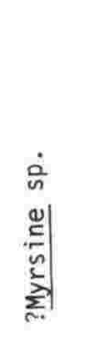 & 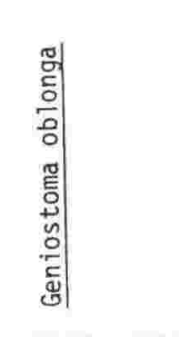 & 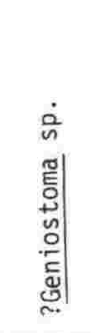 & 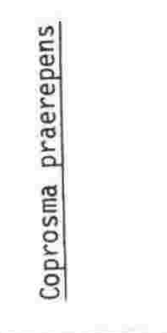 & 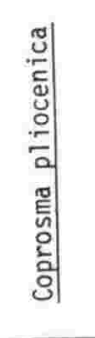 & 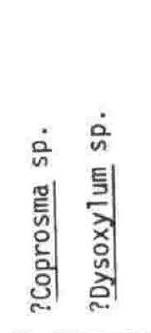 \\
\hline
\end{tabular}




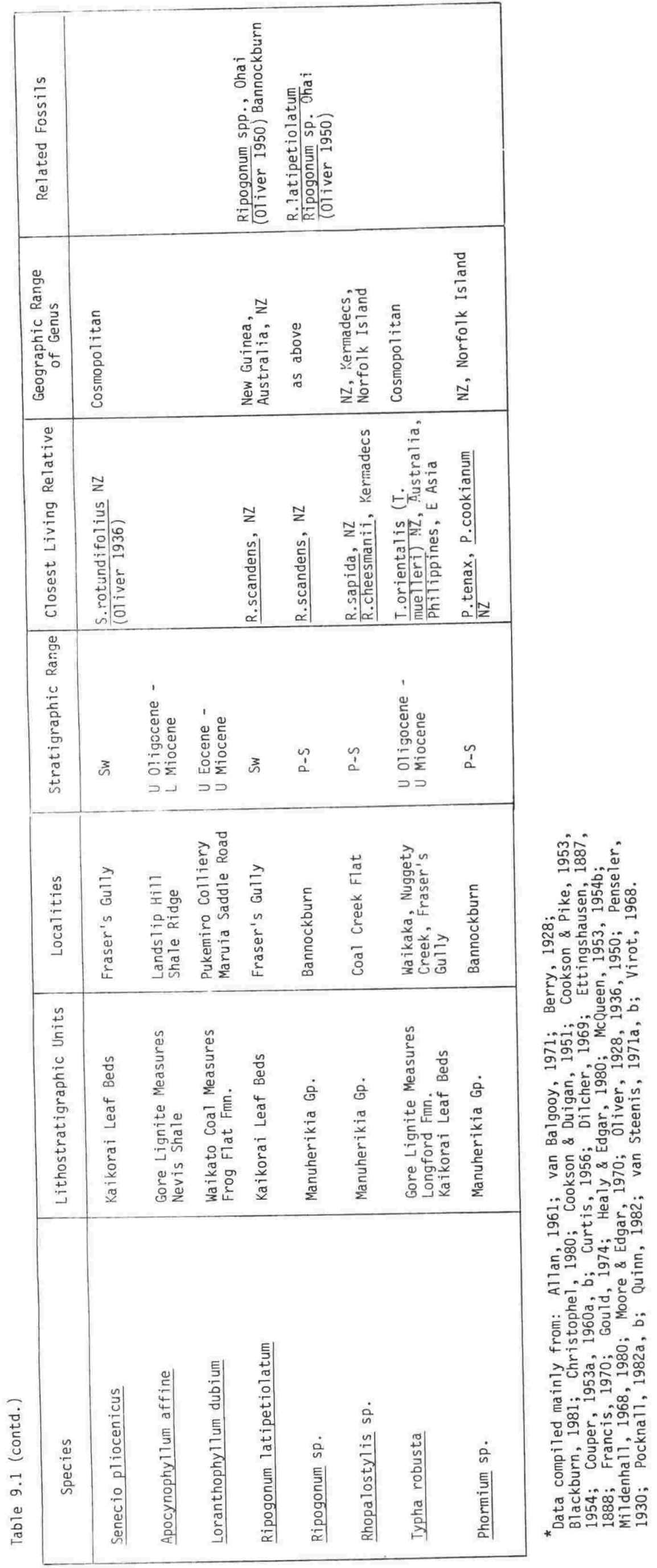


(1965) and the latter by Croizat 1952; 1964). Both Darlington's and Croizat's hypotheses were put forward before plate tectonic theory was fully developed. Other writers, for example van Steenis (1962) van Balgooy (1971), Raven and Axelrod (1972) and Whitmore (1973) have adopted a variety of positions between the dispersalist and vicariance extremes.

Darlington (1965) doubted that land connections had ever existed between New Zealand and any part of Gondwanaland, citing as evidence the absence of dinosaurs, snakes, monotremes and marsupials. He concluded that the entire New Zealand biota including Nothofagus, frogs, Onychophora and earthworms must have arrived as a result of long distance dispersal across an ocean barrier, in spite of evidence (Preest 1953) that Nothofagus is unlikely to be able to cross a water gap of more than 2-3 kilometres. The discovery of a vertebra of a theropod dinosaur (Mollnar 1981) in Cretaceous sediments of Hawkes Bay has rendered much of Darlington's argument untenable. The absence of fossil snakes, monotremes and marsupials is probably explained by the time of opening of the Tasman Sea about 80 MY B.P. (Crook and Belbin 1978).

Fleming (1979) suggested that conifers, Nothofagus, ratite birds, Sphenodon and other elements of the New Zealand biota are Gondwanic but that many important Tertiary and Recent taxa arrived after the opening of the Tasman sea by transoceanic dispersal, particularly in the west wind drift. Mildenhall (1980), basing his conclusions on pollen alone, essentially follows Fleming. Lange (1982) assessing the impact of plate tectonics on Australian biogeography discussed in some detail the failure of the reconstructions, at least in their present form, as an all-embracing explanation of plant distributions.

Problems remain, even as far as the supposed Gondwanic element is concerned. Mildenhall (1980) drew attention to the fact that the evolutionary development of Nothofagus (at least from the pollen aspect) followed similar patterns in New Zealand, Australia and South America, suggesting trans-oceanic dispersal of Nothofagus, possibly as viable pollen, in spite of strong evidence for poor seed dispersal ability.

The identification of migration routes and source areas from present distribution patterns of related taxa, which figures prominently in the work of Fleming $(1962,1979)$ and others is open to question. The areas 
occupied by the plants and animals in question today may not be those occupied by their ancestors at the time the supposed migrations took place (Croizat 1952). This is well illustrated by the Casuarinaceae. The genus Gymnostoma is held to contain the most primitive Casuarinaceae (Barlow 1959). At present the genus is more or less entirely tropical with most species in New Caledonia and New Guinea. Cryptostome Casuarinae show more derived characters and a number of species occur in temperate parts of Australia. It is tempting to propose an origin for the family in the 0ld World tropics. However fossil evidence (Frengue11i 1943; Christophe1 1980; Campbell and Holden 1981) shows that Gymnostoma occurred in Australia, New Zealand and South America in the early to mid Tertiary. The oldest known fossil pollen is from the lower Paleocene of New Zealand (Muller 1981). Moreover the evidence from Australia (Christophel 1980) shows that Gymnostoma had a widespread distribution in the Eocene prior to the separation from Antarctica, when Australia was in higher latitudes than today. On this evidence a Gondwanic origin seems probable, the present distribution of Gymnostoma being relictual.

Cockayne (1928) considered that the New Zealand flora of today originated from the Late Cretaceous flora of a "great New Zealand" which extended from Northern Queensland and New Guinea to Antarctica and eastward to the Chatham Islands, and included the New Hebrides, New Caledonia, the Kermadecs and Lord Howe and Norfolk Islands, but without direct connection with temperate eastern Australia and Tasmania. Regional elements of the former biota then developed independently through the Tertiary and Quaternary following foundering of large areas of the former land mass.

At least two major crises have occurred in the post-Cretaceous history of the New Zealand flora. The first of these was from the end of the Eocene through the Oligocene, when there is evidence from oxygen isotope ratios and planktonic foraminifera that there was a marked and rapid fall in sea temperatures of from $4-5^{\circ} \mathrm{C}$ in New Zealand (Devereux 1968) and about $10^{\circ} \mathrm{C}$ in Antarctica (Shackelton and Kennett 1975; Kennett 1978). There is some contradictory evidence (Hornibrook 1971) as shallow marine benthos (Beu 1966) and plant microfossils (McQueen et al. 1968) indicate that conditions remained warm in New Zealand during the 01igocene. There is evidence that the fall in sea temperatures was on a global scale (Frakes 1978 ) and that this was accompanied by a global fall in relative sea levels 
(Vail et al. 1977; Loutit and Kennett 1981) although this is masked to some extent in New Zealand and Australia by widespread marine transgressions over the period Eocene to late Oligocene (Glennie et al. 1968; Fleming 1979). Cockayne (1928) suggested that the reduction in land area and impoverishment of soils due to the long period of peneplanation during the late Cretaceous to Miocene led to many extinctions, particularly among cool temperate taxa.

Pollen records show (Mildenhall 1980) that a large number of new taxa appeared for the first time in the early Miocene when tectonic activity was renewed and land forms and soils presumably were rejuvenated. It is not possible to tell whether this was due to explosive vicariant radiation of survivors of the transgression, or to a spate of successful colonisations of newly created niches by long distance dispersal, or to a combination of both. A better knowledge of Eocene plant megafossils may assist in resolving the problem.

The second crisis reached a climax in the Pleistocene, when the Kaikoura Orogeny and repeated glaciations caused extensive extinctions. These did not all take place at once. A number of taxa survived one or more glacial episodes before disappearing from the record (Fleming 1979; Mildenhall 1980).

Fleming (1962) drew up a series of maps showing reconstructions of New Zealand paleogeography from Eocene to Pleistocene. These maps are based on the assumption that all of the 480 kilometres of transcurrent displacement on the Alpine Fault took place during the Rangitata Orogeny. These maps need revising in light of current thinking.

Some workers (Grindley et al. 1977; Lillie 1980) conclude that at least $330 \mathrm{~km}$ of dextral slip took place during the Rangitata Orogeny, the rest later, perhaps post-Miocene, assuming that transcurrent movement and oroclinal bending were contemporaneous. Wellman (1975) considered that most of the bending and dextral slip took place in post-01igocene, and perhaps even post-Miocene, times. Petrographic studies on arenite clasts from conglomerates in the Maruia Basin (Rappahannock Group, Frog Flat and Spargo Formations) (Cutten 1979) support a hypothesis that approximately $420 \mathrm{~km}$ of dextral shift on the Alpine Fault has taken place since the Late Miocene, although uplift of regions east of the fault obviously began earlier. The timing of the horizontal and vertical movements on the Alpine Fault could 
have important implications for paleoclimates, particularly with regard to rainfall distribution, and to the distribution of vegetation types. Two scenarios have been prepared, one following Fleming with all transcurrent movement in pre-0ligocene times and one with most of the transcurrent movement in post-Miocene times, using a reconstruction of Wellman $\&$ Korsch (unpub1.) as a base map. (figs 9.1, 9.2A, 9.2B).

Frakes and Kemp (1972) attempted to reconstruct world weather patterns for the Eocene and Mid Oligocene. They suggest that New Zealand would have had a humid climate during the period Eocene through 01igocene although both temperatures and rainfall were lower in the 0ligocene than in the Eocene. It is probable that similar conditions persisted through the Miocene as well. On a land surface of low relief there may be less precipitation than might be expected. Figures published by the N.Z. Meteorological Service (1973) suggest that rainfall gradients between mountainous areas of New Zealand and adjacent lowland plains are steep. For instance total rainfall in the Rai Valley in the Marlborough ranges is just over twice that at Nelson airport 30 air $\mathrm{km}$ to the south west.

Tertiary vegetation patterns are still unclear. Megafossil and microfossil assemblages reflect different aspects, megafossils representing local vegetation and microfossils the vegetation a wider area. Few megafossil assemblages have so far been studied and these are widely scattered both in space and time. If the Nevis Oil Shale and the Gore Lignite Measures are contemporaneous there may have been some regional variation in vegetation in the late 0ligocene and earliest Miocene, although the seemingly small emergent land surface at maximum transgression may have favoured rather uniform vegetation.

The Dunedin Volcanic Complex and the Longford Formation of the Buller region are approximately contemporaneous if the potassium-argon dates on the former are correct. The Dunedin flora is poorer in species than that from Longford. There is also a difference in the beech species present, Nothofagus australis and N. kaikoraiense, species with leaves similar in appearance to those of some modern South American deciduous beeches, not being found at Longford, while Nothofagus oliveri and $\underline{N}$. oblonga have not been found at Dunedin. This may reflect the effects of vulcanicity in the Dunedin area as discussed earlier (Chapter 6) or local climatic factors. The Longford assemblage with its high diversity and large average leaf 
Figs 9.1, 9.2A, 9.2B. Possible paleogeographic reconstructions for mid-Tertiary.

(Dotted outlines in $9.2 \mathrm{~A}$ and $9.2 \mathrm{~B}$ show configuration of New Zealand as reconstructed by Korsch and Wellman (ms). Solid lines in all diagrams show my distribution of land, much modified after Fleming (1962), Carter and Norris (1976) and other minor sources).

SMA $=$ Stokes Magnetic Anomaly

Warm and cold ocean currents are indicated by red and blue arrows respectively.

Key to paleogeographic zones:

1. West coast flood plain; warm temperate to subtropical rainforest and local swamps.

2. Axial ranges; rapidly eroding fault blocks of probably only moderate elevation.

3. Late Cretaceous to early Tertiary peneplain; 1akes, swamps and swamp forest on overmature soils, possibly some savanna in late Miocene and Pliocene.

4. East coast floodplain; vegetation little known at present.

5. Areas subject to volcanic disturbance; South Island east coast probably influenced by offshore cold current. 
$\because::$ : Tongaporutuan

Duntroonian

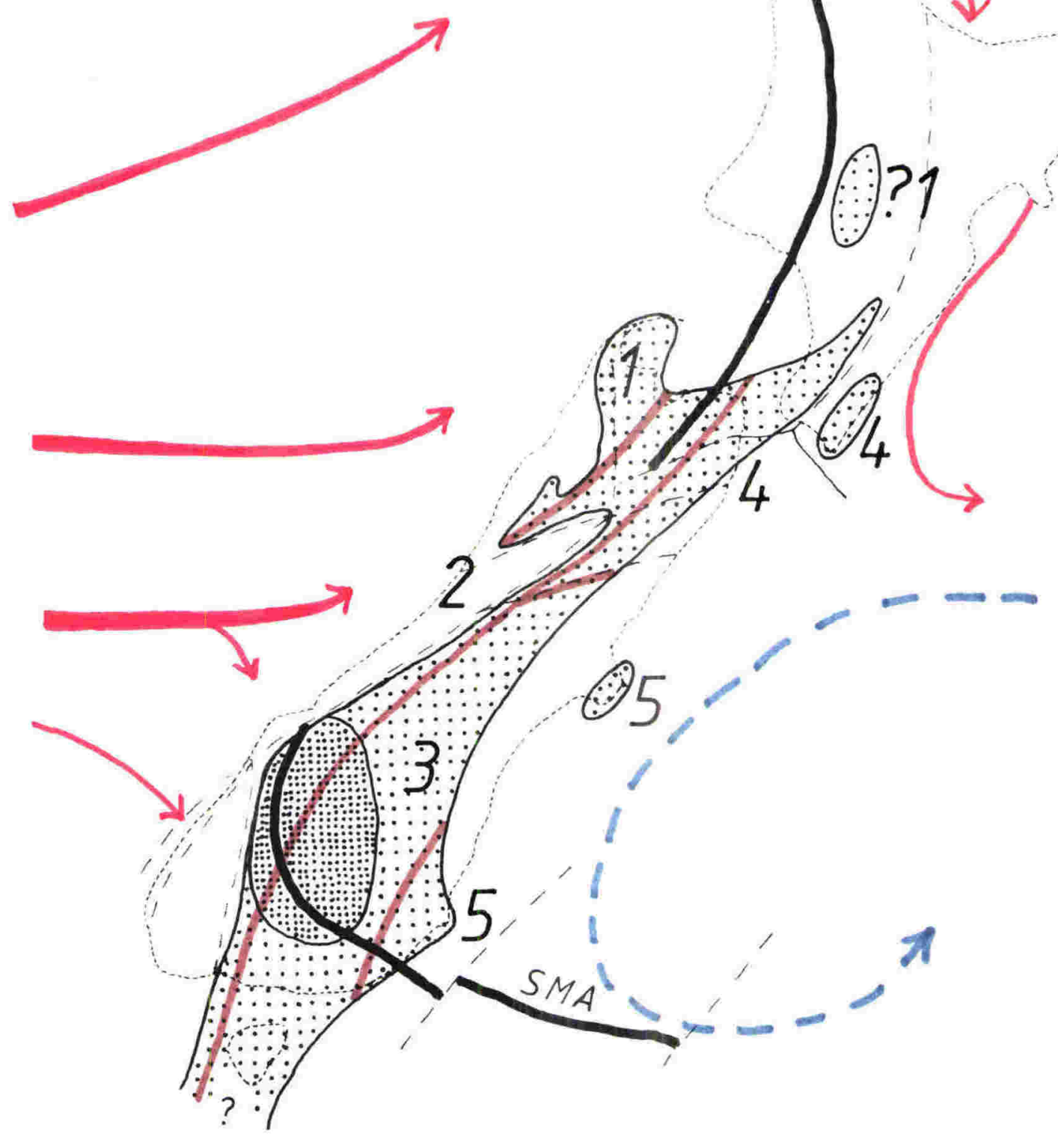

Fig. 9.1 Possible paleogeography of New Zealand for Upper Oligocene [Duntroonian Stage] \& Upper Miocene [Tongaporutuan Stage]. assuming all transcurrent movement on the Alpine Fault was pre-Tertiary. 


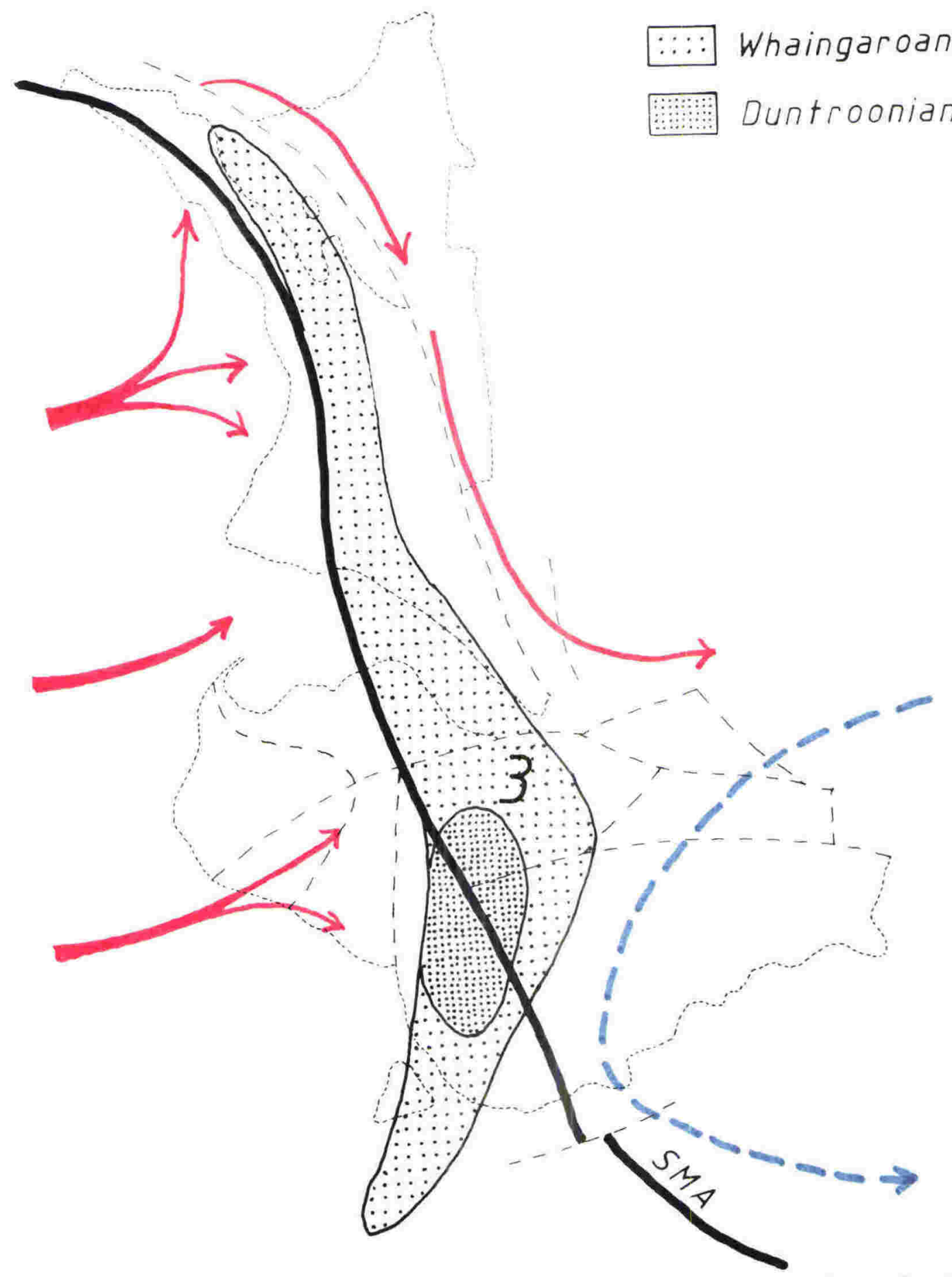

Fig. 9.2A Possible paleogeography of New Zealand for Oligocene [Whaingaroan and Duntroonian Stagesl assuming major transcurrent movements on the Alpine Fault are post-Miocene. 


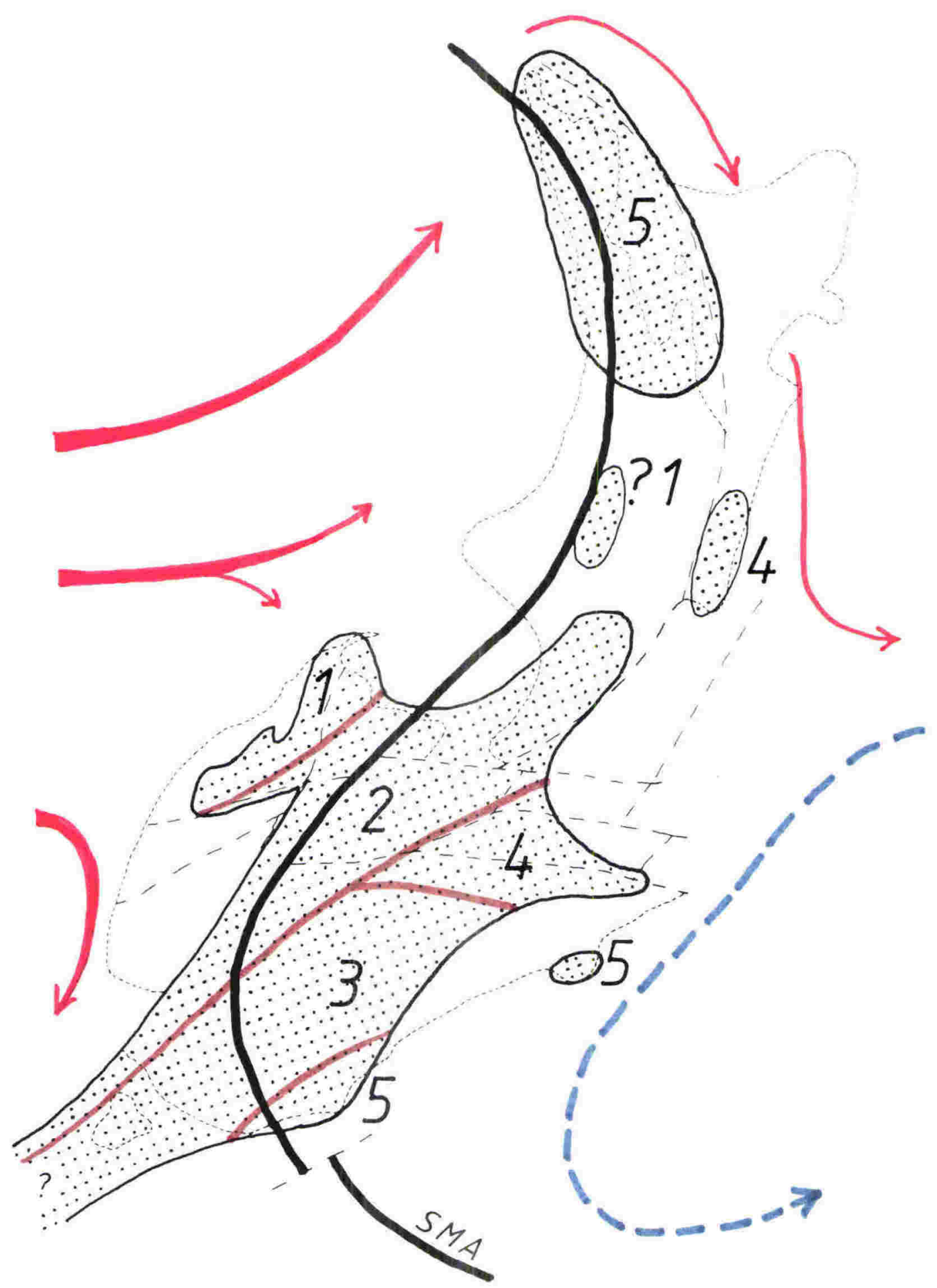

Fig. 9.2B Possible paleogeography of New Zealand for Upper Miocene [Tongaporutuan Stagel assuming major transcurrent movements on the Alpine Fault are post-Miocene. 
size suggests warm-temperate to subtropical rainforest. The Dunedin assemblage suggest somewhat cooler conditions, although still probably warmer than Dunedin today. Sea surface temperatures on the South Island east coast today are $2-4^{\circ} \mathrm{C}$ cooler than at corresponding latitudes on the west coast (Garner and Ridgeway 1962a; 1962b) due to the dominating influence of the cold Bounty-Campbell gyral and the relatively weak effect of the warmer inshore Southland Current (Burling 1960). The presence of a warm water Indo-Pacific element in molluscan and floraminiferal faunas from Altonian sediments at Clifden, western Southland, and its absence from east coast South Island rocks of similar age (Hornibrook 1969) suggests that this temperature difference existed at least as early as Southland times, and probably earlier. Ocean circulation patterns in the Southwest Pacific have probably been much as they are today since the separation of Antarctica and Australia in the Eocene.

Areas upwind of a cold current are considered dry as compared with those downwind from high surface water temperatures (Frakes and Kemp 1972), and this, together with the rainshadow effects of the Southern Alps and the Fiordland Mountains may be a contributory cause to low rainfall in Central Otago today. A southwestward extension of New Zealand towards Antarctica during the Tertiary, as suggested by Fleming (1962; 1979) would result in enhancement of the influence of cold currents on the east coast climate by further reducing the flow of subtropical water round the south of New Zealand, or eliminating it altogether.

Dunedin is at present some 4 to 5 degrees of latitude south of the BullerInangahua region and if this was also the case in the Miocene difference in latitude could have had an additional effect on climate. Evidence for a Caples Terrane provenance for arenite clasts in the Maruia and Murchison basins (Cutten 1979) indicate that the latitudinal separation was significantly less than $4-5^{\circ}$ in the mid to late Miocene and latitude was probably not a significant factor in controlling vegetational differences.

The similarities between the floras of Dunedin and Great Barrier Island may be due to the influence of intense vulcanicity or to similarities between mid Miocene climates on the east coast of the South Island and late Miocene climates in the North Island.

Miocene assemblages from Central Otago are in marked contrast to those from 
elsewhere. This may in part be due to their age, most of those studied so far probably falling within the Pareora Series. Pollen assemblages throughout Central Otago are hard to date unless certain characteristic index taxa are present, and vegetation patterns may have been relatively stable through much of Pareora and Southland times. Beech and conifer wood was present in lignite from Roxburgh examined by Evans (1937) indicating an Agathis/Podocarpaceae/Nothofagus component in the peatforming forest. However Nothofagus leaves are rare in spite of abundant pollen, and the trees probably had only a local presence. If parts of the Central Otago sequence do overlap with the fresh water sequence in the Murchison basin, then an important biological barrier of some sort is indicated, perhaps a rain shadow effect caused by ranges to the west, or the difference between vegetation developed on juvenile soils and that developed on over-mature soils.

Coarse clastics and redeposited marine sediments in the upper units of the Bob's Cove Beds indicate uplift along fault lines immediately to the west of the area occupied by Manuherikia Group sediments at some time in the later Cenozoic, probably the Upper Miocene (Turnbull et al. 1975). A late Southlandian or Taranakian date for the beginning of this uplift is also suggested by erosional truncation of the Dell Sandstone Member of the Nevis Formation in the Nevis Valley (Williams 1974). Sedimentation patterns in the Maruia and Murchison basins suggest rising land to the North west of the Central Otago area as well. Such fault block ranges may have had some rainshadow effect during later stages of the deposition of the Central Otago Manuherikia Group and any effect would have been enhanced by the east coast cold current. This could account for increasing proportions of Eucalyptus-type pollen in Upper Miocene and Pliocene sediments from central Otago (D.C. Mildenhall, pers. comm.).

Climate may not however have been the most important factor in the development of a distinctive vegetation in Central otago during the time that most of the Manuherikia Group was deposited. It does not appear to have been important in the development of sclerophyllous scrub and forest in Southland during 0ligocene times. The highly leached, overmature soils of the Tertiary peneplain would have been low in important major plant nutrients, particularly phosphorus. There is evidence that low levels of soil phosphate and the development of sclerophylly are 
related (Beadle 1966). Marked differences have been observed in the composition of forest vegetation in the humid tropics between forest growing on tropical red earths, young river terraces and other sites with soils relatively rich in plant nutrients, and that growing on pure quartz sands, older river terraces and other nutrient depleted soils (Richards 1941; Kostermans 1958; Wright 1959). In such warm, moist conditions there is a gradual change from a floristically rich forest of gross feeding species to a degraded forest type, frequently less rich in species, of plants tolerant of lower nutrient status, and finally, where the development of subsoil pans results in impeded drainage and temporary perched water tables, to savanna (Wright 1959). Beard (1953) regarded sclerophyll scrub and savanna in northern parts of tropical America as the characteristic vegetation type of highly mature soils on senile land forms. While New Zealand Tertiary climate has at no time been fully tropical (Hornibrook 1971), not even during the Eocene and early Miocene climatic optima, leaching was obviously intense, and effects on vegetation may well have been similar to those observed in the tropics.

The large number of taxa present in some Central Otago and Southland pollen samples does not necessarily imply relatively fertile soils. The vegetation developed on toxic serpentinite soils in New Caledonia is floristically rich (Jaffre 1980) as is the flora of the nutrient poor Hawkesbury Sandstone of New South Wales (Beadle et al. 1972). This richness appears to result from intense speciation. Many of the families (for example Apocynaceae, Cunoniaceae, Myrtaceae, Proteaceae, Fagaceae, Sapotaceae, Araucariaceae, Podocarpaceae) better represented on serpentinite soils than on soils derived from other parent material in New Caledonia (Jaffré 1980) also figure prominently in Southland and Central otago pollen and megafloras, and many of these same families are also prominent in vegetation of depleted gumland and Pakihi soils (Esler \& Rumbal1, 1975) in New Zealand today. There are also similarities at generic level. A number of authors have suggested that the ancestors of sclerophyllous species of Myrtaceae and Proteaceae (Andrews, 1913; Johnson and Briggs 1975; Barlow 1981), both families prominent in these communities, evolved from ancestors growing in mesic ranforest environments in response initially to poor soils.

The broad similarities of composition at family and generic level between modern scrub communities on poor soils in New Zealand and New Caledonia, and to a lesser extent in Australia and Tasmania, and the fossil communities 
from peneplained areas are summarised in Table 9.2. The fact that these similarities can be traced back to at least mid-Tertiary times suggests that scrub communities characterised by gymnosperms, Myrtaceae, Proteaceae, Epacridaceae and Casuarinaceae are ancient, and possibly of Gondwanic origin. Important differences exist, for example, Leptospermum, prominent in New Zealand is not present in New Caledonia, its place being taken by the morphologically similar Baeckia (Virot 1956). Both genera however occur in heaths in Australia (Beadle 1981). These differences probably result from a number of factors including regional differences in the vegetation of eastern Gondwanaland, and evolutionary divergence and differing climatic histories of Australia, New Zealand and New Caledonia since the separation of the New Zealand microcontinent and the isolation of its constituent parts. 


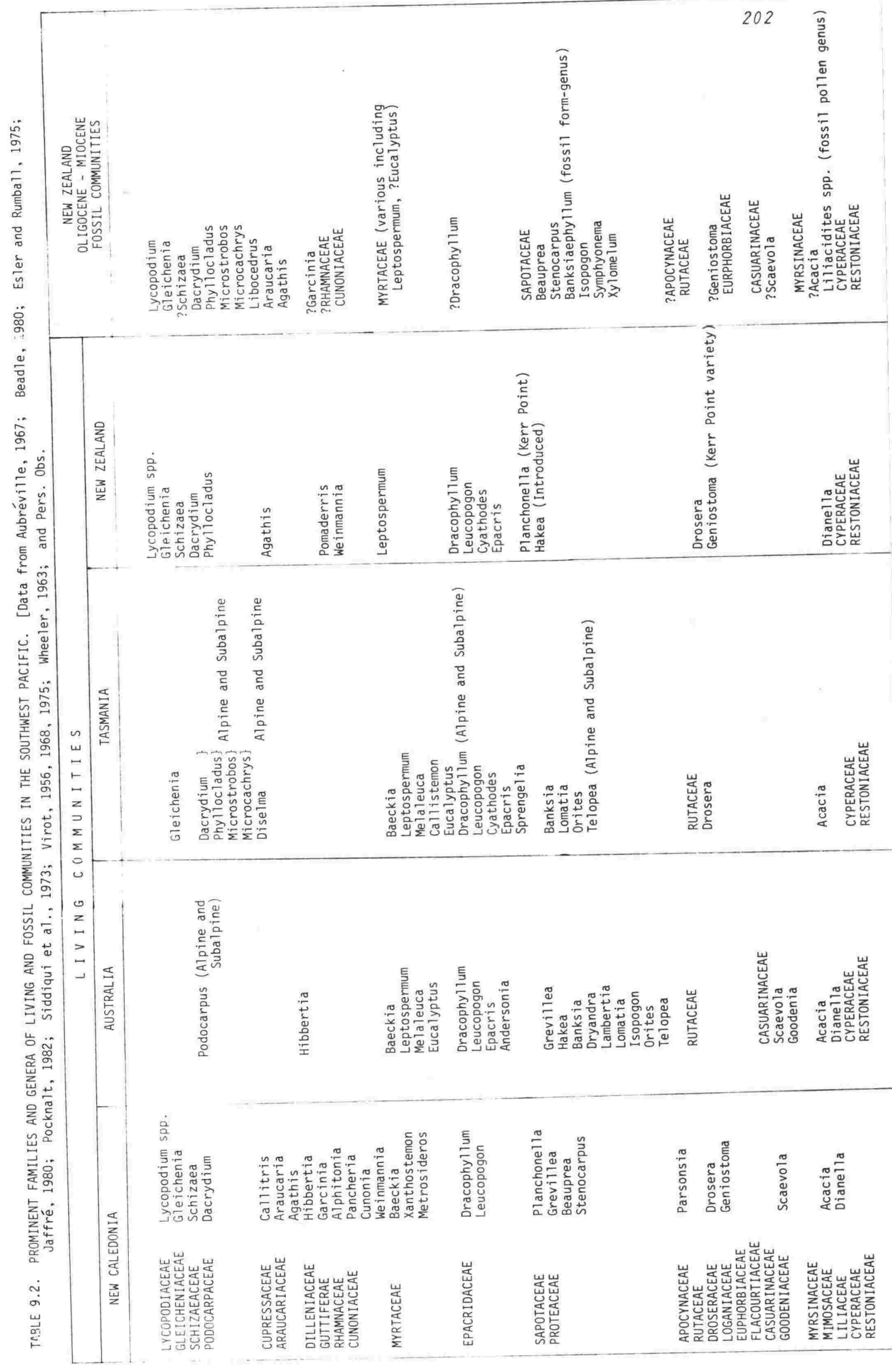


REFERENCES

ALLAN, H.H., 1961. Flora of New Zealand, Volume 1. Government Printer, Wellington.

ALLEN, J.R.L., 1962. Petrology, origin and deposition of the highest 01d Red Sandstone of Shropshire, England. Journal of Sedimentary Petrology 32: 657-679.

, 1963. Depositiona1 features of Dittonian rocks, Pembrokeshire compared with the Welsh Borderland, Geological Magazine 100: $385-400$.

, 1970. Studies in fluviatile sedimentation: a comparison of fining-upwards cyclothems, with special reference to coarsemember composition and interpretation. Journal of Sedimentary Petrology 40: 298-323.

AMBROSE, G.J. \& R.B. FLINT, 1981. A regressive Miocene lake system and silicified strandlines in northern South Australia: implications for regional stratigraphy and silcrete genesis. Journal of the Geological Society of Australia 28: 81-94.

ANDERSON, A.J., 1981. A fourteenth-century fishing camp at Purakanui Inlet, Otago. Journal of the Royal Society of New Zealand 11: 201-221.

ANDREWS, E.C. 1913. The development of the natural order Myrtaceae. Proceedings of the Linnaean Society of New South Wales 38 : 529-568.

AUbríville, A. 1967. Volume 1. Sapotacées. In A. Aubréville (ed), Flore de la Nouvelle Calédonie et Dépandances. Muséum National d'Histoire Naturelle, Paris.

AVIAS, J., 1953. Contribution á 1'étude stratigraphique et pal'entologique des formations antécrétackes de la Nouvelle Calédonie Centrale. Sciences Terre 1-2: 1-276.

AXELROD, D.I., \& H.P. Bailey, 1969. Palaeotemperature analysis of Tertiary floras. Palaeogeography, Palaeoclimatology, Palaeoecology 6: 163-195.

BAILEY, I.W. \& E.W. SINNOTT, 1915. A botanical index of Cretaceous and Tertiary climate. Science 41: 831-834. 
BAILEY, I.W. \& E.W. SINNOTT, 1916. The climatic distribution of certain types of angiosperm leaves. American Journal of Botany 3: 24-39.

BALGOOY, M.M.J.van, 1971. Plant geography of the Pacific. Blumea, supplement volume 4.

BANDULSKA, H. 1924. On the cuticles of Recent and fossil Fagaceae. Botanical Journal of the Linnaean Society 46: 427-444.

BARLOW. B.A., 1959. Chromosome numbers in the Casuarinaceae. Australian Journal of Botany 7: 230-237. , 1981. The Australian flora: its origin and evolution. In A.S. George (ed), Flora of Australia Volume 1: Introduction. Australian Government Publishing Service, Canberra.

BARRETT, P.J., 1965. Geology of the area between the Axel Heiberg and Shackleton Glaciers, Queen Maud Range, Antarctica; part 2, Beacon Group. New Zealand Journal of Geology and Geophysics 8: 344-370.

BARTRUM, J.A., 1921. Notes on the geology of Great Barrier Island, New Zealand. Transactions of the New Zealand Institute 53: 115-127.

BAYLEY, I.A.E., 1967. The fauna and chemical composition of some athalassic saline waters in New Zealand. New Zealand Journal of Marine and Freshwater Research 1: 105-117.

BAYLEY, I.A.E. \& W.D. WILLIAMS, 1972. Inland waters and their ecology. Longman, Australia.

BEADLE, N.C.W., 1966. Soil phosphate and its role in moulding segments of the Australian flora and vegetation, with special reference to xeromorphy and sclerophylly. Ecology 47: 992-1007. , 1981. The vegetation of Australia. Cambridge University Press.

BEADLE, N.C.W., O.W. EVANS, R.C. CAROLIN \& M.D. TINDALE, 1972. Flora of the Sydney region; second edition. A.H. \& A.W. Reed, Sydney. 
BEARD, J.G., 1953. The savanna vegetation of northern tropical America. Ecological Monographs 23.

BENSON, W.N., 1935. Some landforms in southern New Zealand. Australian Geographer 2: 2 .

, 1942. The basic igneous rocks of east Otago and their tectonic environment; Part 2. Transactions of the Royal Society of New Zealand 62: 85-118.

, 1959. Dunedin Volcanic Complex; in C.A. F1eming (ed.), Lexique Stratigraphique Internationale 6 (4): 91-93.

, 1959b. Kaikorai Leaf Beds; in C.A. Fleming (ed.), Lexique Stratigraphique Internationale 6 (4): 157.

, 1968. Dunedin District, $1: 50,000$. New Zealand Geological Survey, Miscellaneous Series, Map 1.

BERRY, E.W., 1926. Cocos and Phymatocaryon in the Pliocene of New Zealand. American Journal of Science 5, 12: 181-184. , 1928. Tertiary fossil plants from the Argentine Republic. Proceedings of the U.S. National Museum 73, 22: 1-27.

BEU, A.G., 1966. Sea temperatures in New Zealand during the Cenozoic era as indicated by molluscs. Transactions of the Royal Society of New Zealand: Geology 4: 177-187.

BEU, A.G., \& P.A. MAXWELL, 1968. Molluscan evidence for Tertiary sea temperatures in New Zealand. Tuatara 16: 68-74.

BLACK, M., 1929. Drifted plant beds of the Upper Estuarine Series of Yorkshire. Quarterly Journal of the Geological Society, London 85: 389-439.

BLACKBURN, D.T., 1981. Tertiary megafossil flora of Maslin Bay, South Australia: numerical taxonomic study of selected leaves. Alcheringa 5: 9-28.

, 1981. The potential for palaeoecological studies of Australian brown coal floras: an example from the Latrobe Valley, Victoria (abstract). Abstracts, 13th International Botanical Congress, Sydney, 21-28 August 1981: 202. 
BOWEN, F.E., 1964a. Geological Map of New Zealand 1:250,000;

Sheet 15, Buller. Department of Scientific and Industrial Research, Wellington.

, 1964b. Geology of the Ohai Coalfield. N.Z. Geological Survey Bulletin 51 ns..

BRADLEY, W.H., 1931. Origin and microfossils of the oil shale of the Green River Formation of Colorado and Utah. U.S. Geological Survey Professional Paper 168.

BRANDT, C.W., 1939. The resins from some New Zealand coal measures. New Zealand Journal of Science and Technology B30: 306-310.

BRATTSTROM, B.H., 1963. Barcena Volcano 1952; its effect on the fauna and flora of San Benedicto Island, Mexico. In Gressit (ed), Pacific Basin Biogeography. 10th Pacific Science Congress, Honolulu 1961: 499-524.

BRENNER, G.J., 1976. Middle Cretaceous floral provinces and early migration of angiosperms. In C.B. Beck (ed.), Origin and early evolution of angiosperms. Columbia University Press, New York: 23-47.

BROWNLIE, G., 1969. Volume 3, Ptéridophytes. In A. Aubréville (ed.) Flore de 1a Nouvelle Calédonie et Dépandances. Muséum National d'Histoire Naturelle, Paris.

, 1977. The Pteridophyte Flora of Fiji. Beihefte zur Nova Hedwigia, Heft 55.

BRÜCKNER, W.D., 1966. Origin of silcretes in Australia. Nature 209: 496-497.

BUCHHOLTZ, J.T. \& N.E. GRAY, 1948. A taxonomic revision of Podocarpus. Journal of the Arnold Arboretum 29: 49-63.

BURLING, R.W., 1960. Currents in the southern New Zealand region, $1: 3,394,000$. N.Z. Oceanographic Institute Chart, Miscellaneous Series 1.

CAMPBELL, J.D. \& A.M. HOLDEN, 1984. Miocene casuarinacean fruiting cones from Southlarid and Central Otago, New Zealand. New Zealand Journal of Botany 22: in press. 
CARLQUIST, S., 1965. Island Life; a natural history of the islands of the world. Natural History Press (American Museum of Natural History) New York.

CARTER, R.M. \& R.J. NORRIS, 1976. Cainozoic history of southern New Zealand: an accord between geological observations and plate tectonic predictions. Earth and Planetary Science Letters 31: 85-94.

CHALONER, W.G. \& M.M. GAY, 1973. Scanning electron microscopy of latex casts of fossil plant impressions. Palaeontology 16: 645-649.

CHRISTOPHEL, D.C., 1980. Occurrence of Casuarina megafossils in the Tertiary of south eastern Australia. Australian Journal of Botany 28: 249-259.

CHRISTOPHEL, D.C. \& D.T. BLACKBURN, 1978. Tertiary megafossil flora of Maslin Bay, South Australia - a preliminary report. Alcheringa 2: 311-319.

CLOSE, R.C., N.T. MOAR, A.I. TOMLINSON \& A.D. LOWE, 1978. Aerial dispersal of biological material from Australia to New Zealand. International Journal of Biometeorology 22: 1-19.

COCKAYNE, L., 1928. The vegetation of New Zealand. Second edition. Engelmann, Leipzig.

COLlinson, J.D., 1978. Alluvial Sediments. In H.G. Reading (ed.), Sedimentary environments and facies. Blackwe11: 25-60.

COOKSON, I.C., 1953. Records of the occurrence of Botryococcus braunii, Pediastrum and the Hystrichosphaeridae in Cenozoic deposits of Australia. National Museum of Victoria Memoir 18: 102-122.

COOKSON, I.C. \& S.L. DUIGAN, 1951. Tertiary Araucariaceae from southeastern Australia with notes on living species. Australian Journal of Scientific Research B 4: 415-449.

COOKSON, I.C. \& K.M. PIKE, 1953. The Tertiary occurrence and distribution of Podocarpus (section Dacrycarpus) in Australia and Tasmania. Australian Journal of Botany 1: 71-82.

$\&$ , 1954. The fossil occurrence of Phyllocladus and two other podocarpaceous types in Australia. Australian Journal of Botany 2: 60-68. 
COOKSON, I.C. \& K.M. PIKE, 1955. The pollen morphology of Nothofagus B1. subsection Bipartitae Steen. Australian Journal of Botany 3: 197-206.

COOMBS, D.S., 1965. Dunedin Volcanic complex and Waipiata Volcanic Formation (Upper Miocene - Early Pliocene). In: B.N. Thompson \& L.0. Kermode, New Zealand Volcanology - South Island. Department of Scientific and Industrial Research Information Series 51: 54-67.

COOMBS, D.S., A.J.R. WHITE \& D. HAMILTON, 1960a. Age relations of the Dunedin Volcanic Complex and some paleogeographic implications; Part 1. New Zealand Journal of Geology and Geophysics 3: 325-336. $\&$ , 1960b. Age relations of the Dunedin Volcanic Complex and some paleogeographic implications; Part II. New Zealand Journal of Geology and Geophysics 3: 572-579.

COOPER, R.A., 1975. New Zealand and south east Australia in the early Palaeozoic. New Zealand Journal of Geology and Geophysics 18: $1-20$.

, 1976. The fit of New Zealand against Australia-Antartica in the 1ate Mesozoic. Geological Society of New Zealand Newsletter 42: $31-34$.

COTTON, C.A., 1917. Block Mountains of New Zealand. American Journal of Science, fourth series, 44: 249-293.

, 1941. Landscape - as developed by the processes of normal erosion. Cambridge University Press.

COUPER, R.A., 1953a. Upper Mesozoic and Cainzoic spores and pollen grains from New Zealand. N.Z. Geological Survey Palaeontological Bulletin 22.

, 1953b. Plant microfossil dating of some New Zealand Upper Tertiary volcanic rocks. New Zealand Journal of Science and Technology B34: 373-377.

, 1959. Gore Lignite Measures; In: C.A. Fleming (ed.), Lexique Stratigraphique Internationale 6, (4): 110-111. 
COUPER, R.A., 1960a. New Zealand Mesozoic and Cainozoic plant fossils. N.Z. Geological Survey Palaeontological Bulletin 32.

, 1960b. Southern hemisphere Mesozoic and Tertiary Podocarpaceae and Fagaceae and their palaeogeographical significance. Transactions of the Royal Society, London, B 152: 491-500.

COUPER, R.A. \& D.R. MCQUEEN, 1953. Pliocene and Pleistocene plant fossils of New Zealand and their climatic interpretation. New Zealand Journal of Science and Technology B35: 398-420.

CRANWELL, L.M., 1949. An outline of New Zealand peat deposits, with notes on the conditions of rainfed cushion bogs. Proceedings of the 7th Pacific Science Congress 5: 186-208.

, 1959. Fossil pollen from Seymour Island, Antarctica. Nature 184: $1783-1785$.

CRAW, R.C., 1978. Two biogeographical frameworks: implications for the biogeography of New Zealand. A review. Tuatara 23: 81-114.

CROIZAT, L., 1952. Manual of Phytogeography. W. Junk, The Hague. , 1964. Space, Time, Form: the biological synthesis. L. Croizat, Caracas.

CRONQUIST, A., 1968. The evolution and classification of flowering plants. Thos. Nelson and Sons, London and New York.

CROOK, K.A.W. \& BELBIN, L., 1978. The southwest Pacific area in the last 90 million years. Journal of the Geological Society of Australia 25: 23-40.

CURTIS, W.M., 1956. The student's flora of Tasmania; part 1. Government Printer, Tasmania.

CUTTEN, H.N.C., 1979. Rappahannock Group; late Cenozoic sedimentation and tectonics contemporaneous with Alpine Fault movement. New Zealand Journal of Geology and Geophysics 22: 535-553.

DALLIMORE, W. \& A.B. JACKSON, 1966. A handbook of Coniferae and Ginkgoaceae, 4th edition revised by S.G. Harrison. Edward Arnold, London. 
DAPPLES, E.C., 1967. Silica as an agent in diagenesis. In: G. Larsen (ed.), Diagenesis in Sediments. Developments in Sedimentology 8. E1sevier, Amsterdam: 323-342.

, 1979a. Diagenesis in sandstones. In: G. Larsen and G.V. Chillingar (eds.). Diagenesis in sediments and sedimentary rocks. Developments in Sedimentology 25A; Elsevier, Amsterdam: $31-97$.

, 1979b. Silica as an agent in diagenesis. In: G. Larsen and G.V. Chillingar (eds.). Diagenesis in Sediments and Sedimentary rocks. Developments in Sedimentology 25A. Elsevier, Amsterdam: 99-141.

DARLINGTON, P.J., 1965. Biogeography of the southern end of the world. Harvard University Press, Cambridge, Massachusetts.

DARRAH, W.C., 1939. Textbook of Paleobotany. (lst ed.). The Century Biological Series, R. Heyener (ed.). D. Appleton - Century Co. Inc., New York and London.

DAWSON, J.W., 1963. New Caledonia and New Zealand, a botanical comparison. Tuatara 11: 178-193.

, 1966. Observations on Nothofagus in New Caledonia. Tuatara 14: $1-7$.

, 1976. Pacific capsular-Myrtaceae XI. Redefinition of Metrosideros Banks ex Gaertn. and definition of infrageneric categories, Blumea 23: 7-11.

DEVEREUX, I., 1968. Oxygen isotope palaeotemperatures from the Tertiary of New Zealand. Tuatara 16: 41-45.

DILCHER, D.L., 1969. Podocarpus from the Eocene of North America. Science 164: 299-301.

, 1974. Approaches to the identification of angiosperm leaf remains. The Botanical Review 40: 1-157.

DOLPH, G.E. 1979. Variation in leaf margin with respect to climate in Costa Rica. Bulletin of the Torrey Botanical Club 106: 104-109.

DOUGLAS, B.J., 1980. The St. Bathans Delta, Central Otago: a potential coal resource. Program and Abstracts, Geological Society of New Zealand Annual Conference, Christchurch, 24-27 November 1980: 32 . 
DOUGLAS, B.J., I.M. TURNBULL, R.M. CARTER \& C.A. LANDIS, 1978. Lignite resources and Cainozoic Manuherikia Group Sediments in Central Otago. Route Guide for Tour D, Geological Society of New Zealand Conference, Queenstown, 1978.

DRAKE, H. \& C.J. BURROWS, 1980. The influx of potential macrofossils into Lady Lake, north Westland, New Zealand. New Zealand Journal of Botany 18: 257-274.

DUFF, P. McL. D., 1967. Cyclic sedimentation in the Permian coal measures of New South Wales. Journal of the Geological Society of Australia 14: 293-307.

DUFF, P. McL. D., A.G. HALLAM \& E.K. WALTON, 1967. Fluvial regimes. In: Cyclic sedimentation. Developments in Sedimentology 10. Elsevier, Amsterdam: 22-47.

ECROYD, C.E., 1982. Biological flora of New Zealand 8: Agathis australis (D. Don.) Lind. (Araucariaceae), Kauri. New Zealand Journal of Botany 20: 17-36.

EGGLESTON, J.R. \& W.E. DEANE, 1976. Freshwater stromatolitic bioherms in Green Lake, New York. In: M.R. Walter (ed.) Stromatolites. Developments in Sedimentology 20, Elsevier, Amsterdam: 479-488.

ESLER, A.E. \& P.J. RUMBALL, 1975. Gumland vegetation at Kaikohe, Northland, New Zealand. New Zealand Journal of Botany 13: 425-436. ETTINGSHAUSEN, C. von, 1887. Beitrage zur kenntnis der fossilen flora Neuseelands, Denkschriften der Mathematisch-naturwissenschaftlichen Klasse der Kaiserlichen Akademie der Wissenschaften, Wien 53. 143-194.

, 1891. Contributions to the knowledge of the fossil flora of New Zealand. Transactions and Proceedings of the New Zealand Institute 23: 237-310.

, 1888. Contributions to the Tertiary flora of Australia. Memoirs of the Geological Society of New South Wales, Palaeontology 2. 
EVANS, W.D., 1965. Facets of organic geochemistry. In: E.G. Hallsworth \& D.V. Crawford (eds.), Experimental Pedology: 14-28.

EVANS, W.P. 1931. A fossil Nothofagus (Nothofagoxylon) from the Central Otago coal measures. Transactions and Proceedings of the New Zealand Institute 62: 98 .

, 1934. Microstructure of New Zealand 1ignites; part III: Lignites apparently not altered by igneous action: A. Coal Creek Flat, Roxburgh, Central 0tago. New Zealand Journal of Science and Technology B 15: 365-385.

, 1936. Microstructure of New Zealand Lignites; part III: Lignites apparently not altered by igneous action: A. Coal Creek Flat, Roxburgh, Central Otago: A typical podocarp stem. New Zealand Journal of Science and Technology B 17: 649-658.

, 1937. Note on the flora which yielded the Tertiary lignites of Canterbury, Otago and Southland. New Zealand Journal of Science and Technology B 19: 188-193.

, 1938. Note on the flora which yielded the Tertiary lignites of Canterbury, Otago and Southland. New Zealand Journal of Science and Technology B 20: 15B.

FLEMING, C.A., 1962. New Zealand Biogeography - a palaeontologist's approach. Tuatara 10: 53-108.

, 1979. The geological history of New Zealand and its life. Auckland/Oxford University Presses, Auckland.

FLINT, E.A., 1975. Phytoplankton in some New Zealand lakes. In: V.H. Jolly and J.M.A. Brown (eds.) New Zealand Lakes, Auckland and Oxford University Presses, Auckland: 163-192.

FLORES, E.M., 1977. Developmental studies in Casuarina (Casuarinaceae) III: the anatomy of the mature branchlet. Revista de Biologia Tropical 25: 65-88.

FLORIN, R., 1940. The Tertiary fossil conifers of south Chile and their phytogeographical significance; with a review of the fossil conifers of southern lands. Kunglica Svenska Vertenskapsakademiens Handlingar 19: 1-107. 
FLORIN, R., 1963. The distribution of conifer and taxad genera in time and space. Acta Horti Bergiani, Band 20, 4.

FRAKES, L.A., 1978. The long term climatic record, Cenozoic climates: Antarctica and the Southern Ocean. In: Climatic change and variability, a southern perspective; A.B. Pitlock, L.A. Frakes, D. Jenssen, J.A. Petersen and J.W. Zillman (eds.). Cambridge University Press: 53-69.

FRAKES, L.A. \& E.M. KEMP, 1972. The influence of continental positions on Early Tertiary Climates. Nature 240: 97-100.

FRASER, C. \& J.H. ADAMS, 1907. The geology of the Coromandel Subdivision. New Zealand Geological Survey Bulletin ns. 4.

FRANCIS, W.D., 1970. The Australian Rainforest, 3rd Edition. Department of National Development, Forestry and Timber Bureau, Australian Government Publishing Service.

FRANKLIN, D.A., 1968. Biological flora of New Zealand 3: Dacrydium cupressinum Lamb. (Podocarpaceae), Rimu. New Zealand Journal of Botany 6: 493-513.

FRENGUELLI, J., 1943. Restos de Casuarina en el Mioceno de el Mirador, Patagonia Central. Notas de1 Museo de la Plata 8. Paleontologia 56: 349-354.

FREYTET, P. \& J.C. PLAZIAT, 1965. Importance des constructions algaires dues a des Cyanophycées dans les formations continentales du Crétacée Superieur et de L'Éocene du Languedoc. Bulletin Société géologique de France (7) VII: 679-691.

FRIEDRICH, W.L. \& F. SCHAARSCHMIDT, 1977. Zwei- und drei-dimensionale Floureszenzaufnahmen von fossilen Pflanzen. Courier Forschungsinstitut Senckenberg 24: 31-49.

FRITSCH, F.E. \& C.F.A. PANTIN, 1946. Calcareous concretions in a Cambridgeshire stream. Nature 157: 397-399.

FRYE, J.C. \& A.M. LEONARD, 1957. Ecological interpretations of Pliocene and Pleistocene Stratigraphy in the Great Plains region American Journal of Science 255: 1-11. 
FYFE, H.E., 1968. Geology of the Murchison Subdivision. New Zealand Geological Survey Bulletin ns 36.

GAGE, M., 1949. Late Cretaceous and Tertiary geosynclines in Westland, New Zealand. Transactions of the Royal Society of New Zealand 77: $325-337$.

, 1980. Legends in the rocks; an outline of New Zealand geology. Whitcoulls.

GARNER, D.M. \& N.M. RIDGEWAY, 1962a. New Zealand Region winter sea surface temperatures 1956. 1:5,900,000 N.Z. Oceanographic Institute Chart, Miscellaneous Series 2. , \& , 1962b. New Zealand Region summer sea surface temperatures 1957. 1:5,900,000 N.Z. Oceanographic Institute Chart, Miscellaneous Series 3.

GILL, E.D., 1975. The evolution of Australia's unique flora and fauna in relation to plate tectonics theory. Proceedings of the Royal Society of Victoria 87B: 215-234.

GLENIE, R.C., J.C. SCHOFIELD \& W.T. WARD, 1968. Tertiary sea levels in Australia and New Zealand. Palaeogeography, Palaeoclimatology, Palaeoecology 5: 141-163.

GOLUBIC, S., 1973. The relationship between blue-green algae and carbonate deposits. In: N.G. Carr \& B.A. Whitton (eds.), The Biology of Blue-green Algae. Botanical Monographs 9: Blackwe11 Scientific: $434-472$.

GOULD, R.E., 1974. The fossil flora of the Walloon Coal Measures: a survey. Proceedings of the Royal Society of Queensland 85: 33-41.

, 1982. Early Australian vegetation history, evidence from Late Paleozoic and Mesozoic plant megafossils. In: J.M.B. Smith (ed.), A History of Australian Vegetation. McGraw-Hill, Sydney: $32-43$.

GRANT, K. \& G.D. AITCHISON, 1970. The engineering significance of silcretes and ferricretes in Australia. Engineering Geology 4: 93-120.

GRIFFITHS, J.R., 1971. Reconstructions of the south west Pacific margin of Gondwanaland. Nature 234: 203-206. 
HEALY, A.J. \& E. EDGAR, 1980. Flora of New Zealand, Volume 3. Government Printer, Wellington.

HEALY, J., 1936. Whakaea Subdivision. N.Z. Geological Survey 30th Annual Report (ns): 6-9.

HEALY, J. \& R.W. WILLETT, 1937. Waikaia Subdivision. N.Z. Geological Survey 31st Annual Report (ns): 10-14.

HECTOR, J., 1870. The Geology of the Cape Colville District. N.Z. Geologica1 Survey Reports of Geological Exploration 6: 88-103.

, 1879. On the fossil flora of New Zealand (Abstract). Transactions and Proceedings of the New Zealand Institute 11: 536-537.

HENDERSON, J., 1923. Notes on the geology of the Nevis Valley, Otago. New Zealand Journal of Science and Technology B 6: 123-128.

, 1929. Late Cretaceous and Tertiary rocks in New Zealand. Transactions and Proceedings of the New Zealand Institute 60: 271-299.

HILL, P.J. \& J.D. COLLEN, 1978. The Kapuni Sandstones from Inglewood 1 well, Taranaki - petrology and the effects of diagensis on reservoir characteristics. New Zealand Journal of Geology and Geophysics 21: 215-228.

HILL, R.S., 1980. A numerical taxonomic approach to the study of Angiosperm leaves. Botanical Gazette 141: 213-229.

, 1981. Consequences of long-distance dispersal of plant macrofossils, New Zealand Journal of Botany 19: 241-242.

HODGSON, M. \& R. PAINE, 1971. A field guide to Australian wildflowers. Rigby, Australia.

HOLDEN, A.M., 1982a. Fossil Nothofagus from the Longford Formation Murchison, New Zealand. Journal of the Royal Society of New Zealand 12: 65-77.

, 1982b. Fossil Lauraceae and Proteaceae from the Longford Formation, Murchison, New Zealand. Journal of the Royal Society of New Zealand 12: 79-90.

HORNIBROOK, N. de B., 1959. Waitakian Stage. In C.A. Fleming (ed.) Lexique Stratigraphique Internationale 6 (4): 426-429.

, 1969. Foraminifera1 Biostratigraphy. In B.L. Wood, Geology of the Tuatapere Subdivision, western Southland.

N.Z. Geological Survey Bulletin ns 79. 
HORNIBROOK, N de B., 1971. New Zealand Tertiary Climate. N.Z. Geological Survey Report 47.

HOSKING, J.R., 1929. Kauri Resins. Recueil des Travaux Chimiques de Pays-Bas 48. 622-636.

HUGHES, N.F., 1963. The assignment of species of fossils to genera. Taxon 12: $336-337$.

, 1976. Palaeobiology of Angiosperm origins. Cambridge University Press.

, 1978. Proposal for a new palaeobotanical appendix for the International Code of Botanical Nomenclature, Taxon 27: 497-504 HUTCHINSON, J., 1967. The Genera of flowering plants. Oxford University Press.

HUtTON, J.T., C.R. TWIDALE, A.R. MILNES \& H. ROSSER, 1972. Composition and genesis of silcretes and silcrete skins from the Beda Valley, South Arcoona Plateau, South Australia. Journal of the Geological Society of Australia 19: 31-39.

ISAAC, M.J., 1980. Multiple seam lignite deposit at Mataura, Southland. Program and Abstracts, Geological Society of New Zealand Annual Conference, Christchurch, 24-27 November 1980: 55 .

, 1981a. Lignite, eastern Southland. N.Z. Geological Survey Report M83.

, 1981b. The Southland and Central Otago lignite deposits. Geological Society of New Zealand Newsletter 53: 18-22.

, 1981c. Central Otago Coalfield. N.Z. Geological Survey Report M86.

JAFFRÉ, T., 1980. Étude écologique du peuplement végétal des sols dérivés de roches ultrabasiques en Nouvelle Calédonie, Travaux et Documents de 1'ORSTOM 24.

JOHNSON, L.A.S., 1980. Notes on Casuarinaceae. Telopea 2: 83-84. , 1982. Notes on Casuarinaceae 2. Journal of the Adelaide Botanic Garden 6: 73-87.

JOHNSON, L.A.S. \& B.G. BRIGGS, 1975. On the Proteaceae - the evolution and classification of a southern family. Botanical Journal of the Linnaean Society 70: 83-182. 
KATZ, H.R., 1973. Contrasts in tectonic evolution of oregenic belts in the southeast Pacific. Journal of the Royal Society of New Zealand 3: 333-362.

KEAR, D., 1959. Beeson's Island Volcanics. In C.A. Fleming (ed.), Lexique Stratigraphique International 6, (4): 44-45.

KELLY, S.R.A. \& A. McLachlan, 1980. The use of silicone rubbers in the preparation of casts from natural fossil moulds. Geological Magazine 117: 447-454.

KENNETT, J.P., 1967. Recognition and correlation of the Kapitean Stage (Upper Miocene, New Zealand). New Zealand Journal of Geology and Geophysics 10: 1051-1063.

, 1978. The development of planktonic biogeography in the Southern Ocean during the Cenozoic. Marine Micropaleontology 3: 301-345.

KERR, M.H., 1955. On the occurrence of silcretes in southern England. Proceedings of the Leeds Philosophical and Literary Society, Scientific Section 6: 328-337.

KIRK, T., 1868. On the botany of Great Barrier Island. Transactions and Proceedings of the New Zealand Institute 1: 88-101.

KOSTERMANS, A.J.G.H., 1958. Note on the lowland vegetation of Borneo. In: Study of Tropical Vegetation. Proceedings of the Kandy Symposium, UNESCO: 154-158.

LAMPLAUGH, G.W., 1902. Calcrete. Geological Magazine 9: 575.

LANGE, R.T., 1978. Carpological evidence of fossil Eucalyptus and other Leptospermae (subfamily Leptospermoidae of Myrtaceae) from a Tertiary deposit in the South Australian arid zone. Australian Journal of Botany 26: 221-233.

, 1982. Australian Tertiary Vegetation. In J.M.B. Smith (ed.), A History of Australasian Vegetation. McGraw Hill, Sydney: 44-89.

LANGFORD-SMITH, T. \& G.H. DURY, 1965. Distribution, character and attitude of the duricrust in the northwest of New South Wales and the adjacent area of Queensland. American Journal of Science 263: 170-190. 
LAUBENFELS, D.J. de, 1972. Gymnospermes; Volume 4, Flore de la Nouvelle Calédonie et Dépandances, A. Aubréville (ed.). Muséum National d'Histoire Naturelle, Paris.

LILLIE, A.R., 1980. Structure and Strata in New Zealand. Tohunga Press, Auckland.

LILLIE, A.R. \& R.N. BROTHERS, 1970. The geology of New Caledonia. New Zealand Journal of Geology and Geophysics 13: 145-183.

LINDQVIST, J.K., 1983. Lignite deposition in deltaic plain environments of the Late Oligocene to Early Miocene Gore Formation, east Southland, New Zealand. Programme, Abstracts and Conference Information, 15th Pacific Science Congress, Dunedin, February 1-11 1983, Volume 1: 148.

LINDQVIST, J.E. \& D.T. POCKNALL, 1983. Stratigraphy and palynology of Late Oligocene to Miocene lignite bearing sediments, eastern Southland. Tour Guide Bf5, 15th Pacific Science Congress, Dunedin, 1-11 February 1983, Section B. Solid Earth Sciences.

LOGAN, B.W., R. REZAK \& R.N. GINZBURG. 1964. Classification and environmental significance of algal stromatolites. Journal of Geology 72: 68-83.

LOUTIT, T.S. \& J.P. KENNETT, 1981. Australasian Cenozoic sedimentary cycles, global sea level changes and the deep sea sedimentary record. Oceanologica Acta 1981. Proceedings of the 26th International Geological Congress, Geology of Continental Margins Symposium, Paris, July 7-17, 1980: 45-63.

LULY, J., I.R. SLUITER \& A.P. KERSHAW, 1980. Pollen studies of Tertiary brown coals: preliminary analysis of lithotypes within the Latrobe Valley, Victoria. Monash Publications in Geography 23.

MACK, R.N., 1981. Initial effects of ashfall from Mt. St. Helens on vegetation in eastern Washington and adjacent Idaho. Science 213, 4507: 537-539.

MACGINITIE, H.D., 1953. Fossil plants of the Florissant Beds, Colorado. Carnegie Institute of Washington Publication 599.

MACMILLAN, B.H., 1972. Biological flora of New Zealand 7. Ripogonum scandens J.R. et G. Forst. (Smilacaceae), Supplejack, Kareao. New Zealand Journal of Botany 10: 641-672. 
MACPHAIL, M.K., 1980. Fossil and modern Beilschmiedia (Lauraceae) pollen in New Zealand. New Zealand Journa1 of Botany 18: 453-457.

MARSHALL, P., 1901. On the leaf beds in the Kaikorai Valley (abstract). Transactions and Proceedings of the New Zealand Institute 34: 586-587.

, 1906. The Geology of Dunedin, New Zealand. Quarterly Journal of the Geological Society, London 62: 381-424.

MARTIN, H.A., 1978. Evolution of the Australian flora and vegetation through the Tertiary: evidence from pollen. Alcherringa 2: 181-202.

MARWICK, J., 1929. Tertiary molluscan fauna of Chatton, Southland. Transactions and Proceedings of the New Zealand Institute 59: 903-934.

MASON, G., 1951. Some notes of the vegetation of Great Barrier Island. Tane 4: 25-27.

McDOUGALL, I. \& D.S. COOMBS, 1973. K-Ar ages for the Dunedin Volcano and outlying volcanics. New Zealand Journal of Geology and Geophysics 16: 179-188.

McGILL, D., 1980. Ghost Towns of New Zealand. A.H. \& A.W. Reed, Wellington.

McGOWRAN, B., 1978. Stratigraphic record of early Tertiary oceanic and continental events in the Indian Ocean region. Marine Geology 26: 1-39.

McKAY, A., 1897. The geology of the Cape Colville Peninsula. New Zealand Mines Reports C9: 1-75.

McKELLAR, I.C., 1966. Sheet 25, Dunedin, 1st Edition. Geological Map of New Zealand 1:250,000. Department of Scientific and Industrial Research, Wellington.

MCKELLAR, M.H., 1973. Dispersal of Nothofagus pollen in eastern Otago, South Island, New Zealand. New Zealand Journal of Botany 11: 305-310.

MCQUEEN, D.R. 1953. A fossil flora from the Pliocene of Rangitikei Valley. New Zealand Journal of Science and Technology B 35. 134-140. 
MCQUEEN, D.R., 1954a. Palaeozoic plants from New Zealand. Nature 173: 88 .

, 1954b. Fossil leaves, fruits and seeds from the Wanganui Series (Plio-Pleistocene) of New Zealand. Transactions of the Royal Society of New Zealand 82: 667-676.

, 1969. Macroscopic plant remains in Recent lake sediments. Tuatara 17: 13-19.

, 1976. The ecology of Nothofagus and associated vegetation in South America. Tuatara 22: 38-68.

, 1977. The ecology of Nothofagus and associated vegetation in South America, part II. Tuatara 22: 233-244.

McQUEEN, D.R., D.C. MILDENHALL \& C.J.E. BELL, 1968. Palaeobotanical evidence for changes in the Tertiary climate of New Zealand. Tuatara 16: 49-56.

MIALL, A.D., 1977. A review of the braided river depositional environment. Earth Science Reviews 13: 1-62.

MILDENHALL, D.C., 1968. The fossil flora of the Pakawau Group, NW Nelson, New Zealand. Unpublished MSc Thesis, Victoria University of Wellington Library.

, 1970a. Checklist of valid and invalid plant macrofossils from New Zealand. Transactions of the Royal Society of New Zealand, Earth Sciences 8: 77-89.

, 1970b. Discovery of a New Zealand member of the Permian Glossopteris flora. Australian Journal of Science 32: 474-475.

, 1972. New name for the plant fossil Haastia Ettingshausen 1887 (non Haastia Hook. f. 1864). New Zealand Journal of Geology and Geophysics 15: 181-182.

, 1973. A guide to morphological characteristics for use in the description of extant and fossil dicotyledonous leaves. Tuatara 20: 75-87.

, 1976. Exotic pollen rain in the Chatham Islands during the 1ate Pleistocene. New Zealand Journal of Geology and Geophysics 19: 327-334. 
MILDENHALL, D.C., 1980. New Zealand Late Cretaceous and Cenozoic plant biogeography: a contribution. Palaeogeography, Palaeoclimatology, Palaeoecology 31: 197-233.

MILDENHALL, D.C. \& W.F. HARRIS, 1971. Status of Haloragacidites (a1. Triorites) harrisii (Couper) Harris comb. nov. and Haloragacidites trioratus Couper 1953, New Zealand Journal of Botany 9: 297-306.

MILLENER, L.H., 1960. Our plant world. In T.J. Dwyer (ed.), The New Zealand Junior Encyclopaedia. New Zealand Educational Foundation, Wellington: 310-336.

MOAR, N.T., 1969. Possible long distance transport of pollen to New Zealand. New Zealand Journal of Botany 7: 424-426.

MOLNAR, R.E., 1981. A Dinosaur from New Zealand. In M.M. Cresswell \& P. Vella (eds.), Gondwana Five, selected papers and abstracts of papers presented at the Fifth International Gondwana Symposium, Wellington, New Zealand, 11-16 February 1980. A.A. Balkema Rotterdam: 91-96.

MONTGOMERY, A., 1883. Some fossil plants, Pukerau, (Letter to the Editor), New Zealand Journal of Science 1: 141-2.

MONTY, C.L.V., 1976. The origin and development of cryptalgal fabric. In M.R. Walter (ed.), Stromatolites. Developments in Sedimentology 20; E1sevier, Amsterdam: 191-249.

MONTY, C.L.V. \& L.A. HARDIE, 1976. The geological significance of the freshwater blue-green algal calcareous marsh. In M.R. Walter (ed.), Stromatolites. Developments in Sedimentology 20; E1sevier, Amsterdam: 447-477.

MOORE, D.M., 1979. Origins of temperate island floras. In D. Bramwell (ed.), Plants and Islands. Academic Press, London \& New York: 69-85.

MOORE, L.B., 1973. Botanical notes on three high peaks overlooking the Hauraki Gulf. Tane 19: 213-220.

MOORE, L.B. \& E. EDGAR, 1970. Flora of New Zealand, Volume 2. Government Printer, Wellington.

MOORE, L.R., 1968. Some sediments closely associated with coal seams. In D. Murchison \& T.S. Westoll (eds.), Coal and Coal-bearing Strata. Oliver \& Boyd, Edinburgh: 105-123. 
MORGAN, P.G., 1914. The Waikaka gold mining field. New Zealand Geological Survey (ns) 8th Annual Report: 147-152.

, 1920. The Tertiary beds of Central 0tago. New Zealand Journal of Science and Technology B 3: 29-33.

, 1924. The geology and mines of the Waihi District, Hauraki Goldfield. New Zealand Geological Survey Bulletin (ns) 4.

MORETON, J. \& M. MILLER, 1968. The New Zealand Sea Shore. Collins, London \& Auckland.

MOUTON, J.A., 1966. Sur 1a systématique foliare en paléobotanique. Société Botanique de 1a France 113: 492-502.

MULLER, J., 1981. Fossil pollen records of extant angiosperms. The Botanical Review 47: 1-142.

MUTCH, A.R., 1963. Sheet 23, Oamaru (1st edition). Geological Map of New Zealand 1:250,000. Department of Scientific and Industrial Research, Wellington.

MYERS, J.V., 1973. A note on the dispersal of Nothofagus pollen in Canterbury, New Zealand. New Zealand Journal of Botany 11: 311-316.

NICHOLLS, J.L., 1963. Vulcanicity and indigenous vegetation in the Rotorua District. Proceedings of the New Zealand Ecologica1 Society 10: 58-65.

N.Z. METEOROLOGICAL SERVICE, 1973. Summaries of Climatological observations to 1970. Stations in New Zealand and outlying islands, including the Cook Group, Tokelau Islands, Pitcairn Island, Niue Island and Western Samoa. New Zealand Meteorological Service Miscellaneous Publication 143.

NORRIS, R.J., R.M. CARTER \& I.M. TURNBULL, 1978. Route Guide, Queenstown - Dunedin. Geological Society of New Zealand Annual Conference, Queenstown, November 1978.

OLIVER, W.R.B., 1928. Flora of the Waipaoa Series of New Zealand. Transactions of the Royal Society of New Zealand 59: 287-303. , 1936. The Tertiary flora of the Kaikorai Valley, Otago, New Zealand. Transactions of the Royal Society of New Zealand 66: 284-304. 
OLIVER, W.R.B., 1950. The fossil flora of New Zealand. Tuatara 3: $1-11$.

PAERL. H.W., G.W. PAYNE, A.L. MACKENZIE, P.E. KELLAR \& M.T. DOWNS, 1979. Limnology of nine Westland beech forest lakes. New Zealand Journal of Marine and Freshwater Research 13: 47-57.

PAIJMANS, K., 1976. Vegetation. In K. Paijmans (ed.), New Guinea Vegetation. Australian National University Press, Canberra: 23-105.

PARK, J., 1903. On the geology of North Head, Waikouaiti and its relations to the geological history of Dunedin. Transactions and Proceedings of the New Zealand Institute 36: 418-430.

, 1906. The geology of the area covered by the Alexandra Sheet, Central Otago Division. New Zealand Geological Survey (ns) Bulletin 2.

, 1908. The geology of the Cromwell Subdivision. New Zealand Geological Survey (ns) Bulletin 5.

PENSELER, W.H.A., 1930. Fossil leaves of the Waikato District. Transactions and Proceedings of the New Zealand Institute 61: 452-477.

PIKE, K.M., 1953. Fossil Fruiting cones of Casuarina and Banksia from Tertiary deposits in Victoria. Proceedings of the Royal Society of Victoria 65 (ns): 1-9.

POCKNALL, D.T., 1978. Relative pollen representation in relation to vegetation composition, Westland, New Zealand. New Zealand Journal of Botany 16: 379-386.

, 1982a. Early Miocene vegetation at Kapuka, Southland, New Zealand: a study based on pollen analysis. New Zealand Geological Survey, Paleontological Report 48.

, 1982b. Palynology of late Oligocene Pomanhaka Estuarine Bed sediments, Waikoikoi, Southland, New Zealand. New Zealand Journal of Botany 20: 263-287.

POISSON, J., 1874. Récherches sur les Casuarines, et en particulieur sur ceux de la Nouvelle Calédonie. Nouvelles Archives Muséum d'Histoire Naturelle, Serie 1, 10: 59-111. 
POOLE, A.L., 1949. New data concerning the distribution of Nothofagus. Proceedings of the 7th Pacific Science Congress 5: 159-164.

POOLE, A.L. \& N.M. ADAMS, 1980. Trees and shrubs of New Zealand. Government Printer Wellington.

PREEST, D.S., 1963. A note on the dispersal characteristics of the seed of New Zealand podocarps and beeches and their biogeographical significance. In: J.L. Gressit (ed.) Pacific Basin Biogeography. 10th Pacific Science Congress, Honolulu 1961; Bishop Museum Press: 415-424.

QUINN, C.J., 1970. Generic boundaries in the Podocarpaceae. Proceedings of the Linnaean Society of New South Wales 94: 166-172. , 1982. Taxonomy of Dacrydium Sol. ex Lamb. emend. de Laub. (Podocarpaceae). Australian Journal of Botany 30: 311-320.

RAESIDE, J.D., E.J.B. CUTLER \& R.D. MILLER, 1966. Soil and related irrigation problems of part of the Maniototo Plains, Otago. Soil Bureau Bulletin 23.

RAMSAY, W.R.H., 1971. Geology of south central Great Barrier Island. Unpublished MSc Thesis, University of Auckland Library.

RAVEN, P.H., 1973. Evolution of subalpine and alpine plant groups in New Zealand. New Zealand Journal of Botany 11: 177-200.

RAVEN, P.H. \& D.I. AXELFORD, 1972. Plate tectonics and Australian biogeography. Science 176: 1379-1385.

RETALLACK. G.J., 1977. A biostratigraphy for terrestrial Triassic rocks of Gondwanaland. Unpublished $\mathrm{PhD}$ Thesis, University of New England, Armidale, New South Wales, Australia.

, 1977b. Triassic palaeosols in the Upper Narrabeen Group of New South Wales, Part 1: Features of the palaeosols. Journal of the Geological Society of Australia 23: 383-400.

, 1977c. Reconstructing Triassic vegetation of eastern Australasia, a new approach for the biostratigraphy of Gondwanaland, Alcheringa 1: 247-278.

, 1979. Middle Triassic coastal outwash plain deposits in Tank Gully, Canterbury, New Zealand. Journal of the Royal Society of New Zealand 9: 397-414. 
RETALLACK, G.J., 1981. Middle Triassic megafossil plants from Long Gully near Otemata, North Canterbury, New Zealand. Journal of the Royal Society of New Zealand 11: 167-200.

RICHARDS, P.W., 1941. Lowland tropical podsols and their vegetation. Nature 148: 129-131.

ROMERO, E.J., 1980. Arquitectura foliar de las especies sudamericanas de Nothofagus Blume. Boletin de la Sociedad Argentina de Botanica 19: 289-308.

SCHAARSCHMIDT, F., 1981. The significance of lianas in Eocene forests of Central Europe. (abstract). Abstracts, 13th International Botanica1 Congress, Sydney, 21-28 August 1981: 197.

SELLEY, R.C., 1978. Ancient Sedimentary Environments, second edition. Chapman \& Hall, London.

SEWARD, A.C., 1898. Fossil Plants, Volume 1. Cambridge University Press. , 1919. Fossil Plants, Volume 4. Cambridge University Press.

SEXTON, A.N., 1941. Notes on the Kauri-Beech (Nothofagus truncata) association in Omahuta State Forest. New Zealand Journal of Forestry 4: 308-310.

SHACKLETON, N.J., \& J.P. KENNETT, 1975. Paleotemperature history of the Cenozoic and the initiation of Antarctic glaciation. Initial reports, Deep Sea Drilling Project 29: 743-755.

SIDDIQUI, M.Y., R.C. CAROLIN \& D.J. ANDERSON, 1973. Studies in the ecology of coastal heath in New South Wales. Proceedings of the Linnaean Society of New South Wales 97: 211-224.

SIEVER, R., 1962. Silica solubility, $0-200^{\circ} \mathrm{C}$ and the diagenesis of siliceous sediments. Journal of Geology 70: 127-151.

SIMMONS, D.R. \& J.B. WRIGHT, 1967. Use of the polarising microscope for classifying quartzite artefacts from South Island sites. Transactions of the Royal Society of New Zealand (General) 2: $71 \sim 8$.

SKINNER, D.N.B., 1962. The geology of Moehau-Cape Colville District, Coromandel Peninsula. Unpublished MSc Thesis, University of Auckland Library. 
SKINNER, D.N.B., 1967. Geology of the Coromandel region with emphasis on some economic aspects. Unpublished $\mathrm{PhD}$ Thesis, University of Auckland Library.

, 1976. Sheet $\mathrm{N} 40$ and parts of sheets N35, N36 and N39, Northern Coromandel (first edition). Geological Map of New Zealand 1:63,000, Department of Scientific and Industrial Research, Wellington.

SLUITER, I.R. \& D.T. POCKNALL, 1983. A comparison of Late Oligocene Early Miocene vegetation from south-eastern Australia and Southland, New Zealand. Programme, Abstracts and Congress Information, 15th Pacific Science Congress, Dunedin, February 1-11 1983, Volume 2: 218.

SMALE, D., 1973. Silcretes and associated silica diagenesis in Southern Africa and Australia. Journal of Sedimentary Petrology 43: 1077-1089.

SMITH, A.G. \& J.C. Briden, 1977. Mesozoic and Cenozoic paleocontinental maps. Cambridge University Press.

SMITH, A.G. \& A. HALLAM, 1970. The fit of the southern continents. Nature 225: 139.

SPEIGHT, R., 1931. Coal Creek Flat, Roxburgh. New Zealand Journal of Science and Technology B 12: 207-214.

SPICER, R.A., 1980. The importance of depositional sorting to the biostratigraphy of plant megafossils. In D.L. Dilcher \& T.N. Taylor (eds.), Biostratigraphy of fossil plants, Dowden, Hutchinson \& Ross Inc., Strandsberg, Pennsylvania: 171-183.

SPORNE, K.R., 1965. The Morphology of Gymnosperms: the structure and evolution of primitive seed plants. Hutchinson University Library.

SQUIRES, D.F. 1962a. Additional Cretaceous and Tertiary corals from New Zealand. Transactions of the Royal Society of New Zealand, Geology 1: 133-150.

, 1962b. A Scleractinian coral faunule from Cape Rodney. New Zealand Journal of Geology and Geophysics 5: 501-514. 
STAFLEU, F.A., et al. (eds.), 1978. International Code of Botanical nomenclature, adopted by the 12 th International Botanical Congress, Leningrad, July 1975. Bohn Scheltema \& Holkema, Utrecht.

STEENIS, C.G.G.J. van, 1962. The land bridge theory in botany. Blumea 11: 235-372.

, 1971a, Nothofagus, key genus of plant geography in time and space, living and fossil, ecology and phylogeny. Blumea 19: 65-98.

, 1971b. Revision of Nothofagus in New Caledonia. Adansonia, Series 2, 11: 615-624.

, 1976. Nothofagus. In Flora Malesiana Volume 7, C.G.G.J. van Steenis (ed.); Noordhoff International Publishing, Leyden: 277-294. STEPHENS, C.G., 1964. Silcretes of Central Australia. Nature 203: 1407.

, 1971. Laterite and silcrete in Australia: a study of the genetic relationships of laterite and silcrete and their companion materials, and their collective significance in the formation of the weathered mantle, soils, relief and drainage of the Australian continent. Geoderma 5: 5-52.

SUGGATE, R.P., 1959. New Zealand coals: their geological setting and its influence on their properties. New Zealand Department of Scientific and Industrial Research Bulletin 134.

SWINEFORD, A. \& P.C. FRANKS, 1959. Opal in the Ogallala Formation in Kansas. In H.A. Ireland (ed.) Silica in sediments. Society of Economic Paleontologists and Mineralogists Special Publication 7: 111-120.

TANSLEY, A.G., 1949. The British Isles and their vegetation, Volume 2. Cambridge University Press.

TAYLOR, N.H., 1947. Native vegetation as a soil forming factor in North Auckland. Wellington Botanical Society Bulletin 15: 3-5. 
TAYLOR, G. \& I.E. SMITH, 1975. The genesis of sub-basaltic silcrete from the Monaro, New South Wales. Journal of the Geological Society of Australia 22: 377-385.

THOMPSON, B.N., 1960. Sheet 2B, Barrier (first edition). Geological Map of New Zealand 1:250,000. Department of Scientific and Industrial Research, Wellington.

TOWNROW, J.A., 1965. Notes on Tasmanian pines II. Athrotaxis from the Lower Tertiary. Papers and Proceedings of the Royal Society of Tasmania 99: 109-115.

TURNBULL, I.M., J.M. BARRY, R.M. CARTER \& R.J. NORRIS, 1975. The Bob's Cove Beds and their relationship to the Moonlight Fault Zone. Journal of the Royal Society of New Zealand 5: 355-394.

UNGER, F., 1864. Reise der "Novara", Geologie, Palaeontologie 1, (2): 5-6.

VAIL, P.R., R.M. MITCHUM Jr. \& S. THOMPSON, 1977. Seismic Stratigraphy and global changes in sea leve1, part 3: relative changes of sea level from coastal onlap. American Association of Petroleum Geologists Memoir 26: 63-81. , 1977b. Seismic stratigraphy and global changes in sea level, part 4. Global cycles of relative changes of sea level. American Association of Petroleum Geologists Memoir 26: 83-97.

VIROT, R., 1956. La Végétation Canaque. Mémoires du Muséum National d'Histoire Naturelle, Serie B, Botanique 7.

, 1968. Proteacées; Volume 2. In A. Aubréville (ed.), Flore de la Nouvelle Calédonie et Dépandances. Muséum National d'Histoire Naturelle, Paris.

, 1975. Volume 6, Epacridacées. In A. Aubréville (ed.), Flore de la Nouvelle Calédonie et Dépandances. Muséum National d'Histoire Naturelle, Paris.

VISHER, G.J., 1965. Fluvial processes as interpreted from ancient and recent fluvial deposits. In G.V. Middleton (ed.), Primary sedimentary structures and their hydrodynamic interpretation. Society of Economic Palaeontologists and Mineralogists special publication 12: 116-132. 
VISHER, G.J., 1972. Physical characteristics of fluvial deposits. In: Rigby and Humblin (eds.), Recognition of ancient sedimentary environments. Society of Economic Paleontologists and Mineralogists Special Publication 16: 84-97.

WARDLE, P., 1968. Evidence for indigenous pre-Quaternary element in the mountain flora of New Zealand. New Zealand Journal of Botany 6: $120-125$.

WATSON, J. \& K.L. ALVIN, 1976. Silicone rubber casts of silicified plants from the Cretaceous of Sudan. Palaeontology 19: 641-650.

WATTS, S.H., 1977. Major element geochemistry of silcrete from a portion of inland Australia. Geochimica et Cosmochimica Acta 41: 1164-1167.

, 1978. A petrographic study of silcrete from inland Australia. Journal of Sedimentary Petrology 48: 987-994.

WEBB, L.J., 1959. A physiognomic classification of Australian rainforests. Journa1 of Ecology 47: 551-570.

WELLMAN, H.W., 1952. Interpretation and discussion of analyses. In: M. Gage 1952, The Greymouth Coalfield. New Zealand Geological Survey Bulletin (ns) 45: 78-106.

, 1975. New Zealand sixty million years ago. Bulletin of the Australian Society of Exploration Geophysicists 6: 55-56.

WESTOLL, R.S., 1968. Sedimentary rhythms in coal bearing strata. In Murchison \& T.S. Westoll (eds.), Coal and Coal-bearing Strata; Oliver \& Boyd, Edinburgh: 71-103.

WHEELER, J.M., 1963. The vegetation of the North Cape area. Tane 9: 63-84.

WHITMORE, T.C., 1973. Plate tectonics and some aspects of Pacific plant geography. New Phytologist 72: 1185-1190.

WILlCOX, J.B., P.A. SYMONDS, K. HINZ \& D. BENNET, 1980. Lord Howe Rise, Tasman Sea - preliminary geophysical results and petroleum prospects. BMR Journal of Australian Geology and Geophysics 5: $225-236$. 
WILLETT, R.W., 1943a. The Nevis oil shale deposit, Nevis Survey District, Otago Central. New Zealand Journal of Science and Technology B 24: 239-254.

, 1943b. Oil shales at Cambrian, Freshford and Waitati, Otago and Southland. New Zealand Journal of Science and Technology B 24: 255-271.

WILLETT, R.W., 1948. Preliminary report on the lignite deposits of the Mataura Valley, Eastern Southland Coalfield. New Zealand Journal of Science and Technology B 29: 228-246.

WILLETT, R.W. \& H.W. WELLMAN, 1940. The oil shale deposit of Orepuki, Southland. New Zealand Journal of Science and Technology B 22: 84-99.

WILLIAMS, G.J., 1974. Cenozoic geology of the Lower Nevis Basin, with special reference to the oil shale deposit. New Zealand Department of Scientific and Industrial Research Bulletin 212.

WILLIAMSON, J.H., 1933. Naseby Subdivision. New Zealand Geological Survey 27th Annual Report (ns): 7-10.

, 1939. The geology of the Naseby Subdivision. New Zealand Geological Survey Bulletin (ns) 39.

WILLIAMSON, W.O., 1957. Silicified sedimentary rocks in Australia. American Journal of Science 255: 23-42.

WILSON, T.H. \& P.R. MOORE, 1973. The hot springs of Great Barrier Island. I. Physical measurements and chemical analyses. Tane 19: 129-140.

WOLFE, J.A., 1971. Tertiary climatic fluctuations and methods of analysis of Tertiary floras. Paleogeography, Palaeoclimatology, Palaeoecology 9: 29-57.

WOLFE, J.A. \& D.M. HOPKINS, 1967. Climatic changes recorded by Tertiary land floras in northwestern North America. In Tertiary Correlations and climatic changes in the Pacific. 11th Pacific Science Congress, Tokyo: $67-76$. 
WOOD, B.L., 1956. The geology of the Gore Subvidision. New Zealand Geological Survey Bulletin (ns) 53.

, 1962. Sheet 22, Wakatipu (first edition). Geological Map of New Zealand 1:250,000. Department of Scientific and Industrial Research, Wellington.

, 1966. Sheet 24, Invercargill (first edition). Geological Map of New Zealand 1:250,000. Department of Scientific and Industrial Research, Wellington.

, 1968. Notes to Benson, W.N., 1968, Dunedin District 1:50,000. New Zealand Geological Survey Miscellaneous series, Map 1. Department of Scientific and Industrial Research, Wellington.

WOOLNOUGH, W.G., 1927a. The chemical Criteria of peneplanation. Journal and Proceedings of the Royal Society of New South Wales 61: 17-24. , 1927b. The duricrust of Australia. Journal and Proceedings of the Royal Society of New South Wales 61: 24-53.

WRIGHT, A.C.S., 1959. The soil factor in plant ecology (2). Wellington Botanical Society Bulletin 31: 6-10.

WRIGHT, A.C.S. \& R.B. MILLER, 1952. Soils of south west Fiordland. New Zealand Soil Bureau Bulletin 7 (ns). 
ACKNOWLEDGEMENTS .

Thanks are due to my supervisors, Professor P. Vella and Dr. J.D. Collen (Geology Department, Victoria University of Wellington) and Dr. J.W. Dawson (Botany Department, Victoria University of Wellington) for their help and advice, and for reading and criticising the manuscript; and to Dr. D.R. McQueen (Botany Department, Victoria University of Wellington), Mr. C. Vucetich (Geology Department, Victoria University of Wellington), Mr. D.C. Mildenha11, Dr. D.T. Pocknall and Dr. J.I. Raine (Palynology section, N.Z. Geological Survey, Lower Hutt), and Professor J.D. Campbell (Geology Department, Otago University) for many helpful discussions. The writer also thanks Dr. R.P. Suggate (Director, N.Z. Geological Survey) and Mr. R. Beck (Southland Museum, Invercargil1) for loan of specimens; Dr. P.J. Brownsey for access to the National Museum Herbarium; Dr. P. Morat for access to the O.R.S.T.O.M. Herbarium, Noumea, New Caledonia and Dr. G. McPherson (Missouri Botanic Gardens) for assistance in the field in New Caledonia. Photographs are the work of Mr. Derek Bircham (Longford fossils, infra-red photographs), Mr. John Casey of the Photographic Unit, Victoria University, (Landslip Hill fossils, reproduction of photographic plates) and the writer.

Thanks are also extended to the staff of the Electron Microscopy Unit, Victoria University, for their assistance, to Mr. Kerry Stevens of the Geology Department for X ray diffraction analyses and to Mrs. Jenny Brown and Mr. John Carter, also of the Geology Department for preparing thin sections. The writer particularly expresses her appreciation to Mrs. Helen Hines for typing the manuscript and Ms. Val Hibbert of the Geology Department for typing tables 9.1 and 9.2.

The work was completed with the aid of a grant from the Jacob Joseph Scholarship Fund. 
APPENDIX A
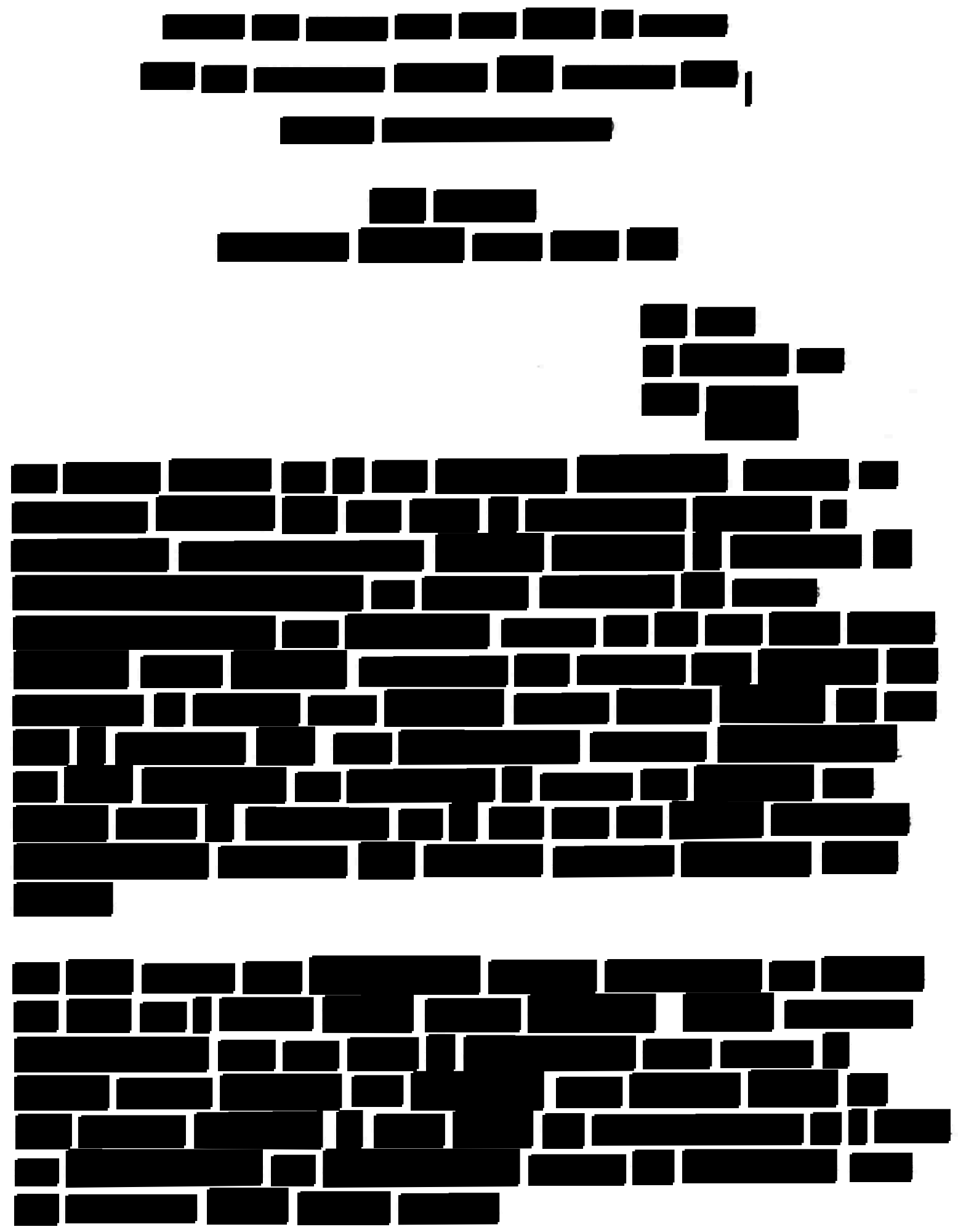
TABLE 1. Pollen and spore percentages, for samples G43/f2A and $B$ and $\mathrm{H} 41 / \mathrm{f} 28$. X signifies less than $1 \%$.

$\begin{array}{llll} & \text { G43/f2A } & \text { G43/f2B } & \text { H41/f28 } \\ \text { grid ref. } & 214193 & 214193 & 577888\end{array}$

Angiosperms

Compositae (Tubuliflorae)

Couperipollis mortonii n.sp.

Cranwellia striata

Cupanieidites major (sensu Cooper 1960)

C. orthoteichus

Elaeocarpaceae

Elytranthe

Epacridaceae

Fuchsia

Glencopollis ornatus n.sp.

Gramineae

Haloragacidites haloragoides

H. harrisii

Leptospermum

Liliacidites variegatus

Lymingtonia cenozoica n.sp.

Malvacipollis subtilis

Monoporopollenites psilatus n.sp.

Monosulcites otagoensis

Myrtaceae

G43/f $2 A$

214193

577888

Nothofagidites asperus

N. cranwellae

N. Iachlanae

N. matauraensis

N. spinosus

Palaeocoprosmadites sp.

Parsonsidites psilatus

Periporopollenites polyoratus

Proteacidites duplus n.sp.

P. minimus

P. pseudomoides

P. stratosus n.sp.

P. subscabratus

P. symphyonemoides

Restionaceae

Rhoipites alveolatus

R. pilatus

R. sphaerica

Sapotaceae

Sparganiaceaepollenites barungensis

Sparsipollis papillatus

Tetracolporites ixerboides

T. sphericus

Tricolporopollenites endobalteus

T. pseudostriatus

Triorites dubius

T. scabratus

\begin{tabular}{|c|c|}
\hline$x$ & $\mathrm{x}$ \\
\hline 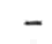 & $x$ \\
\hline 2 & - \\
\hline $\mathrm{x}$ & - \\
\hline - & $\mathrm{x}$ \\
\hline - & - \\
\hline 1 & - \\
\hline$x$ & $x$ \\
\hline$x$ & - \\
\hline $\mathrm{x}$ & - \\
\hline - & $\mathrm{x}$ \\
\hline 4 & 2 \\
\hline 26 & 32 \\
\hline 2 & - \\
\hline $\mathrm{x}$ & $x$ \\
\hline$x$ & - \\
\hline - & - \\
\hline$x$ & - \\
\hline 2 & $\mathrm{x}$ \\
\hline 16 & 10 \\
\hline 3 & 4 \\
\hline 22 & 29 \\
\hline 8 & 8 \\
\hline - & - \\
\hline 2 & - \\
\hline $\mathrm{x}$ & $x$ \\
\hline$x$ & - \\
\hline$x$ & - \\
\hline - & - \\
\hline$x$ & - \\
\hline- & - \\
\hline - & - \\
\hline - & - \\
\hline - & - \\
\hline$x$ & $\overline{-}$ \\
\hline 1 & 3 \\
\hline $\mathrm{x}$ & - \\
\hline- & - \\
\hline $\mathrm{x}$ & - \\
\hline $\mathrm{x}$ & - \\
\hline - & - \\
\hline - & - \\
\hline 5 & 4 \\
\hline 1 & - \\
\hline - & - \\
\hline - & $x$ \\
\hline
\end{tabular}


Gymnosperms

Araucariacites cf, australis

Dacrycarpus

Dacrydium bidwillii/biforme

D. cupressinum

Libocedrus

Phyllocladus

Podocarpidites

Podosporites brevisaccatus

Pteridophytes

Baculatisporites disconformis

Cyathidites

cf. Grammitis

Lycopodium cf. scariosum

Monoletes

Osmundaceae

Polypodiaceoisporites tumulatus

Polypodiisporites radiatus n.sp.

Rugulatisporites cf. mallatus

Trilites tuberculiformis

$\begin{array}{ccc}1 & - & - \\ \mathrm{x} & \mathrm{x} & \mathrm{x} \\ - & \mathrm{x} & \mathrm{x} \\ \mathrm{x} & \mathrm{x} & \mathrm{x} \\ - & \mathrm{x} & - \\ \mathrm{x} & \mathrm{x} & \mathrm{x} \\ \mathrm{x} & \mathrm{x} & 2 \\ - & - & \mathrm{x}\end{array}$

Summary

The assemblages obtained from G43/f2A and B are very similar with only minor differences relating to the presence or absence of rare taxa. Casuarina (Haloragacidites harrisii) is the most abundant in both with brassi beech (Nothofagidites cranwellae), Myrtaceae (many forms), fusca beech (N. lachlanae), Macaranga-Mallotus (Tricolporopollenites endobalteus), menziesii beech (N. asperus), Palmae (Monosulcites otagoensis) and Loranthaceae (E1ytranthe and Cranwellia striata) of secondary importance. These assemblages are indicative of full forest growing under moist, humid and warm temperate conditions although Macaranga-Mallotus are of ten found in dry forest margin situations in the sub-tropics. There are very few pollen types with subtropical affinities recorded. Locally, wetland sites were inhabited by Haloragis (Haloragacidites haloragoides), Sparganium and Restionaceae.

The sample from St Bathans differs from the point that brassi beech is overwhelmingly abundant a1though fusca beech, Myrtaceae and Palmae are still common. Elaeocarpaceae pollen, only identifiable to family level is recorded (5\%); it is not recorded at Roxburgh. Casuarina accounts for 
only $4 \%$ of the total count and although this is a significant difference percentage-wise it probably only reflects the difference between a local presence as recorded at Roxburgh and a regional presence as recorded at St Bathans. Palaeoenvironment was probably warm temperate with the area mostly under forest; however the absence of Macaranga-Mallotus at St Bathans may signify slightly higher rainfall than at the time of deposition at Roxburgh.

The age of these samples is not readily determinable because of the lack of key taxa nonetheless the assemblages are similar to those recorded from samples collected at Vinegar Hill, St Bathans (Mildenhall 1981) and Kawarau River section Cromwell (Mildenhall 1977) of early to middle Miocene age.

\section{REFERENCES}

Mildenha11, D.C. 1977. Preliminary palynological thoughts on the Lower Miocene, Kawarau River, Central Otago. Geological Society of New Zealand 22nd Conference, Queenstown. Abstracts p.44.

1981. Early to mid-Miocene palynology, Vinegar Hill, St. Bathans, Central Otago, New Zealand. Unpublished Palynology Section Report DCM 51/80, 8 p.

Pocknall, D.T. 1981. Results of palynological analysis of samples from a drillhole at Gimmerburn, near Haughtons Hill, Central Otago, New Zealand (Metric Sheet H42). Unpublished Palynology Section Report DTP 15/81, 9 p. 


\section{APPENDIX B.}

Fossil Diatomaceae from some Neogene fresh-water sediments.

Margaret A. Harper, Department of Geology, Victoria University of Wellington.

In the following tables alkalinity refers to the $\mathrm{pH}$ requirements of each species and varies from those species confined to alkaline waters (alkalibiontic) to those only occurring in acid waters (acidobiontic). Salt refers to the salt tolerance of the species, and varies from halobiontic species which require salt to halophobic species which only occur in waters with low concentrations of dissolved salts. Cassie's Index is determined from recorded occurrences of diatom species in New Zealand, and refers to New Zealand only.

$\underline{\text { Key }}$

$$
\begin{aligned}
& \text { Alkalinity } \\
& \text { Salt } \\
& + \text { alkalibiontic } \\
& \text { + halobiontic } \\
& + \text { halophilic } \\
& T \text { oligohalobic } \\
& \text { I indifferent } \\
& \text { I indifferent } \\
& \text { - halophobic } \\
& 1 \text { epipelic } \\
& \text { e epiphytic } \\
& \text { - acidophilic } \\
& \text {-- acidobiontic }
\end{aligned}
$$

\section{Cassie's Index}


TABLE 1. Samp1e V2850 Bannockburn.

$\% * \quad$ Species

崩

65 Melosira granulata (Ehr.) Ralfs.

Opephora martyii Herib.

5 Cyclotella stelligera C1. \& Grun.

5 Amphora ovalis (Kutz) Kütz

3 Achnanthes lanceolata Breb. ex Kütz

2 Fragilaria brevistriata Grun.

1 Cymbella microcephala Grun.

1 C. ventricosa Kütz

1 C. turgida (Greg.) Cleve

1 Melosira italica (Ehr.) Kütz

1 Navicula pseudoscutiformis Hust.

1 N. cocconeiformis Greg. ex Grev.

1 N. capitata Ehr.

1 N. pupula Kütz

1 Fragilaria leptostauron (Ehr.) Hust.

1 Cocconeis diminuta Pant.

1 C. placentula Ehr.

1 Synedra acus Kütz

1 Nitzschia amphibia E. Smith

Sparse $(<1 \%)$

+ Achnanthes minutissima Kütz

+ Diploneis smithii (Breb.) Cleve

+ Neidium affine (Ehr.) Cleve

+ Amphora perpusilla (Grun.) Grun.

+ Gomphonema olivaceum (Lynb.) Kütz

+ Fragilaria capucina Desmoz.

Rare - only one specimen seen on the slide

Navicula radiosa Kütz

Caloneis bacillum (Grun.) Mere.

Pinnularia divergens W. Smith

Rhopalodia gibba (Ehr.) 0. Mul1.

Nitzschia lorenziana Grun.

N. filiformis (W. Smith) Hust.

Epithemia sorex Kutz
+ T P ML 57

H T/ e 30

I $\quad \mathrm{P} \quad 36$

$+\mathrm{T} 1 \mathrm{~T}$

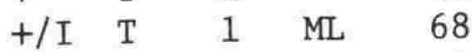

+ T tp 4

$+\mathrm{T}$ e 23

I $\mathrm{T}$ e 44

$+\mathrm{T}$ e 47

$+/ \mathrm{I} \quad \mathrm{T} \quad \mathrm{P} \quad \mathrm{MF} \quad 44$

$+/ \mathrm{I} r \mathrm{~T} \quad 1 \quad 12$

I/ 1 - 1

$+\quad+/ \mathrm{T} 1 / \mathrm{ae} \quad 28$

$\begin{array}{lllll}\text { I } & \text { T } & 1 & \text { MF } & 46\end{array}$

+ T tp FO 1

$+\quad+$ e MF 5

$+\quad+/ T$ e ML 69

+ I e/p 13

+1 ML 49

$\begin{array}{rlllr}+ & \text { I } & 1 & & 41 \\ + & + & 1 & \text { FO } & 4 \\ + & \text { T } & 1 & & 11 \\ + & \text { T } & 1 & & 0 \\ + & \text { T } /+ & \text { e } & \text { FO } & 0 \\ + & \text { T } & \text { tp } & & 37\end{array}$

$\begin{array}{llll}\text { I } & \text { T } & 1 & 41\end{array}$

+ I 1136

I - 14

$++120$

I +10

+ I e ML

Summary

Alkalinity

(7\%) $2+$

(79\%) $16+$

(5\%) $3+/ I$

(6\%) $5 \mathrm{I}$

(2\%) $1 \mathrm{I} /-$ $\underline{\text { Salt }}$

(1\%) $1+$

(7\%) $4+$

(10\%) $4 \mathrm{~T} /+$

(80\%) $1 \mathrm{~T}$

(1\%) $1 \mathrm{I} / \mathrm{T}$

(1\%) $2 \mathrm{I} /-$
Cassie's Index

(1\%) 3 FO

(3\%) $3 \mathrm{MF}$

(75\%) 6 ML

(0\%) 0 LO
(14\%) $\quad 17.1$

(12\%) $8 \mathrm{e}$

(3\%) 3 tp

(71\%) $3 \mathrm{p}$

(0\%) 1 ae
1

4

0




\section{Comments}

The siliceous fraction of Bannockburn shale is fairly diatomaceous but also contains some quartz grains, flakes and amorphous material. The diatom flora is rich. The dominant species is the planktonic diatom Melosira granulata which is often found in warm, eutrophic water following blooms of other algae, but can also be found in temperate oligotrophic water. It is heavily silicified and requires more silicate than Cyclotella stelligera: it also requires fairly turbulent lake water to remain in suspension and is often found in lake waters stirred up by wind.

Nearly all the species found prefer somewhat alkaline water and many tolerate the presence of a little salt, but this may be related to their occurrence in water of high conductivity rather than suggesting the presence of sea water nearby. Few of the species are associated with high flow rates which suggests a lake rather than a river. As $71 \%$ of the diatoms are planktonic, this suggests a lake deeper than Lake Poukawa ( $3 \mathrm{~m}$ depth), possibly of the order of $10 \mathrm{~m}$, but the proportion of littoral and epiphytic species rules out a deep, steepsided body of water. The high proportion of mainly living diatoms is partly due to the fact that only 25 out of 88 papers examined by Cassie (1980) dealt with fossil diatoms. 
TABLE 2. Sample V2849 Nevis.

$\%$ Species

\begin{tabular}{|c|c|c|c|}
\hline 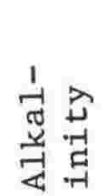 & $\begin{array}{l}\vec{\pi} \\
\text { ద }\end{array}$ & & 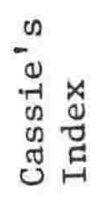 \\
\hline
\end{tabular}

91 Melosira granulüta (atypical form)

7 Fragilaria construens var. $\begin{array}{rrrrr}+ & \text { I } & \text { p } & \text { ML } & 1 \\ + & \text { I } & \text { tp } & & 17\end{array}$ venter (Ehr.) Grun.

1 Navicula exigua (Greg.) Grun.

+ Melosira italica (Ehr.) Kutz

+ Navicula reinhardtii (Grun.) Grun,

+ N. elmorei Patr.

(N. confervacea Kütz)

+ Cymbella aspera (Ehr.) Grun.

Achnanthes sp.

Navicula pseudoscutiformis Hust.

$\begin{array}{llll}+/ \mathrm{I} & \mathrm{T} & 1 & 19\end{array}$

$+/ \mathrm{I} \quad \mathrm{T} \quad \mathrm{P} \quad \mathrm{MF} \quad 44$

$\begin{array}{llll}+(+) & \mathrm{T} & 1 & 1\end{array}$

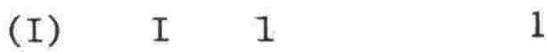

+ T e/ae 29

$+\quad \mathrm{I} / \mathrm{T} \quad 1$

12

Summary

\begin{tabular}{|c|c|c|c|c|}
\hline Alkalinity & Salt & Habitat & & Cassie's Index \\
\hline $0+$ & $0+$ & $(91 \%)$ & $2 \mathrm{p}$. & \\
\hline$(98 \%) 5+$ & $0+$ & $(1 \%)$ & 51 & $(0 \%) 1 \mathrm{MF}$ \\
\hline$(1.5 \%) 2+/ I$ & $(1 \%) \times 4 \mathrm{~T}$ & & $1 \mathrm{e}$ & $(91 \%) \quad 1 \mathrm{ML}$ \\
\hline ?O I & $1 \mathrm{I} / \mathrm{T}$ & $(7 \%)$ & 1 tp & \\
\hline $0-$ & $(98 \%) 2 I$ & & & \\
\hline $0--$ & $0-$ & & & \\
\hline
\end{tabular}

\section{Comments}

The deposit is diatomaceous, but with some flakes of siliceous material. The assemblage is dominated by a form of Melosira granulata which does not have the characteristic separation cells with long spines. Many of the diatoms are fragmented and partly collapsed, suggesting that they come from faecal pellets of crustaceans, a feature typical of deep water deposits. I would suggest that this was the deepest lake of the set $(\mathrm{ca} .100 \mathrm{~m})$, and possibly steep sided. The sample is from a deep part of the lake. There are fewer species having a slight salt demand than occur at Bannockburn and most of the species are indifferent in this regard. The water was possibly more alkaline than at Bannockburn but not certainly so as no alkalibiontic species were found. 
TABLE 3. Sample B411 Great Barrier Island.

\begin{tabular}{|c|c|c|c|c|c|c|}
\hline$\% *$ & Species & 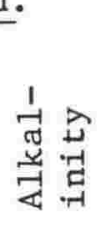 & $\begin{array}{l}\stackrel{\sim}{-1} \\
\text { ஸ }\end{array}$ & 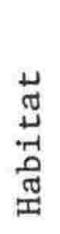 & $\begin{array}{l}\text { on } \\
-0 \\
0 \\
-1 \\
0 \\
0 \\
0 \\
0 \\
0 \\
0\end{array}$ & 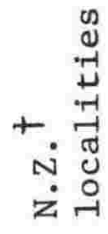 \\
\hline 64 & Melosira granulata (Ehr.) Ralfs. & + & $\mathrm{T}$ & $\mathrm{p}$ & ML & 57 \\
\hline 23 & Cymbella cymbiformis (Kütz) van Heurck & + & I & e & & 7 \\
\hline 3 & Navicula viridula Kütz & I & $\mathrm{I}$ & 1 & & 12 \\
\hline 2 & Surirella angustata Kütz & + & $I$ & 1 & & 34 \\
\hline 2 & Rhopalodia gibberula & + & $I$ & e & & 3 \\
\hline 1 & R. gibba (Ehr.) Grun. & + & $I$ & $\mathrm{e}$ & & 20 \\
\hline 1 & Pinnularia gibba Ehr. & I & I & 1 & & 46 \\
\hline 1 & Synedra acus Kiltz & + & $I$ & e & & 13 \\
\hline 1 & Anomoeneis sphaerophora (Knütz) Pfitzer & + & + & 1 & & 7 \\
\hline 1 & Navicula gastrum (Ehr.) Küz & + & + & 1 & & 11 \\
\hline 1 & Frustulia vulgaris (Thwaites) de Toni & + & $\mathrm{I}$ & 1 & ML & 60 \\
\hline+ & Nitzschia 1inearis W. Smith & I & $I$ & 1 & & 35 \\
\hline+ & Cyclotella stelligera Cleve \& Grun. & I & $I$ & $\mathrm{p}$ & ML & 36 \\
\hline+ & Navicula radiosa Kütz & $\mathrm{I}$ & $I$ & 1 & & 41 \\
\hline+ & Fragilaria brevistriata Grun. & + & I & e & & 4 \\
\hline
\end{tabular}

Summary

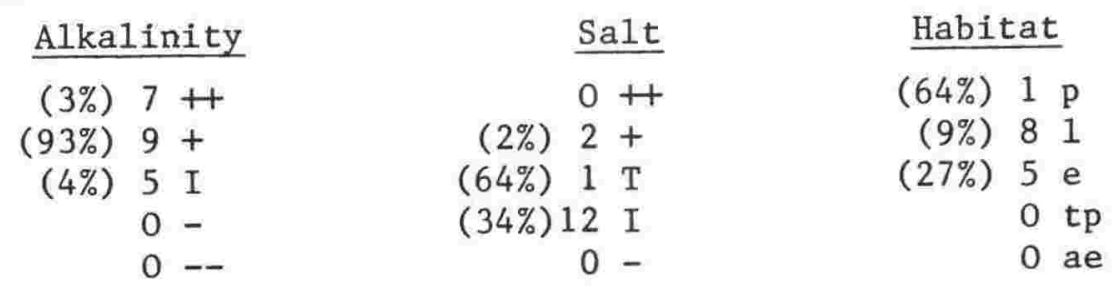

Comments

Most diatoms preferred alkaline waters. Most are also indifferent to the presence of low concentrations of salt, but Anomoeneis sphaerophera requires some salt. The water appears to have been somewhat eutrophic rather than strictly oligotrophic. There is a higher proportion of planktonic diatoms than in Lake Poukawa (Recent, Hawke's Bay, New Zealand, depth about 1-3 m), but a lower proportion than in Lake Malawi (Recent, Africa, depth about $100 \mathrm{~m})$. A lake at least $10 \mathrm{~m}$ deep and thermally stratified at least seasonally is indicated. The relatively high numbers of epiphytic diatoms suggest abundant aquatic macrophytes, and the presence of abundant Melosira granulata probably indicates some turbulence. 
TABLE 4. Sample V2855 St. Bathans

No. $\quad$ Species

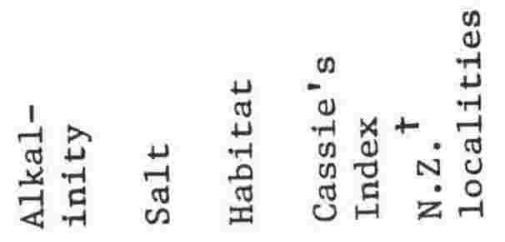

4 Melosira italica (Ehr.) Kütz

$\begin{array}{lllll}+/ \mathrm{I} & \mathrm{T} & \mathrm{p} & \mathrm{MF} & 44\end{array}$

3 Stephanodiscus astrea var. minutula $\begin{array}{llll}\text { I } & \mathrm{T} & \mathrm{P} & 19\end{array}$ (Kutz) Grun.

2 Cymbella cistula (Hemp.) Grun.

1 Fragilaria pinnata Ehr.

1 Cyclote1la meneghiana Kütz

1 Anomoeneis sphaerophora (Kütz) $+\mathrm{T}$ e 65

+ T tp 25

$+\quad+136$ Pfitzer

Summary
Alkalinity
Sa1t
Habitat
(3) $2+$
(2) $2+$
$0+$
(7) $2 \mathrm{p}$
(2) 21
(2) $1 \mathrm{e}$
(4) $1+/ I$
(1) $1+$
(1) $1 \mathrm{~T} /+$
(1) $1 \mathrm{tp}$
(4) $1 \mathrm{MF}$
(3) $1 \mathrm{I}$
(10) $4 \mathrm{~T}$
0 -
$0 \mathrm{I}$
0 --
0 -

Cassie's Index

The water was probably somewhat alkaline and contained moderate amounts of mineral salts. Melosira italica is found in more oligotrophic lakes than $\underline{\text { M. granulata }}$ (Lund 1962). The diatoms are very sparse and mostly in the form of fragments. Some shards, possibly of volcanic glass are present. 
TABLE 5. Sample V2847 Fraser's Gully, Kaikorai, Dunedin.

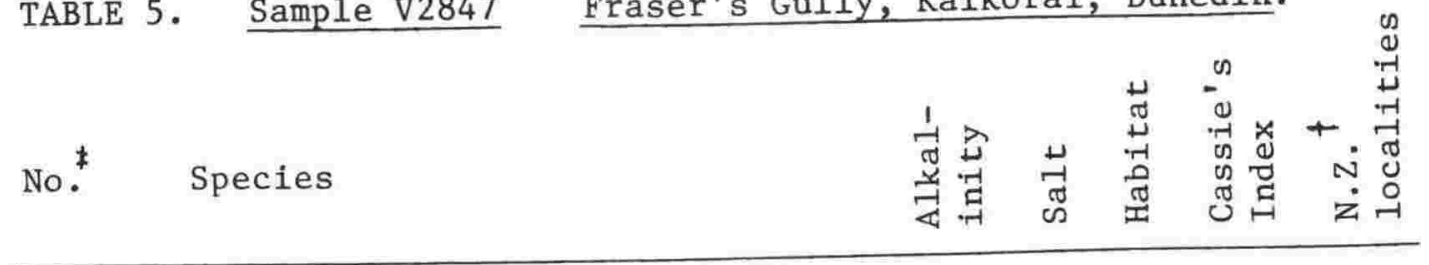

7 Gomphonema subclavatum Grun.

6 Melosira distans (Ehr.) Kütz

4 Cymbella sinuata Greg.

2 Nitzschia parvula Greg.

1 Navicula seminulum Grun.

1 Pinnularia sp. fragment

1 Achnanthes sp. fragment

$\begin{array}{ccccr}\text { I } & \text { I } & \text { e } & & 10 \\ - & - & \text { P } & \text { ML } & 35 \\ \text { I } & \text { T } & \text { e } & & 11 \\ \text { I } & \text { T } & 1 & & 4 \\ \text { I/- } & \text { I/+ } & 1 & & 0 \\ \text { ?- } & & 1 & & \\ & & \text { e } & & \end{array}$

1 Amphora sp. fragment

$\underline{\text { Summary }}$
Alkalinity
$\underline{\text { Salt }}$
Habitat
$0+$
$0+$
(13) $3 \mathrm{I}$
(1) $1 \mathrm{I} /-$
(7) 2 -
$0--$
(6) 51
(11) 2 e
$0+$
(1) $1 \mathrm{I} /+$
(6) $1 \mathrm{p}$
(6) $1 \mathrm{ML}$

Cassie's Index

\section{Comments}

This water appears to have been neutral to acid, very shallow and weedy, and probably eutrophic. Oliver (1936) studied a different sample site in Fraser's Gully and found Melosira granulata, Navicula placentula, N. cryptocephala and Pinnularia viridis. Apart from $\underline{\text { P. }}$ viridis, these prefer alkaline water and are tolerant of slight salinity. His results suggest a water body more like that of St. Bathans, but the present sample came from a shallower, more eutrophic acidic pool containing humus or from the margin of a lake. The water may have been deoxygenated as a result of volcanic eruption

Summary of Results

\begin{tabular}{lccccc}
\hline Locality & Plantonic \% & $\begin{array}{c}\text { Hard Water } \\
\text { Indicator } \\
\%\end{array}$ & $\begin{array}{l}\text { Salt } \\
\text { Indicator } \\
\%\end{array}$ & $\begin{array}{l}\text { Salt } \\
\text { Tolerant } \\
\%\end{array}$ & $\begin{array}{c}\text { Number } \\
\text { Species }\end{array}$ \\
\hline Bannockburn & 71 & 86 & 11 & 80 & 32 \\
Nevis & 91 & 98 & 0 & 1 & 9 \\
Great Barrier & 64 & 96 & 2 & 94 & 15 \\
St. Bathans* & $(50)$ & $(25)$ & $(20)$ & $(80)$ & 6 \\
Kaikorai $^{*}$ & $(25)$ & $(0)$ & $(0)$ & $(50)$ & $(8)$
\end{tabular}


Most abundant species: Bannockburn Melosira granulata 65\% (646)

\begin{tabular}{|c|c|c|}
\hline Nevis & M. granulata & \\
\hline & (atyp.) & $91 \%(337)$ \\
\hline Great Barrier & M. granulata & $65 \%(337)$ \\
\hline St. Bathans ${ }^{*}$ & M. italica & $(30 \%) \quad(4)$ \\
\hline Kaikorai $^{*}$ & $\frac{\text { Gomphonema }}{\text { subclavatum }}$ & $(30 \%) \quad(7)$ \\
\hline
\end{tabular}

* diatoms sparse so all percentages approximate and in parentheses.

According to Cassie's (1980) classification 3 taxa are "fossil only" in New Zealand, 5 are "mainly fossil" and 11 are "mainly living". None of the taxa found are classified as "living only".

\section{References}

Cassie, V., 1980. The fossil and living fresh water diatom flora of New Zealand. Proceedings of the 6th Symposium on Recent and Fossil Marine Diatoms; Sunnonsen (ed.). Nova Hedwigia : 321-338.

Foged, N., 1979. Diatoms in New Zealand; the North Island. Bibliotheca Phycologica Band 47 . J. Cramer, Vaduz.

Lund, J.W.G., 1962. Phytoplankton from some lakes in Northern Saskatchewan and from Great Slave Lake. Canadian Journal of Botany $40: 1499-1514$.

Oliver, W.R.B., 1936. The Tertiary flora of the Kaikorai Valley, Otago, New Zealand. Transactions of the Royal Society of New Zealand 66 : 284-304. 
APPENDIX C

CATALOGUE OF UNDESCRIBED SPECIES

LDF012 Hymenophy11um sp. 2ff. Eznguinolentum Plate 8.1

Illustrated specimen: B7.2,B7.26 (counterparts), Longford Formation, Waiauan to Tongaporutuan Stages, Mid to Upper Miocene, M29/f8606, Dress Circle, Longford, M29/579347, S.M. Bell and R.P. Suggate. 1949.

Stratigraphic range: Mid-Upper Miocene.

FFF006 ?Trichomanes sp. Figs $17.1,17.2,17.3,17.4$ Illustrated specimens: B38.99, Frog Flat Formation, Waiauan to Tonga-
porutuan Stages, Mid to Upper Miocene, M30/f8503, various localities on Maruia Saddle Road, R.P. Suggate, D. Kear, J.C. Schofield and E.T. Annear, 1949. Other material examined: B38.77, B38.112, from the same locality. Stratigraphic range: Mid to Upper Miocene.

FFF007 Dicksonia sp. aff. 1anata

Fig 17.6

Illustrated specimen: B36.13, Frog Flat Formation, Waiauan to Tongaporutan Stages, Mid to Upper Miocene, M30/f8501, "20 chains south of Maruia Saddle", M30 514078, R.P. Suggate et al. 1949.

Stratigraphic range: Mid Miocene to Recent.

\section{NFM002 Cyatheaceae}

Material examined: V2849.14, V2849.54, Nevis Formation, Oil Shale Member,

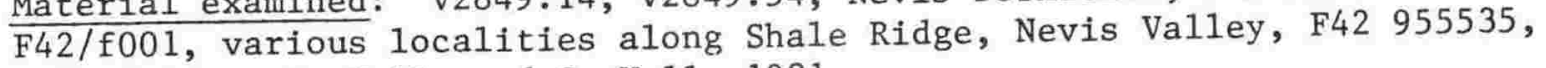
A.M. Holden, P. Vella and C. Vella 1981.

LDF013 Phymatosorus sp.aff. diversifolium(Willd.) Pic. Ser. Fig 17.5

Illustrated specimen: B7.57, Longford Formation, Waiauan to Tongaporutuan Stages, Mid to Upper Miocene, M29/f8606, Dress Circle, Longford, M29 579347, S.M. Bell and R.P. Suggate, 1949.

Stratigraphic range: Upper Oligocene (spores) to Recent.

KLBO12 Hypolepis sp. aff. tenuifolia (Forst.f.) Bernh. var pellucida

Illustrated specimens: V2846.46, Kaikorai Leaf Beds, Waiauan Stage, Mid Miocene, J44/f002, Taiaroa Head, J44 333898, A.M. Holden and P. Vella 1981.

Stratigraphic range: Mid Miocene to Recent. 

BIV002 Pteridium aquilinum (L.) Kuhn. var. esculentum (Forst. f.) Kuhn.

Illustrated specimens: B92.2, B92.3, Beeson's Island Volcanics, Taranaki to Wanganui Series, Upper Miocene to Pliocene, S08/f9502, Oruawharo Bay, Great Barrier Island, S08 225606, D. Kear, 1956.

Stratigraphic range: Miocene to Recent.

FFF008 ?Antrophyum sp. Figs 17.11,17.12

Illustrated specimens: B36.3, B36.4, Frog Flat Formation, Waiauan to Tongaporutuan Stages, Mid to Upper Miocene, M30/f8501, "20 chains south of Maruia Saddle", M30 514078, R.P. Suggate et al. 1949.

Other material examined: B36.2, from the same locality.

Stratigraphic range: Mid to Upper Miocene.

FFF009

Fig 17.13

Illustrated specimen: B38.90, Frog Flat Formation, Waiauan to Tongaporutuan Stages, Mid to Upper Miocene, M30/f8503, various localities on Maruia Saddle Road, R.P. Suggate, D. Kear, J.C. Schofield and E.T. Annear, 1949.

Stratigraphic range: Mid to Upper Miocene.

OLMO10 Blechnum sp.

Figs $18.1,18.2,18.3$

Illustrated specimens: B1036.42, B1036.47, B1036.49, Central Otago Lignite Measures, Manuherikia Group, Pareora to Southland Series, Lower to Mid Miocene, F41/f9513, basal beds of Mid-Tertiary section exposed west of bridge to Cairnmuir Station across Bannockburn, F41 088624, R.I. McPherson, 1968.

Other Material examined: B1036.26, B1036.27, from the same locality, Stratigraphic range: Lower to Mid Miocene.

LDF014 Blechnum sp. aff. discolor

Fig 18.4

Illustrated specimen: V2835.9, V2835.12 (counterparts), Longford Formation, Waiauan to Tongaporutuan stages, Mid to Upper Miocene, M29/f155, Mangles Valley television translator track, M29 585326, A.M. Holden and J.D. Collen, 1979.

Stratigraphic range: Mid Miocene to Recent.

\section{BIV003 ?Podocarpaceae}

Figs $18.5,18.7$

Illustrated specimens: B411.10, B411.11, Beeson's Island Volcanics, Taranaki to Wanganui Series, Upper Miocene to Pliocene, "200 yards from road north from Okupu, 200 yards above road near where road crosses fence on exposed spur, 80 chains at $50^{\circ}$ from trig Whangapara", K. Black, 1952.

\section{FFF010 ?Podocarpaceae Fig 18.6}

Illustrated specimen: B36.5, Frog Flat Formation, Waiauan to Tongaporutuan Stages, Mid to Upper Miocene, M30/f8501 "20 chains south of Marula Saddle", M30 514078, collected by R.P. Suggate et al. 1949. 
Illustrated specimen: V2849.41, Nevis Formation, Oil Shale Member, Pareora Series, Lower Miocene, F42/f001, various localities along Shale Ridge, Nevis Valley, F42 955535, A.M. Holden, P. Vella and C. Vella, 1981.

\section{GLM017 ? Agathis}

Fig 18.10

Illustrated specimen: V2841.22, Gore Lignite Measures, Duntroonian to Waitakian Stages, Upper 01igocene to Lower Miocene, G45/f058, Lands lip Hill, siliceous boulders at south end of hilltop, $200 \mathrm{~m}$ from plantation boundary, G45 125530, A.M. Holden and P. Vella, 1981.

GLMO16 ?Araucariaceae

Fig 18.9

Illustrated specimen: B149.6, Gore Lignite Measures, Duntroonian to Waitakian Stages, Upper Oligocene to Lower Miocene, G45/f8497, Landslip Hi11, G45 125530, J. Hector, 1869.

Stratigraphic range: Upper Oligocene to Lower Miocene.

\section{LDFO15 ?Pseudowintera $\quad$ Figs $18.11,18.12$}

Illustrated specimens: B2.32, Longford Formation, Waiauan to Tongaporutuan Stages, Mid to Upper Miocene, M29/f6579, Nuggety Creek, M29 604410 , R.P. Suggate, D. Kear, E.T. Annear and W.A. Sara 1951; V2841.11, Gore Lignite Measures, Duntroonian to Waitakian Stages, Upper O1igocene to Lower Miocene, G45/f058, Landslip Hill, siliceous boulders at south end of hilltop $200 \mathrm{~m}$ from plantation boundary, G45 125530, A.M. Holden and P. Vella, 1981.

Other Material examined: V2825.9, Longford Formation, M29/f154, Dress Circle, Longford, M29 579347, A.M. Holden and J.D. Collen 1979. Stratigraphic range: Upper Oligocene to Upper Miocene.

OLMO 11

Fig 18.13

I1lustrated specimen: V2850.13, Central Otago Lignite Measures, Manuherikia Group, Pareora to Southland Series, Lower to Mid Miocene, F41/f209, new road cut $200 \mathrm{~m}$ north of new bridge across Bannockburn F41 088622, A.M. Holden, P. Vella and C. Vella, 1981. Stratigraphic range: Lower to Mid Miocene.

\section{FFF011 ?Winteraceae}

Fig 19.1

Illustrated specimen: B38.16, Frog Flat Formation, Waiauan to Tongaporutuan Stages, Mid to Upper Miocene, M30/f8503, various localities on Maruia Saddle Road, R.P. Suggate, D. Kear, J.C. Schofield and E.T. Annear, 1949.

Stratigraphic range: Mid to Upper Miocene.

LDF016 Hedycarya

Figs $19.2,19.3,19.4$

Illustrated specimens: V2835.11 (counterparts), Longford Formation, Waiauan to Tongaporutuan Stages, Mid to Upper Miocene, M29/f155, Mangles 
Valley television translator road, M29 585326, collected by A.M. Holden and J.D. Collen, 1979; B38.101, Frog Flat Formation, Waiauan to Tongaporutuan Stages, Mid to Upper Miocene, M30/f8503, various localities on Maruia Saddle road, collected by R.P. Suggate, D. Kear, J.C. Schofield and E.T. Annear, 1949.

Stratigraphic range: Mid to Upper Miocene.

\section{GLM018 ?Monimiaceae \\ Plate 8.3 , Fig 19.5}

Illustrated specimen: V2841.33, Gore Lignite Measures, Duntroonian to Waitakian Stages, Upper Oligocene to Lower Miocene, G45/f058, Landslip Hill, $200 \mathrm{~m}$ from plantation boundary, siliceous boulders at south end of hilltop, G45 125530, A.M. Holden and P. Vella 1981. Stratigraphic range: Upper Oligocene to Lower Miocene.

OLMO12

Fig $19.6,19.7$

Illustrated specimens: B197.3, Central Otago Lignite Measures, Manuherikia Group, Pareora to Southland Series, Lower to Mid Miocene, Bannockburn, A. McKay, 1882; B1036.47, Manuherikia Group, Pareora to Southland Series, F41/f9513, basal beds of mid-Tertiary section exposed west of bridge to Cairnmuir Station across Bannockburn, F41 088624, R.I. McPherson 1968.

Stratigraphic range: Lower to Mid Miocene.

GLMO19

Fig $19.8,19.9,19.12$

I1lustrated specimens: V2841.29, V2841.64A and 70 (counterparts), Gore Lignite Measures, Duntroonian to Waitakian Stages, Upper 0ligocene to Lower Miocene, G45/f058, Landslip Hill, siliceous boulders at south end of hilltop $200 \mathrm{~m}$ from plantation boundary, G45 125530, A.M. Holden, and P. Vella, 1981.

Stratigraphic range: Upper Oligocene to Lower Miocene.

\section{OLM013 ?Cryptocarya}

Figs $19.10,9.11$

Illustrated specimens: V2850.28, Central Otago Lignite Measures, Manuherikia Group, Pareora to Southland Series, Lower to Mid Miocene, F41/f209, new road cut $200 \mathrm{~m}$ north of new road bridge across Bannockburn, F41 088622, A.M. Holden, P. Vella and C. Ve1la, 1981; V2856.34, 34A (counterparts), Central Otago Lignite Measures, St. Bathans Beds, Pareora to Southland Series, H41/f028, clay seam in sluiced ground, west end of Blue Lake, St. Bathans, Central Otago, H41 577888, A.M. Holden, P. Vella and C. Vella, 1981.

Stratigraphic range: Lower to Mid Miocene.

LDF017 Beilschmiedia tarairoides Pens. Figs 20.1,20.2 Beilschmiedia tarairoides Penseler 1930: 466, figs 17-19 Beilschmiedia tarairoides Pens., Holden 1982: 82, figs 2.1,2.2

Holotype: B56.6, Waikato Coal Measures, Upper Eocene, S14/f7005, Pukemiro Colliery, Waikato, W.H.A. Penseler 1930; N.Z. Geological Survey. 
Illustrated specimens: V2825.24, Longford Formation, Waiauan to

Tongaporutuan Stages, Mid to Upper Miocene, M29/f154, Dress Circle, Longford, M29 579347, A.M. Holden and J.D. Collen 1979; B2.48, Longford Formation, M29/f6579, Nuggety Creek, M29 604410, R.P. Suggate, D. Kear, E.T. Annear and W.A. Sara, 1951.

Other material examined: B2.2, M29/f6579, Nuggety Creek, M29 604410, R.P. Suggate, D. Kear, E.T. Annear and W.A. Sara 1951; B7.4 and B7.33 (counterparts), M29/f8606, Dress Circle, Longford, M29 579347, S.M. Be11 and R.P. Suggate, 1949; V2827.4, M29/f150, B1ue Duck Creek, M29 587314 , A.M. Holden and J.D. Collen 1979.

Stratigraphic range: Upper Eocene to Upper Miocene.

LDF018 Cryptocarya murchisoniensis Holden Cryptocarya murchisoniensis Holden 1982:

Fig 20.3,20.4 83 , figs $2.3,2.4$

Holotype: VH102, Longford Formation, Waiauan to Tongaporutuan Stages, Mid to Upper Miocene, M29/f154, Dress Circle, Longford, M29 579347, A.M. Holden and J.D. Collen 1979. Victoria University, Wellington. Illustrated specimens: B38.94, Frog Flat Formation, Waiauan to Tongaporutuan Stages, M30/f8503, various localities on Maruia Saddle road, R.P. Suggate, D. Kear, J.C. Schofield and E.T. Annear, 1949.

Other material examined: V2838.6, Frog Flat Formation, M30/f028, cutting at end of new bridge, true right bank of Glenroy River, Upper Matakitaki Valley, M30 550113, A.M. Holden and J.D. Collen 1979; V2832.9, M30/f026, Maruia Saddle, south side of summit, M30 512072, A.M. Holden and J.D. Collen 1979; B36.1, B36.2, B36.3,M30/f8501, "20 chains south of Maruia Saddle", M30 514078, R.P. Suggate et al. 1949.

Stratigraphic range: Mid to Upper Miocene.

LDF019 Cryptocarya bulleriana Holden Cryptocarya bulleriana Holden 1982:
Fig 20.6

84 , fig 2.5

Holotype: VH107, Longford Formation, Waiauan to Tongaporutuan Stages, Mid to Upper Miocene, M29/f155, Mangles Valley television translator road, M29 585326, A.M. Holden and J.D. Collen 1979.

Stratigraphic range: Mid to Upper Miocene.

GLM020 ?Lauraceae

Fig 20.5

Illustrated specimen: B150.23, Gore Lignite Measures, Duntroonian to Waitakian Stages, Upper Oligocene to Lower Miocene, G45/f8496, Landslip Hill, G45 125530, J. Park, 1886.

Stratigraphic range: Upper Oligocene to Lower Miocene.

LDFO20 ?Cinnamomum miocenicum Holden

Fig 20.7

?Cinnamonum miocenicum Holden 1982:

84 , fig 2.7

Holotype: VH101, Longford Formation, Waiauan to Tongaporutuan Stages, Mid to Upper Miocene, M29/f154, Dress Circle, Longford, M29 579347, A.M. Holden and J.D. Collen 1979; Victoria University, Wellington. Stratigraphic range: Mid to Upper Miocene. 
LDF021 ?Ascarina Plate 8.4, Figs 20.8, 20.9,20.10

Illustrated specimens: V2835.15, Longford Formation, Waiauan to Tongaporutuan Stages, Mid to Upper Miocene, M29/f155, Mangles Valley television translator track, M29 585326, A.M. Holden and J.D. Collen 1979; B2.46, B2.52, M29/f6579, Nuggety Creek, M29 604410, R.P. Suggate, D. Kear, E.T. Annear and W.A. Sara 1951.

Stratigraphic range: Mid to Upper Miocene.

\section{LDF022 ?Macropiper Figs 20.11,20.12}

Illustrated specimens: B2.51, Longford Formation, Waiauan to Tongaporutuan Stages, Mid to Upper Miocene, M29/f6579, Nuggety Creek, M29 604410 , R.P. Suggate, D. Kear, E.T. Annear and W.A. Sara 1951; B7.23 and B7.27, (counterparts), M29/f8606, Dress Circle, Longford, M29 579347 , S.M. Be11 and R.P. Suggate, 1949.

Other material examined: B7.38, B7.50, B7.71, M29/f8606, Dress Circle, Longford, M29 579347, S.M. Be11 and R.P. Suggate, 1949. Stratigraphic range: Mid to Upper Miocene.

LDF023 ?Cryptocarya tutakiae Holden Figs 21.1,21.2

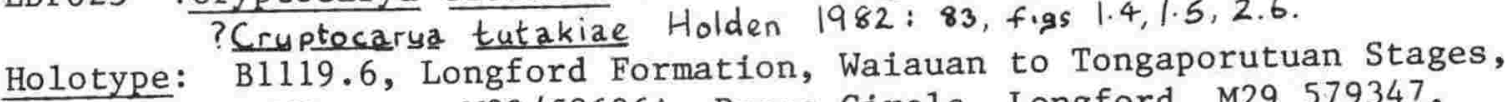
Mid to Upper Miocene, M29/f8606A, Dress Circle, Longford, M29 579347 , D.C. Mildenhall et al. 1978; N.Z. Geological Survey.

Illustrated specimen: B2.29, Longford Formation, M29/f6579, Nuggety Creek, M29 604410, R.P. Suggate, D. Kear, E.T. Annear and W.A. Sara, 1951. Other material examined: B38.84, Frog Flat Formation, Waiauan to Tongaporutuan Stages, M20/f8503, various localities on Maruia Saddle road, R.P. Suggate, D. Kear, J.C. Schofield and E.T. Annear 1949. Stratigraphic range: Mid to Upper Miocene.

\section{LDF024 ?Melicytus}

Fig 21.3

Illustrated specimen: B2.52, Longford Formation, Waiauan to Tongaporutuan Stages, Mid to Upper Miocene, M29/f6579, Nuggety Creek, M29 604410, collected by R.P. Suggate, D. Kear, E.T. Annear and W.A. Sara, 1951.

Other material examined: B38.103, Frog Flat Formation, Waiauan to Tongaporutuan Stages, M30/f8503, various localities on Maruia Saddle road, R.P. Suggate, D. Kear, J.C. Schofield and E.T. Annear, 1949. Stratigraphic range: Mid to Upper Miocene.

KLBO13 Calpidia zealandica Oliver Calpidia zealandica Oliver 1936 294,fig 13

Fraser's Gully, Kaikorai Valley, I44 135797, W.R.B. Oliver, 1929; National Museum, Wellington.

Illustrated specimens: B2.1, Longford Formation, Waiauan to Tongaporutuan Stages, Mid to Upper Miocene, M29/f6579, Nuggety Creek, M29 604410 , R.P. Suggate, D. Kear, E.T. Annear and W.A. Sara, 1951; B1036.37, B1036.49, B1036.35, Central Otago Lignite Measures, Manuherikia Group, Pareora to Southland Series, Lower to Mid Miocene, F41/f9513, basal beds of mid-Tertiary section exposed west of bridge ta Cairnmuir Station across Bannockburn, F41 088624, R.I. McPherson 1968. 
Other material examined: WELT 44561, WELT 44562, WELT 44563, WELT 44564, WELT 44565 from the type locality. V2847.8, Kaikorai Leaf Beds, I44/f134, Fraser's Gully, Kaikorai Valley, I44 135797, A.M. Holden, P. Ve11a and J.D. Campbe11 1981; B256.13, Longford Formation, M29/f8683, Murchison-Nelson road, north end of Longford Bridge, M29 572353, H.W. Wellman 1951; V2825.15, Longford Formation, M29/f154, Dress Circle, Longford, M29 579347, A.M. Holden and J.D. Collen 1979. Stratigraphic range: Lower to Upper Miocene.

OLM014 Proteaceae, ?Stenocarpus

Figs 22.5, 22.6

Illustrated specimens: V2856.44, V2856.72 (counterparts), Central Otago Lignite Measures, St. Bathans Beds, Pareora to Southland Series, Lower to Mid Miocene, H41/f028, clay seam in sluiced ground, west end of Blue Lake, St. Bathans, H4l 577888, A.M. Holden, P. Vella and C. Vella 1981. Stratigraphic range: Lower to Mid Miocene.

LDF025 Kermadecia merytifolia Holden

Fig 22.8 Kermadecia merytifolia Holden 1982:

89 , figs $3.2,3.10,4 \cdot 1,4 \cdot 2$

Holotype: VH109, Longford Formation, Waiauan to Tongaporutuan Stages, Mid to Upper Miocene, M29/f154, Dress Circle, Longford, M29 579347, A.M. Holden and J.D. Collen 1979: Victoria University, Wellington.

Other Material examined: B7.36, B7.63, M29/f8606, Dress Circle, Longford, M29 579347, S.M. Be11 and R.P. Suggate 1949; VH110, Frog Flat Formation, Waiauan to Tongaporutuan Stages, Mid to Upper Miocene, L30/f031, Rappahannock, L30 474037, A.M. Holden and J.D. Collen 1979.

Stratigraphic range: Mid to Upper Miocene.

GLM021 Proteaceae, ?Banksia

Figs $22.6,22.7$

Illustrated specimens: V2841.22, Gore Lignite Measures, Duntroonian to Waitakian Stages, Upper Oligocene to Lower Miocene, G45 f058, Landslip Hill, siliceous boulders at south end of hilltop $200 \mathrm{~m}$ from plantation boundary, G45 125530, A.M. Holden and P. Vella 1981; B149.6, G45/f8497, Landslip Hill, G45 125530, J. Hector 1869.

Other material examined: V2841.29 G45/f058, Landslip Hill, G45 125530, A.M. Holden and P. Vella 1981.

Stratigraphic range: Upper 01igocene to Lower Miocene.

FFF012 ?Proteaceae, ?Beauprea

Figs $22.9,22 \cdot 10$

Illustrated specimens: B38.74, Frog Flat Formation, Waiauan to Tongaporutuan Stages, Mid to Upper Miocene, M30/f8503, various localities on Maruia Saddle road, R.P. Suggate, D. Kear, J.C. Schofield and E.T. Annear, 1949; V2849.47, Nevis Formation, Oil Shale Member, Pareora Series, Lower Miocene, F42/f001, various localities along Shale Ridge, Nevis Valley, F42 955535, A.M. Holden, P. Vella and C. Vella 1981.

Stratigraphic range: Lower to Upper Miocene.

KLBO14 Knightia oblonga 01iver Figs $23.1,23.2$

Knightia oblonga Oliver 1936: 294, fig 12

Knightia oblonga Oliver, Holden 1982: 88, figs $3.3,3.4,3.5,4.3$

Holotype: WELT 44546, Kaikorai Leaf Beds, Waiauan Stage, Mid Miocene, 
Fraser's Gully, Kaikorai Valley, I44 135797, W.R.B. Oliver, 1929; National Museum, Wellington.

Illustrated specimen: B2.18, Longford Formation, Waiauan to Tongaporutuan Stages, Mid to Upper Miocene, M29/f6579, Nuggety Creek, M29 604410, R.P. Suggate, D. Kear, E.T. Annear and W.A. Sara 1951.

Other material examined: B7.66 M29/f8606, Dress Circle, Longford, M29 579347, S.M. Bel1 and R.P. Suggate 1949; VH108, M29/f149, B1ue Duck Creek, M29 589315, A.M. Holden and J.D. Collen 1979.

Stratigraphic range: Mid to Upper Miocene.

GLM022

Fig 23.3

Illustrated specimen: B33.9, Gore Lignite Measures, Duntroonian to Waitakian Stages, Upper Oligocene to Lower Miocene, F45/f9575, Waikaka F45 987505, B.L. Wood 1948.

Stratigraphic range: Upper Oligocene to Lower Miocene.

OLM015 ?Proteaceae

Fig 23.4

I1lustrated specimen: V2850.32, Central Otago Lignite Measures, Manuherikia Group, Pareora to Southland Series, Lower to Mid Miocene, F41/f209, new road cut $200 \mathrm{~m}$ north of new road bridge across Bannockburn, F41 088622, A.M. Holden, P. Vella and C. Vella 1981.

Stratigraphic range: Lower to Mid Miocene.

GLM023 ?Proteaceae Figs 23.5,23.6

Illustrated specimens: B33.10, Gore Lignite Measures, Duntroonian to Waitakian Stages, Upper Oligocene to Lower Miocene, F45/f9575, Waikaka, F45 987505, B. Wood 1948; V2841.2, V2841.2A, (counterparts), G45/f058, Landslip Hill, siliceous boulders at south end of hill, $200 \mathrm{~m}$ from plantation boundary; G45 125530, A.M. Holden and P. Vella 1981. Stratigraphic range: Upper Oligocene to Lower Miocene.

LDF026 Longfordia banksiaefolia Holden Longfordia banksiaefolia Holden 1982: 89, fig 3.6

Holotype: B2.50, Longford Formation, Waiauan to Tongaporutuan Stages, Mid to Upper Miocene, M29/6579, Nuggety Creek, M29/604410, R.P. Suggate, D. Kear, E.T. Annear and W.A. Sara 1951: N.Z. Geological Survey. Stratigraphic range: Mid to Upper Miocene.

GLM024 ?Proteaceae

Fig 23.8

Illustrated specimen: B33.8, Gore Lignite Measures, Duntroonian to Waitakian Stages, Upper Oligocene to Lower Miocene, F45/f9575, Waikaka, F45 987505, B. Wood 1948.

Stratigraphic range: Upper Oligocene to Lower Miocene. 
Illustrated specimens: V2843.2, Gore Lignite Measures, F46/f063,

Tuturau, east bank of Mataura River, floats on riverbank downstream from outcrop of Gore Lignite Measures, F46 308887, A.M. Holden and P. Vella 1981; B38.101, Frog Flat Formation, Waiauan to Tongaporutuan Stages, Mid to Upper Miocene, M30/f8503, various localities on Maruia Saddle Road, R.P. Suggate, D. Kear, J.C. Schofield and E.T. Annear 1949.

Other material examined: B148.14, G45/f8498, Landslip Hil1, G45 125530 , J. Hector; V2841.29, V2841.29A (counterparts), G45/f058, Landslip Hil1, G45 125530, A.M. Holden and P. Vella 1981.

Stratigraphic range: Upper Oligocene to Upper Miocene.

\section{GLM026 Banksiaephy11um}

Fig 23.11

Illustrated specimen: V2841.72, Gore Lignite Measures, Duntroonian to Waitakian Stages, Upper Oligocene to Lower Miocene, G45/f058, Landslip Hill, siliceous boulders at south end of hilltop, $200 \mathrm{~m}$ from plantation boundary, G45 125530, A.M. Holden and P. Ve1la 1981. Stratigraphic range: Upper Oligocene to Lower Miocene.

\section{OLM016}

Figs $24 \cdot 1,24 \cdot 2,24 \cdot 3$

Illustrated specimens: V2848.12, Central Otago Lignite Measures, Manuherikia Group, Pareora to Southland Series, Lower to Mid Miocene, G43/f002, Harliwick's Opencast, Coal Creek Flat, Roxburgh, overburden from small gully, west side of pit, G43 214193, A.M. Holden, P. Vella and C. Vella 1981; B38.101, Frog Flat Formation, Waiauan to Tongaporutuan Stages, Mid to Upper Miocene, M30/f8503, various localities on Maruia Saddle Road, R.P. Suggate, D. Kear, J.C. Schofield and E.T. Annear 1949; V2850.30, Central Otago Lignite Measures, Manuherikia Group, F41/f209, new road cut $200 \mathrm{~m}$ north of new bridge across Bannockburn, F41 088622, A.M. Holden, P. Vella and C. Vella 1981.

Other material examined: B197.55, Bannockburn, A. McKay, 1882; V2856.70, St. Bathans Beds, H41/f028, clay seam in sluiced ground, west end of Blue Lake, St. Bathans, H41 577888, A.M. Holden, P. Vella and C. Vella 1981. Stratigraphic range: Lower to Upper Miocene.

OLMO 17

Figs $24.4,24.5,24.8$

I1lustrated specimens: V2850.16, 16A (counterparts), V2850.46, Central Otago Lignite Measures, Manuherikia Group, Pareora to Southland Series, Lower to Mid Miocene, F41/f209, new road cut $200 \mathrm{~m}$ north of new bridge across Bannockburn, F41 088622, A.M. Holden, P. Vella and C. Vella 1981; $\mathrm{B} 1036.51 \mathrm{~A}$ and $51 \mathrm{~B}$ (counterparts), F41/f9513, Bannockburn, basal beds of mid-Tertiary section exposed west of bridge to Cairnmuir Station across Bannockburn, F41 088624, R.I. McPherson 1968.

Stratigraphic range: Lower to Mid Miocene.

OLM0 18

Figs $24.6,24.7$

Illustrated specimens: V2850.26, Central Otago Lignite Measures, Manuherikia Group, Pareora to Southland Series, Lower to Mid Miocene, F41/f209, new road cut $200 \mathrm{~m}$ north of new bridge across Bannockburn, F41 088622 , 
A.M. Holden, P. Ve1la and C. Vella 1981; B38.68, Frog Flat Formation, Waiauan to Tongaporutuan Stages, Mid to Upper Miocene, M30/f8503, various localities on Maruia Saddle road, R.P. Suggate, D. Kear, J.C. Schofield and E.T. Annear 1949.

Stratigraphic range: Lower to Upper Miocene.

OLMO19

Fig 24.9

Illustrated specimen: V2850.12,12A (counterparts), Central Otago Lignite Measures, Manuherikia Group, Pareora to Southland Series, Lower to Mid Miocene, F41/f209, new road cut $200 \mathrm{~m}$ north of new bridge across Bannockburn, F41 088622, A.M. Holden, P. Vella and C. Vella 1981.

Other material examined: B1039, Manuherikia Group, F42/f7516, shale/ sandstone beds directly in contact with silica sand in basal beds of mid Tertiary, silica sand pit, Adams Gully, west side of road to Shepherd's Creek, old coal working below sand pit F42 076589, R.I. McPherson 1968. Stratigraphic range: Lower to Mid Miocene.

FFF013 Myrtaceae

Fig 24.10

Illustrated specimen: B38.98, Frog Flat Formation, Waiauan to Tongaporutuan Stages, Mid to Upper Miocene, M30/f8503, various localities on Maruia Saddle road, R.P. Suggate, D. Kear, J.C. Schofield and E.T. Annear 1949. Stratigraphic range: Mid to Upper Miocene.

\section{LDF027 Metrosideros sp.}

Figs $25.1,25.2$

I11ustrated specimens: V2825.6 and 19 (counterparts), V2825.18, Longford Formation, Waiauan to Tongaporutuan Stages, Mid to Upper Miocene, M29/f154, Dress Circle, Longford, M29 579347, A.M. Holden and J.D. Collen 1979.

Other material examined: V2825.16, from the same locality; B7.69, B7.71, M29/f8606, Dress Circle, Longford, M29 579347, S.M. Be11 and R.P. Suggate 1949; V2827.8, M29/f150, Blue Duck Creek, M29/587314, A.M. Holden and J.D. Collen 1979; B38.99, Frog Flat Formation, Waiauan to Tongaporutuan Stages, M30/f8503, various localities on Maruia Saddle road, R.P. Suggate, D. Kear, J.C. Schofield and E.T. Annear 1949.

Stratigraphic range: Mid to Upper Miocene.

FFF014 ?Myrtaceae

Figs $25.3,25.4$

Illustrated specimens: B38.71, B38.110, Frog Flat Formation, Waiauan to Tongaporutuan Stages, Mid to Upper Miocene, M30/f8503, various localities on Maruia Saddle road, R.P. Suggate, D. Kear, J.C. Schofield and E.T. Annear 1949.

Other material examined: B38.75, from the same locality. Stratigraphic range: Mid to Upper Miocene.

KLB015 Metrosideros sp.

Fig 25.5

Illustrated specimen: V2846.32, Kaikorai Leaf Beds, Waiauan Stage, Mid Miocene, J44/f002, Taiaroa Head, Dunedin, J44 333898, A.M. Holden and P. Vella 1981.

Stratigraphic range: Mid Miocene. 
Illustrated specimens: V2849.90, 90A (counterparts), Nevis Formation, Oil Shale Member, Pareora Series, Lower Miocene, F42/f001, various localities along Shale Ridge, Nevis Valley, F42 955535, A.M. Holden, P. Vella and C. Vella 1981.

Stratigraphic range: Lower Miocene.

\section{GLM027 Myrtaceae}

Figs $25.7,25.8,25.9$

Illustrated specimens: B33.11, B33.12, Gore Lignite Measures, Duntroonian to Waitakian Stages, Upper O1igocene to Lower Miocene, F45/f9575, Waikaka, F45 987505, B.L. Wood 1948; V2851.7, Central Otago Lignite Measures, Manuherikia Group, F41/f210, true right bank Kawerau River $100 \mathrm{~m}$ from mouth of Bannockburn, bluffs below road, F41 086628, A.M. Holden, P. Vella and C. Vella 1981.

Other material examined: B33.13, B33.14, F45/f9575, Waikaka, F45 987505 B.L. Wood 1948; B150.12, G45/f8496, Landslip Hill, G45 125530, collected by J. Park, 1886 .

Stratigraphic range: Upper Oligocene to Mid Miocene.

\section{OLM020 ?Myrtaceae}

Figs $25.10,25.11,25.12$

Illustrated specimens: V2850.1, 1A (counterparts), Central Otago Lignite Measures, Manuherikia Group, Pareora to Southland Series, Lower to Mid Miocene, F41/f209, new road cut $200 \mathrm{~m}$ north of new bridge across Bannockburn, F41 088622, A.M. Holden, P. Vella and C. Vella 1981; B1036.20, Manuherikia Group, F41/f9513, Bannockburn, basal beds of mid Tertiary section exposed west of bridge to Cairnmuir Station across Bannockburn, F41 088624, R.I. McPherson 1968.

Stratigraphic range: Lower to Mid Miocene.

\section{NFM005 ?Myrtaceae Figs $26.1,26.3$}

Illustrated specimen: V2849.40, V2849.46, Nevis Formation, Oil Shale Member, ?Pareora Series, Lower Miocene, F42/f001, various localities along Shale Ridge, Nevis Valley, F42 955535, A.M. Holden, P. Vella and C. Vella 1981. Stratigraphic range: Lower Miocene.

\section{OLM021 ?Myrtaceae}

Fig 26.4

Illustrated specimen: V2856.85, Central Otago Lignite Measures, St. Bathans Beds, Pareora to South1and Series, Lower to Mid Miocene, H41/f028, clay seam in sluiced ground, west end of Blue Lake, St. Bathans, H41 577888, A.M. Holden, P. Vella and C. Vella 1981. Stratigraphic range: Lower to Mid Miocene.

FFF015 ?Myrtaceae or ?Moraceae

Fig 26.5

Illustrated specimen: B38.90, Frog Flat Formation, Waiauan to Tongaporutuan Stages, Mid to Upper Miocene, M30/f8503, various localities on Maruia Saddle road, R.P. Suggate, D. Kear, J.C. Schofield and E.T. Annear 1949.

Stratigraphic range: Mid to Upper Miocene. 
Illustrated specimen: B411.11, Beeson's Island Volcanics, Taranaki to 200 yards from road north from Okupu, 200 yards above road near where road crosses fence on exposed spur, 80 chain at $50^{\circ}$ from Trig Whangapara, K. Black 1952.

Stratigraphic range: Upper Miocene to Pliocene.

\section{FFF016 ?Lophomyrtus}

Figs $26.7,26.8$

Illustrated specimens: B36.1, Frog Flat Formation, Waiauan to Tongaporutuan Stages, Mid to Upper Miocene, M30/f8501, "20 chains south of Maruia Saddle, M30 514078, R.P. Suggate, et al., 1949; B411.10, Beeson's Island Volcanics, Taranaki to Wanganui Series, Upper Miocene to Pliocene, Great Barrier Island, "200 yards from road north from Okupu, 200 yards above road near where road crosses fence on exposed spur, 80 chain at $50^{\circ}$ from Trig Whangapara, K. B1ack 1952.

Other material examined: B411.6, B411.11, from the same locality.

Stratigraphic range: Mid Miocene to Pliocene.

\section{NFM006 ?Myrtaceae}

Figs $26.9,26.10$

Illustrated specimens: V2849.24A, V2849.29A (counterparts), Nevis Formation, Oil Shale Member, Pareora Series, Lower Miocene, F42/f001, various localities along Shale Ridge, Nevis Valley, F42 955535, A.M. Holden, P. Vella and C. Vella 1981; V2850.17, Central Otago Lignite Measures, Manuherikia Group, Pareora to Southland Series, Lower to Mid Miocene, F41/f209, new road cut about $200 \mathrm{~m}$ north of new bridge across Bannockburn, F41 088622, A.M. Holden, P. Vella and C. Vella 1981.

Other material examined: V2850.31, 31A (counterparts), F41/f209, Bannockburn, F41088622, A.M. Holden, P. Vella and C. Vella 1981.

Stratigraphic range: Lower to Mid Miocene.

\section{OLM022 ?Myrtaceae}

Fig 27.1

Illustrated specimen: B1036.41A, 41B (counterparts), Central Otago Lignite Measures, Manuherikia Group, Pareora to Southland Series, Lower to Mid Miocene, F41/f9513, Bannockburn, basal beds of mid Tertiary section exposed west of bridge to Cairnmuir Station across Bannockburn, F41 088624, R.I. McPherson 1968.

Stratigraphic range: Lower to Mid Miocene.

\section{OLM023 ?Garcinia}

Figs $27.2,27.3$

Illustrated specimens: V2850.11, V2850.11A (counterparts), Central Otago Lignite Measures, Manuherikia Group, Pareora to Southland Series, Lower to Mid Miocene, F41/f209, new road cut $200 \mathrm{~m}$ north of new bridge across Bannockburn, F41 088622, A.M. Holden, P. Vella and C. Vella 1981. Stratigraphic range: Lower to Mid Miocene. 
GLM028 Elaeodendron rigidum Ett.

Elaeodendron rigidum Ettingshausen 1891:
Figs $27.4,27.5$

281, fig 29.1

Illustrated specimens: B150.3, Gore Lignite Measures, Duntroonian to Waitakian Stages, Upper Oligocene to Lower Miocene, G45/f8496, Landslip Hil1, G45 125530, J. Park 1886.

Other material examined: B150.5, B150.7, from the same locality.

Stratigraphic range: Upper Oligocene to Lower Miocene.

LDF028

Figs $27.6,27.7$

Illustrated specimens: B256.11, B256.14, Longford Formation, Waiauan to Tongaporutuan Stages, Mid to Upper Miocene, M29/f8683, MurchisonNelson road, north end of Longford Bridge, M29 572353, H.W. Wellman 1951. Other material examined: B256.12, B256.16, from the same locality. Stratigraphic range: Mid to Upper Miocene.

OLM24

Figs $27.8,27.9,27.10$

Illustrated specimens: B1036.3, B1036.22, Centra1 Otago Lignite Measures, Manuherikia Group, Pareora to Southland Series, Lower to Mid Miocene, basal beds of mid-Tertiary section exposed west of bridge to Cairnmuir Station across Bannockburn, F41 088624, R.I. McPherson 1968; V2850.38, F41/f209, new road cut $200 \mathrm{~m}$ north of new bridge across Bannockburn, F41 088622 , A.M. Holden, P. Vella and C. Vella 1981.

Other material examined: B1036.26, B1036.37, B1036.38, B1036.49, F41/f9513, Bannockburn, F41 088624, R.I. McPherson 1968.

Stratigraphic range: Lower to Mid Miocene.

FFF017

Fig 27.11

Illustrated specimen: B38.17, Frog Flat Formation, Waiauan to Tongaporutuan Stages, Mid to Upper Miocene, M30/f8503, various localities on Maruia Saddle road, R.P. Suggate, D. Kear, J.C.Sohofield and E.T. Annear 1949.

Other material examined: B38.56, В38.64, В38.97, В38.112, from the same locality.

Stratigraphic range: Mid to Upper Miocene.

OLM0 25

Fig 27.12

Illustrated specimen: V2848.33, Central Otago Lignite Measures, Manuherikia Group, Pareora to Southland Series, Lower to Mid Miocene, G43/f002, Harliwick's Opencast, Coal Creek Flat, Roxburgh, overburden from small gully at west side of pit, G43 214193, A.M. Holden, P. Vella and C. Vella 1981 .

NFM007 Cunoniaceae

Figs $28.1,28.2,28.3$

Illustrated specimens: V2849.98, V2849.55, Nevis Formation, Oil Shale Member, Pareora Series, Lower Miocene, F42/f001, various localities along Shale Ridge, Nevis Valley, F42 955535, A.M. Holden, P. Vella and C. Vella 1981; V2856.81, Central Otago Lignite Measures, St. Bathans Beds, Pareora 
to Southland Series, Lower to Mid Miocene, H41/f028, clay seam in sluiced ground, west end of Blue Lake, St. Bathans, H41 577888, A.M. Holden, P. Vella and C. Vella 1981.

Other material examined: V2849.45, V2849.64, F42/f001, Nevis Valley, F41 955535, A.M. Holden, P. Vella and C. Vella 1981.

Stratigraphic range: Lower to Mid Miocene.

KLB016 Ixerba semidentata 01iver

Ixerba semidentata Oliver 1936:

Fig 28.4

296, fig 15

Holotype: WELT 44548, Kaikorai Leaf Beds, Waiauan Stage, Mid Miocene, Fraser's Gully, Kaikorai Valley, Dunedin, I44 135797, W.R.B. Oliver 1929. National Museum, Wellington.

Dimensions: $44 \mathrm{~mm}$ long and $20 \mathrm{~mm}$ broad.

Other material examined: V2846.25, Kaikorai Leaf Beds, J44/f002, Taiaroa Head, J44 333898, A.M. Holden and P. Vella 1981.

Stratigraphic range: Mid Miocene.

LDF029

Figs $28.5,28.6$

Illustrated specimens: B256.3, Longford Formation, Waiauan to Tongaporutuan Stages, Mid to Upper Miocene, M29/f8683, Murchison-Nelson Road, north end of Longford Bridge, M29 572353, H.W. Wellman 1951; B38.46, Frog Flat Formation, Waiauan to Tongaporutuan Stages, M30/f8503, various localities on Maruia Saddle road, R.P. Suggate, D. Kear, J.C. Schofield and E.T. Annear 1949. Other material examined: B256.16, M29/f8683, Longford, M29 572353, H,W. Wellman 1951.

Stratigraphic range: Mid to Upper Miocene.

NFM008

Figs $28.7,28.8,28.9$

I1lustrated specimens: V2849.57, 57A (counterparts), V2849.74, Nevis Formation, Oil Shale Member, Pareora Series, Lower Miocene, F42/f001, various localities along Shale Ridge, Nevis Valley, F42 955535, A.M. Holden, P. Vella and C. Vella 1981.

Other material examined: V2849.1, B2849.38, V2849.49, from the same locality.

Stratigraphic range: Lower Miocene.

OLMO26

Figs $28.10,28.11,28.12$, $28.15,28.16$

Illustrated specimens: B1036.3, B1036.16, B1036.22, B1036.23, B1036.29, Central Otago Lignite Measures, Manuherikia Group, Pareora to Southland Series, Lower to Mid Miocene, F41/f9513, basal beds of mid-Tertiary section exposed west of bridge to Cairnmuir Station across Bannockburn, F41 088624, R.I. McPherson 1968.

Other material examined: B1036.8, B1036.26, B1036.27, B1036.44, from the same locality.

Stratigraphic range: Lower to Mid Miocene. 
Illustrated specimens: B1036.49, Central Otago Lignite Measures, Manuherikia Group, Pareora to Southland Series, Lower to Mid Miocene, F41/f9513, basal beds of mid-Tertiary section exposed west of bridge to Cairnmuir Station across Bannockburn, F41 088624, R.I. McPherson 1968; V2849.23, Nevis Formation, Oil Shale Member, Pareora Series, F42/f001, various localities along Shale Ridge, Nevis Valley, F42 955535, A.M. Holden, P. Vella and C. Ve11a 1981. Stratigraphic range: Lower to Mid Miocene.

OLM028 Fig 28.17

Illustrated specimen: B1036.49, Central Otago Lignite Measures, Manuherikia Group, Pareora to Southland Series, Lower to Mid Miocene, F41/f9513, basal beds of mid-Tertiary section exposed west of bridge to Cairnmuir Station across Bannockburn, F41 088624, R.I. McPherson 1968.

Stratigraphic range: Lower to Mid Miocene.

BIV005

Fig 28.18

Illustrated specimen: B411.7, Beeson's Island Volcanics, Taranaki to Wanganui Series, Upper Miocene to Pliocene, Great Barrier Island, 200 yards from road north from Okupu, 200 yards above road, near where road crosses fence on exposed spur, 80 chains at $50^{\circ}$ from $\operatorname{Tr} i g$ Whangapara, K. Black 1952.

Stratigraphic range: Upper Miocene to Pliocene.

OLM029 Papilionaceae or Caesalpinaceae Fig 29.1,29.2

Illustrated specimens: V2850.27, 27A (counterparts), Centra1 Otago Lignite Measures, Manuherikia Group, Pareora to Southland Series, Lower to Mid Miocene, F41/f209, new road cut $200 \mathrm{~m}$ north of new bridge across

Bannockburn, F41 088622, A.M. Holden, P. Vella and C. Vella 1981; V2849.89, Nevis Formation, Oil Shale Member, Pareora Series, Lower Miocene, F42/f001, various localities along Shale Ridge, Nevis Valley, F42 955535, A.M.

Holden, P. Vella and C. Vella 1981.

Stratigraphic range: Lower to Mid Miocene.

NFM009 Papilionaceae or Caesalpinaceae Fig 29.3

Illustrated specimen: V2849.36, Nevis Formation, Oil Shale Member, F42/f001, various localities along Shale Ridge, Nevis Valley, F42 955535 , A.M. Holden, P. Vella and C. Vella 1981.

Stratigraphic range: Lower Miocene.

OLM030 ?Streblus

Fig 29.4

I1lustrated specimen: V2856.80, 80A (counterparts), Central Otago Lignite Measures, St. Bathans Beds, Pareora to Southland Series, Lower to Mid Miocene, H41/f028, clay seam in sluiced ground at west end of Blue Lake, St. Bathans, H41 577888, A.M. Holden, P. Vella and C. Vella 1981.

Stratigraphic range: Lower to Mid Miocene. 


\section{FFF028 ?Paratrophis}

Fig 29.5

Illustrated specimen: B38.36 and B38.85 (counterparts), Frog F1at Formation, Waiauan to Tongaporutuan Stages, Mid to Upper Miocene, $\mathrm{M} 30 / \mathrm{f} 8503$, various localities on Maruia Saddle road, R.P. Suggate, D. Kear, J.C. Schofield and E.T. Annear 1949.

Other material examined: B38.72, B38.74, B38.95, from the same locality; B7.64, B7.67, Longford Formation, Waiauan to Tongaporutuan Stages, M29/f8606, Dress Circle, Longford, M29 579347, S.M. Be11 and R.P. Suggate 1949; VH103, Frog Flat Formation, M30/f024, roadside cutting on true right bank of Glenroy River close to bridge, M30 550113, A.M. Holden and J.D. Collen 1979; V2832.11, M30/f026, road cut about $1.2 \mathrm{~km}$ south of Maruia Saddle, M30 512072, A.M. Holden and J.D. Collen 1979.

Stratigraphic range: Mid to Upper Miocene.

\section{BIV006 ?Loranthaceae}

Fig 29.7

Illustrated specimen: B411.9, Beeson's Island Volcanics, Taranaki to Wanganui Series, Upper Miocene to P1iocene, Great Barrier Island, "200 yards from road from Okupu, 200 yards above road near where road crosses fence on exposed spur, 80 chains at $50^{\circ}$ from Trig Whangapara, K. Black 1952 .

Other material examined: B38.39, Frog Flat Formation, Waiauan to Tongaporutuan Stages, Mid to Upper Miocene, M30/f8503, various localities on Maruia Saddle road, R.P. Suggate, D. Kear, J.C. Schofield and E.T. Annear 1949.

Stratigraphic range: Mid Miocene to Pliocene.

\section{OLM031 ?Rutaceae}

Fig 29.8

Illustrated specimen: V2850.21, Central Otago Lignite Measures, Manuherikia Group, Pareora to Southland Series, Lower to Mid Miocene, F41/f209, new road cut 200 m north of new bridge across Bannockburn, F41 088622, A.M. Holden, P. Vella and C. Vella 1981.

Stratigraphic range: Lower to Mid Miocene.

\section{LDF031 ?Sapindaceae, ?Cupaniopsis}

Fig $29.9,29.14,29.15$

Illustrated specimens: B1119.3, B1119.9, Longford Formation, Waiauan to Tongaporutuan Stages, Mid to Upper Miocene, M29/f8606A, Dress Circle, Longford,M29 579347, D.C. Mildenhall et al., 1978; V2825.31 from the

Other material examined: B2.24, B2.29, B2.36, B2.47, B2.53, M29/f6579, Nuggety Creek, M29 604410 , R.P. Suggate, D. Kear, E.T. Annear and W.A. Sara 1951; B7.74, M29/f8606, Dress Circle Longford, M29 579347, S.M. Bell and R.P. Suggate 1949; V2838.1, Frog Flat Formation, Waiauan to Tongaporutuan Stages, $\mathrm{M} 30 / \mathrm{f024}$, roadside cutting on true right bank of Glenroy River close to bridge, M30 550113, A.M. Holden and J.D. Collen 1979.

Stratigraphic range: Mid to Upper Miocene.

\section{LDF032 ?Sapindaceae}

Fig 29.10

I1lustrated specimen: V2825.6, Longford Formation, Waiauan to Tongaporutuan Stages, Mid to Upper Miocene, M29/f154, Dress Circle, Longford, M29 579347, A.M. Holden and J.D. Collen 1979.

Stratigraphic range: Mid to Upper Miocene. 
Illustrated specimen: V2849.84, Nevis Formation, Oil Shale Member, ?Pareora Series, Lower Miocene, F42/f00l, various localities along Shale Ridge, Nevis Valley, F42 955535, A.M. Holden, P. Vella and C. Vella 1981.

Stratigraphic range: Lower Miocene.

LDF030 ?Alectryon

Fig 29.12,29.13

Illustrated specimen: V2825.30, Longford Formation, Waiauan to Tongaporutuan Stages, M29/f154, Dress Circle Longford, M29 579347, A.M. Holden and J.D. Collen 1979, B2.35, M29/6579, Nuggety Creek, M29 604410, R.P. Suggate, D. Kear, E.T. Annear and W.A. Sara 1951. Stratigraphic range: Mid to Upper Miocene.

\section{LDF033}

Fig 30.1

Illustrated specimen: B7.58, Longford Formation, Waiauan to Tongaporutuan Stages, Mid to Upper Miocene, M29/f8606, Dress Circle, Longford, M29 579347, S.M. Bel1 and R.P. Suggate 1949.

Stratigraphic range: Mid to Upper Miocene.

KLB017 Nothopanax distans Oliver Nothopanax distans Oliver 1936:
Fig 30.2

299, fig 20

Holotype: WELT 44566, Kaikorai Leaf Beds, Waiauan Stage, Mid Miocene, Fraser's Gully, Kaikorai Valley, Dunedin, I44 135797, W.R.B. Oliver 1929; National Museum, Wellington.

Dimensions: $69 \mathrm{~mm}$ long and $25 \mathrm{~mm}$ broad.

Stratigraphic range: Mid Miocene.

\section{FFF020 ?Araliaceae}

Fig 30.3

Illustrated specimen: B38.69, Frog Flat Formation, Waiauan to Tongaporutuan Stages, Mid to Upper Miocene, M30/f8503, various localities on Maruia Saddle road, R.P. Suggate, D. Kear, J.C. Schofield and E.T. Annear 1949.

Stratigraphic range: Mid to Upper Miocene.

NFM011 ?Araliaceae

Fig 30.4

Illustrated specimen: V2849.26, Nevis Formation, Oil Shale Member, Pareora Series, Lower Miocene, F42/f001, various localities along Shale Ridge, Nevis Valley, F42 955535, A.M. Holden, P. Vella and C. Vella 1981. Other material examined: V2850.46, Central Otago Lignite Measures, Manuherikia Group, Pareora to Southland Series, Lower to Mid Miocene, F41/f209, new road cut $200 \mathrm{~m}$ north of new bridge across Bannockburn, F4l 088622 , A.M. Holden, P. Vella and C. Vella 1981.

Stratigraphic range: Lower to Mid Miocene.

LDF034 ?Parafatsia Blackburn

Fig 30.5

Illustrated specimen: VH97, Longford Formation, Waiauan to Tongaporutuan Stages, Mid to Upper Miocene, M29/f154, Dress Circle, Longford, M29 579347, 
A.M. Holden and J.D. Collen 1979.

Stratigraphic range: Mid to Upper Miocene.

KLB018 Kaikoraia gracilis 01iver Kaikoraia gracilis Oliver 1936:

Figs $30.6,30.9,30.10$

301 , figs, 21a,21b

Holotype: WELT 44556, Kaikorai Leaf Beds, Waiauan Stage, Mid Miocene, Fraser's Gully, Kaikorai Valley, Dunedin, I44 135797, W.R.B. Oliver 1929. Dimensions: $119 \mathrm{~mm}$ long and $30 \mathrm{~mm}$ broad.

Illustrated specimens: WELT 44557 from the type locality; B38.4, Frog

Flat Formation, Waiauan to Tongaporutuan Stages, Mid to Upper Miocene, M30/f8503, various localities on Maruia Saddle road, R.P. Suggate, D. Kear, J.C. Schofield and E.T. Annear 1949.

Other material examined: WELT 44558, WELT 44559, WELT 44560, from the type locality; V2849.94, Nevis Formation, Oil Shale Member, Pareora Series, Lower Miocene, F42/f001, various localities along Shale Ridge, Nevis Valley, F42 955535, A.M. Holden, P. Vella and C. Vella 1981. Stratigraphic range: Lower to Upper Miocene.

FFF021 ?P1anchone1la

Fig 30.7

Illustrated specimen: V2838.3, Frog Flat Formation, Waiauan to Tongaporutuan Stages, Mid to Upper Miocene, M30/f024, roadside cutting, true right bank of Glenroy River, close to bridge, M30 550113, A.M. Holden and J.D. Collen 1979.

Stratigraphic range: Mid to Upper Miocene.

LDF035 ?Myrsinaceae

Fig $30.8,30.11$

Illustrated specimens: V2825.20, Longford Formation, Waiauan to Tongaporutuan Stages, Mid to Upper Miocene, M29/f154, Dress Circle, Longford, M29 579347, A.M. Holden and J.D. Collen 1979; V2834.24, Frog

Flat Formation Waiauan to Tongaporutua Stages, L30/f031, roadside cutting on Rappahannock road $200 \mathrm{~m}$ from junction with main highway, mudstone band, L30 474039, A.M. Holden J.D. Collen 1979.

Stratigraphic range: Mid to Upper Miocene.

\section{GLM029 ?Myrsine}

Fig 31.1

Illustrated specimen: B33.15, 16 (counterparts), Gore Lignite Measures, Duntroonian to Waitakian Stages, Upper Oligocene to Lower Miocene, F45/f9575, Waikaka, F45 987505, B.L. Wood 1948.

Stratigraphic range: Upper Oligocene to Lower Miocene.

FFF022

Figs $31.2,31.3$

Illustrated specimens: B38.93, Frog Flat Formation, Waiauan to Tongaporutuan Stages, Mid to Upper Miocene, M30/f8503, various localities on Maruia Saddle Road, R.P. Suggate, D. Kear, J.C. Schofield and E.T. Annear 1949; B1036.39, Central Otago Lignite Measures, Manuherikia Group, Pareora to Southland Series, Lower to Mid Miocene, F41/f9513, Bannockburn, basal beds of mid-Tertiary section exposed west of bridge to Cairnmuir Station across Bannockburn, F41 088624, R.I. McPherson 1968.

Stratigraphic range: Lower to Upper Miocene.

KLB019 Geniostoma oblonga Oliver Geniostoma oblonga O1iver 1936:

$$
\text { 301, figs } 22 \text {. } 22,31.7,31.8
$$

Holotype: WELT 44567, Kaikorai Leaf Beds, Waiauan Stage, Mid Miocene, Fraser's Gully, Kaikorai Valley, Dunedin, I44 135797, W.R.B. Oliver 1929; National Museum, Wellington.

Dimensions: $84 \mathrm{~mm}$ long and $33 \mathrm{~mm}$ broad.

Illustrated specimens: B7.43, B7.59, Longford Formation, Waiauan to Tongaporutuan Stages, Mid to Upper Miocene, M29/f8606, Dress Circle, 
Longford, M29 579347, S.M. Bel1 and R.P. Suggate, 1949.

Other material examined: B2.51, Longford Formation, M29/f6579, Nuggety Creek, M29 604410, R.P. Suggate, D. Kear, E.T. Annear and W.A. Sara 1951; B7.64, B7.65, B7.69, M29/f8606, Longford, M29 579347, S.M. Be11 and R.P. Suggate, 1949; B38.46, B38.47, B38.108, Frog Flat Formation, Waiauan to Tongaporutuan Stages, M30/f8503, various localities on Maruia Saddle Road, R.P. Suggate, D. Kear, J.C. Schofield and E.T. Annear 1949.

Stratigraphic range: Mid to Upper Miocene.

\section{OLM032 ?Geniostoma}

Figs $31.5,31.6,31.10,31.11$

Illustrated specimens: V2856.10, V2856.54, Central Otago Lignite Measures, St. Bathans Beds, Pareora to Southland Series, Lower to Mid Miocene, H4l/f028, clay seam in sluiced ground, west end of Blue Lake, St. Bathans, H41 577888, A.M. Holden, P. Vella and C. Vella 1981;

B1036.4, B1036.37, Central Otago Lignite Measures, Manuherikia Group, Pareora to Southland Series, F41/f9513, basal beds of mid-Tertiary section exposed west of bridge to Cairnmuir Station across Bannockburn, F41 088624 , R.I. McPherson, 1968.

Other material examined: V2856.5, V2856.6A, V2856.12, V2856.17, V2856.31, V2856.39, V2856.43, V2856.46, V2856.48, V2856.50, V2856.56, V2856.58, V2856.62, V2856.65, V2856.67, V2856.71, V2856.74, V2856.75, H41/f028, St. Bathans, H42 577888, A.M. Holden, P. Vella and C. Vella 1981.

Stratigraphic range: Lower to Mid Miocene.

LDF036

Fig 31.9

Illustrated specimen: B7.47, Longford Formation, Waiauan to Tongaporutuan Stages, Mid to Upper Miocene, M29/f8606, Dress Circle, Longford, M29 579347, S.M. Bell and R.P. Suggate 1949.

Stratigraphic range: Mid to Upper Miocene.

GLM030 Apocynophy1lum affine Ett.

Fig $31.12,31.13$

Apocynophyllum affine, Ettingshausen 1891: 277, p1.xxvii.13

Illustrated specimens: V2841.50, Gore Lignite Measures, Duntroonian to Waitakian Stages, Upper Oligocene to Lower Miocene, G45/f058, Landslip Hill, siliceous boulders at southern end of hill, $200 \mathrm{~m}$ from plantation boundary, G45 125530, A.M. Holden, P. Vella and C. Vella 1981; V2849.18, V2849.18A, Nevis Formation, Oil Shale Member, Pareora Series, Lower Miocene, F42/f001, various localities along Shale Ridge, Nevis Valley, Central Otago, F42 955535, A.M. Holden, P. Vella and C. Vella 1981. Other material examined: V2841.10, V2841.17, V2841.18, V2841.19, V2841.22, V2841.28, V2841.40, V2841.41, V2841.42, V2841.49, V2841.67, V2841.75, G45/f058, Landslip Hill, G45 125530, A.M. Holden, P. Vella and C. Vella 1981; V2842.6, V2842.9, G45/f063, Landslip Hill, fallen boulders at foot of slip scarp, G45 124533, A.M. Holden and P. Vella 1981, Stratigraphic range: Upper Oligocene to Lower Miocene.

KLB020 Coprosma praerepens Oliver Coprosma praerepens Oliver 1936:
Fig 31.14

302, fig 23

Holotype: WELT 44568, Kaikorai Leaf Beds, Waiauan Stage, Mid Miocene, Fraser's Gully, Kaikorai Valley, Dunedin, I44 135797, W.R.B. Oliver 1929; National Museum, Wellington.

Dimensions: $40 \mathrm{~mm}$ long and $30 \mathrm{~mm}$ broad.

Stratigraphic range: Mid Miocene. 
KLB021 Coprosma pliocenica Oliver

Fig $31.15,32.1$

Holotype: WELT 44569, Kaikorai Leaf Beds, Waiauan Stage, Mid Míocene, Fraser's Gully, Kaikorai Valley, Dunedin, I44 135797, W.R.B. Oliver 1929; National Museum, Wellington. Dimensions: $50 \mathrm{~mm}$ long and $23 \mathrm{~mm}$ broad.

Illustrated specimen: WELT 44573, from the type locality. Other material examined: WELT 44571, WELT 44572, from the type locality. Stratigraphic range: Mid Miocene.

FFF023 ?Coprosma

Fig 32.1

Illustrated specimen: B38.64, Frog Flat Formation, Waiauan to Tongaporutuan Stages, Mid to Upper Miocene, M30/f8503, various localities on Maruia Saddle Road, R.P. Suggate, D. Kear, J.C. Schofield and E.T. Annear 1949.

Stratigraphic range: Mid to Upper Miocene.

KLB022 Senecio pliocenica O1iver Senecio pliocenica Oliver 1936:
Fig 32.3

303, fig 25

Holotype: WELT 44570, Kaikorai Leaf Beds, Waiauan Stage, Mid Miocene, Fraser's Gully, Kaikorai Valley, Dunedin, I44 135797, W.R.B. Oliver 1929; National Museum, Wellington.

Dimensions: $54 \mathrm{~mm}$ long and $41 \mathrm{~mm}$ broad.

Stratigraphic range: Mid Miocene.

GLM031 cf. Avicennia

Fig 32.4

Illustrated specimen: B88.4, Gore Lignite Measures, Upper Oligocene

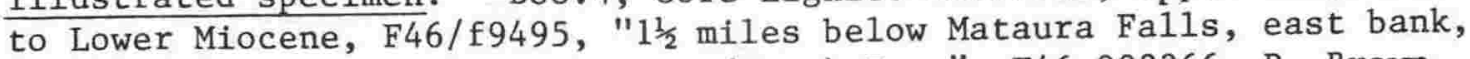
first terrace above R.J. McMurray (Gore) Farm", F46 902366, R. Brown, 1944.

Other material examined: B88.5, from the same locality. Stratigraphic range: Upper Oligocene to Lower Miocene.

\section{BIV007 ?Dysoxylum}

Fig 32.5

Illustrated specimen: B93.1, Beeson's Island Volcanics, Taranaki to Wanganui Series, Upper Miocene to Pliocene, S08/f9502, Oruawharo Bay, Great Barrier Island, S08 225606, D. Kear 1956.

Other material examined: B6.18, Longford Formation, Waiauan to Tongporutuan Stages, Mid to Upper Miocene, M29/f8593, Blue Duck Creek, M29 535313, D. Kear, 1948.

Stratigraphic range: Mid Miocene to Pliocene.

OLM033

Fig $32.6,32.7,32.8$

Illustrated specimens: V2851.9, 9A (counterparts), Central Otago Lignite Measures, Manuherikia Group, Pareora to Southland Series, Lower to Mid Miocene, F41/f210, true right bank of Kawerau River $100 \mathrm{~m}$ from mouth of Bannockburn, bluffs below road, F41 086628, A.M. Holden, P. Vella and C. Vella 1981; V2853.1, 1A (counterparts), Manuherikia Group, F41/f212, true left bank of Kawerau River opposite mouth of Bannockburn, fallen blocks, F41 085629, A.M. Holden, P. Vella and C. Vella 1981; B197.1, Manuherikia Group, Bannockburn, A. McKay, 1882. Stratigraphic range: Lower to Mid Miocene. 
Illustrated specimens: B197.24, Central Otago Lignite Measures, Manuherikia Group, Pareora to Southland Series, Lower to Mid Miocene, Bannockburn, A. McKay, 1882; B1036.37, B1036.46b, Manuherikia Group, $\mathrm{F} 1 / \mathrm{f} 9513$, basal beds of mid-Tertiary section exposed west of bridge to Cairnmuir Station across Bannockburn, F41 088624, R.I. McPherson 1968.

Other material examined: B197.14, Bannockburn, A. McKay 1882; B1036.23, F41/f9513, Bannockburn, F41 088624, R.I. McPherson 1968. Stratigraphic range: Lower to Mid Miocene.

\section{GLM0 32}

Fig 32.12

Illustrated specimen: V2851.65, Gore Lignite Measures, Duntroonian to Waitakian Stages, Upper Oligocene to Lower Miocene, G45/f058, Lands1ip Hill, siliceous boulders at south end of hilltop $200 \mathrm{~m}$ from plantation boundary, G45 125530, A.M. Holden, P. Vella, 1981. Stratigraphic range: Upper Oligocene to Lower Miocene.

FFF024 Loranthophy11um dubium Unger Loranthophyllum dubium Unger 1864: Loranthophyllum dubium Unger, Penseler 1930: 470, fig 33

Holotype: Not seen, Waikato Coal Measures, Upper Eocene.

ILlustrated specimens: B38.18, B38.104, Frog Flat Formation, Waiauan to Tongaporutuan Stages, Mid to Upper Miocene, M30/f8503, various localities on Maruia Saddle road, R.P. Suggate, D. Kear, J.C. Schofield and E.T. Annear 1949.

Other material examined: B38.41, B38.42, B38.96, from the same locality. Stratigraphic range: Upper Eocene to Upper Miocene.

OLM035

Fig $33.3,33.4,33.5,33.6$

Illustrated specimens: V2848.1, V2848.40 (counterparts), Central Otago Lignite Measures, Manuherikia Group, Pareora to Southland Series, Lower to Mid Miocene, G43/f002, Harliwick's opencast, Coal Creek Flat, Roxburgh, overburden from sma11 gully at west side of pit, G43 214193, A.M. Holden, P. Vella and C. Vella 1981; V2829.13, Longford Formation, Waiauan to Tongaporutuan Stages, Mid to Upper Miocene, M29/f152, boulder in creek bed about $300 \mathrm{~m}$ from junction with Buller River, Nuggety Creek, M29 606409, A.M. Holden and J.D. Collen 1979; VH106, Frog Flat Formation, Waiauan to Tongaporutuan Stages, $\mathrm{M} 30 / \mathrm{f024}$, roadside cutting on true right bank of Glenroy River close to bridge, M30 550113, A.M. Holden and J.D. Collen 1979. Stratigraphic range: Lower to Upper Miocene.

Illustrated specimens: V2842.6, V2942.9 (counterparts), Gore Lignite Measures, Duntroonian to Waitakian Stages, Upper Oligocene to Lower Miocene, G45/f063, Landslip Hill, fallen boulders at foot of slip scarp, G45 124533, A.M. Holden and P. Vella 1981; B256.18, B256.30, B256.31 (parts of same impression), Longford Formation, Waiauan to Tongaporutuan Stages, Mid to Upper Miocene, M29/f8683, Murchison-Nelson road, north end of 
Longford Bridge, M29 579353, H.W. Wellman 1951.

Stratigraphic range: Upper Oligocene to Upper Miocene.

OLMO36

Fig $34.1,34.2,34.3,34.4,34.5$

I1lustrated specimens: V2856.4 and V2856.41 (parts of same impression), V2856.6, V2856.12, Central Otago Lignite Measures, St. Bathans Beds, Pareora to Southland Series, Lower to Mid Miocene, H41/f028, clay seam, sluiced ground at west end of Blue Lake, St. Bathans, Central Otago, H41 577888, A.M. Holden, P. Vella and C. Vella 1981; V2850.22, Manuherikia Group, Pareora to Southland Series, F41/f209, new road cut $200 \mathrm{~m}$ north of bridge across Bannockburn, F41 088622, A.M. Holden, P. Vella and C. Vella 1981; V2851.1, 1A (counterparts), Manuherikia Group, F41/f210, true right bank of Kawerau River $100 \mathrm{~m}$ from mouth of Bannockburn, bluffs below road, F41 086628, A.M. Holden, P. Vella and C. Vella 1981.

Stratigraphic range: Lower to Mid Miocene.

LDF037

Fig 34.6

Illustrated specimen: B6.1, Longford Formation, Waiauan to Tongaporutuan Stages, Mid to Upper Miocene, M29/f8593, Blue Duck Creek, M29 535313 , D. Kear 1948 .

Stratigraphic range: Mid to Upper Miocene.

LDF038

Fig 34.7

I1lustrated specimen: B2.30, Longford Formation, Waiauan to Tongaporutuan Stages, Mid to Upper Miocene, M29/f6579, Nuggety Creek, M29 604410, R.P. Suggate, D. Kear, E.T. Annear and W.A. Sara 1951 ,

Stratigraphic range: Mid to Upper Miocene.

LDF039

Fig 34.8

Illustrated specimen: V2825.11, Longford Formation, Waiauan to Tongaporutuan Stages, Mid to Upper Miocene, M29/f154, Dress Circle, Longford, M29 579347, A.M. Holden and J.D. Collen 1979.

Other material examined: V2825.29 from the same locality.

Stratigraphic range: Mid to Upper Miocene.

OLM037

Fig 34.9

Illustrated specimen: B1036.19, Central Otago Lignite Measures, Manuherikia Group, Pareora to Southland Series, Lower to Mid Miocene, F41/f9513, basal beds of mid-Tertiary section exposed west of bridge to Cairnmuir Station across Bannockburn, F41 088624, R.I. McPherson 1968. Stratigraphic range: Lower to Mid Miocene.

FFF025

Fig 34.10

Illustrated specimen: V2838.10, Frog Flat Formation, Waiauan to Tonga- 
porutuan Stages, Mid to Upper Miocene, M30/f024, roadside cutting on true right bank of Glenroy River close to bridge, M30 550113, A.M. Holden and J.D. Collen 1979.

Stratigraphic range: Mid to Upper Miocene.

KLB023 ?Compositae, ?Smilacaceae

Fig 35.1

Illustrated specimen: V2847.10, Kaikorai Leaf Beds, Waiauan Stage, Mid Miocene, I44/f134, Fraser's Gully, Kaikorai Valley, Dunedin, I44 135797 , A.M. Holden, P. Vella and J.D. Campbel1 1981.

Stratigraphic range: Mid Miocene.

LDF040 Palmae

Fig 35.2

Illustrated specimen: B1119.11, Longford Formation, Waiauan to Tongaporutuan Stages, Mid to Upper Miocene, M29/f8606A, Dress Circle, Longford, M29 579347, D.C. Mildenha11 et a1. 1978.

Other material examined: B11 $19.10, B 1119.11, \mathrm{~B} 1119.12, \mathrm{~B} 1119.14, \mathrm{~B} 1119.18$, $\mathrm{B} 1119.19, \mathrm{~B} 1119.20, \mathrm{~B} 1119.21, \mathrm{~B} 1119.22, \mathrm{~B} 1119.23, \mathrm{~B} 1119.24$, from the same locality; V2827.1, Longford Formation, M29/f150, fallen boulders on true left bank of Blue Duck Creek about $1.7 \mathrm{~km}$ from junction with Mangles River, M29 587314, A.M. Holden and J.D. Collen 1979; V2833.1, Frog Flat Formation, Waiauan to Tongaporutuan Stages, Mid to Upper Miocene, $\mathrm{L} 30 / \mathrm{f} 030$, road cutting $100 \mathrm{~m}$ south of Frog Flat Junction, L30 489059, A.M. Holden and J.D. Collen 1979; V2848.3, Central Otago Lignite Measures, Manuherikia Group, Pareora to Southland Series, Lower to Mid Miocene, G43/f002, Harliwick's Opencast, Coal Creek Flat, Roxburgh, overburden from small gully at west side of pit, G43 214193, A.M. Holden, P. Vella and C. Vella 1981.

Stratigraphic range: Lower to Upper Miocene.

FFF026

Fig 35.3

Illustrated specimen: B38.101, Frog Flat Formation, Waiauan to Tongaporutuan Stages, Mid to Upper Miocene, M30/f8503, various localities on Maruia Saddle Road, R.P. Suggate, D. Kear, J.C. Schofield and E.T. Annear 1949.

Other material examined: B38.55, B38.83, from the same locality.

Stratigraphic range: Mid to Upper Miocene.

GLM033

Fig 35.4

Illustrated specimen: B148.26, Gore Lignite Measures, Duntroonian to Waitakian Stages, Upper Oligocene to Lower Miocene, G45/f8498, Landslip Hil1, G45 125530, J. Hector.

Other material examined: V2841.7, V2841.9, V2841.29, V2841.30, V2841.31, V2841.37, V2841.76, V2841.78, V2841.80, G45/f058, Landslip Hil1, siliceous boulders at southern end of hilltop, $200 \mathrm{~m}$ from plantation boundary, G45 125530, A.M. Holden and P. Vella 1981.

Stratigraphic range: Upper Oligocene to Lower Miocene. 
KLB024 Typha robusta 01iver

Figs $35.5,35.6$

Typha robusta 01iver 1936:

289, fig 3

Holotype: WELT 44543, Kaikorai Leaf Beds, Waiauan Stage, Mid Miocene, Fraser's Gully, Kaikorai Valley, Dunedin, I44 135797, W.R.B. Oliver 1929; National Museum, Wellington.

Dimensions: $63 \mathrm{~mm}$ long and $22 \mathrm{~mm}$ wide.

Illustrated specimens: B2.43, Longford Formation, Waiauan to Tongporutuan Stages, Mid to Upper Miocene, M29/f6579, Nuggety Creek, M29 604410 , R.P. Suggate, D. Kear, E.T. Annear and W.A. Sara 1951; B33.2 Gore Lignite Measures, Duntroonian to Waitakian Stages, Upper Oligocene to Lower Miocene, F45/f9575, Waikaka, F45 987505.

Other material examined: WELT 44544, from the type locality.

Stratigraphic range: Upper Oligocene to Lower Miocene.

NFM012 ?Zingiberaceae

Figs $35.6,35.7$

Illustrated specimens: V2849.58, 58A (counterparts), Nevis Formation, 011 Shale Member, Pareora Series, Lower Miocene, F42/f001, various localities along Shale Ridge, Nevis Valley, F42 955535, A.M. Holden, P. Vella and C. Vella 1981.

Stratigraphic range: Lower Miocene.

GLM034

Figs $36.1,36.2$

Illustrated specimens: V2841.3 (rubber cast), Gore Lignite Measures, Duntroonian to Waitakian Stages, Upper Oligocene to Lower Miocene, G45/f058, Landslip Hill, siliceous boulders at southern end of hilltop $200 \mathrm{~m}$ from plantation boundary, G45 125530, A.M. Holden and P. Vella 1981. Stratigraphic range: Upper Oligocene to Lower Miocene.

GLM035

Plate 9.1 , Figs $36.3,36.4,36.5,36.6$

Illustrated specimen: V2842.6B, fossil and rubber casts, Gore Lignite Measures, Duntroonian to Waitakian Stages, Upper Oligocene to Lower Miocene, G45/f063, Landslip Hill, fallen boulders at foot of slip scarp, G45 124533, A.M. Holden and P. Vella 1981.

Stratigraphic range: Upper Oligocene to Lower Miocene.

GLM036

Plate 9.3 , Fig 36.7

Illustrated specimens: V2842.10A, Gore Lignite Measures, Duntroonian to Waitakian Stages, UpDer 0ligocene to Lower Miocene, G45/f063, Landslip Hill, fallen boulders at foot of slip scarp, G45 124533, A.M. Holden and P. Vella

Other material examined: B148.23, G45/f8498, Landslip Hil1, G45 125530 , J. Hector.

Stratigraphic range: Upper Oligocene to Lower Miocene.

GLM037

Plate $9.2,9.5$, Figs $36.8,36.9$

Illustrated specimens: V2842.13, 13A (counterparts), Gore Lignite Measures, Duntroonian to Waitakian Stages, Upper Oligocene to Lower Miocene, G45/f063, Landslip Hill, fallen boulders at foot of slip scarp, G45 124533, A.M. Holden and P. Vella 1981.

Stratigraphic range: Upper Oligocene to Lower Miocene. 
Illustrated specimens: V2841.47, Gore Lignite Measures, Duntroonian to Waitakian Stages, Upper Oligocene to Lower Miocene, G45/f058, Landslip Hill, siliceous boulders at southern end of hilltop $200 \mathrm{~m}$ from plantation boundary, G45 125530, A.M. Holden and P. Vella 1981.

Stratigraphic range: Upper Oligocene to Lower Miocene.

FFF027

Fig 37.3

Illustrated specimen: B36.16, Frog Flat Formation, Waiauan to Tongaporutuan Stages, Mid to Upper Miocene, M30/f8501, "20 chains south of Maruia Saddle", M30 514078, R.P. Suggate et al. 1949

Stratigraphic range: Mid to Upper Miocene.

LDF04 1

Fig $37.4,37.5$

Illustrated specimen: B256.32, Longford Formation, Waiauan to Tongaporutuan Stages, Mid to Upper Miocene, M29/f8683, Murchison-Nelson road, north end of Longford Bridge, M29 572353, H.W. Wellman 1951.

Other material examined: B36.16, Frog Flat Formation, Waiauan to Tongaporutuan Stages, M30/f8501, "20 chains south of Maruia Saddle", R.P. Suggate et al. 1949.

Stratigraphic range: Mid to Upper Miocene.

OLM038 ?Rhopalostylis

Fig $37.6,37.7$

Illustrated specimens: V2848.29, V2848.29A, Central Otago Lignite Measures, Manuherikia Group, G43/f002, Harliwick's Opencast, Coal Creek Flat, Roxburgh, overburden from small gully at west side of pit, G43 214193, A.M. Holden, P. Vella and C. Vella 1981.

Stratigraphic range: Lower to Mid Miocene.

GLM039

Figs $37.8,37.9,37.10$

Illustrated specimens: V2843.17 (isolates from large block), Gore Lignite Measures, Waitakian Stage, Upper Oligocene to Lower Miocene, F46/f063, east bank of Mataura River, Tuturau, floats from riverbank downstream of outcrop of Gore Lignite Measures, F46 308887, A.M. Holden and P. Vella 1981. Other material examined: Numerous other fruits from same block. Stratigraphic range: Upper Oligocene to Lower Miocene.

GLM040

$$
\text { P1ate } 10.1,10.2,10.3
$$

Illustrated specimen: B148.1027, Gore Lignite Measures, Duntroonian to Waitakian Stages, Upper Oligocene to Lower Miocene, G45/f8498, Landslip Hill, G45 125530, J. Hector.

Stratigraphic range: Upper Oligocene to Lower Miocene.

GLM0 41

Plates $10.4,11.4$

Illustrated specimen: V2841.25, Gore Lignite Measures, Duntroonian to Waitakian Stages, Upper Oligocene to Lower Miocene, G45/f058, Landslip 
Hil1, siliceous boulders at southern end of hilltop, $200 \mathrm{~m}$ from plantation boundary, G45 125530, A.M. Holden and P. Vella 1981. Stratigraphic range: Upper Oligocene to Lower Miocene.

\section{GLM042}

Plate 11.1

Illustrated specimen: V2841.77, Gore Lignite Measures, Duntroonian to Waitakian Stages, Upper Oligocene to Lower Miocene, G45/f058, Landslip Hill, siliceous boulders at southern end of hilltop $200 \mathrm{~m}$ from plantation boundary, G45 125530, A.M. Holden and P. Vella 1981.

Other material examined: V2842.19, G45/f063, Landslip Hill, fallen boulders at foot of slip scarp, G45 124533, A.M. Holden and P. Vella 1981. Stratigraphic range: Upper Oligocene to Lower Miocene.

GLM0 43

Plate 11.2

Illustrated specimen: V2840.5, Gore Lignite Measures, Duntroonian to Waitakian Stage, Upper Oligocene to Lower Miocene, G45/f064, Lands1ip Hill, G45 125530, J. Thornton.

Stratigraphic range: Upper O1igocene to Lower Miocene.

GLM044

P1ate $11.3,11.5$

Illustrated specimen: V2842.4, Gore Lignite Measures, Duntroonian to Waitakian Stages, Upper 01igocene to Lower Miocene, G45/f063, Landslip Hill, fallen boulders at foot of slip scarp, G45 124533, A.M. Holden and P. Vella 1981.

Stratigraphic range: Upper Oligocene to Lower Miocene.

\section{GLM045}

Plate 12.1

Illustrated specimen: B148.7, Gore Lignite Measures, Duntroonian to Waitakian Stages, Upper Oligocene to Lower Miocene, G45/f8498, Landslip Hil1, G45 125530, J. Hector. Stratigraphic range: Upper Oligocene to Lower Miocene.

GLM046

Plate $12.2,12.3$

Illustrated specimens: V2841.84,V2841.91, Gore Lignite Measures, Duntroonian to Waitakian Stages, Upper Oligocene to Lower Miocene, G45/f058, Landslip Hill, Pukerau near Gore, Southland, siliceous boulders at southern end of hill $200 \mathrm{~m}$ from plantation boundary, G45 125530, A.M. Holden and P. Vella 1981.

Other material examined: V2841.11, G45/f063, Landslip Hill, fallen boulders at foot of slip scarp, G45 124533, A.M. Holden and P. Vella 1981. Stratigraphic range: Upper Oligocene to Lower Miocene.

OLM039

Plate $12.4,12.5$

Illustrated specimens: V2852.1, V2852.4, Central Otago Lignite Measures, Manuherikia Group, Pareora to Southland Series, Lower to Mid Miocene, F41/f213, true right bank of Kawerau River at junction with Bannockburn, 
clay bed associated with lignite seam, F41 086627, A.M. Holden, P. Vella and C. Vella 1981.

Other material examined: V2852.2, V2852.3, from the same locality. Stratigraphic range: Lower to Mid Miocene. 
FIG. 1.

1.1. Podocarpus obtusifolius 0liver; WELT 44542, Holotype, $x 4$.

$1.2,1.3,1.5,1.6$. Podocarpus sp. aff. totara G. Benn, ex D. Don. 2. V2841.36, part of hypotype, $x 4 ; 3$. V2841.36A. part of hypotype, $\mathrm{x} 4$; 5. V2841.36A, hypotype, $\mathrm{xl} ; 6 . \mathrm{V} 2841.36 \mathrm{~A}$, part of hypotype, $\mathrm{x} 4$.

1.4. Dacrycarpus sp. aff. dacrydioides (A. Rich.) de Laub.; v2849.67, hypotype, $x 4$.

$1.7,1.8,1.9,1.10,1.11$; Dacrydium sp. aff. cupressinum Lamb. 7. B148.21, $\mathrm{x} 4 ;$ 8. B148.1026, $\mathrm{x} 4$. 9. V2841.11A, silicone rubber cast, $x 4 ; 10 . V 2841.3, x 4 ; 11 . \mathrm{V} 2841.53$, hypotype, silicone rubber cast, $\mathrm{x} 4$. 

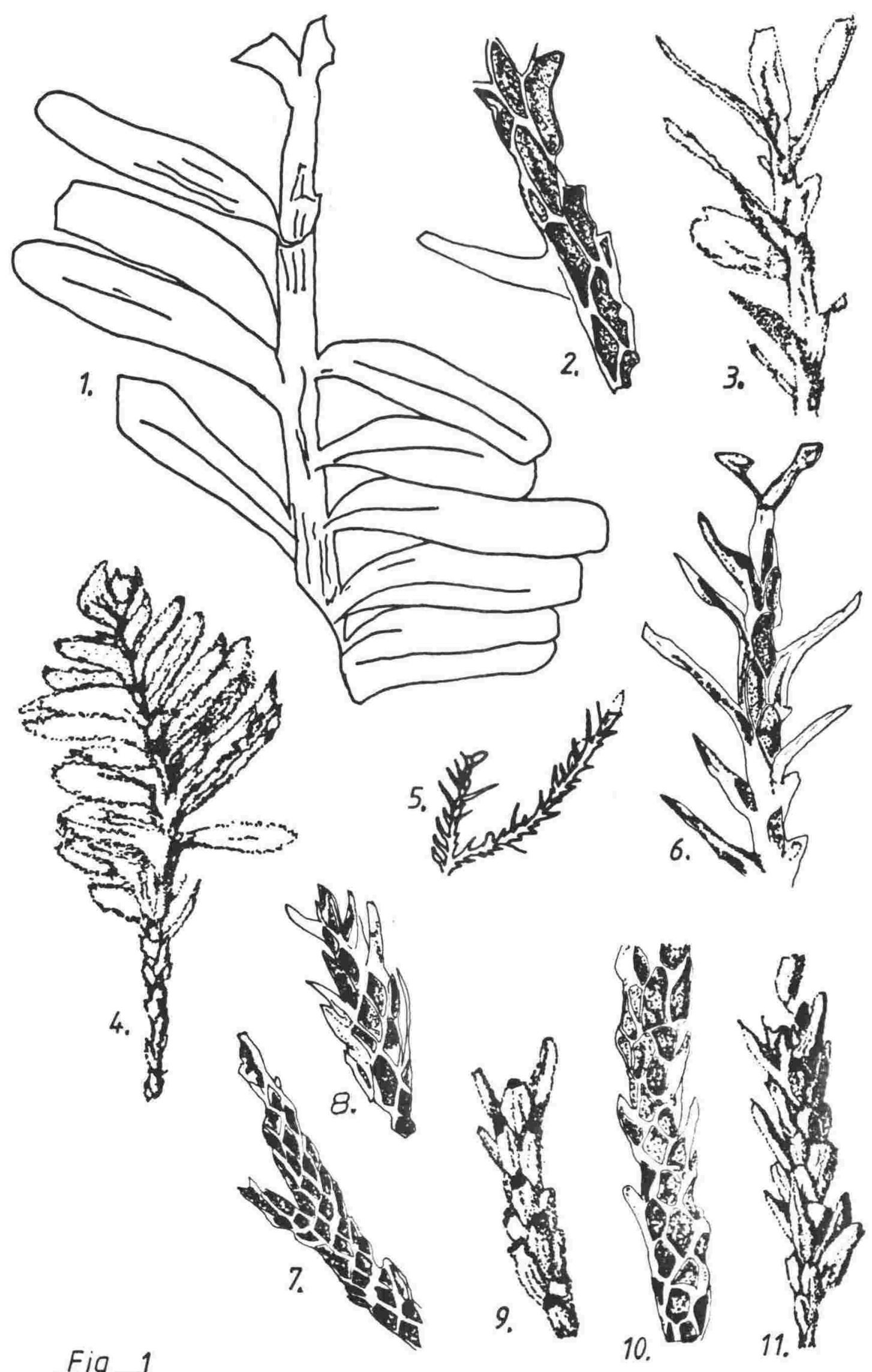

$\underline{\underline{F}} g, 1$ 


\section{FIG. 2.}

2.1, 2.2, 2.3. Dacrydium franklinoides sp. nov.

1. V2841.22, part of holotype, silicone rubber cast, $x 12$;

2. B148.13, part of specimen, silicone rubber cast, $x 6$;

3. V2841.22, part of holotype, silicone rubber cast, $x 6$.

$2.4,2.5,2.6,2.7$. Microcachrys imbricata sp. nov.

4. V2841.17, silicone rubber cast, x12; V2841.63, holotype, silicone rubber cast, $x 6 ; 6 . \mathrm{V} 2841.2$, silicone rubber cast, $x 6$;

7. v2842.10 x6.

2.8. Phyllocladus strictus sp. nov. B411.1, holotype, xl.

2.9, 2.10. Phyllocladus sp.

9. V2843.10, x1; V2843.18, x1.

2.11, 2.12. Libocedrus compressa sp. nov.

11. V2841.44, holotype, x6; 12. V2841.87, x6.

2.14. Libocedrus sp. V2841.64, x1.

$2.13,2.15,2.16$. Araucaria sp.

13. B150, unnumbered, $\mathrm{x} 1 ;$ 15. V2841.1, x1; 6. B150.9, x1.

$2.19,2.20,2.22,2.24$. Agathis sp aff. australis. Salisb.

19. V2841.74, x1; 20. V2829.24, hypotype, $x 1 ; 22 . \mathrm{V} 2829.3$ counterpart of hypotype, $x 1 ; 24$. B150.17, x1.

2.21. Agathis sp. V2841.51, xl.

2.23. ?Araucaria sp. B2.58, x1. 

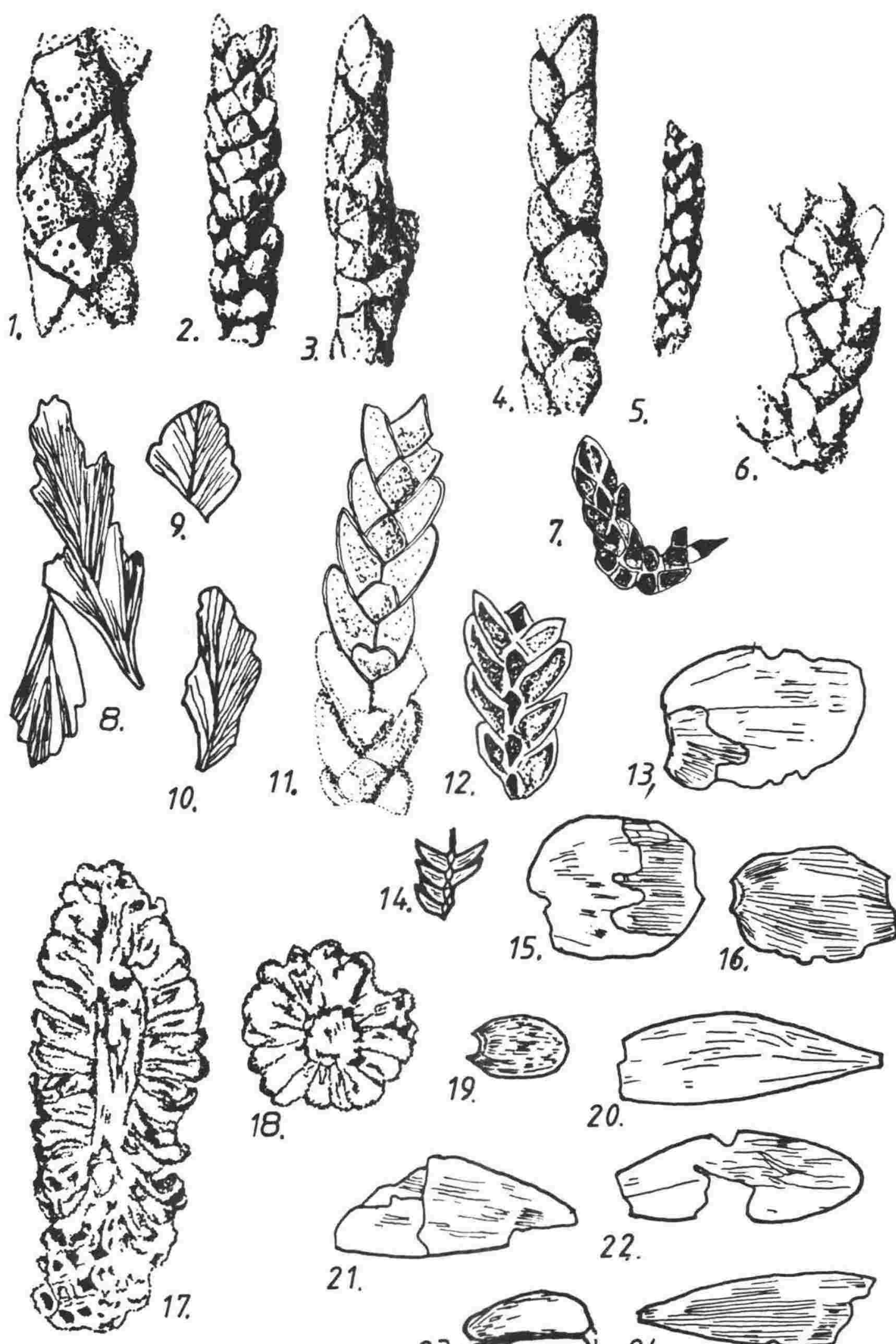

18.
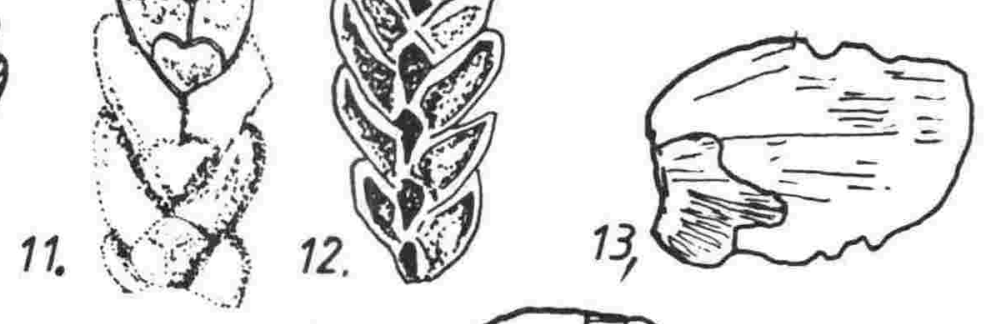

Fig $g, \underline{\underline{2}}$

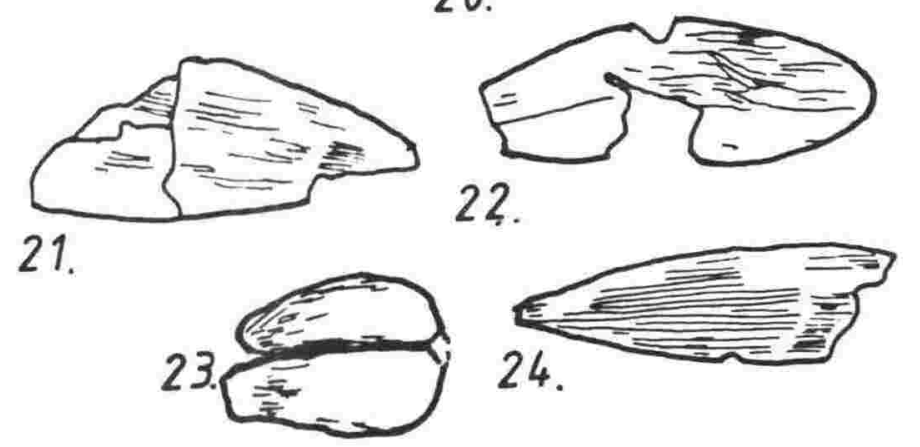


FIG. 3.

$3.1,3.2,3.3,3.4,3.5$. Nothofagus southlandica sp. nov.

1. V2841.13A, Holotype, $\mathrm{x1}$; B149.6, x1; 3. B150.5, x1.

4. V2849.59A, x1; 5. V2849.93, x1.

$3.6,3.7,3.8,3.9,3.10,3.11,3.12$. Nothofagus novae-zealandiae (Oliver) Holden.

6. V2830.1, x1; 7.VH93, $\mathrm{x} 1 ; 8 . \mathrm{B} 7.64, \mathrm{x} 1$;

9. B2.26, $\mathrm{x} 1 ; 10 . \mathrm{V} 2841.38, \mathrm{xl} ; 11$. WELT 44482, Holotype, $\mathrm{x} 1$.

12. V2841.21, $\mathrm{x} 1$. 

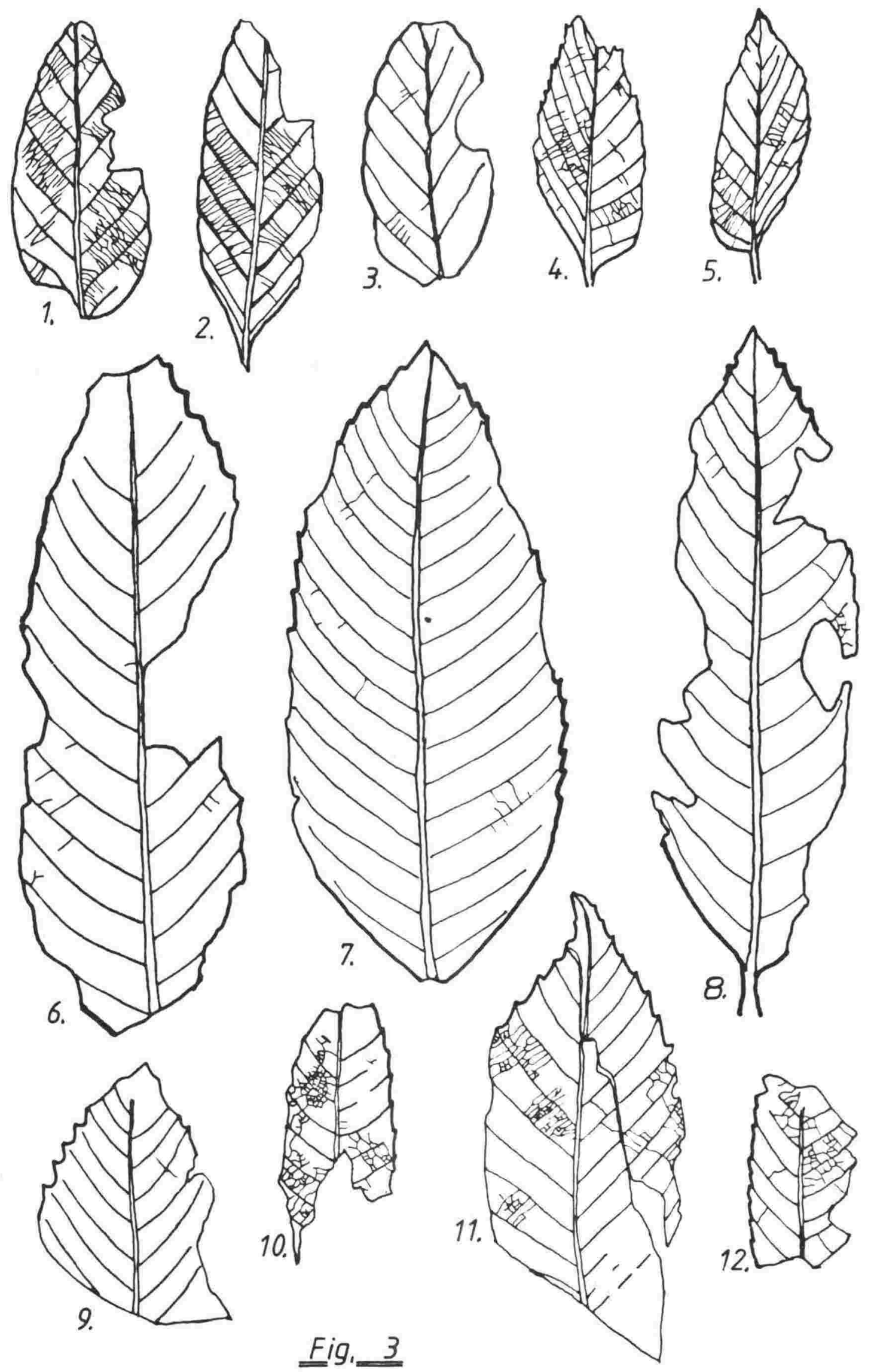
FIG. 4.

$4.1,4.2,4.3,4.4,4.5,4.6,4.7,4.8$. Nothofagus bidentatus Holden.

1. B2.54, holotype, $\mathrm{x1} ; 2$. VH96, $\mathrm{x} 1 ; 3$. B411.4, $\mathrm{x1}$;

4. V2849.82, x1; 5. B7.14, x1; 6. B411.7, x1; 7. V2849.32, xl;

8. $\mathrm{v} 2849.66, \mathrm{x} 1$.

4.9, 4.10, 4.11. Nothofagus pinnata (Oliver) Holden, comb. nov. 9. WELT 44532, x1; 10. WELT 44484, x1; 11. WELT 44519, holotype, $\mathrm{xl}$. 

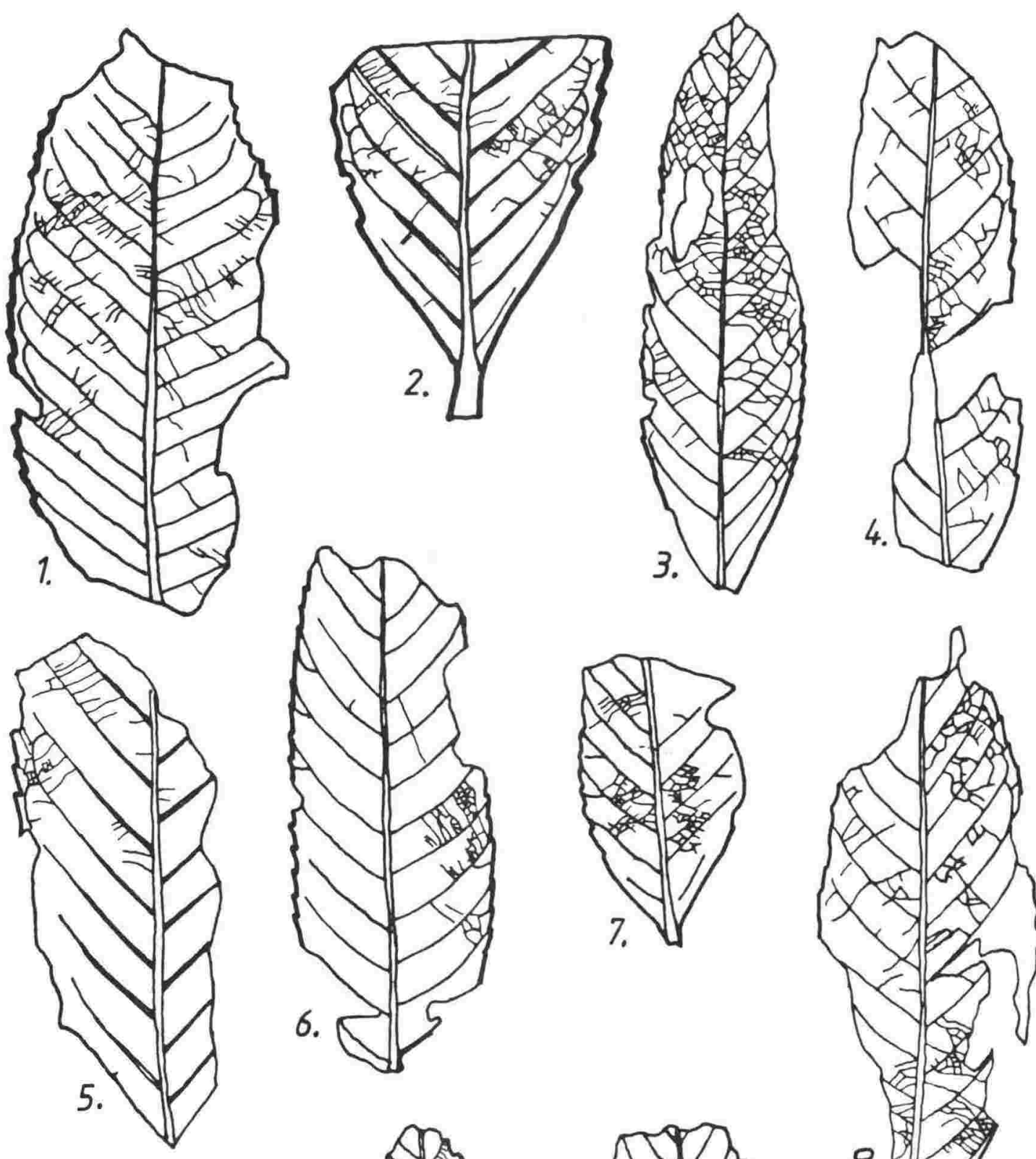

6.
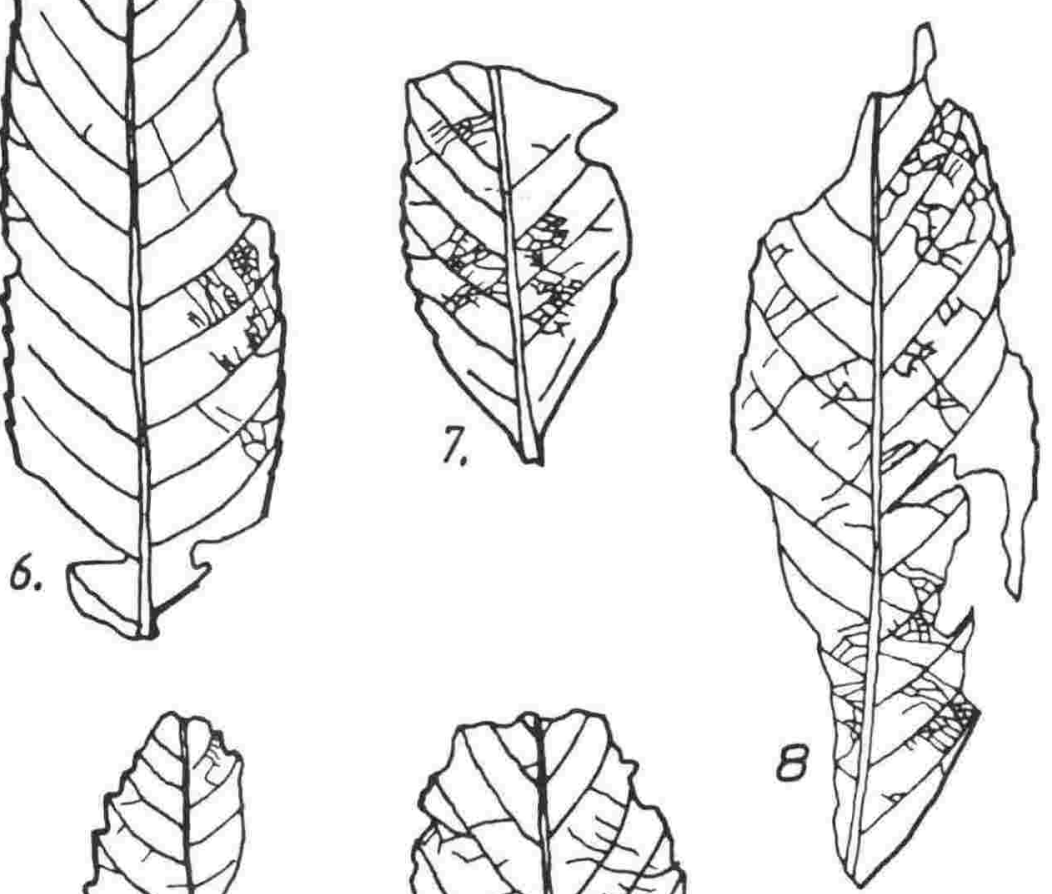

Fig. 4 
FIG. 5 .

$5.1,5.2,5.3,5.4$. Nothofagus oblonga Holden

1. B7.56, holotype, $\mathrm{x} 1 ; 2$. B38.14, $\mathrm{x} 1$; 3. B7.28, $\mathrm{xl}$;

4. B7. 15, $\mathrm{x} 1$.

$5.5,5.6,5.7,5.8$. Nothofagus oliveri Holden.

5. B2.59, x1; 6. B2.23, x1; 7. B2.49, holotype, $x 1 ; 8$. VH99, $x 1$. 

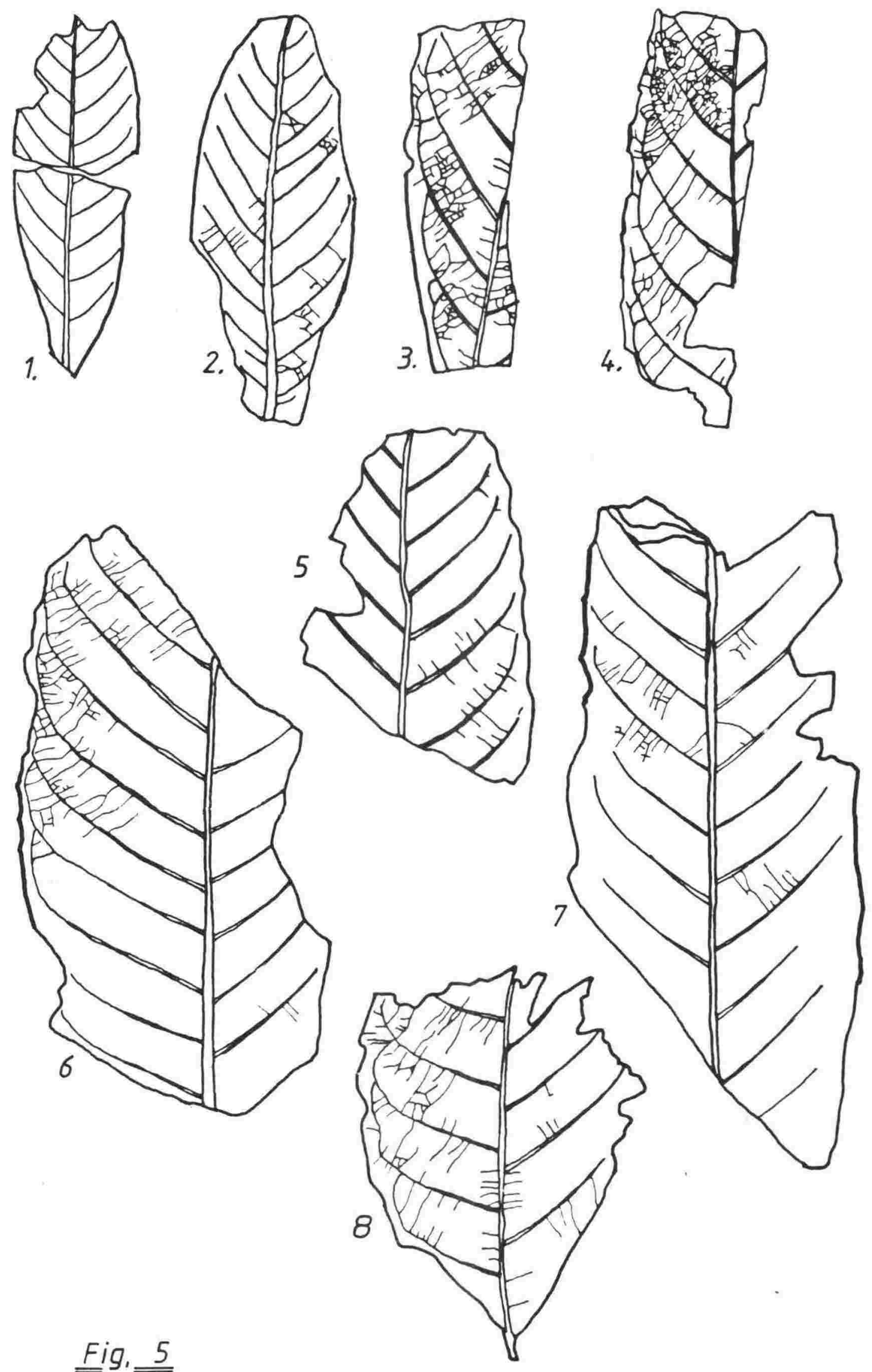


\section{FIG. 6 .}

$6.1,6.2,6.3,6.4,6.5,6.6,6.7,6.8,6.11$. Nothofagus australis (01iver) comb. nov.

1. V2846.46, x1; 2. WELT 44498, holotype, x1; 3. V2851.10A, x1;

4. WELT 44487, x1; 5. V2849.20, x1; 6. V2850.29, x1;

7. V2850.40, $\mathrm{x} 1 ; 8 . \mathrm{B} 411.2, \mathrm{x} 1 ; 11 . \mathrm{V} 2851.16, \mathrm{x} 1$.

$6.9,6.10,6.12,6.13,6.14$. Nothofagus kaikoraiensis (Oliver) comb. nov. 9. WELT 44545A, x1; 10. WELT 44545, x1; 12. WELT 44509, holotype, x1; 13. V2846.28, x1; 14. V2846.25, x1. 

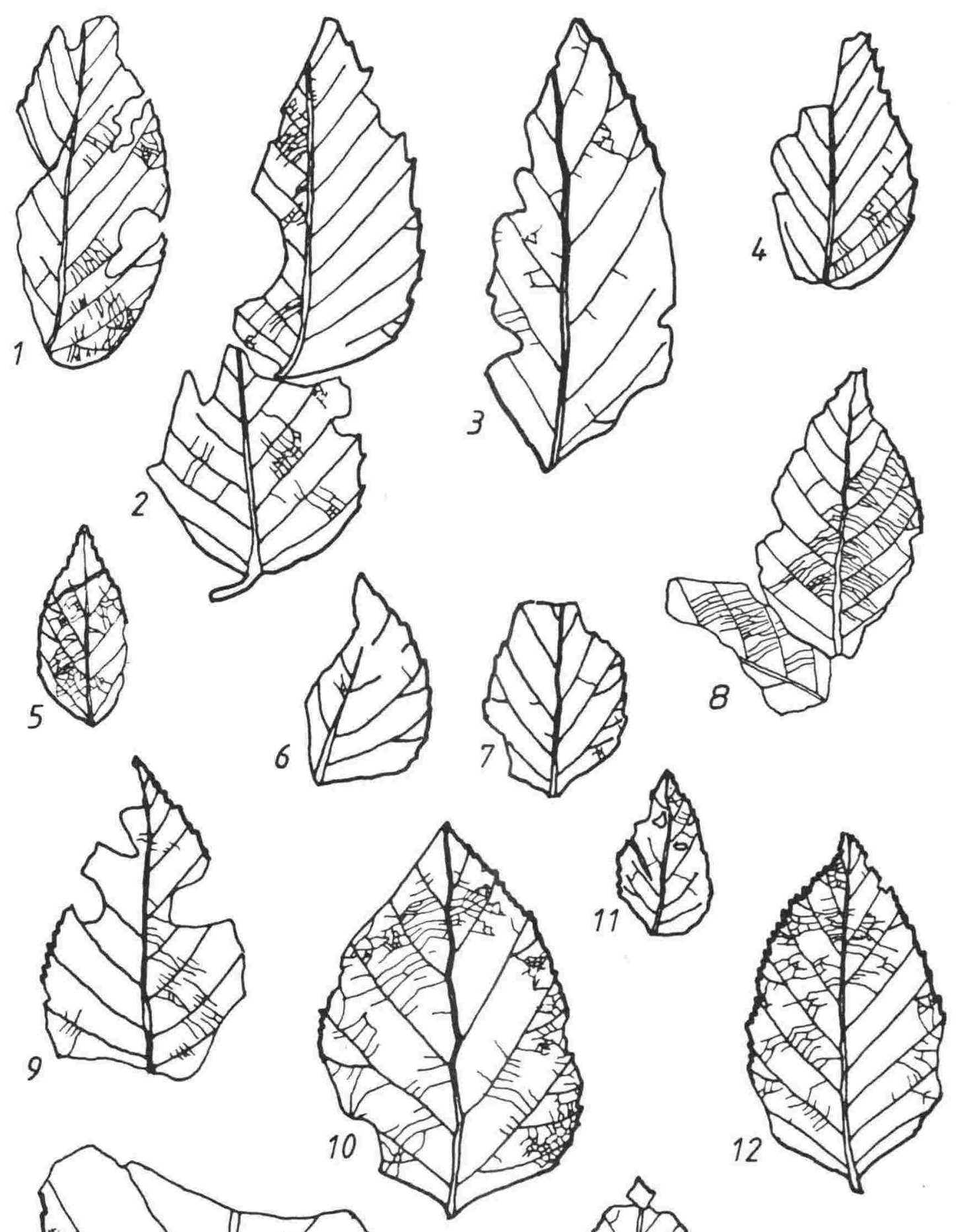

$\underline{\underline{F}} g, \underline{\underline{6}}$ 
FIG. 7.

7.1, 7.2, 7.3. Gymnostoma stellata Campbell and Holden. Sp. nov.

1. V2840.4, holotype, silicone rubber cast, $\times 3$;

2. 3., V2841.63, silicone rubber cast, $x 3$.

7.4, 7.5. Gymostoma crassa sp. nov.

4. V2840.8, silicone rubber cast, x3; 5. B148.1026, holotype, silicone rubber cast, $\mathrm{x} 3$.

7.6, 7.7, 7.8. Casuarina avenacea Campbell and Holden. sp. nov.

6. V2850.43A, silicone rubber cast, $\times 3$; 7. V2851.8, x3;

8. V2851.14A, $\times 3$.

7.9. Casuarina sp., B38.27, holotype, x12. 

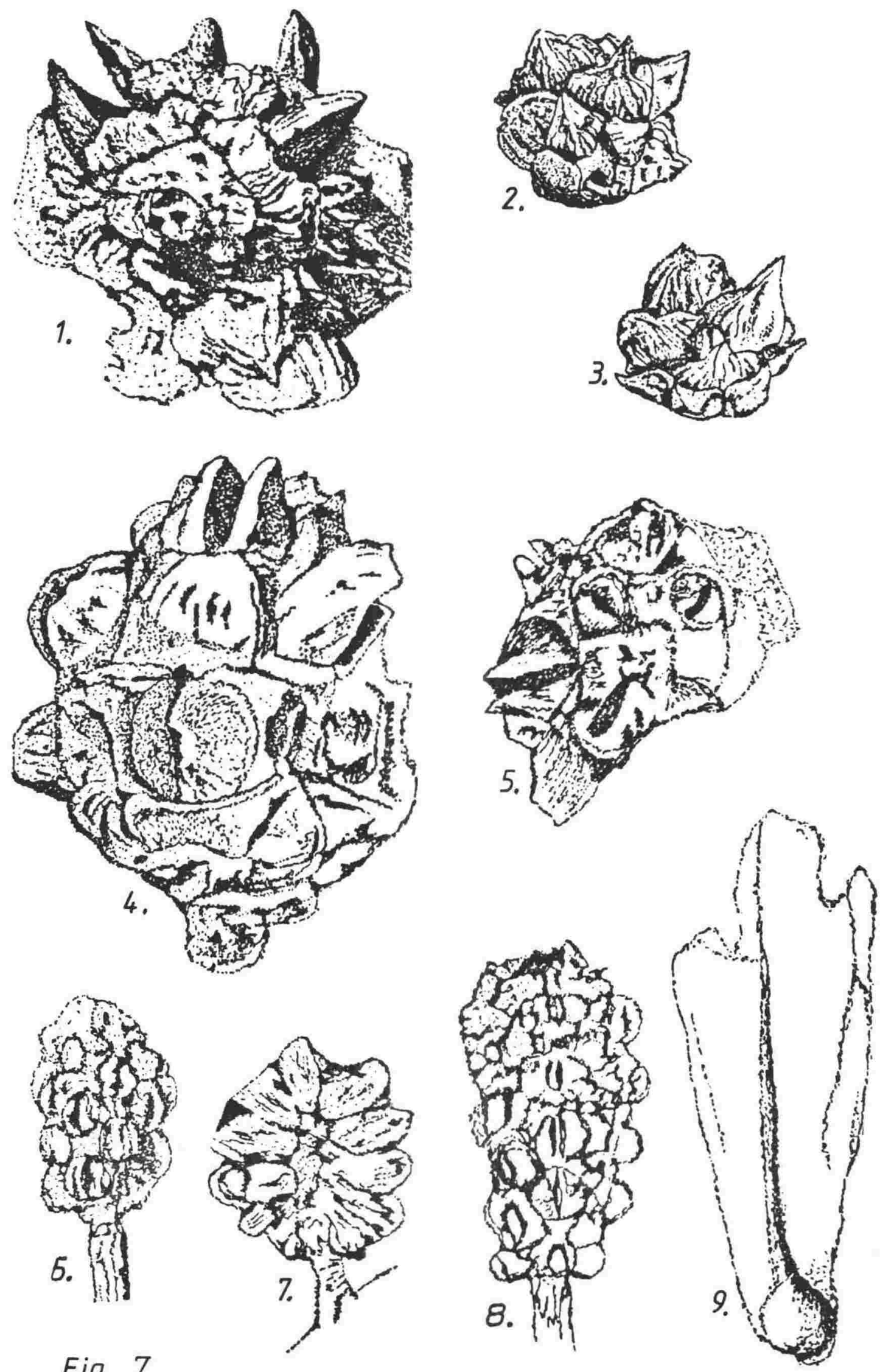

Fig. 7 
FIG. 8.

8.1, 8.2, 8.3, 8.4. Leptopteris hymenophy1loides (A. Rich.)

Pres1. 1. B38.98, hypotype, x2; 2. B38.42, x2; 3. B38.42,

camera lucida drawing showing venation, x10; 4. B38.98, hypotype,

camera lucida drawing showing venation, $x 10$.

8.5, 8.6. Gleichenia southlandica sp. nov.

5. C76.469.6, holotype, part of frond, $x 15 ; 6$. C76.469.6, holotype, $\mathrm{xl}$. 

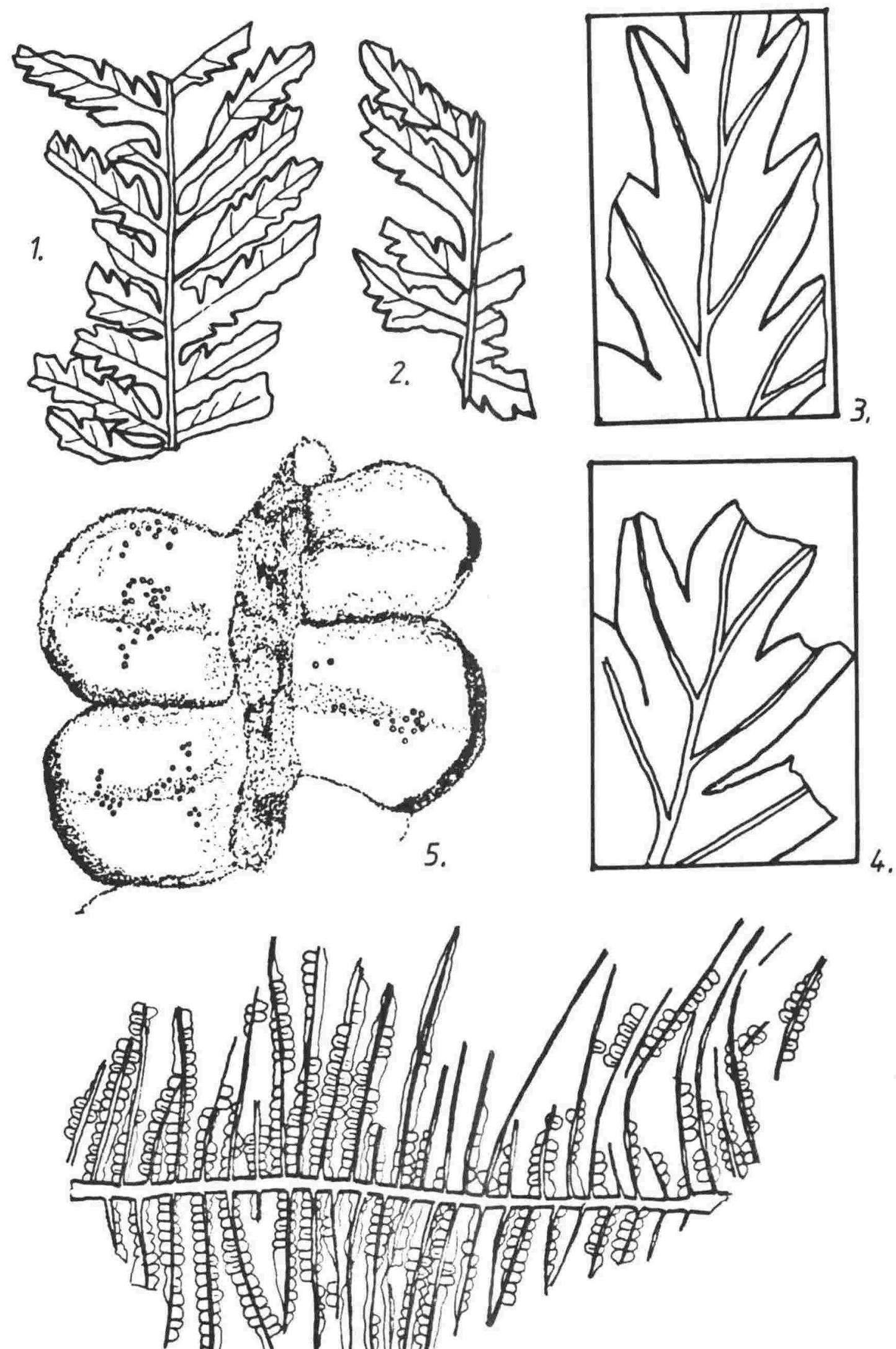

6.

9

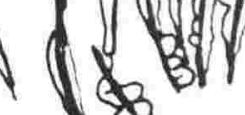

Fig. 8 
FIG. 9.

9.1, 9.2, 9.3, 9.4. Alsophila sp. aff. tricolor (Col.) Tryon

1. V2857.9A, x1; 2. B412, x1; 3. B412, obverse, $x 1$;

4. B36.13, hypotype, $x 1$.

9.5, 9.6, 9.7. Davallia tasmanii H.C. Field.

5. B38.34, hypotype, x2; 6. B38.32, x2; 7. B38.34, hypotype, camera lucida drawing showing indusia, $x 15$. 

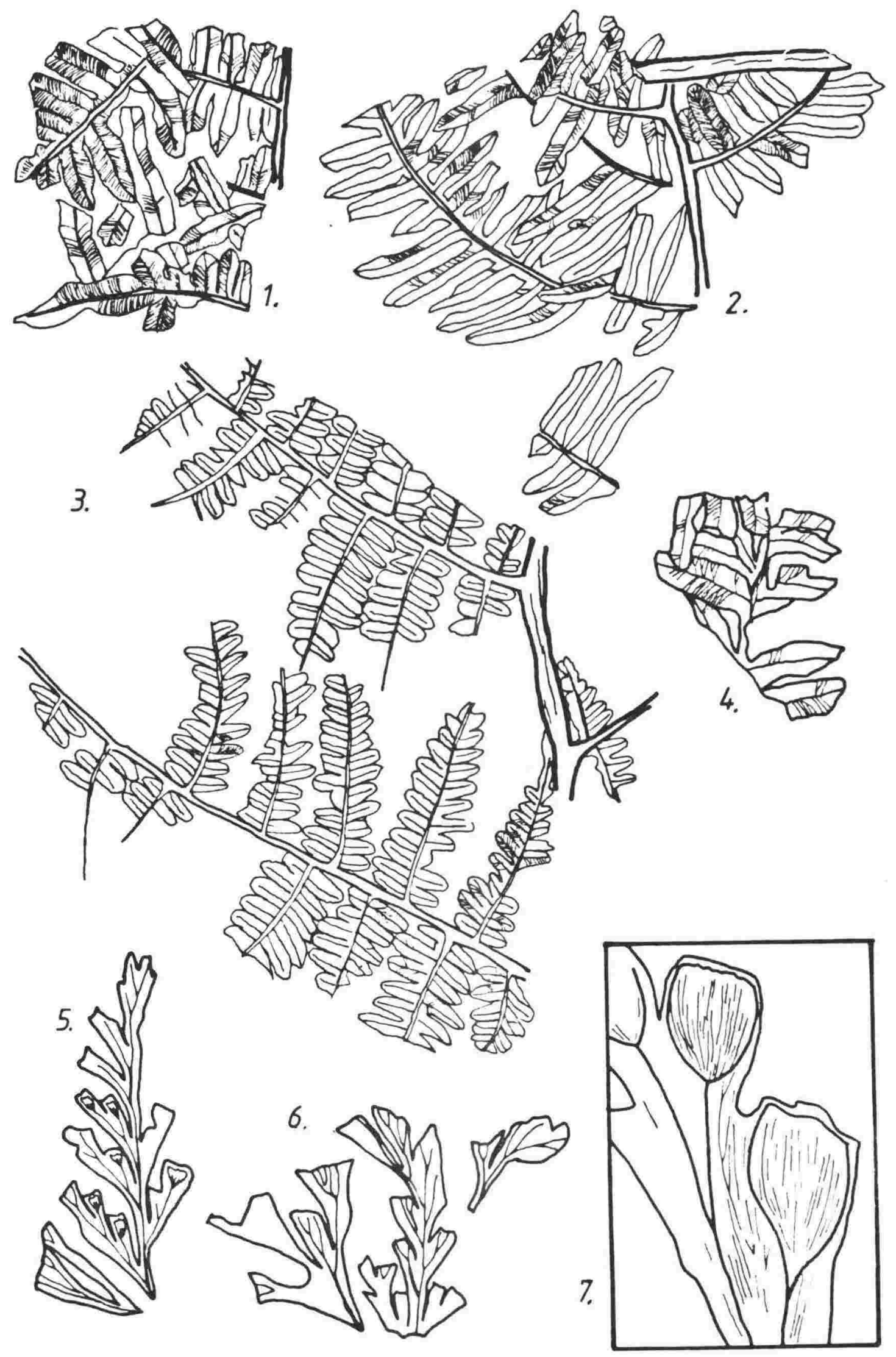

Fig $\underline{\underline{9}}$ 
FIG. 10.

10.1 Blechnum maruiense sp. nov.; B256.3 and B256.6, holotype, x1.

$10.2,10.3,10.4,10.6$. Blechnum proceroides (Oliver) comb. nov.

2. B38.17, x1; 3. B2.41, x1; 4. B2.14, x1; 5. WELT P4954, x1.

10.5, 10.7. Hypolepis maruiensis sp. nov.

B38/18, holotype, camera lucida drawing of venation, x10.

7. B38.18, holotype, xl. 


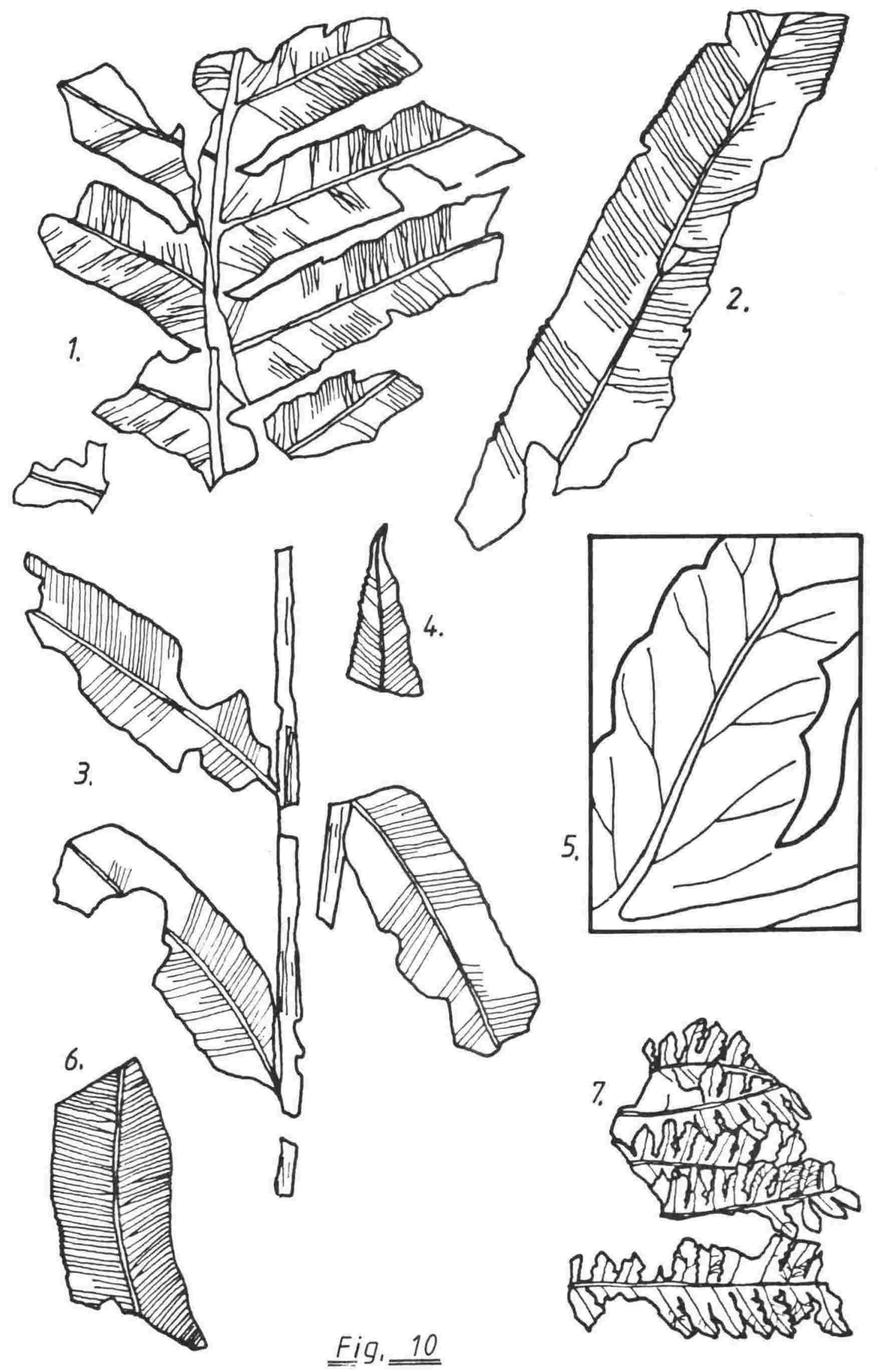


FIG. 11.

$11.1,11.2,11.3,11.4,11.5,11.6,11.7,11.8$, Laurelia cuneata Oliver.

1. WELT 44550, holotype, $x 1$; 2. B38.97, x1; 3. B38.16, x1;

4. B7.38, $x 1 ;$ 5. B7.46, $x 1 ; 6 . V 2846.1, x 1 ; 7 . v 2846.36, x 1$,

8. B7.44, $\mathrm{x} 1$.

$11.9,11.10,11.11,11.12$. Cryptocarya longfordiensis Holden.

9. B7.70, holotype, $\mathrm{x} 1 ;$ 10. B2.54, x1; 11. B7.43, x1.

12. B256.20 and B256.24, x1.

$11.13,11.14$. Litsea dawsoniana Holden.

13. B2.39, x1; 14. V2836 (VH105), holotype, x1. 

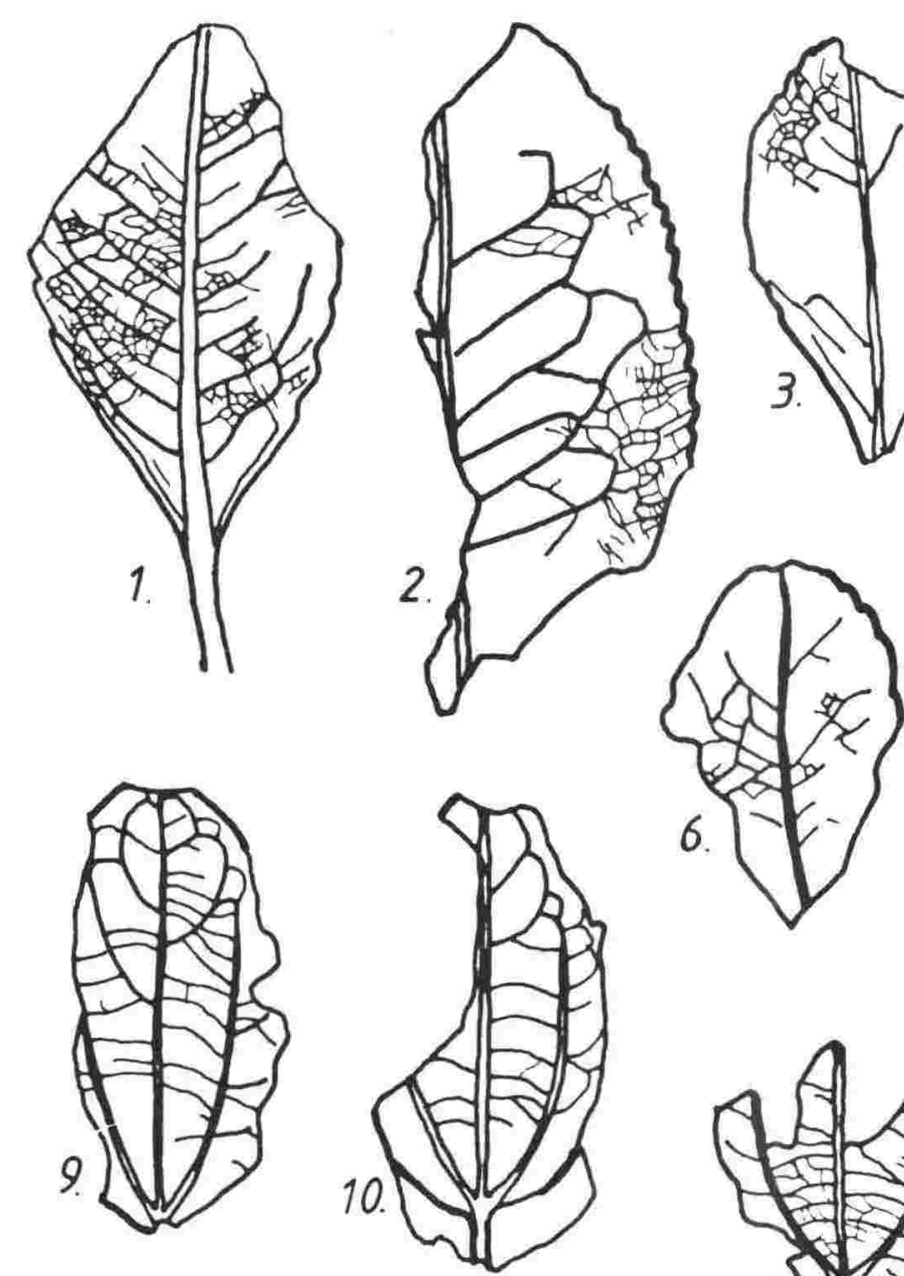

6. .
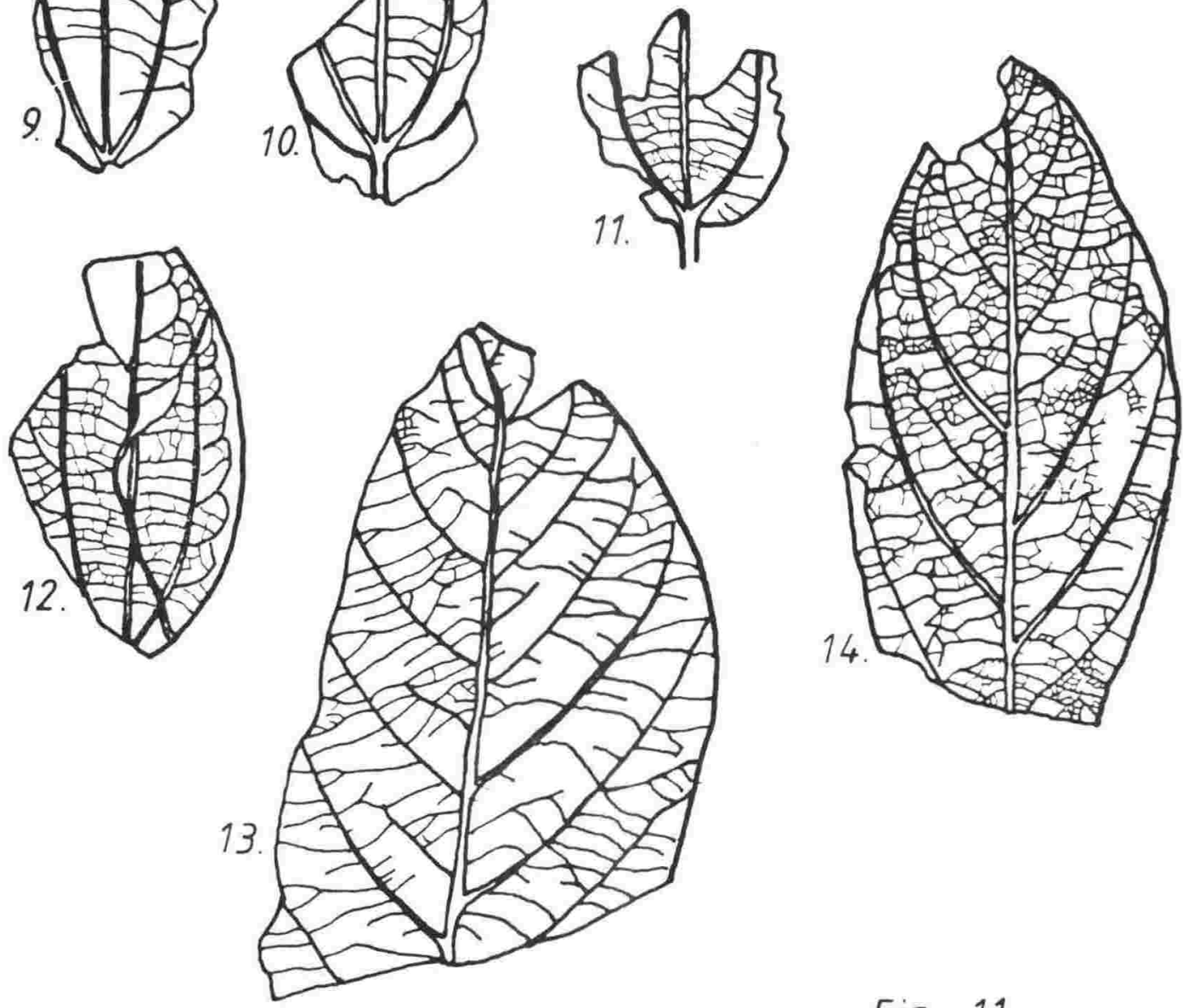

$\underline{\underline{F}} \underline{\underline{\underline{11}}}$ 
FIG. 12.

12.1, 12.2. Litsea dawsoniana Holden.

1. V2856.83, x1; 2. V2849.13, x1.

$12.3,12.4,12.5,12.7,12.8,12.9,12.10,12.11$. Ceratopetalum kaikoraiense 0liver.

3. WELT 44551, holotype, x1; 4. V2849.16, x1; 5. V2849.15, $\mathrm{xI} ;$ 7. V2841.7, x1; 8. B411.1, x1; 9. V2849.17, xl;

10. V2841.37, $\mathrm{x} 1 ; 11 . \mathrm{V} 2838.1, \mathrm{x} 1$.

12.6. Cryptocarya sp.; V2856.59, holotype, x1.

$12.12,12.13,12.14$. Mallotus sp.

12. B256.5, x1; B256.1, holotype, $\mathrm{xl} ; 14 . \mathrm{B} 36.3, \mathrm{x} 1$. 

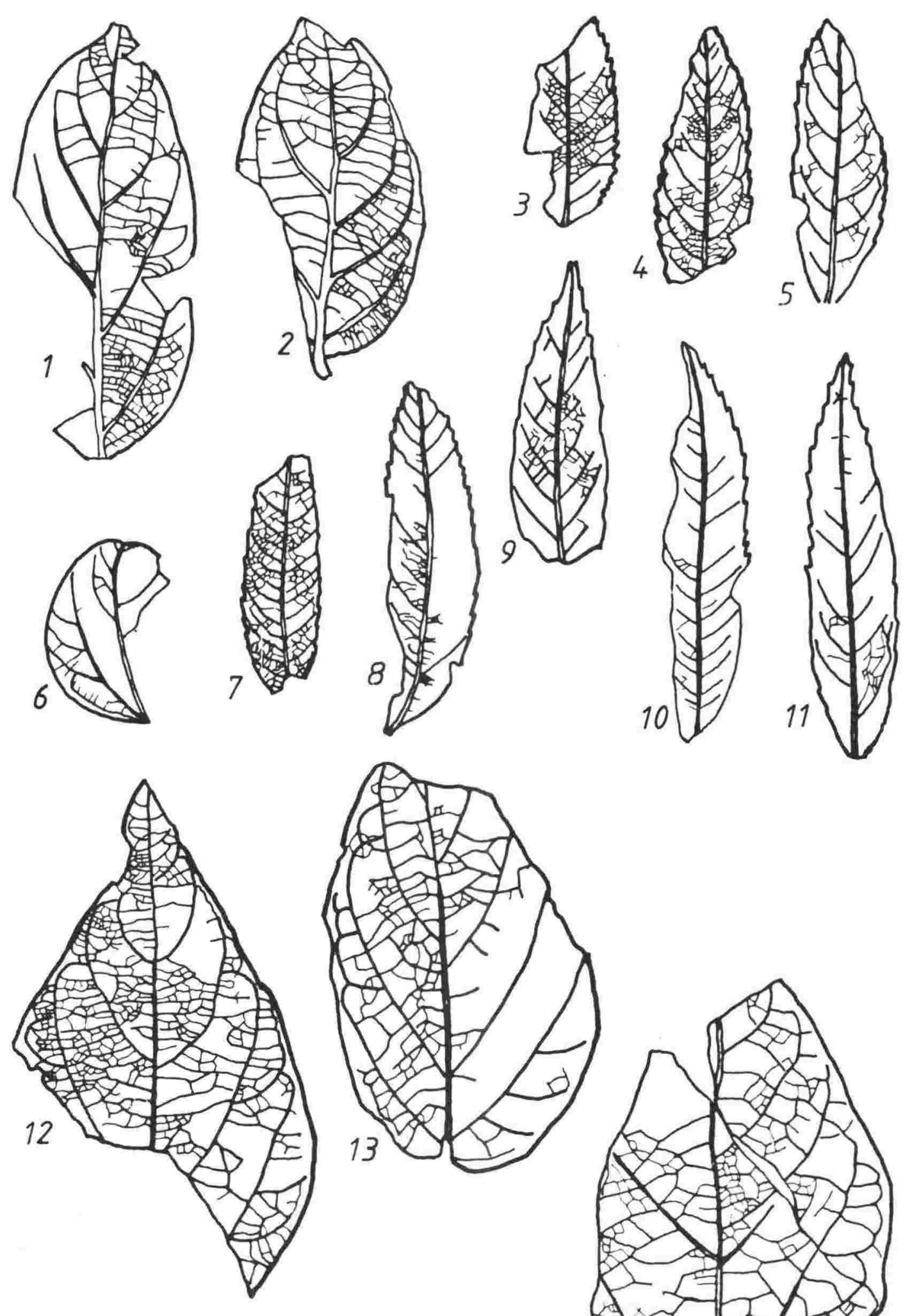

$\underline{\underline{F}} i \underline{\underline{12}}$

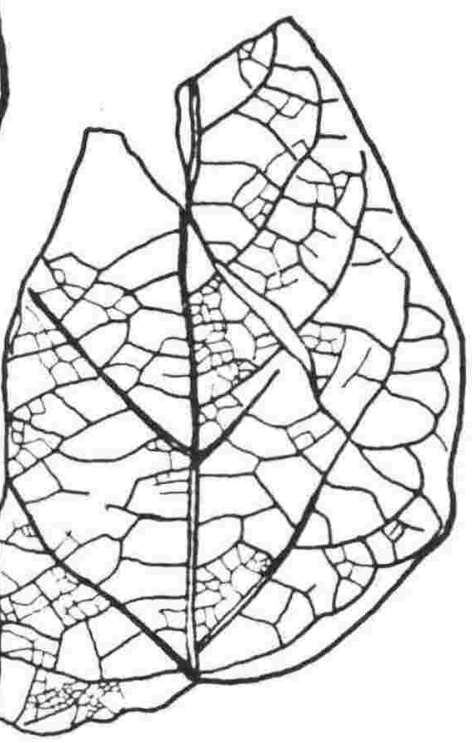


FIG. 13.

13.1, 13.2. Metrosideros diffusoides sp. nov.

1. B7.68, holotype, x2.5; 2. V2827.6, x2.5.

$13.3,13.4,13.5,13.8$. Metrosideros pliocenica O1iver

3. WELT 44554, holotype, x1; 4. B36.3, x1; 5. B38.4, x1;

8. B1036.18, x1.

13.6, 13.7, 13.11. Metrosideros laeta Oliver

6. V2835.15, x2.5; 7. B38.112, x1; 11. WELT 44555, holotype, $\mathrm{x} 1$.

13.9, 13.12. Xanthostemon sp.

9. B256.12, holotype, $\mathrm{xl} ;$ 12. B256.3, x1.

$13.10,13.13,13.14,13.15$. Eucalyptus roxburghiensis sp. nov.

10. V2848.15, holotype, $x 1 ; 13$. V2850.30A, x1;

14. V2850.30, x1; 15. V2848.43, x1. 

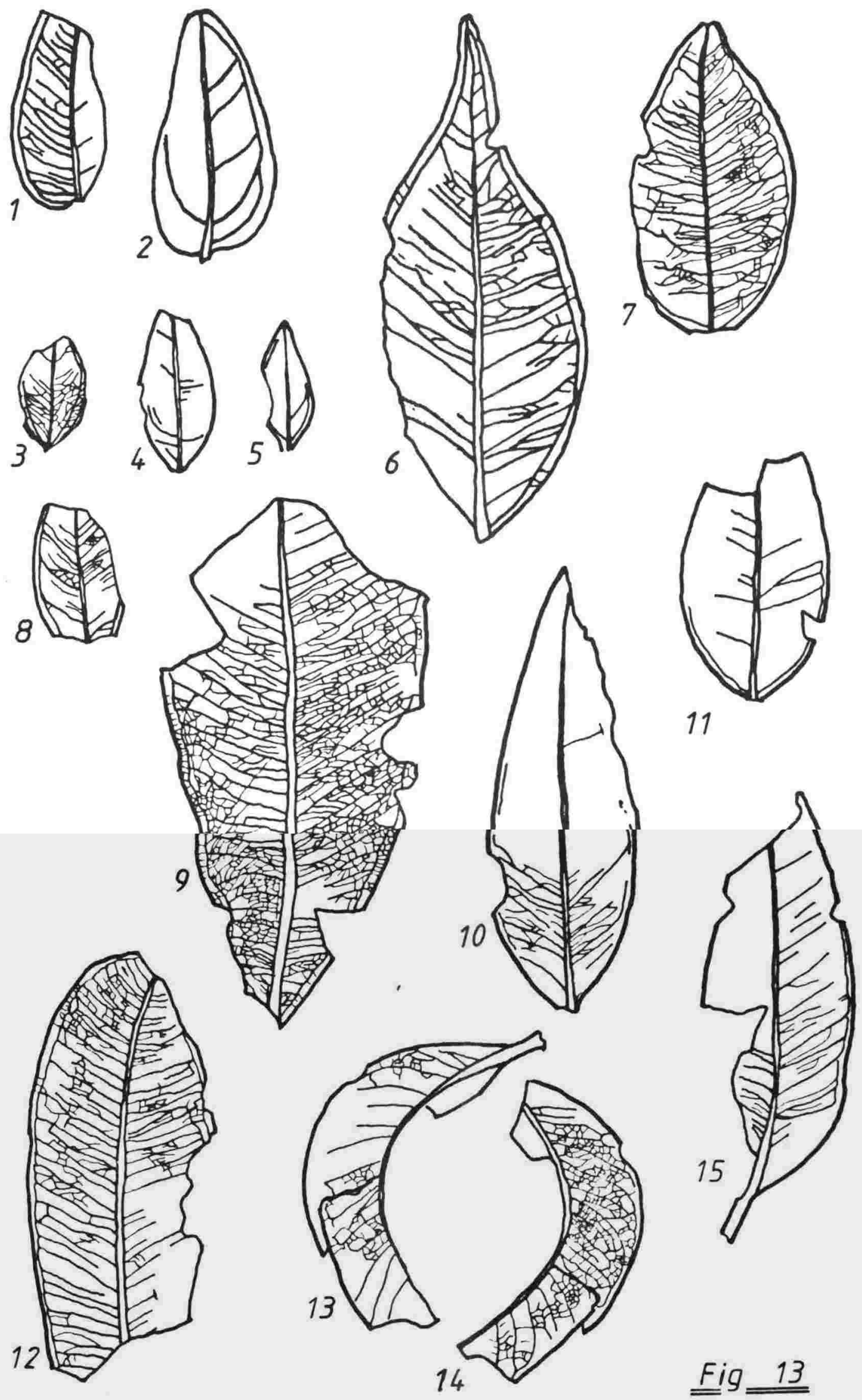

$\underline{\underline{F i g}} \underline{\underline{ }}$ 
FIG. 14 .

$14.1,14.2,14.3,14.4,14.5$. Dicotyledones incertae sedis Species A.

1. V2856.38A, holotype, $\mathrm{x} 1 ; 2$ 2. B1036.47, x1; 3. B1036.36, x1;

4. B38.1, x1; 5. V2850.25A, x1.

14.6. Dicotyledones incertae sedis Species B. V2856.19, holotype $\mathrm{x} 1$. 


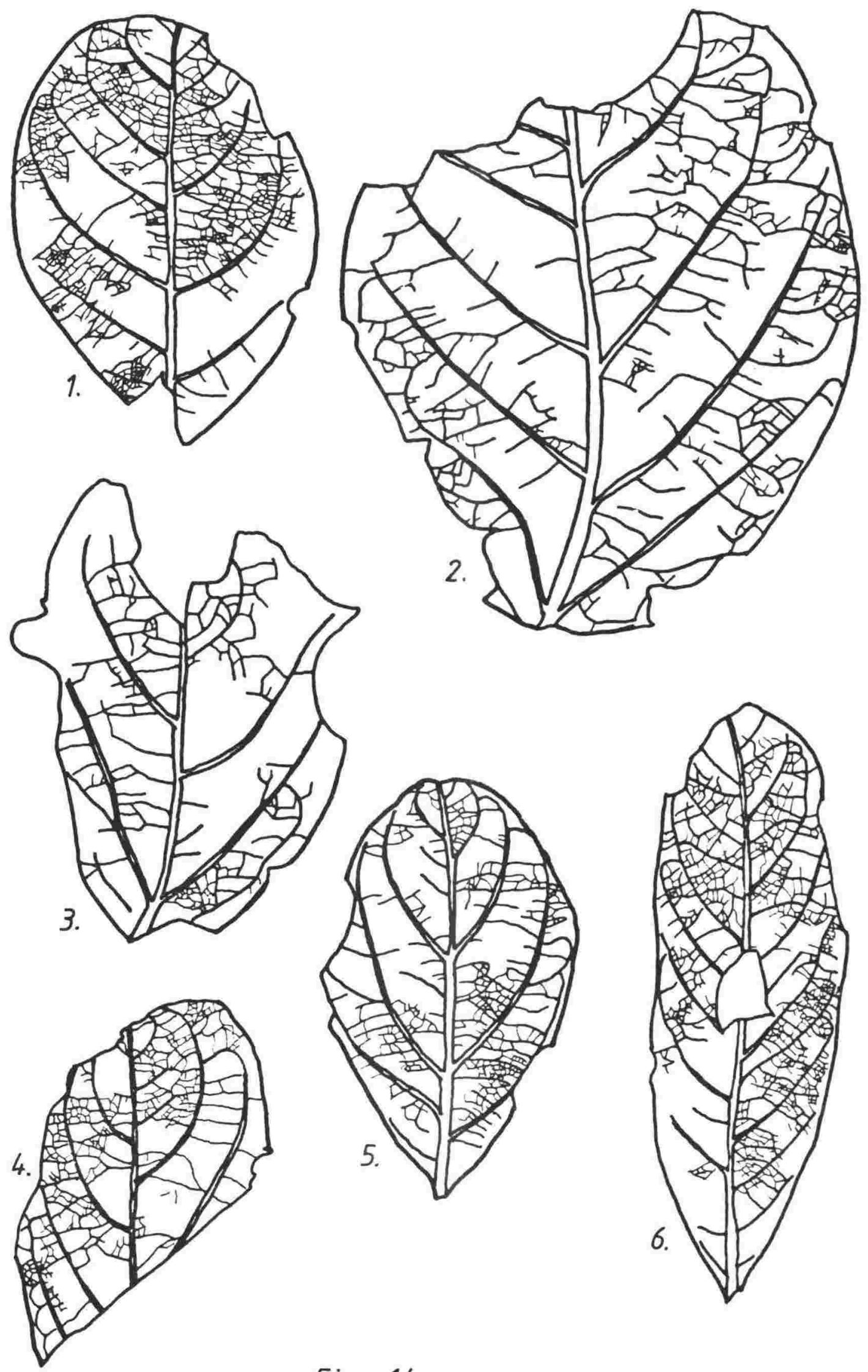

Fig 14. 
FIG. 15 .

15.1, 15.2, 15.3. Dicotyledones incertae sedis Species C.

1. V2856.51, holotype $\mathrm{xl} ; 2$ 2. V2856.27, x1; 3. B38.77, xl.

$15.4,15.5,15.6,15.7,15.9,15.10$. Dicotyledones incertae sedis Species D.

4. B197.5, holotype, x1; 5. V2850.19A, x1; 6. V2856.32, x1;

7. V2853.3, x1; 9. V2856.45, x1; 10. V2856.1, x1.

15.8, 15.11. Dicotyledones incertae sedis Species E.

8. V2841.27A, holotype, x1; 11. V2841.87A, x1. 


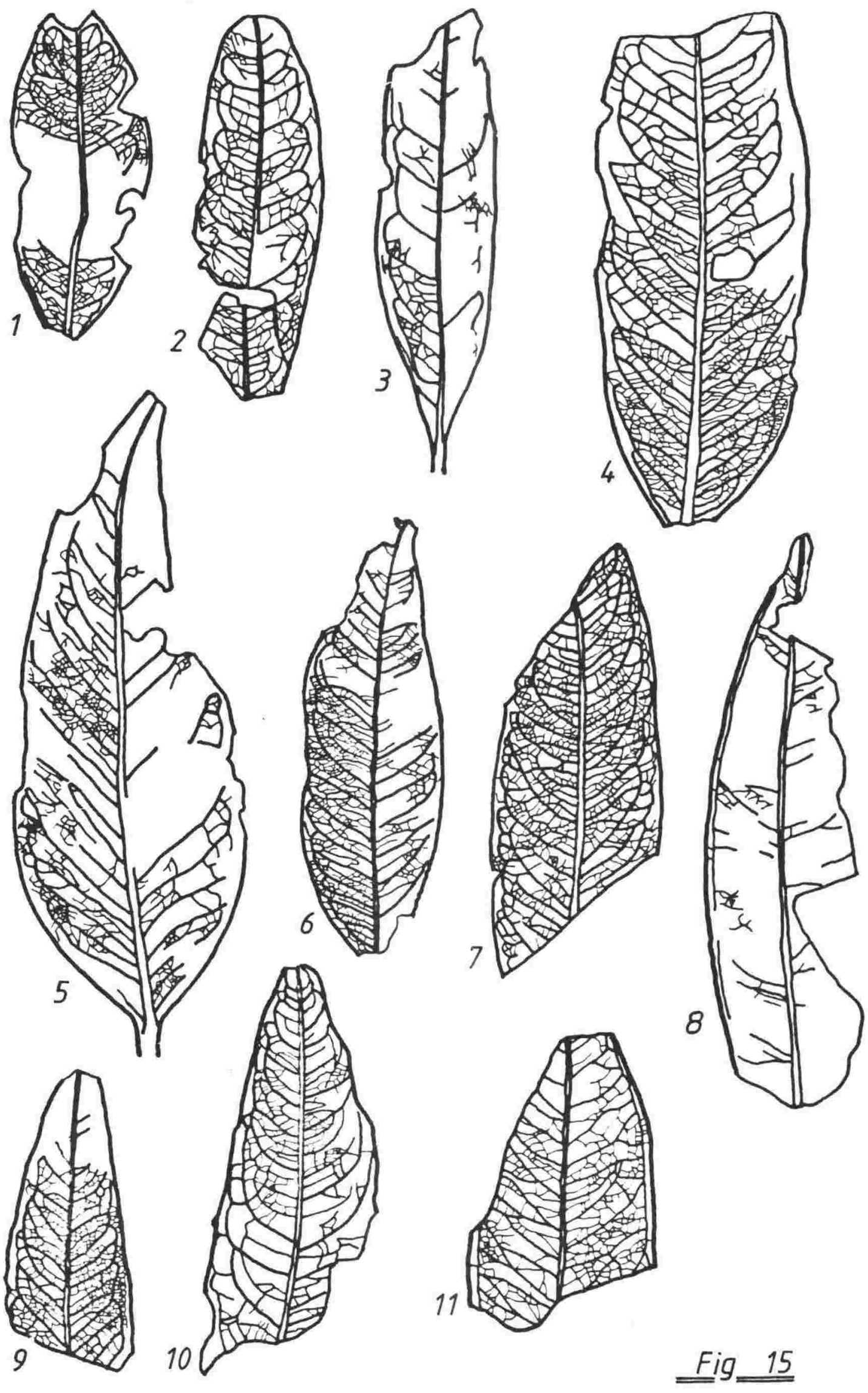


FIG. 16.

$16.1,16.2,16.3,16.4,16.5$. Dicotyledones incertae sedis Species F.

1. V2856.77, x1; V2856.20, holotype, $\mathrm{x1}$; 3. B1036.47, x1;

4. V2856.3, x1; 5. B1036.38, x1.

16.6, 16.7, 16.8. Ripogonum latipetiolatum (Oliver) comb. nov.

6. WELT 44553, holotype, x1; 7. V2846.12, x1; 8. V2846.17, x1.

16.9. Ripogonum sp. B1036.35, holotype, x1. 

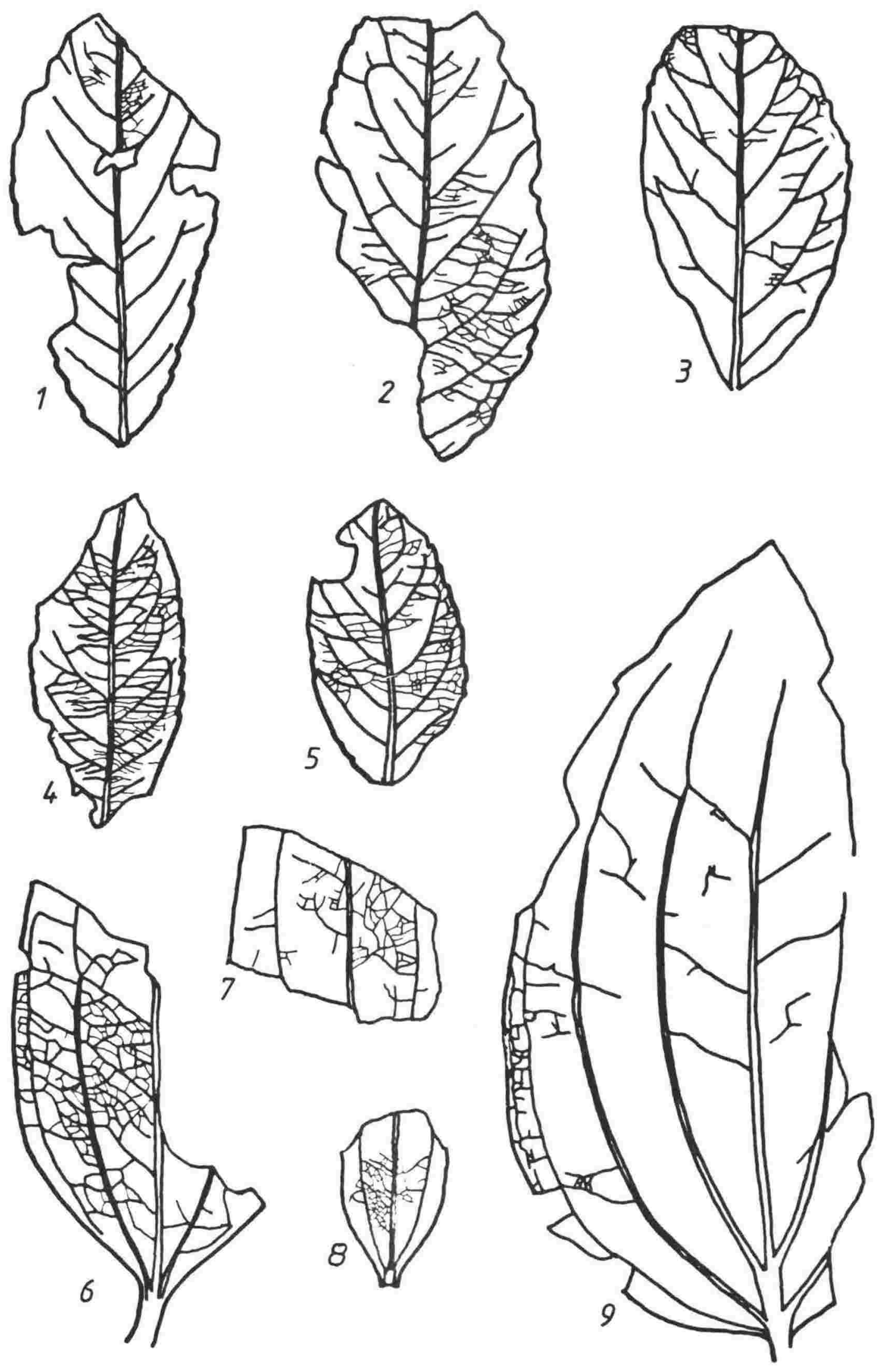

$\underline{\underline{F}}$ 16 
FIG. 17.

17.1, 17.2, 17.3, 17.4. FFF006, ?Trichomanes sp.

1. B38.99, x1; 2. B38.99, x1; 3. B38.99 x 1; 4. B38.99, detail of cell structure, $x 10$.

17.5. LDF013, Phymatosurus sp. aff. diversifolium: (Willd.) Pic.Ser. B7.57, x1.

17.6. FFF007, Dicksonia sp. aff. 1anata Co1. B36.13, x10.

17.7, 17.8. KLB012, Hypolepis sp. aff. tenuifolium (Forst. f.) Bernh. var. pellucida (Co1.) Hook.

7. V2846.46, x4; 8. V2846.46, obverse, $\times 4$.

17.9, 17.10. BIV002, Pteridium aquilinum (L) Kuhn. var. esculentum (Forst. f.) Kuhn.

9. В93.3, x1; 10. В93.2, x1.

17.11, 17.12. FFF008, ?Antrophyum sp. 11. В36.3, $\mathrm{x} 1 ; 12$. В36.4, $\mathrm{x} 1$.

17.13. FFF009, B38.90, x1. 

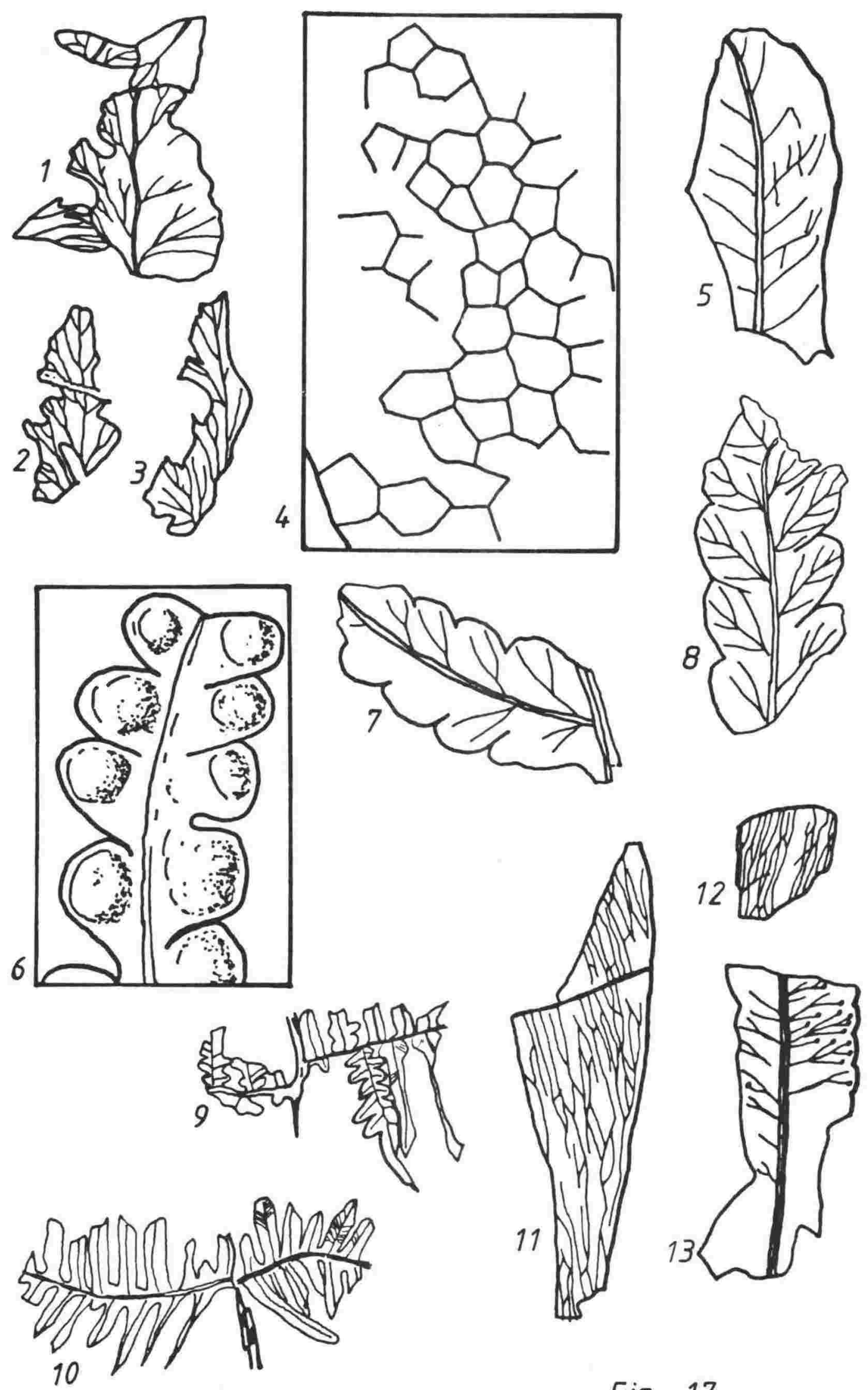

$\underline{\underline{F}} \underline{\underline{117}}$ 
FIG. 18.

18.1, 18.2, 18.3. OLMO10, B1echnum sp.

1. B1036.47, $x 1 ; 2 . B 1036.49, x 1 ; 3 . B 1036.42, x 1$.

18.4. LDF014, Blechnum sp. aff. discolor (Forst. f.) Keys, V2835.12, xl.

18.5, 18.7. BIV003, Podocarpaceae.

5. B411.11, x4; 7. B411.10, x4.

18.6. FFF010, Podocarpaceae, B36.5, x4.

18.8. NFM003, Podocarpaceae, V2849.41, x4.

18.9. GLM016, ?Araucariaceae, B149.6, x4.

18.10. GLMO17. ?Agathis, V2841.22, x1.

18.11, 18.12. LDF015, ?Pseudowintera

11. B2.32, x1; 12. V2841.11, x1.

18.13. OLMO11, V2850.13, x1. 

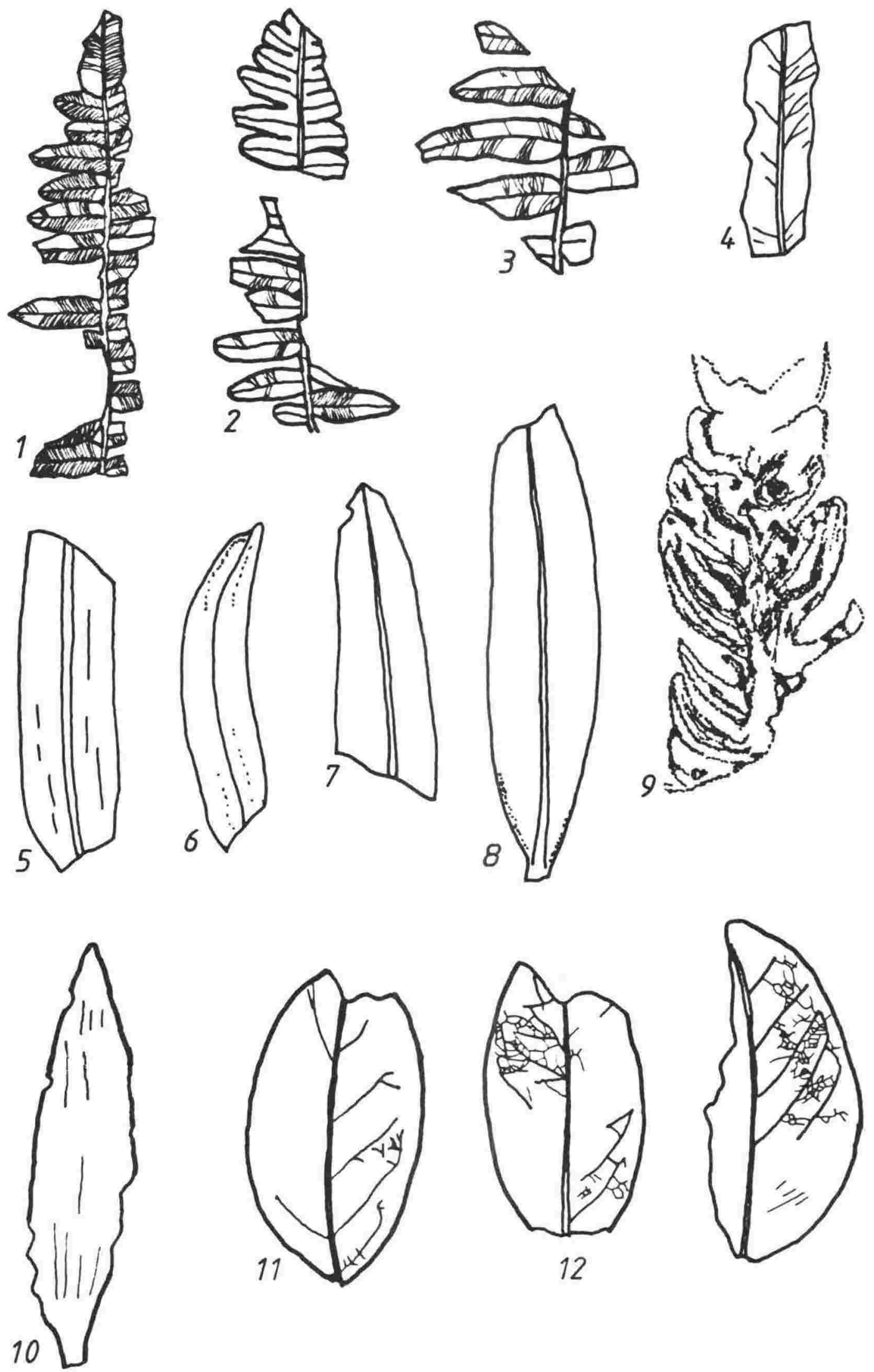

$\underline{\underline{F}} \underline{\underline{18}}$ 
FIG. 19.

19.1. FFF011, ?Winteraceae, B38.16, x1.

19.2, 19.3, 19.4. LDF016, Hedycarya

2. B38.101, x1; 3. V2835.11, x1; 4. V2835.11A, x1.

19.5. GLM018, ?Monimiaceae, V2841.3; .x1.

$19.6,19.7$. OLMO12.

6. B197.2, x1. 7. B1036.47, x1.

$19.8,19.9,19.12$. GLMO19.

8. V2841.29B, x1; V2841.64A, x1; 12. V2841.70, x1.

19.10, 19.11. OLMO13, ?Cryptocarya.

10. V2850.28, x1; 11. V2849.34, x1. 


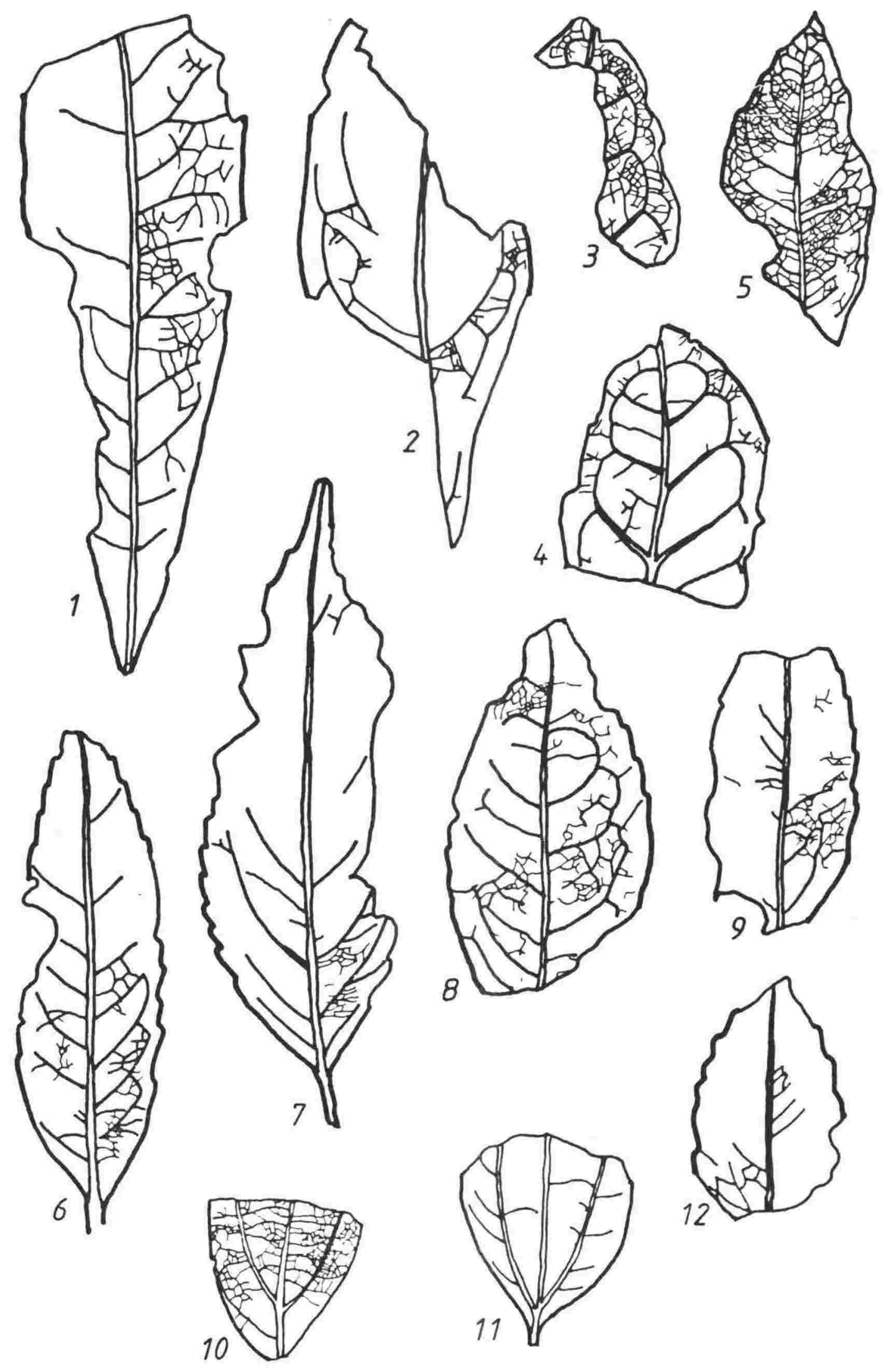

Fig 19 
FIG. 20.

20.1, 20.2. LDF017, Beilschmiedia tarairoides Pens.

1. V2825.24, x1; 2. B2.48, x1.

20.3, 20.4. Cryptocarya murchisoniensis Holden.

3. VH102, holotype, $x 1 ; 4$. V2825.31, x1.

20.5. GLMO20, ?Lauraceae. B150.23, x1.

20.6. LDF019. Cryptocarya bulleriana Holden, VH107, x1.

20.7. LDF020, Cinnamomum miocenicum Holden, VH101, holotype, xl.

20.8, 20.9, 20.10. LDF021, ?Ascarina.

8. B2.52, x1; 9. V2835.15, x1; 10. B2.46, x1.

20.11, 20.12. LDF022. ?Macropiper.

11. B2.51, x1; 12. B7.23, x1. 

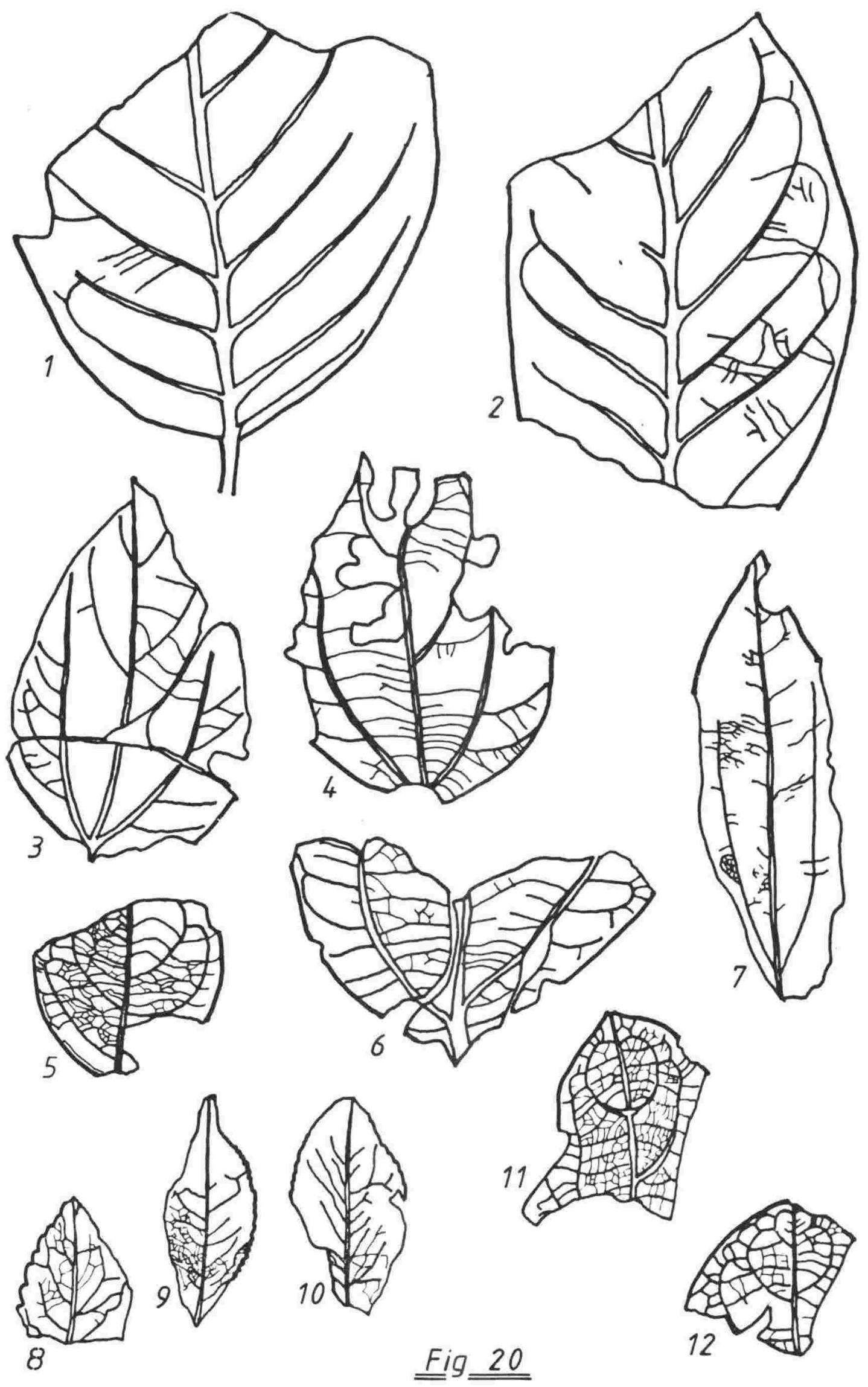
FIG. 21.

21.1, 21.2. LDF023, Cryptocarya tutakiae Holden.

1. B1119.6, holotype, $x 1$; 2. B2.29, x1.

21.3. LDF024, ?Melicytus, B2.52, x1.

$21.4,21.5$. KLB012, Calpidia zealandica Oliver

4. B2.1, x1; 5. WELT 44549, holotype, x1. 


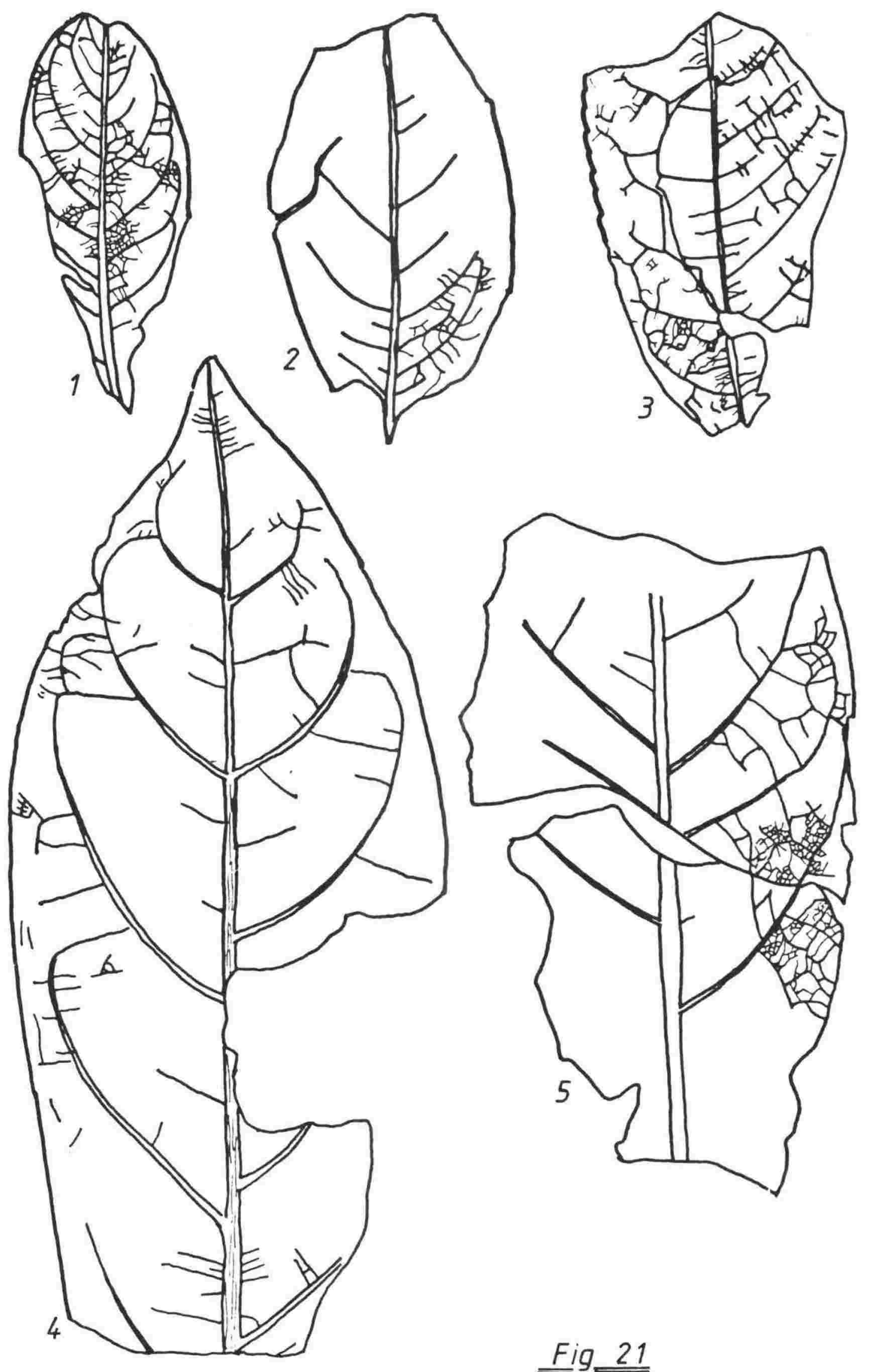


FIG. 22.

22.1, 22.2, 22.3. KLB013, Calpidia zealandica Oliver.

1. B1036.35, x1; 2. B1036.49, x1; 3. B1036.37, xl.

22.4, 22.5. OLM014, ?Proteaceae, ?Stenocarpus.

4. V2856.72, x1; 5. V2856.44, x1.

22.6, 22.7. Proteaceae, ?Banksia

6. V2841.22, x1; 7. B149.6, x1.

22.8. LDF025. Kermadecia merytifolia Holden, VH109, holotype, x1.

22.9, 22.10. FFF012, ?Beauprea.

9. V2849.47, x1; 10. B38.74, xl. 

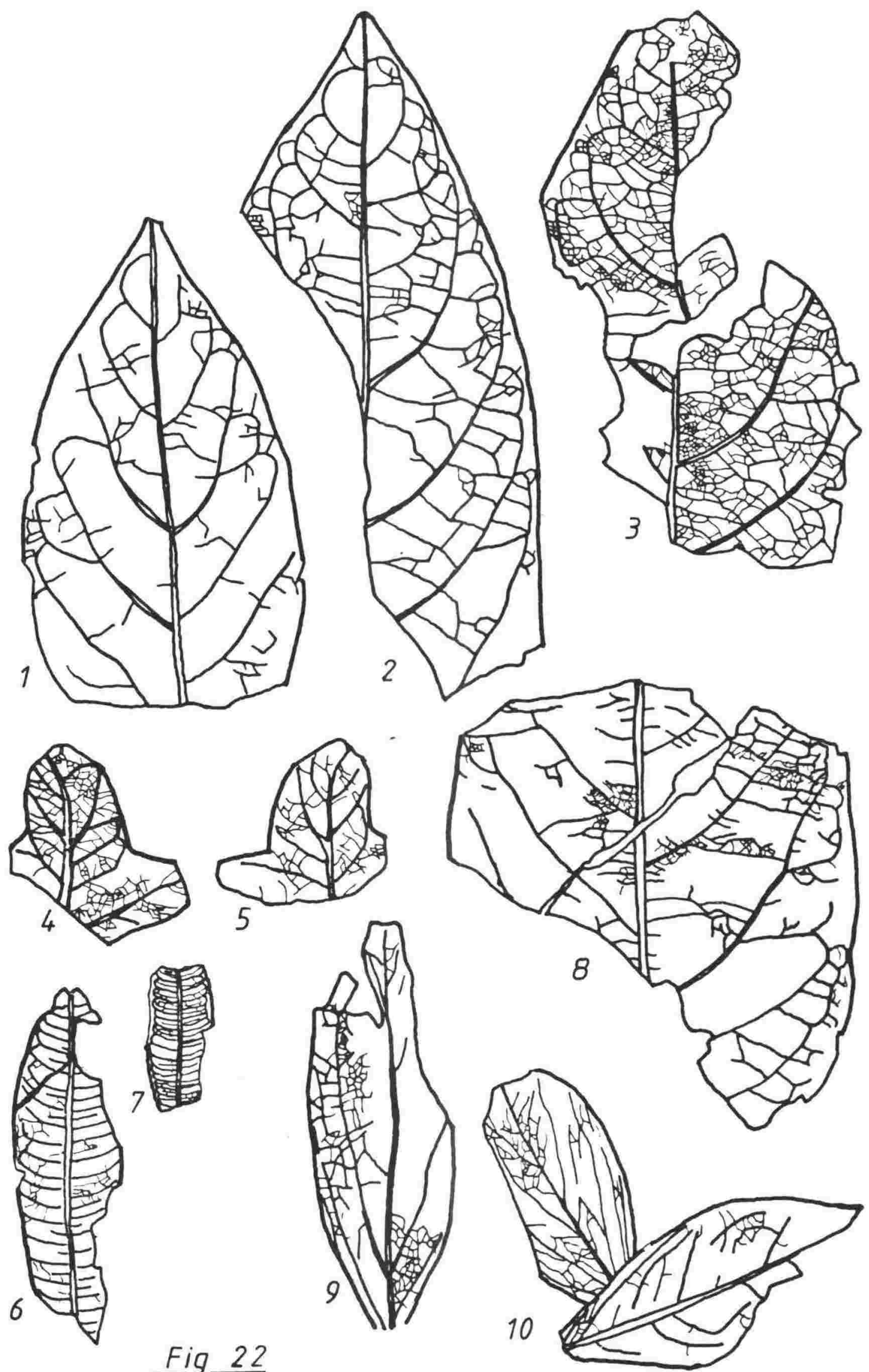

Fig 22
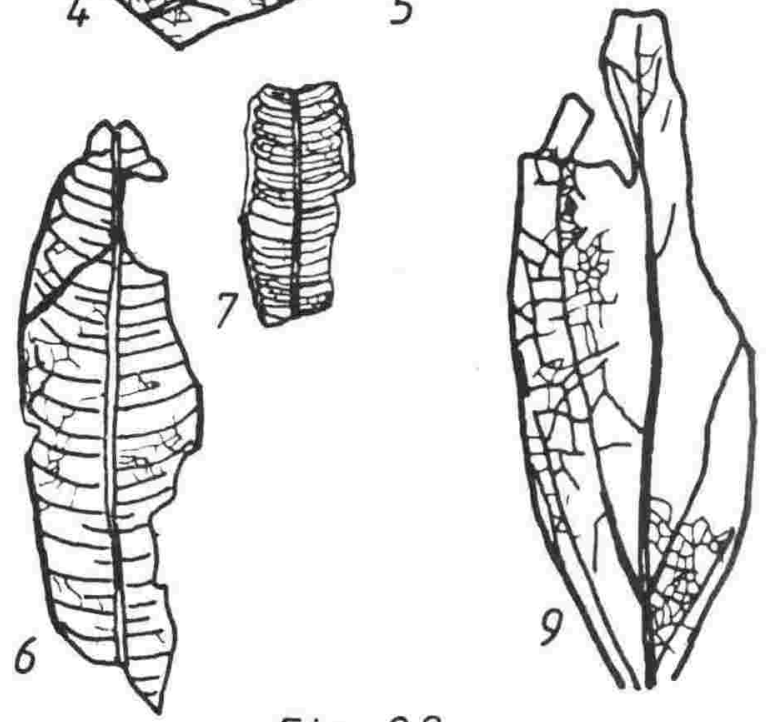
FIG. 23.

23.1, 23.2. KLB014, Knightia oblonga Oliver.

1. B2.18, x1; 2. WELT 44546, Holotype, x1.

23.3. GLMO22. B33.9 x1.

23.4. OLMO15, ?Proteaceae, V2850.32, x1.

23.5, 23.6. GLMO23, ?Proteaceae.

5. B33.10, x1; 6. V2841.2B, $\mathrm{x} 1$.

23.7. LDF026, Longfordia banksiaefolia Holden. B2.50, holotype, x1.

23.8. GLMO24. ?Proteaceae. B33.8, x1.

$23.9,23.10$. GLMO25.

9. B38.101, x1; 10. V2843.2, x1.

23.11. GLMO26. Banksiaephyllum, V2841.72, x6 

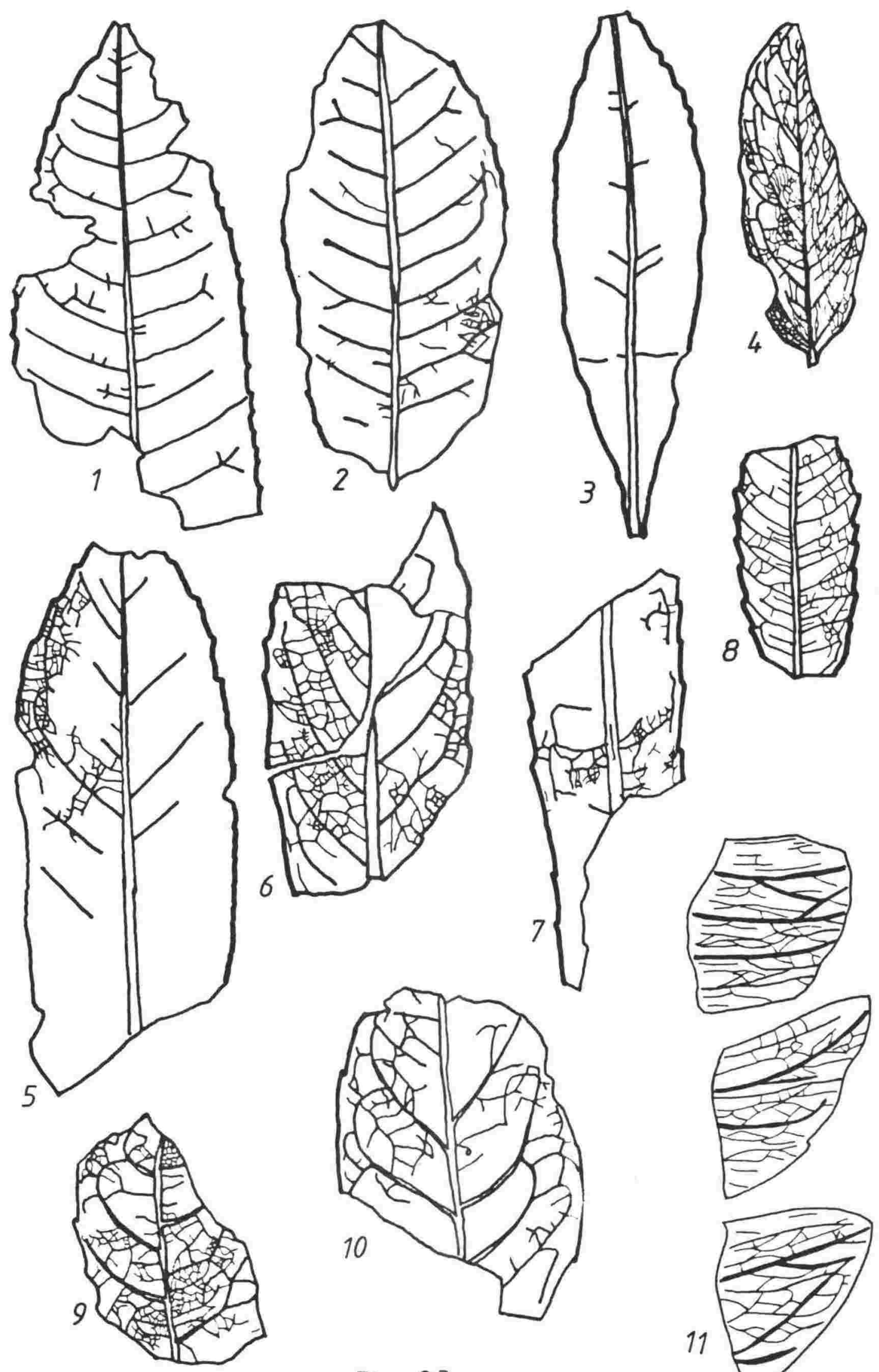
FIG. 24.

$24.1,24.2,24.3$. OLMO16.

1. V2848.12, $\mathrm{x} 1 ;$ 2. B38.101, $\mathrm{xl}$; V2850.30. xl.

$24.4,24.5,24.8$. OLMO17.

4. V2850.46, x1; 5. V2850.16A, x1; V2850.16, x1.

$24.6,24.7$. OLMO18.

6. B38.68, $\mathrm{x} 1 ; 7 . \mathrm{V} 2850.26, \mathrm{xl}$.

24.9. OLMO19, V2850.12, x1.

24.10. FFF013, Myrtaceae, B38.98, x1. 


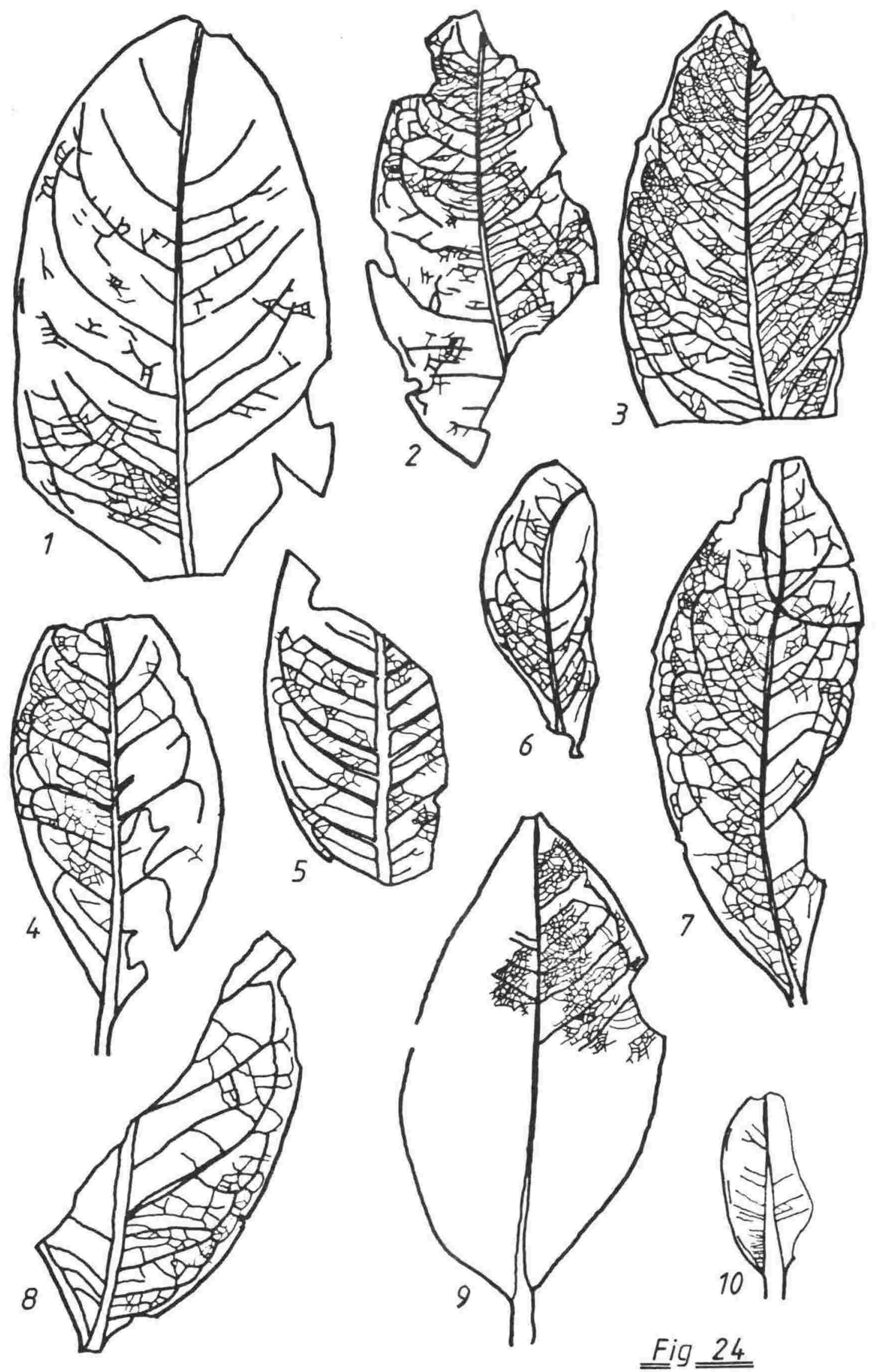


FIG. 25 .

25.1, 25.2. LDF027 Metrosideros sp.

1. V2825.6, x1; 2. V2825.18, x1.

25.3, 25.4. FFF014, ?Myrtaceae

3. В38.110, $\mathrm{x} 1 ;$ 4. B38.71, $\mathrm{x} 1$.

25.5. KLB015 Metrosideros sp.; V2846.32 x1.

25.6. NFM004; V2849.90, $\times 1$.

$25.7,25.8,25.9$. GLMO27, Myrtaceae.

7. В33.11, $\mathrm{x} 1 ; 8$. В33.12, $\mathrm{xl}$ 9. V2851.7, x1.

$25.10,25.11,25.12$; OLMO20

10. V2850.1A, x1; 11. B1036.20, x1; 12. V2850.1, x1. 


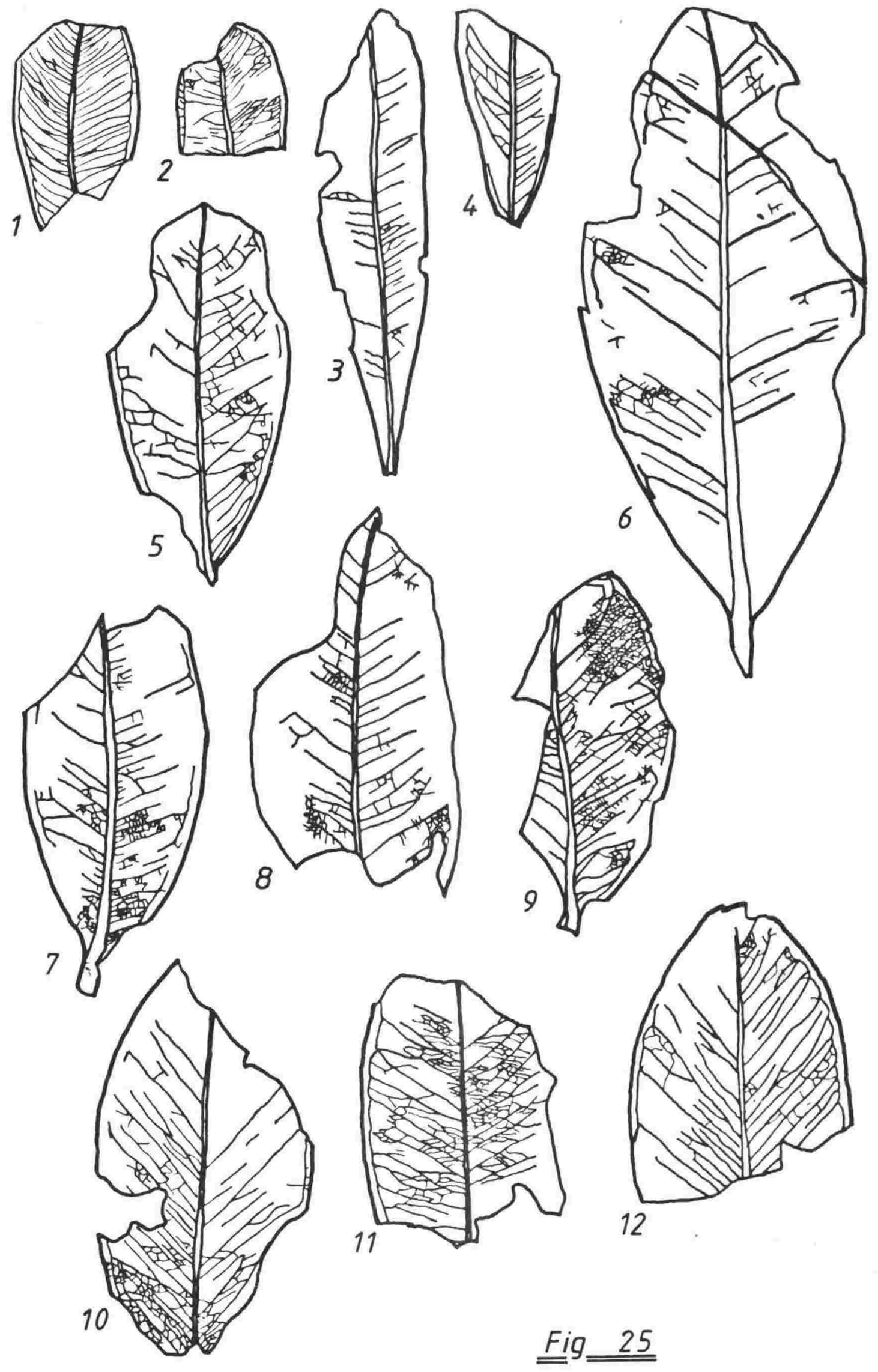


FIG. 26.

26.1, 26.3. NFM004, Myrtaceae

1. V2849. 40, x1; 3. V2849.46, x1.

26.2. NFM005. Myrtaceae. V2849.90A, x1.

26.4. OLMO21. Myrtaceae. V2856.85, x1.

26.5. FFF015. ?Myrtaceae or ?Moraceae. B38.90, x1.

26.6. BIV003. ?Myrtaceae, ?Leptospermum. B411.11, x8.

26.7, 26.8. FFF016. Lophomyrtus.

7. B36.1, $\mathrm{xl} ; 8 . \mathrm{8} 411.10, \mathrm{x} 4$.

26.9, 26.10. NFM006. ?Myrtaceae.

9. V2850.17, x1; 10. V2849.24, x1. 

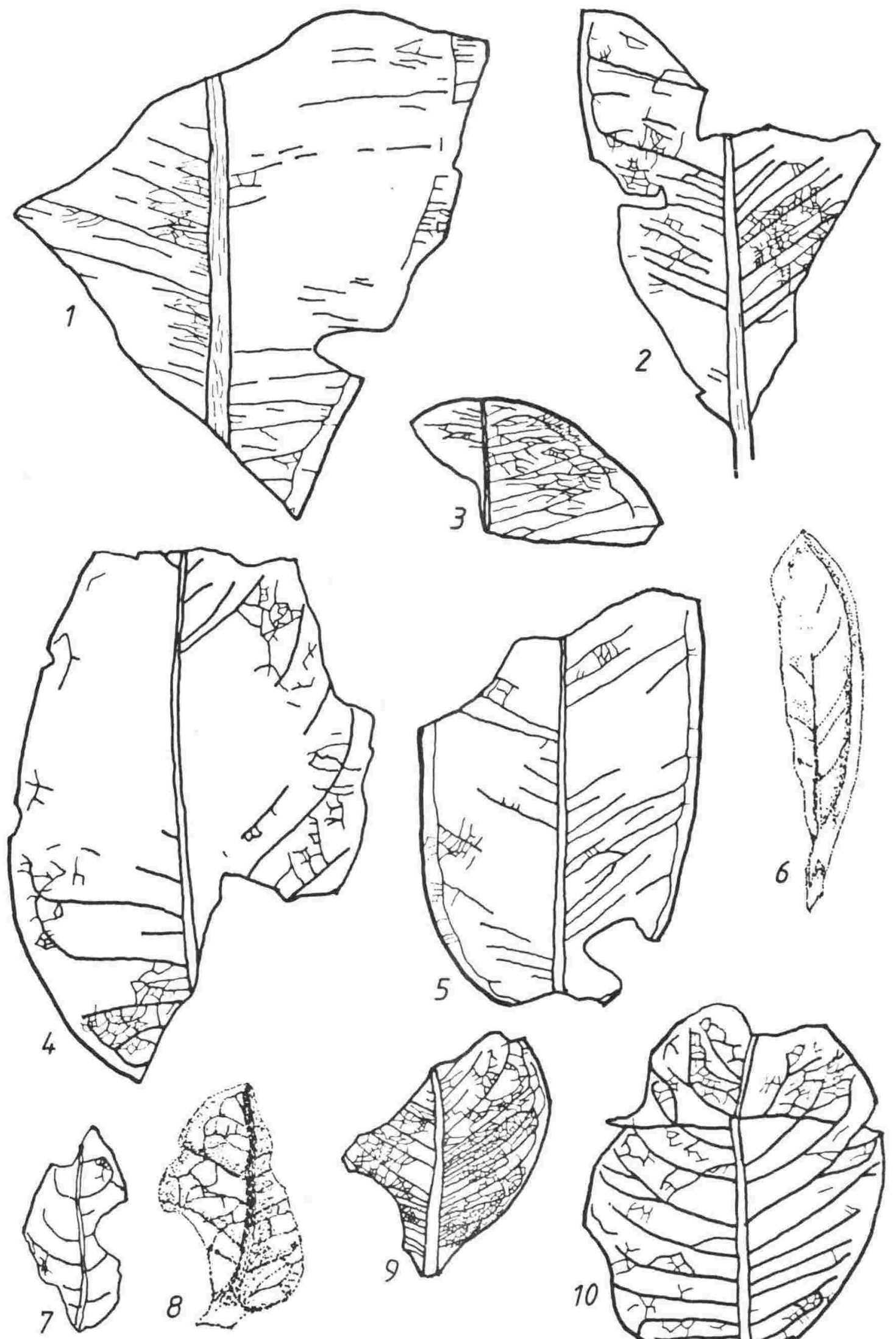


\section{FIG. 27.}

27.1. OLMO22. ?Myrtaceae. B1036.41b, x8.

27.2, 27.3. OLMO23. ?Garcinia.

2. V2851.11, x1; 3. V2851.11A, x1.

27.4, 27.5. GLMO28. Elaeodendron rigidum. Ett.

4. B150.3, x1; 5. B150.3, x1.

$27.6,27.7$. LDF028.

6. B256.11, x1; 7. B256.14, x1.

$27.8,27.9,27.10$. OLMO24.

8. B1036.13, x1; 9. B1036.22, x1; 10. V2850.36, x1.

27.11. FFF017, B38.17, x1.

27.12. OLMO25, V2848.33, x1. 


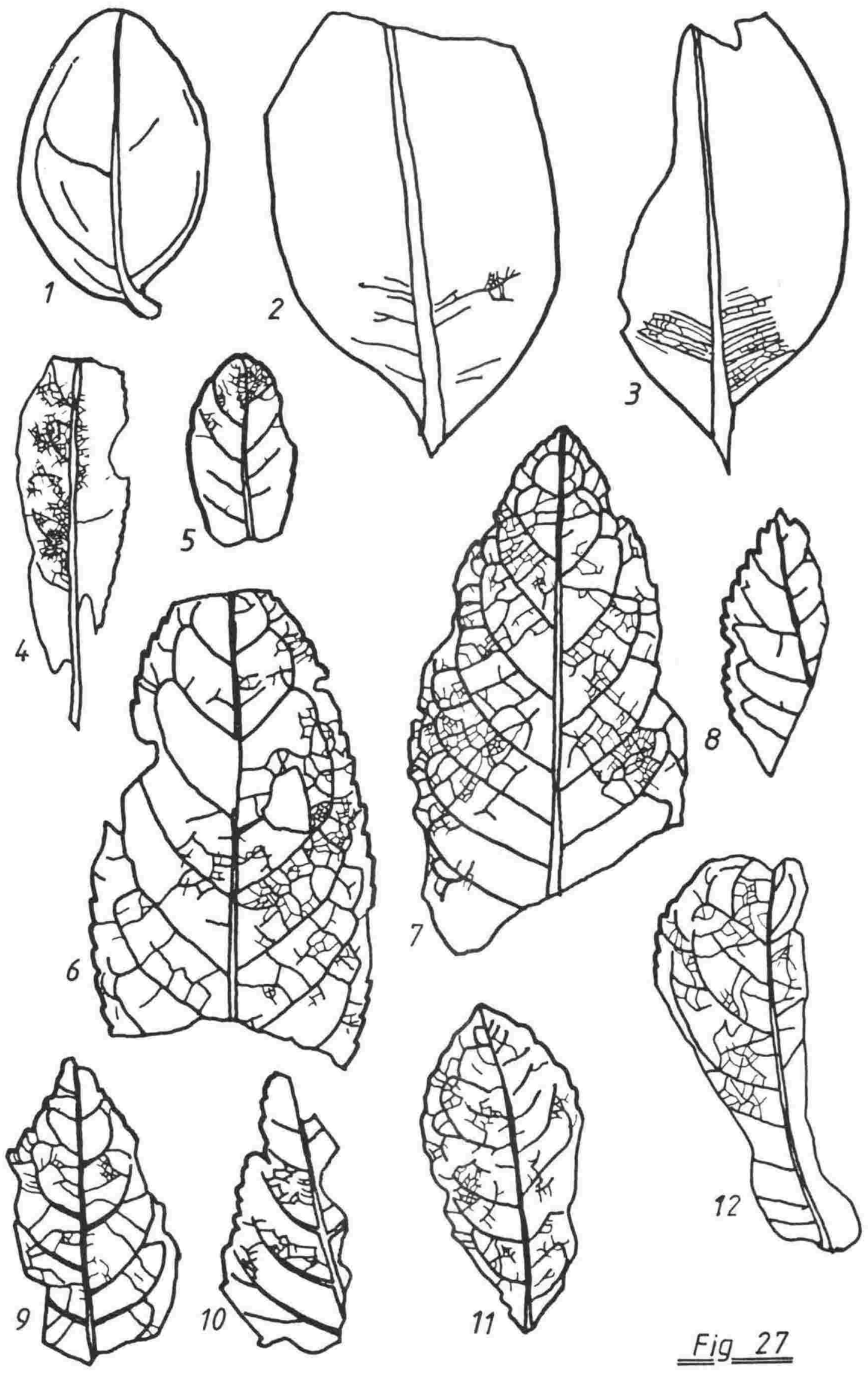


FIG. 28.

$28.1,28.2,28.3$. NFM007, Cunoniaceae

1. V2849.55, x1; 2. V2856.81, x1; 3. V2849.98, x1.

28.4. KLB016. Ixerba semidentata Oljver; WELT 44548, holotype, xl.

28.5, 28.6. LDF029.

5. B38.46, xl; 6. B256.2, x1.

$28.7,28.8,28.9$. NFM008.

7. V2849.57, xl; 8. V2849.97, xl; 9. V2849.57A, xl.

$28.10,28.11,28.12,28.15,28.16$. OLMO26.

B1036.29, x1; 11. B1036.3, x1; 12. B1036.16, x1;

15. B1036.23, x1; 16. B1036.22, x1.

$28.13,28.14$. OLMO27.

13. V2849.23, $\mathrm{xl} ; 14 . \mathrm{B} 1036.49, \mathrm{xl}$.

28.17. OLMO28. B1036.49, x1.

28.18. BIV005. B411.7, xl. 


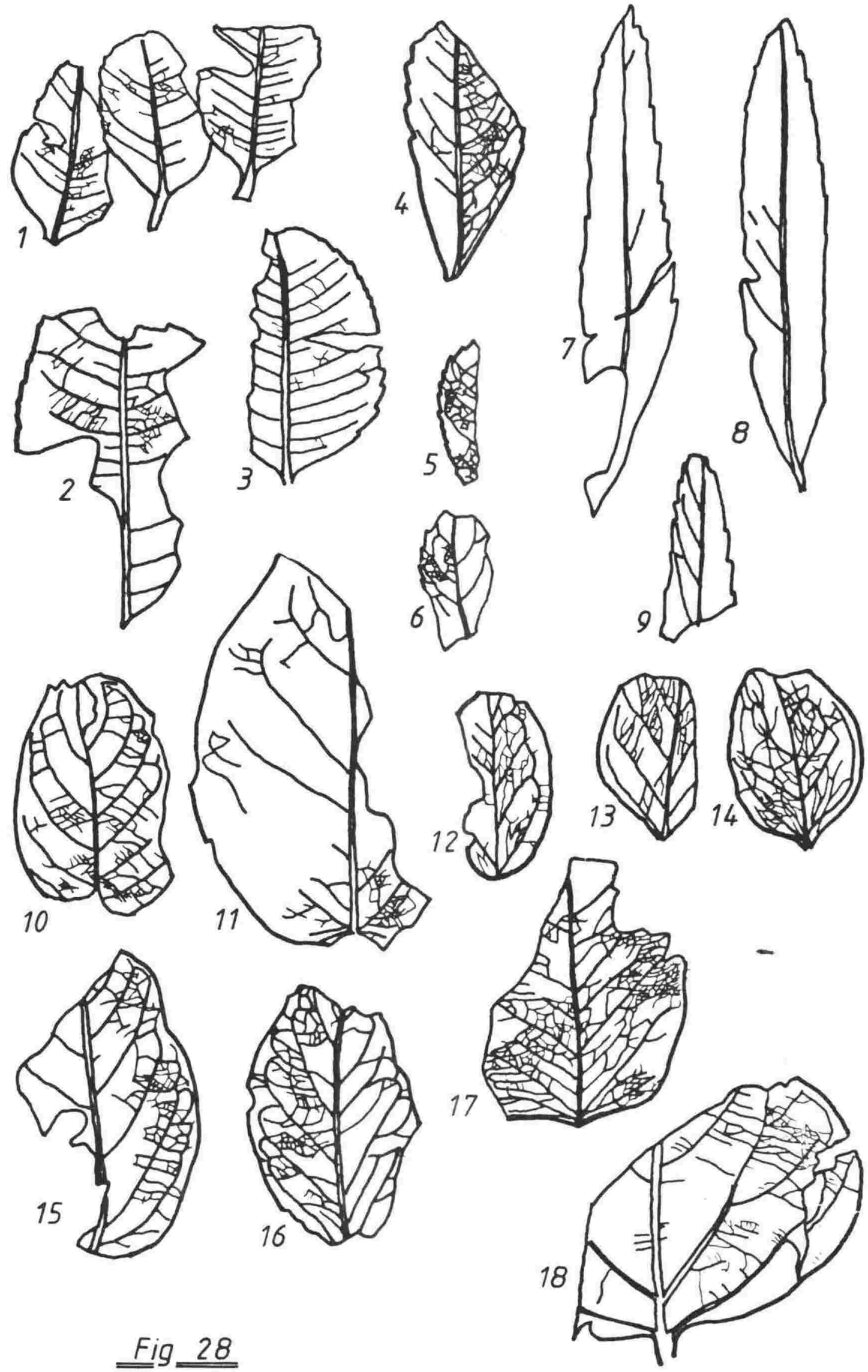


FIG. 29.

29.1, 29.2. OLM029. Papilionaceae or Caesalpinaceae.

1. V2850.27, x1; 2. V2849.89, xl.

29.3. NFMO09. Papilionaceae or Caesalpinaceae. V2849.36, x1.

29.4. OLм030. ?Streblus. V2856.80, x1.

29.5, 29.6. FFF028. ?Paratrophis

5. B38.36, $\mathrm{x} 1 ;$ 6. V2832.11, $\mathrm{x} 1$.

29.7. BIV006. ?Loranthaceae. B411.9, x1.

29.8. OLM031. ?Rutaceae, V2850.21, x1.

29.9, 29.14, 29.15. LDF030. ?Sapindaceae, ?Cupaniopsis.

9. B1119.9, x1; 14. B1119.3, xl; 15. V2825.31, x1.

29.10. LDF031. ?Sapindaceae. V2825.6, x1.

29.11. NFM010. ?Sapindaceae. V2849.84, x1.

29.12, 29.13. LDF032. Alectryon.

12. V2825.30, $\mathrm{x} 1 ; 13 . \mathrm{B} 2.35, \mathrm{x} 1$. 


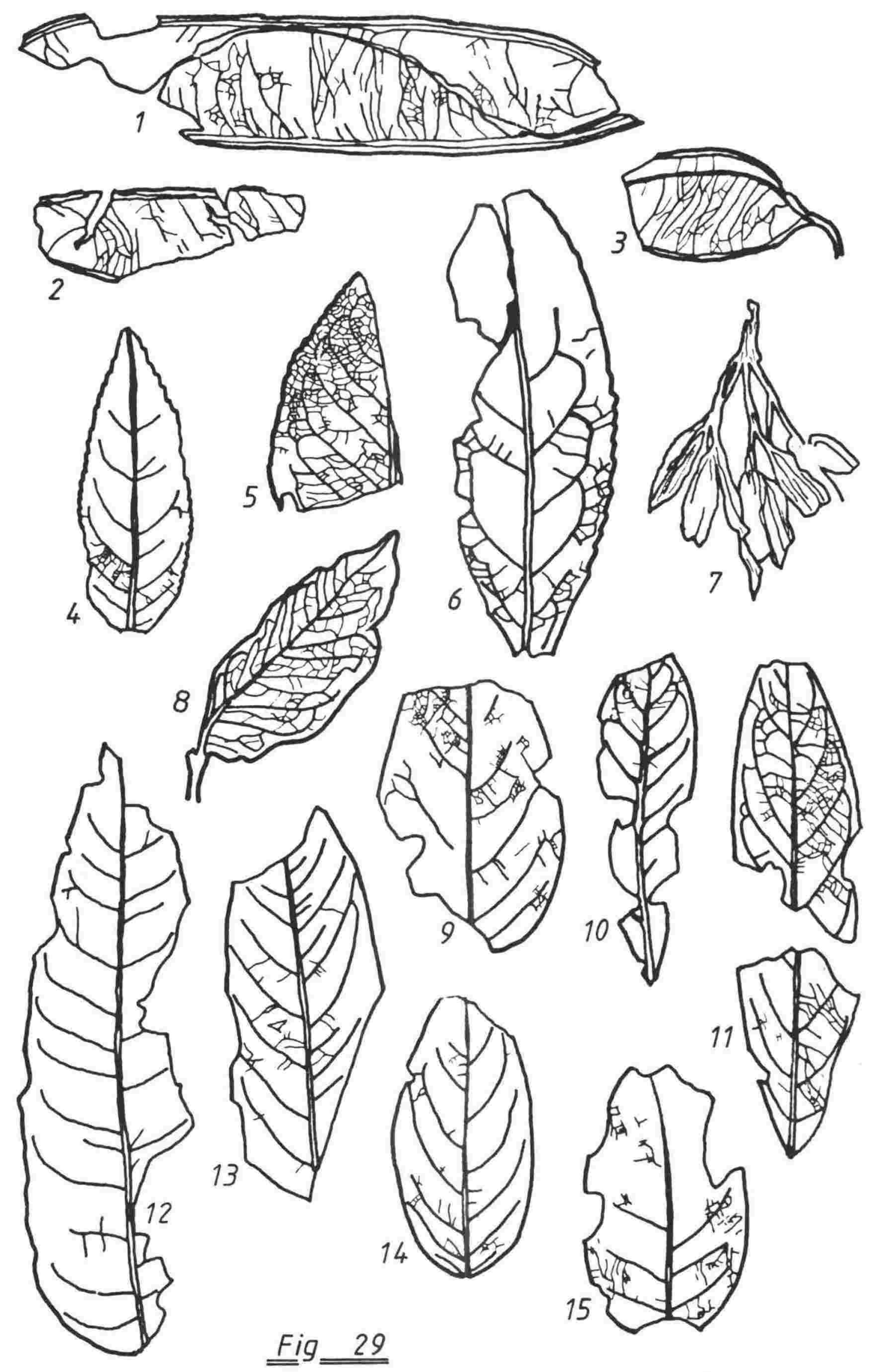


FIG. 30.

30.1. LDF033. B7.58, $\mathrm{x} 1$.

30.2. KLB017. Nothopanax distans 01iver. WELT 44566, holotype, $x 1$.

30.3. FFF020. ?Araliaceae. B38.69, x1.

30.4. NFMO11. ?Araliaceae. V2849.26, x1.

30.5. LDF034. ?Araliaceae, Parafatsia Blackburn, VH 97, x1.

$30.6,30.9,30.10$. KLB018. Kaikoraia gracilis Oliver.

6. WELT 44556, holotype, x1; 9. WELT 44557, x1; 10. B38.4, x1.

30.7. FFF021. ?P1anchonella. V2838.3, x1.

30.8, 30.11. LDF035. ?Myrsinaceae.

8. V2834.24, x1; 11. V2825.20, x1. 


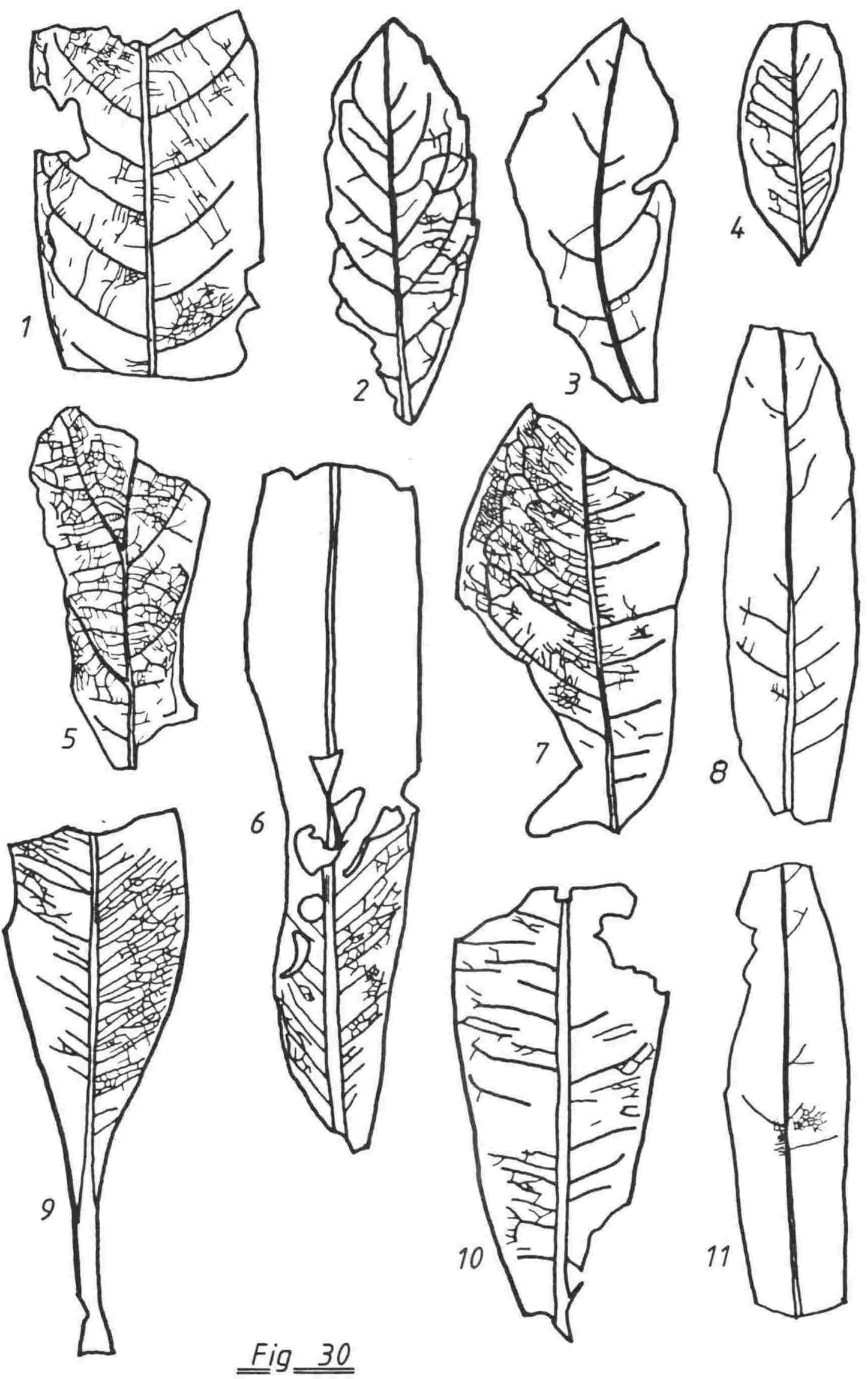


FIG. 31.

31.1. GLM029. Myrsine. B33.15, x1.

$31.2,31.3$. FFF022.

2. B38.98, $\mathrm{x} 1 ; 3$ 3. B1036.39, $\mathrm{x} 1$.

$31.4,31.7,31.8$, KLBO19. Geniostoma oblonga 0liver.

4. WELT 44567, holotype, x1; 7. B7.43, x1. 8. B7.59, x1.

$31.5,31.6,31.10,31.11$. OLM032. ?Geniostoma.

5. V2856.54, x1; 6. V2856.10, x1; 10. B1036.4, x1.

11. B1036.11, $\mathrm{x} 1$.

31.9. LDF036. B7.47, $\mathrm{x} 1$.

31.12, 31.13, GLMO30. Apocynophyllum affine Ett.

12. V2841.50, $\mathrm{xl} ; 13 . \mathrm{V} 2849.18, \mathrm{x} 1$.

31.14. KLB020. Coprosma praerepens 01iver. WELT 44568, holotype, x1.

31.15. KLB021. Coprosma pliocenica 01iver, WELT 44573, x1. 


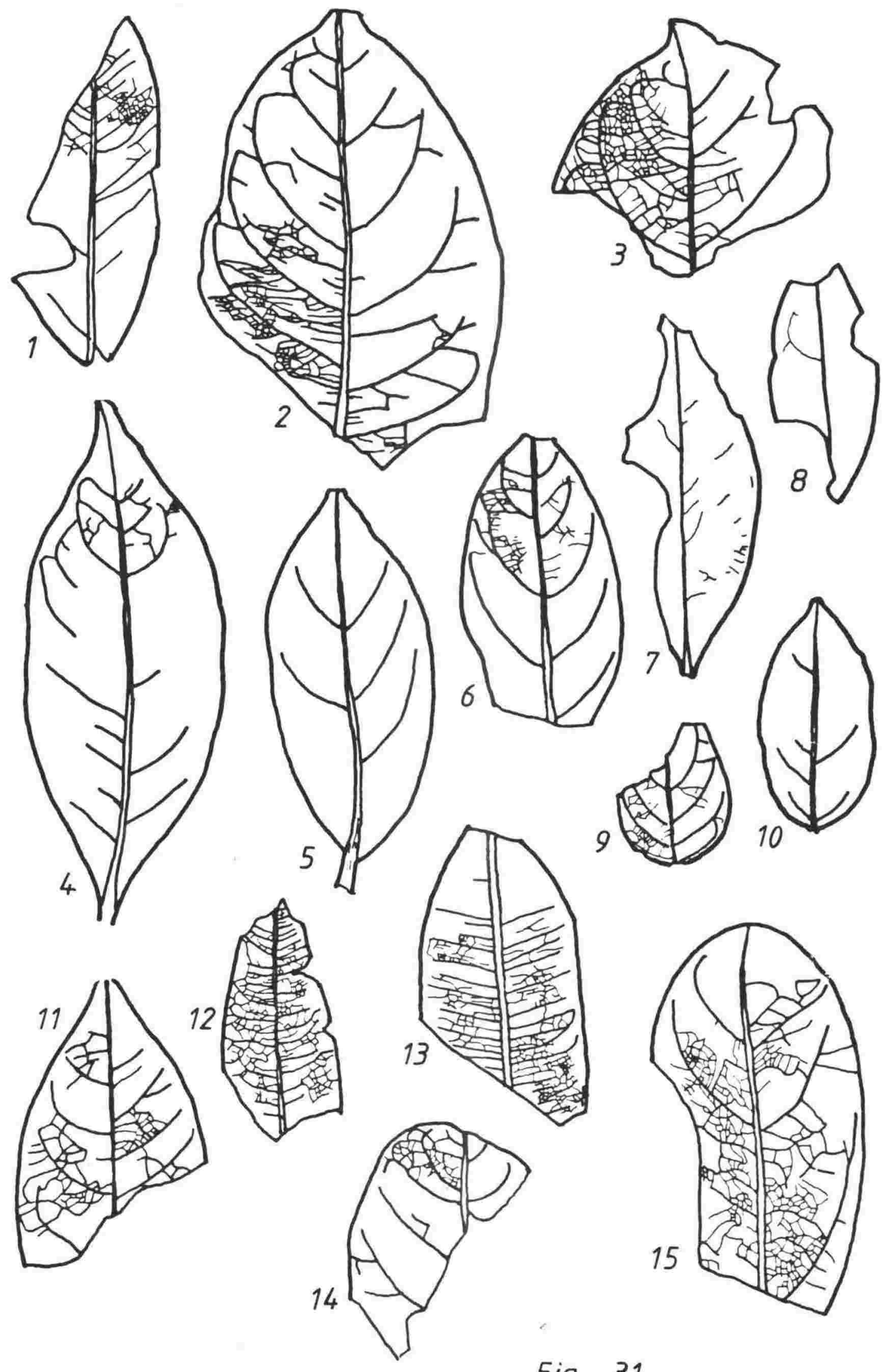

$\underline{\underline{F}} \underline{\underline{31}}$ 
FIG. 32 .

32.1. KLB021. Coprosma pliocenica 01iver. WELT 44569, holotype $\mathrm{x} 1$.

32.2. FFF023. ?Coprosma B38.64, x1.

32.3 KLB022. Senecio pliocenica 01iver. WELT 44570, holotype, x1.

32.4. GLM031. cf. Avicennia B88.4, x1.

32.5. BIV007. ?Dysoxylum B93.1, x1.

$32.6,32.7,32.8$. ОLM033.

6. V2853.1A, x1; 7. V2851.9A, x1; 8. B197.1, x1.

$32.9,32.10,32.11$. OLMO34.

9. B197.24, xl; 10. B1036.37, x1; 11. B1036.41b, xl.

32.12. GLM032. V2841.65, x1. 

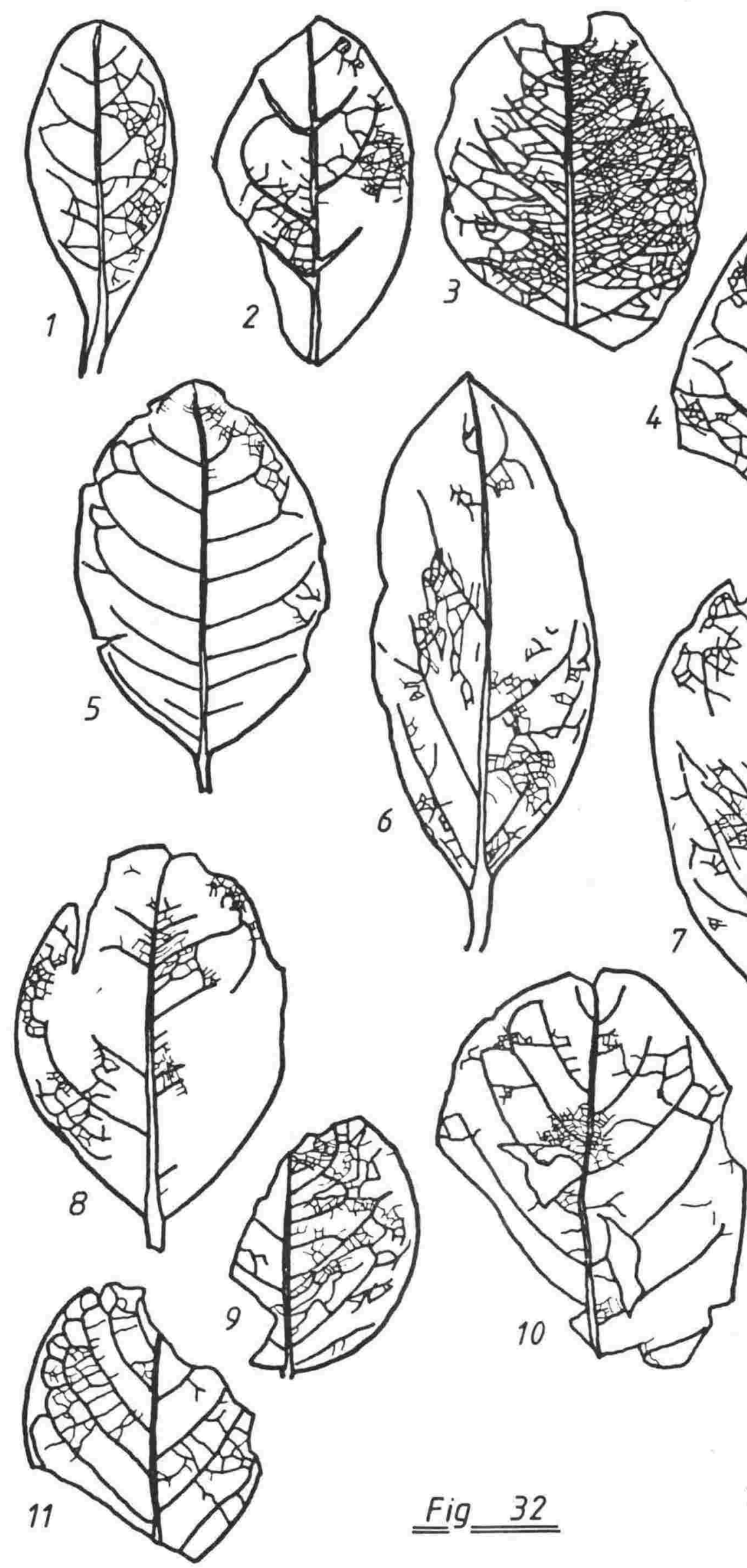

$\underline{\underline{F}} \underline{\underline{32}}$

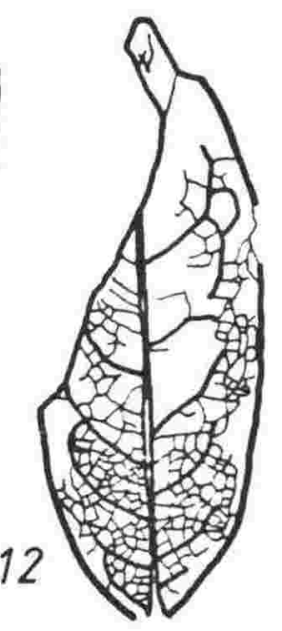


FIG. 33.

33.1, 33.2. FFF024. Loranthophyllum dubium Unger.

1. B38.104, xl; 2. B38.18, x1.

$33.3,33.4,33.5,33.6$. OLMO35.

3. V2848.1, x1; 4. V2848.40, x1; 5. V2829. 13, x1;

6. VH106, $\mathrm{x} 1$.

$33.7,33.8$. GLMO32.

7. V2842.9, x1; 8. B256.18, B256.30, B256.31, x1. 

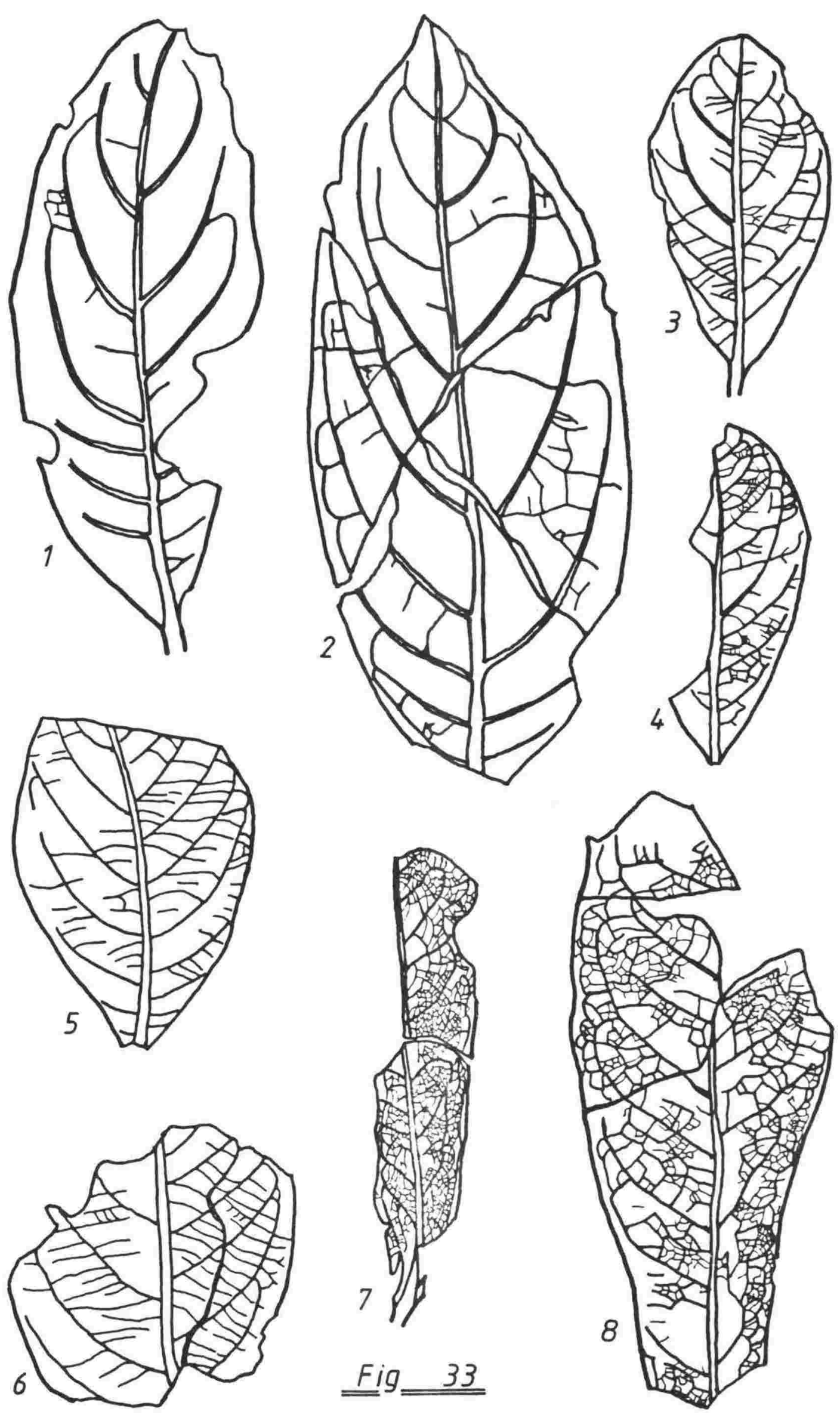
FIG. 34 .

$34.1,34.2,34.3,34.4,34.5$. OLM036.

1. V2856.4, V2856.41, x1; 2. V2856.12, x1;

3. V2856.6, xl; 4. V2850.22, x1; 5. V2851, x1.

34.6. LDF037. B6.1, $x 1$.

34.7. LDF038. B2.30, x1.

34.8. LDF039. V2825.11, x1.

34.9. OLM037. B1036, 19, x1.

34.10. FFF025. V2838.10, x1. 


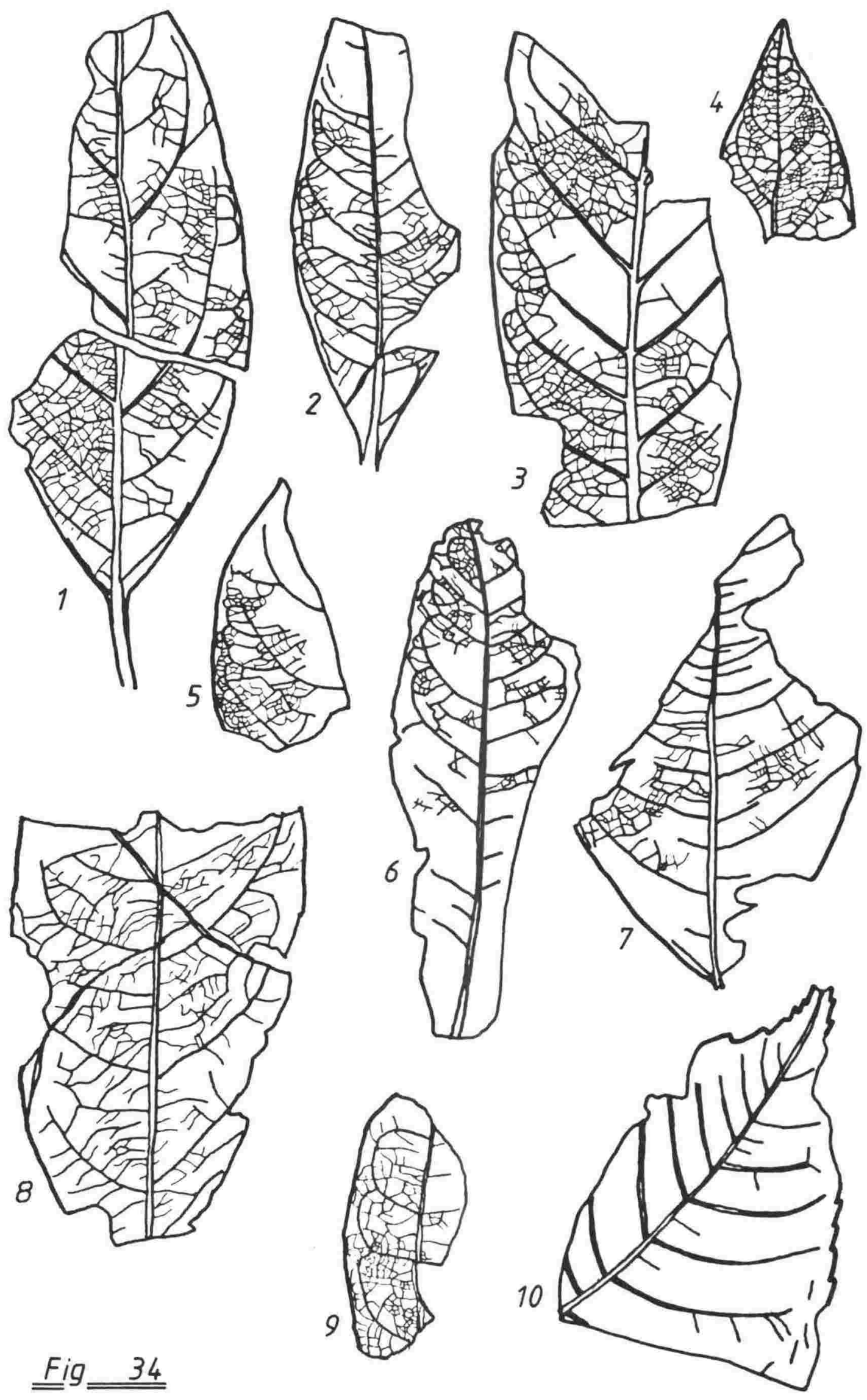


FIG. 35.

35.1. KLB023. V2847.10, $\mathrm{x} 1$.

35.2. LDF040, Palmae. B1119.11, x1.

35.3. FFF025. B38.101, x1.

35.4. GLM033. B148.26, $\mathrm{x} 1$.

35.5. 35.6. KLB024. Typha robusta Oliver

5. B2.43, x1; 6. B33.2, $\mathrm{x} 1$.

35.7, 35.8. NFMO12. ?Zingiberaceae

7. V2849.57, $\mathrm{xl} ; 8 . \mathrm{V} 2849.58, \mathrm{x} 1 .$. 


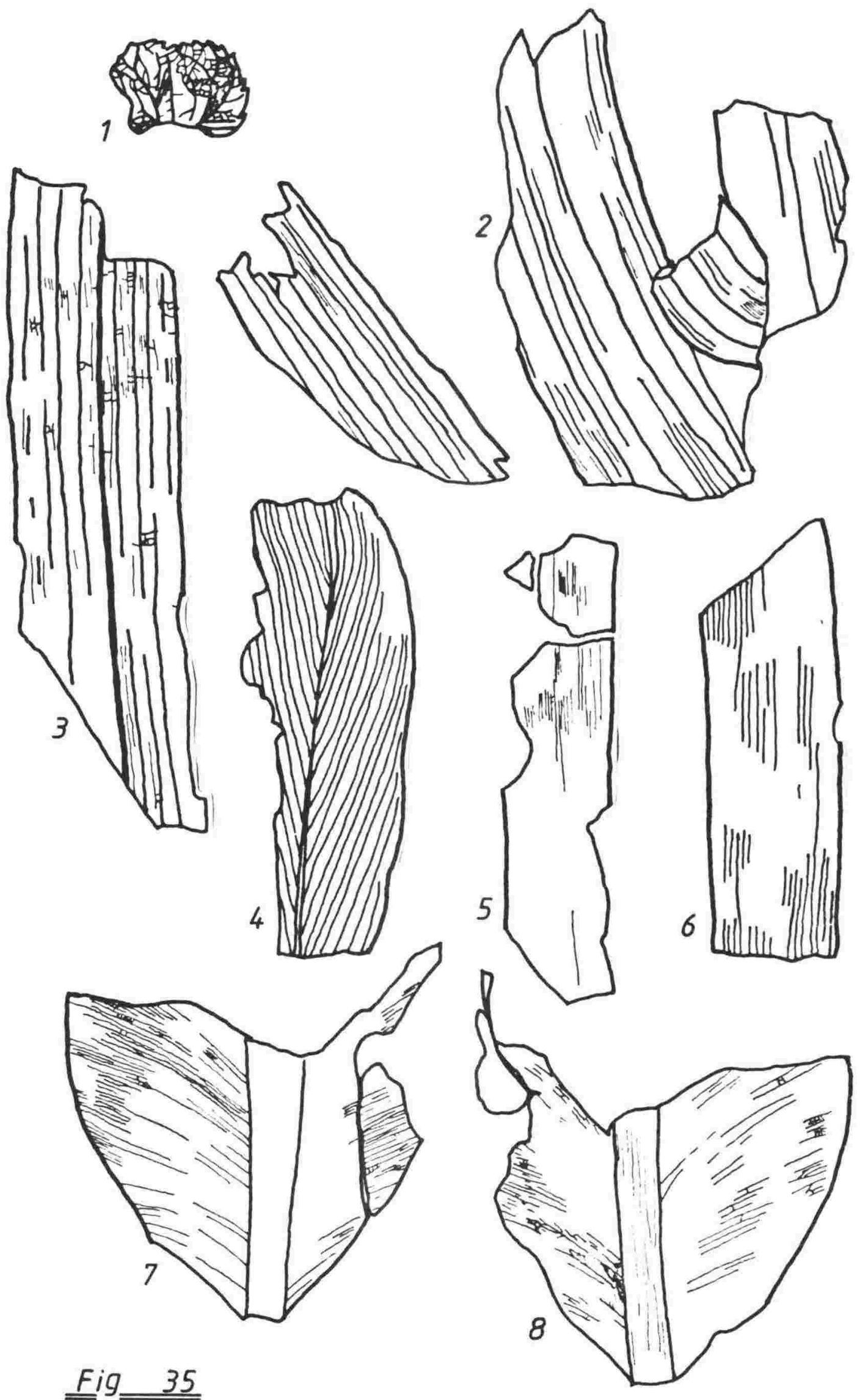


FIG. 36.

$36.1,36.2$. GLMO34.

1. V2841.3, silicone rubber cast, side view, $x 5$.

2. V2841.3, silicone rubber cast, end view, $x 5$.

$36.3,36.4,36.5,36.6$. GLM035.

3. V2842.6B, steinkern, $x 5$; 4. V2842.6B, x5;

5. V2842,6B, silicone rubber cast, basal view, $x 5$;

6. V2842.6B, silicone rubber cast, side view, $x 5$.

36.7. GLMO36. V2842.10A, side view, x5.

$36.8,36.9$. GLM037.

8. V2842.13, x5; 9. V2842.13A (counterpart), x5. 

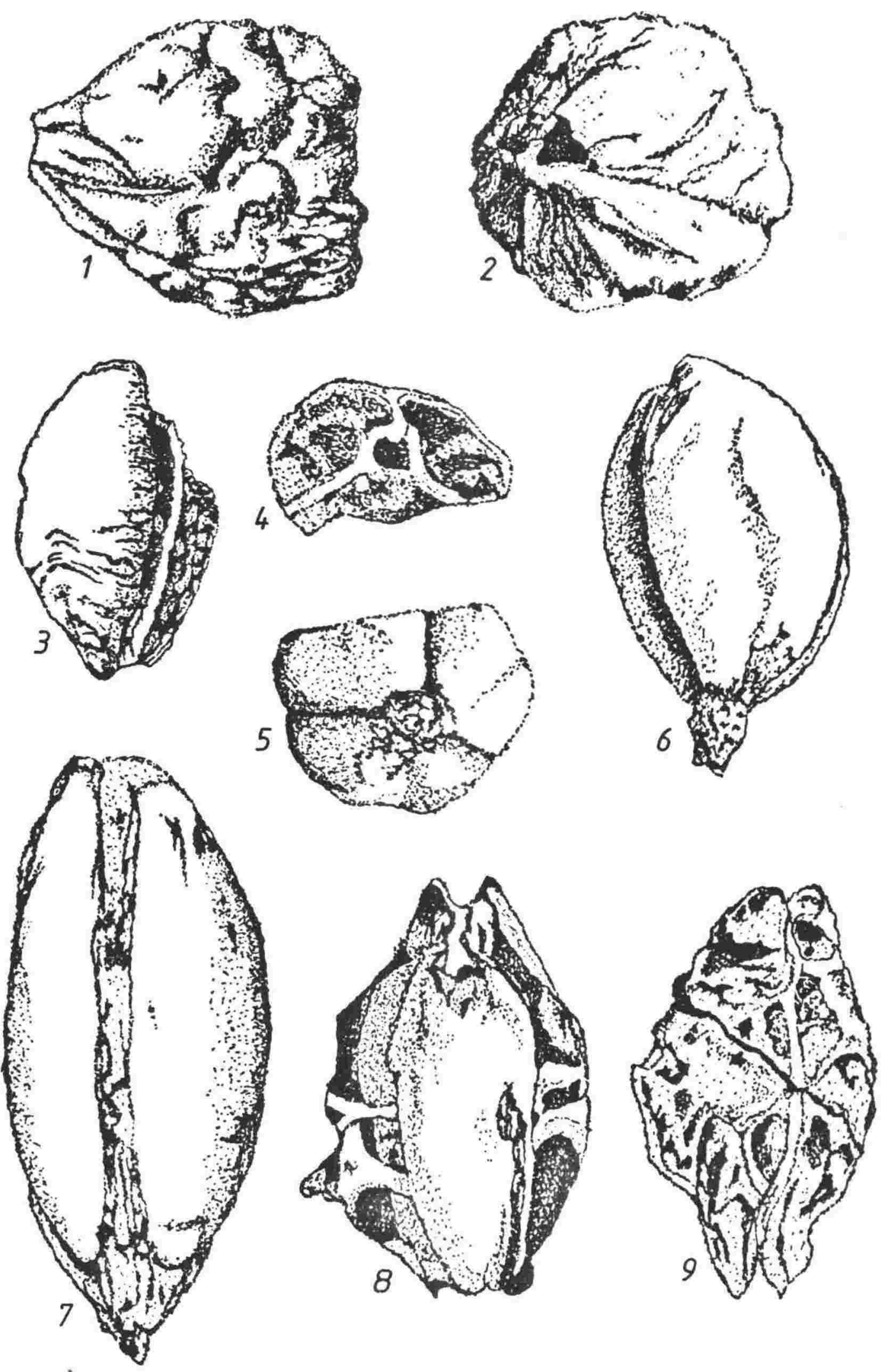

Fig 36 
FIG. 37.

37.1, 37.2. GLMO38. Elaeocarpaceae.

1. V2841.47, silicone rubber cast, x5; 2. V2841.47, x5.

37.3. FFF026. B36.16, $\times 15$.

37.4, 37.5. LDF041.

4. B256.32, x5; 5. B256.32, obverse, x5.

37.6, 37.7. OLM038. ?Rhopalostylis.

6. V2848.29, x5; 7. V2848.29A, x5.

$37.8,37.9,37.10$. GLM039.

8. V2843.17, x5; 9. V2843.17, x5; 10. V2843.17, side view, $x 5$. 

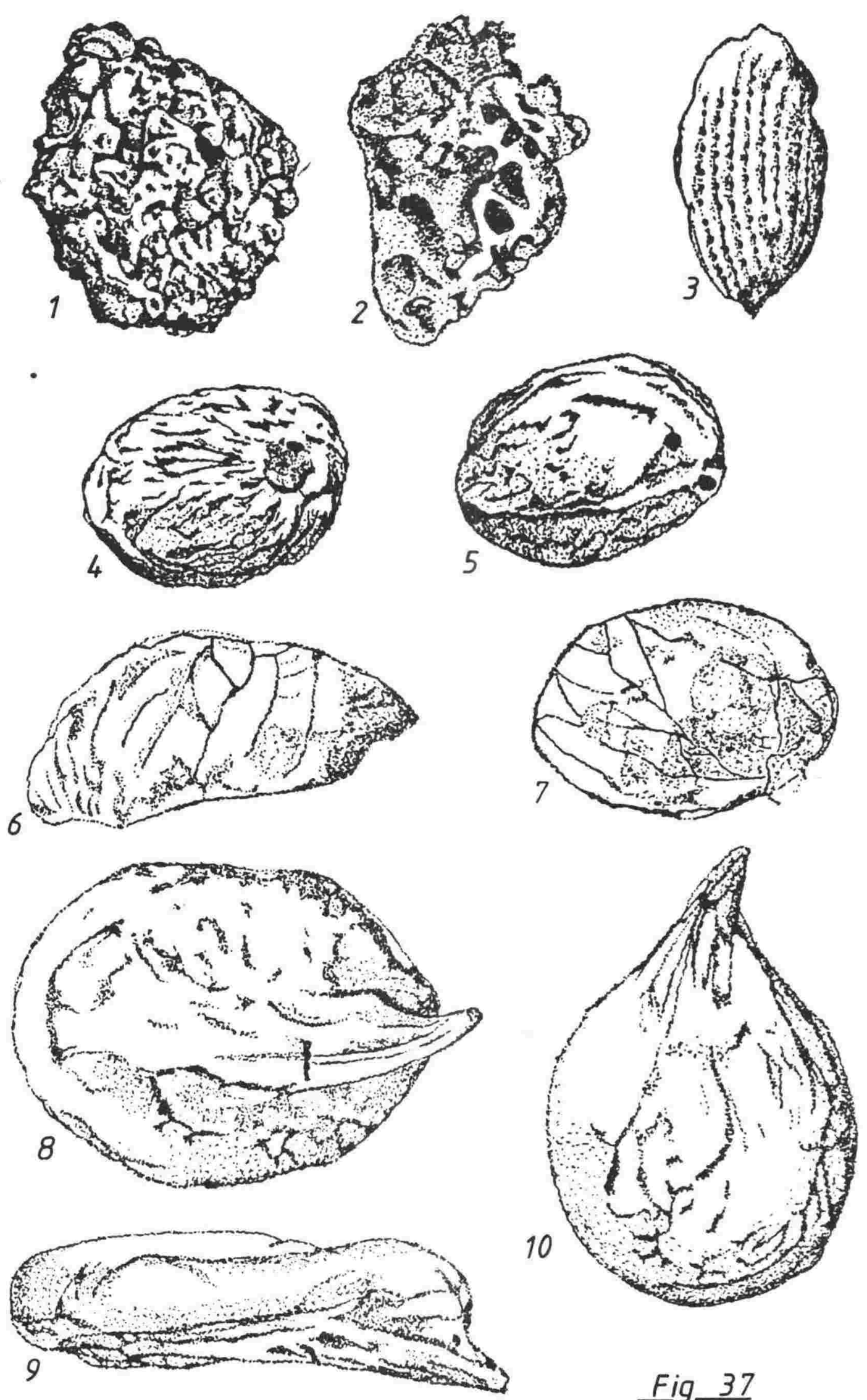

Fig 37 

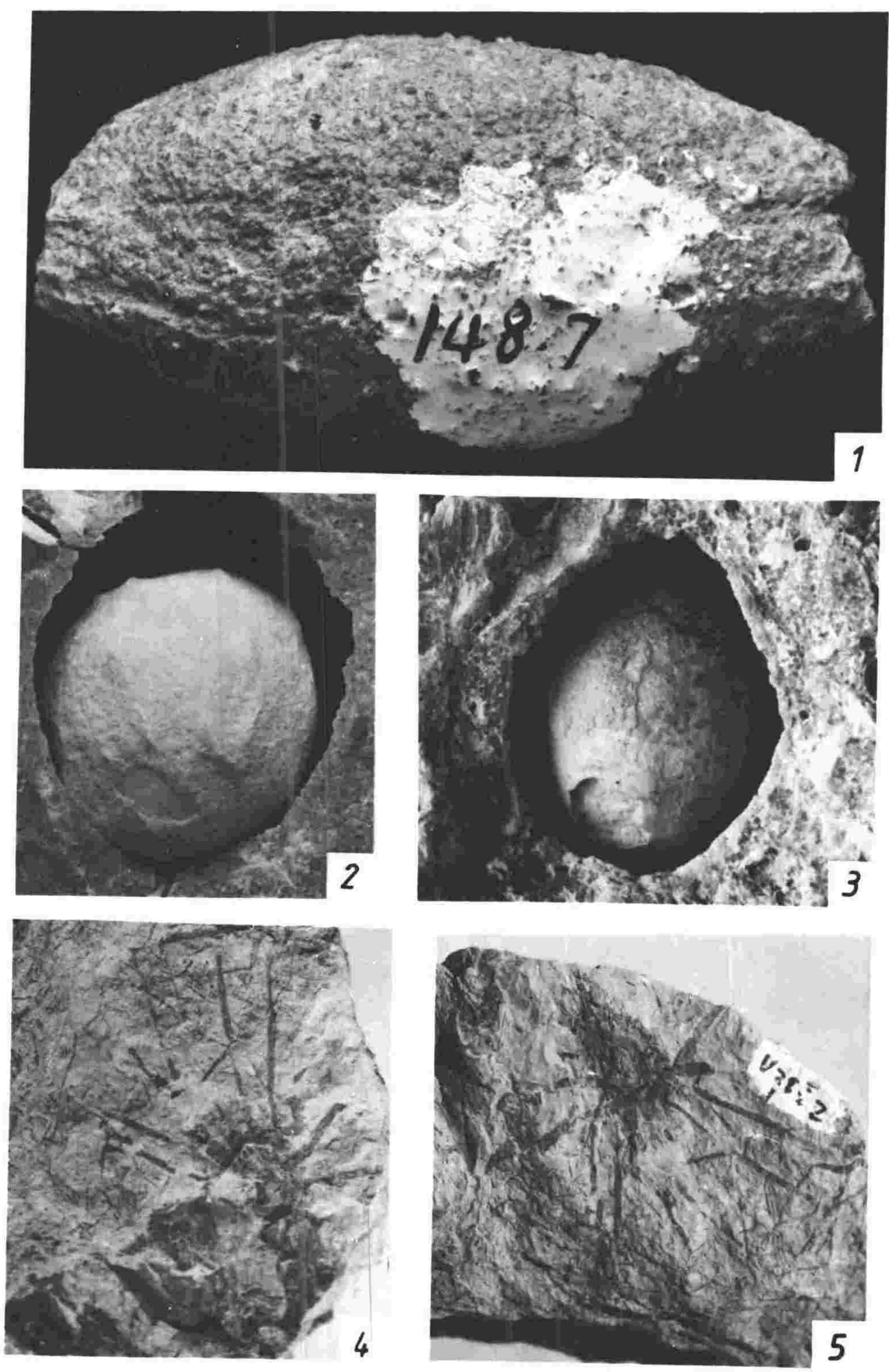

\section{PLATE 12}


PLATE 12.

12.1. GLMO46, B148.7, ?fruit, Landslip Hill, X4.

12.2, 12.3. GLM047, ?fruit, Landslip Hill.

2. V2841.84, X3.75. 3. V2841.91, X2.75.

12.4, 12.5. OLM039, rootstocks, Gramineae or Cyperaceae, Bannockburn. 4. V2852.4, X1. 5. V2852.1, X1. 

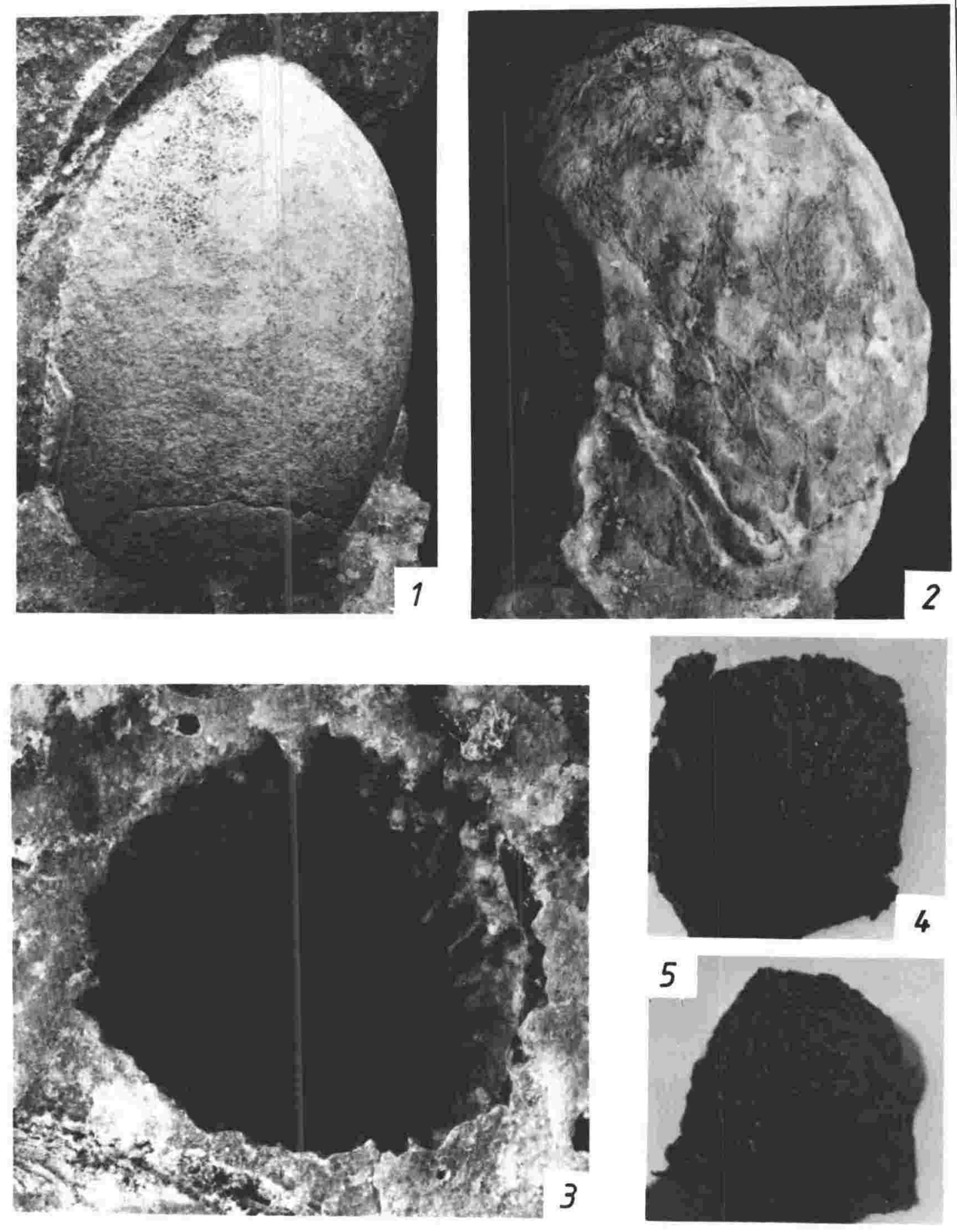

\section{PLATE 11}


PLATE 11.

11.1. GLM042, V2841.77, Landslip Hi11, X3.

11.2. GLM043, V2840.5, Landslip Hill, X4.

11.3, 11.5. GLM044, ?fruit, V2842.4, Landslip Hill.

3. Natural mould, X3. 5. Silicone rubber cast, X1.75.

11.4. GLM041, V2841.25, silicone rubber cast, X1.75. 

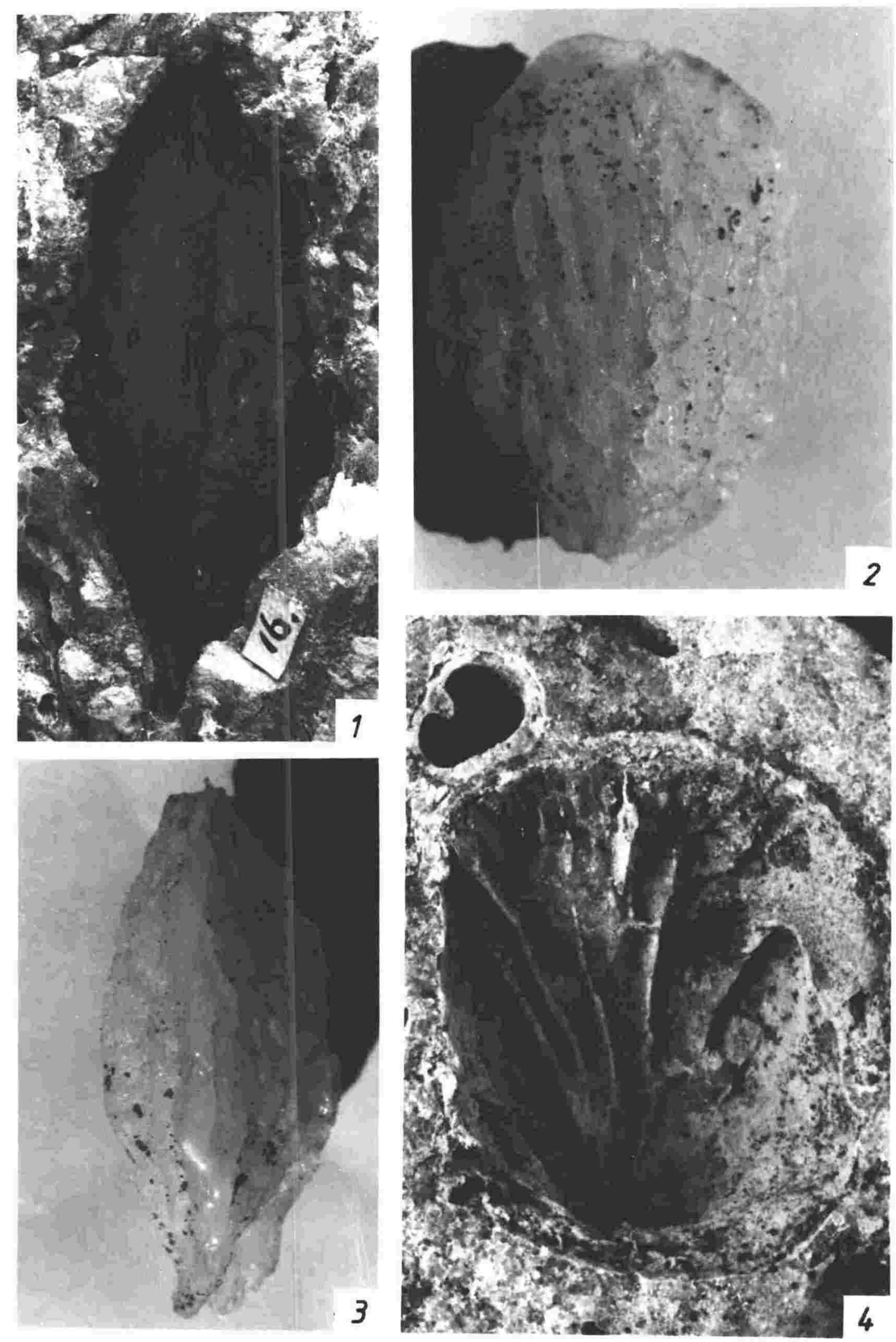

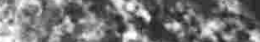

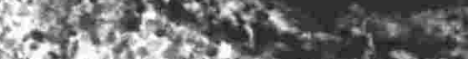

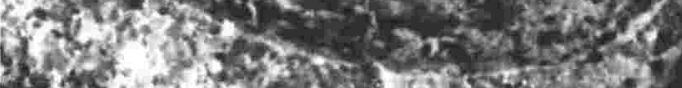

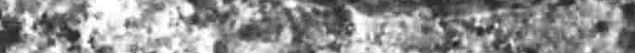

3 fow 
PLATE 10.

10.1, 10.2, 10.3. GLM040, B148.1027, Landslip Hill.

1. Natural mould (half), X2. 2. Silicone rubber cast, surface view, Xl.5. 3. Silicone rubber cast, side view, $\mathrm{X} 1.5$.

10.4. GLM041. V2841.25, Landslip Hil1, natural mould, X3. 

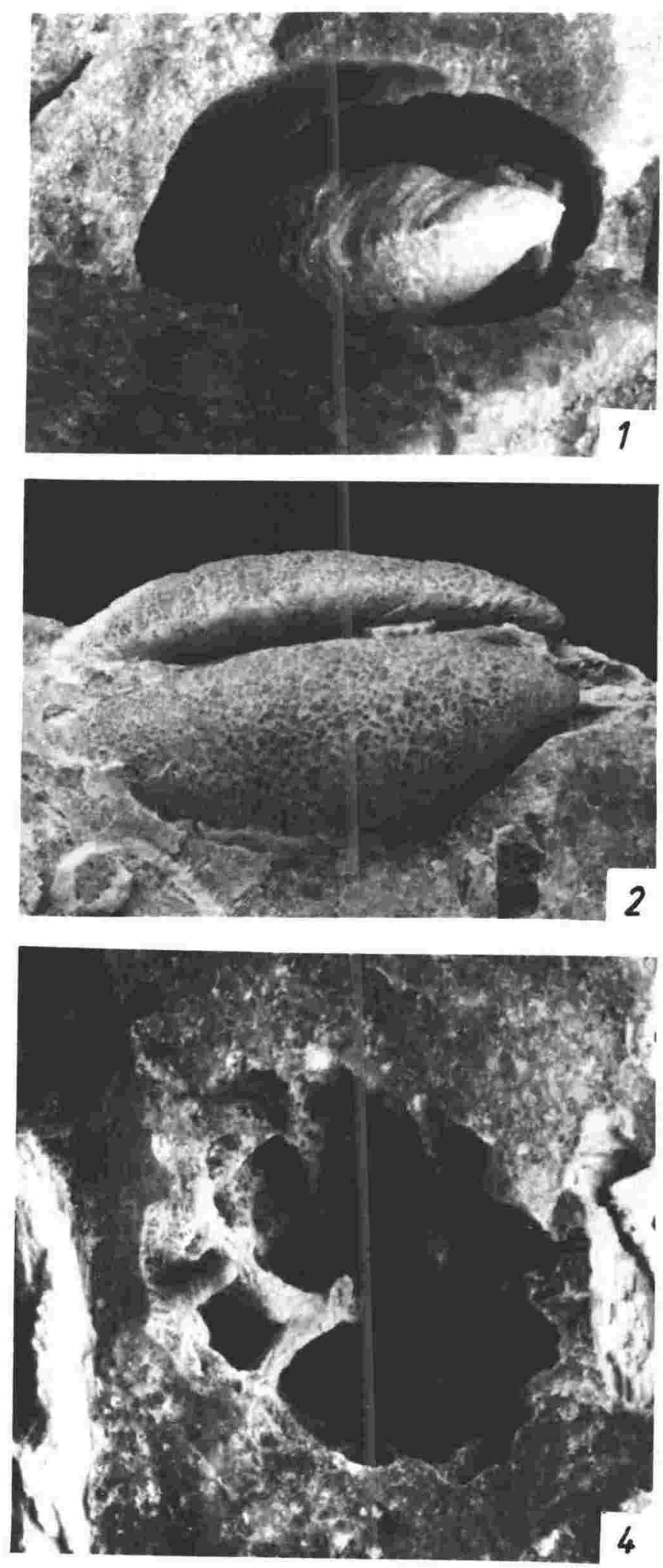

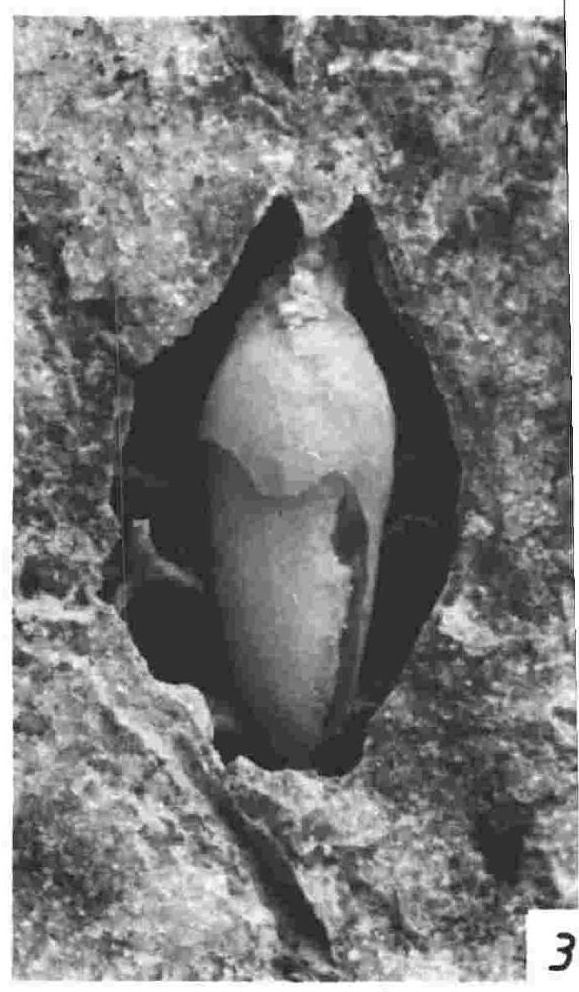

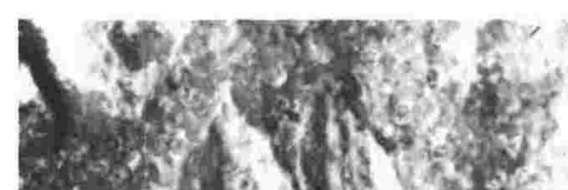

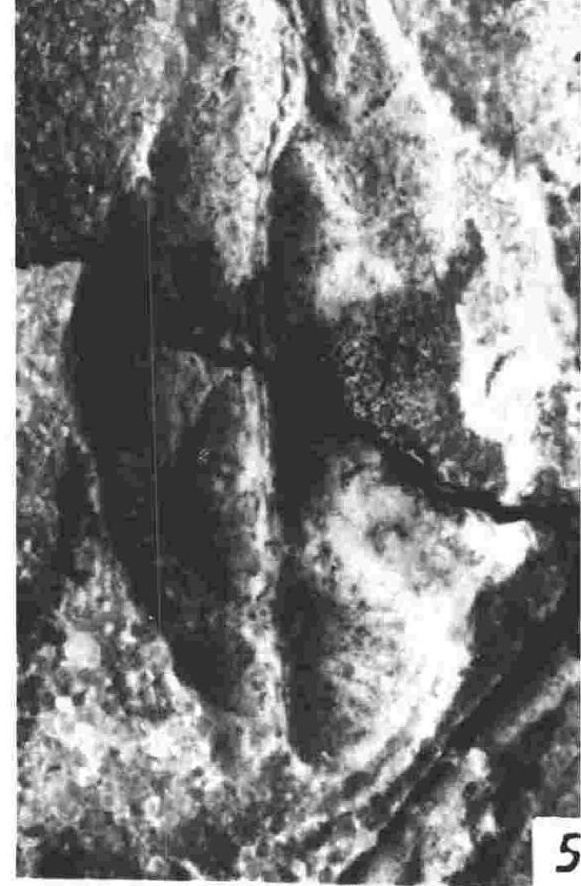

\section{PLATE 9}


PLATE 9.

9.1. GLM035, fruit, external and internal mould, V2842.6B, Landslip Hill, X4.

9.2. GLM036, fruit, V2842.10A, Landslip Hill, X4.

9.3, 9.5. GLM037, fruit, Landslip Hill.

3. V2842.13, X4. 5. V2842.13A, X5 .

9.4. GLM038, ?Elaeocarpaceae, fruit, Landslip Hil1, X3. 

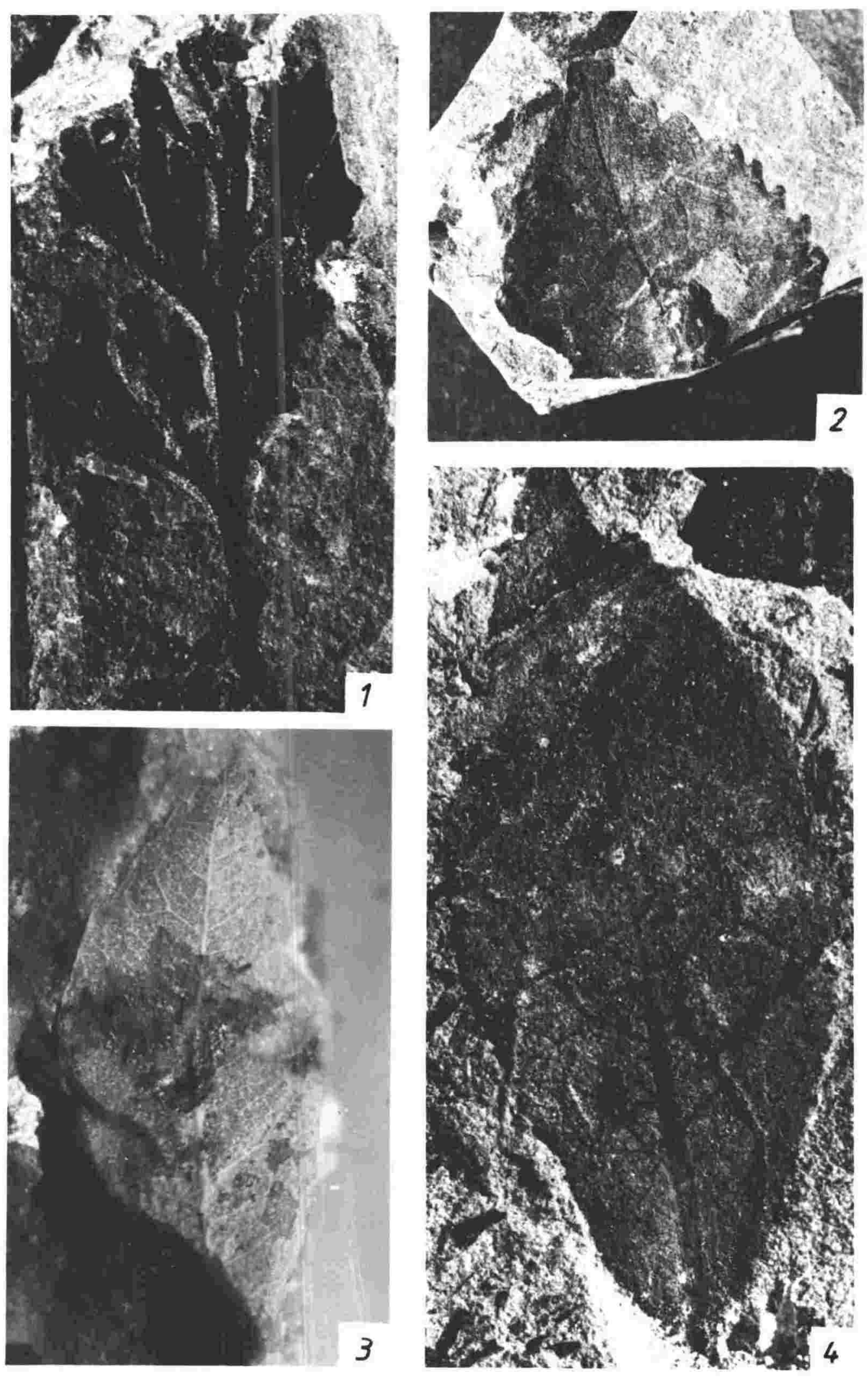

PLATE 8 


\section{PLATE 8.}

8.1. Hymenophy1lum mio-zealandicum, B7.26, Dress Circle, Longford, X5.

8.2. Laurelia cuneata Oliver B7.46, Dress Circle, X3.

8.3. GLM018, ?Monimiaceae, V2841.33, Landslip Hill, X6.

8.4. LDF021. ?Ascarina, V2835.15, Mangles Valley, X4. 

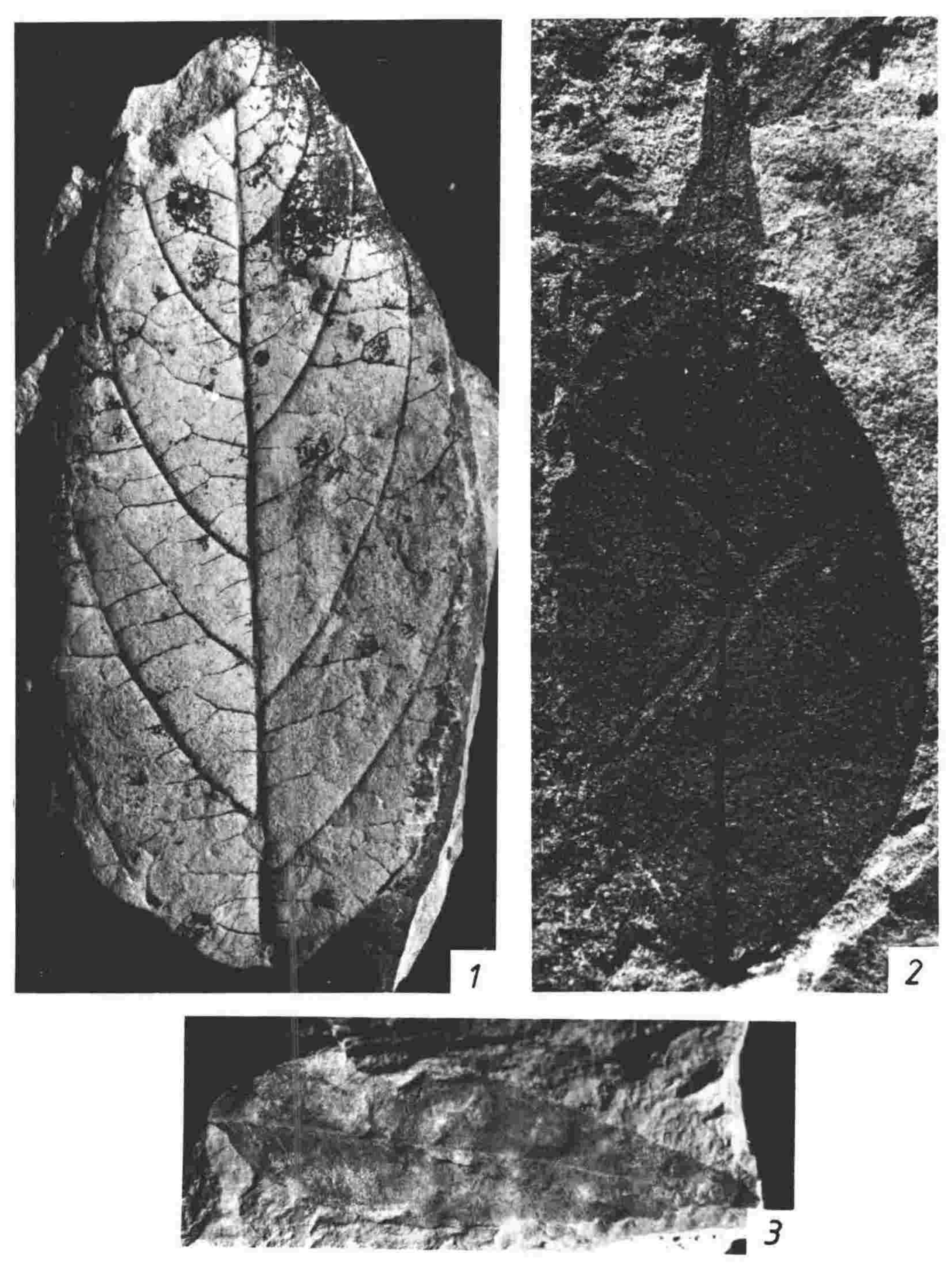

\section{PLATE 7}




\section{PLATE 7.}

7.1. Litsea dawsoniana Holden, holotype, VH105, Dress Circle, Longford, X 1.75 (approx.).

7.2. Metrosideros 1aeta Oliver, V2835.15, Mangles Valley, X3 (approx.).

7.3. ?Eucalyptus roxburghiensis, holotype, v2848.15, Coal Creek Flat, Roxburgh, X 1.25 (approx.). 

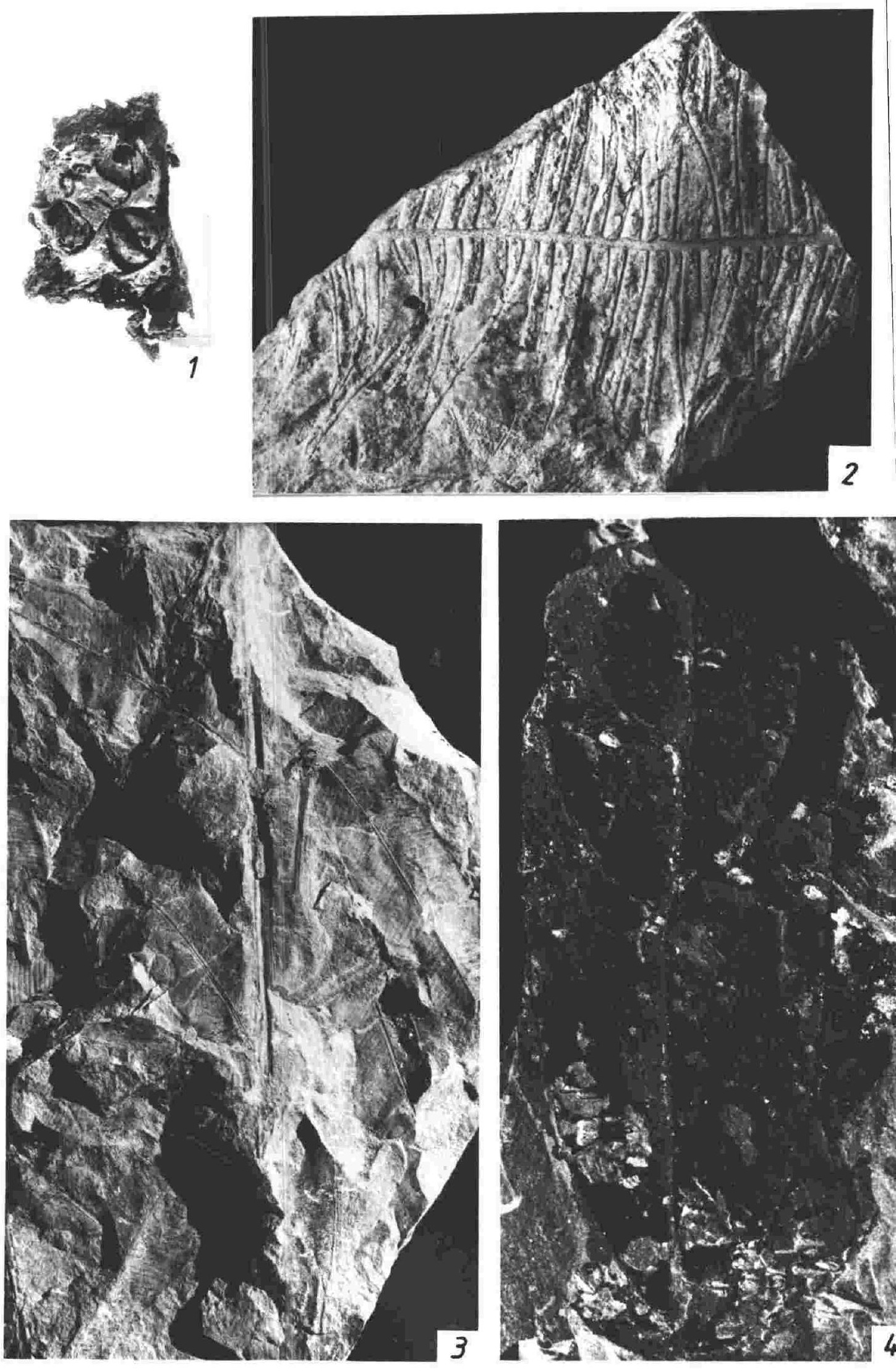
PLATE 6.

6.1. Gymnostoma crassa, Holotype, mature female cone, B148.1026, silicone rubber cast, Landslip Hill, X3 (approx.).

6.2. Gleichenia southlandica Holotype, C76.469.6, Pukerau, $\mathrm{X} 0.75$.

6.3. Blechnum proceroides (O1iver), B2,14, Nuggety Creek, $\mathrm{X} 1$ (approx.).

6.4. Cryptocarya longfordiensis Holden, Holotype, B7.70, Dress Circle, Longford, X2 (approx.). 

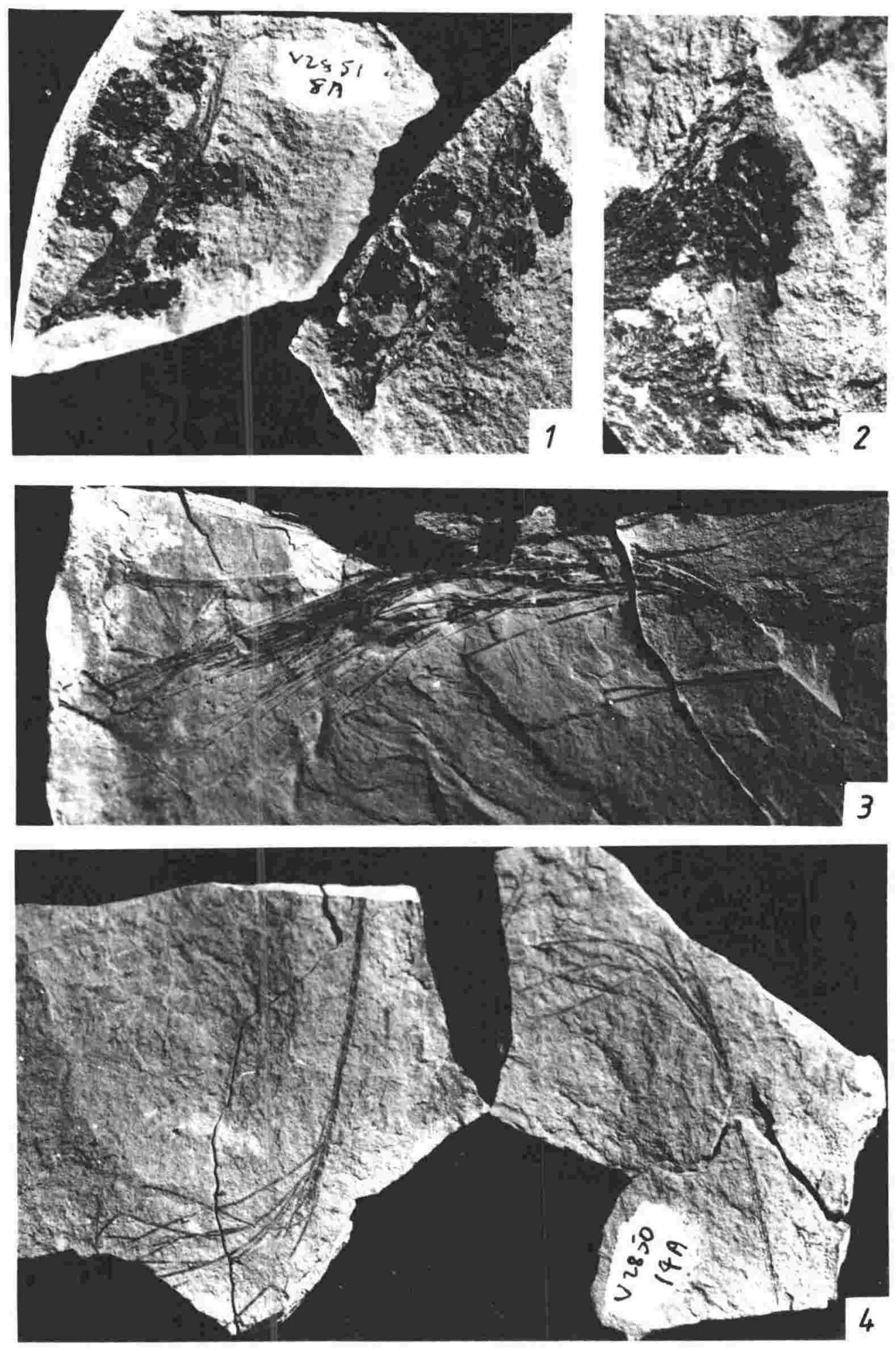

\section{PLATE 5}


PLATE 5 .

$5.1,5.2,5.3,5.4$. Casuarina avenacea Campbell and Holden, female cones and foliage.

1. V2851.8, 8A, Bannockburn, X1 (approx). 2. V2851.14A, Bannockburn, X2 approx. 5.3. V2850.20, foliage, Bannockburn, X1 (approx.). 4. 2850.14, 14A, follage, Bannockburn, X1 (approx.). 

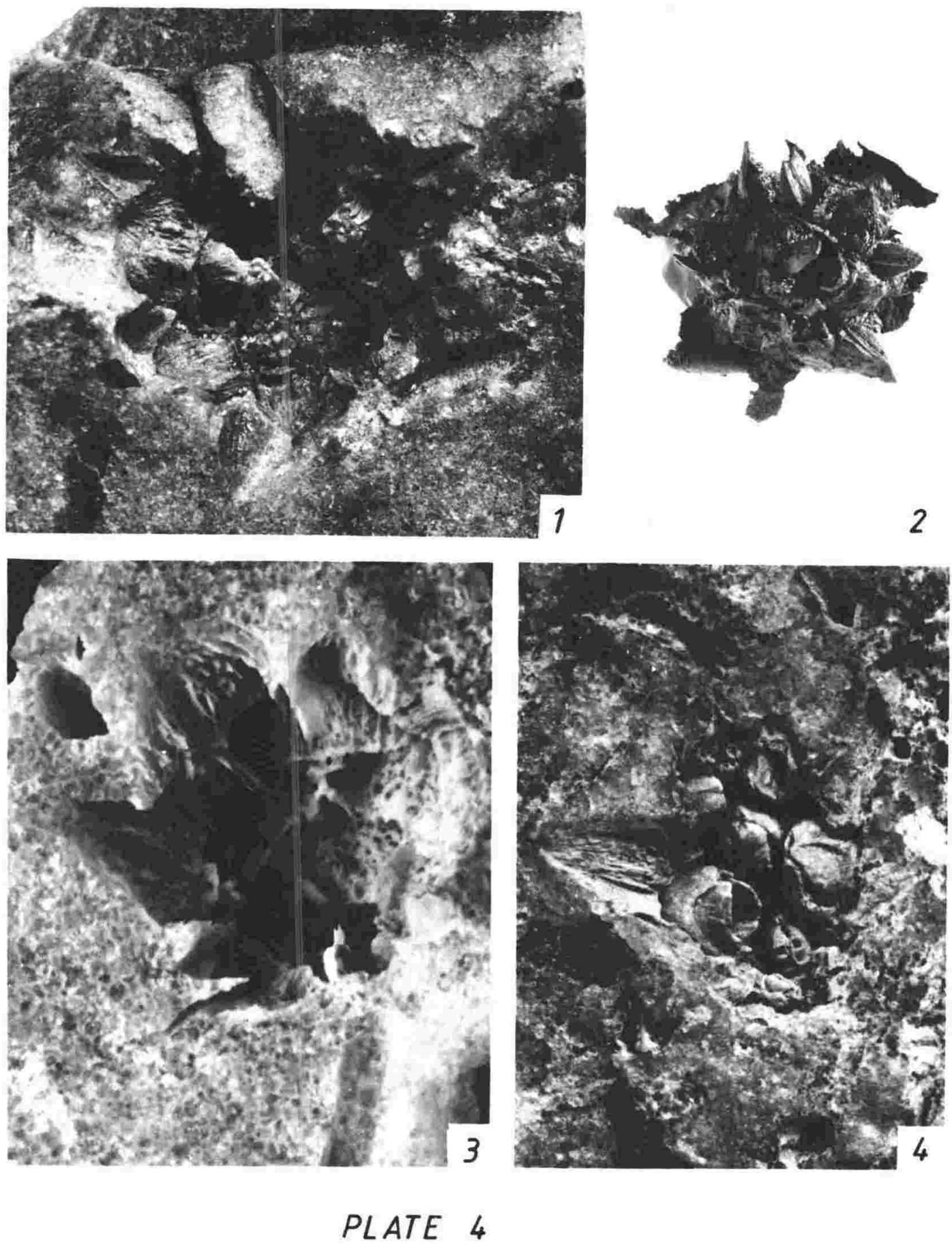
PLATE 4

4.1, 4.2, 4.3, 4.4, Gymnostoma stellata Campbell and Holden, female cones.

1. V2840.4, Holotype, mature cone, Landslip Hill, X 3 (approx.).

2. V2840.4, silicone rubber cast from holotype, X 2 (approx.).

3. V2841.63, immature cone, X 7;

4. V2842.4, mature cone, X 3 (approx.). 

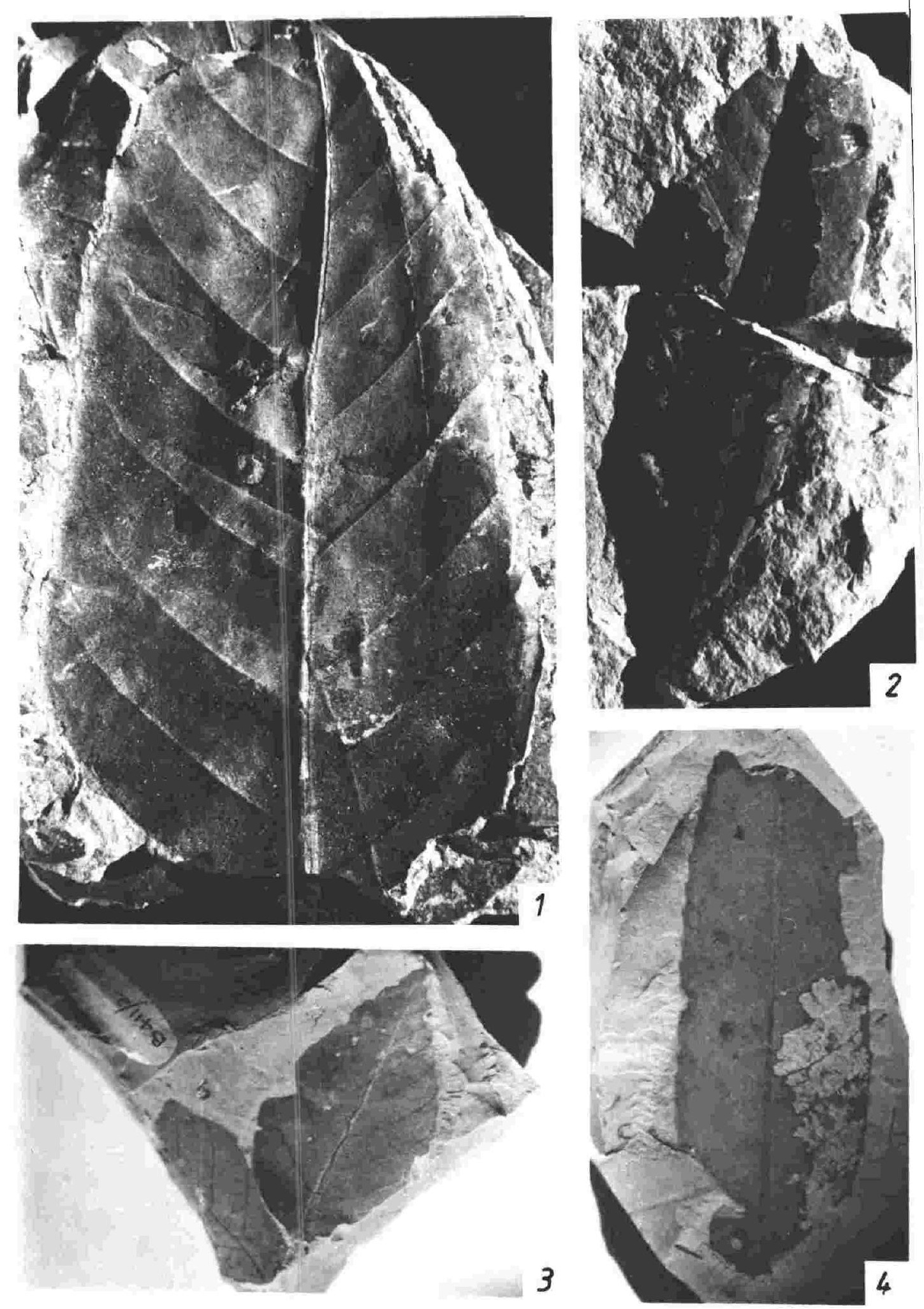

PLATE 3 
PLATE 3

3.1. Nothofagus oliveri Holden, B2.59, Nuggety Creek, X 2 (approx.).

3.2. Nothofagus oblonga Holden, Holotype, B7.56, Dress Circle, Longford, X 1.75 (approx.).

3.3. Nothofagus australis (01iver), B411.2, Great Barrier Island, X 1 (approx.).

3.4. Nothofagus bidentatus Holden, B411.7, Great Barrier Island, X approx. 1. 

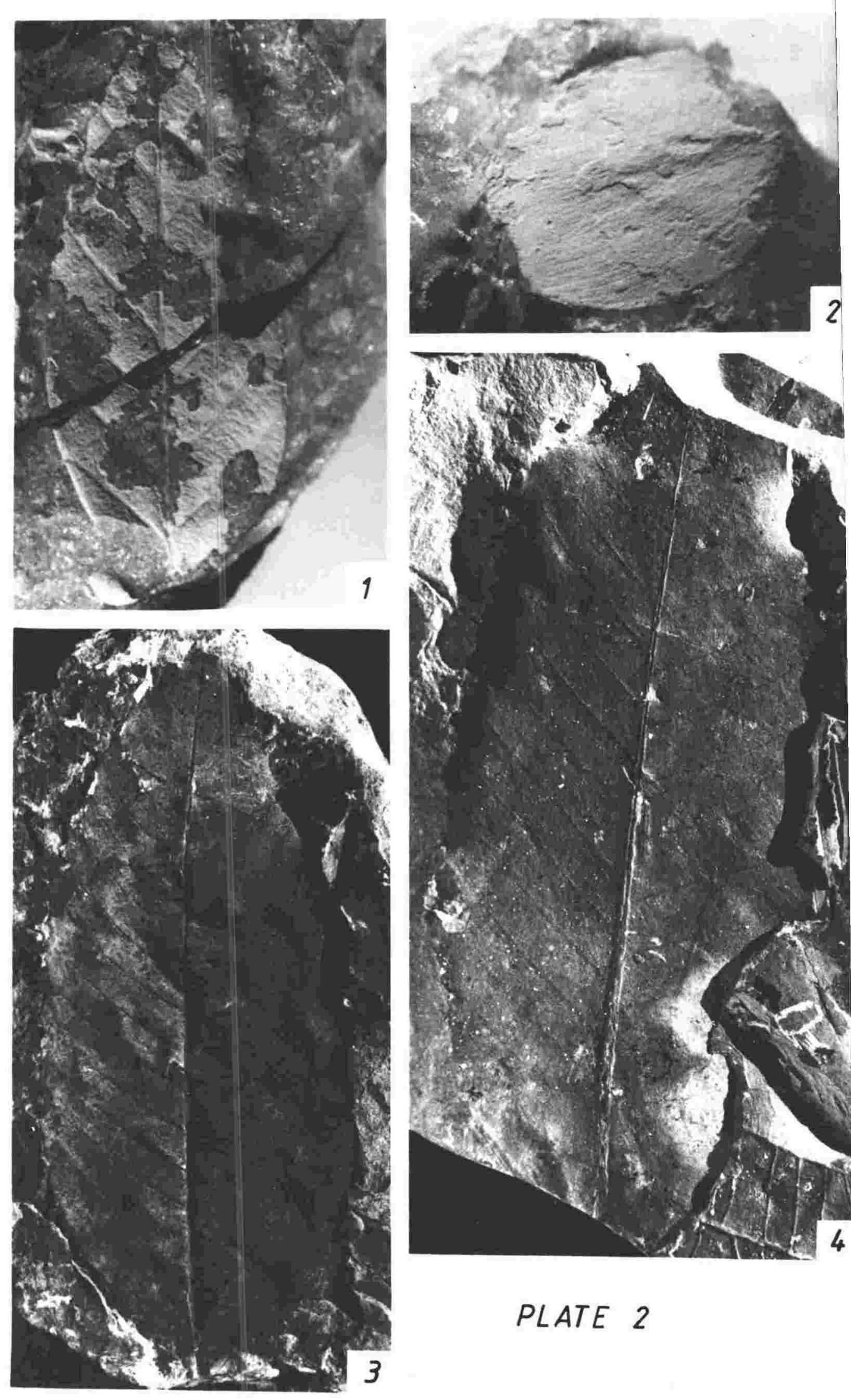

PLATE 2 


\section{PLATE 2}

2.1. Nothofagus southlandica sp. nov. Holotype, V2841.13A, Landslip Hill, X 2 (approx.).

2.2. ?Araucaria sp., leaf, V2841.1, Landslip Hill, X 2 (approx.).

2.3. Nothofagus novae-zealandiae (Oliver) Holden, VH93, Dress Circle, Longford, X 1.25 (approx.).

2.4. Nothofagus bidentatus Holden, B2.54, Nuggety Creek, Holofype. X 1.75 (approx.). 

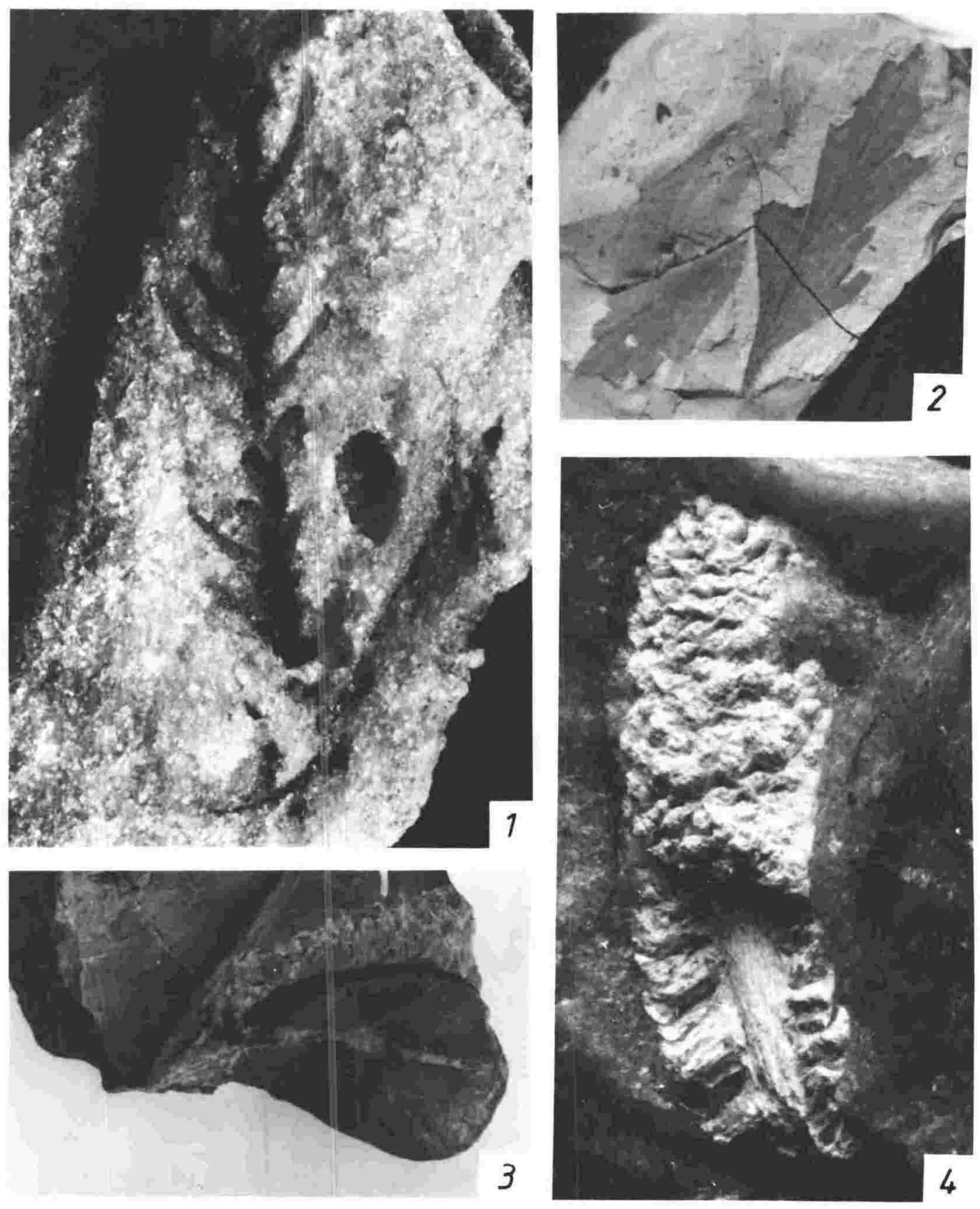

PLATE 1 
PLATE 1

\section{Lamb.}

1.1. Dacrydium sp. aff. cupressinum $h$ natural mould of branchlet fragment, B33.1, Waikaka, X 4 (approx.). sp.nov.

1.2. Phy1locladus strictus/ Holotype, B411.1, Great Barrier Island, X 1 (approx.).

1.3. ?Araucaria sp. (seed), Holotype, B2.58, Nuggety Creek, X 2 .

1.4. Agathis or Araucaria sp. (pollen cone), Holotype, v2841.85, Landslip Hill, X 3 (approx.). 